\title{
COLLECTED PAPERS ON ACOUSTICS
}

WALLACE CLEMENT SABINE 


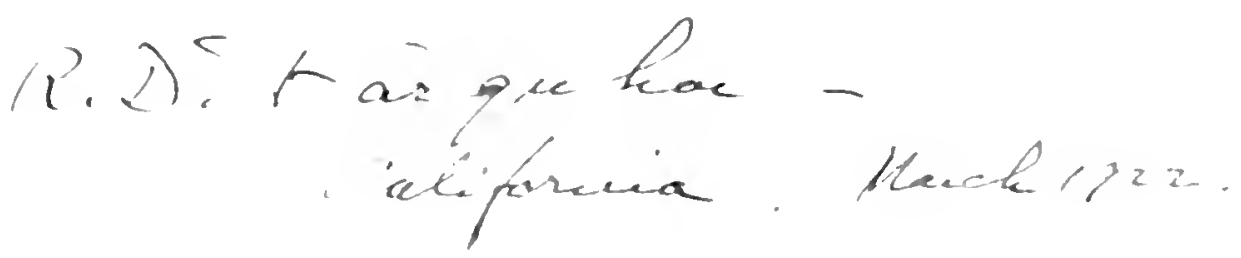




COLLECTED PAPERS ON ACOUSTICS 



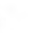




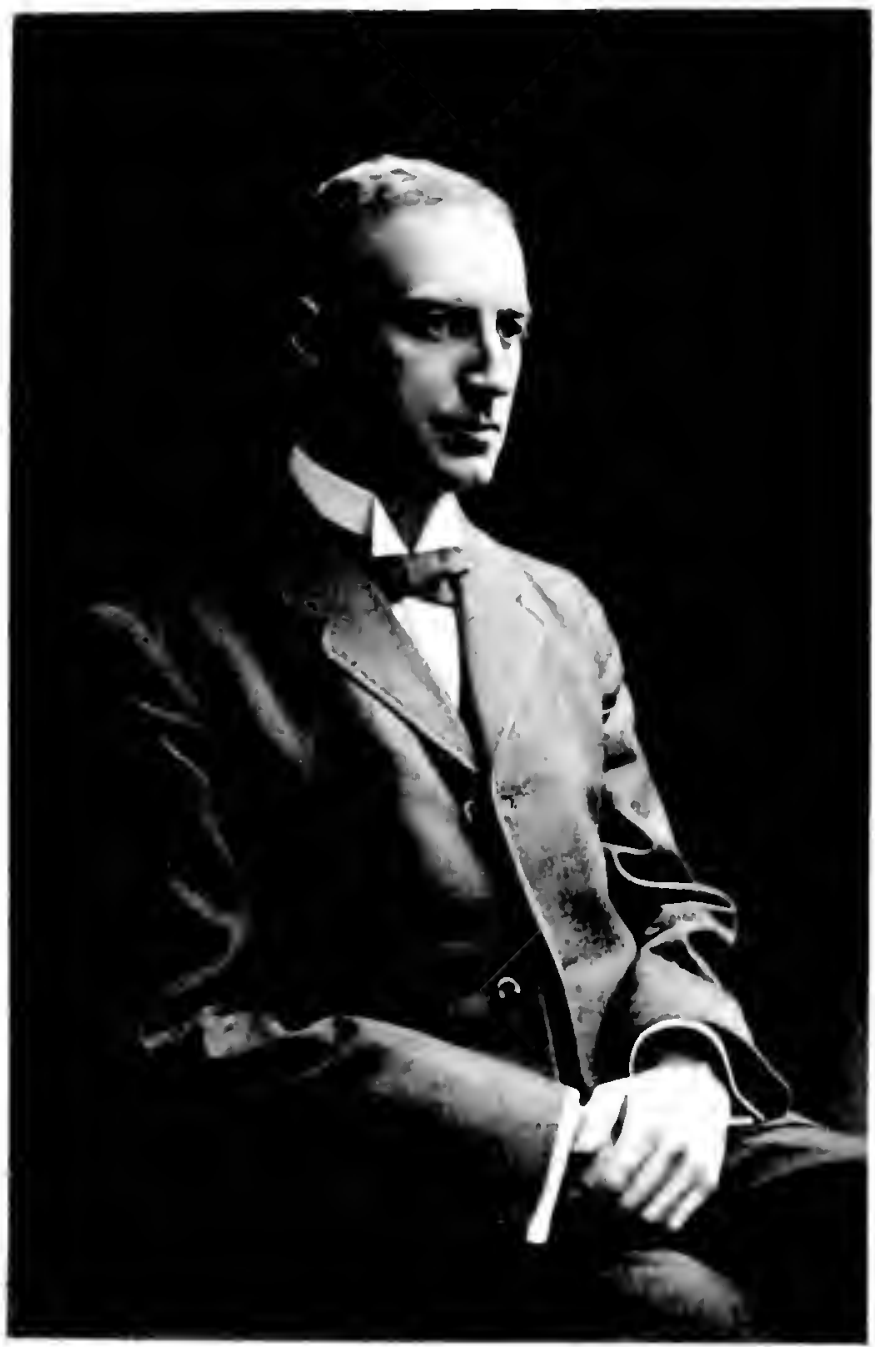

Wareare Prain 


\title{
COLLECTED PAPERS ON ACOUSTICS
}

\author{
BY \\ WALLACE CILUENT SABINE

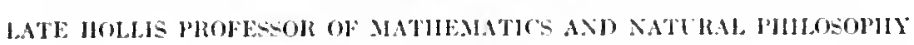

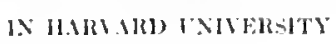

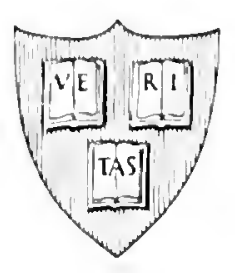

CAMBRIJ)Gi:

HARVARI) INALRSTT MRES

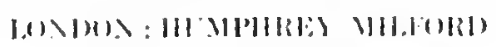

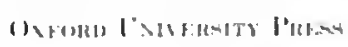

1928 
COP'R RIGHT, 1922

H.HWIID CNIVERST PRESS 


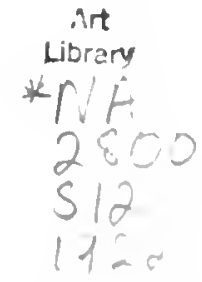

\section{PREFACE}

Tus volume aims to contain all the important contributions to the subject of acconstice from the pen of the late Profesinor W. C. Sabine. The greater part of these papers appeared in a number of different architeretural joumals amel were therefore addressed to a changing andience. little acounintefl with physical science, and to whose members the subject wats altogether novel. Indere these circumstances a certain anount of repetition was net only mavoidable, but desirable. Little attempt lats been made to reduce this repetition lut in one calse an onn ission seemed wise. The material contaned in the author's aurliest papers on acousties, which appeared in the Proceedings of the American Institute of Architects in 1898. is repeated almost completely in the paper which forms the first chapter of this volume: it has, therefore. been omitted from this collection with the exception of a few extracts which have heen inserted as footuotes in the first chapter.

No apologe is made for the preservation of the paper from the Procedings of the Franklin Institute, for. thongh much of the matterial therein is to be found in the earlier chapters of this volume the article is valuable as a summary amel as such it is recommended to the reacler who desires to obtain a general view of the subject.

In aclelition to the papers alveaty in print at the time of the anthors death the only available material comsisted of the mamuscripts of two atrtieles. one on Eechoes, the ofleer on Whispering Galleries. ant the full notes on four of the leetures on acountien delivered at the sorbemme in the spring of $191 \%$. Of this material, the first

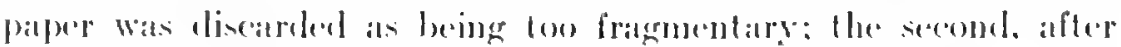

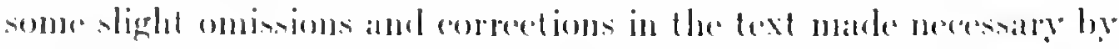

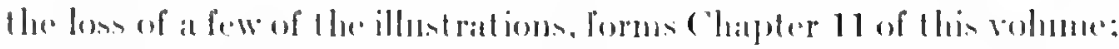

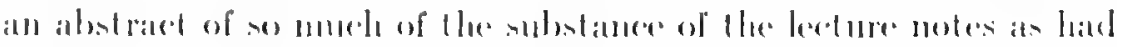

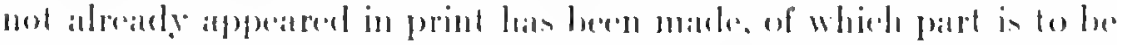

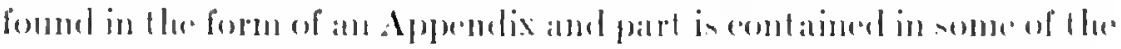
following paragratple.

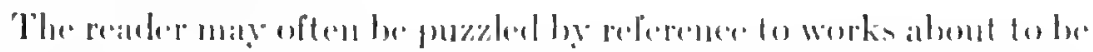
published hut of whind no trane is to be foumd in this volumes. It is 


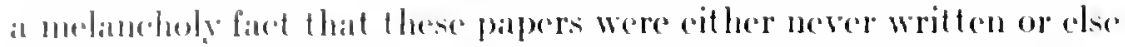
were dent loverel hy their anthor: no trace of them can be found. 'The extront of the lathors of which no adequate recomt remains may best be judgeel from the following extracts taken from the notes on the Paris leotures just mentioned.

"On the ono hand we hate the problem (Reverberation) which we latve beren discossing up to the present moment. and on the ofleed the whede question of the transmission of sommel from one room to ancther. through the walls, the dooss, the eciling and the floors; and the tolephonic I ransmission, if I may so call it, through the length of the structure. It is five years ago since this second problem was first

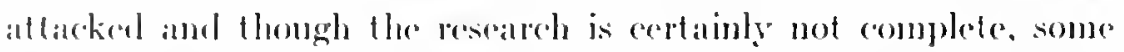
groment has becen covered. I quantitatively exact method has been establisheet and the transmission of somed through about twenty diflerent kinds of partitions has been determined.

"For eximple: 'Transmission of sound through four kimels of aloors has beens studied: two of oak. two of pine, one of aad kind was pancled and was relatively thin and light: one of each kimd was rery heary, mealy four centimet res thick: throngh four kinds of windows. one of plate glass, one with common panes, one double with an air space of two centimetres betwern, one with small panes set in lead stedh as one seres in churcles: through brick walls with plaster on both silles: through walls of tile similarly plastered: thromgly walls of a (hatrater not common in France and which we call grpsum block; througl plaster on lath; through about ten diflerent kinds of sound iumblators, patented, and sold in quantilies representing hundreds of

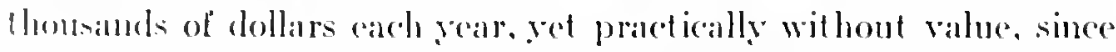
one can casily converse through six thicknesses of these substances anel talk in a low tone through three. while a single thickness is that ordinarily comployed. 'The boharior of an air space has been studied. the efferet of the thickness of this air space, and the result of filling the space with sand. saw-rhast and asbestos. In spite of all this, the renearrele is far from complete and many other forms of construction munt he investigaterl before it rill be possible to publish the results: then doterminations must be made with the greatest exactness as very important interests are involved. . . 
"The researeh is particularly laborious because resonance has a special importance in a greall number of forms of construction. It is a much greater factor in transmission than in absorption.

"I shall not enlarge on this subject here for 1 wo reasons: first, I believe that it is not of ipeceial interest, at least, in its present state, and secomd, becanse it is net proper to present a formal discussion of this subject while the resenech is still unfinished."

The last paragraph is characteristic. The severity of the criticism which Professor silbine always applied to his own productions increased with tine, and it is to this extreme self-criticism and repression that we must asceibe the loss of much invaluable sejentific material,

'Thanks are due to 'The American Institute of Archilects and to the editors of The Ameriesn Arehitect. The Briclbuilder, The Engine'ring Record. and The Journal of the Franklin Institute, for permission to reprint the anticles which originally appeared in theje resperetive Jominals.

The Eelitor is also greatly obliged to Dr. Paul sabine anel Mr. Clifford M. Swan for a great deal of vahuable matelial, and to Mr. Frank C'hontean 13 rown for his assistance in seeing the book through the press. IIe is particularly indebted to his colleagute Profesisor F. A. siandeles for his invaluable ad in all matters touching the correct presentation of the material of 1 his volume.

THEODORE LMMAX

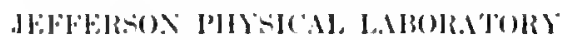

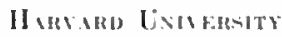

J111:. 1:1:1 



\section{CONTENTS}

PAGE

1. Reverberation

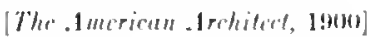

2. The Accuracy of Musical 'Taste in Regard to Architectural Acomalies. The Variation in Rererheration with Variation in Pitch

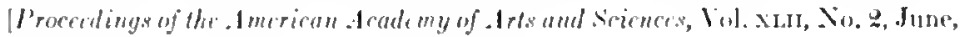
$190(i)$

3. Meloxly and the Origin of the Musical Scale

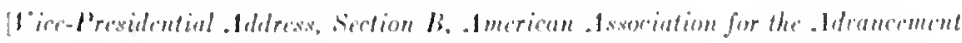
of siciente, (licango, 1900i]

4. Liffects of Air Currents and of Timperalure

[Limgineriun Record, Junn, 1!10]

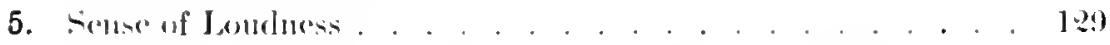

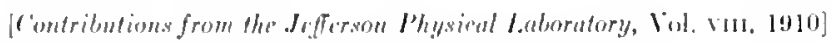

6. The correction of Acoustival I)ifliculties . . . . . . . . . 131

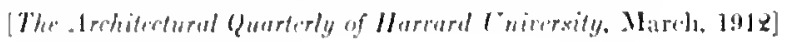

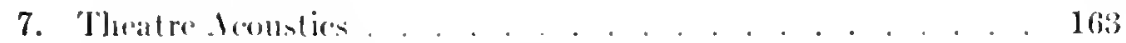

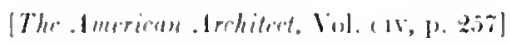

8. Building Material and Musical Pited . . . . . . . . . 19!9

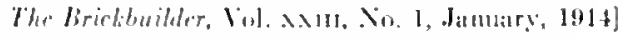

9. Arediteretural Acomatice . . . . . . . . . . . . \$19

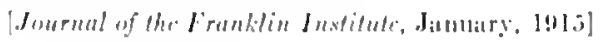

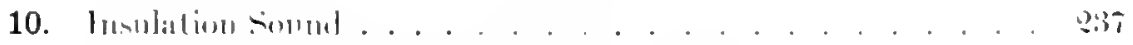

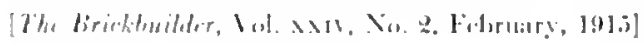

11. Whispering Gallerien. . . . . . . . . . 958

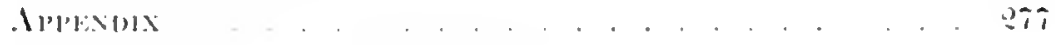

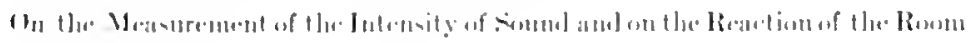
"1pens Hu. Sonsml 



\section{COLLECTED PAPERS ON ACOUSTICS}





\section{REVERBERATION'}

\section{IN'TRODIC'TION}

$\mathrm{T}$

IIE following investigation was not undertaken at first by choice, but devolved on the writer in 1895 through instructions from the Corporation of IIarvard Iniversity to mopose changes for remedying the acomstical difliculties in the lectme-loom of the Fogg Art Musem, a building that had just bean eomploted. About two years were spent in experimenting on this room, and permanent changes were then masle. Almost immediately afterward it became certain that a new Boston Music Mall would be erected, and the questions arising in the consideration of its plans forced a not unwelcome conlinuance of the general insestigation.

No one can appreciale Ihe condition of architectural acoustics the scienee of sound as inplied to buildings - who has not with a pressing ease in hamd somght through the seattered literature for some salfe gnidance. Responsibility in a larese and irretrievable expemeliture of money compols a careful consideration, and amphasizes the meagermess and inconsistency of the current suggestions. 'Thus the most definite and often repeated statements are such ats the following, that the dimensions of a room shoubl be in the ratio

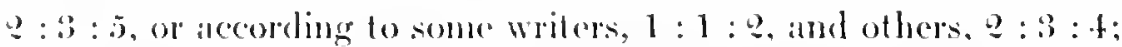
it is probuthle that the basis of these suggestions is the ratios of the hatmonic intervals in musie, lont the connection is untralced amb re-

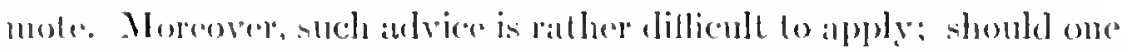
measure the length to the batek or to the front of the galle ries, to the

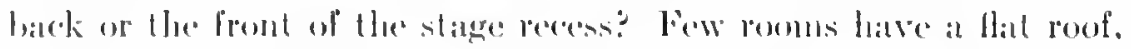
where hould the height be measumed: One writer, who had seen the

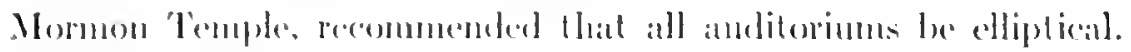

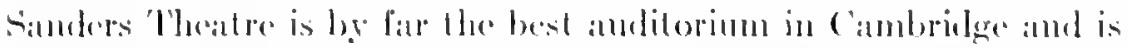

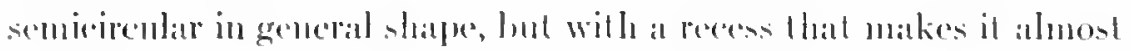
anvething: and, on the other hamel, the lecture-loom in the liogg dret 
Wurem is also semicireular, indeed was modeled after Sanders 'Tle"atre, and it was the worst. But Samelers Theatre is in wood and the lingg lecture-roon is plaster on tile; one seizes on this only to be immediately reminded that silyles Hall in Providenec is largely lined witl wood and is bat. Curionsly enough, each suggestion is advaneed an if it alone were suffieient. As examples of remedies, mare be eited the placeng of vases about the room for the sake of resonance, wrongly supposed to hatre been the olyeet of the vases in Greck theatres, and the stretching of wires, even now a frequent though niseless deviee.

The problem is necessarily complex, and each room presents many' conditions, each of which contributes to the result in a greater or less degree areording to circumstances. To take justly into aceount these varied conditions, the solution of the problem should be quantitative, not merely qualitative: and to reach its highest usefulness it should be such that its application ean precede, not follow, the construetion of the building.

In order that hearing may be good in any anditorium, it is necessary that the somnd should be sufliciently lond; that the simultaneous eomponents of a complex sound should maintain their proper relative intensities; and that the sucessive sounds in rappilly moving articulation, either of speed or musie, should be clear and distinct. free from eacly other and from extrancous noises. These three are the necessary, as they are the entirely sufficient, conditions for good hearing. The architectural problem is, correspondingly, threefold, and in this introduetory papes an attempt will be made to sketely and define briefly the subject on this basis of classifieation. Within the three fields thus defined is comprised without execption the whole of arehitectural acousties.

1. Loudness. - Starting with the simplest conceivalble anditorium - a level and open plain, with the ground hare and hard, a single person for an andience - it is clear that the sound spreads in a hemispherieal wave diminishing in intensity as it increases in size, proportionally: If, instead of being hare, the ground is oceupied by a large audience, the sound diminishes in intensity even more rapidly, being now alssorbed. 'The upper part of the sound-wave eseapes unaffected, but the lower edge - the only part that is of service to an 
andience on a plain - is rapilly lost. The first and most olvious improvement is to raise the speaker above the level of the andience; the second is to raise the seats at the rears: and the third is to place a wall behind the speakel. 'The result is most altradively illustrated in the Creek thealre. These changes being mate, still all the somed rising at any consiclerable angle is lost through the ofening above, and only part of the speaker's efforts serve the andienes. When to this anditorimm a roof is added the arerage intensity of sound throughomt the room is greatly increased. repecially that of sustained tomes: and the infensity of sound at the front and the rear is more nearly explatized. If, in andition, galleries be constructed in order to elevate the dintant part of the andienes and bring it neatree to the fromt, we have the general form of the modern anditorim. 'The problem of ealendat ing llo londuess at diflerent parts of such an andi-

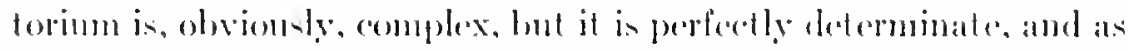

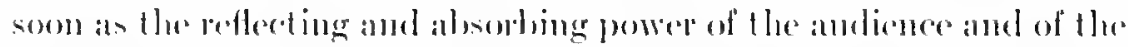
varions wall-surfaces alle knewn it atu be solved approximatedy". londer this head will he considered the affece of sounding-hoards, the

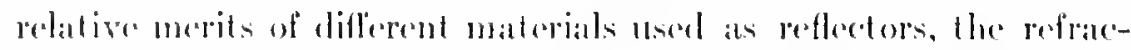
tion of somed, and the influenere of the variable temperalue of

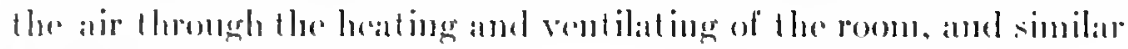
silojects.

\section{Q. Distortion of Complex Somuls: Interference and Resonence.}

In disconsing the subject of londeless the direet and refleeted soumds

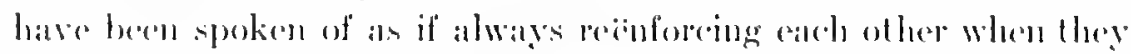

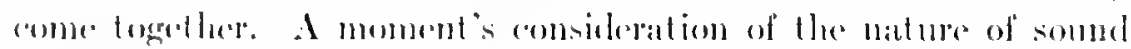
will blow that, als a mather of farel it is entirely possible for them lo

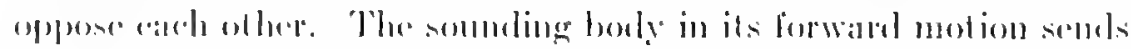

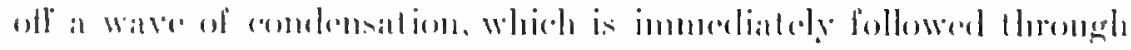

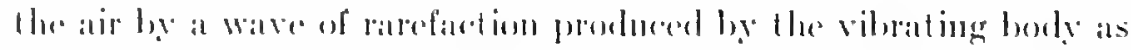

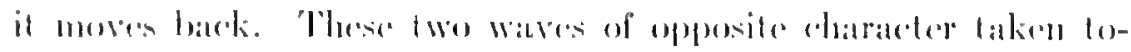

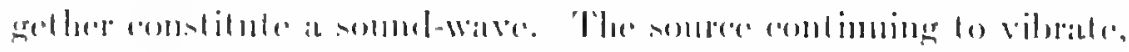

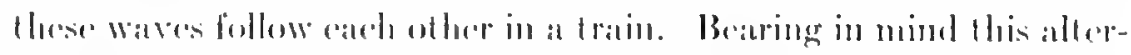

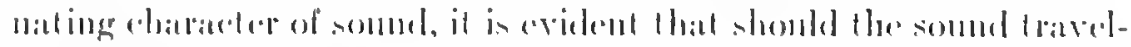

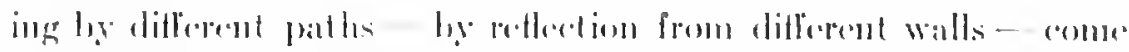

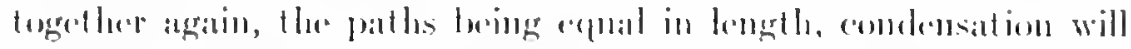

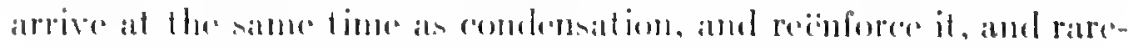


faction will, similarly, reienforen rarefaction. But should one path

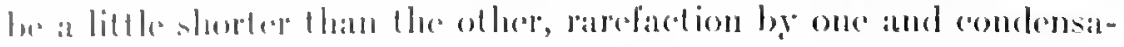
tion he Hee other maly atrive al the same time, and at this point there will be comparat ive silenee. The whole room may be mapped ont inter regions in which the sonnd is lond and regions in which it is ferble. When there are many refleceling surfices the interferenee is much more complex. When the note changes in pitch the interference sisten is antirely allered in chatrateder. A single incident will serve to illustrate this point. There is a room in the Jeflerson l'lysical baboratory, known as llae constant-fomperature room. that has been of the utmost service throughout these experiments. It is in the center of one wing of the butklings is entirely meler

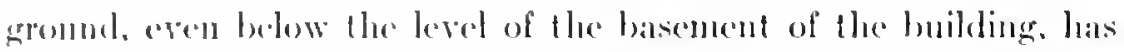
separate foumdations and double walls, atcle wall being very thick and of brick in coment. It was originally designed for investigntions in lacat recpuiring constant temperature. and its perouliar locattion and construetion were for this purpose. As it was not so in une. lowerer, it wats turned over to these experiments in sound, and at room more suitable could not be designed. From its locat ion and construction it is extremely quiet. Withont windows, its walls, Heor, and ceriling - all of solid mitonnry - are smooth and unbroken. The single door to the reom is plain and flush with the wall. The dimensions of the room are, on the floor, $4.97 \times 6.10$ melers: its height at the walls is a.jt meters, but the ceiling is slightly arehed, giving a hejght at the center of 3.17 meters. This reom is lace described at length becanse it will be frecquently referred to. particularly in this matter of interference of sound. While working in this room with a trehle $c$ gemshorn organ pipe blown by at steady wind-pressure, it was observed that the pitch of the pipe apparently (hlanged an octase when the olsserver straightened up in lis chanir from a position in whieh he was leaning forward. The "xplanation is this: 'Tlar organ pipe did not give a single pure note, lunt give a fundamental treble c aecompanied by several overtones, of which the strongest was in this case the octave above. Eaeh note in the whole complex sound had its own interference system, which, as long ats the sound remained constant, remained fixed in position. It so happened that at these two points the region of silence for one 
note coincided with the region of reinforcement in the other, and vice eerse. Thus the observer in one position heard the fundanental note. and in the other, the first overtone. The change wats exceedingly striking, and as the notes remained constant, the experiment could be tried again ant again. With a little seated it was possible to fincl other points in the room at which the same phenomenom appeared, but eqenerally in less perfecetion. The distortion of the relative intensities of the components of a chord that may thus be produced is evielent. Practically almost every sombl of the voice in sprecele and somg, and of instrumental music, event single-jart music so-called, is more or less complex, and, therelore, suljecet to this distertion. It will be necessiony, later, to show moler what circomstances this phenomenon is a formielable dangeres and how it

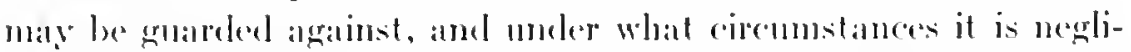
gible. It is evident from the above ocenrence that it mag be a most serious matler. for in this room two gersons sile by side cam talk together with hut little comfort, most of the difliculty being caused log the interference of sommel.

'Jhere is another phenomenon, in its ocenerences allied to interference, lunt in mature distinct - Hhe phenomenon of resonance. Buth, howerer, oceatsion the same evil - the distortion of that nice aljustment of the relative intensities of the components of the complex sommels that constifute speed and music. 'The phenomenon of interference just discussed merely alters the distribution of sound in the room, calusing the intensity ol an one pure sustaincel note to be above or below the arerage intensity at near points. Resonance, on the other hand, alters the fotal amomnt of somme in lle whole room and always incereases it. This phenomemen is noticealle at times in wing the veree in a small room, or even in

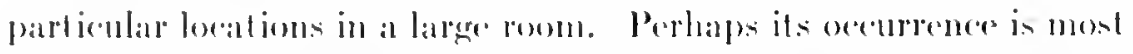

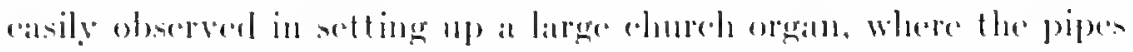

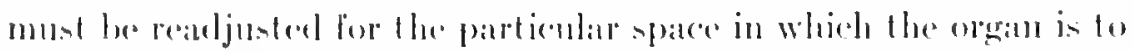

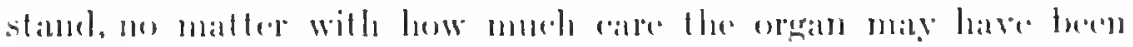

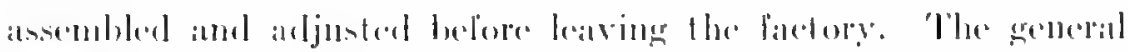

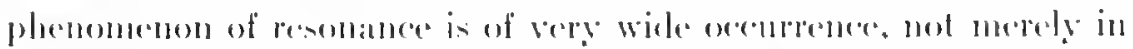

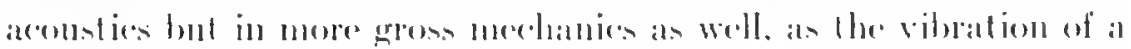

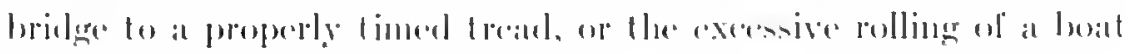


in certain seits. The principle is the same in all cases. The following conception is an eing one to gratsp, and is closely analogons to acenstical resonanese: If the palm of the hamel be placed on the center of the surface of water in a large basin or tank and quiekly depressed and ratised onee it will callse a wave to spread, which, reflected at the ergere of the water, will return, in part at least. to the hand. If, just as the wave reaches the hamd, the hand repeats its motion with the same force, it will reeinforee the wave tratreling over the witer. Thus reeinforced, the wave goes ont stronger than hefore and return, again. By contimued repetition of the motion of the lamel so timed as to rearuforce the wave as it returns, the wave gets to be very strong. Insteat of restraining the hand each time until the wave traveling to and fro returns to it, one may so time the motion of the hamd as to have several expal waves following each of her orer the water, and the hand each time reënforeing the ware that is passing. 'This, obvionsly, can be done by dividling the interval of time between the suecessive mot ions of the hand by any whole number whatever, and moving the hand with the frecpuency thus defined. The result will be a strong reënforcement of the waves. If, howerer, the motions of the hand be not so timed, it is obvious that the reeinforeement will not be perfect, and, in fact, it is possible to so time it as exactly to oppose the returning waves. The applieation of this reasoning to the phenomenon of souml. where the air takes the place of the water and the sounding body that of the hand, needs little adelitional explanation. Some notes of a complex somel are recinforeed. some are not, and thus the quality is altered. This phenomenon enters in two forms in the architectural problem: there may be either resonance of the air in the room or resonance of the walls, and the two cases must receive separate discussion; their eflects are totally" different.

The word "resintinee" hats been used loosely as synonymous with "reverheration," and even with "echo," and is so given in nome of the more voluminous lut less exact popular dictionaries. In scientific literature the term has received a very definite and preciere alpulieation to the phenomenon, wherever it may occur, of the growth of a vibratory motion of an elastic boty mder periodic forees timed to its natural rates of vibration. A word having this 
significance is necessary: and it is very desirable that the ferm should not, even popularly, hy meaning many things, cease to mean anything exactly.

3. Confusion: Reterberation, Echo and listraneons Sounds.- Sound, being energy, once produced in a confined space, will eontinue until it is either tramsmitted ly the boundiry walls, or is transformed into some other kind of energy, generally heat. 'This process of decay is called absorption. 'Thus, in the lecture-room of Harvard University, in which. and in behalf of which, this investigation was begum, the rate of alssorption wass so small that al word spoken in an ordinary tone of voice was aludithe for five and a half seconds afterwards. During this time cren a very deliberate speaker woukl have utlered the fwelve or fifteen sueceeding sillatbles. 'Thus the suceessive conurciations bended into a loud sound, through which and alhove which it was necessitry to hear and distinguish the orderly progeresion of the speech. Arross the room this conld not be done; even neitr the speaker it conld be done only with an eflort weatrisone in the extrene if long maintamed. With an andience filling the roon the conditions were not so bad, but still not folerahte. This mily be regarded, if one so chooses, ats a process of multiple reflection from walls, from ceiling and from floor, first from one and then another, lesing a little at each reflection until ullinately inamelible. This phememenom will be called re-

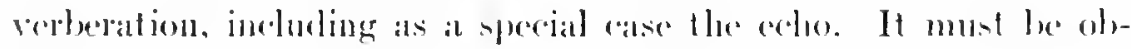
served, howerer. that, in gemeral, pererberation results in a matss of somed filling the whole room and incalgalde of analysis into its dis-

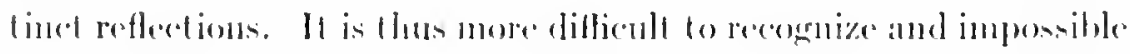

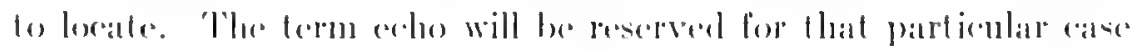

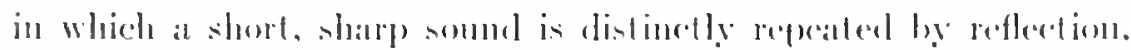

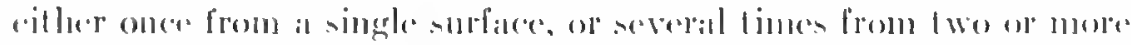

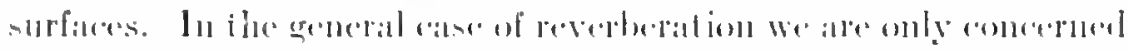

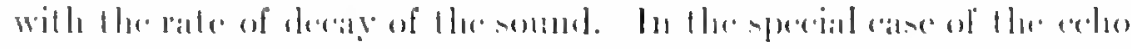

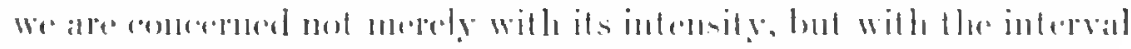

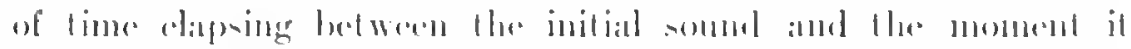

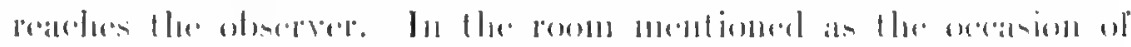

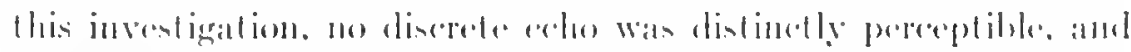

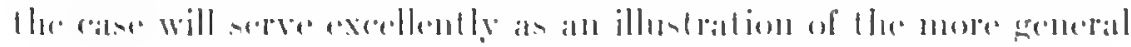




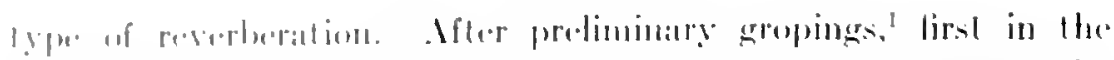

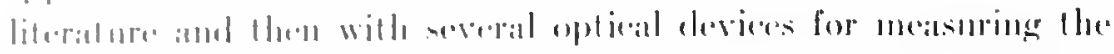

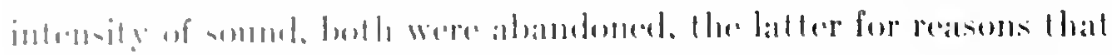

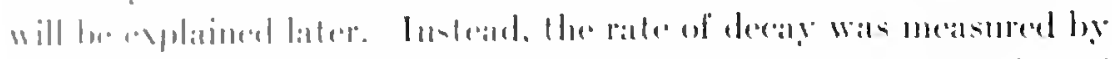
mantring what was inversely proportional lo it - the duration of

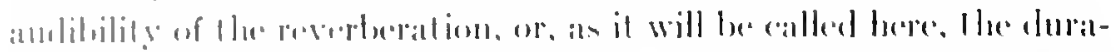

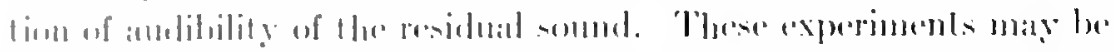

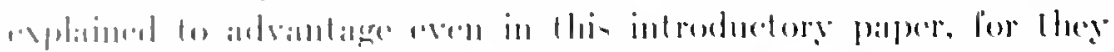

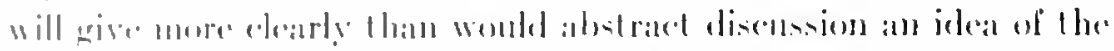

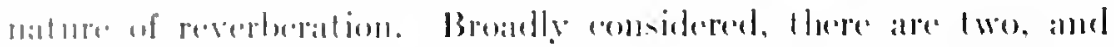

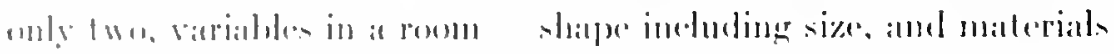

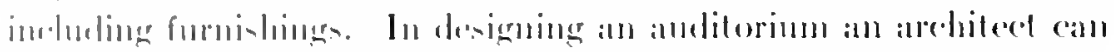

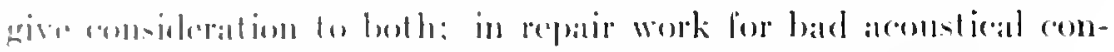

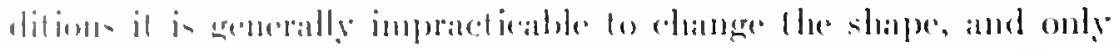
vatriatind in malerials and furnishings are allowable. This was, therefore. Hhe line of work in this cases. It was evident that, othere

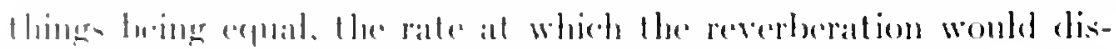
apperate was proportional to the rate at which the somml was ahstrherl. "The firs work, therefore, was lo determine the relative

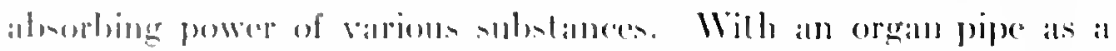

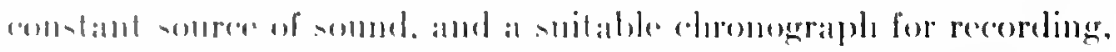

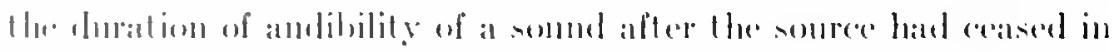

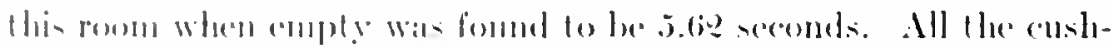

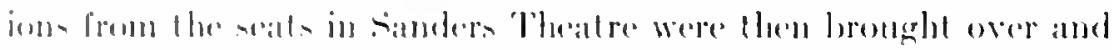

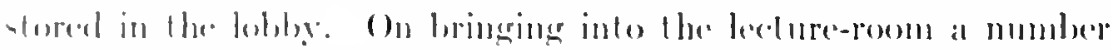

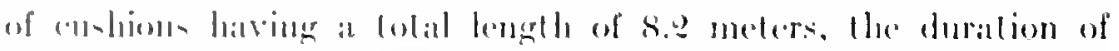

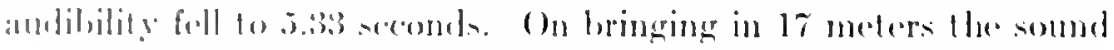

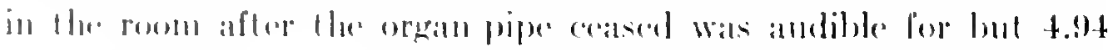

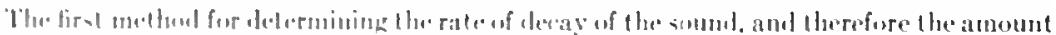

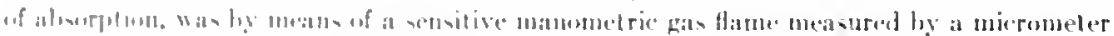

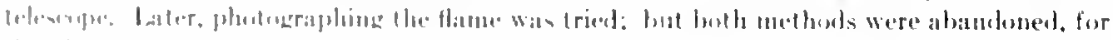

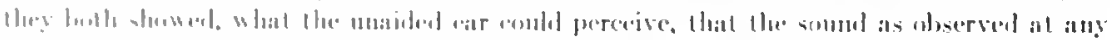

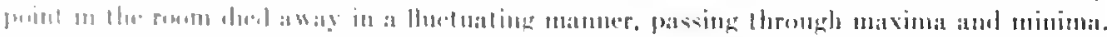

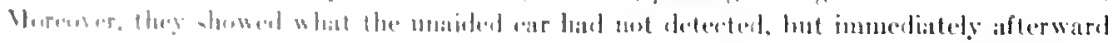

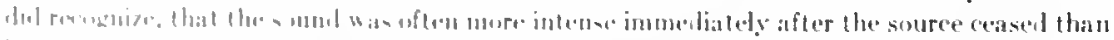

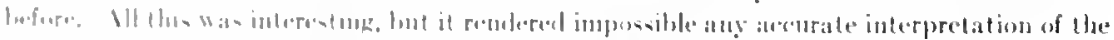

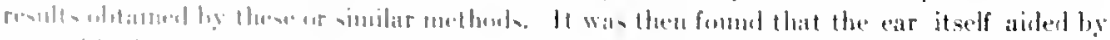

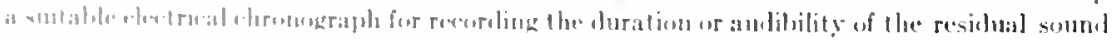

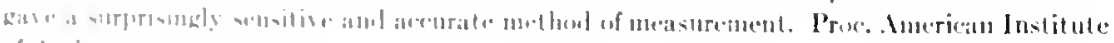

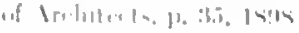


secomds. Evidently, the cushions were strong atsorbents and rapidly improving the room, at least to the extent of diminishing the reverteration. 'The result was interenting and the precess wats continued. Little by little the eushions were bronght into the room, and carch time the doration of amblithility was measured. Whene all the seats (4.36 in number) were covered, the sommel wats aludible for Q.033 seconds. Thlen the aisles were covered, and then the plat lorm. Still there were more colstrions - almost half as many more. Threse were brouglat inlo the room, a few at a time, as belore, and drajped on a saffolding that hatd been ereeded around the room. the daration of the sound being recorded eacle time. Finally, when all the colshions from at theatre seat ing nearly filtern hume leed persoms were placed in the room - covering the sats. the aisles. the plat form. the rear wall to the ceiling - the duration of andilility of the residllal sound wals $1.1+$ secomds. This experiment, requiring of course. several nights" work, having been completed, all the cushions were removed and the room was in realiness for the test of other absorteents. It was evident that a standated of comparison had been established. Curtains of eluenille. 1.1 meters wide and 18 meters in total length, were draperl in the poom. The duration of anditility

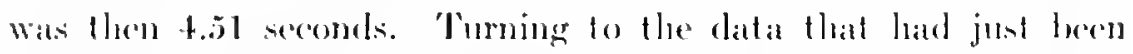
collected it apperared that this amount of chenille was equivalent to 30 meters of Sinders 'Theatre cuslions. Oriental rugs, Herez, Demirjik, and Jlindoostance, were fested in a similan mamers: as were also cretome doth, anvas, and hair felt. Similar experiments, but in at smaller room, determined the alsorting power of a man and of a womban, alway's by determining the mumber of running meters of simders 'Theat re els shions that would produce the

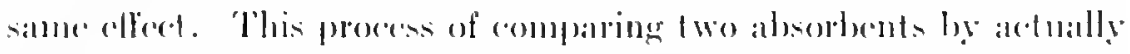

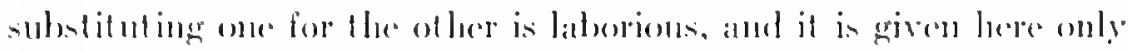

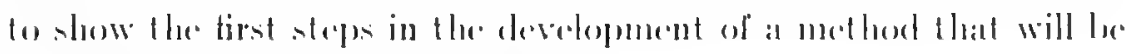
expanded in the following papers.

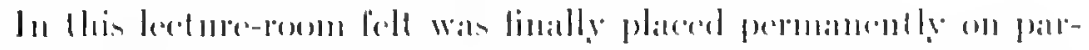

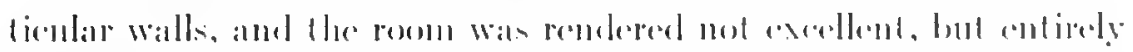

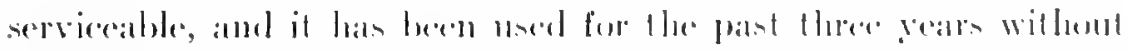

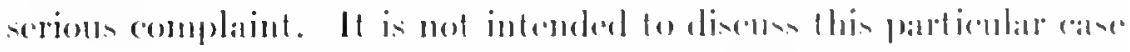

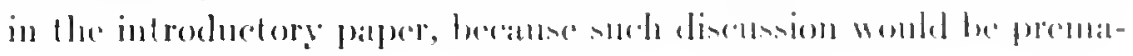




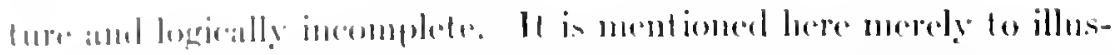

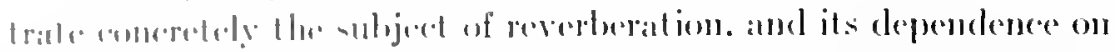
aberpulion. If would le at mistake lo suppose that all absorbent is

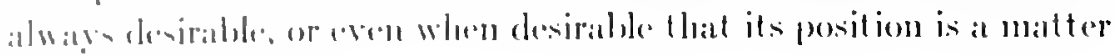
of 110 (10)

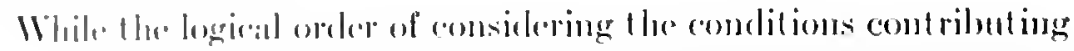
tore introfering with distind hearing would he that employed above.

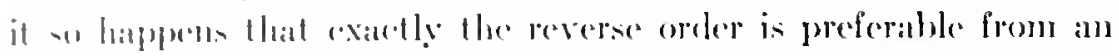

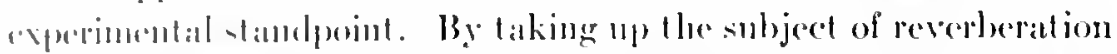
timt it is ponsible on determine the coefticients of absorption and

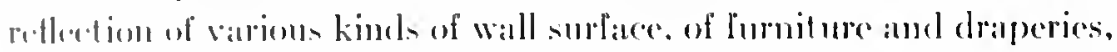
and of an andience. The inbestigation of reverberation is now. after firc years of experimental work, completed. and an account will be remelered in the following bateres. Some data have also been secenred on the other topjes and will be published as soon ats rounded into detinitis form.

This patper maty be regarded as introductory to the general subjecet of anchitertural acousties. and immediately introductory to a series of atrticles dealling with the sulject of reverberation, in which the general line of procedure will be, briefly, as follows: 'The alsorbing power of wall-strlates will be determined. and the law aceording ta whicla the reverberation of a room depends on its volme will be remomatrated. The atsolute rate of deray of the residual somel in a mumber of rooms, and in the same room muler different eonditions, will then be determined. In the fiftl patper a more exact analysis

\footnotetext{
1 There is uo simple treatment that an cure all cases. "There may be inalequate alsorption

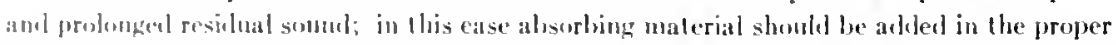

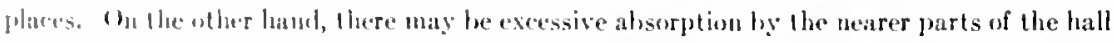
and by the marer andience and the sound may un penel rate to the greater distanees. Oh. vinnals the treatment should not be the same. There is such a room belonging to the Ini-

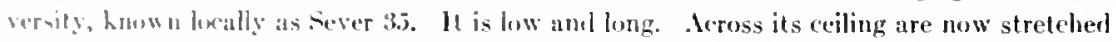
humbruls of wires amd many yards of coth. The furmer has the merit of being harmless, the

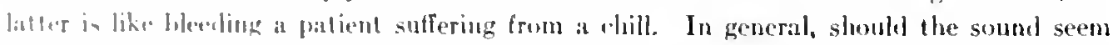

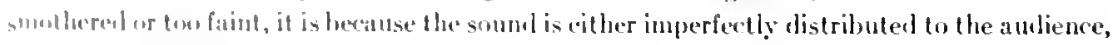
w in bus in wase blaces. The first may oreur in at very low and long rowm, the second in one whth sergy high ceiling. The first can be remedied only slightly at best, the latter ean be improwes hy the use of reflecturs behind and alwwe the speaker. On the other hand, should the

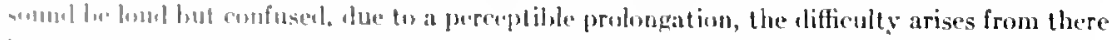

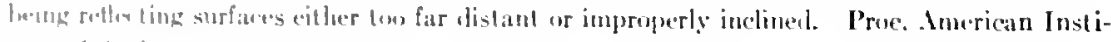

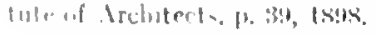


will be given, and it will be shown that. ly very different lines of attack, starting from different datil, the same numerical results are secorrel. Tables will be given of the absorbing power of varions Wall-surfices, of furniture, of an andience, and of all the materials ordinarily fomnd in any quantity in an anditorimm. Finally, in illustration of the calculation of exerberation in advance of construction, will be cited the new Bosten Music Hall, the most interesting calse that hats arisen.

\section{ABSORBINO POWER OF WALLSIRFACE}

Ix the introductory article the prohlem was divided into considerattions of lomblness, of distortion, and of confusion of somds. Confusion mily alrise from extraneous distumbing somnds - street moises and the noise of ventilating fans - or from the prolongation of the otherwise discrete sounds of muse or the voies into the succeeding sommls. The latter phomemenom, known as reverberation, results in what may" be called, with alecuracy and suggestiveness, residual somed. The duration of this residnal soment wats shown to depend on the almomint of absorbing material inside the room, and also, of contre, on thes absorbing and transmitting power of the walls; and at method was ontlined for determining the absording power of the former in terms of the ahsorbing power of some material chosen ans a standared and used in a prelininary calibrattion. A moment's consideration demonstrates that this method, which is of the general type known as a "substitution method," while ellective in the delermination of the absorbing power of forniture and corrective material, and, in general, of anything that can be brought into or remoxed from at room, is insullicient for determinating the absorts-

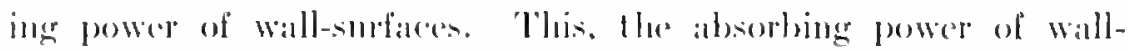
surfaces, is the suljecet of the present palper: and as the method of detremination is an extemsion of the above worke and linds its justification in the striking consistaney of the result of the oberrations.

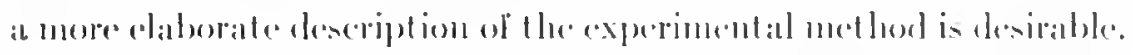

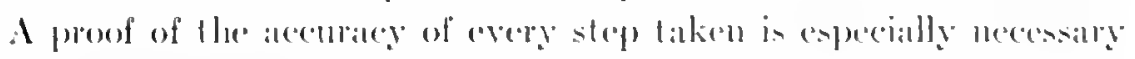

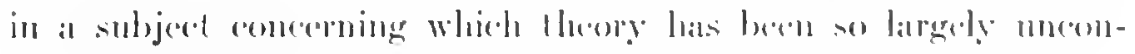
trolled sperentation. 
liarle in the imsentigation it was fommd that measmrements of

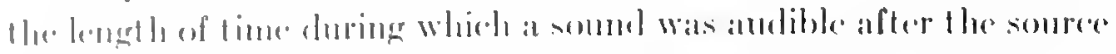

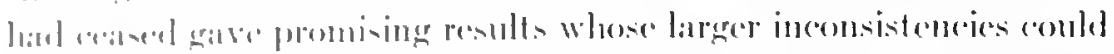

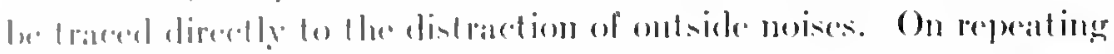

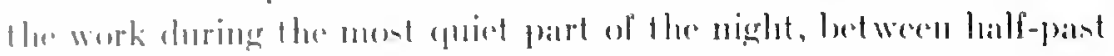

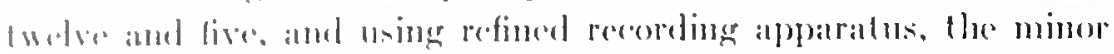
irregularitien. dere to redaxed attention or of her personal variations.

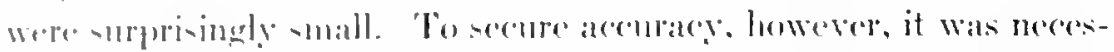

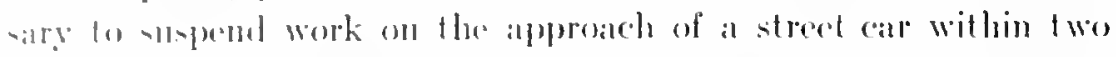
block- of on the paseng of a train a mile distant. In Cambridge these intermptions were not scrioms: in Boston and in Nerv lork

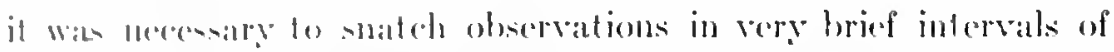
quiet. In erery ane a single determination of the duration of the

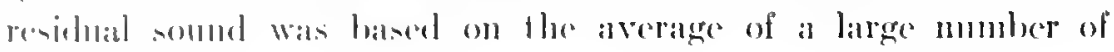
ohurvitions.

In organ pipe, of the gemshorn stop, an octave albove middle $c$

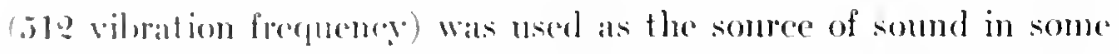
preliminary experiments, amd has been retained in sulsecpuent work

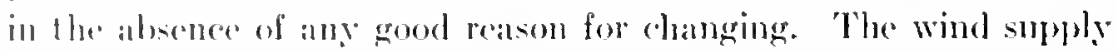

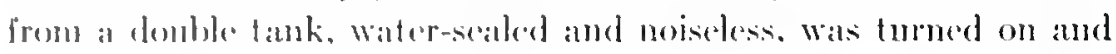
oll the organ pipe hạ an alectro-pnemmatic valve, desigmed by Mr.

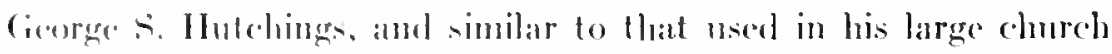
organs. The elextric corrent controlling the valve also controlled the chromegratph. and was made and hroken by a key in the hands of the oherever from any" part of the reom. 'The chronograph emphereel in the lalere experiments, after the more nsual patterns had been fried and discapded. Was of special design. and answered wedl the recpuirements of the work - porferel moliselessness. portability. and capalcity to meatolure iutervals of time from a half second to tem recomels with eomsiderable arecurarey. It is shown in the adjacont diagram. The corrent whose cessition stopped the sounding of the orgatn pipe aloc gave the initial record on the chronograph, and the mbly duty of the olserver was to make the record when the somed (ralaed lo he andible.

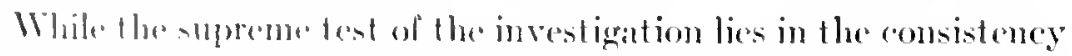
and sinnplicitg of the whole solution as outlined later, three preliminary ariteriat are found in (1) the agreement of the olsservations 
obtained at one sitling, (2) the angreement of the mesults oltained on different nights and after the lapse of montlss, or even years, by the same ohserver under similat conditions, and (3) the agreenent of indepement determinations by ditferent observers. The first (an best be discussed, of course, by the recognazed plysical methods for examining the arenracy of an extended series of observations;

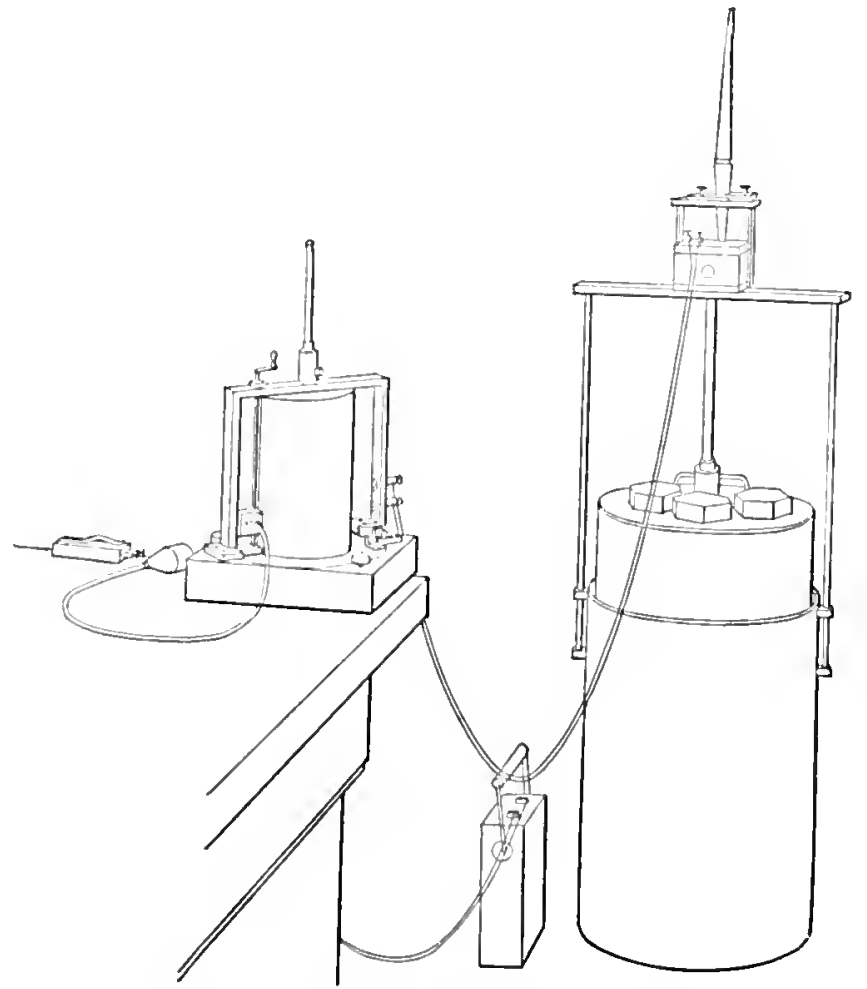

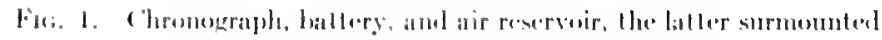

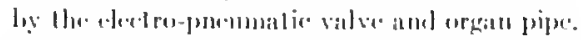

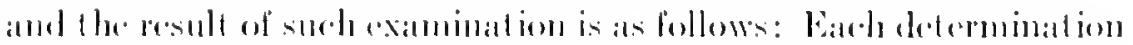

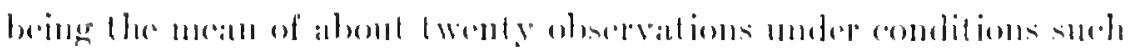

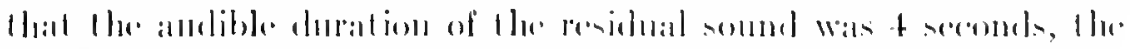

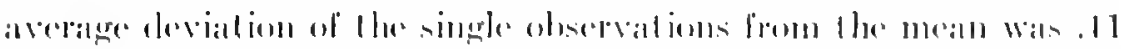

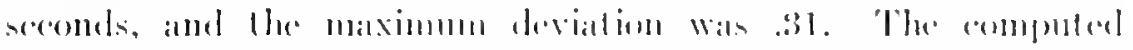

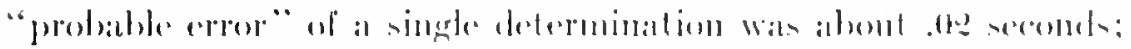

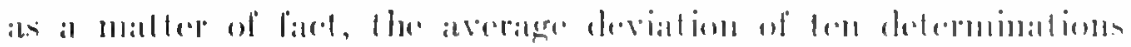

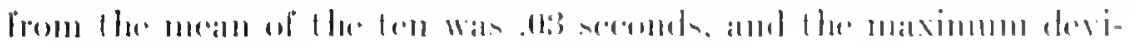




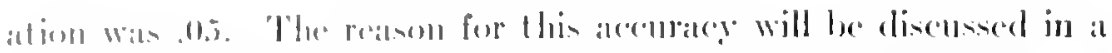

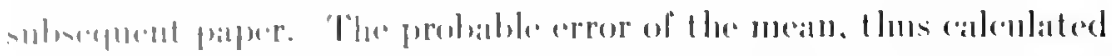

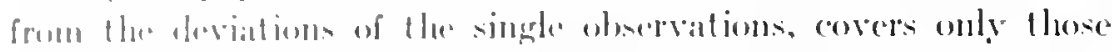

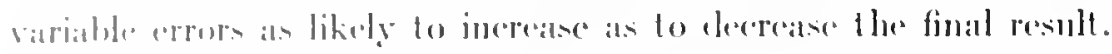
fived instrumental errors, and the comstant crrors commonle re-

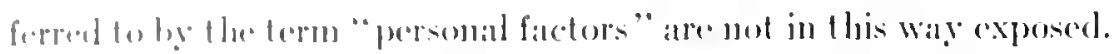
"l'her were, hemerer. repulatle lested for by comparison with a wheh lesiling secomls, and wore very satisfactorily shown not to

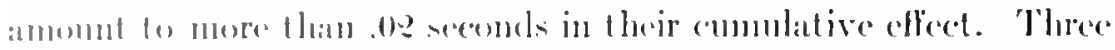

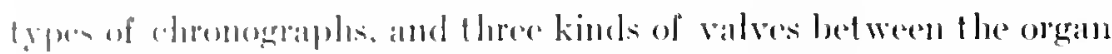

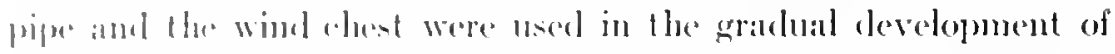

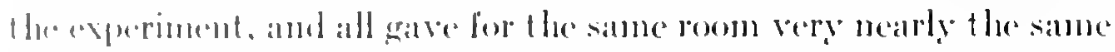

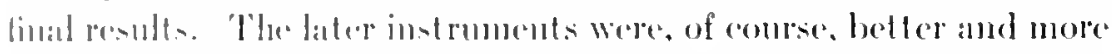
ilcroritile.

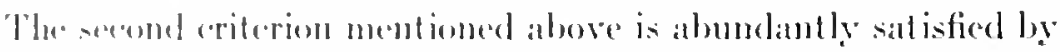
the averiments. OHscrvations taken every second or thisd night for two menthe in the leceture-room of the Fogg Art Museum gave

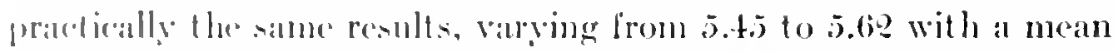

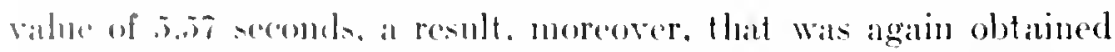
after the lapere of one and then of three years. Equally satisfactory agreement was obtained at thre beginning and at the culd of three years in simders 'lluetre, and in the constant-temperature room

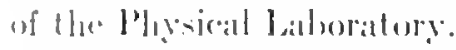

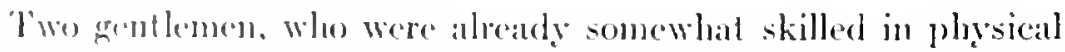
observation. Mr. (iillord J a (Cloar and Mr. E. I). Densmore, gave the necenary time to lent the third point. After several nights fractice their result dillered but slightly, being os seconds and .10 seconds lomerer than those olstined ly the writer, the total duration of the somnd lecing 4 seconds. This agrecment, showing that the results are probably very nealy those that would be obfaned hy any auditor of normal hearing. gives to them additional interest. It sbould be stated. however, that the final development of the subject will adapt it with perfect generality to cither normal ur alomormal acenterless of hearing.

Nhow the first step in the inventigation was to establish the following three fundimentally important facts. Later work has

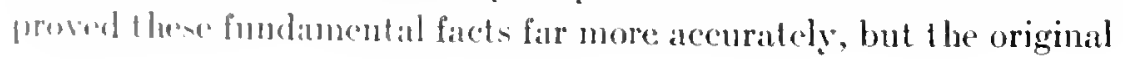


experinests are here given as being those upon which the conchlusions were based.

The duration of audibility of the residual sound is nearly the same in all parts of an auditorium. - Early in the investigation an c $\mathrm{x}$ periment to test this point was made in Steinert Hall, in Boston. 'The sonree of sound remaining on the platform at the point narked
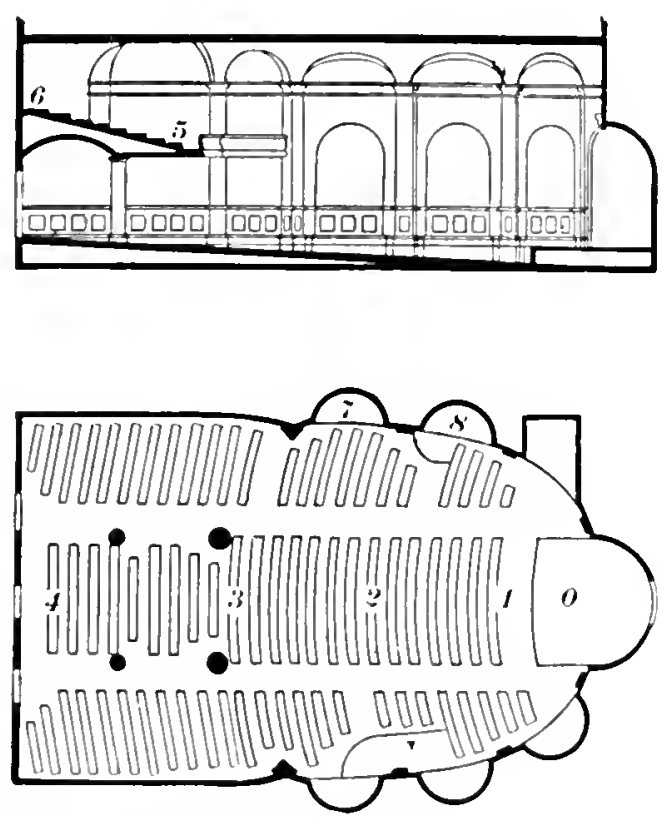

Pui. 2. Steimert llall, Buston: position of air reservoir and organ pipe at "): positions of observer $1-s$.

$O$ in the diagran, observations were made in suceession at the points mathed 1 to 8 , with the results shown in the table:

\begin{tabular}{|c|c|c|c|}
\hline Station & Dutution & Station & Duration \\
\hline 1 & 9.1 & i. & 9.83 \\
\hline $\mathcal{Q}$ & 2.17 & 6. & . 9.97 \\
\hline 3. & . 9.83 & $\tau$ & , …ㄴ1 \\
\hline 4. & . 2.211 & s. & $\therefore \geq 3(i$ \\
\hline
\end{tabular}

On first inspection these results secon fo indieate that the deration of andihility is very sligluly greater at a distance from the source.

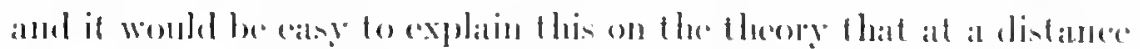

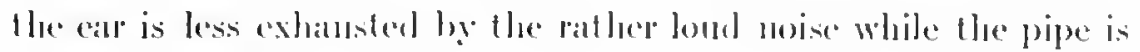

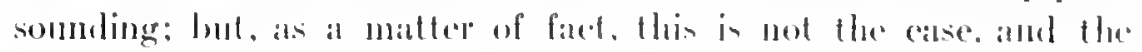




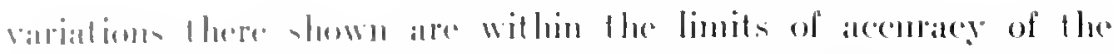

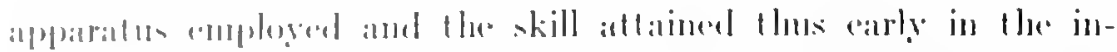

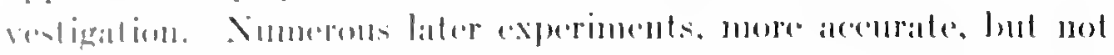

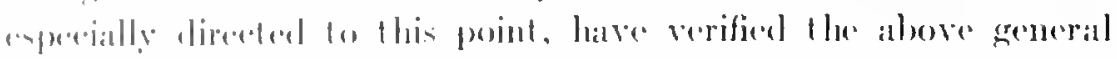

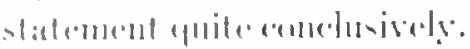

The duration of andibility is nearly independent of the position of

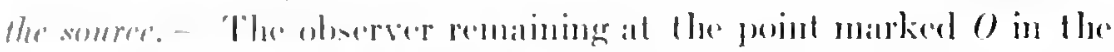
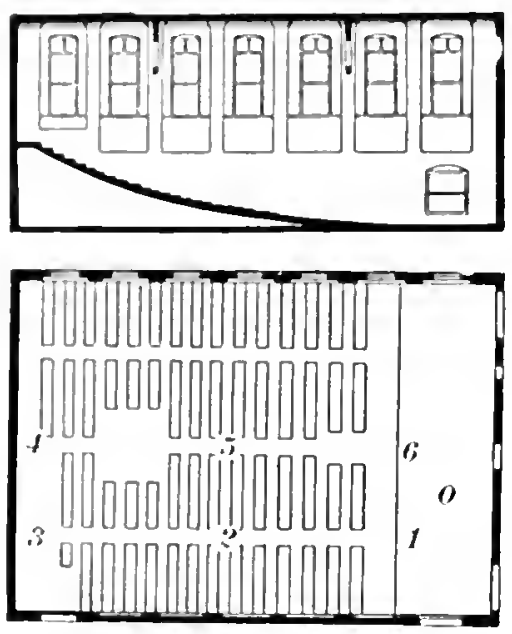

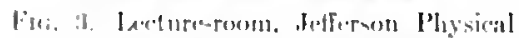
lableralory: ponilion of ohsarver al 0 :

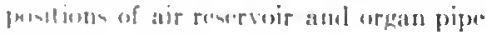
$1 \mathrm{ii}$.

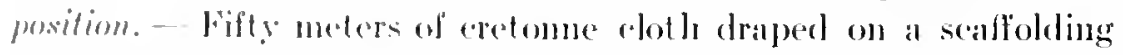
maler the pallue low coiling at the biek of the lecture-room of thre fouge Mnsemm, as shown in the next diagram, reduced the amdilule duration of the residual somel by rery nearly the same amonnt, regurdlens of the section in which it hung, as slown in the following table, the initial duration heing 5.57 seconds:

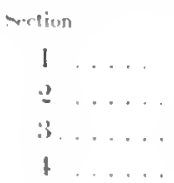

In -ome bater aprepinents five and a balf times as much cretomne

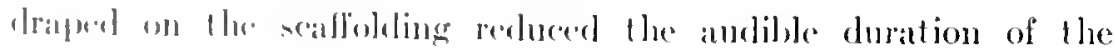


residual sound to 3.85 seconds; and when hung fully exposed in the high dome-like coiling, gare 8.99 seconds, confirming the albove statement.

These facts, simple when proved, were by no means self-evident so tong as the problem was one of reverberation, that is, of suleces. sive reflection of sound from wall to wall. They indicated that, at least with reference to amelitorimus of not too great dimensions, another point of view would be more suggestive, that of regarding the whole ats an colergy" problem in which the sontere is at the organ pipe and the decay at the walls and at the contained al sombling material. The above results, then, all point to the evident, but perhaps not appreciated, facet that the dispersion of somel between all parts of a hall is very rapid in comparison with the total tinne recurired for its complete alsorption, and that in a very short time after the sonure has ceased the intensity of the residual somend, exeept for the phenomanon of interference to le considered later, is very nearly the silme crevywhere in the room.

This much being determined. the investigation was eontimued in the fol-

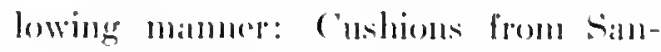
dars theatre were tramserred to the

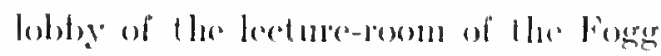
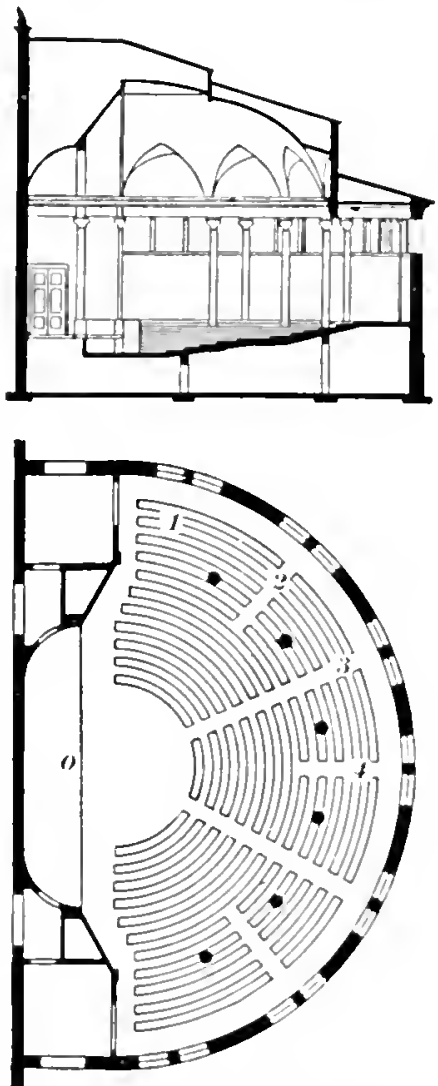

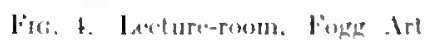
Muselum: pasition of olmerver ant (); ponitions of aluorlueul at I 1. and in the dunte.

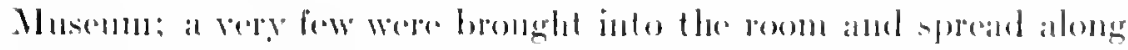
the fromt row of seats: the duration of and libility of the resilual

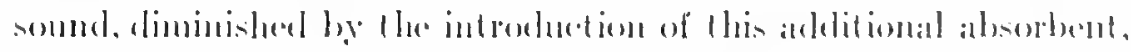

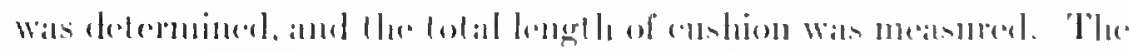

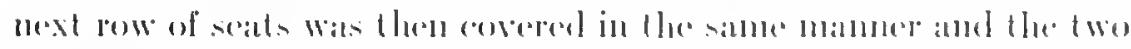

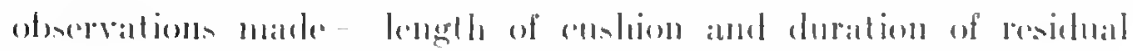




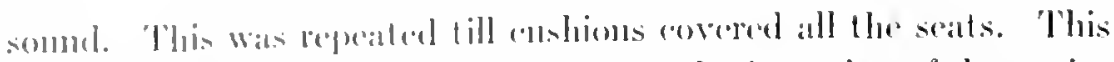
work was at first undertaken solely with the intention of determin-

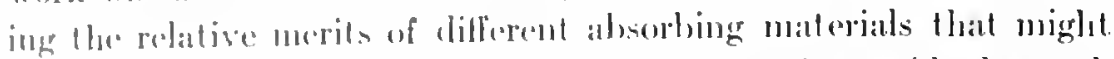

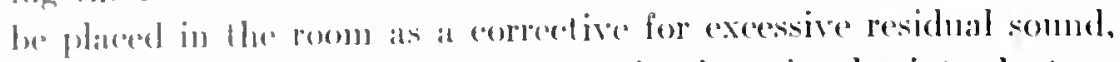
and the ancentut of this appliation is given in the introductory

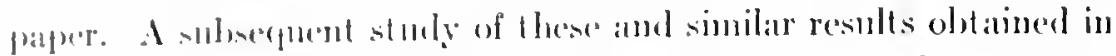
many other roomo has shown their applicability to the acenrate deternination of the alsoblhing power of wall-surfaces. 'This appliattion may he slown in a purey analytical mamer, but the exposition is greatly lacheol by a graphical representation. The manner in which the duration of the residual sound in the Fogg lectureroom is dependent on the amomnt of absorhing material present is - hown in the following tahle:

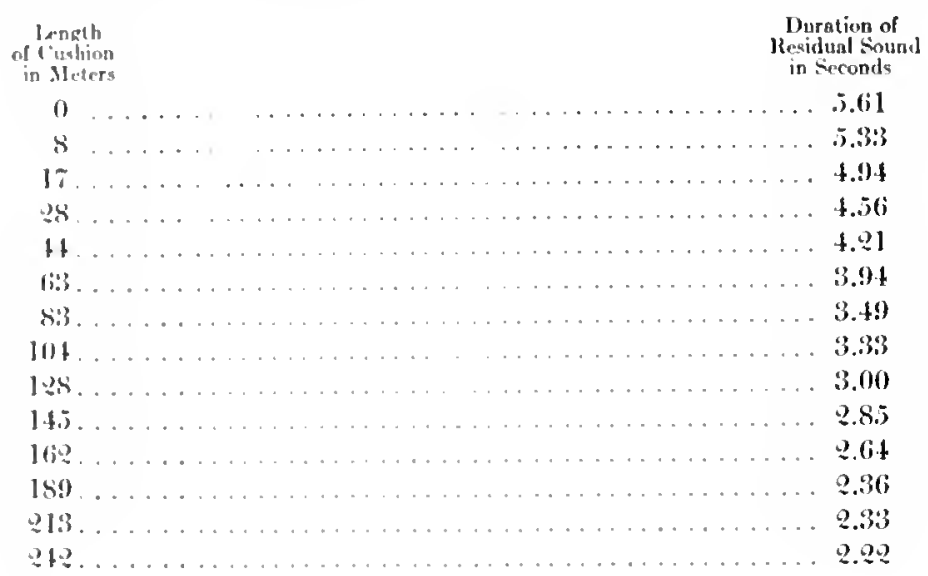

'This table, repuesented graphlically in the conventional mannerlength of enshion plotted horizontally and duration of sound vertically - grives points through which the curve may be drawn in the acempanving diagran. 'Ho discover the law from this curve we represent the lengthe of cushion by $x$, and the corresponding duralions of somul, the vertical distances to the curve, by $t$. If we now seok the Formula comnecting $x$ and $t$ that most nearly expresses the

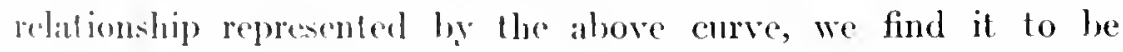
$\left(a+x^{2}\right) l=k$, which is the familiar formula of a rectangular hyperbola witl its origin dispheed along 1 lac axis of $x$, one of its asymplotes, by an anomnt a. 'To make this formula most closely fit our 
curve we must, in this case, give to the constant, a, the numerical value, 146, and to $k$ the value, 813 . The accuracy with which the formula represents the curve may be seen by comparing the durations calculated by the formula with these determined from the curve; they nowhere difler by more than .0t of at second, and have, on an average, a difference of only .0 0 of a second. This is entirely satisfactory, for the calculated points fall off from the curve by scarcely the hreadth of the pen point with wheh it was drawn.

The determination of the absorbing power of the wall-surface depends on the interpretation of the constint, $a$. In the formula,

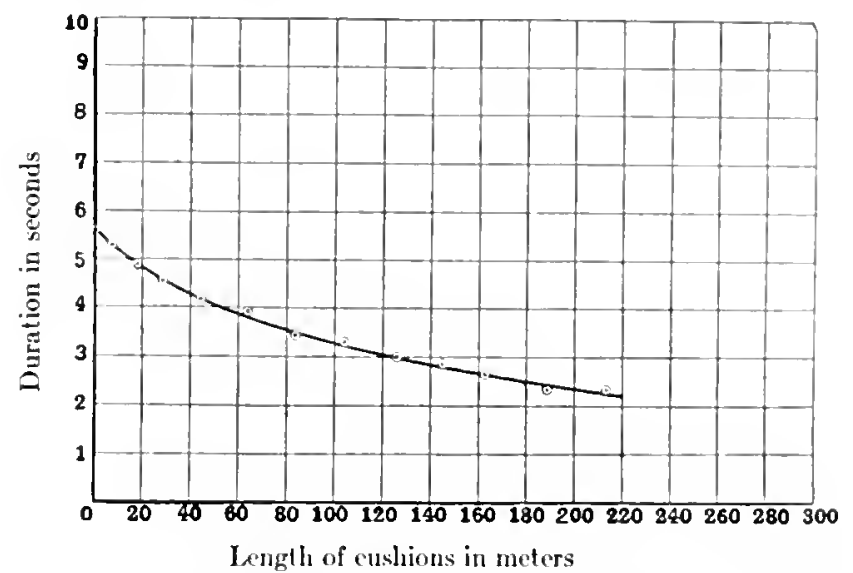

Fis. .j. Curve showing the ralation of the duration of the residual sound to the added absorbing material.

the position of a, indieating that $x$ is to be added to it, suggeents that $x$ and $a$ are of a like nature, and that $a$ is a measure of the absorling power of the bare room; in order to determine the curve this was increated by the introduction of the enshions. This is exen better shown hy the diagram in which the portion of the curve experimentally determined is fittert into the curve ats a whole. ilnd a and $x$ are indicated. Thuss, the abuorbing power of the roomthe walls, partly plaster on stone, partly plister on wire lith. Hhe

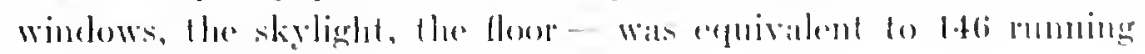
meters of simelers Thentre cushlions.

The last statement shows the neensity for lwo subsielialry inrestigations. 'The first, to axperes the results in some more permat-

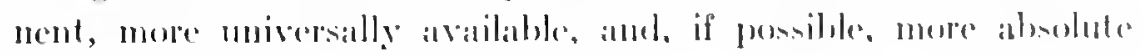




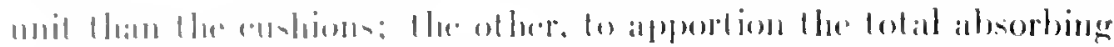

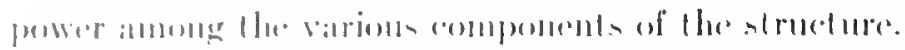

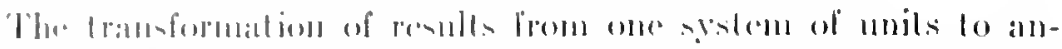

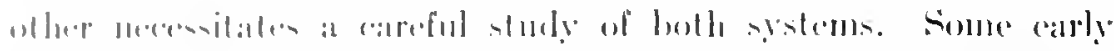

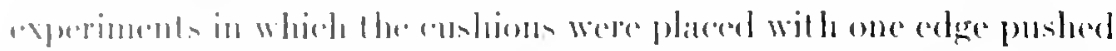

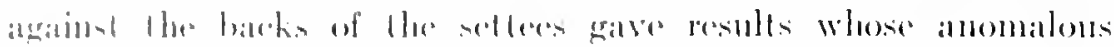

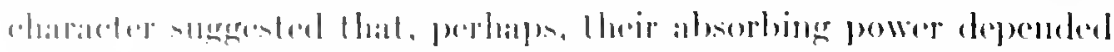

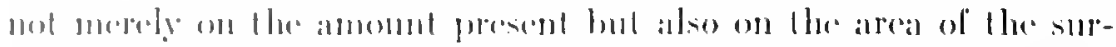

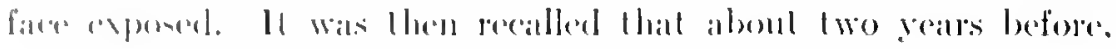

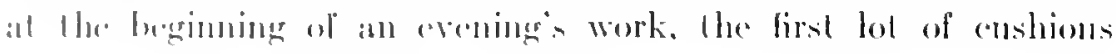

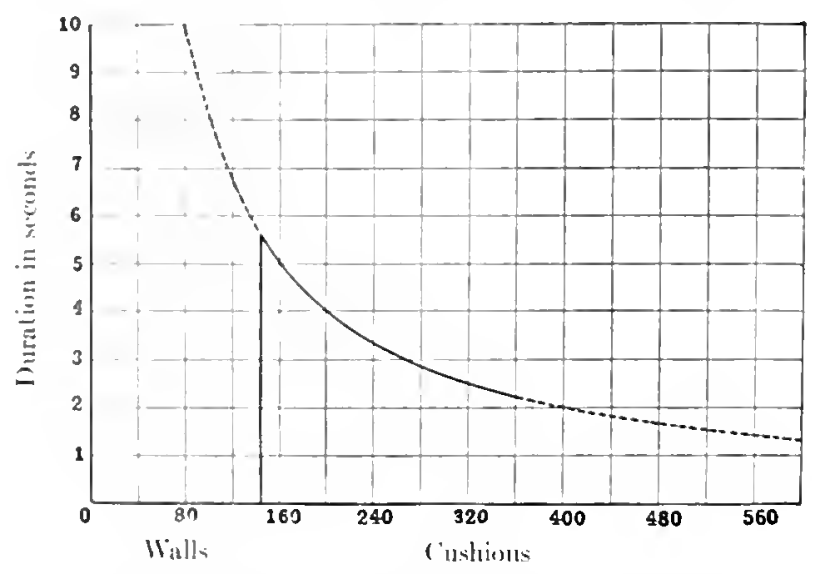

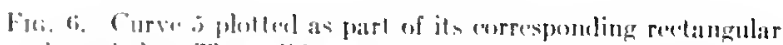
hypertwh. 'l'he solit part was eletermined experimentally; tha dioplacentent of this to the right measures lhe absorbing puser of the walls of the romm.

bromght inte tla room were placed on the floos, side by side, with

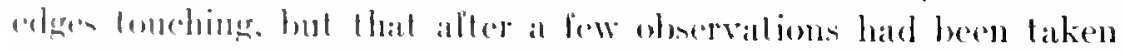
1he colliem were scattered about the room, and the work was repreated. Ththis was done mol at all to uncover the edgess, but in

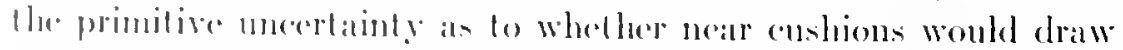

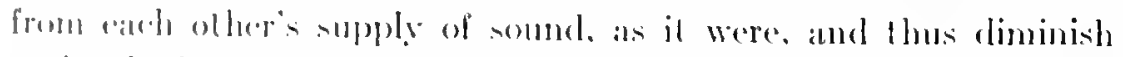

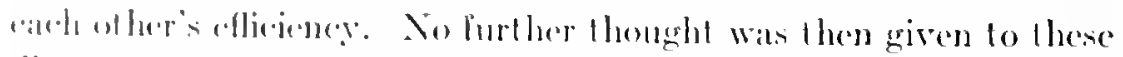

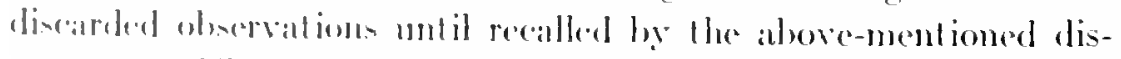

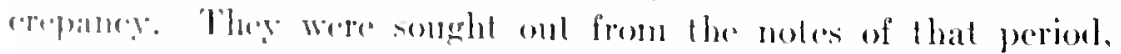

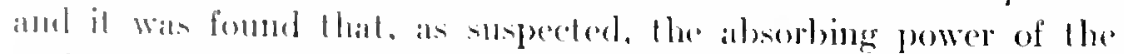

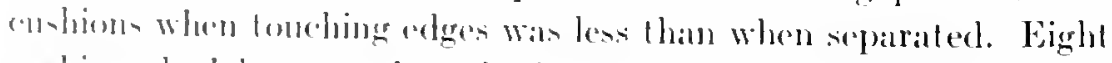

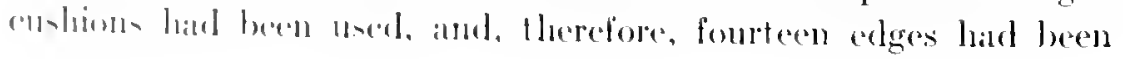


louching. A record was found of the length and the breadth of the enshions used, ande assuming that the absorbing power was proportional to the area exposed, it wats possible to calculate their llickness by comparing lle andible duration of the residual sound in the two sets of observations; it was thes calculated to be $7 . t$ centimeters. On stacking up the same (ushions and measuring thejp total thickness, the aredage thickness was found to be f.g contimeters, in very dose argrement with the thickness estimated from their absorption of souml. Therefore. the measurements of the enshions should be, not in rumning meders of cushion, lunt in square meters of exposed surfices.

For the purposes of the present investigntion. it is wholly unnecessary to distinguish between the transformation of the encregs of the sound into heal and its transmision into ontside space. Both shall be called absorption. The former is the special atecomplishment of cushions. the latter of open windows. It is obvions, Inwever, that if both comshoms and windows are to be classed ats abserlents, the open window, becallse the more universally accessible and the more permanent, is the betler unit. 'The cushions, on the ofleer landel, are by lar the more convenient in practice, for it is possible only on very rare oceasions lo work accurately with the windows open, not at all in smmmer on account of night noisesthe nevise of erickels and other insects - and in the winter only when there is but the slightest wind; and further, but few rooms have suflicient window surface to produes the desired alsorption. It is necessary, llerefore, to work will culligun, but to express the results in open-window mils.

Turning now to the wnit into which the results are to be transformed, an esperially quiet winter nierht was taken to determine whether the absorbing power of open windows is proportional to

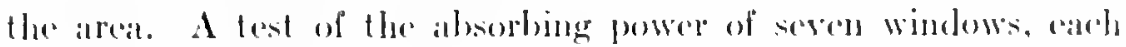
1.10 meters wide, when opened so, .t0, and so meter, gave results that atre plotted in the diagram. 'The points, lye falling in at saight lince, stom that, at least for moledate breadthe, the absorbing

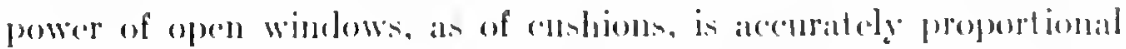

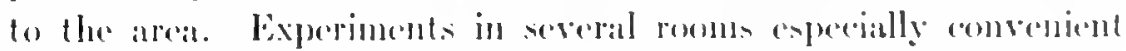
for the purpose determined the alborbing powere of the enshioms to 
lue sil of that of an enpal areas of open wimelows. These cushions were of harir, onverenl with canvas and light damask. "Elastic

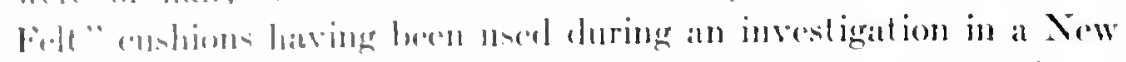

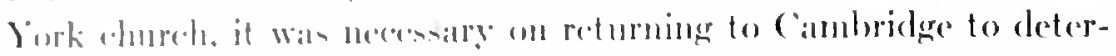

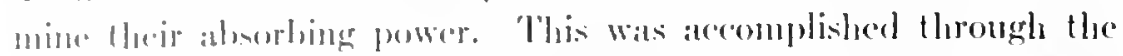
courlenge of the manufacturers, Messes. Sperry \& Beale, of Xew

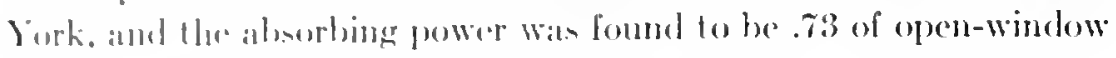

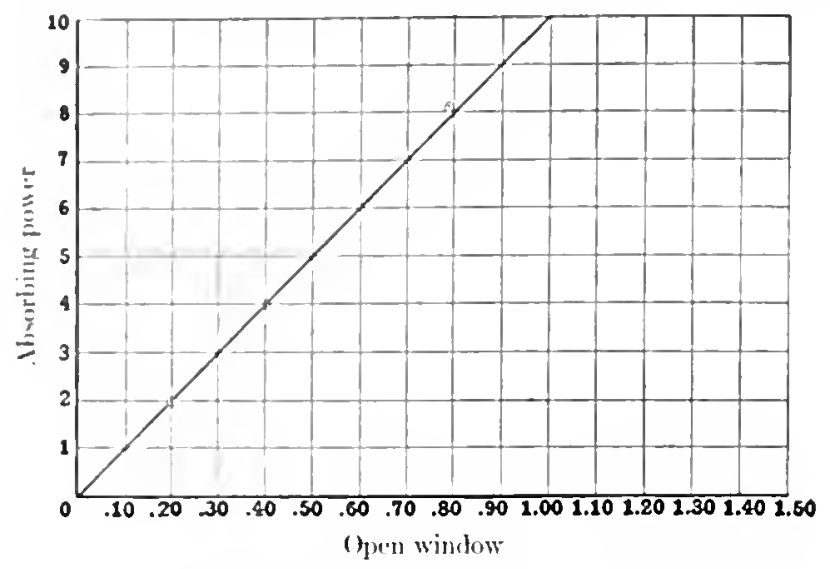

Fir. 7. The aborbing pouser of open windows plotted against the areas of the openings, showing them to be proportional.

units - an interesting figure, since these cushions are of frecuent une and of standarel rataracter.

Hercafter all reaults, though ordinarily obtained hy means of enshions, will be axpessed in terms of the albsorbing power of open wimlows a mut as permanent, universally accessible, and as morly absolute as possible. In these units the total absorbing power of the walls. coiling, floor. windows and chairs in the leeturerocun of the Fonger Muarum is 7.5.5.

Siext in order is the apportiomment of the total absorbing power anomg the varions components of the structure. Iet $s_{1}$ be the area of the plaster on tile. and $a_{1}$ its absorbing power per square meter; $s_{2}$ and $a_{2}$ the corresponding values for the plaster on wire lath; $s_{3}$ and a for window surface, ete. 'Then

$$
a_{1} x_{1}+a_{2} s_{2}+a_{3} s_{3}+a_{4} s_{4} \text { etc. }=75.5,
$$

$s_{1}, s_{2}, s_{3}$, ctc., are known, and $a_{1}, a_{2}, a_{3}$, etc. - the eocffieients of aborption - are mbinown, and are being sought. Similar equa- 
tions may be obtained for other rooms in whicla the proportions of wall-surface of the various kinds are greally different, until there are as many equations ats there ane unknown quantities. It is then possible by alimination to eletermine the alsorbing power of the varions materials used in construction.

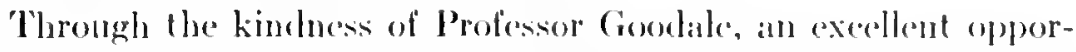
tumity for securing some fumdamentally interesting diatid was afforded by the new Botanical Laboratory and Greenhouse recently given to the Iniversity. These rooms - the oflice, the laboral ory and the greenhouse - were exchsively finished in hard-pine sheat lying. gliss, and cement; the three rooms, fortunately, combined the three materials in very different proportions. They and the constant-temperature room in the lhysical Laboratory - the latter being almost wholly of briek and cement - gatre the following diatia:

\begin{tabular}{|c|c|c|c|c|}
\hline & $\begin{array}{l}\text { Ares of } \\
\text { Jiard l'ine } \\
\text { sheathing }\end{array}$ & Area of Cilass & $\begin{array}{l}\text { Irea ol Brick } \\
\text { and Cement }\end{array}$ & $\begin{array}{l}\text { Combined } \\
\text { llisorbing } \\
\text { Ponwer }\end{array}$ \\
\hline 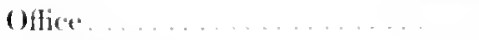 & 127.0 & $\gamma$ & $(1$ & $8.3 \%$ \\
\hline 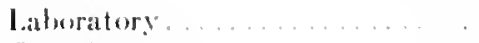 & $8+.8$ & G & 30 & 5.11 \\
\hline Gircenthouse"............. . & 13.7 & 80 & 8.5 & t.fit \\
\hline Constant-temperature renon.... & 3.1 & 0 & $1 \div 4$ & 3.08 \\
\hline
\end{tabular}

This table gives for the three components the following coreflicients of absorption: latrd pine sleathing .058, grlatss ogt, hrick act in cement 0 .0?3.

\section{APPROAIMATE SOLITION}

Is the preceding paper it was slown that the chration of the residual somel in at partientar room was propertionial inversely to the absorbing power of the bomeling walls and the contained

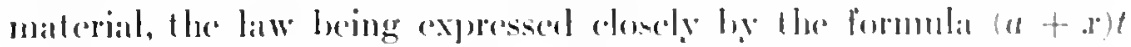
$=k$, the formula of a displaced rectingulate legperbolis. In the present paper it is proposed to show that this formula in general. and applieable to any room; that in adaptime it fo diflerent remens

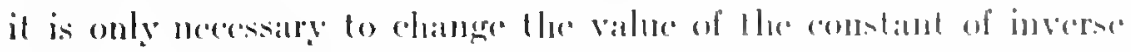
proportionality $k$; that $k$ is in turn proportional $k$ the solume of 


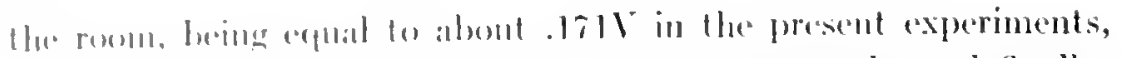
lut alegremlent on the intial intersuly of the sommd: and finally, that hy sulutituting the villue of $l$ thus determined, and also the

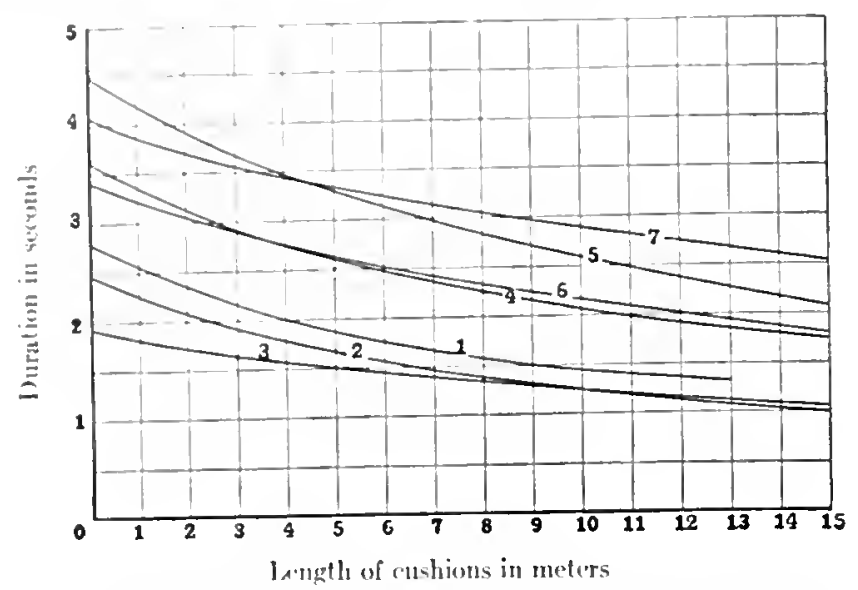

Fir.s. Curveshowing the pelation of the duration of the residual sound to the added absorbing malerial, - rooms 1 to $\%$.

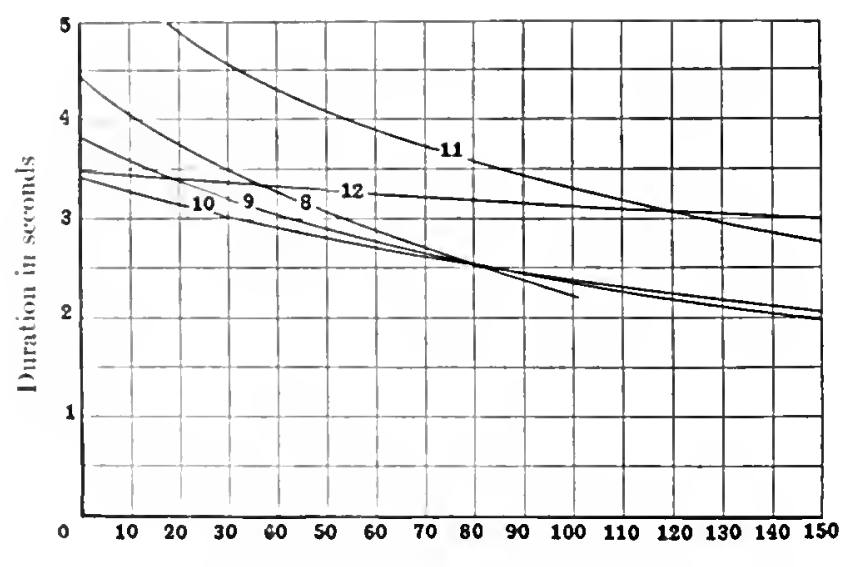

Inength of cushions in meters

Ftc. 9. Curves showing the relation of the duration of the residual sound to the added absorling malerial, - rooms 8 to 12.

valle of $a$, the absorbing power of the walls, and of $x$, the absorbing power of the furniture and andience, it is possible to calculate in alvance of construction the duration of audibility of the residual simel. 
The truth of the first proposition - the gemerall applicaluility of the layperbolic law of inverse proportionality - can be sattisfactorily shown by a condensed statement of the results obtained from data collected early in the inventigation. These observations were made in rooms varying (xtremely in size and shate, from a sunall committee-room to a theatre having a seating capacity for nearly fifteen humelred. Figures 8 and 9 give the curves experimentally determined, the duration of andibility of the resiclual

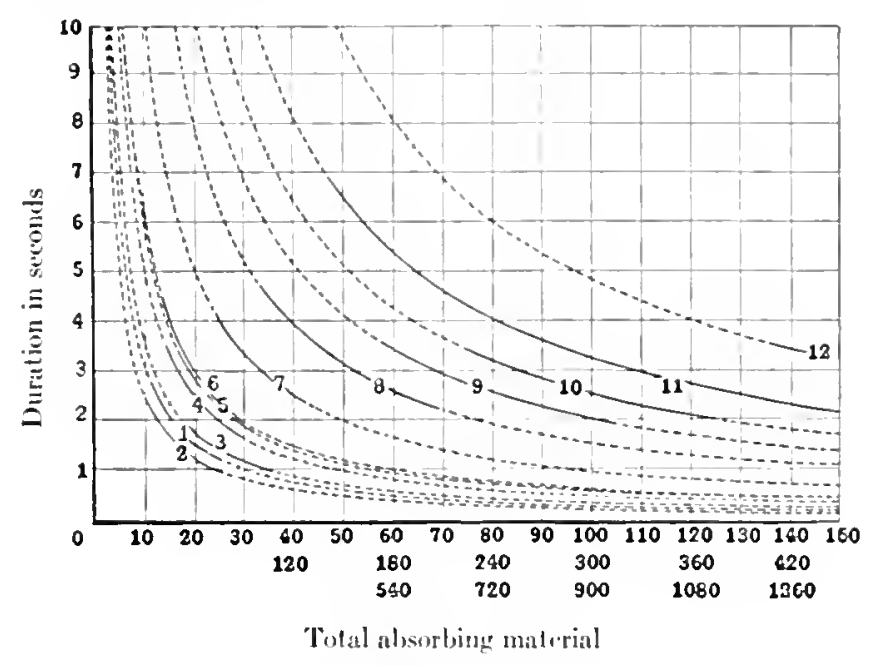

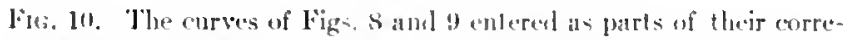

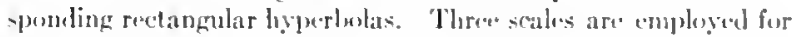
the volumes, lye groups $1-7,811$, and 12.

sound being plotted agramst rumning meters of andioms. Two diagrams are given in oreler to comploy a smaller scalle for the larger

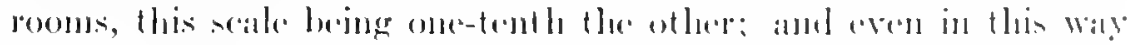

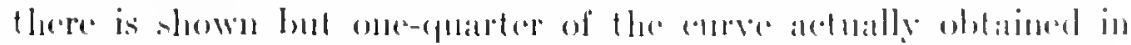

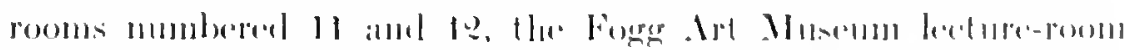

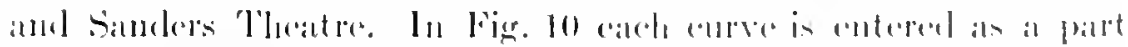

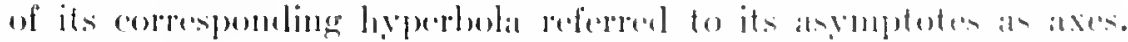

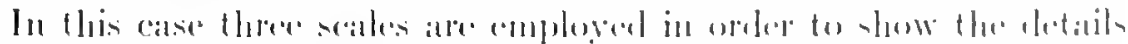

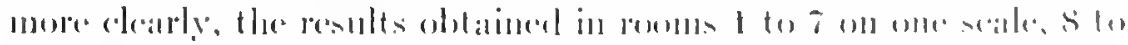

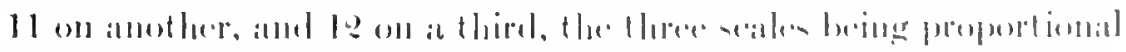

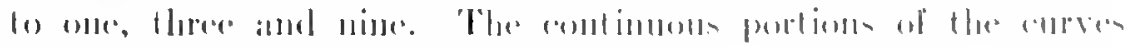

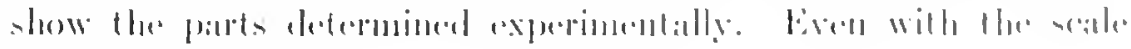




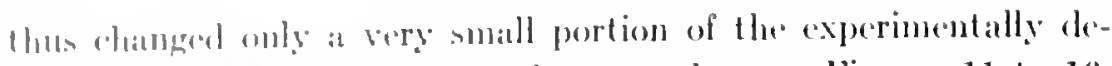
forminul parts of alleves 11 and 19 arre shown. Fignres 11 to 16 , inchusive, all drawn to Hhe salme scalle, show the great variation in

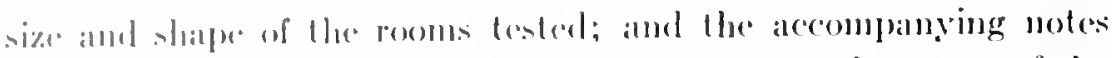

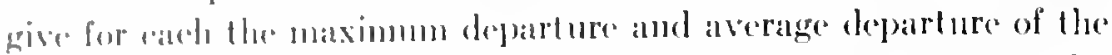

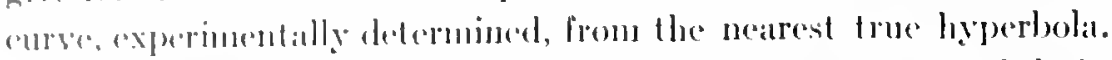

1. Commitler-ponm, Inivelsily Itall; plaster on wood lath,

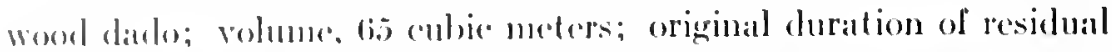
somel hefore the introluction of ausc cushions, Q.89 seconds; maxi-

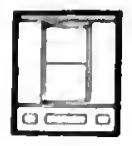

1

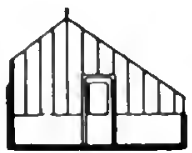

5

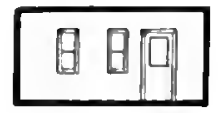

2

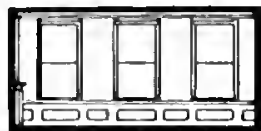

6

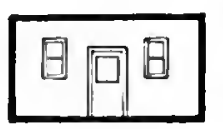

3

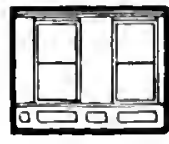

4

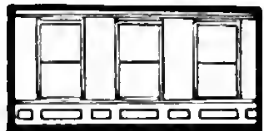

$\gamma$

Futi. 11. 1. ('ummitheremm. Q. Ialnuralory, Botanie Gardens. 3. Office,

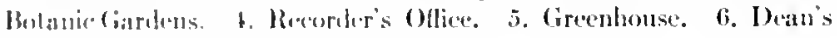

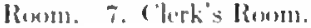

monn departure of experiment ally detemnined eurve from the nearest hyperbolis, obs second; average departure, .03 second.

@. Iathoratory, Botanic Ciardens of IHavad Thiversity; hard pine walls and reiling. cennenl floor; volume, 89 cubje meters; orierinal duration of the residual somml, 2.39) seconds; maxinmm

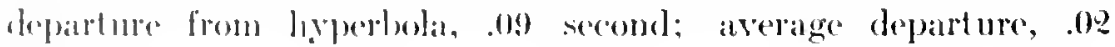
sere(onde.

3. Oflice. Botanice (Bardens; hard pine walls, ceiling and floor:

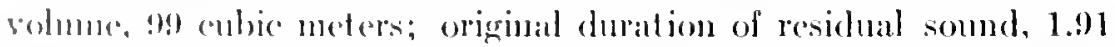
seromds; maximum depanture from ligperbola, ol second; average departure. .00 seremend.

4. Rereneder's (Othice, Iniversity Hall; plaster on wood lath,

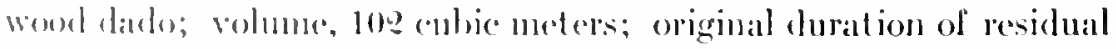
smomd. S3.tis seconde: maximmm departure from liyperbola, .10

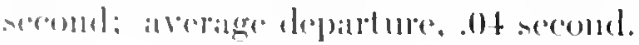


5. Grecohouse, Botanic Gardens; glass roof and sides, cement floor; volume, 1:3t cubic metem: original duration of residual

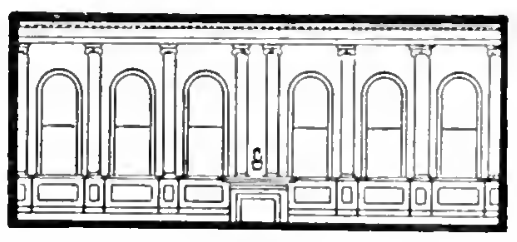

lig. 12. laculty-roum.

sound, t.40 seconds: maximum departure from hyperbola, os

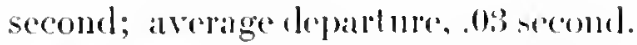

(i. Dean's Roon, Iniversity IIall; plaster on wood hath, wood dado; volume, 16 (

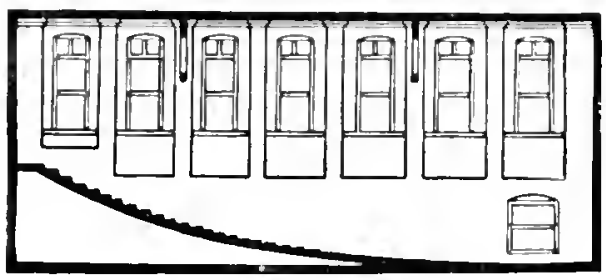

Fis. 13. Jacture-rum.

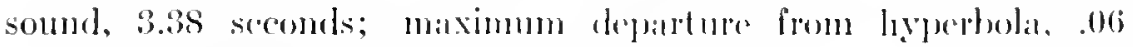
second; alverage departure, ot sorend.

7. Clerk's Room, Inivernity Itall: plister on wood lath, wood dado; volume, gel cubie meters; originat duration of residnal

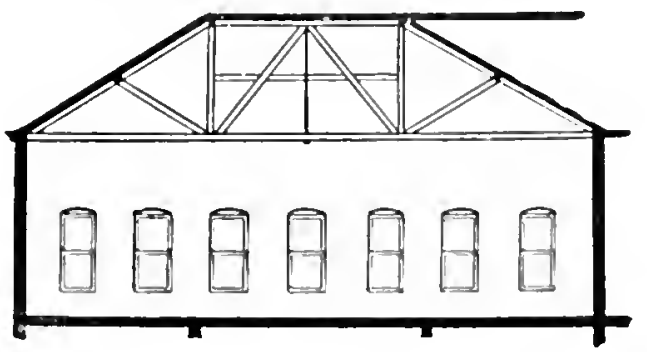

lirs. It. Inlmoralory.

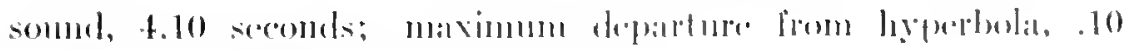

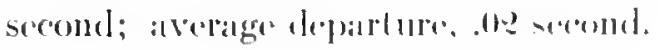




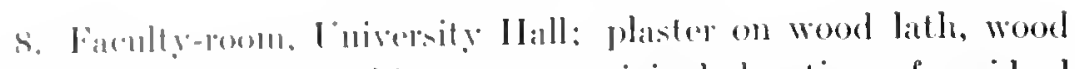
dialo: volume, 1.tso colsie moters: original aluration of resiclual somml. 7.0t secomls: maximum departure from hyperbola, 18

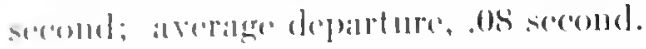

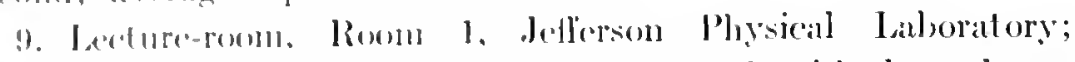
brick walls. plater on wool latll ceiling: furnished; volume, 1.630) (mubic meters: origriual duration of residual sound, 3.91

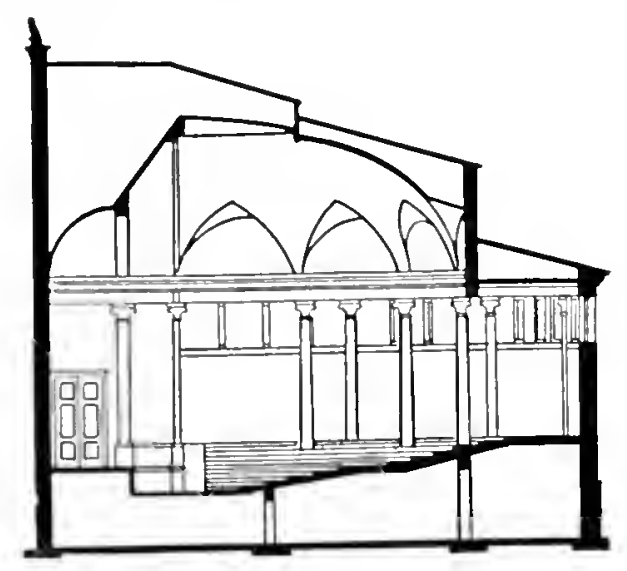

Fig. 1.5. Lecture-room.

seconds: maximum departume from hyperbola, .10 second; average departure. ont secend.

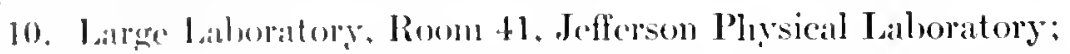
brick walls, plaster on wood lath coiling; furnished; volume, 1 ,9)(6) enhic metters: original durat ion of residual sound, 3.40 seconds; miximum departure from hyperbola, .03 sceond; average departure, ol seromit.

11. Ineture-room, logegr Art Musenum: plaster on tile walls, plaster on wire-lath eciling: volume, s.7to culnic meters; original duration of residual somml. 5.6i seronds: maximum depanture from lypepholat, ot second: average departure, og second. The exprerinments in this room were carricel so far that the original duration of renilual solund of 5.61 seconds was reeluced to .75 second.

18. Samders 'lluatre; plastor on wood lath, but with a great deal of hard-wood slathling nsed in the interior finish; volume, 9.300 (uldic meters; origrinal duration of residual somme, 3.42 
seconds; maximum departure from hapelolat, of seronel; atverage dejarture, og scound.

It thus appears that the haperbolic law of inverse proportionality holels under extremely diverse comelitions in regald to the size, shatpe and material of the roum. Ant as the cuslions used in the calibration were placed ahout quile at raudoun, it also alpuears that in rooms small or large, with high or low coiling, will flat or curved

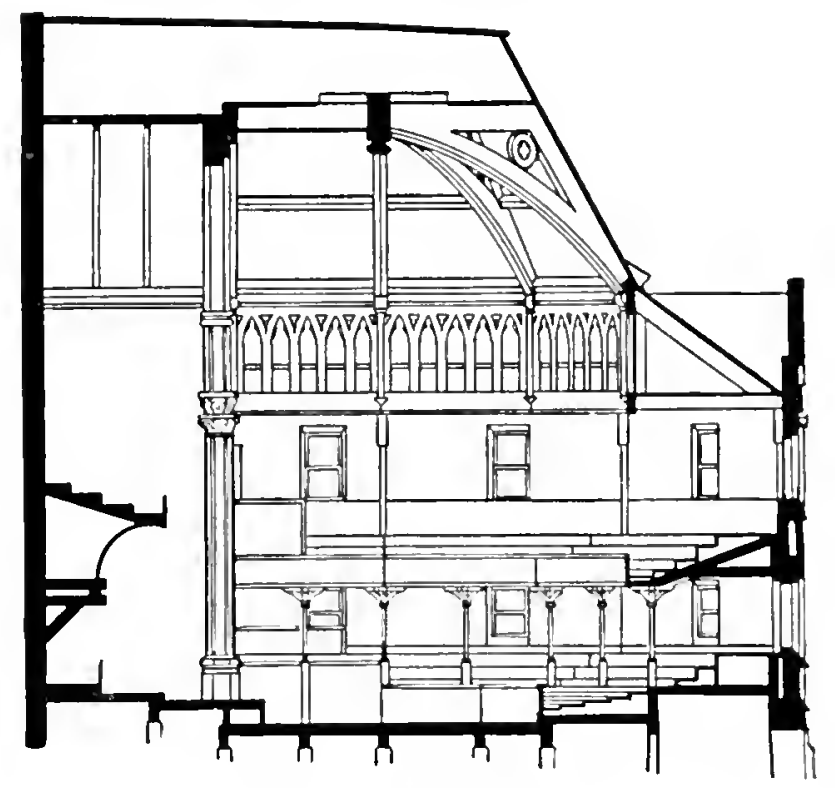

Fig. 16. Sanders Theatre.

walls or coiling. even in roomss witl galleries. He cushions, wherevero

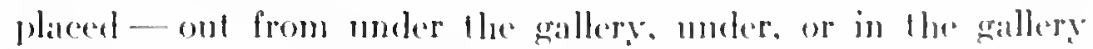

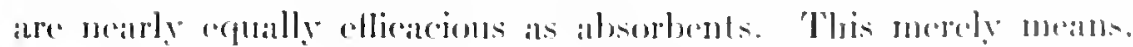

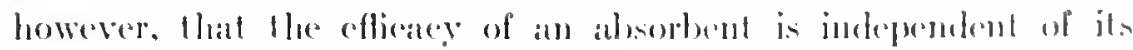

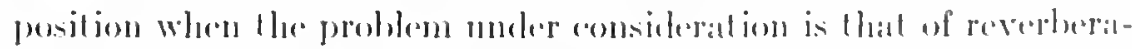

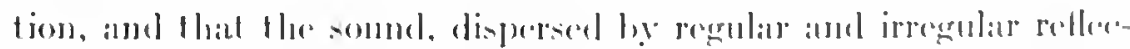
lion and hy diffraction, is of neally lhe same inldesity all all parts of

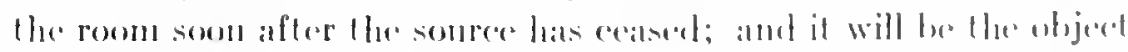

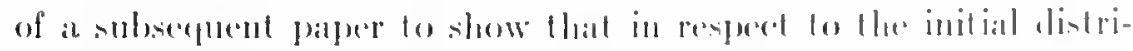

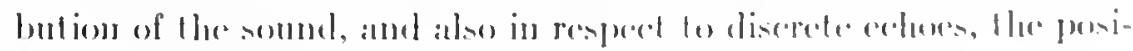

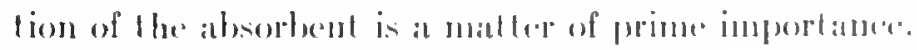




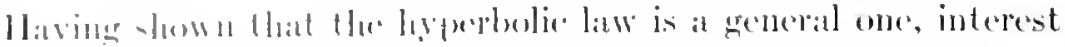

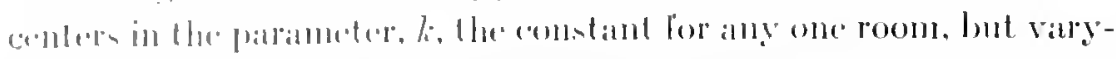

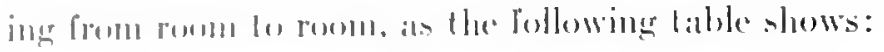

\begin{tabular}{|c|c|c|c|}
\hline licks!n & Volume & $\begin{array}{l}\text { Mlsorhing Power of } \\
\text { Walla, ctec, }=a\end{array}$ & Parameter $k$ \\
\hline 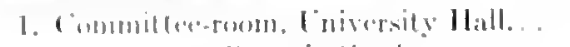 & (i.j) & 4.76 & 13.6 \\
\hline 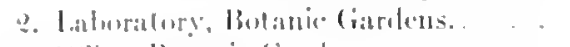 & 82 & H.6.5 & 11.1 \\
\hline 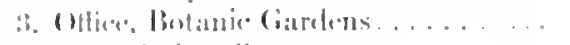 & $9 !$ & 8.118 & 1.5 .4 \\
\hline 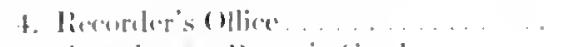 & 102 & 5.91 & 91.8 \\
\hline 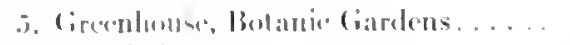 & 131 & .5 .87 & 9.5 .8 \\
\hline 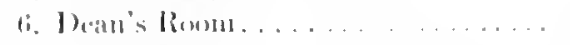 & $16(i)$ & 7.50 & $9.5 .+1$ \\
\hline 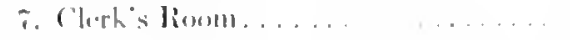 & 991 & 10.6 & $\$ 3.5$ \\
\hline s. lacully-romm ..... & $1,1.80$ & 84.5 & $94: 3.0$ \\
\hline 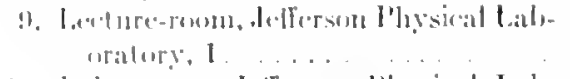 & 1.6330 & 69.0 & 970.0 \\
\hline 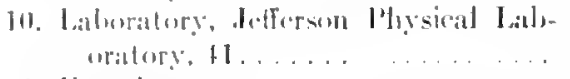 & $1.9(0)$ & 101.0 & 345.0 \\
\hline 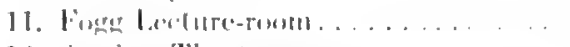 & $2.7+0$ & 7.5 .0 & 195.0 \\
\hline 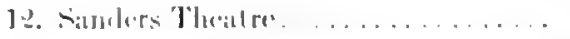 & 9.300 & +6.5 .0 & ] .590 .0 \\
\hline
\end{tabular}

The values of the alsorbing power, $a$, and the parameter, $b$, ale

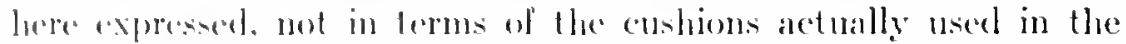
rxproments, hut in terms of the open-window units, shown to be proferalle in the preceoling anticle.

In the diagram, Figure 17, the values of le are plotted against the correstunding volumes of the ronoms: lere again there different scalles alle empleyed in moler to magnify lle results obtained in the smallere roums. The remulting straight line shews that the value of

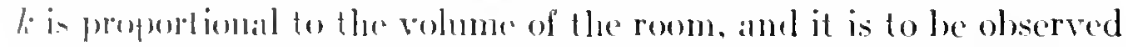
llat the laregent room was nearly one lomdred and fifty times larger

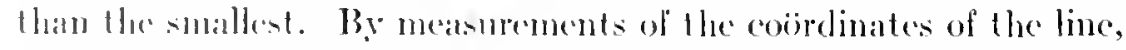
or lye arerigging the results foumd in calcenlating $\frac{k}{j}$ for all the rooms

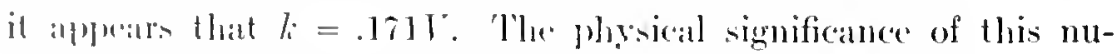

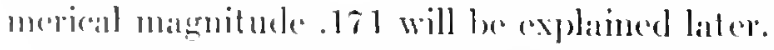

'llis sinfle relationship betwe'en the value of $k$ and the volume uf Har mon- the rooms testorl varring so greatly in size and shate - atlorels adelitional proof, hy at rather delicate test, of the acruracy of the method of experimenting, for it shows that the ex- 
perimentally determined corves approximate not merely to lyperbolas but to a systematio family of hyperbolas. It also furnishes at more pleasing prospect, for the laborious hamdling of enslisons will be unnecessary. A single experiment in a room and a knowled ge of the volume of the room will furnish sufficient datal for the calculattion of the alssorbing power of its components. Conversely, a knowledge of the volume of a room and of the coeflievents of absorption of its varions components, including the andience for which it is designed, will enable one to calculate in inlvance of eonstruction the duration of andibility of the residual somd, which measures

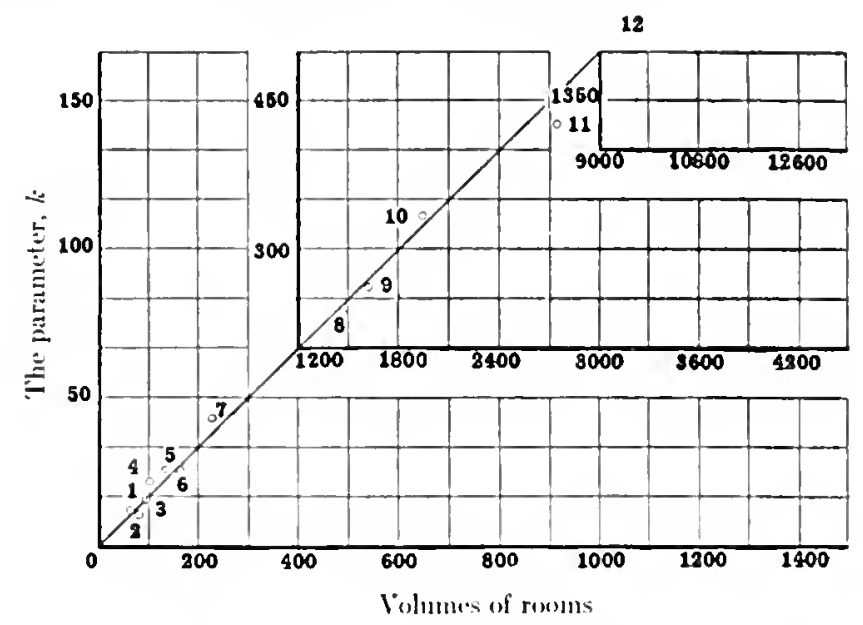

lici. 17. The parameler, k, plolled against lle volumes of the rooms, slowing the [wo propurtional.

that acoustical property of a room commonly called reserteralion. Therefores this phatse of the prohlem is solved to at first ipproximation.

The explanalion of the face that $k$ is proportional to $l$ is foumel in the following reasoning. Consider two pooms, constructed of

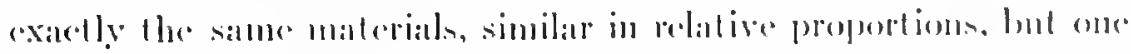

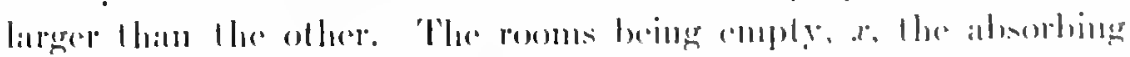
power of the contaniued material, is zero, and we hatse $a^{\prime} t^{\prime}=l^{\prime}$

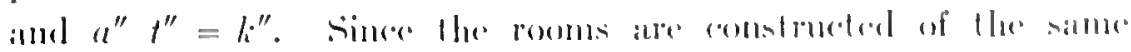

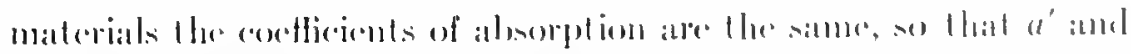

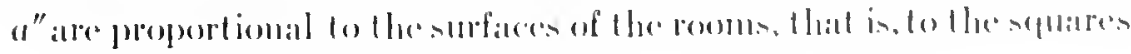




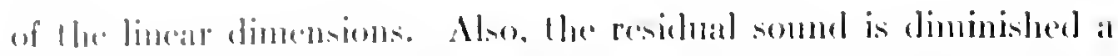

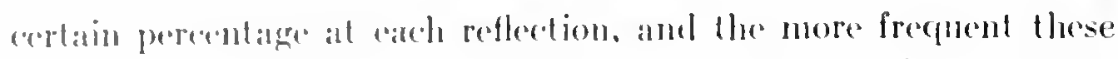
reflections are the shorter is the duration of its andibility; whence $t^{\prime}$ and $l^{\prime \prime}$ arre inversedy proportional to the frecpuency of the reflecetions, and hence direetly propentional to the linear dimensions. Therefore, $l^{\prime}$ and $l^{\prime \prime}$, which are equal lo $a^{\prime} t^{\prime}$ and $a^{\prime \prime} t^{\prime \prime}$, are proporlional fo the cubes of the linear dimensions. and hence to the viohmes of the rooms.

Further, when the shape of the roent varies, the volume remaining the sime, the number of reflections per secont will vary. Therefore, $l i$ is a function not merely of the volume, but also of the shape of the room. But that it is only a slighty varying function, comparatively, of the shape of the room for practical cases, is shown by the face that the points fall so near the straight line that averages Herevalues of the ratio $\frac{k}{l}$.

'The value of $h$ is also a function of the initial intensity of the somml: but the consideration of this element will be taken up in a following pruper.

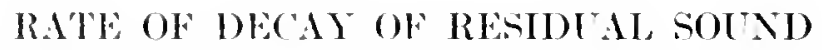

Ix a subsegutent discussion of the interference of sound it will be shown by pholographs that the residnal sound at any one point in the room as it dies away passes flurough maxima and minima, in many eases hegimning to rise in intensity immediately after the sonree has ceased: and that these maxima and minima succed areh other in a far from simple manner as the interference system shifts. On this accomnt it is quite impossible to use any of the numeroms direct methods of measuring somel in experiments on reverberation. Or, rather, if such methods were nsed the results would be a mass of data extremesy difficult to interpret. It was for this reason that altempts in this direction were abaneloned early in the investigation, and the method alrearly described adopted. In addition to the fact that this method only is feasible, it has the alvantage of making the measurements elirectly in terms of those units with which onte is here concerned - the minimum andible 
intensity. It is now proposed to extend this method to the determination of the rate of decay of the averatge intensity of somm in the room, and to the determination of the intensity of the initial sound, and thence to the determination of the mean free path between reflections, - all in preparation for the more exact solution of the problem.

The first careful experiment on the absolute rate of decay was in the lecture-room of the IBoston Public Library, a large room,

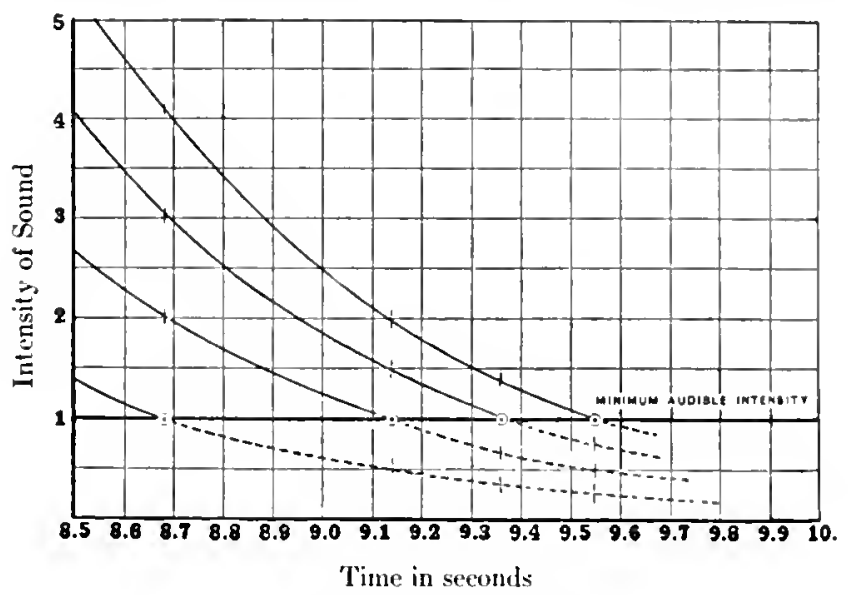

Fig. 18. Decay of sound in the lecture-room of the Boston Public Library from the initial sound of one, two, three, and four organ pipes, showing only the last seeond.

finished, with the exception of the platform, in material of very slight absorbing power - tile ceiling, plaster on tile walls, and polished cement floor. ${ }^{1}$ The reverberation was very great. 8.69 seconels. On the platform were placed four organ pijes, all of the same pitch, each on its own tank or winel supply, and each having its own electro-pnemmatic valve. All these valves, howerer, were comnected to one chronograph, kery, and battery, so that one, two, three, or all the pipes, might be started and stopped at once, and when less than four were in use any desired combination conld be made. One pipe wats sounded and the duration of andibility of the residual sound determined, of course, as alwayss in these experiments, by repeated observations. 'The experiment was then mathe

I Terrazzo centent flewr. 
will two orgitn pipes insteat of one; then witl three pipes; and, linally, wilh font. 'Tlue whole series was then repeated, but beginning with at different pipe and combining different pipes for the two amel thren pipe sols. In this ware the series was repeated fom times, Hae counbinations being so manle Hat each pipe was given an ecqual woight in the defermination of the duration of andibility of the revidual semul muler the fone diflerent conditions. It is safe to am-ume that with experinents conducted in this manner the arerage initial intensities of the somd with one, two, three, and fomr pipes were to atelle ofleer as one, two, three and four. The corresponding durations of andibitity shall be called $t_{1}, t_{2}, t_{3}$ and $t_{4}$. The following remults were olstainerl:

$$
\begin{aligned}
& t_{1}=8.69 \text { seconds } \quad t_{2}-t_{1}=.45 \text { second } \\
& t_{2}=! 1.14 \quad \text { " } t_{3}-t_{1}=.67 \quad \text { " } \\
& t_{3}=.9 .86 \quad " \quad t_{4}-t_{1}=.86 \quad " \\
& l_{4}=9.5 .5 \quad " *
\end{aligned}
$$

It is first to be olserved that the difference for one and two organ pipes. .t.5. is, within two-linndredtlis of a second, hall that for one anel four organ pipes, sti. 'This sugegests that the difference is propurtional to the logarithu of the initial intensity; and further inspertion shows that the intermediate result with three organ pipes. efi. is even more nearly, in fact well within a lundredth of an second, proportional to the logatrithm of three. This reenforees the verg natural conception that howerer mueh the residual sound at any ome promt in the rom may lluctuate, passing throngh maxinnarel minima. the arelage intensity of sound in the room dies away logarithunically. 'Thus, if one plots the last part of the residual somin- thal which remains aller eight seconds have elapsed ont the ansmention that the intensity of the sound at any instant is proportional to the initial intensity, the result will be as shown in the diagran, Fig. 1s. The point at which the diminishing sound crunes the line of minimum andibility in cach of the four cases is known, the corresponding ordinates of the other curves being multiples or submultiples in proportion to the initial intensity. 'The results are obviously logarithmic.

Let $I_{1}$ be the arerage intensity of the steady sound in the room when 1 le single organ $p^{\text {sipe }}$ is somnding, $i$ the intensity at any instant 
during the decay, saly $t$ secombls after the pije hats ceatsed, then $-\frac{d i}{d t}$ will be the rate of decay of the sound, and since the absorption of sound is proportional to the int ensity

$$
-\frac{d i}{d t}=d i \text {, where }-1 \text { is the constant of proportionality, }
$$

the ratio of the rate of decay of the residhal somet to the intensity at the inst ant.

$$
-\log _{\mathrm{e}} i+r^{\prime}=.11,
$$

a result that is in accord with the abore experiments. The constant of integration ('may be determined by the fact that when $t$ is zero $i$ is equal to $I_{1}$; whence

$$
\begin{aligned}
C^{\prime} & =\log _{\mathrm{e}} I_{1} \text {, and the above equation becomes } \\
I_{1} & =.11 .
\end{aligned}
$$

At the instant of minimum andibility $t$ is equal to $t_{1}$, the whole duration of the resiclual somel, and $i$ is ecplat to $i$, - an the intensity of the least andithe sound will hereafter be denoted. 'Therefore

$$
\log _{*} I_{1}=.1 I_{1}
$$

'This applied to the experiment with two, three and four pipes gives similar ecpuations of the form

$$
\log y_{c} \frac{n I_{1}}{i^{\prime}}=.1 H_{t \prime}
$$

where $n$ is the number of organ pipes in use. By the climination of

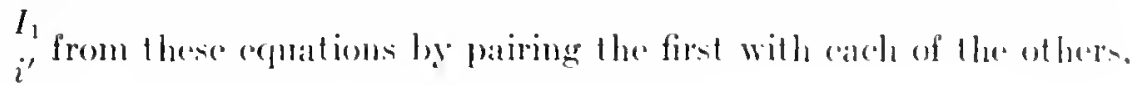

$$
\begin{aligned}
& .1=\frac{\log _{1 .} 2}{t_{2}-t_{1}}=1 . i \mathrm{t}, \\
& .1=\frac{\log _{n} .3}{t_{3}-t_{1}}=1.62 . \\
& .1=\frac{\log _{0} t}{t_{4}-t_{1}}=1 . \text { (i1 } \\
& .1 \text { (averatine) }=1.5 \% \text {, }
\end{aligned}
$$

where $t$ is the ratio between the rate of decaly and the alveriger intensity at any instant. 


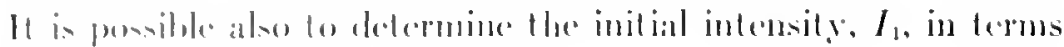
of the minimum andible intematy,

$$
\begin{aligned}
& \text { lin! } l_{1} i_{1}=.1 t_{1} \text {. } \\
& \left.I_{1}=i^{\prime} \log g_{1}{ }^{1} .1 t_{1}=i^{\prime} \log g_{1}^{-1}(1.59) \times 8.69\right)=1,000,000 i^{\prime} .
\end{aligned}
$$

Ililh this valure of the intial introbity it is possible to calculate the intellsily i of the resiclual soumd at any instand during the decay, lig Iho formula

$$
\log _{1} I_{1}-\log g_{\mathrm{e}} i=.1 t \text {. }
$$

and the renult when photlad is shown in Figure 19, the mit of inlensily beillg minimum andibility.

A pracelical trial anly in the year hat shown lhat it would be imporible to use this locture-boom as an anditorium, and the ex-

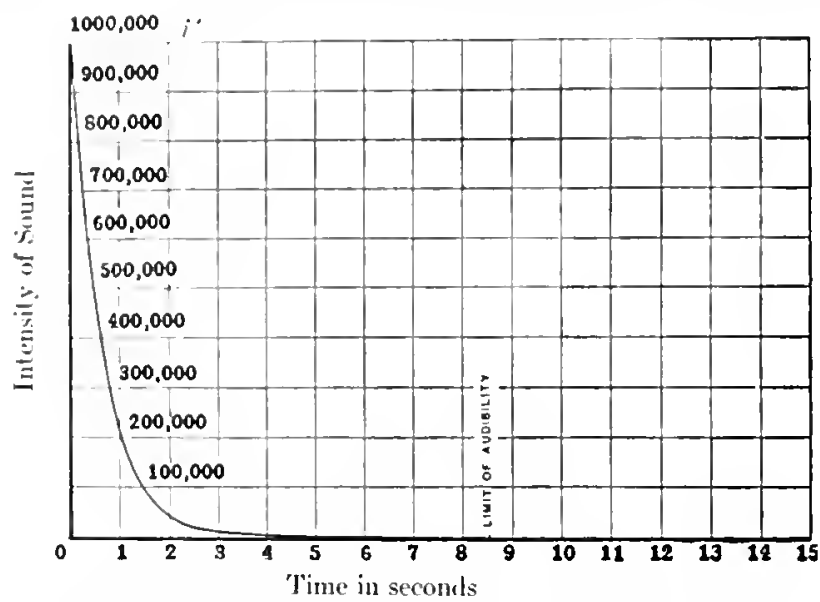

Fig. 19. Dacay of sumd in the lecture-room of the Boston Public Library beginuing inmediately after the cessation of one organ pipe.

perinests described alnove, with others, wore in anticipation of changes designed to remedy the difliculty. IIair felt, in considerable quantities, was placed on the rear wall. 'The experiments with the four organ pipes were then repeated and the following results nore obtained:

$$
\begin{aligned}
& t_{1}=3 .(i . j) \\
& t_{2}-t_{1}=.90 \\
& \therefore .1=3 .+1 \\
& t_{2}=3.8 .5 \\
& t_{3}-t_{1}=.31 \\
& \therefore A=3.54 \\
& t_{3}=3.96 \\
& t_{4}-t_{1}=.42 \\
& \therefore A=3.99 \\
& t_{4}=4.0 \% \\
& I_{1}=8.50 .000 i^{\prime} \\
& d=\overline{3.41} \text { (average) }
\end{aligned}
$$


A few nighats bater the apparatus was moved down to the attendant's reception-room near the main entrance - a small room but similar in proportions to the lecture-room. Here a carchul experiment extending over several nights was carried on, and it galve the following results:

$$
\begin{aligned}
& t_{1}=4.01 \quad t_{2}-t_{1}=.19 \quad \therefore .1=3 .(0.5) \\
& t_{2}=4.90 \quad t_{3}-t_{1}=.88 \quad \therefore .1=3.90 \\
& t_{3}=4.99 \quad t_{4}-t_{1}=.37 \quad \therefore .1=3.75 \\
& t_{4}=4.38 \\
& I_{1}=3,800,000 i^{\prime} \\
& .1=\overline{3.76} \text { (average) }
\end{aligned}
$$

The first interest lies in an attempt to commert the rate of decaly, obtained by means of the four organ pipe experiments, with the absolute coefficient of absorption of the walls, obtained by the experiments with the open and elosed windows: and ho this end reconrse will be had to what shall here he called "the mean free path between reflections." 'The residnal somml in its process of decaly travels across the room from wall to wall, or ceiling, or floor, in all conceivalle directions; some paths atre the whole length of the room, some cren longer, from one comere to the opposite, but in the main the free path between retlections is less, becoming eren infinitesimally small at an angle or a corner. Bulween the two or three humbled reflect ions that ocener during its andibility the residual sound establishes an arerage distance between reflections that depends merely on the dimensions of the room, and may be called "its mean free path."

$$
a=\frac{1711^{\circ}}{t_{1}}
$$

is the absorbing power of the room, measured in open-window units.

Lect

$$
\begin{aligned}
& s=\text { silrfaces. } \\
& V^{\circ}=\text { volume. } \\
& A=\text { rate of deray of the sommd. }
\end{aligned}
$$

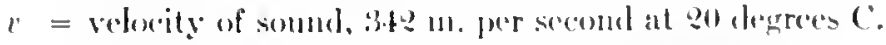

$$
\begin{aligned}
& p=\text { length of the mean free path between reflections. }
\end{aligned}
$$

Whence ${ }_{p}^{c}=$ the arerage number of reflection per serome and

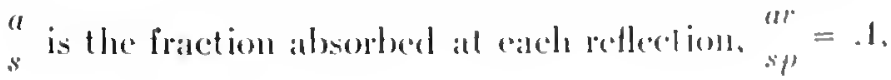




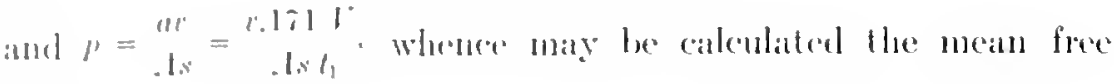
[itllı, p.

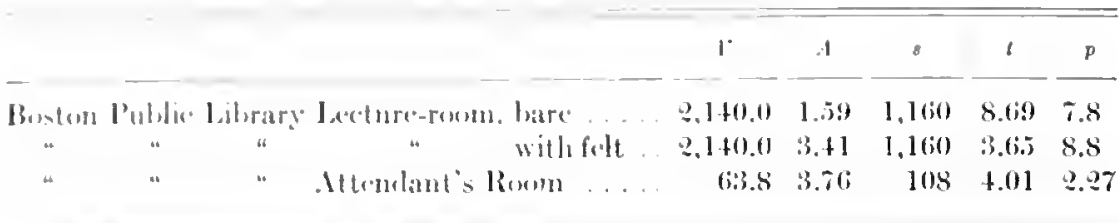

'The length of the mean free path in ilee lecture-room, bare or (raperl, onght to be the same, for the lelt was placed out from the wall at at distame imperceptihly small in comparison with the dimensions of the room: lut 7.8 and 8.8 differ more than the experimental errors juslify. Agam, the attenelant's room had very nearly the same relative propontions as the lecture-room (about g: : : (i), but cach linear elimension reduced in the ratio $3.29: 1$. The mean frec path. obvionsly, shombl be in the same ratio; but when the mean free path in the attemelant's room, 9.9\%, is multiplied ly. 3.9. it gives 7.35, departing again from the of her values, 7.8 and s.s. more than experimental crrors justily. The explamation of this is to be found in the fact that the initial intensity of the sound in the rooms for the eletermination of $t_{1}$ was not the same but hat the values respectively, $1.000 .0000 i^{\prime}, 950.0010 i^{\prime}$ and $3,800,000 i^{\prime}$. Since $/ 1$ las been shown proporlional to the logarithms of the initial intensities, these threes numbers, 7.s, s.s ant 7.35 , may be corrected in an obvinus manner, and reduced to the comparable values they would have had if the initial intensity had been the same in all three catses. 'The results of this reduction are $7.8,8.0$ and 8.0 , a satisfactory atgrecentent.

'The length of the mean liree path is. therefore, as was to be expecteel. prepertional to the lincar dimensions of the room, and such al complutism is interesting. 'There is no nore reason, however, for comparing it with onc dimension than anolher. Moreover, most romens in regated to whieh the inguiry might be made are too irregular in -hape lo athuit of any one atetual distance being taken ats standard. 'Thur, in a semicircular room, still more in a horseshoe-shaped room suclu ats the common thatre, it is indeterminable what should be 
ealled the breadth or what the length. On acesunt. therefore, of the complicated nature of prictical conditions one is fored to the adoption of an ideal dimension, the rube root of the volume. $f^{13}$, the length of one side of a cubical room of the same calpicrity. 'The above

data give as the ratio of ${ }_{p^{1} 13}^{p}$ the value, 62 .

It now becomes possible to present the subjocet ly exact ansalysis, and free from approxinations; but before doing so it will be well to review from this new standpoint that which hats already becen done.

It wass obvious from the beginning, aren in dedueding the hyperbolic law, that some acconnt should be taken of the reduetion in the initial intensity of the sound ats more and more alsorthing material was brought into the room, aven when the source of somml remained unchanged. 'Thus each sueceedling value of the shation of the residual somd was less as more and more aboubing material wits brought into the room, not merely becinte the rate of decaly. wats greater, but also because the initial intensity wask lens. Had the initial intensity in some way been kept ne to the sime value throughtont the series, the resulting enrve would have been and exilet hyperbola. As it was, however, the curve sloped a little more ritpidly on account of the additional reduction in the duration arising from 1 lue reduction in intial intensily of the somel. At the time, there was no way to make allowanere for this. That it was a rery smill errem, however, is shown by the fact that the stepartures from the true hyperbolat that were talmbiated atre so small.

Turning now to the parameter, $h$, it is evident that this also was an approxination, though a close one. In the first placese als junt

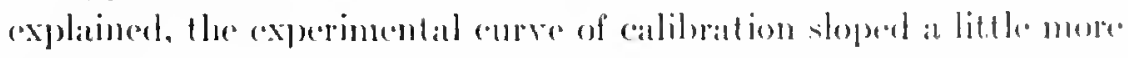
rapidly than the true hyperbolat. It follows that the meatrent hyperbola fitting the atedial experimental results wats alwaye of at little

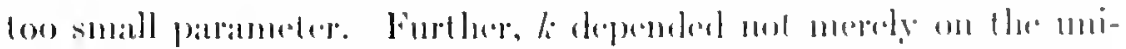
formity of the intitial intensity during the calithation of the loweme

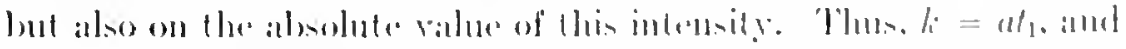

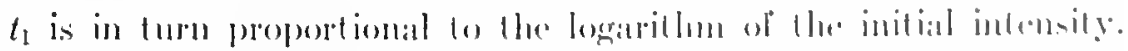

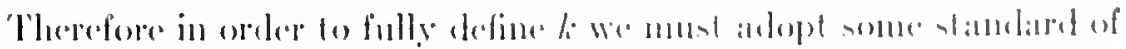

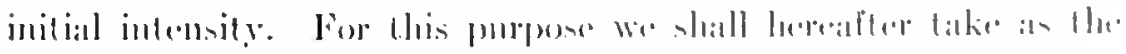


stanclarel conclition in initial intensity, $I=1,000,000 i^{\prime},\left(I=10^{6} i^{\prime}\right)$, where is is lle minimunu andible intensitg, as this is the nearest round number to the arverage iutensity prevaiting during these experiments. If, therefore, during the preceding experiments the intial intensity was above the standard, the value deduced for $k$ womld be a lithle high, if below standarel, a little low. 'This variation of the parameter, $k$, would be slight ordinarily, for $k$ is proportional to the logatithm, nest direetly to the value of the initial intensity. slight ardinatrily. but not always. Altention was first directed to its practical inportance "arly in the whole investigation by an experincent in the dining-room of Memorial Hall - a very large room

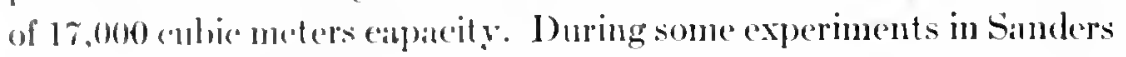
'Theatre the organ pipe was moved across to this dining-room, and an experinent begun. The reverberation was of very short duration, althongh it would have been long had the initial intensity been sandard. for in rooms constructed of similar materials the reverberation is anproximately proportional to the cube roots of the voluntes. 'There was no opportunity to carry the experiment farther than to observe the fact that the duration was surprisingly short, for the frighterned appesurance of the wonen from the sleepingrooms at the top of the hall put an end to the experiment. Finally. $l_{i}$ is a function not merely of the volume but also of the shape of the room: that is to say of the moan free path, as has already been explained.

11 wats early recognized that with a constant source the arerage inlensity of the sound in different rooms varies with variations in sime and construction, and that proper allowance should be made therefor. The above results call renewed attention to this, and point the way. In the following paper the more exact analysis will be enivell and applied. 


\section{HXIC"] SOLT"JION}

TuE present paper will carry forward the more exact analysis proposed in the last paper.

for the sake of reforence the momenedature so far inlloduced is here labulated.

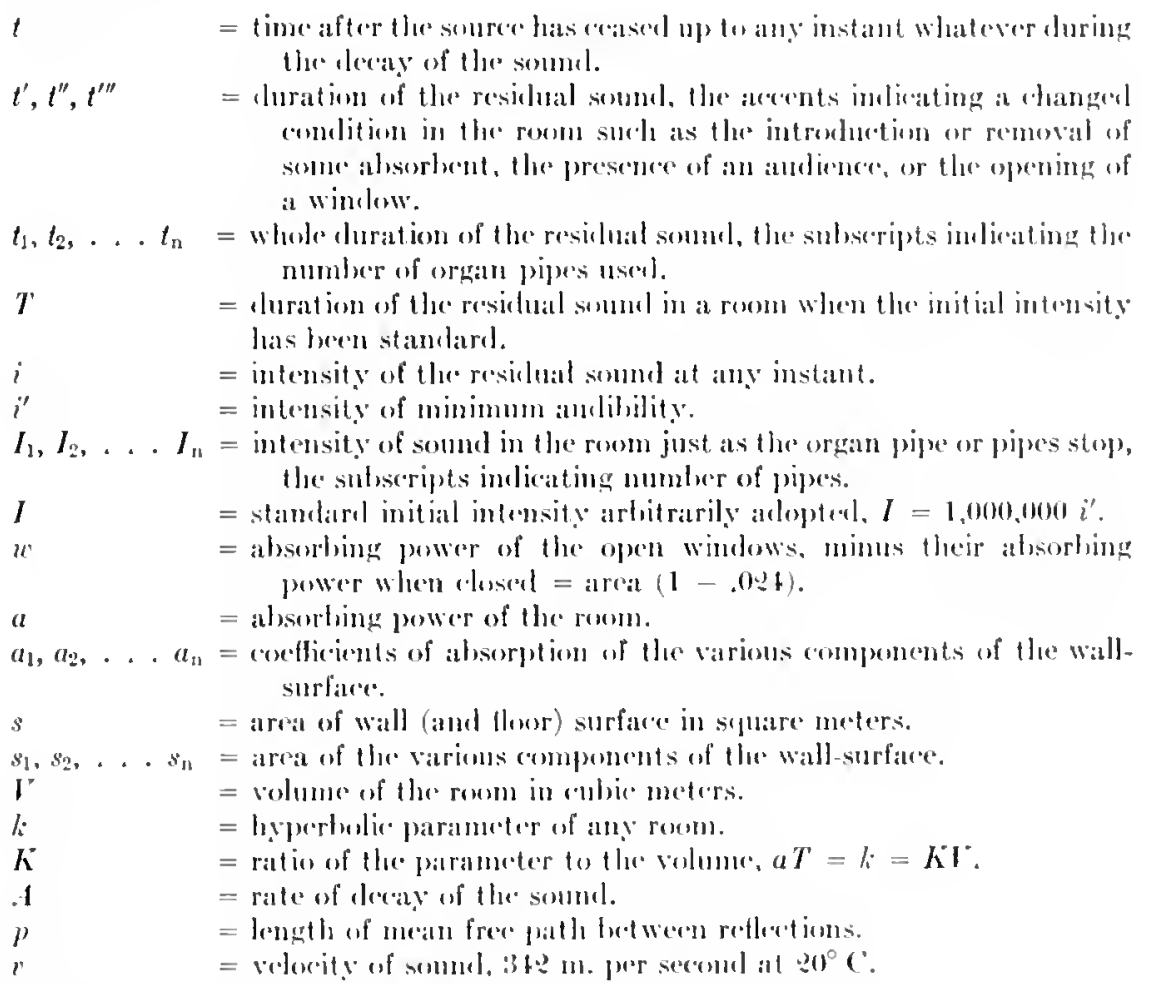

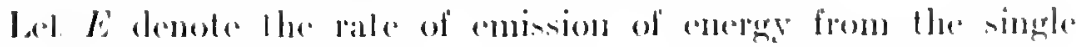
orean jipe.

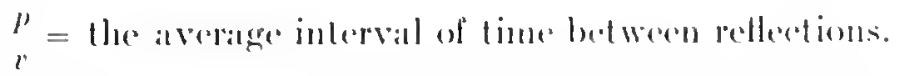

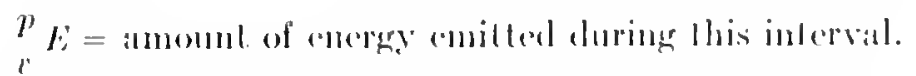

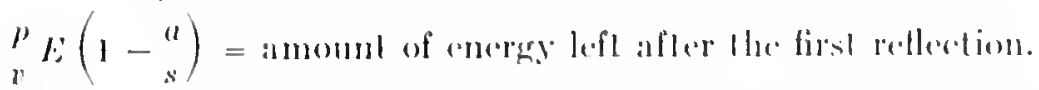

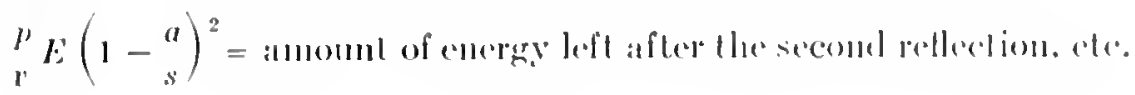


If the argin pipe continues to somul, the energy in the room con-

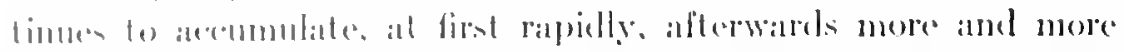

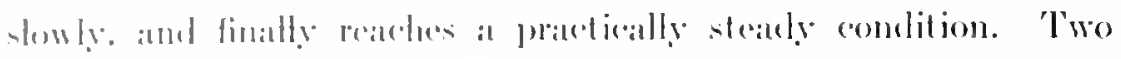
twint alle luere interesting -- the time rectuired for the sound to

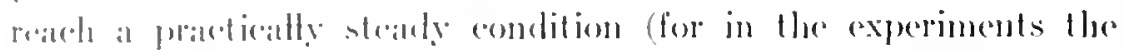

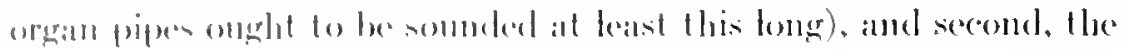
interneity of the sound in the steaty and final condition. At any instimt. the total conergy in the rom is that of the sound just issuing frem the pipk. not hatring sulfered any reflection, plus the energy of that which hat sulfered one reflertion, that which hats suffered two, that which hate suttered three, and so on back to that which first inened from the pijere, als:

$$
{ }_{n}^{\prime \prime} E\left[1+\left(1-{ }_{s}^{a}\right)+\left(1-\frac{a}{s}\right)^{2}+\left(1-\frac{a}{s}\right)^{3}+\ldots\left(1-\frac{a}{s}\right)^{n}\right] .
$$

where $n$ is the mumber of reftections suffered by the somel that first

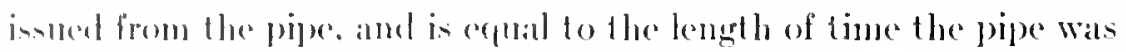
blown divided lye the average interval of time between reflections. The abore series, which is an ordinary geometric progression, mily le written

$$
\frac{1-\left(1-\frac{a}{s}\right)^{n}}{v} \frac{1-\left(1-\frac{a}{s}\right)}{1-}
$$

"i hy mature ponitive and less than unity. If $n$ is very large or if $\left(1-\frac{a}{s}\right)$ is small this may be written

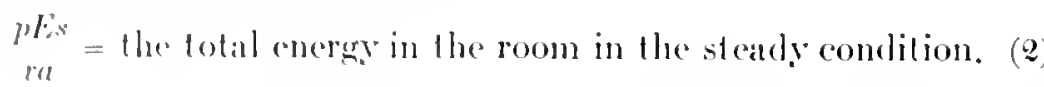

$$
I_{1}=\frac{p l s}{a l s}
$$

i. the atrerage internity of somm in the room as the organ pipe stop. Subutituting in this equation the values of $a$ and $p$ alreatly feruml.

$$
\begin{aligned}
a & =\frac{k T}{T}, \\
\text { and } & p=\frac{r a}{s+1}=\underset{v K Y}{.1 T},
\end{aligned}
$$




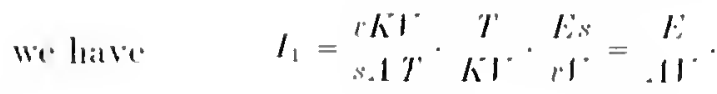

Also

Whene.

$$
I_{1}=\log _{c}^{-1} \cdot I_{1}
$$

$$
l=1.10 \% \varphi^{2} \cdot 1 t_{1}
$$

where the unit of encreg is the energe of minimm andibility in at culic meler of air.

It remains to determine $K$ and $a$. 'los this end the four orean pipe experiments munt be mate in a reonn with the windows closed amel wilh them open, and the values of . l'anel al" determined. 'The following analysis 1 hen beromes anvilalsle:

$$
u=\frac{K l}{T^{\prime}} \text {. and } u+u=\frac{K l}{T^{\prime \prime}}
$$

whence.

$$
u+\|=\frac{T "}{T^{\prime}}
$$

For standard comblitions in rearar to intial intensity

$$
\begin{aligned}
& .1^{\prime} T^{\prime \prime}=. I^{\prime \prime} T^{\prime \prime}=\log _{\mathrm{e}} I=\log _{\mathrm{e}}\left(10^{6}\right)=13.5 . \\
& T^{\prime \prime}={ }^{\prime \prime} I^{\prime \prime} \text {, and } T^{\prime}=\begin{array}{l}
18.8 \\
.1^{\prime}
\end{array} \text {. }
\end{aligned}
$$

subletituliug thene valuen,

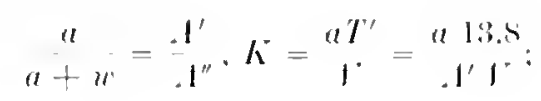

whence.

$$
a=.1^{\prime \prime} " 1^{\prime \prime}-.1^{\prime}
$$

:1111

$$
K=\frac{13.8 \%}{I^{\prime}\left(.1^{\prime \prime}-.1^{\prime}\right)} .
$$

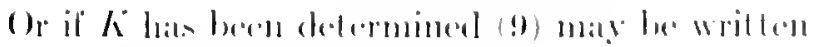

$$
u=\frac{l_{1} \mathrm{KI}^{\circ}}{13.8}
$$

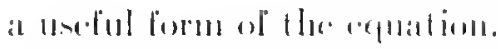

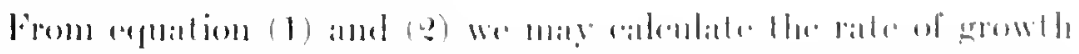

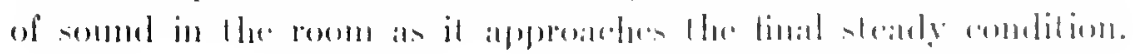


'Thus, dividing (1) hẹ (9), the result, $1-\left(1-\frac{a}{s}\right)^{n}$, grives the in-

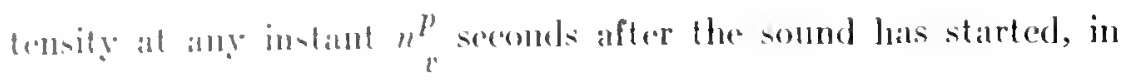
larme of the linal steitly" intensity. Of all the rooms so far experimented on, Hhe erowth of the sommd was slowest in the lecture-room of the Bonton Public library in its unfurnished comdition. For this room ${ }_{s}^{a}=.03 \%$, amel $p=8.0$ meters. The following table shows the growth of the sound in this room, and the corresponding number of reflections which the sombl that first issued from the pipe had undergone.

\begin{tabular}{|c|c|c|c|c|c|}
\hline \multicolumn{6}{|c|}{ 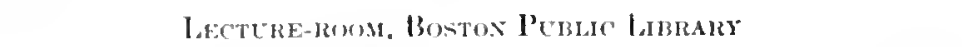 } \\
\hline$n$ & Time & $\begin{array}{l}\text { Sucraze } \\
\text { Intensity }\end{array}$ & $n$ & Time & $\begin{array}{l}\text { Average } \\
\text { Intensity }\end{array}$ \\
\hline 1 & .02 & $.0 t$ & 30 & .69 & .68 \\
\hline$j$ & .11 & .17 & 40 & .92 & .78 \\
\hline 10 & $.8: 3$ & .31 & 50 & 1.15 & .85 \\
\hline 1.5 & $.3 t$ & .43 & 100 & 9.30 & .98 \\
\hline 20 & .46 & .5 .3 & 1.50 & 3.45 & .997 \\
\hline & & & $\infty$ & $\infty$ & 1.00 \\
\hline
\end{tabular}

It thus appears that in this particular room the organ pipe must sound for ahout three seconds in order that the average intensity of the somnd may get within nincty-nine per cent of its final steady viluc. As throughout this work we are concerned only with the logarithm of the initial infensity, ninety-nine per cent of the steady comblition in abmulantly near. This consideration - the necessary lesgetl of time the organ pipe should somme - is carefully regarded throughout these experiments. It varies from room to room, being greater in large rooms. and less in rooms of great absorbing power.

'To determine the value of $E$, the rate of emission of sound by the pipe, formula (s), $E=V^{\prime}+\log _{\mathrm{e}}^{-1}+t_{1}$, is available. It is here to be ohserved that as this involves the antilogarithm of $A t_{1}$ these quantities must be determined with the greatest possible accuracy. The first essential to this end is the choice of an appropriate room. Withont giving the argument in detail here. it leads to this, that the hest rooms in which to experiment are those that are large in volume and have little alssorbing power. In fact, for this purpose, smiall rooms are almost useless, lut the accuracy of the result in- 
creases rapidly with an increase in size or a decrease in albsorbing power. On this account the lecture-room of the Boston Public Library in its unfurnished condition was by far the best for this determination of all the avialable rooms. Inserting the numerical magnitudes obtained in this room in the equation,

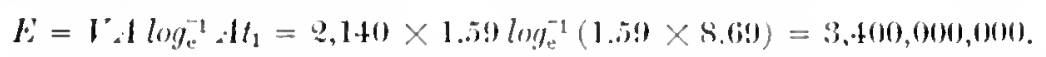

If the observations in the same room after the int roduction of the felt, already referred to, are used in the efpution the result ing value of $E$ is $3,900,000,000$. 'The agreement between the two is merely fortunate, for the second conditions were very inferior to the first, and but little reliance should be placed on it. In fact, in both results the second figures, 4 and $g$, are doubtful, and the round number, $3,000,000,000$, will be used. It is sufficiently alceurate.

The next equation of interest is that giving the value of $K$, number (10). It contains the expression, $A^{\prime \prime}-A^{\prime}$, the difference between the rates of decay with the windows open and with themelosed; $A^{\prime \prime}$ and $f^{\prime}$ depend linearly on the difference in durat ion of the residual sound with four organ pipes and with one, and als both sets of difforences are at best small, it is evident that these experinents also must be conducted with the utmost aire and under the best conditions. 'The best conditions would be in rooms that are latrge, that have small absorbing power, and that afford window areat suflicient to about double the absorbing power of the room. Practically this woukd be in large rooms that are of tike, brick. or cement walls. ceiling and lleor, and have an avaibable window ancel equal to about one-thirtietlu of the total areat.

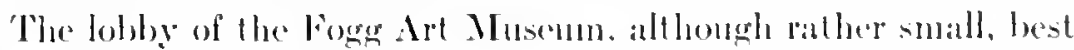
sitfisfed the desired conditions. Sixteren organ pipes were used, arranged four on each air tank and, therefore, neall logether. Thas arranged, the sixteen pipes had 7.6 times the internsity of once als

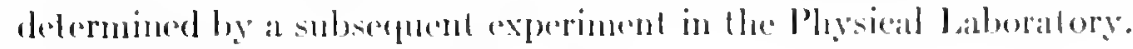
'The following results were obtained:

and

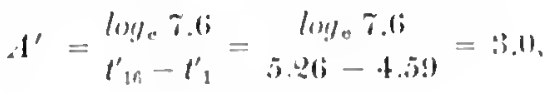

$$
\begin{aligned}
& t^{\prime \prime}=\frac{\log 907.6}{3.43-3.100}=4.7 .
\end{aligned}
$$




$$
K=\frac{1.8 .40}{\left.1.1^{\prime \prime}-.1^{\prime}\right)}=\frac{13.8 \times 1.8 .5}{96 \times 1.8}=.1 .56
$$

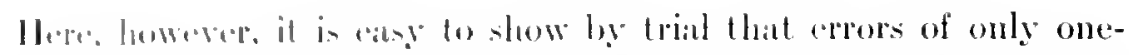

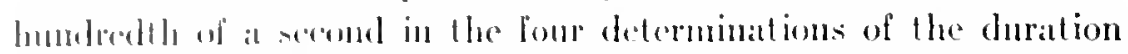
of the lenidnal sommel would, if additive. give at total crror of twenty prer cont in the roult.

It is impursibte, apereially with open windews, to lime with an

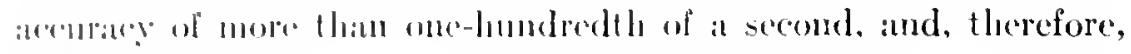
this furmulit.

$$
K=\frac{13.8 u^{\prime}}{\Gamma\left(. I^{\prime \prime}-. I^{\prime}\right)}
$$

while analytically exact and aflractive in its simplicity, is practically mureviceable on alecomt of the sensilive mamner in which the olserations enter into the alculations.

The bollowing intulysis, however, results in an equation much more forbidding in appearance, it is trur, but vastly better practi"ally. for it imolves the ditta of difficult determination only logarithmikally, and then only ats part of a compatratively small correcting term. For the room with the windows cloned:

$$
I^{\prime} t_{1}^{\prime}=\log \% I_{1}^{\prime}{ }_{1}
$$

and for standarl conditions in regard to initial intensity

$$
1^{\prime} T^{\prime}=\log _{\mathrm{c}} I \text {. }
$$

whrowe

henere

$$
\begin{aligned}
& T^{\prime}=t^{\prime}-{ }^{\prime} \log _{0} I^{\prime} I_{1}: \\
& T^{\prime} a=\mathrm{Kl}^{\prime},
\end{aligned}
$$

$$
K l=t_{1}^{\prime} a-{ }^{\prime} l^{\prime} \log _{\mathrm{e}} \frac{I_{1}^{\prime}}{I}
$$

and similate sege for the sume room with the windows open give

$$
K V^{*}=t_{1}^{\prime \prime}(u+w)-\frac{(u+w)}{l^{\prime \prime}} \log _{\mathrm{e}} \frac{l^{\prime \prime}}{l} .
$$

Multiplying the first of the last two ecpuations by $l_{1}{ }_{1}$, and the $\therefore$ acmul lig $t_{1}^{\prime}$.

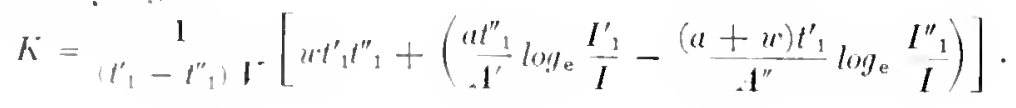


By. conation (j)

$$
\frac{a}{I^{\prime}}=\frac{s p}{r}
$$

and similarly

$$
\stackrel{a+w}{A \prime}=\frac{x p}{r}
$$

Substituling these values in the above cepral ion,

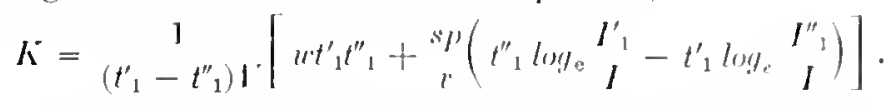

As an illustration of the application of the last equation, He case of the lobby of the Foger Art Musemm is lare worked ont at lengtl!.

$$
\begin{aligned}
& t_{1}^{\prime}=4 . .5 ! \\
& t^{\prime \prime}=3.00 \\
& l^{\circ}=9 \text { (с). m. } \\
& s=125 \mathrm{sq} . \mathrm{m} \text {. } \\
& u^{2}=1.86^{\circ} \\
& a=\frac{.1711^{\circ}}{t_{1}^{\prime}}=3.58 \text { as a lirst alproximation } \\
& p=9.8 \\
& I_{1}^{\prime}=\frac{p l s i s}{r a l^{\circ}}=8.8 \times 10^{6} i^{\prime} \\
& I_{1}^{\prime \prime}=\frac{p W^{\prime}}{r(a+w) 1^{\circ}}=5.8 \times 10^{6} i^{\prime}
\end{aligned}
$$

substituling these values in the above cepualion.

$$
K=\frac{1}{1.5 .2}[9.5 .7+1.02(6.53-8.1)]=.169-.010=.1 .59
$$

where the berm .169) is the value of $k$ that woukl be deduced dis-

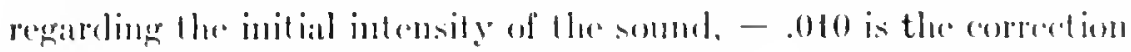

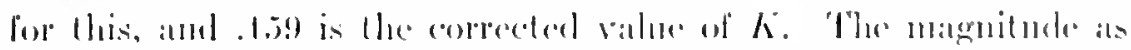

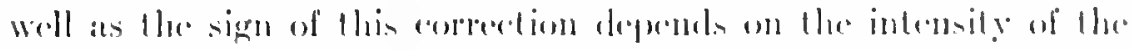
somere of somme. the size of the room and the matrerial of which it

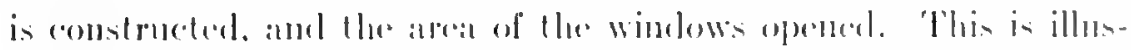

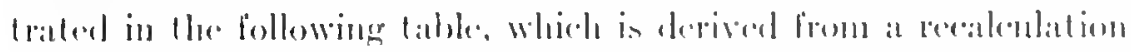

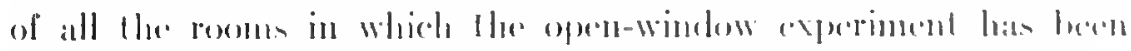

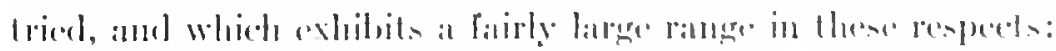




\begin{tabular}{|c|c|c|c|c|c|c|}
\hline llumert & r & $I^{\prime}$ & tr & $\begin{array}{l}\text { Incor- } \\
\text { rerted }\end{array}$ & $\begin{array}{l}\text { Cotrec- } \\
\text { tion }\end{array}$ & $\kappa$ \\
\hline 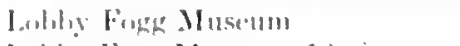 & 96 & $8.800,0001$ & 1.860 & .169 & -.010 & .1.5! \\
\hline 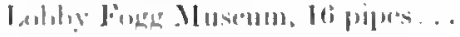 & 96 & $65,0001,000$ & 1.86 & .191 & $-.09 \tau$ & $.16+4$ \\
\hline 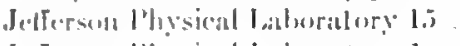 & $90 ?$ & $1.7011,006)$ & 5.10 & .164 & +.00 .5 & .169 \\
\hline 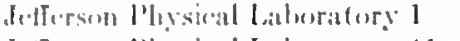 & $1,6: 30$ & $3: 90.61000$ & 19.0 & .150 & +.017 & .16\% \\
\hline \multirow[t]{2}{*}{ 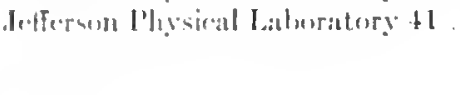 } & 1,060 & 300,000 & 16.0 & .137 & +.094 & .161 \\
\hline & & & Averi & val & of $K=$ & .164 \\
\hline
\end{tabular}

The value, $K=.164$, hatving been adopted, interest next turns to the lletermination of the alsorbing power, $a$, of a room. For this purpese we have choice of three equations, two of which have alrealy been diduced, (9) and (11),

and

$$
a=\frac{. l^{\prime} u}{. I^{\prime \prime}-A^{\prime}}
$$

$$
a=\frac{l^{\prime} \mathrm{KI}^{\prime}}{13.8}
$$

and a third equation may be obtained as follows:

It has bern shown that

:InI

$$
T^{\prime}=t_{1}^{\prime}-\frac{* p}{v a} \log _{\mathrm{e}} \frac{I_{1}^{\prime}}{I},
$$

$$
T^{\prime} a=K l .
$$

'Therefore

$$
a t_{1}^{\prime}-\frac{s p}{r} \log _{0} \frac{I_{1}^{\prime}}{I}=K l^{\circ}
$$

and

$$
a=\frac{1}{t_{1}^{\prime}}\left(K I+\frac{s p}{r^{\prime}} \log _{\mathrm{e}} \frac{I_{I}^{\prime}}{I}\right) .
$$

Of these three ecpuations the first, (9), for reasons already pointed out in regard to a similar equation for $K$, while rigorously correct, yiclds a result of great uncertainty on account of its sensitiveness 16. sight errors in the several determinations of the duration of the roidual soumd. The second, (11), is very much better than the first, but still not satisfactory in this respect. The third, (13), is wholly satisfictory. It has the sime pereentage accuracy as $t^{\prime}$, 
and the only elements of difficult determination enter logarithmically in a small correcting term.

As an illustration of the application of these erpuations we mate again cite the case of the lobly of the loogg Art Museme

hy equation (9), $a=\begin{aligned} & 3.0 \times 1.86 \\ & +.7-3.0\end{aligned}=3.3 ;$

by ecpuation (11), a $=\frac{3.0 \times .16 .4 \times 96}{13.8}=3.4$;

by ecpuation $(13), a=\frac{1}{4.59}\left(.164 \times 96+1.09 \times \log _{\mathrm{e}} 8.8\right)=3.8$.

The first two are approximate only, the last, 3.8, is correct, witl certainty in regard to the last figure.

'l'here is but one other subject demanding consideration in this way, - the calculation of the absolbing power of objects frought inte the room, as cushions, drapery, clatirs, and other furniture. 'This may he atpproateled in two ways, either by means of the rate of decaly of the somnd and the fonr organ pipe experiment, or ty. open-window calibration and a single organ pipe.

Let. $f^{\prime \prime \prime}$ be the rate of decay when the object is in the room, . t $^{\prime}$ being the rate when the room is empty. 'Then if $a$ ' in the absorbing power of the olsecet:

$$
a=\frac{l^{\prime} \mathrm{KI}^{\circ}}{13.8}
$$

atid

$$
a+a^{\prime}=\frac{\mathrm{I}^{\prime \prime \prime} \mathrm{KI} \mathrm{I}^{\prime}}{13 . \mathrm{s}} .
$$

Whincere

$$
a^{\prime}=\left(. I^{\prime \prime \prime}-. \mathrm{I}^{\prime}\right) \frac{\mathrm{KI}^{\circ}}{13 . \mathrm{S}^{\prime}}
$$

Or from the other poinl of vien, enpation (13),

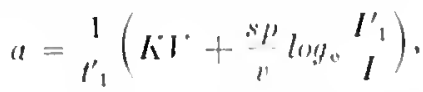

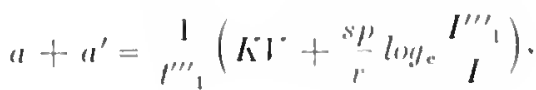

whenere

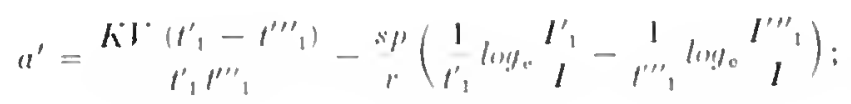




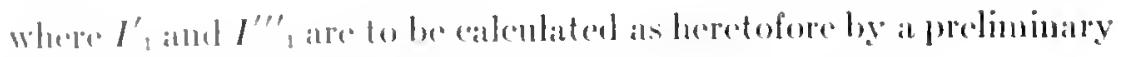
and alpuroximate estimate of a amd $a^{\prime}$.

Il.re also it is assy to show a priori that the first cefuation, (1t), while perferetly correct and amalytically rignoms, is excessively somstive to very slight arors of observation, and that on this ac-

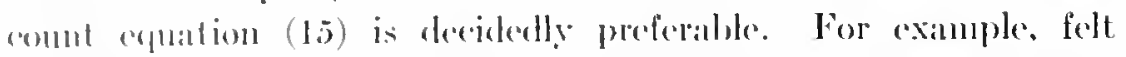
being bromght inte the lohbe of the Foger fecture-room and placed on the floor. the values of . $I^{\prime \prime \prime}$ and $t^{\prime \prime \prime}$, were determined to be, re- pectively, t.9 and 2.79. Bomowing from the preceding experiment, and substituting in erpuations (1.t) and (15) wo have

$$
\begin{aligned}
& a^{\prime}=(4.9-3.0)^{.16 .4 \times 96}+13.8=9.9,
\end{aligned}
$$

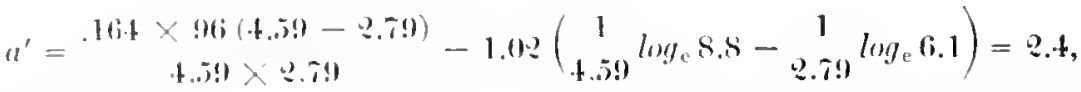

a very sationetory agrennent in vicw of the extreme sensitiveness of arpuation (1t).

Thus three expations hase been deduced, number (12) for the calculation of the paranceter, $l_{\text {, }}$ (13) for the absorling power, $a$, of the wall-strfice, and (15) for the absorbing power. $a^{\prime}$, of introduced material. Each has heen verified by other equations amalytically rigoroms, and developed along very diflerent lines of attack. In arch casce the agrecment was satislactory, especially in view of the extrene sensitiveness of the equations nsed as checks.

In the succeding paper will be deduced, by the method thus cotablished, the cocfticients of absorption of the materials that are used ordinarily in the construction and furnishing of an auditorium.

\section{TIIE ABSORBING POWER OF AN ALDIENCE, ANI O'THER DA'TA}

Ix this paper will be griven all the data ordinarily necessary in calculating the reverberation in any anditorimm from its plans and -precifications. In order to show the degree of confidence to which these data are entitled a very hrief account will be given of the experinents he means of which they were obtained. Such an aceomt is enpecially necessiry in the case of the deternination of the alsorbing power of an andience. This cocflicient is, in the nature 
of things, a factor of every problem. and in a majority of cases it is one of the most important factors; get it can he determined only throngh the courtesy of at latge number of persons, and aven then is attended will difficulty.

The formulats that will be used for the andenlation of alsorbing power are mumbers (19) and (15) in the preceding piper, the correcting terms being at times of considerable importance. The applieattion of these formulas having been illual rated, the whole discussion here will be devoted to the conditions of the experiments and the results obtained.

In every experiment the mavoidable presence of the olsereser increases the absorhing power. In small rooms, and in latroce rooms if bare of furniture, the redative increatse is considerables and should always be subtracted from the immediate results of the experinent in corder to delemine the alsorbing power of the room alone. "The' quantity to be subtrated is constimt, provided the silme clothes are always worn, allel may be determined once for all. For this determination another observer makle a set of experiments in a small and oflerwise empty room before and after the writer had entered with a duplieate set of appialialus, - air tank, chronograph, and bitlerye In fact, two persons mate independent observations, giving consistently the result that the writere in the clothes and with the apparalus comstimtly employed, haul an alborl,ing power of 48 of a mute. For the sake of lorerity no further mentien will be made of this, but throughout the work this correcetion is applied wherever necessary.

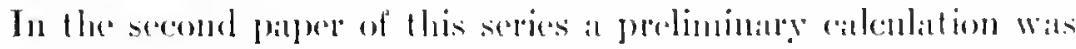

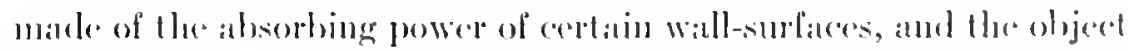

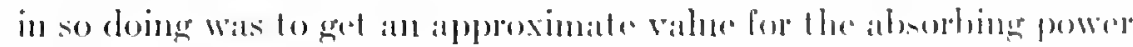

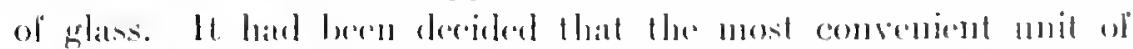

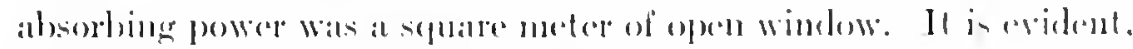

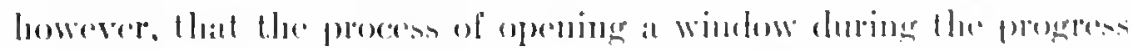

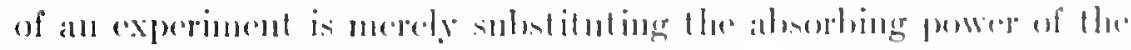

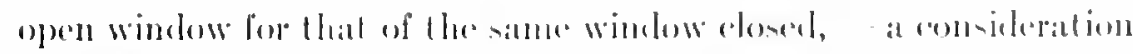

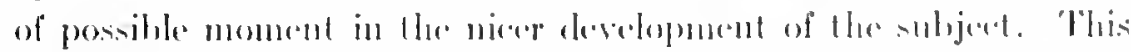

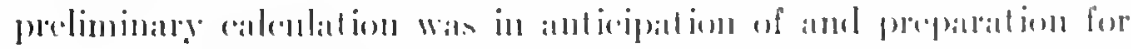

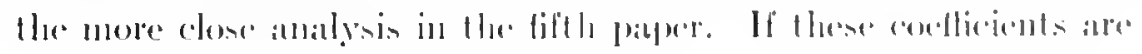


now catlenlathed, maing the corrected formulas of the fifth palper, we arrive at the following renults: ('oment. and brick sed in cement.

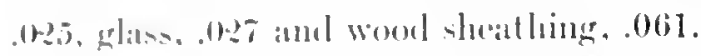

'The apperincuts in the Boston Public Library gave results that are interesting from several points of view. The total alsorbing

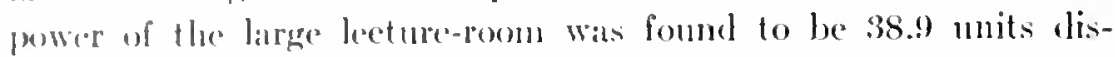
tribulal an follows: A platform of pine sheathing. exposing a total atreab of 70 sefluare meters, hat an alsombing power of $70 \times .061=4.3$; 7. stuare meters of ghass windows had an absorbing power of $7: \times 0.37=1.9:$ three large oil paintings, with a total area of 17.4 stunare meters. had an absorbing power of $17.4 \times .98=4.9$; the romainder. 97.S units. was that of the cement floor, tile ceiling, and planter on tile walls, in total areat 1,095 sequare meters. 'This gives as the coeflicient of alsorption for such construction .0254. A similar calculation of results obtained in the attendant's room in the sime builaling - a room in which the eonstruction of the floor, witls. and ceiling is similar to that in the lecture-room - gives for the value of the coeflicient, .0955. The very close agreement of thene results, and their agrecment with the coeffieient, 0.051 , for coment floor and solid walls of briek set in cement in the constanttemperature room, is satisfactory. However, al far more interesting consideration is the following:

Irectofore in the argument it has been assumed, tacitle, that the fotal absorption of sound in a room is due to the walls, furniture and andience. 'There is one ofler possible absorbent, and only one' - the viscosity of the vibratiug air. It is now possible to present the argument that led to the conchusion that this, the viseosity of the air throughout the body of the room, is entirely negligible in comparison with the other sources of absorption. These two rooms in the Boston Public Library - the lecture-room and the attendant's rom - had, in their bare and unfurnished condition, less absorthing power in the walls than any other rooms of their size yet fomml. 'lherefore, if the riscosity of the air is a practical factor it ought to have shown in these two rooms if ever. Fortunately, also, the two rooms differed greatly in size, the volume of one being about thirty-live limes that of the other. While the ratio of the areas of the wall-surfaces was about twelve. 'That part of the absorption 
due to the walls wats proportional to the areas of the walls, and the part due to the viscosity of the air wits proportional to the volumes of the rooms. As a matter of fact the experinents in these two rooms showed that the whole absorthing power was aceurately proportional to the areas of the walls; how arecurately is abmedantly evidenced by the agreement of the $t$ wo coefficients, $025 t$ and .0255 , deduced on the supposition that the viscessity of the air wats negligible. 'To express it more precisely, hand the riscosity of the air been sufficient to produce one-fiftieth part of the absorption in the attendant's room, these two coefficients would have differed from each other by four per cent, an easily measurable anount. It is safe to conclude that in rooms as bare and nonabsorbent als these the viscosity of the air is inconsilerable, and that in at room filled with an andience it is certainly whotly negligible. Rooms nore suitable for the demonstration of this point than these two roons in the Boston Public Library could hardly be designed, amel access to them Wis good fortune in settling so directly and conclusively this fundatmental question.

The experiments to detemine the absorbing power of plistered walls show it to be variable. If the plaster is applied direetly to tite or brick the absorbing power of the result ing solid wall is mi-

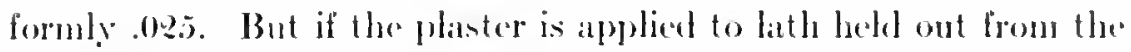
solid wall by studeling, the atsorbing power is not nearly so const ant. varying in dillerent roonss. 'l'he investigation of this hats not been carried far emough to show with absolute certainty the canses, althenesh it probably arises from the diflerent thiekness in which the plaster is applied. For the examination of this point two nuedes of procedure alre posible. - experinenting in a lange number of reoms, or experimenting in one room and rephistering in many

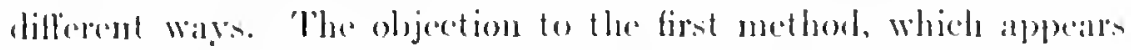

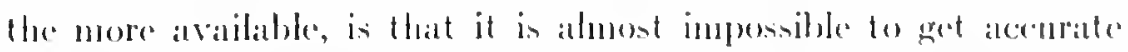
information in regand to the nature of at wall unless one hats complete control of the comstruetion. Ifowerere, there are problably interest-

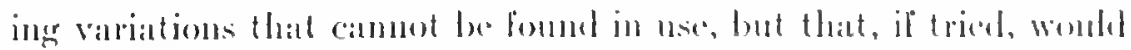
be frutful in sugresestions for fulure construction. The second method - experimenting in one room, phistering and replintering

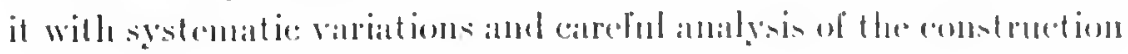




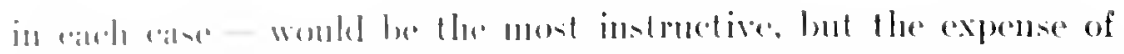

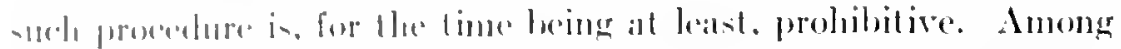

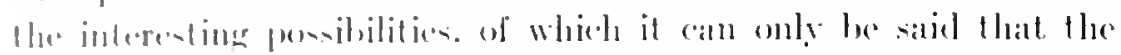

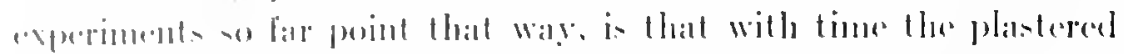

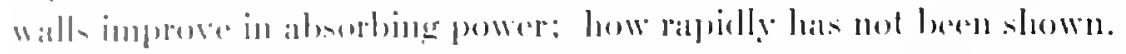

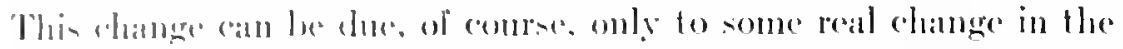

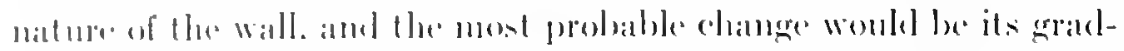

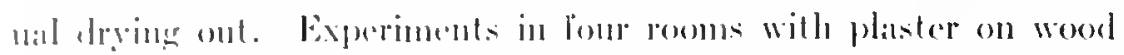

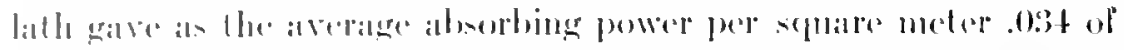

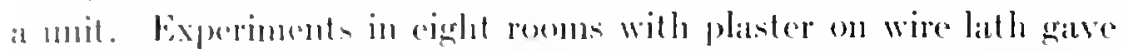

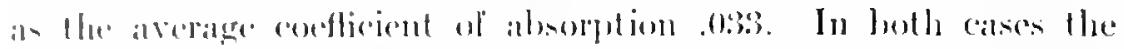

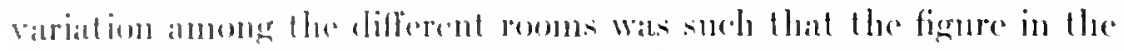

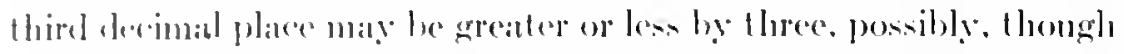
not probably. ha nome. The lacet that a comsiderable part of the wall-surface of sereral of the reome was of meertain construction is partly responsible bor this nurertainly in regated to the cocfficient.

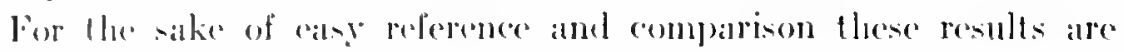
labulated. the unit being the alsorhing power of a sefuare meter of open-window areat.

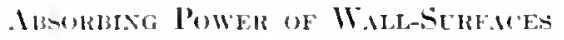

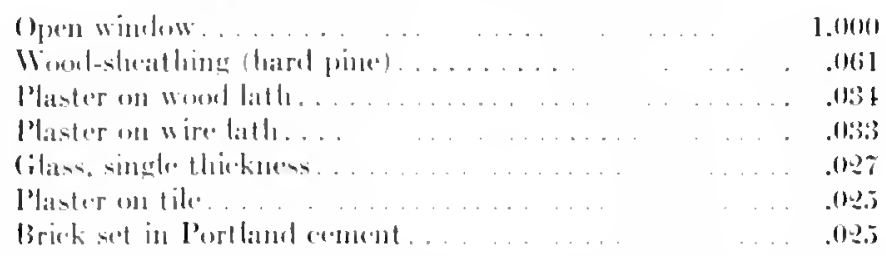

Fext in interest to the absorbing prower of wall-surlatees is that of an andience. During the smmuner of 189\% at the close of a lecture in the Fogg Ant Wusemm. the duration of the residual somel was dedermined hefore and immediately after the andience left. 'The pattenese of the andience amel the silenee preserved ledt nothing to les derext in this direcetion, but a slight rain falling on the roof seringly interfered with the observations. Nevertheless, the result,

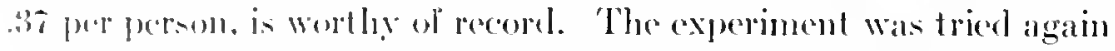
in the smmmer of 1899. wh a much more claborate scale and under the ment liscrablu conclitions, in the large lecture-room of the Jellenen l'hisical Laboratory. In order to get as much datia and 
from is independent sources ats possible, three dhronegralphis were electrically connected with aitch other and with the electro-pnenmatic valve controlling the air supply of the organ pipe. One deronggraph wats on the lecture-table. and the others were an opposite sides in the reall of the hall. The one on the table was in charge of the writer, who also controlled the key luming on and ofl

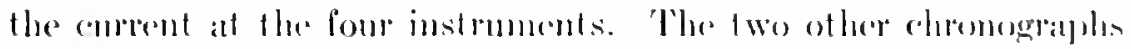

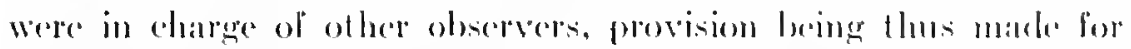
there independent determinations. Alter at test hatel been mille of

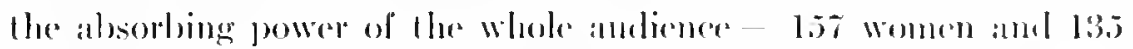

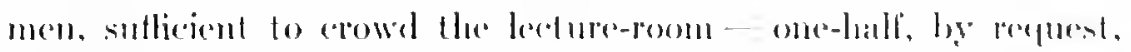
palssed ont, 63 women and 79 men remalining. and observation. were again made. On the following night the lecture was repeated and observitions were agalin taken, there being present 95 women and 39 men. There were thens six independent determinations on three different andiences, and by there observers. In flue following talble the first colmon of figures gives the total absorbing power of

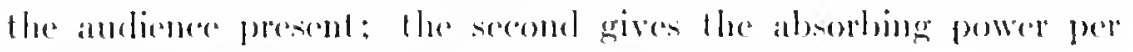
person; the intials indieate the of server.

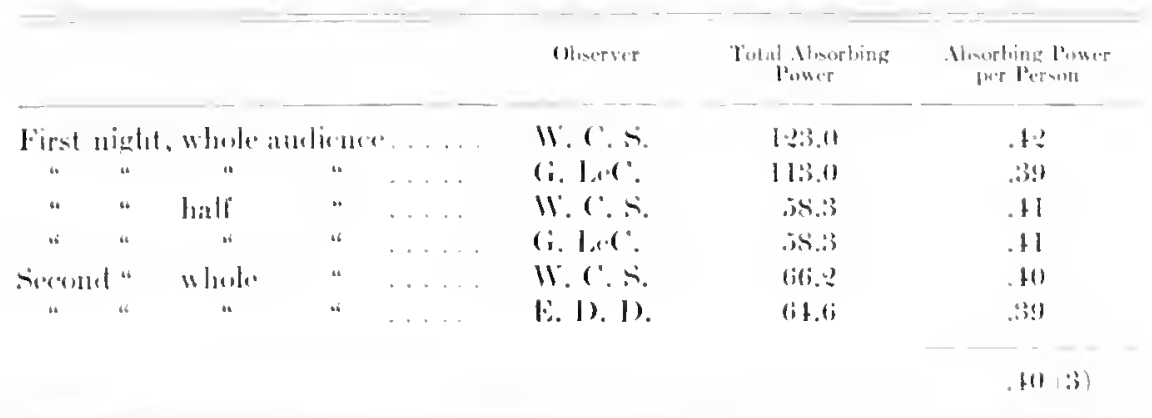

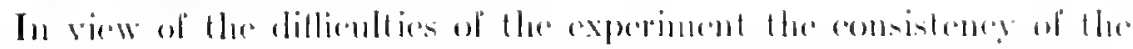

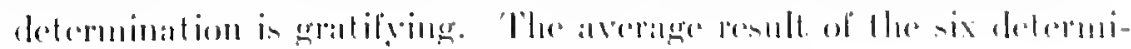

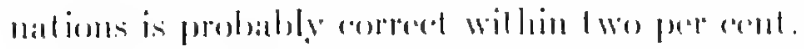

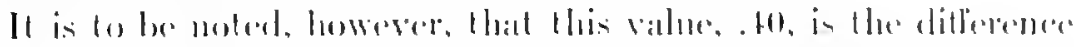

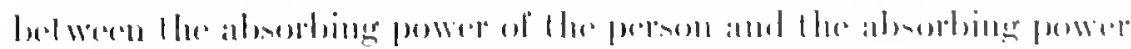

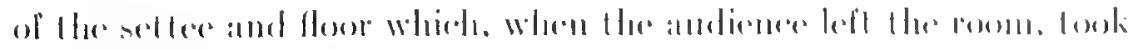

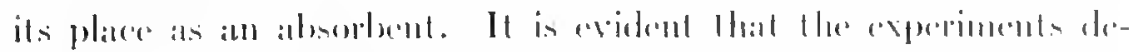

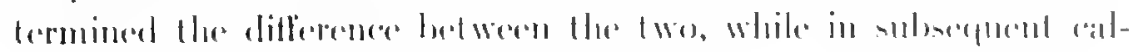


colat ions we hall be concermed with the absolute absorbing power of the amdiente. 'lo delerminse this. on a lollowing night all the selters were ratried ont of the rooms observations being taken be-

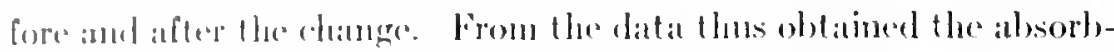

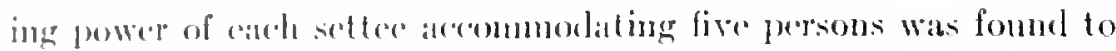
le .083). or for a single soat .007\%. Of nereessily the floor still rematimel. but from a knowledge of its construction the alsorbing powere of as muleh of the floor ats is corered by one person was calcollated to be .030. Adding these together we ged as the ahsorbing power of an atulience, seated with noderate compactness, .4t per persoll.

In some subseduent work it will be necessary to know the absorbing power of an andience, not per person, hut per square neter, the andicner being regatred broatly as one of the bounding surfitces of the room. As each person oceupied on all average .t6 of a stpuare meter of floor areat, it is evilent that the absorbing power per siplate meter wals .9ti of a mit.

Inder certain circumstances the andience will not be compactly satcel, but will be seattrerel about the roon and more or less isolated. for eximple, in a council-room, or in a private music-room, and it is crident that under these conditions the individual will expose a greater surface to the room and his absorbing power will be greater. It is at matter of the greatest case to distinguish between men and wonen coming into a small room, or even between different men. In fact. early in the investigation, two months" work - over three thousand observations - had to be disearded hecause of failure to record the kind of elothing worn by the observer. 'The coefficients given in the following table are averages for three wonen and for sevell men, and were deduced from axperiments in the constantfomperature joom.

\section{A Bsorbaxg Power of AN AUdexce}

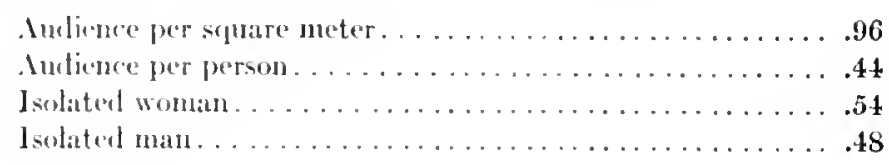

When an andience fills the hall one is but little concerned with the nature of the ehairs - acoustically, but otherwise this becomes 
a matter of considerable inprortance. The settees in the lectureroom of the Physical Laboratory, aldeady mentioned, are of planin ash, and have solid seats, and vertical ribs in the back: they are without upholstering; and it is interesting, in oreler to note the agreement, to compare the alsorling power of such settees prer single scat, .0077, with that of the "hent wool" cluairs in the Boston Public Jibrary, .0082, which are of similar character. In contrast maly be placed the chairs and sottees in the faculty-room. which have cushions of hair covered with leather on seat and back. In the same table will be entered the absorbing powe of Sanders Theatre cushions, which are of hair covered with canvas anel hight danntsk, and of elastic-felt cushions - cotton covered with cordurox.

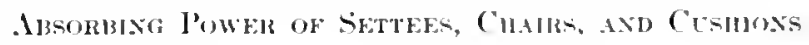

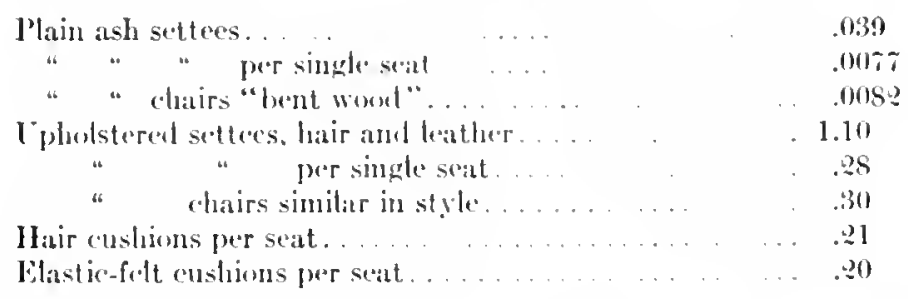

A case has arisen even in the present paper where it is necessary to know the absorbing power of paint ings on canvas. and the question mily not infreguently arise ats to how much service is serenred - or injury incured - aconstically by theje use in particulat roons. 'Tlese oil paintings in the laculty-roon, $1 !$ in number, with

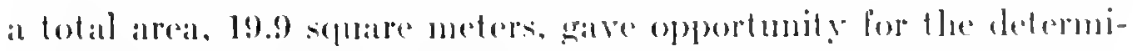
nation of the desired coeflicient: but a duestion arises in regatrel to

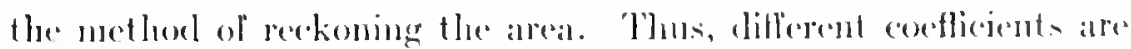

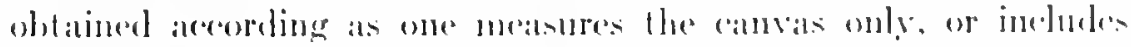

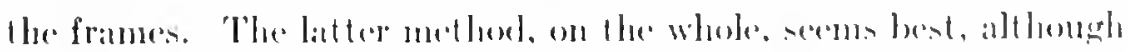
most of the ahoorption is probably by the cambar.

The coeflicient for hense plints. which mily be of palsing. and

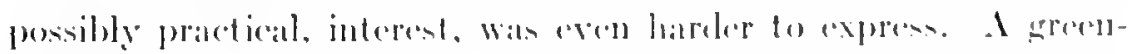

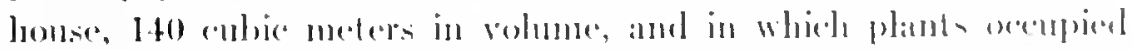

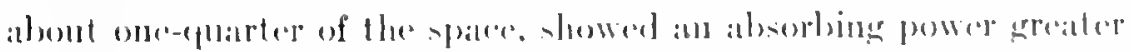

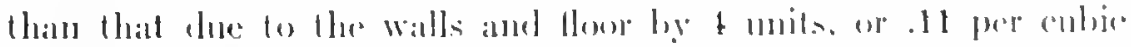

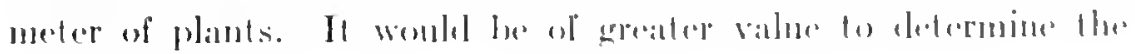




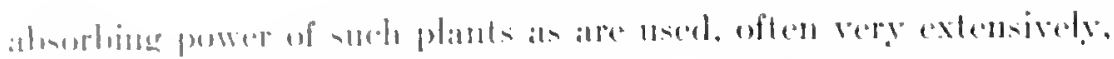

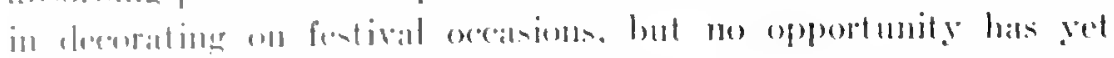

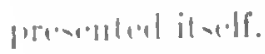

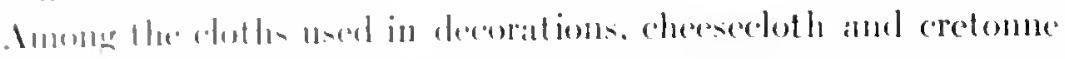

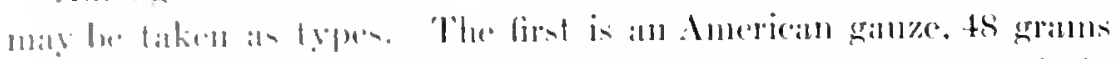

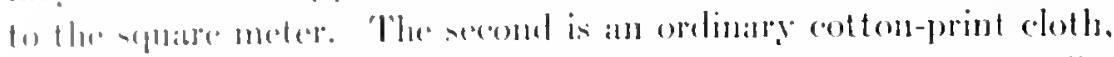

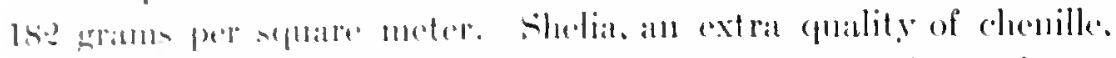

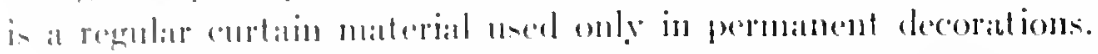

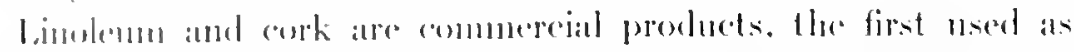
flour covering and the second in Walls. Botls were tested lying

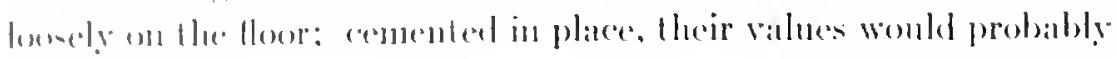
he ditlionent.

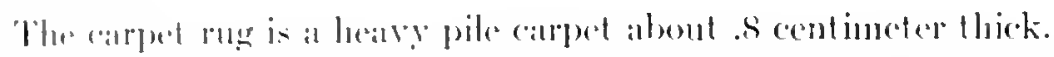

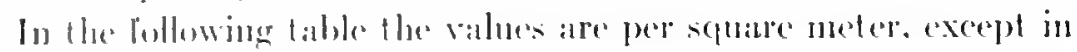

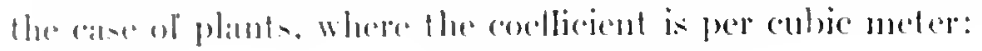

Minr follaneol's

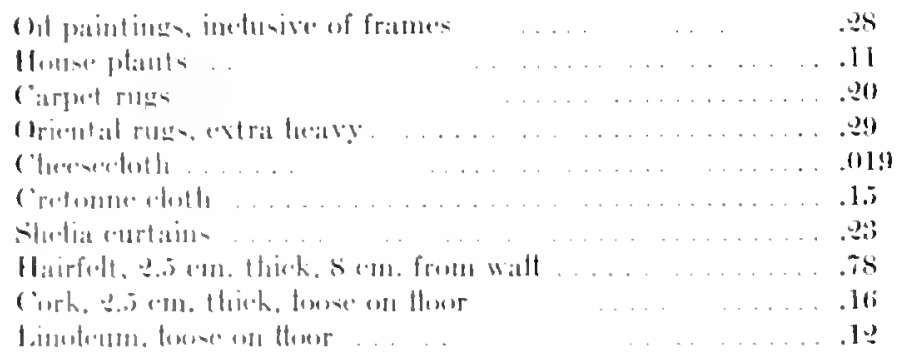

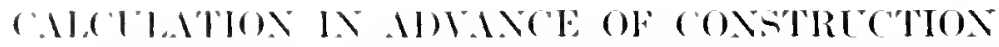

In Hor present papere it in the purpese to show the application of

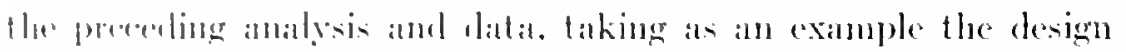
of the new Buston Mure Mall' now under construction. Messrs.

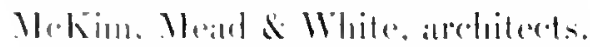

Ju the introulusetery paper the weneral problem of arehitectural

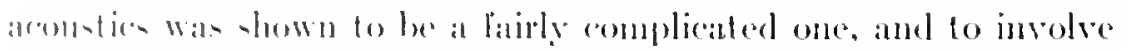

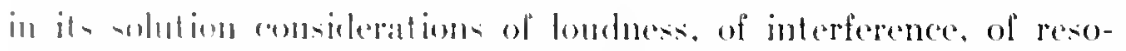

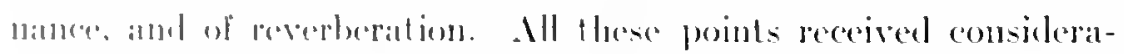

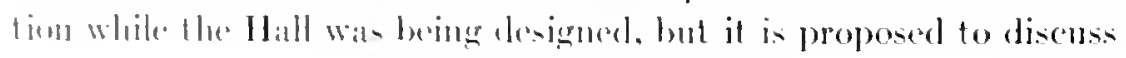


here only the case of reverberalion. In this resperet a music hall is peculiarly interesting. In a theatre for dramsatic performances, Where the music is of cotirely subordinate importance, it is desirable to reduce the reserberation to the lowest possible value in all ways not inimical to londuess; hut in a music hall, concert room, or operat house, this is deciededly not the catse. To redued the reverberation in a hall to at minimum, on to make the conditions such that it is very great, maty, in certain cases, present practical diflicultien to the architeret - theoretically it presents noure. To arljust, in original design, the revertertation of a hall to a particular and alpproved value recpuires at stmey of conditions, of materials, and of arrangement, for which it has been the object of the precerding palpers toprepare.

It is not al all diflicull to slow a priori that in a hall for oredesetral music the reverberation should meither be very great, nor, on the ofleer hamd, extremely smatl. Ilowever, in this matter it was

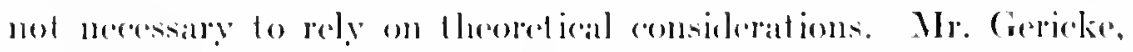
the enductor of the Beston simphong (Brehestra, mate the statement that an orehestrit, meaning hy his a sympluony orelestrat, is never leeard to the best alvalutage in a theatre, that the somed

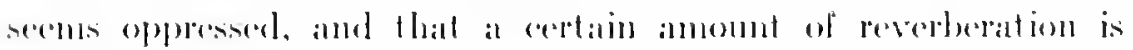
meressitry. An eximinaltien of all the available planse of the halls.

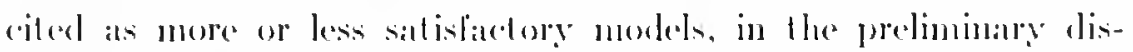
cossion of the plans for the new hatl, slowed that they were surds

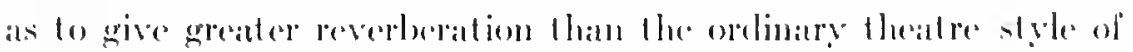

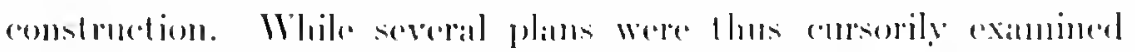

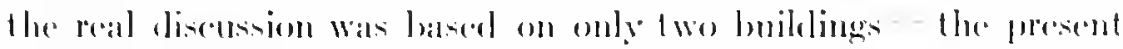

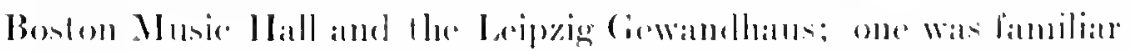

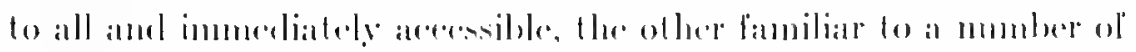

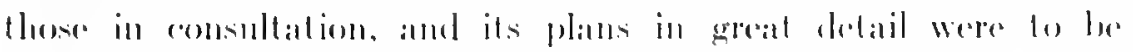

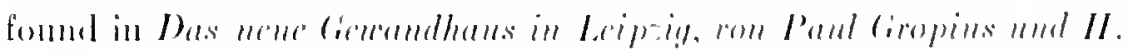

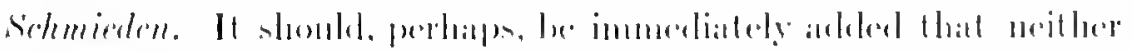

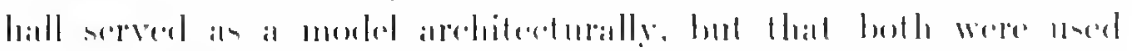

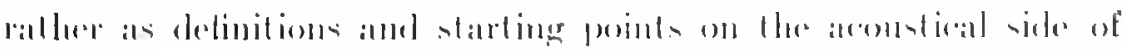

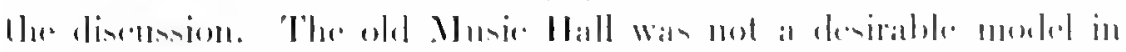

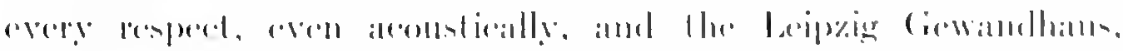

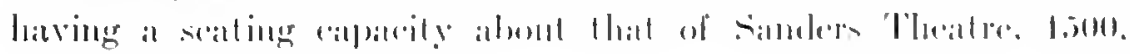




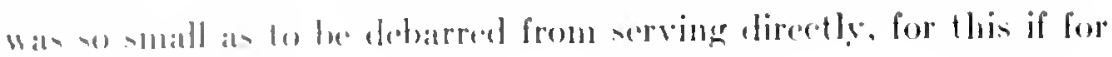
II6) (1ther reamoll.

"The histery of the mew hall is about as follows: A mmober of

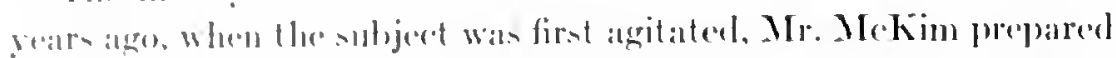

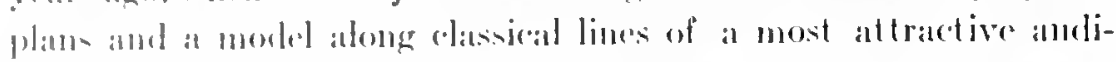
torimm, and ifterwards, at Mr. Iliggmons instanee, visited linrefere for the purpose of consulting with musical and scientific

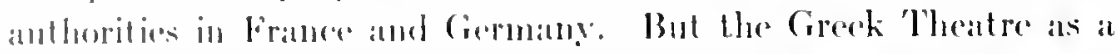
monsc hatl was an untried experiment, and becanse untried was regarded ats of uncertain merits for the purpose by the conductors (emsulted he Mr. Ifigrinson amd Mr. MrKim. It was, therefore,

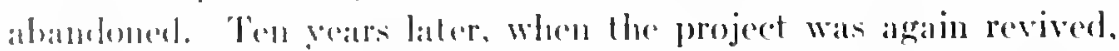
the anrentional rectangulat form was adopted, and the intention of the huilding committere was fo follow the general proportions and arrangement of the leipzig (iewandhats, so conlarged as to increase

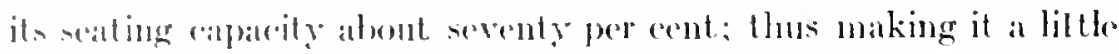
more than equal to the old hatl. At this stage catculation was first «p)lierl.

'Tlue often-repeaterl statement that a eops of an auditorium does not neressitrily possess the same acoustieal qualities is not justified. and invests the sulject with an unwarranted mosticism. the fare in that exiet repies have rarely been made, and ean hardly le expreted. The comstant changes amd improvements in the mat terial maed for interior construction in the line of better fireproofing - wire lath or the application of the plaster direetly to tile walls latre lod to the taking of liberties in what were perdaps regarded as nonesentials: His lass pesulted, as shown by the lables, in at rhangul absorbing power of the walls. Our increasing demands in regard to heal and rentilation, the restriction on the dimensions "nforede by location, the changes in size imposed by the demands for sating aprater. have prevented, in different degrees, copies from being copies, and models from successfully serving as models. $\therefore$ dilferent have beren the results nuler what was thought to be

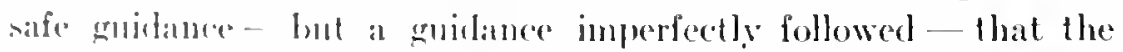
bedief has beeome enrrent that the whole subject is beyond eontrol. Hat the new Music Hall beron culargerl from the Ieipzig Gewandhans to increase the satting caparity seventy perent, whieh, proportions

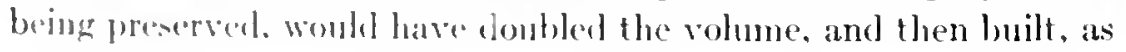


it is being built, according to the most modern methods of fireproof construction, the result, unfortunately, would have been to confirm the belief. No mistake is more easy to make than that of copying an auditorim - but in different materials or on a different seale - in the expectation that the result will be the same. Every departure must be compensated by some other - al change in material by a change in the size or distribution of the andlience, or perhaps by a partly compensating change in the material used in some other part of the hall - a change in size by a change in the proportions or shiaje. For moderate departures from the moded such compensation can be mate, amel the model will serve well as a gnide to a first approxinnation. When the departure is great the approved anditorium, monse discriminatingly used, is liable to be a treacherous guide. In this ease the departure wits necessarily great.

The comparison of halls should be based on the duration of the resielual sound after the cessition of al source that hals producerl over the hall some standarel average intensity of somel, - say one million times the minimum andible intensity, $1,000,000) i^{\prime}$. The means for this calculation was furnisheel in the fifth paper. "Tlue values of $l$ and a for the three halls umler comparison alre shown on the next page.

The length given for the lapeig Gewandhans, 38 meters, is measured from the organ front to the arehitecturally principal wall in the rear. On the floor and by boxes in the balconies the seats extend 3 meters larther back, making the whole length of the hall, exclusive of the organ miche, tl meters. This increalses the volume of the latll abent 900 enbie neters, making the total volume 11 , 400 culic meters.

The height griven for the new Boston Musie IIall, 17.s, is the average leeight from the slepping fleor. 'The length is meatsured on the floor of the main part of the habl; alsere the second gallery it

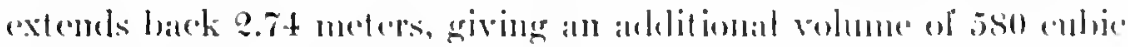
meters. The stage, insteald of being ont in the room, is in al contracted recess having a depth of 7.9 meters, at breatllh. Promt amel back, of 18.3 and 13.6. respretively, and a height. front and back, of 13.t and 10.6, respeetively, with a volume of 1,500 culbe meters. 'The heeight of the stigne recess is determineel hye the absolute re- 


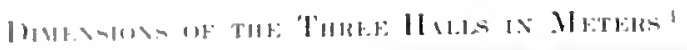

1. . Inth

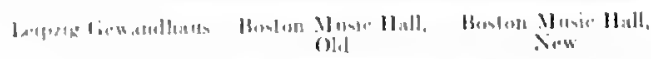

(16.:300)

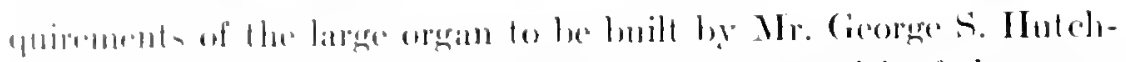
inger. This orean will extend anewes the whoke breadth of the stage. The lotal volume of the new Boston Mlusie Itall is, therefore.

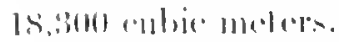

la Ihe following lathe of materials in the there hatls no distinction

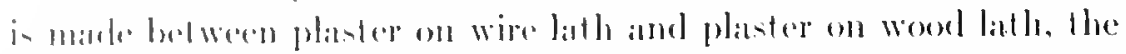

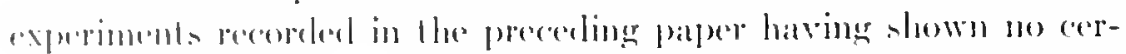

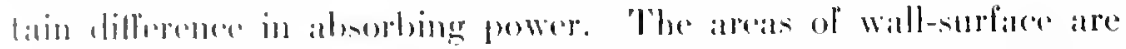

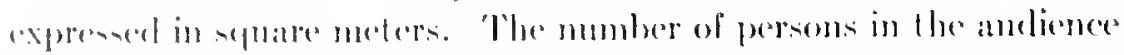
i. reetenest from the number of seats, no areount being taken of stauling roment.

\begin{tabular}{|c|c|c|c|}
\hline & 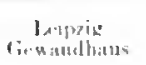 & 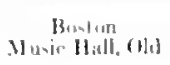 & 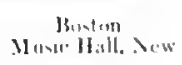 \\
\hline |. & $(1: 1$ & 1239 & $11: 301$ \\
\hline Bremillib & fie & 37 & 3.5 \\
\hline Il-izhth & IX & fiti & 59 \\
\hline Vialumu & $H(m, 18 m 6$ & $(i, 5 t, n)(0)$ & $(555,01011)$ \\
\hline
\end{tabular}

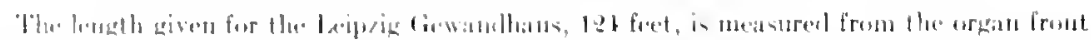

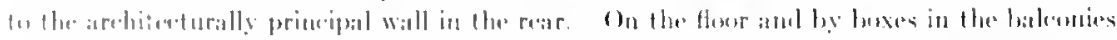

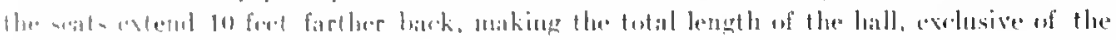

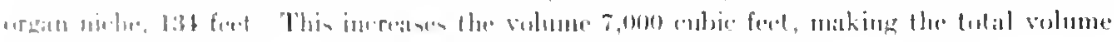
41).

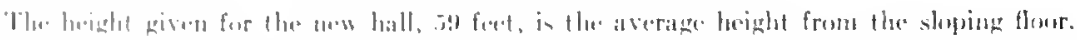

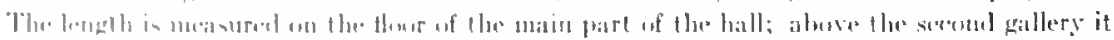

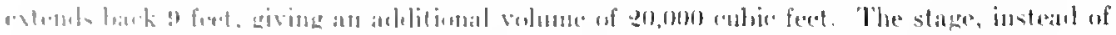

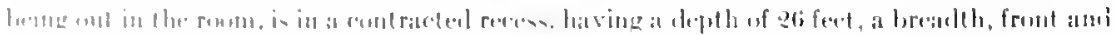

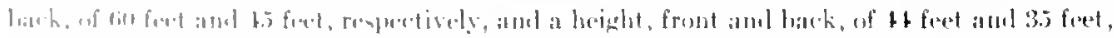

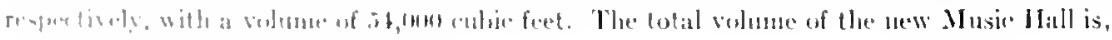

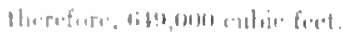




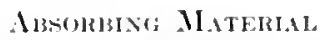

\begin{tabular}{|c|c|c|c|}
\hline & 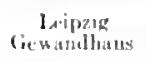 & Bonton, Whate Hall, & $\begin{array}{c}\text { Buntun Music Hall, } \\
\text { Aiew }\end{array}$ \\
\hline Plaster on lath . . . . . . . . & $\because .806$ & $3,11,30$ & 1,040 \\
\hline Plaster on tile. . . . . . . . . & 0 & 11 & $1.8: 30$ \\
\hline (ilitss. . . . . . & 17 & 5.5 & 99 \\
\hline 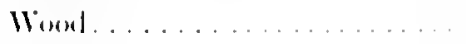 & 然.5 & $i i 1$ & (0.9.5) \\
\hline 1)rapwry . . . . . . . . . . . . & 80 & $t$ & 0 \\
\hline 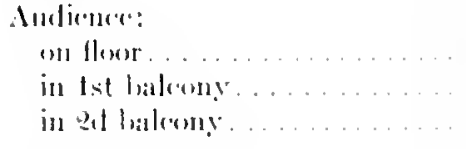 & $\begin{array}{r}990 \\
494 \\
333\end{array}$ & $\begin{array}{r}1.2 .51 \\
680 \\
+60\end{array}$ & $\begin{array}{l}\text { 1. f(iti } \\
\text { (ii)ti } \\
\text { inti }\end{array}$ \\
\hline 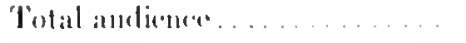 & 1.517 & 2.391 & $2.57 ! 9$ \\
\hline Oriduestra . . . . . . . . . & 80 & so & 80 \\
\hline
\end{tabular}

The trapery in the Leiprig Gewandhats will be rated as sheliat, and in the old Musie Itall ats tretomme, to which it approximates in each case. It is an almost needlless refincment to rate differently the orehest rat and the andience merely because the members of the orelestrat sil more or less cleatr of each other, hut for the sake of at certain formal completeness it will be done. For the abowe materials the coefficients, taken from the precenling palper, are as follows:

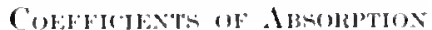

\begin{tabular}{|c|c|c|c|c|}
\hline 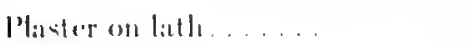 & & & & \\
\hline Plaster on tike. . . . . . . . . & & & & \\
\hline Gilass. .. $\quad \ldots \quad \ldots \quad \ldots . \quad \ldots$ & $\ldots$ & & & \\
\hline Minnl ............. & .. . & $\cdots$ & . & \\
\hline 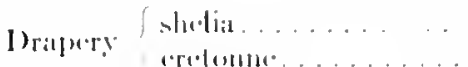 & ... & & & \\
\hline 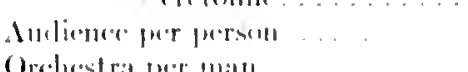 & $\cdots$ & & . & \\
\hline
\end{tabular}

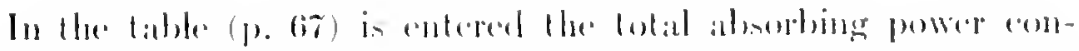

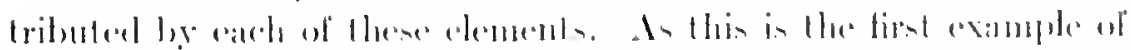

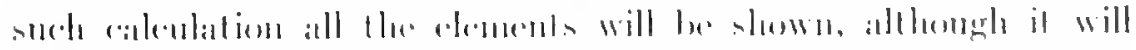
then be inmerliately evident that sume atre of wholly megligible matrinitule. 


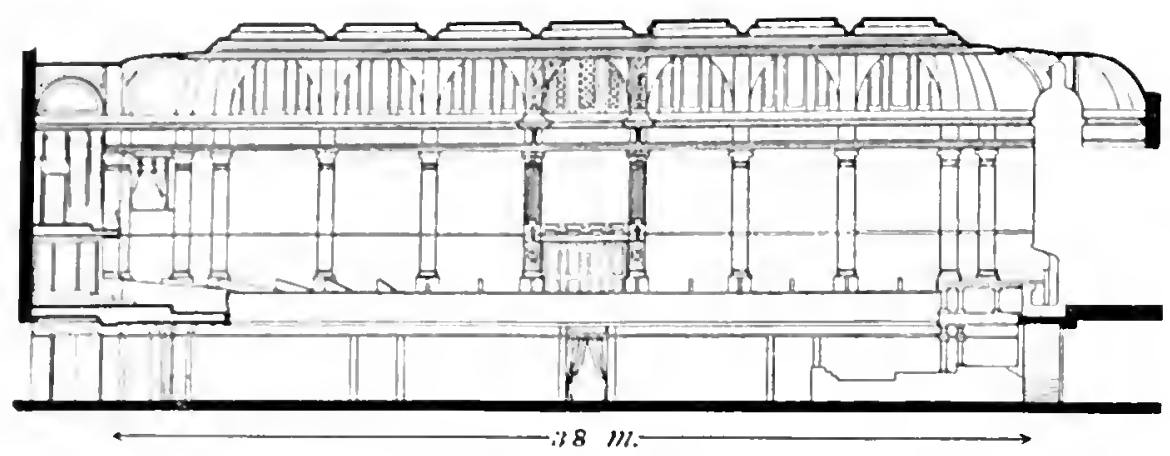

lik. 20. The leciprig (iewandhaus.

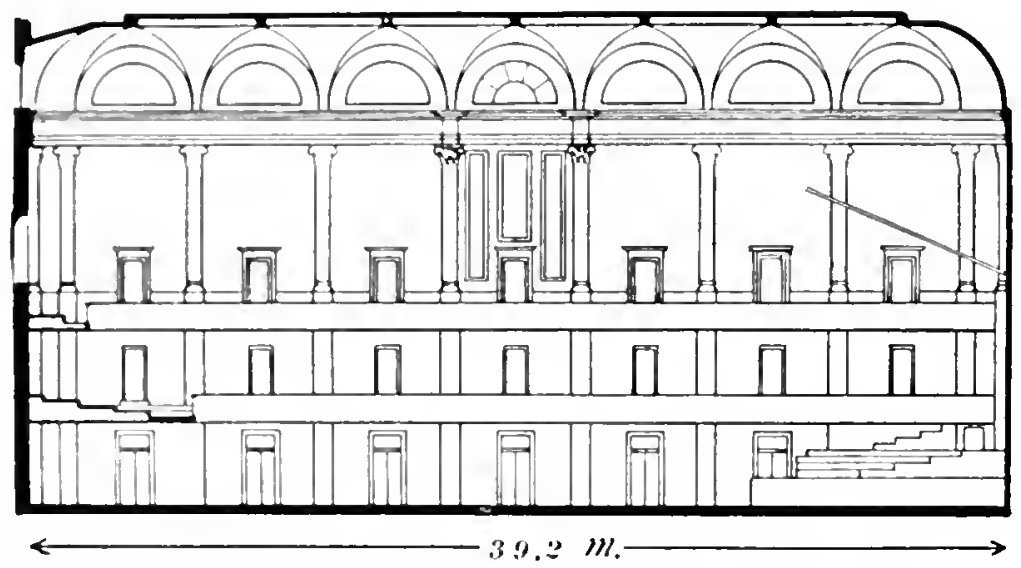

Fig. 21. The Ohl Boston Music Hall.

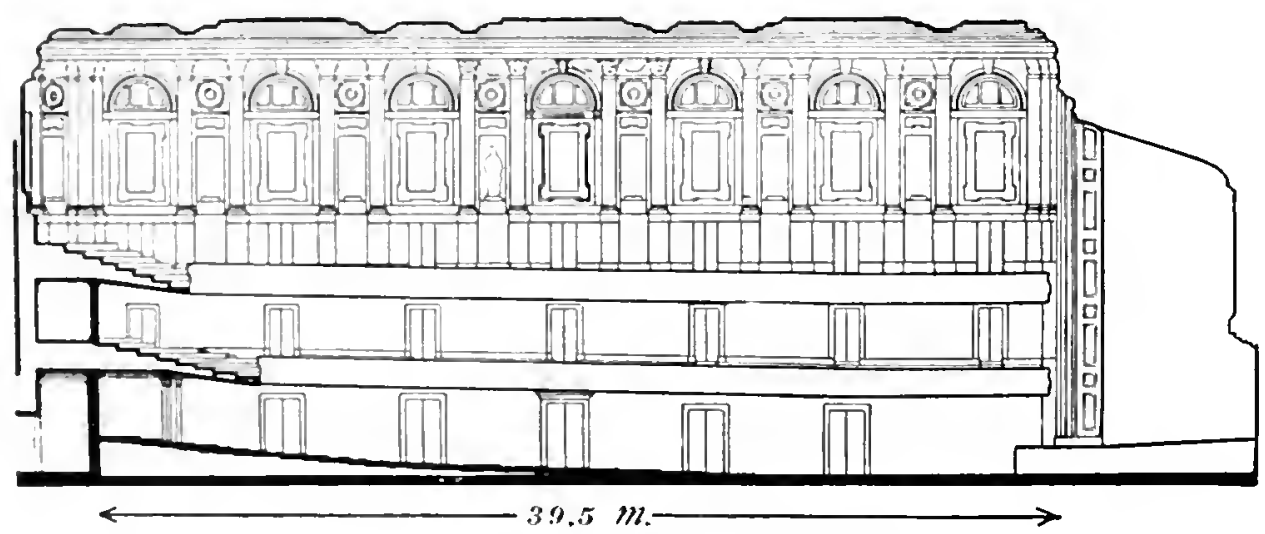

Fig. 然. The Lim Buton Music Hall. 
ABSORHING POWER

\begin{tabular}{|c|c|c|c|}
\hline & $\begin{array}{l}\text { Leipzig } \\
\text { Gewandbus }\end{array}$ & 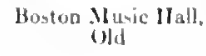 & 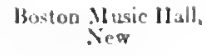 \\
\hline Plaster on lath . . . . . . & 73 & 100 & 34 \\
\hline I'laster on tile. . . . . . . . . . . . & 0 & 11 & 46 \\
\hline Glass. $\quad \ldots \ldots \ldots \ldots \ldots \ldots$ & 0.4 & $1 . .5$ & $0.6 \mathrm{i}$ \\
\hline Woort.......... & $1+$ & $4 \pi$ & 38 \\
\hline Drapery . . . . . . . . . & 18 & 0.6 & 0 \\
\hline Audicnere . . . . . . . . . . . & 667 & 1,052 & $1,1: 35$ \\
\hline Orchestral. . . . . . & 38 & 38 & 38 \\
\hline lotal $=a$. & 810 & 1.230 & 1.292 \\
\hline
\end{tabular}

1 and a being determined for each of the three hatls, the durattion, $T$. of the residnal sound alter stimetarel initial intensity can be (iilculated.

The results, in seconds, atre ats follows:

Inoprig Ciewandlatus.

(M)1 Boston Music I1all...

In other words, the new hall, althongh hatving at sealling calpalcity for over at thousand more than the Gewallothans and neally two lumdred more thatn the old hall, will have a reverberation between the two, and neatrer that of the Gewandhatus than that of the old hall.

It is interesting to contrast this with the result that would harve been obtained had the plan heeen followed of reproducing on an enlarged sate the Gewandhatus. Assuming perfect reproduction of all proportions with like materials, the volume would have been 95.300 culbic meters, and the atborbing power 1,370, resulting in the

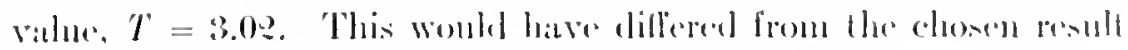
by an amount that would have heen very notichathe.

The new Boston Musie. IIall is, Hererere, not a copy of the

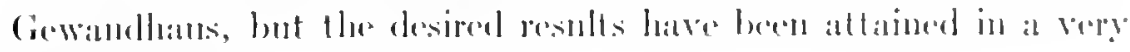
dillerent way.

A fen general eomsiderations, not directly ennected with rererberation. mare be of interest. The three latls are of mearly the same

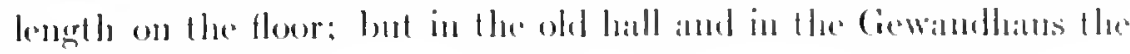




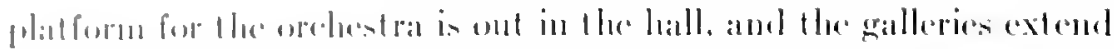

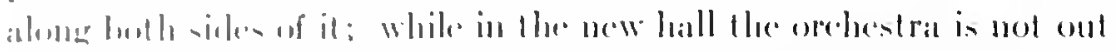
in the man boxly of the room, and for this reason is slightly farther frentlla rease of the hall: but this in more thatu compensated for in

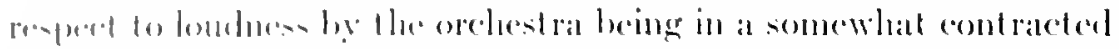
- tage reares. from the sick walls of which the reflection is better

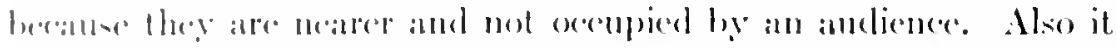
may he moted that lhe new hall is not so high as the old and is not -1) broial.

thus is opened up the quention of houdness, and this hats heen

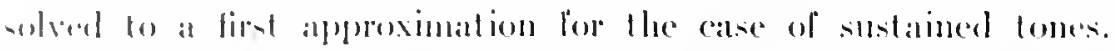

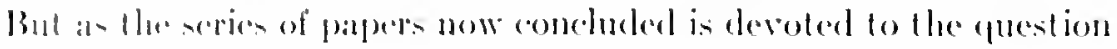
of reverberallion, this new problem must be reserved for a subsegurent dinchasiont. 


\section{ARCHITECTURAL, ACOUSTICS ${ }^{1}$}

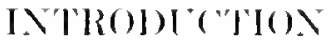

$\mathrm{T}$

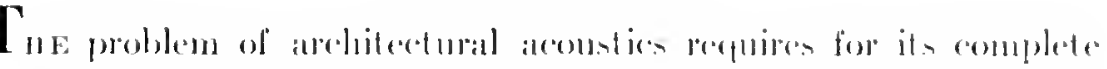

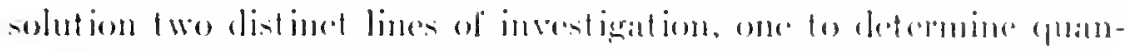

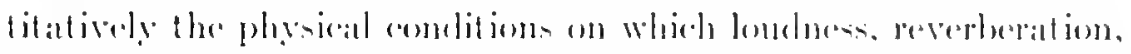

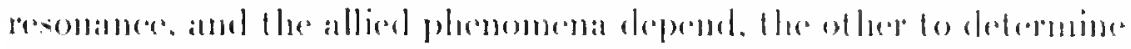

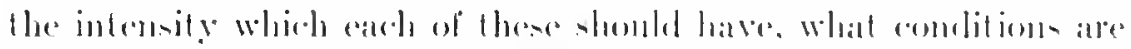

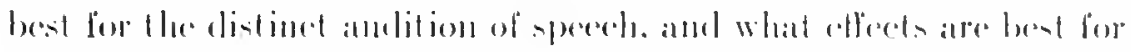

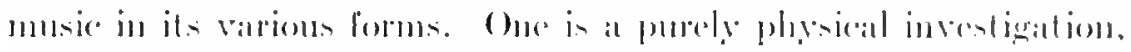

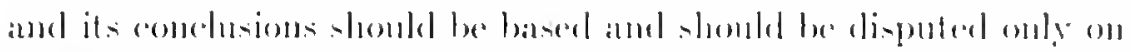

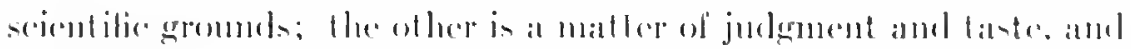

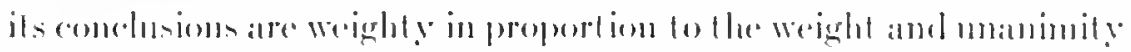
of the suthority in which they fincl theile someres. For this reanom,

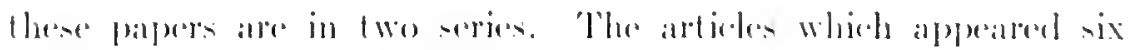

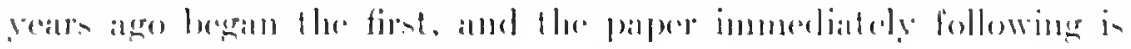

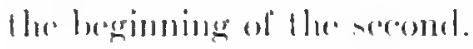

of the lirs series of papes's, which have lo do with the puredy

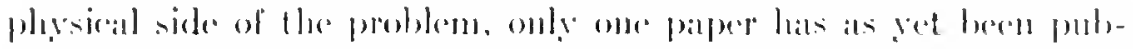

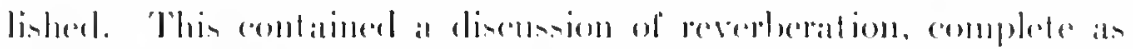

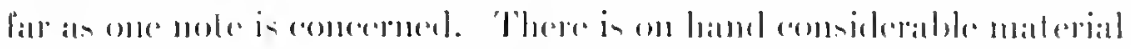

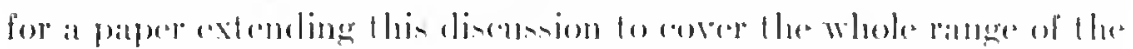

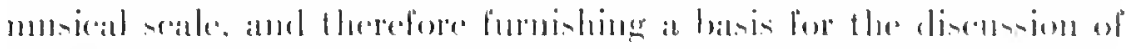

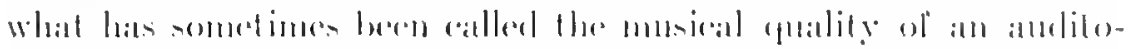

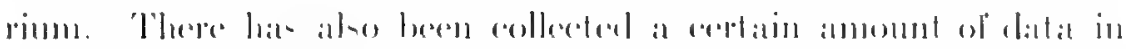

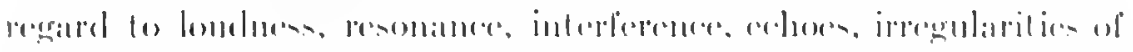

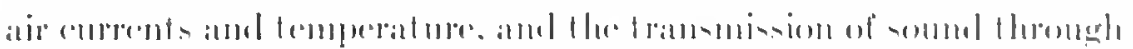

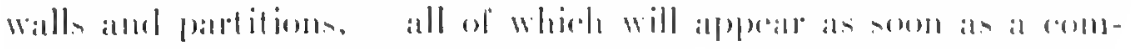

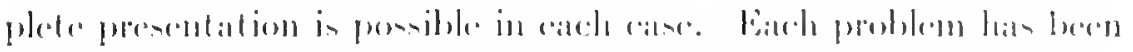

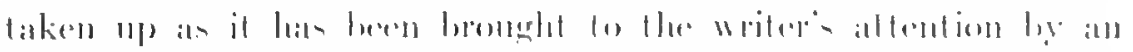

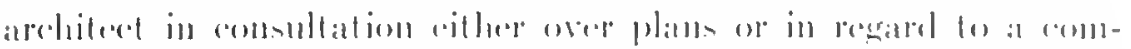

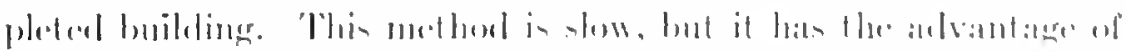

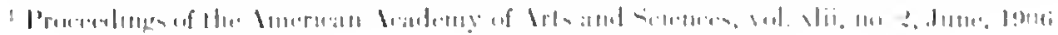


making the work pratetical. and maty be relied on to present the magnilication to mulue impertanee of scientifically interesting but pratetically suberelinate peints. On the other hand, there is the dangere that it may leatl to at frigmentary presentation. An effort has lexen made lo guard against this, and the eflort for completeness is the reatsen for delaty in the appearance of some of the papers.

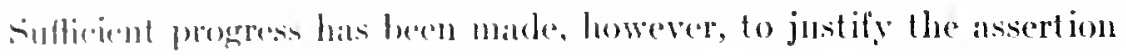
that the plyisical side of the problem is solvalble, and that it should be ponible ultimately to aldalate in adrance of construction all

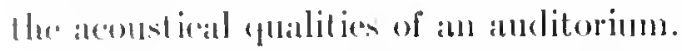

'llum fall it is at legritimate problem in physics, and as such a reasmatble ene for the writer to mulertake.

'The second part of the problen, now being stated, the question an to whal constitutes goot and what constitules poor alcoustics, what elleed ate desirable in an allditorim designed for speaking, anel even more especially in one designed for music, is not a question in physies. It is therefore not one for which the writer is especially fualified. and woukl not be underlaken here were it not in the first Hace absolutely necessiary in oriter lo give effect to the rest of the work, and in the second plater were it not the plan rather to gather and give expression to the judgunent of others acknowledged as qualified to speak, than to grive expression to the taste and judgment of one. It is thus the prurpose to seck expert judgment in regurd to acoustical elfeets, and if possiblt to present the results in a form avaibalshe to arehitects. This will he slow and difficult work. and it is not at all certain that it will be possible to arrive, cven ultimattly; at at finished prokhet. It is worth undertaking, however, if the joly as at whole is worth undertaking, for without it the physical side of the investigation will lose much of its practical value. Thus it is of little vilue to be able to calculate in advance of construction and express in numerical measure the acoustical quality which any binned atuditorium will have, unless one knows also in numerical meatsure the acoustical quality which is desired. On the other hand, if the owner and the architeret can agree on the desired result, and if this is within the limits of possibility considering all the demands (n) the atuliterium, of utility, architecture, and enginecring, this roult can be secured with cerlainty, - at least there need be no 
uncertainty as to whether it will or will not be attained in the completed buileling.

The papers following this introduction will be: The Acenracy of Musical Taste in regard to . Irehitectural a leousties, and I ariation in Reverberation with I'ariation in Pitch.

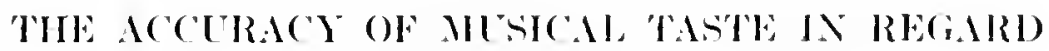

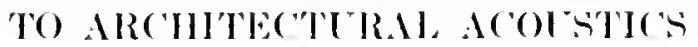

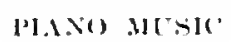

$\mathrm{T}$

112 experiments deseribed in this patper were molertaken in order to determine the reverderation hest sulted to piano music in at music room of molerate size. lunt were so comblucted as to grive a measure of

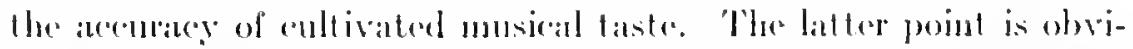

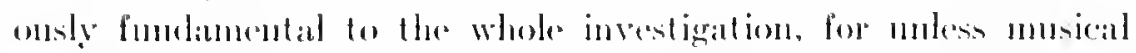

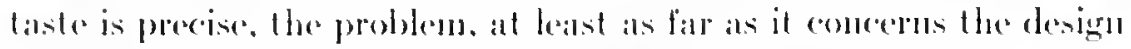
of the atulitorium for musioal purpones, is incleterminate.

The first olserevations in regard to the precosion of musical taster

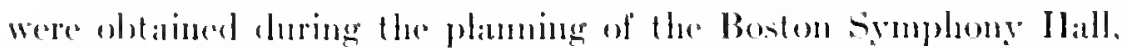

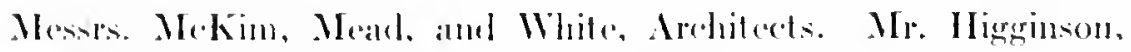

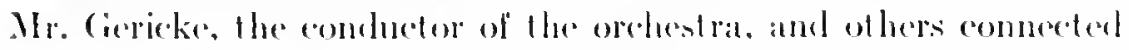
with the Building commitlere expressed opinions in regard to a mumber of anditoriums. These huldings included the old Boston Musice Hall, at that time the home of the orehestrat and the places

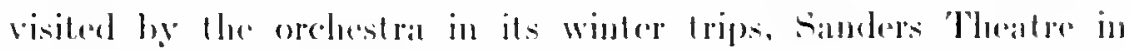

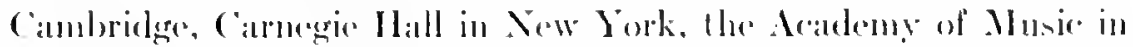
Philadelpluat, and the Musie Hall in Ballimore, and in auldition to

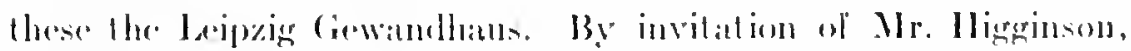

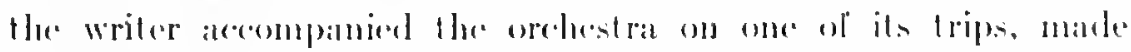

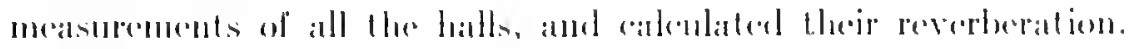

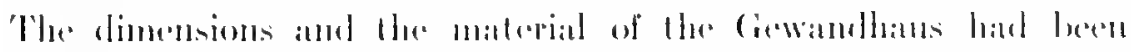

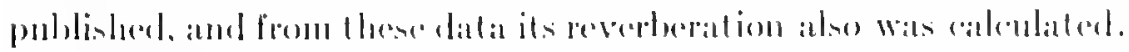

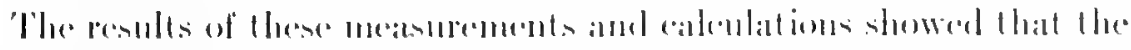

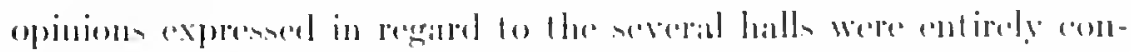

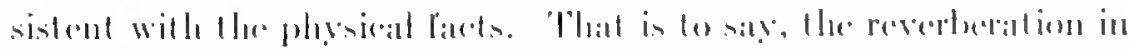

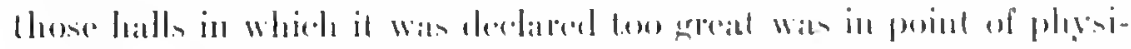

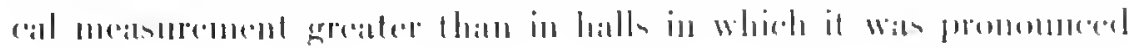




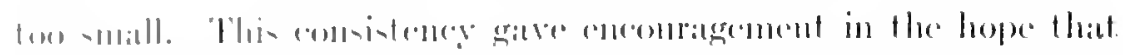

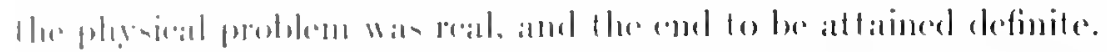

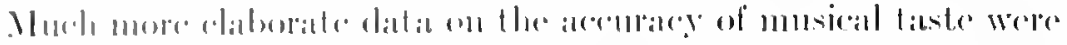

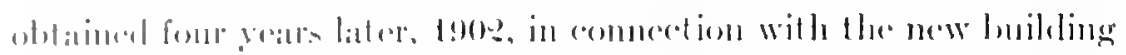

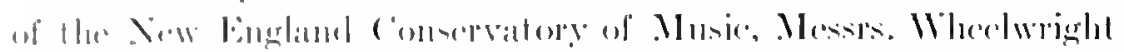

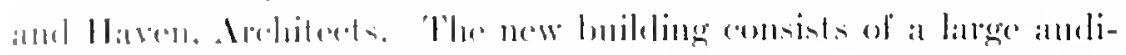

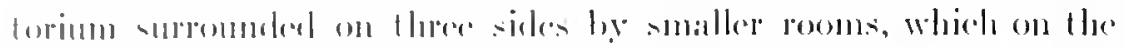

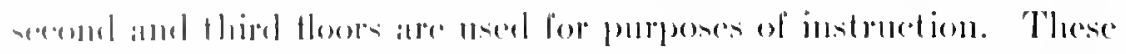

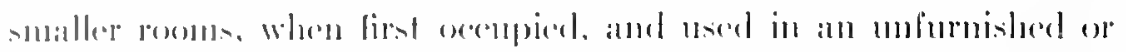

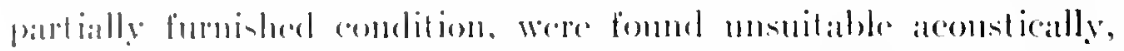

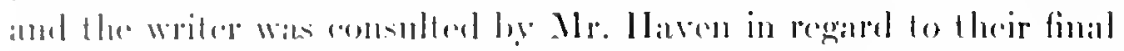

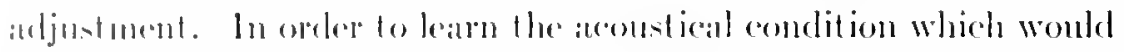

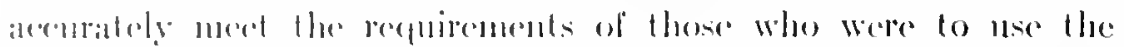

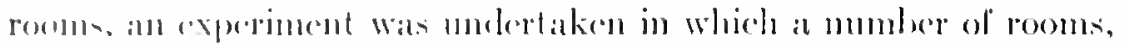

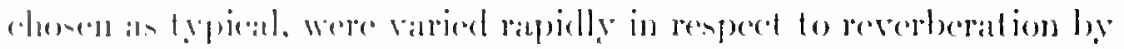

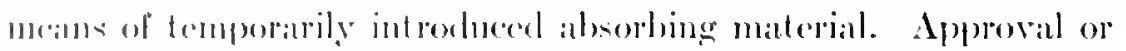

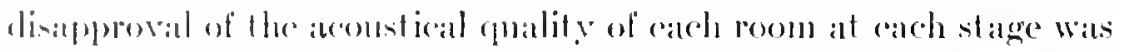

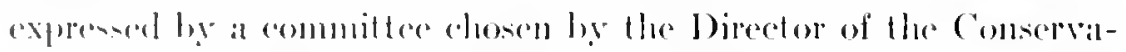
tery. At the elone of these tests, the reverberation in the rooms was

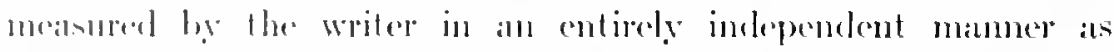
deneribed in the papere on Reverberation (1900). The judges were

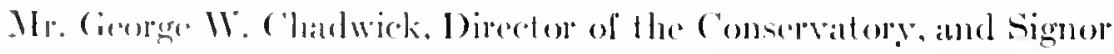
(1)e-ti Bimbeni, Mr. William II. J)mblam, Mr. George Wr. Proctor, andel Mr. William I. Whitney, of He daculty. The writer stegerested

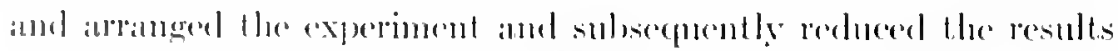

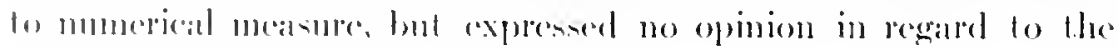
griality of the rooms.

'The merits of anch romen in its varied conditions were judged

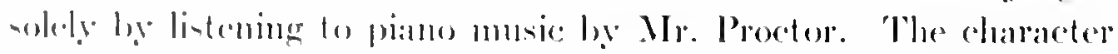

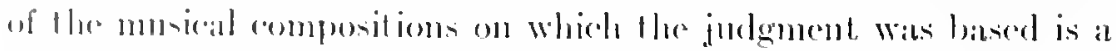

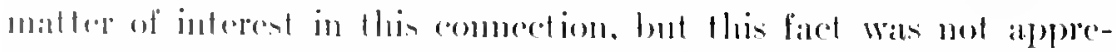
riated at the time amol no recorel of the selections was made. It is

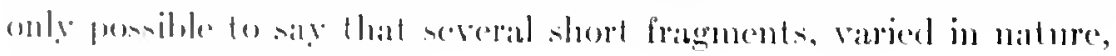
were trient in rileh room.

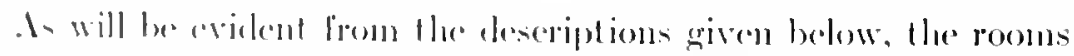

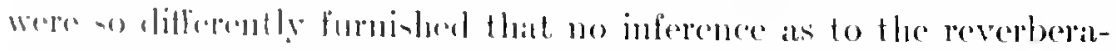
tion combl be drawn from appearances. and it is certan that the 
opinions were batsed solely on the furality of the room ats heared in the piano musie.

'llye five roems chesen as typieal were on the second floom ol the

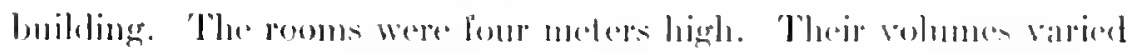

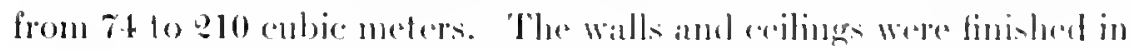
plastere on wire bath, and were meither patpered nor painted. There

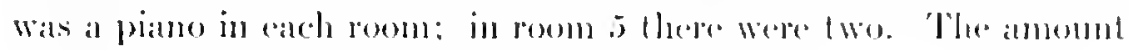
of othere lumiture in the rooms varied greatlę:

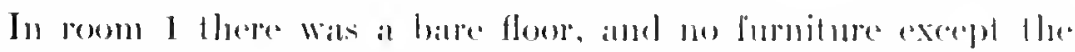
piatme and piano stoul.

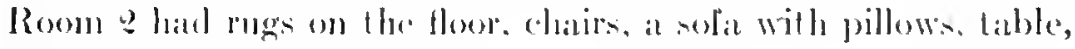
music racks, and a liamp.

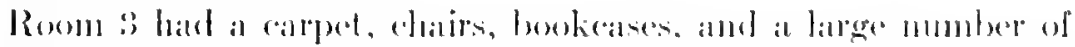
books, which, overflowing the buskeasen, weres stacked alomg the walls.

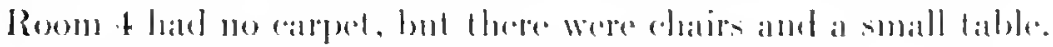

Reom o hakl a carpet, rhairs, and shelia coltalus.

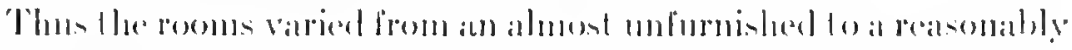

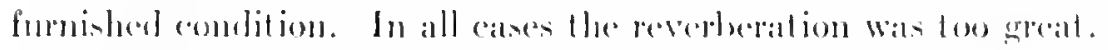

'The experiment was begun in rom 1. 'There weres alt the times,

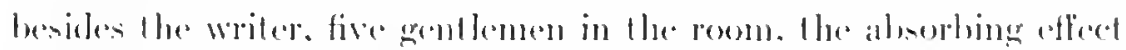

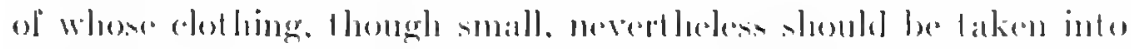

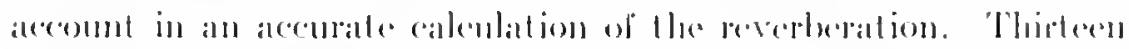

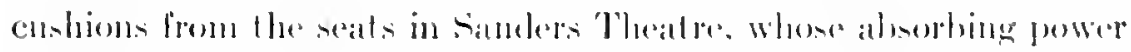

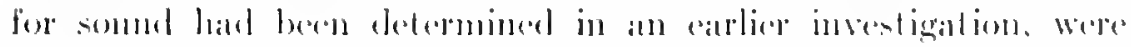

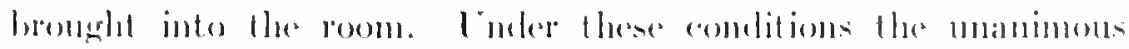

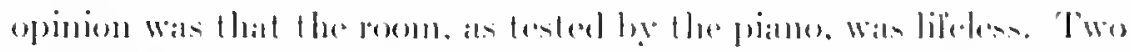

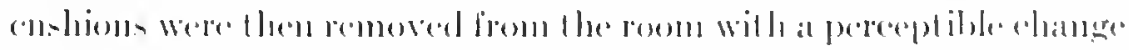

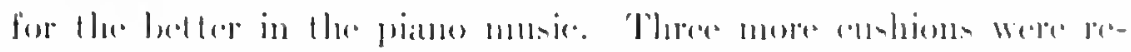

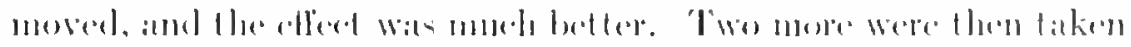

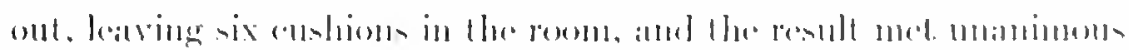

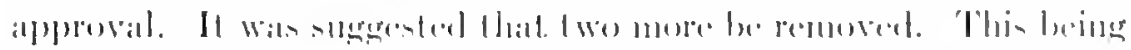

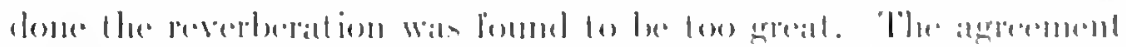

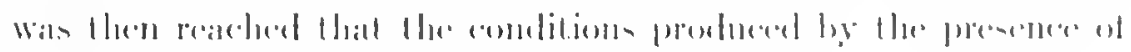

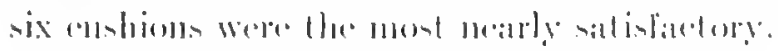

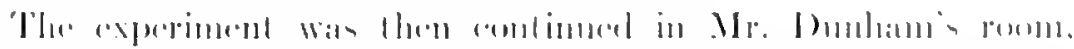

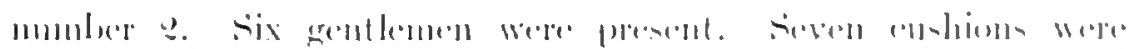


lirenglit inter the room. The music showed an insufliciont reverHeration. 'Jwe of the enshions were then taken ont. The change Wan regillofed al a distince improvement, and the room llats satisfanctorge

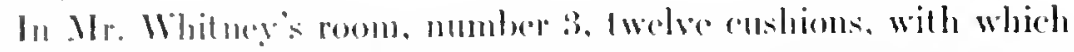

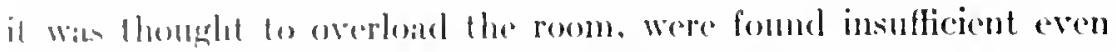
will the presente in this rese of seven gentlemen. 'Three more ashigms wore hrought in and the result decelared satislactory.

In the fourth reom, five, aight, and ten cushions were tried before the anditions were regarderl as satistactory.

In . Mr. Proctor's room, number 5, it was evident that the ten anhions which hata been hrought into the room had overloaded it. Pwo were removed. and afterwards three more, leaving only five, lefore at satisfaretory condition was reached.

This completed the direed experiment with the piano.

'The bringing into a rocom of any absorbing material, such as these rushions, allerets its alcoustical proprerties in several respecets, but principally in resperel to its reverberation. The prolongation of somul in a rown alter the cessation of its souree may be regarded

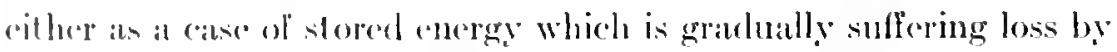
Irannmission through and absorption by the walls and contained material, or it may be regarded as a process of rapid reflection from Wall fo wall with lons all each reflection. In eilher catse it is called mererleration. It is sometimes called, mistakenly as has been explained. resonance. The reverberation may be expressed by the Ahration of andihility of the resielual somd after the cessation of at soureres aldjusted ats to produce an average of sound of some standarel intensily asere the whole room. 'The elirect determination of this, under tha varied eomlitions of this experiment, was impractirahle, hut, hy measuring the duration of audibility of the residual somel after the cessation of a measured organ pipe in each room without any runliuns, and knowing the coefficient of absorption of the andioms. it was posible to calentate accurately the reverberation at carch shage in the test. It was impossible to make these measmrements immoliately after the above experiments, because, althemgle the day wats an esperelally quiet one, the noises from the strent and railway traffic were seriomsly disturbing. Isite the follow- 
ing night the conditions were more fulvorable, atml a series of fairly" good observations wats obtained in each room. The cushioms harl been removed, so that the measurements were made on the rooms in their original condition, furnished ats above described. The apparatus and method employed are described in full in a series of articles in the Engineering Recort ${ }^{1}$ and American Archilect for 1900. The results are given in the aleompanying table.

\begin{tabular}{|c|c|c|c|c|c|c|c|c|c|}
\hline . & 言 & 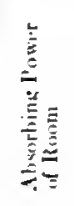 & 吾 & 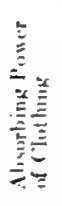 & 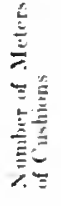 & 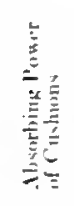 & 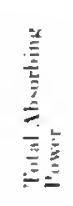 & 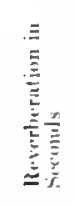 & Remarhe \\
\hline & it & 5.0 & 0 & 0 & 0 & 11 & .5 .11 & 2.43 & \multirow{7}{*}{ 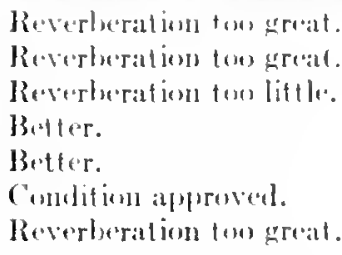 } \\
\hline & & $"$ & .j & 2.1 & 0 & 0 & 7.4 & 1.tit & \\
\hline & & . & $"$ & ${ }^{*}$ & $1: 3$ & $1 \cdot 8.8$ & 80.9 & .60) & \\
\hline & & " & " & . & 11 & 10.1 & 17.5 & . & \\
\hline & & “ & " & “ & 8 & 7.3 & $14 . \pi$ & .833 & \\
\hline & & . & " & $"$ & ii & ד... & $1 \because .99$ & .955 & \\
\hline & & “ & $"$ & $"$ & 4 & 3.6 & 11.0 & $1.2:$ & \\
\hline \multirow[t]{4}{*}{ 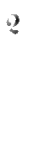 } & $9]$ & 6.3 & (1) & 0 & 11 & 0 & 6.3 & 2.399 & \multirow{4}{*}{ 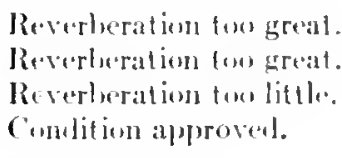 } \\
\hline & & 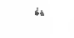 & ii & 9.9 & 11 & $\theta$ & 1.9 & 1.4 .3 & \\
\hline & & " & $*$ & $"$ & i & (i.) & 1.5 .6 & .8 .5 & \\
\hline & & 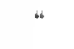 & $*$ & $"$ & ; & +6 & 13.8 & 1.10 & \\
\hline \multirow[t]{4}{*}{3} & חנפ & 14.0 & (1) & 0 & 0 & 1) & 14.11 & 9.46 & \multirow{4}{*}{$\begin{array}{l}\text { Reverlueration too greast. } \\
\text { Revertueration too great } \\
\text { Bedter. } \\
\text { Comlition apprewed. }\end{array}$} \\
\hline & & “ & $\tau$ & 8.4 & 0 & 0 & 17.1 & @.00 & \\
\hline & &. &. & ". & 1:2 & 11.0 & QS.t & 1.91 & \\
\hline & & ". & “ & $"$ & 1.5 & 13.7 & 31.1 & 1.10 & \\
\hline \multirow[t]{4}{*}{4} & 183 & 8.3 & 0 & 0 & 0 & 11 & 8.3 & $\because 615$ & \multirow{4}{*}{ 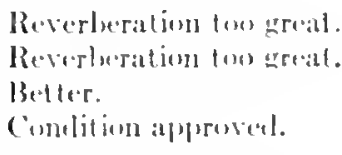 } \\
\hline & & “ & $\tau$ & 8.4 & 0 & 0 & 11.7 & 7.s & \\
\hline & & " & " & ". & 4 & $5 . j$ & 17.2 & 1.96 & \\
\hline & & $"$ &. & $"$ & 111 & 9.1 & 90.8 & $1.09)$ & \\
\hline \multirow[t]{5}{*}{.) } & $9 t i$ & 7.0 & 0 & 0 & 0 & 0 & 0.0 & $\because \therefore 4$ & \multirow{5}{*}{ 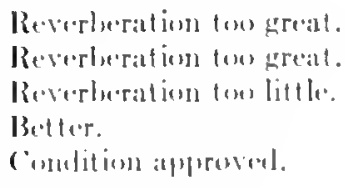 } \\
\hline & & 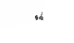 & $t$ & 1.9) & 0 & 0 & $8 . !$ & 1.76 & \\
\hline & & $"$ & " & “ & 10 & 9.1 & 18.0 & . & \\
\hline & & $"$ & ". & " & $s$ & 7.3 & $16 \therefore$ & 89. & \\
\hline & & “ & “ & “" & $\therefore$ & t.17i & 1:3.j & $1.16 i$ & \\
\hline
\end{tabular}

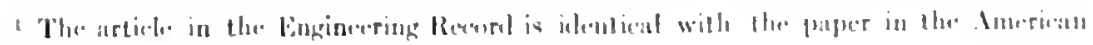

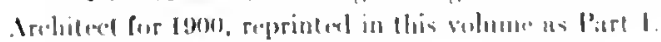




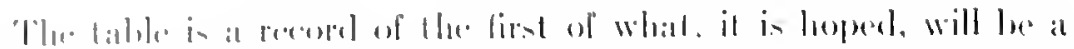

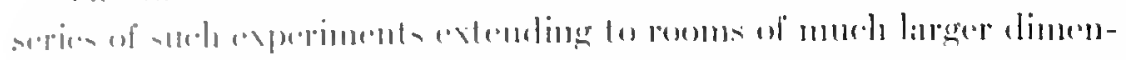

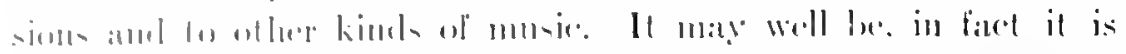

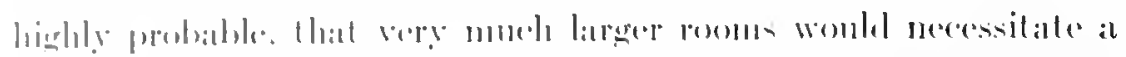

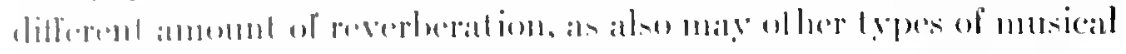

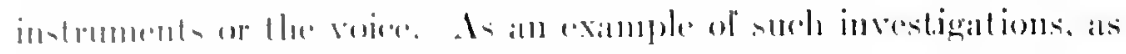

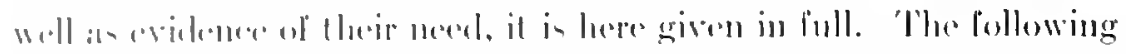

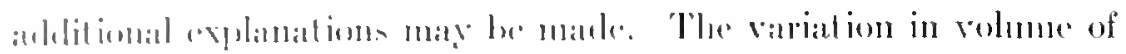

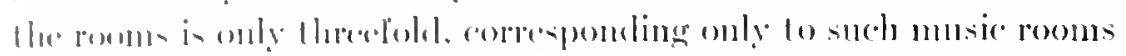

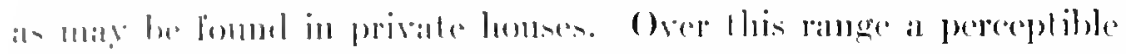

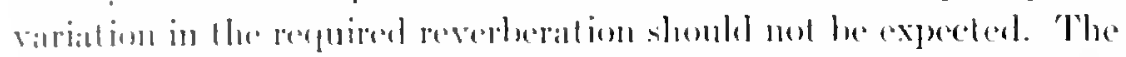
thirel wolum in the table includes in the absotbing power of the room coriling. Walls. furniture, ate. the absombing powers of the

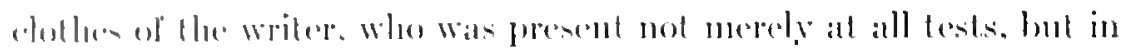

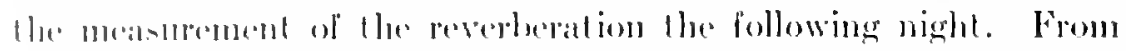

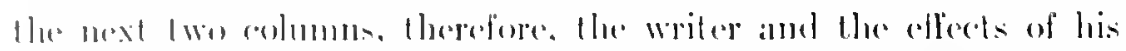

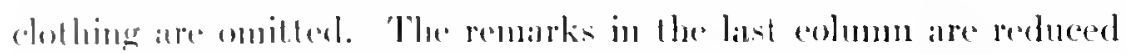

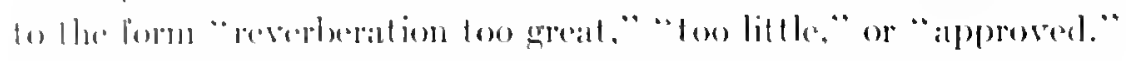
The rematrk at the time were not in this form, howerer. The room

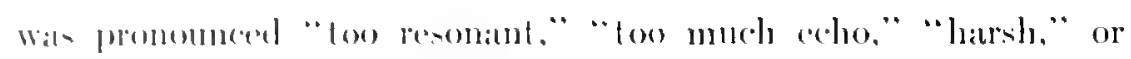
"Jull." "lileden.." "overloaded." expressions to which the forms

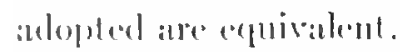

If from the latger lable the reverberation in aich room, in it: mont apposed condition, is separately tabulated, the following is oblinined:

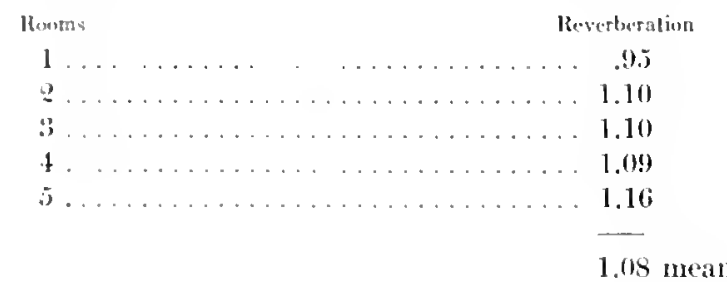

The final renult ohtaned, that the reverberation in a music room in order to serente the best effecet with a plimo should be 1.08 , or in rumel mumbers 1.1. is in itself of considerable practical value; but the live tederminations, he their mutual agreement. give at numeri-

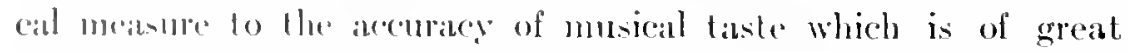
interent. Thus the miximum departure from the mean is .13 seconds, 
ant the average departure is o.j seromels. Five is rather a small

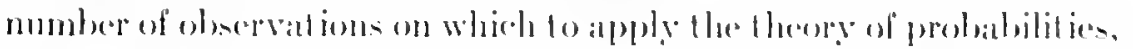
but, atsomming that it justifies such reasoming, the probable arror is os soconds, - smprisingly small.

A close inspertion of the large tahle will hring ont an intereating

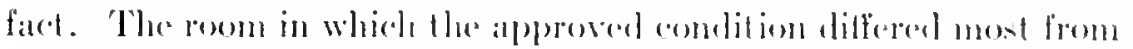

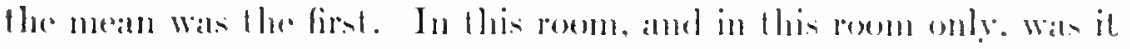
sugerested lig the gentlement present that the axperingent should be

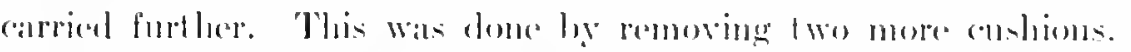

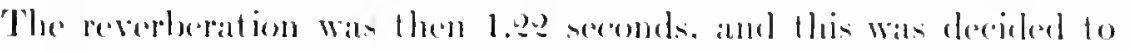

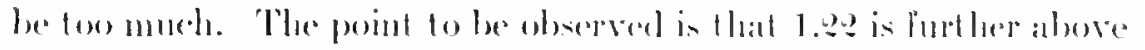

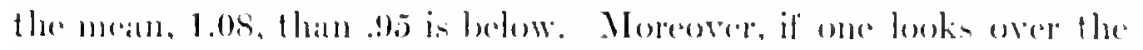

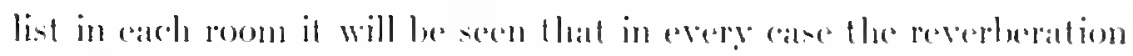
corresponding to the ehonen condition came neatrer to the mean than that of any of here enthlition tried.

It in conceviable that had the roums been alike in all respecets and

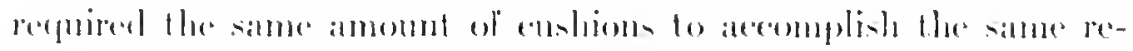

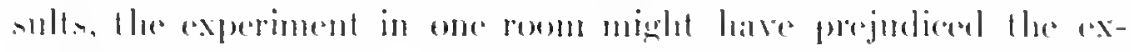
periment in the next. But the rooms being litherent in size and

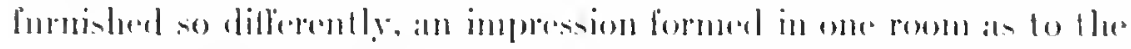

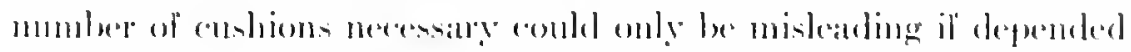

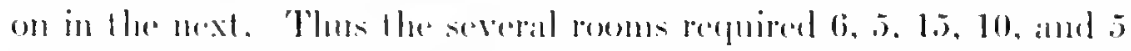

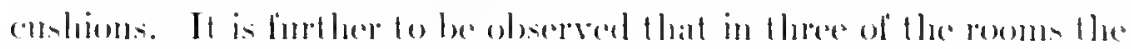

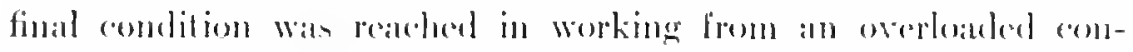
dition, and in the oflere two rooms from the opposite comblition. -

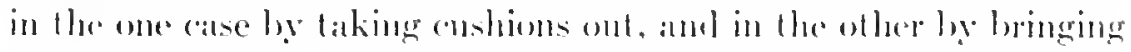
Horm in.

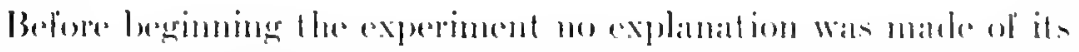

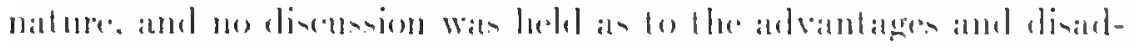

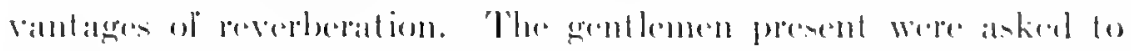

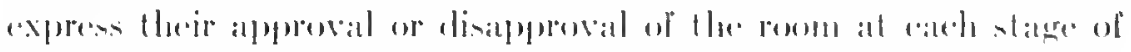

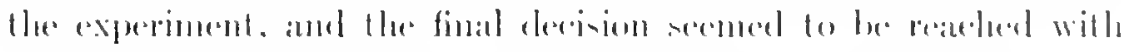

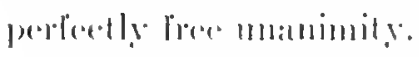

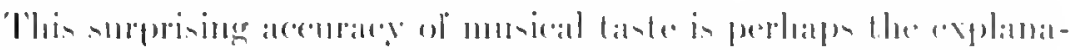

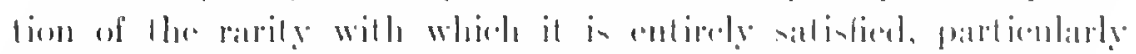

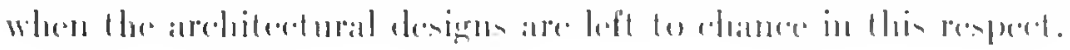




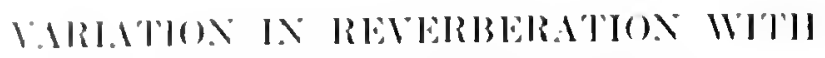

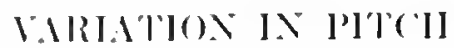

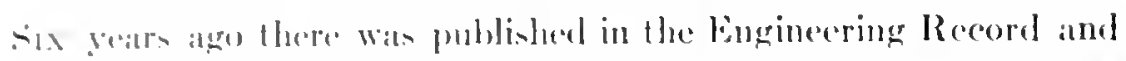
the. Imerican Arehiteret at series of papers on arehitectural alcoustics interuled an a beginning in the general sul ject. The frarticular plase

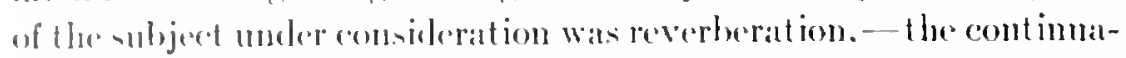
tion of somel in at reom after the sonree has ceased. It was there shewn to depend on two things,-- the volume of the room, and the al horbing charatcher of the watls and of the material with which the rom in lilled. It was also mentioned that the reverberation depends in special catses on the shape of the room. hut these spectial cases were not comidered. The present paper also will not take up these special rases. but pentpene their consideration, although a good deal of material along this line has now heen collected. It is the object laere to cont inte the earlier work rather narrowly along the original lines. The sulject was then investigated solely with reference to sound of onte pitch ('s ste vibuations pere seeond. It is the intention lure to extend this over nearly the whole range of the musieal acille. from cit bit to $C_{i}+096$.

It ean be shown readily that the rarious materials of which the waths of a room are constructerl and the materials with which it is lilled do not have the same absorbing power for all sounds regatedles. of pitch. I'nder such circumstances the previously published work with ( 519 must be regarded as an illustration, as a part of a much larger problem, - the most interesting part, it is true, be"anse near the middle of the scale, but alter all only a part. Thus a room may have great reverberation for somnds of low piteh and very little for sounds of high pitch, or exactly the reverse; or at room may hatce comparatively great reverberation for sounds both of high and of low pitch and serye little for somds near the middle of the scale. In other works, it is not putting it too strongly to sily that a room may hase very dillerent quality in different registers, as different ats does a munical instrument; or, if the room is to be used for spealing purpones, it may have different degrees of excellence or deferet for a whisper and for the full rounded tones of the voice, different for an woman's roiec and for a man's - facts more or less 
well recognized. Not to bave this as a valgue generalization the following casc's may be cited. Recently, in discussing the acoustic's of the proposed cathedral of sonthern California in Los Angeles with Mr. Magimnis, its archited, and the writer, Bishop Conaty tonched on this point very elearly. Ifter discussing the general subjeet with more than the usual insight and experience. posibly in part because (athelic churedes and cathedrals have great reverberation, he added that he foumd it differdt to itroid pritehing his voice to that note which the anditorimm most prolongs not withstanding the fact that he found this the worst pited on which to speak. This brings ont, perhaps more inpressively becamse from practical experience instead of from theoretical considerattions, the two truths that anditorims have very different reverberation for different pitches, and that excessive reverberation is a great hin-

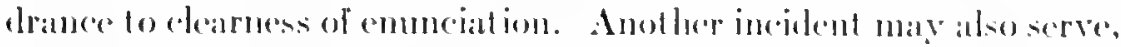
that of a chureh near Boston, in regiand to which the writer has just been consulted. The prenent pastor, in describing the nature of its aconstieal defects, stated that diflerent speakers had dilferent degrees of diflienlty in making themsed ress leard: that he had no difliculty, having at rather high piteled roices: but that the candidate before him, with a louder hat much lower voice. fitiled of the appointment becanse muable to make himself heard. l'ractical experienese of the difference in reverberation with variation of piteh is not immsual, but the above cases are rather striking examples. Correspending effects are not infreduently observed in halls devoled to muscie. Hts observation lere. lowerere, is marked in the bather complieated greneral aflecet. The full discrission of this belonges to another serien of papers, in which will be taken up the subject of the

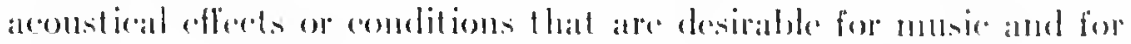

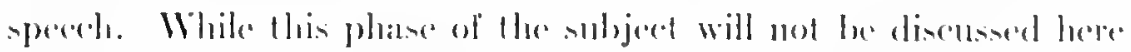
at length. a little considerat ion ol the dat:a to he preanted will show

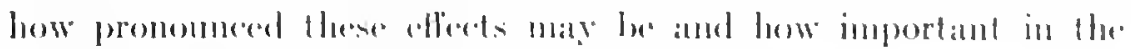

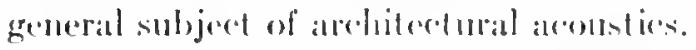

In order to slow the full signilieanee ol this axtemsion of Hee investigation in regard to reverberaltion, it is nesessary to point ont

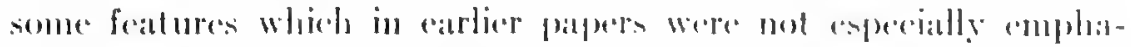
sized. Prinarily the investigation in coneerned with the subject of 


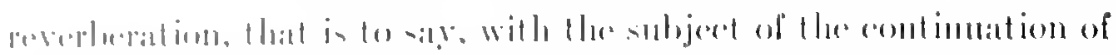

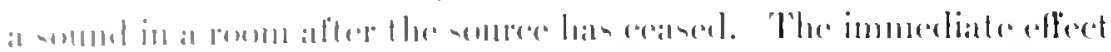

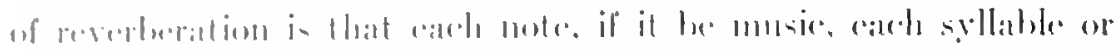

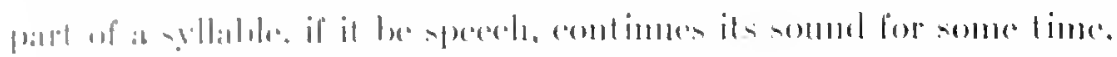

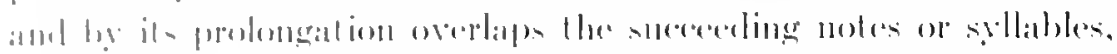

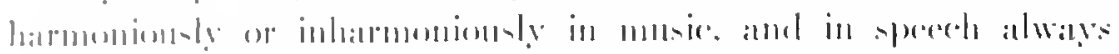

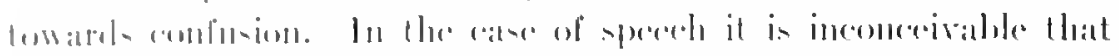

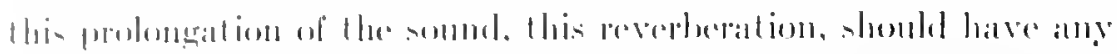

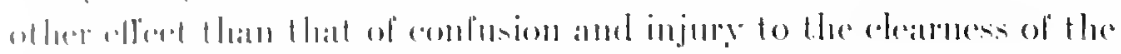

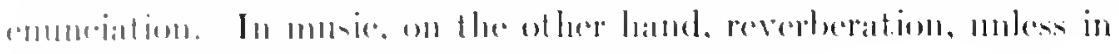

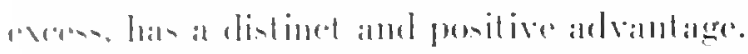

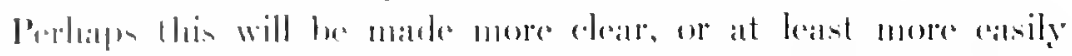

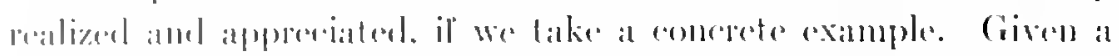

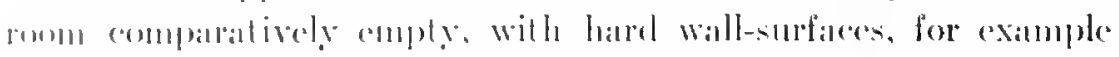

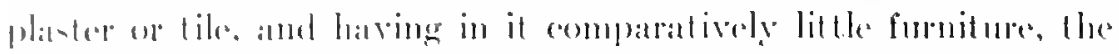

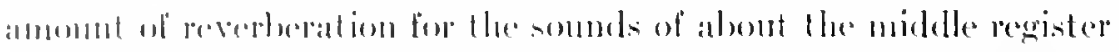

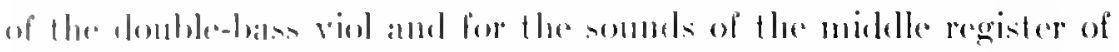

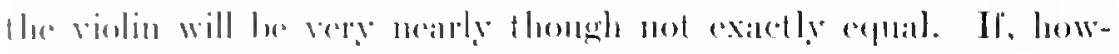

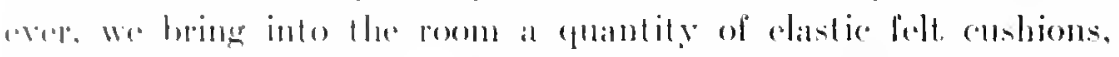

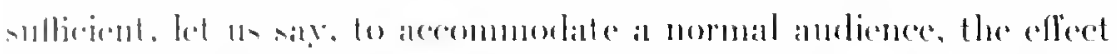

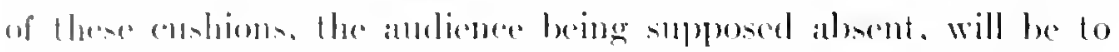

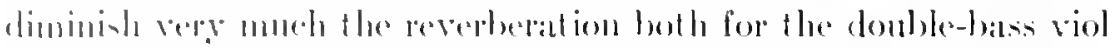
anul for the violin, hut will diminish them in very unecplual amounts.

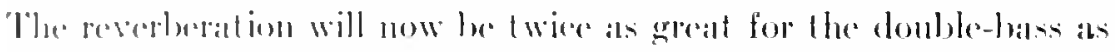

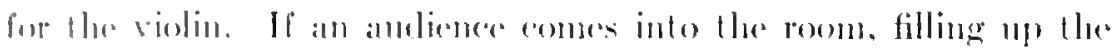

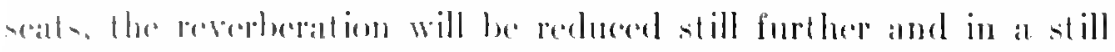

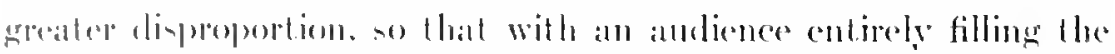

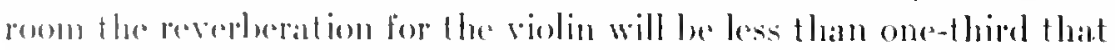
for the demble-bates. When one considers that a diflenence of five prer ant in reverterat ion is a matter for alpproval or disapprovil on the pant of musedane of critieal taste, the importance of consielering

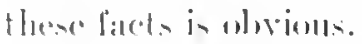

This inventigation, nombinally in megalrel to reverberation, is in reality latging the fomblation for ofleer platses of the problem. It

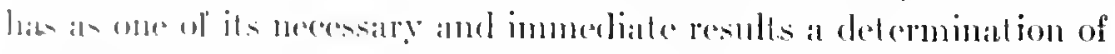

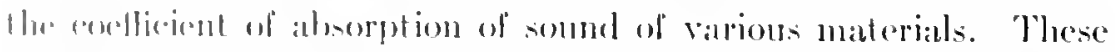

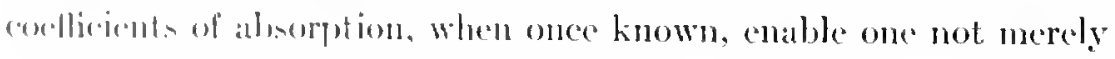


to calculate the probongat ion of the sommol, but alse to calceldate the average lombluess of sllstined tomes. Thus it was shown in onse of

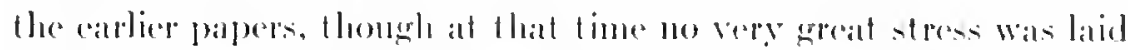

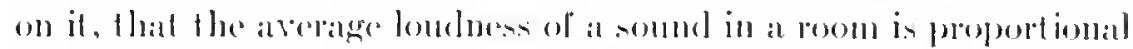

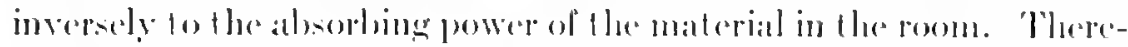

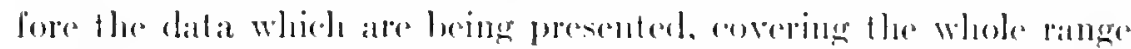

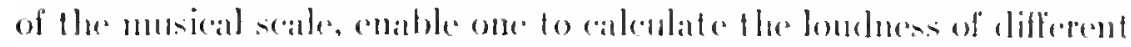
notes over that ranger and make it pessible to slow what efferet the room hat on the piano or the oredentrat in diflerent parts of the registert.

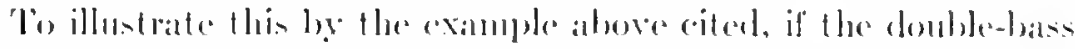

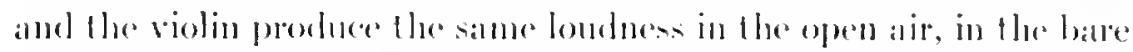

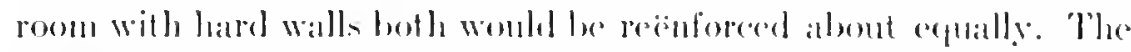

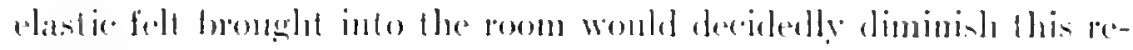

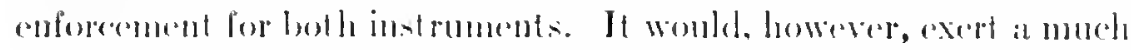

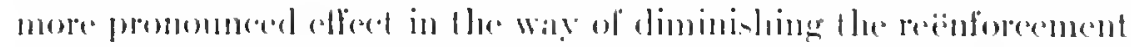
for the violin than for the double-batsis. In finct, the ballance will be

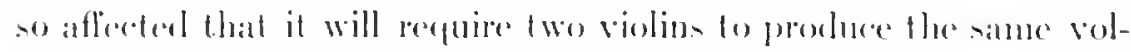

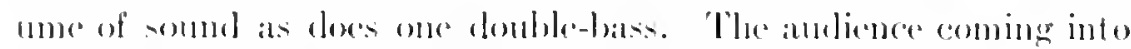

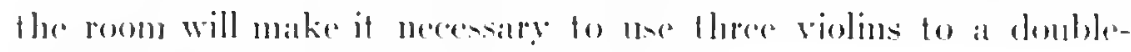

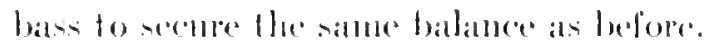

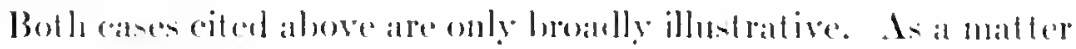
of faret the effecet of the room and the efferet of the andienes in the

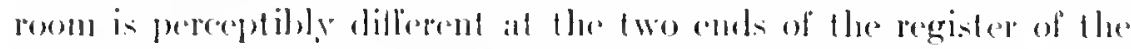
violin and of the doulshe-bals viol.

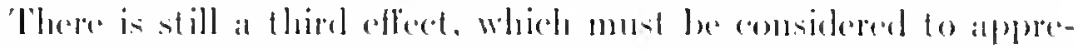

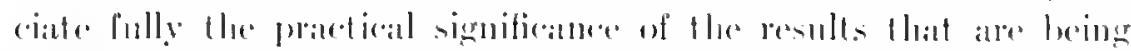

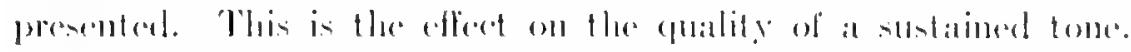

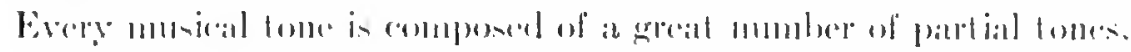
the prealominating one leing takens ats the fumblamental, and it

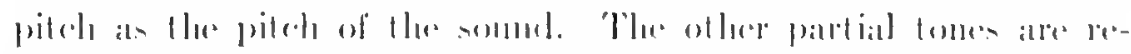

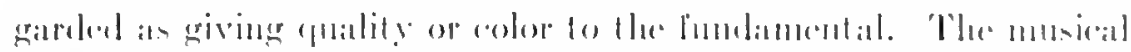

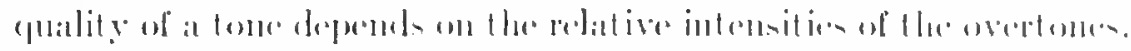

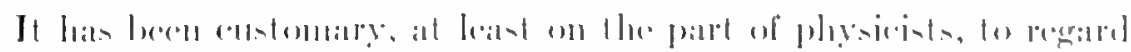

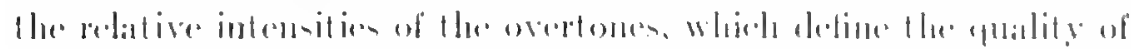

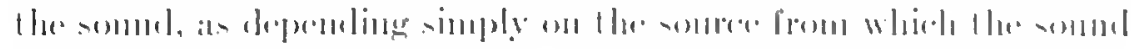

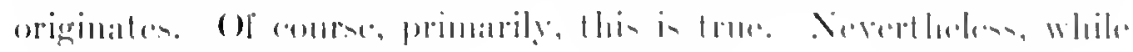




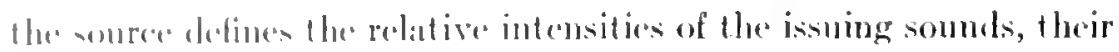
and nal internaties in the room depend uot merely on that, but also, and fo a strprising degrere. on the rom itself. Thus, for eximple. given an erght fout organ pipe, if hlown in ath empty room, such as that deacribed above. the overtomes would be pronounced. If exaretly the simme pipe he blown with the same wind pressure in a room in which the seats have been covered with the clastie felt, the first npere partial will bear to the fundamental a ratio of intensity diminished over to pere cent. Hhe second npper partial a ratio to the funclamental diminished in the same pere cent, the third upper partial a ratio diminished over so per cent, while the fourth upper partial will hear a ratio of intensity to the fundamental diminished aboul bo per cent. (puality experessed numerically in this way

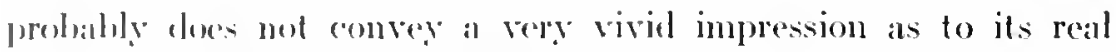
eflecet. It may signify more to say merely that the change in quality. is verye pronomuced and noticeable, even to comparatively untrained "als. () H he other hand, if one were to try the experiment with a -ix-inch instead of with an eight-foot organ pipe, the effect of lringing the elatic felt custions into the room would be to increase the relative intensities of the overtones, and thus to diminish the purity of 1 he tones.

All tomes helow that of a six-inch organ pipe will be purified by hringing into the room elastic felt. All tones above and including that piteh will be remelered less pure. 'The effect of an andience coming into a room is still different. Assuming that the andience has filled the room and so covered all the elastic felt cushions, the "lleret of the audienee is to purify all tones up to violin $\mathrm{C}_{4} 519$, and to have very little aflect on all tones from that pitch upward. On rers low tones the effect of the andience in the room is more pronomered. For example, again take $\mathrm{C}_{1} 64$, the effect of the andience will be to diminish its first overtone about 60 per cent relative to the fundamental and its second overtone over 75 per cent.

"lhe eflect of the material used in the construction of a room, and the contaned furniture, in altering the relative intensities of the fumdamental and the overtones, is to improve or injure its quality arcording to circumstances. It may be, of course, that the tone lesired is a very pure one, or it may be that what is wanted is a 
tone with pronounced upper piutials. 'Talke, for eximple, the "night horn" stop in a pipe orgill. 'This is intended to have a very pure tone. The room in contributing to its purity would inprose its cquality. On the of her hiumd, the mixture stop in a pipe organ is intended to have very pronounced overtones. In fact to this end not one but several pipess alre sounded at once. 'The eflect of the above room to emphasize the fundansental and to wije ont the overtones woukl be in opposition to the original design of the stop. To determine what balance is desirable must he of course with the musicians. The only object of the present series of paipers is 10 point ont the fundimental ficts, and that our conditions may be varied in order to attatin any desired end. One great thing needed is that the judgment of the musical ant herities should be gathered in an arailathle form; lut that is another problem, and the aloore batre outline is intented only to indicate the importance of extending the work to the whole ringe of the musical scale, - the work usulataken in the present paiper.

The method pursued in these experiments is not very unlike thal follewed in the previous axperiments with $C_{4} 51$. It differs in minor detail, but to explain these detaits would involve al great deal of repelition which the morlifications in the methes are not of sufficient inportanee to justify.

Broally, the procedure consists first in the determination of the rate of emision of the somul of an organ pipe for each note to be investigated. This consists in determining the durations of andililil! after the cessation ol two solunds, one having four or more, but at known multiple, times the intensity of the other. From the results it is pessible to determine lla bate of emision be the pipes, anch in termos of the minimum andibility lor that particular tome.

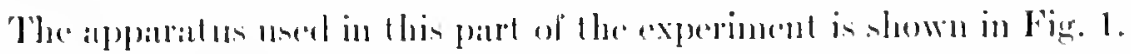
Fonr small orgatus were tixed at a minimm distance of live meters

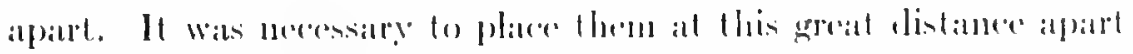

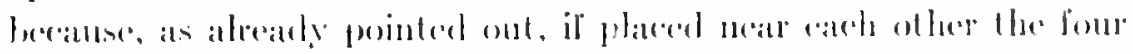

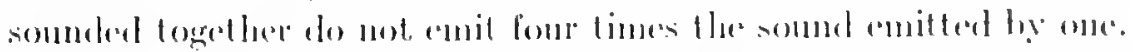

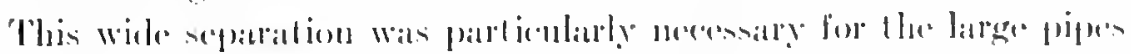

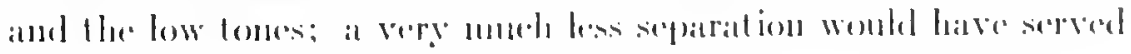
the purpose in the aise of the light tollen. 


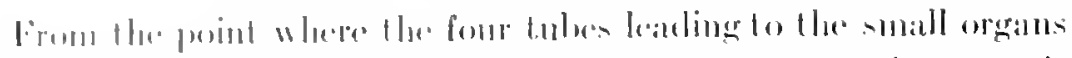

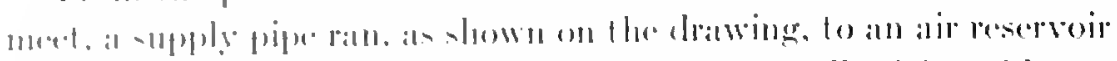

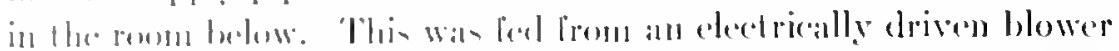

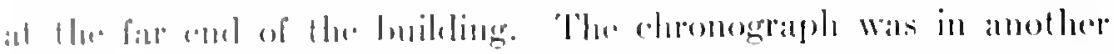
roum. The evgreriment with this alpatratus. like the experiments

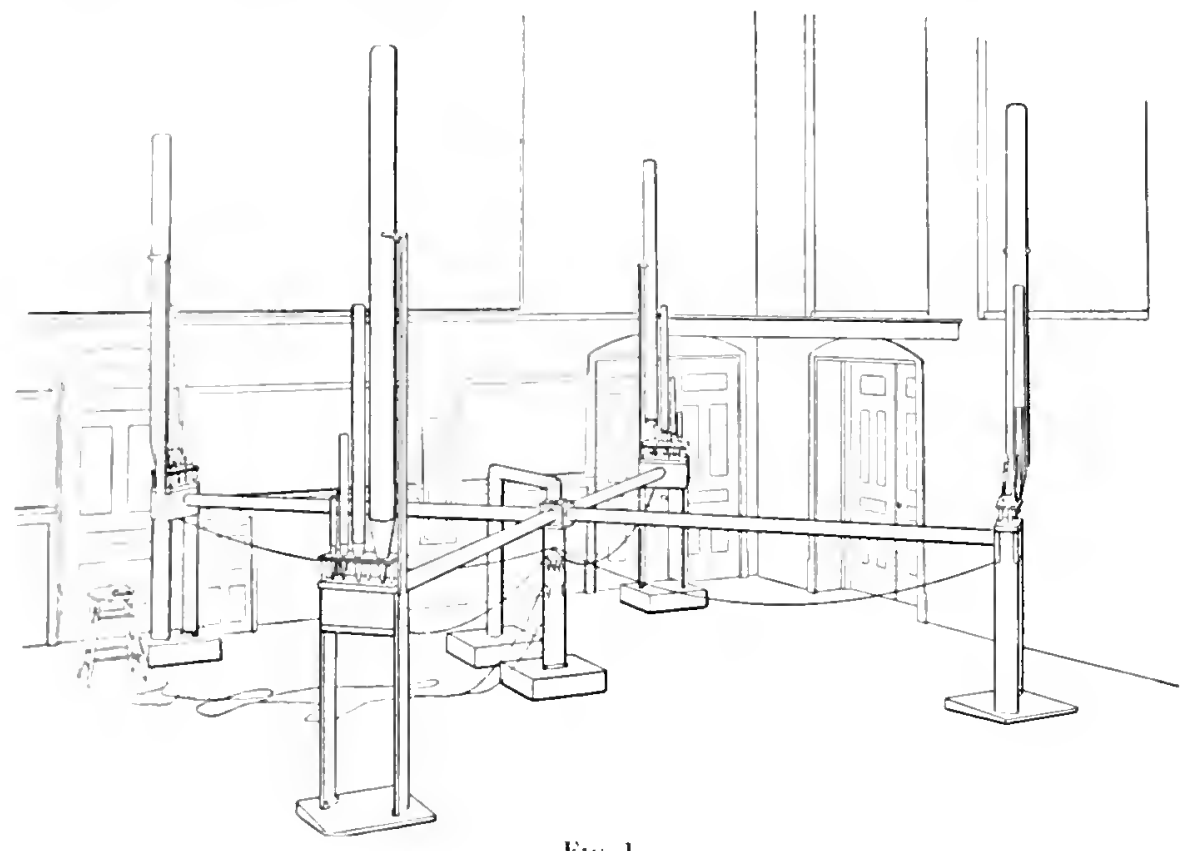

I'I. I

lupentufore reconded. were carried ont at night between twelse and fiver in lexk.

The rate of entisoion of somml hỵ the several pipes laving been determined. the next werk was the determination of the coefficients of aheorption. The methols emploged having already been sulliciently deserilued, only results will he given.

In the very nature of the problem the most important data is the

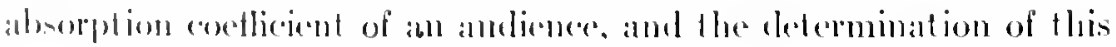
wat the lims task molertaken. By means of a leeture on one of

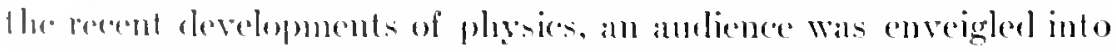

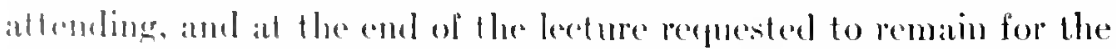
experinumt. In this attempt. the edtort was mate to determine the corllicients for the live octares from (-2 198 to $\mathrm{C}_{6} 20+8$, including 


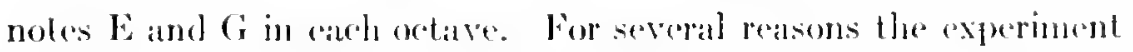
wals not a suceress. A llarealening lhumber storm matle the aturlience a small one, and the sultriness of the al mosphere made open windows necessiry, while the at tempt to cover so many notes, thirteren in all, prolonged the axperiment begond the emblumere of the andi-

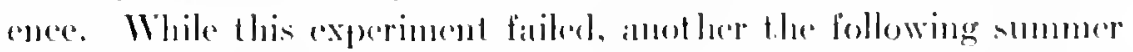

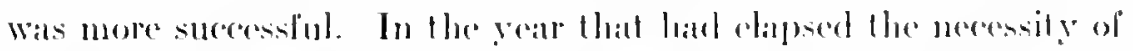
earrying the investigallion further than the limits intended berame

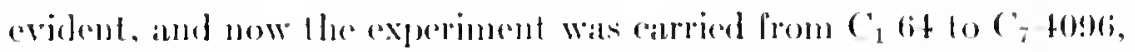
but inchuding only the ( notes, seren notes in all. Moreover, bearing in mind the experiences of the previons smmmer, it was recognized thal even seven moles wonkl come daugeronsly near over-

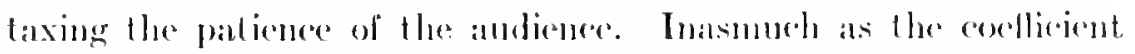

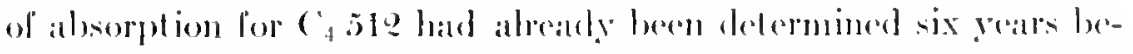
fore in the investigations mentioned, the coesticient for this note wiss not redelermined. The experinent wils therefore carried ont for the lower there and the ujpere three netes of the seven. The andience, on the night of this experiment, wats much latroce tham that which came the previous summer, the night wils a more com-

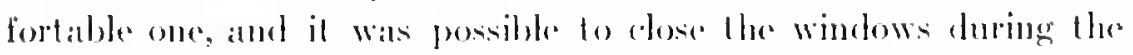
experiment. 'The comelitions were thes fairly satisfactory. In omelere to get as mueh datal ats posible and in ats shert at tine, lhere were

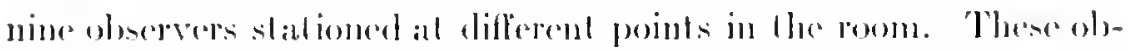

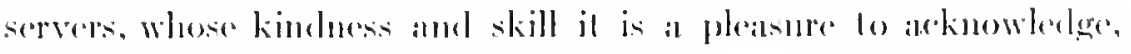

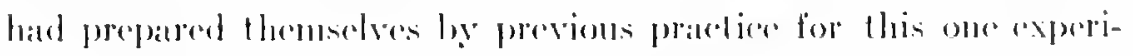

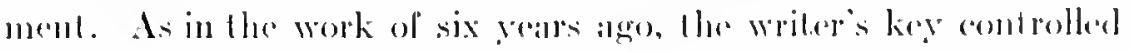

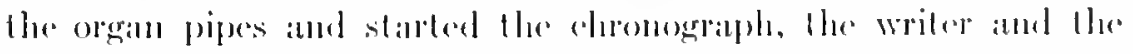

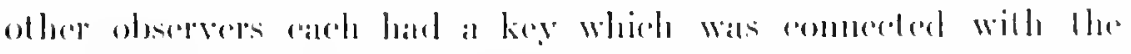

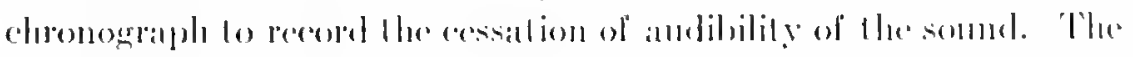

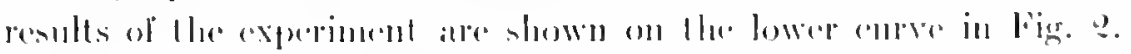

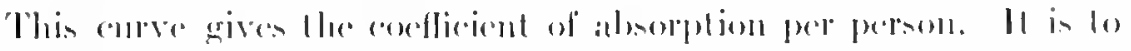

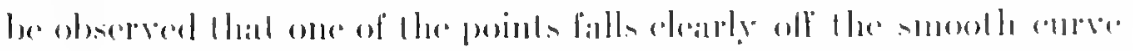

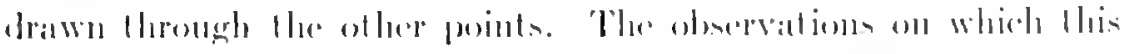

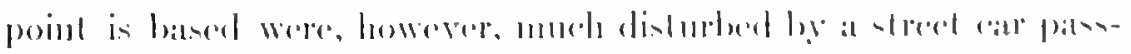

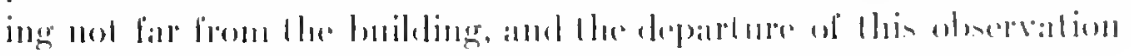

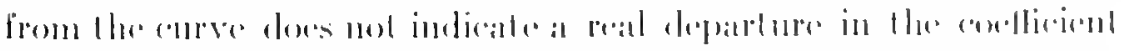

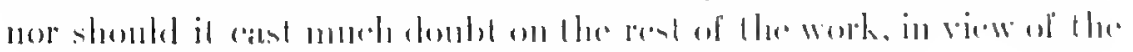


rircumbtances under which it was serored. Counteracting the per-

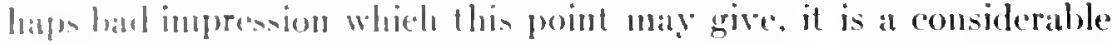

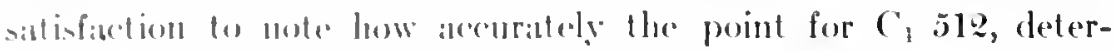

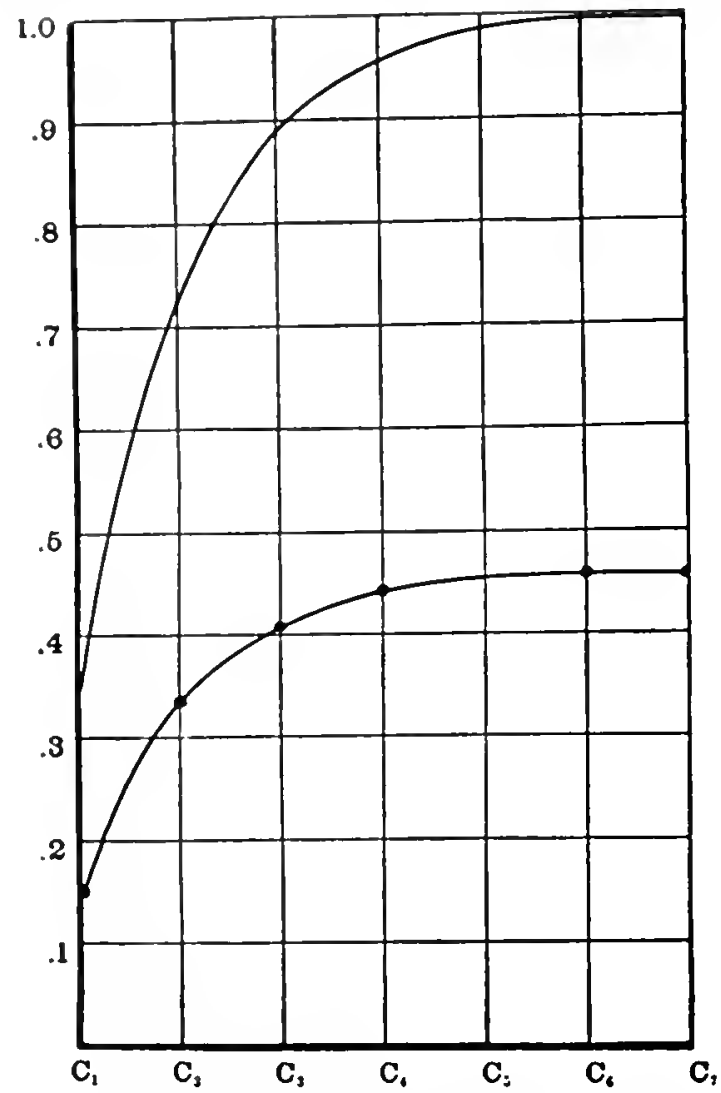

Fiti. 2. The absorbing power of an audience for different notes. 'The lower eurve represonts llie absorbing power of an audience per person. T'he upper curre represents the atsorling power of an audience per square meter ats ordinarily soblet. 'I'he vertieal ordinates are expressed in terms of lotal alysorption hy" a square meter of surface. For the upper curve the ordinates are thus the orlinary corffichents of absorption. The several nutes are at ochave intervals, as follows: C, $\left.64, C_{2}\right] 28$,

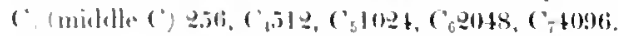

mined six gears hefore by a different set of observers, falls on the smeoth enrve thromgh the remaining points. In the atudience on which thene olservaltions were taken there were if women and 
105 men. The courtesy of the andience in remaining for the experinsent and the really remarkahle silence which they maintabed is gratelully areknowledged.

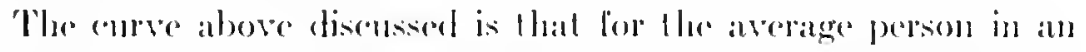
andience. In interesting form in whele ho throw the results is to regand the andience as one siele of a room. We may then look at it

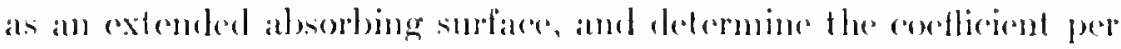
sequalre meter. Workenl ont on this basis the alsorption roeflicient

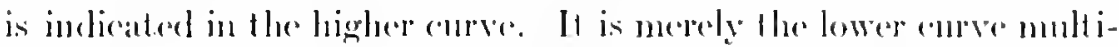
plied by a number which experenses the arratage number of people

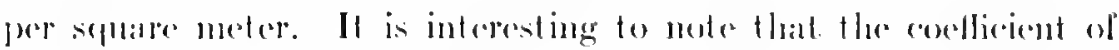

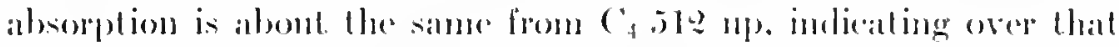
range mearly complete absomption. Bedow that point there is at verye

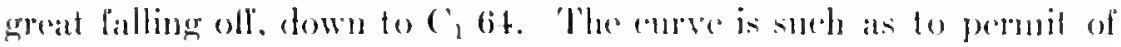

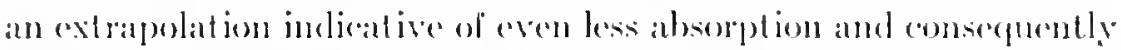
greater reverperation for the still lower motes. Without entering

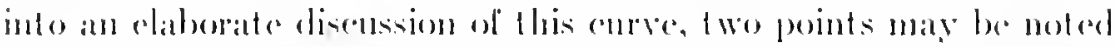

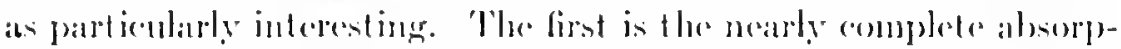
fion for the higher notes, a result which at first sight serms a little inconsistent with lla results wheh will be shown later on in con-

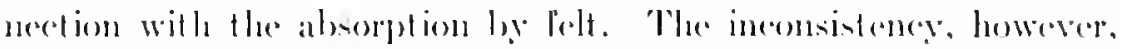

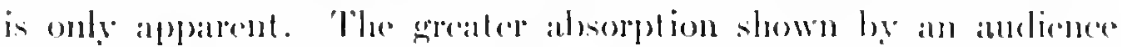
than that shown by thick felt arioes from the lacet that the surlace of the anelience is imengular and dees not result in a single reflecetion,

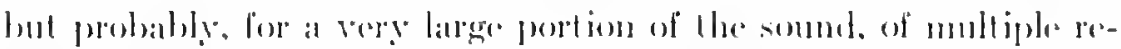

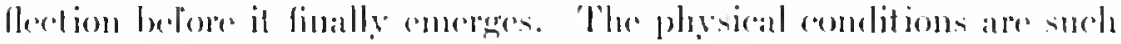

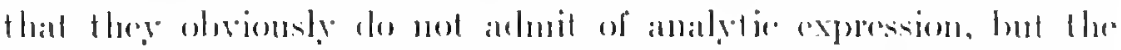

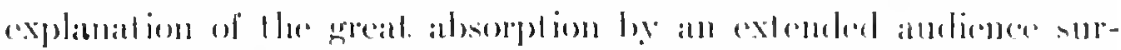

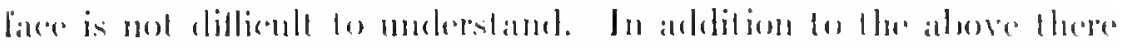

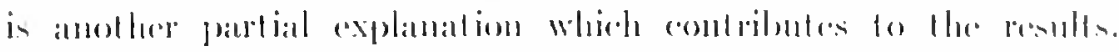

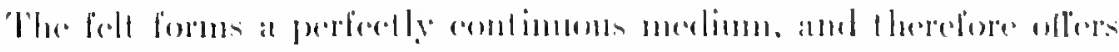

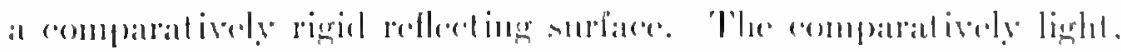

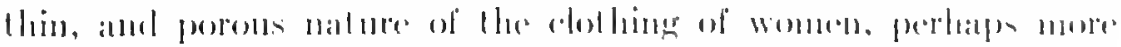

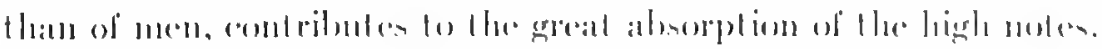

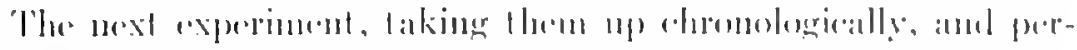

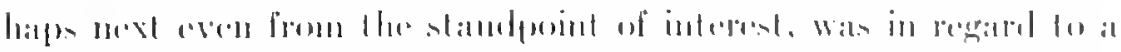

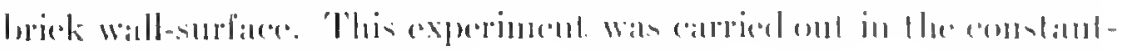




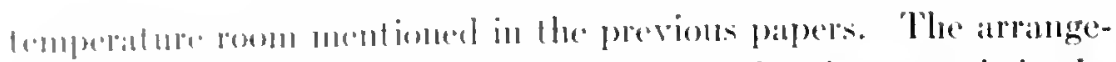
ment of apparatu- is lown in lig. 3, where the at reservoir in the

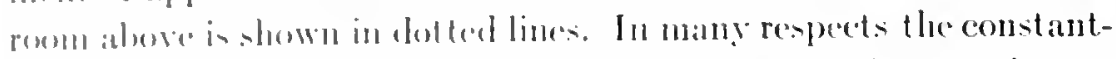

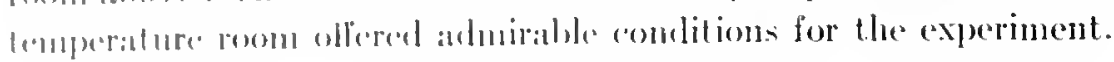

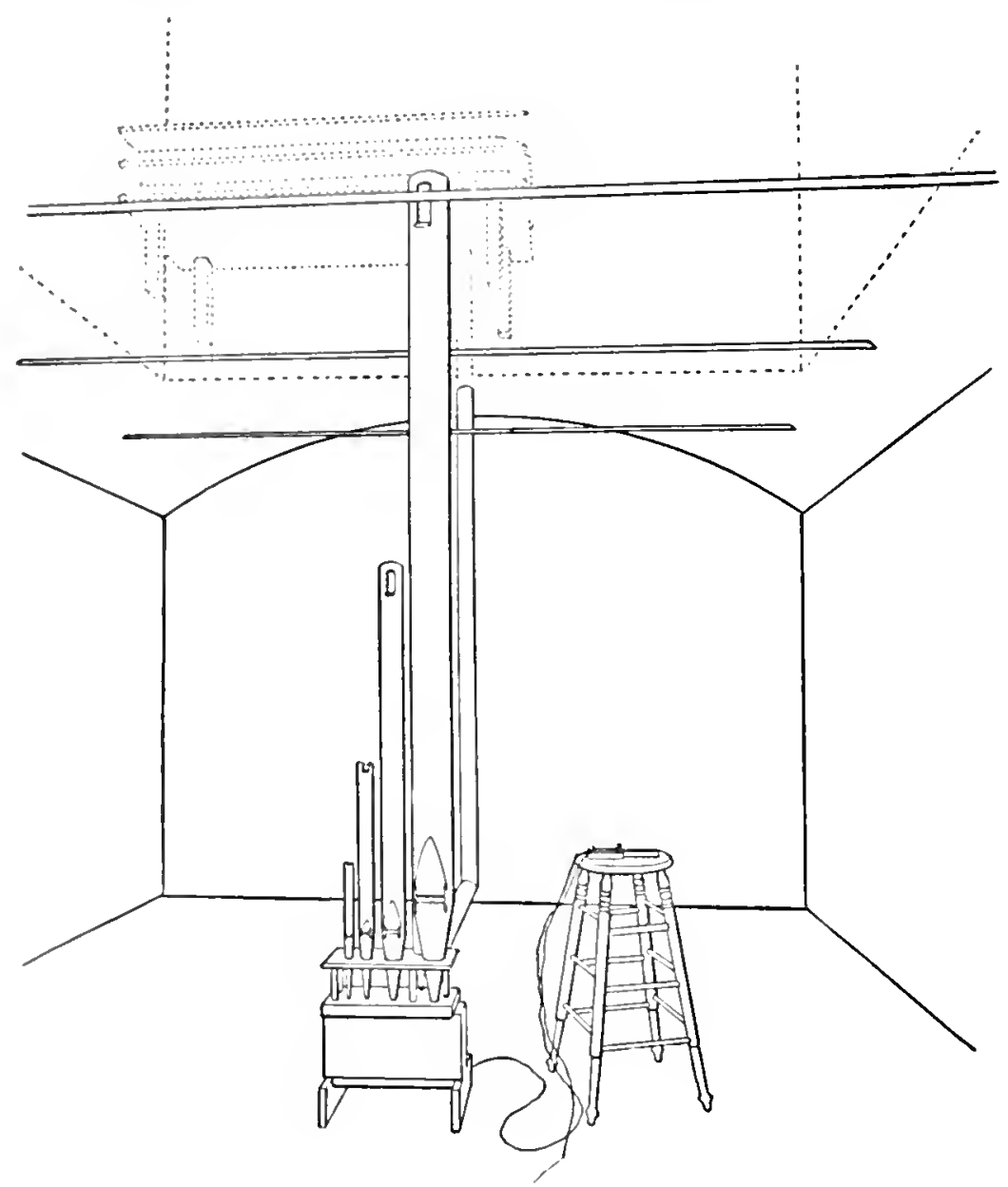

FIG. 3

It - ponition in the conter of the buileling and its depth undergromel made it compatratively free from ontside disturbing noises, - so much o that it was posilale to experiment in this room in the earlier parts of the erening. alt hough not, of conrse. When any one else was at work in the lubliling. While it possesses these advantages, its 
arched coiling, hy placing it in the category of special cases, makes. extrat precantion necessiry. Fortumately, at the beginning of the experinent the walls were mpatinled. Inder these conditions its

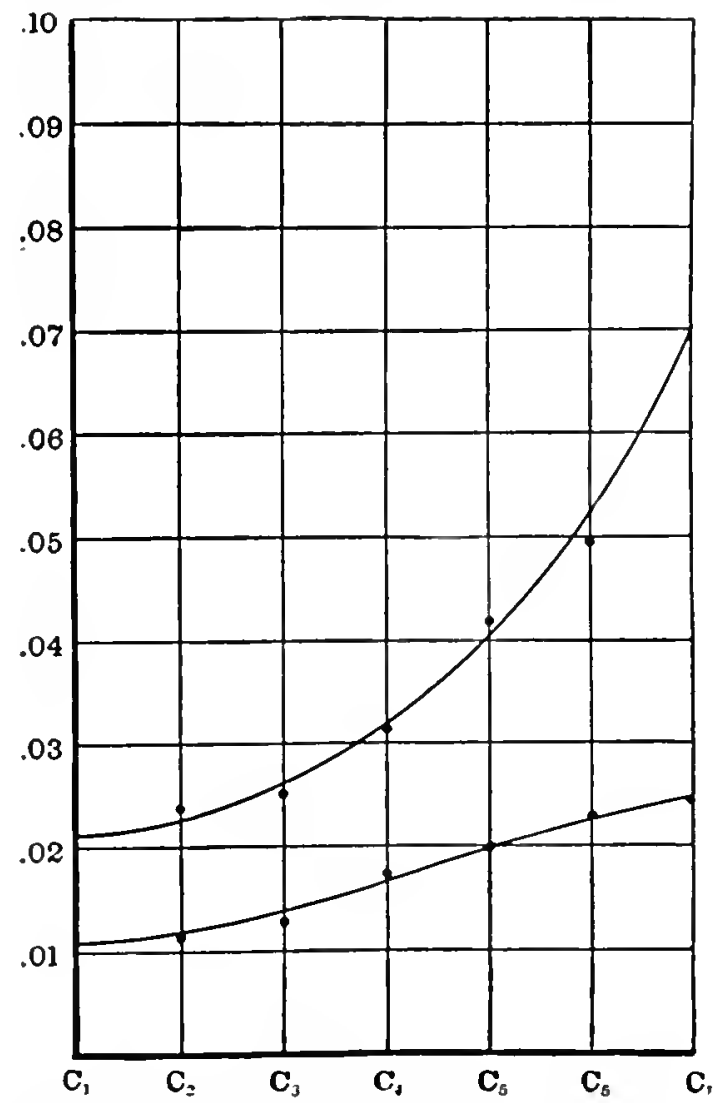

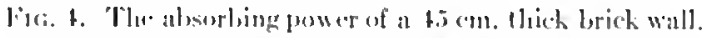

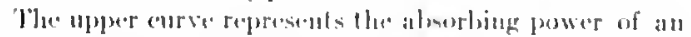

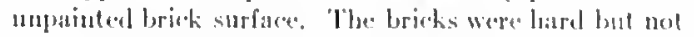

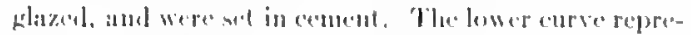

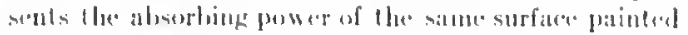

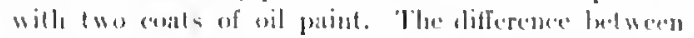

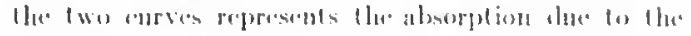

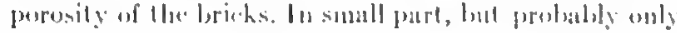

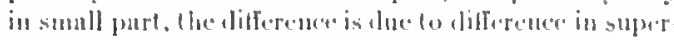

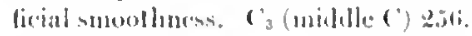

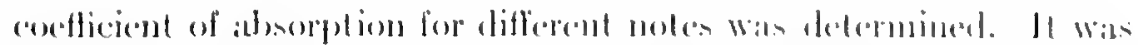

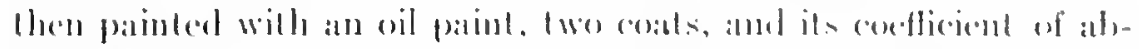

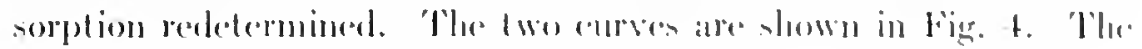




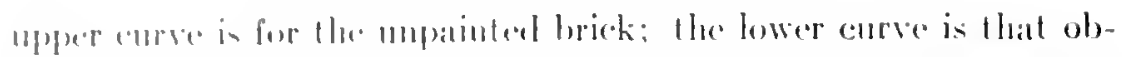

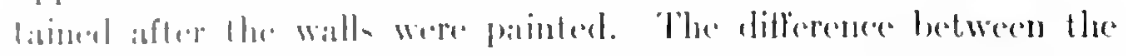

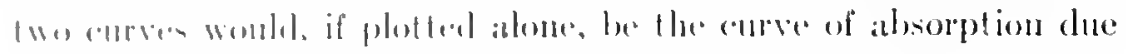

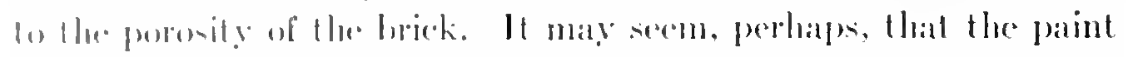

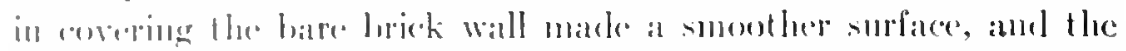

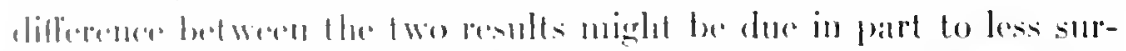

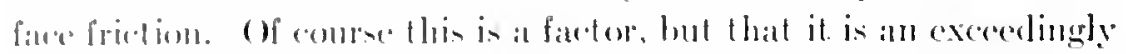

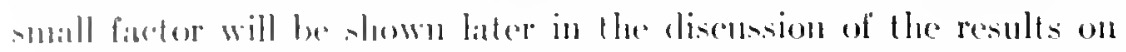

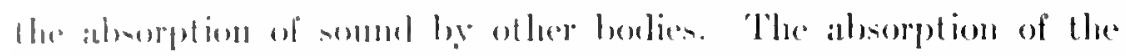

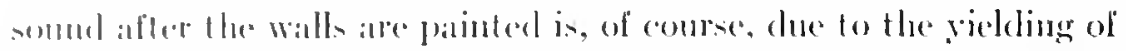
the wall moller the vibration, to the somed actually tramsmitted benlify hy He walls. and to the absolption in the process of trans-

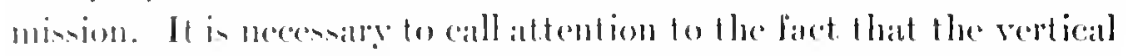
orelinalen atre here magnified tentold over the orelinales shown in the likt rillive.

"Yle next expreriment was on the delcrmination of the absorption of - rmul ly wood sheatling. It is not an easy malter to find conditions -ubtable for this experiment. The room in which the absorption hy woot sheathing was determined in the arlier experiments

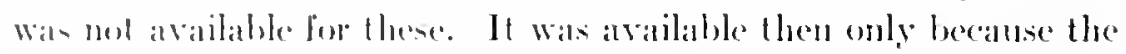
huileling was new and empty. When these more claborate experiments were moler way the poom hatel becomse oceupied, and in a

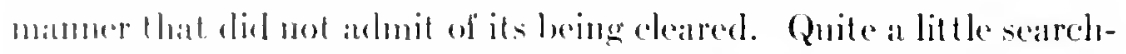

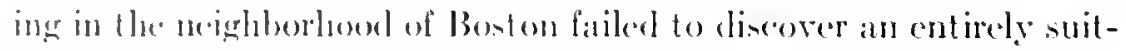

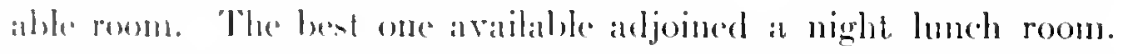
The night hucle was benght ont for a couple of nights, and the experiment was tried. The work of hoth nights was much disturbed. The tratfic pant the hullding did not stop until nearly two o celock, and began again albout form. The interest of those passing by on fout thromghent the night. and the necensity of repeated explanations to the polices greatly interfered with the work. This detailed stalement of the eomelitions under wheh the experiment was tried in mate Lye ware of explanation of the irregulanty of the observation perorded on the enrve and of the latilure to carry this particular lime of work luether. 'The first night seren points were olstaned for

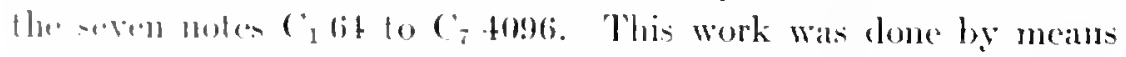
of a portable alpparatus shown in Fig. 5. The reduction of these 
results on the following dity showed variations inclicative of maximat and minima, which to be accurately located would reguire the de-

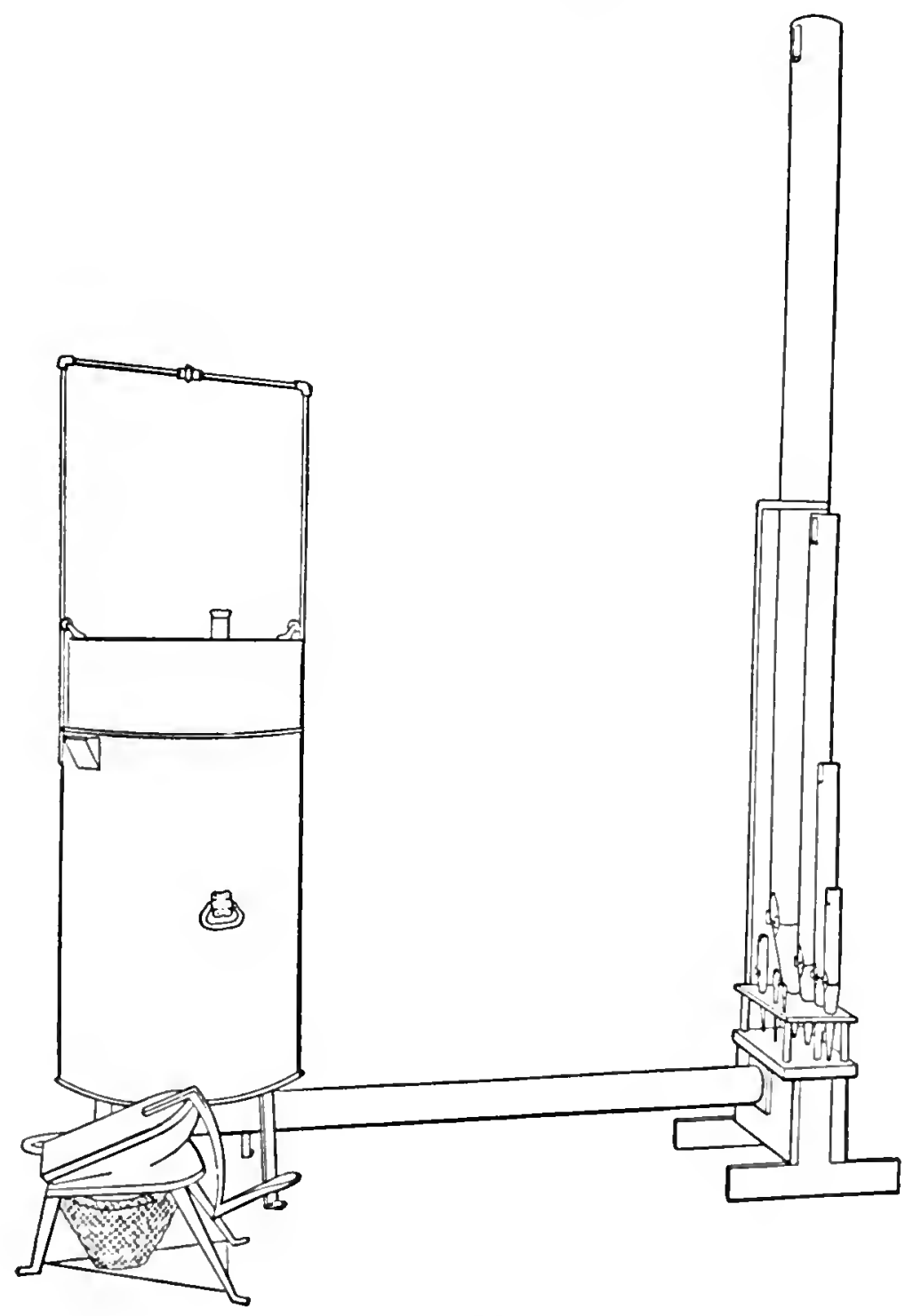

lik, i

termination of intermetiate points. The experiment lle lollowing

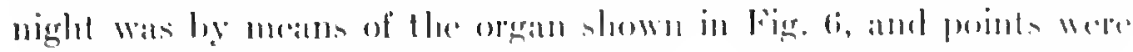




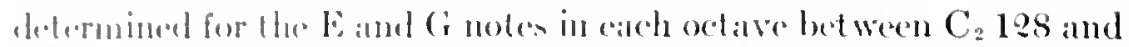

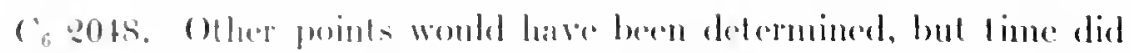

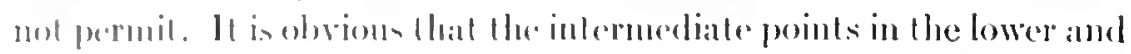

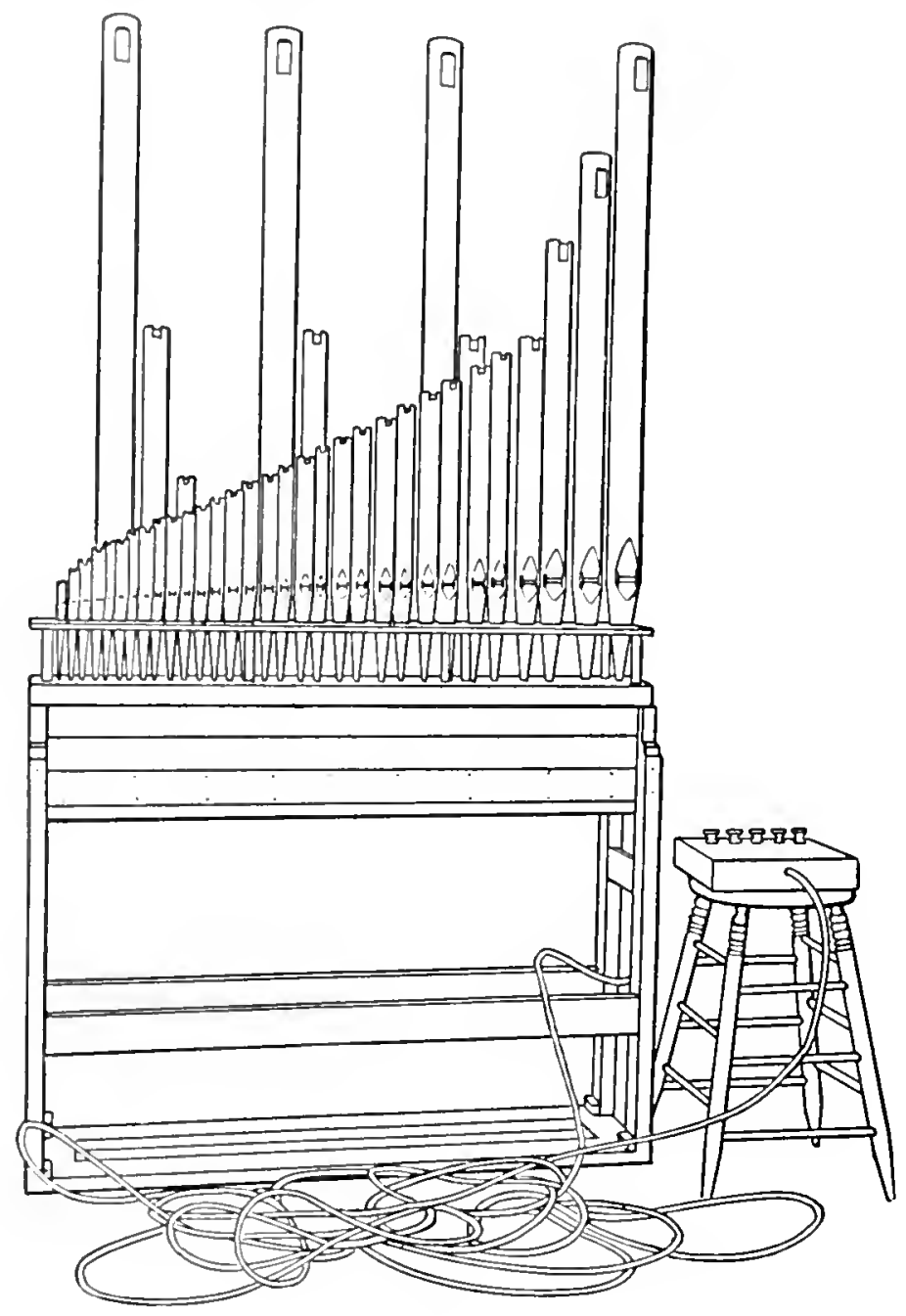

Firi. if

in the highere oxtare were desibable, but no pipes were to be had on sme shert notice for this part of the range, and in their absence the data comld not he oblained. In the diagram, Fig. $\%$, the points lying on the vertical lines were determined the first night. The points 
lying between the vertical limes were determined the second night. The accuracy with which these points fall on a smooth curve is

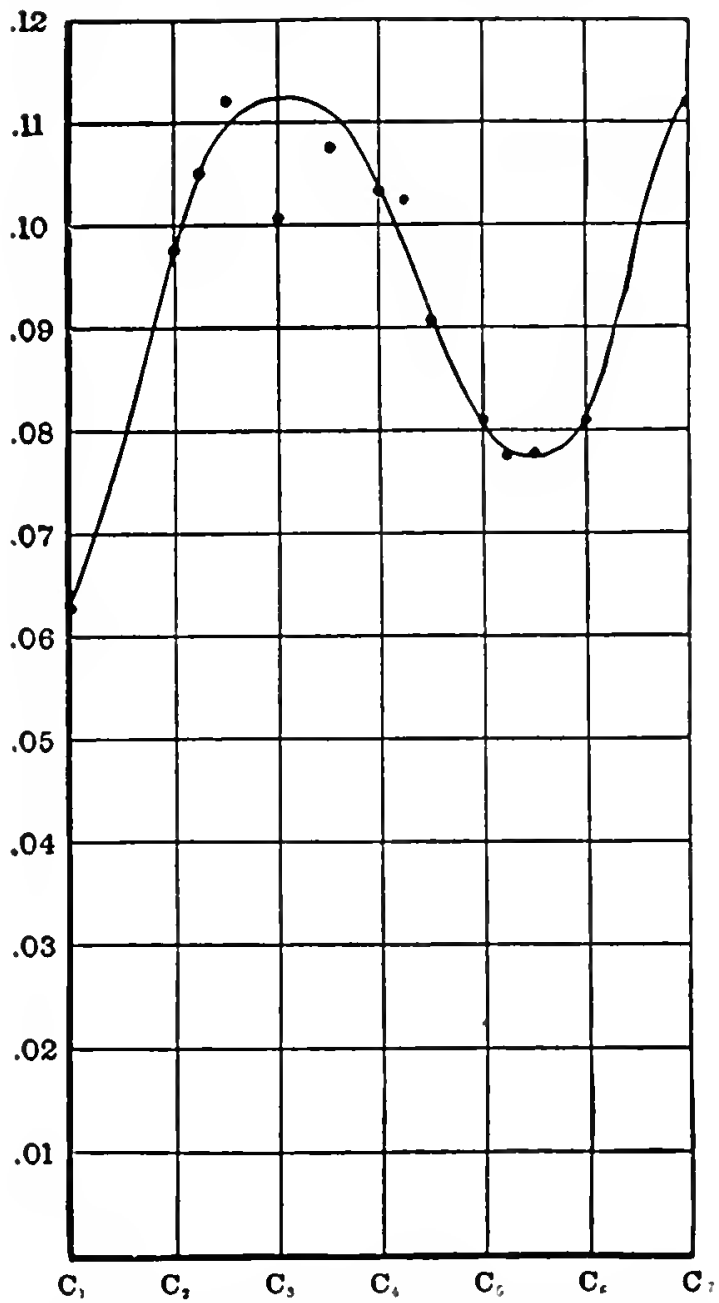

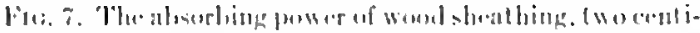

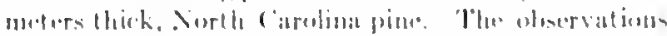

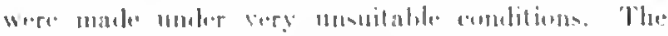

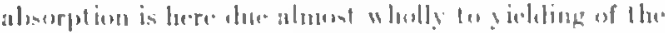

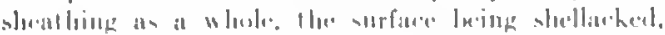

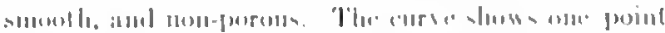

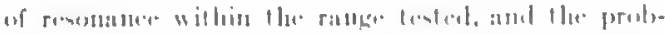

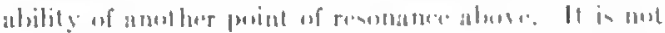

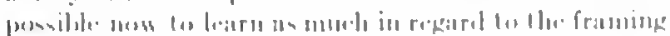

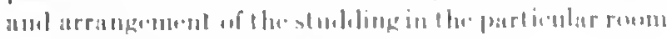

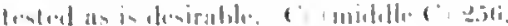


perthes alt that rembl be expereted in view of the diflicalty under which the observations were combleded and the limited time availalle. (Jue puint in particolar falls far off from this curre, the point

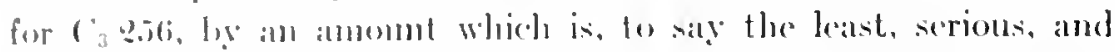

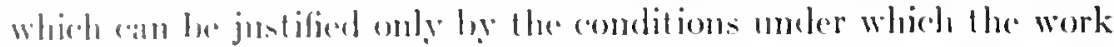

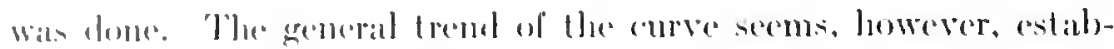
lisherl hejentel reasemable elomht. It is interesting to note that there

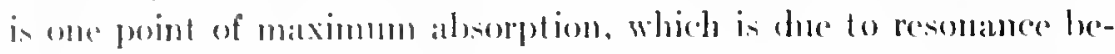
fwerell the watls anel the somml, and that this point of maximum abserption lies in the lenver part. thengh not in the lowest part, of the range of pitele tenterl. It womkl hare been interesting to ketermime. hate the time amel farcilities permithet, the shape of the curve

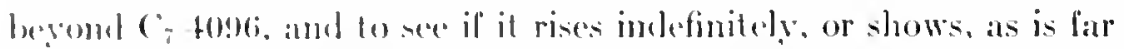
mere likely, a suceension of maxima. The neale employed in this cmre is the same as that emploged in the diagram of the musanted amd panted wall-surfaces. It may pertaps be noted in this connevetion that at the very least the absorption is four times that of painferl brick walls.

'The expreriment wats then dirested to the determination of the absorption of somel hy cuslions, and for this purpose return was made totheremstant-temprerature room. Working in the manner indicated in the earlier palpers for sulsotances which conld be carried in and oul of a room. Hhe courves represented in Fig. 8 were obtained. cime 1 slows the aborption coefliciont for the Sanders Theatre (onshions, with which the whole investigation was begun ten years ages. Thuece (molious were of a particularly open grade of packing, it sort of wiry grass or vegetable fiber. They were covered with "anvas lixking, and that in tum with a very thin eloth covering. Cirve in for colnons borrowed from the Phillips Brooks IIouse. There were of a high grande, filled with long curly hair, and covered with canviss ticking, which was in turn covered by a long nap phesh. Comse s is for the emshions of Appleton Chapel, hair covered with a labllerette, and showing a sharper maximm and a more rapid diminution in absorption for the higher frequencies, as would be experted moler such romelitions. Cimve + is probably the most interenting, heranse for more stantart commercial conditions. It is Hee corre for elastice felt cushions as made by Sperry and Beale. 
It is to be observed that all four curves fall off for the higher frequencies, all show a maximum located within an octave, and three

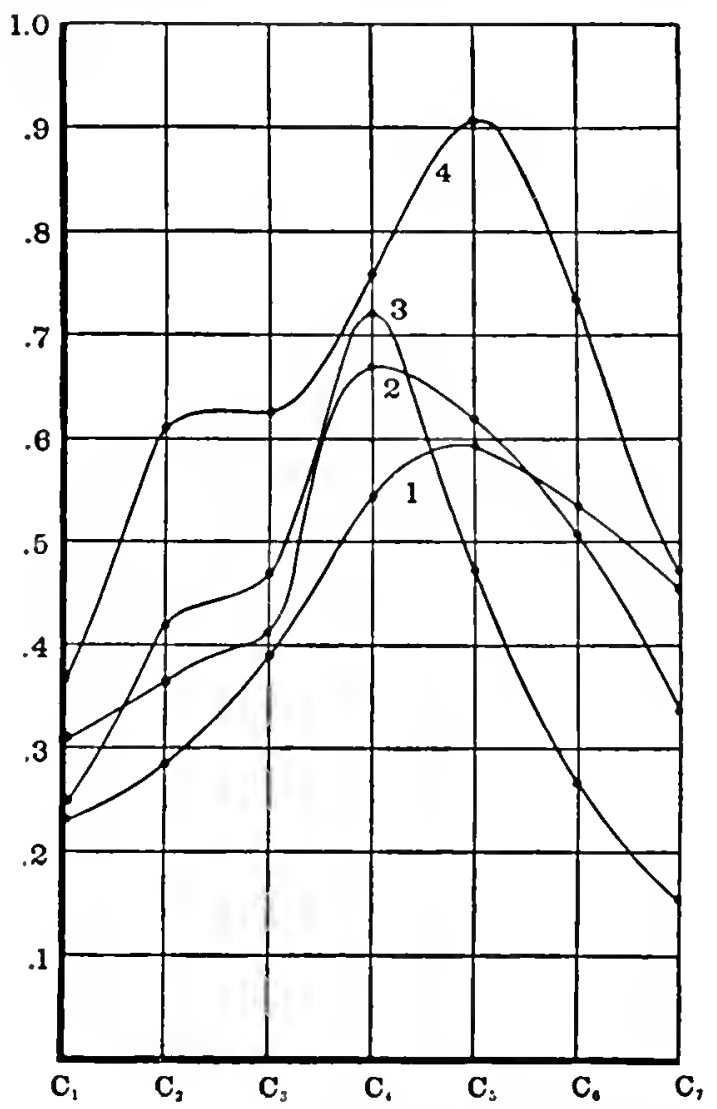

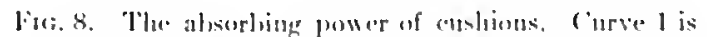

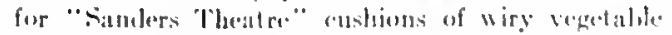

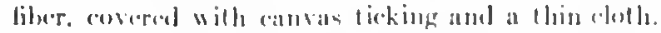

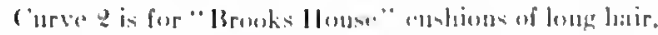

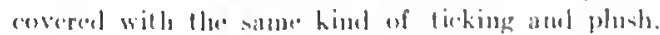

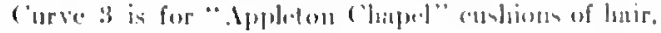

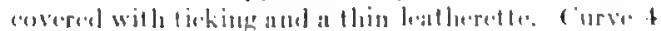

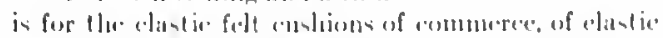

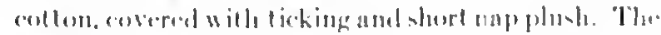
alsorling power is por stuare meler of surface.

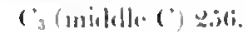

of the curves show at curious hump in the second octave. 'This

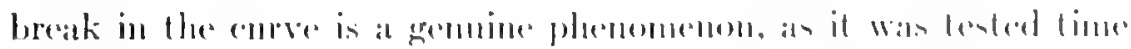

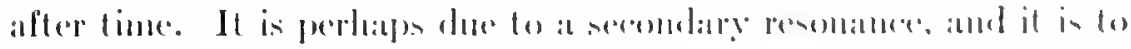


be oherereal that it is the nore promomoned in those curves that have the sharper besmanee in the ir principal naxima.

Ohervations were then obtained on mupholstered chatrs and setken. The result for chairs is shown in Fig. 10. This curve gives the aborption coeflicent pere single chair. The effect was surprisingly small; in fact. when the floor of the constant-temperature room wate entively enered with the chairs spaked at ustal seating fintances. the efferet on the reverberation in the room was exced-

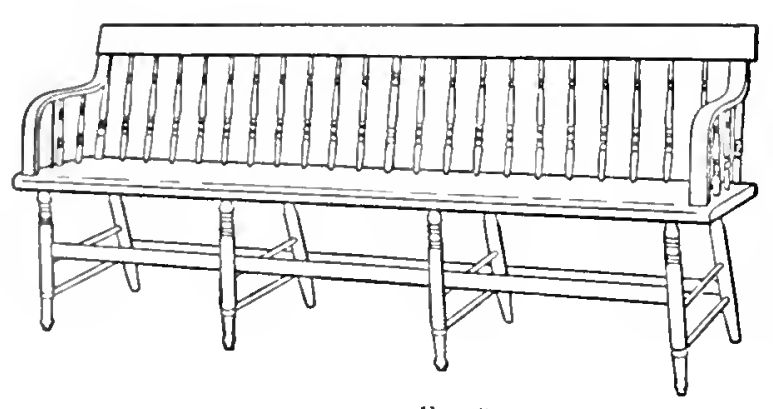

FIG. !

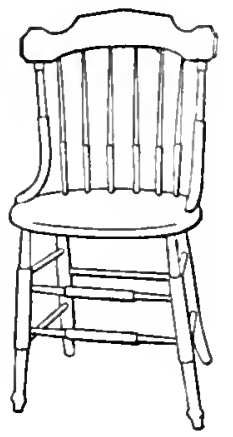

ingly slight. 'The latet that it wats so shight and the consequent difficulty in meatsuring the coefficient is a partial explanation of the variation of the renults as indicated in the fignre. Nevertheless it is probable that the variations there indicated have some real basis, for a repetition of the work showed the points again falling above amel belem the line as in the first experinent. The anomnt that these foll above and helow the line was difficult to determine, and the number of points along the curve were too few to justify attempting to follow their values by the line. In fact the line is chawn on the thigram merely to indieate in a general way the fact that the coetlicient of absorption is nearly the same orer the whole range. A varying resonance phenomenen was unquestionably present, but so small as to le negligible; and in fact the whole absorption by the chair is atn excerelingly small factor. 'The chair was of ash, and its type is shown in the arempanying sketeh, Fig. 9.

'lle results of the observations on settees is shown in Fig. 11. "Thue plotted are the coefficients jer single seat. there being five seats to the settere. The settees were placed at the customary dis- 
tance. Ilere again the principal interest attaches to the fact lhat the coefficient of albsorption is so exceedingly small that the total effect on the reverberation is hardly noticeable. Here also the plotted results do not fall on the line drawn, and the departure is

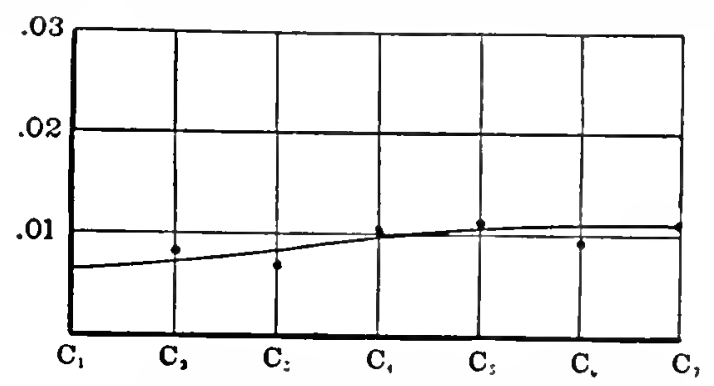

Fir. 10. The alsorbing power of ash chairs shown in Fig. औ.

due probably to some slight resonince. The magnitude of the departure, however, could not be determined with aceduracy beealne of the small magnitude of the totat absorption coeflievent. For these reasons and becaluse flue mumber of points was insuflicient. no at-

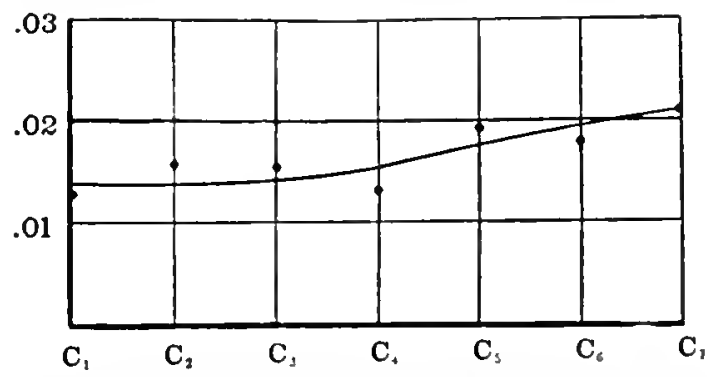

Fici, 11. The absorbing power of atsh settees slewn in

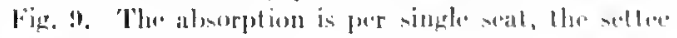
as shown soating live.

tempt was mate to draw the curve thengh the photted points. hut

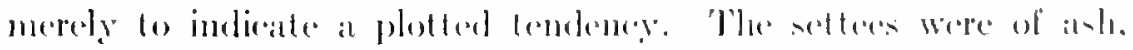
and their general style in shown in the sketelt.

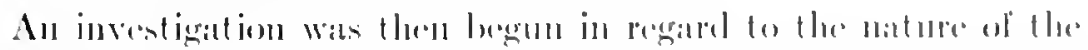

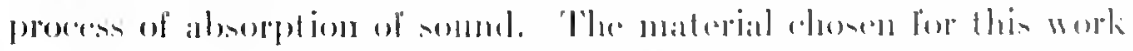

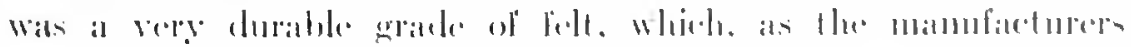

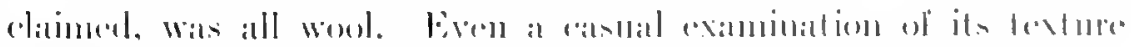

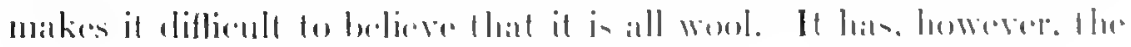


indrantigne of being porens, flexible, and very durable. Almost constant hamelling for weveral vealrs hats appatrently not greatly changed its remaintency. It is to be noted that this felt is not that mentioned in the palpers of six years agro. That felt was of lime-treated cow"s

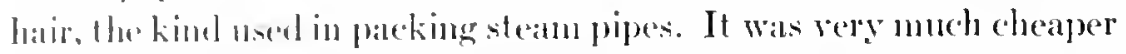
in price, hut stood little hamdling before disintegrat ingr. The folt rmplevent in these experiments comes in sheets of varions thickmenes, the thickness here emploped being ahout $1.1 \mathrm{~cm}$.

The ronfficient of absorption of at single layer of felt was measured for the notes from (') it to $C_{3}+096$ at octave intervals. The experiment was. repeated for two layers, one on top of the other. then for three and so on up to six thicknesses of lelt. Becanse the greater thicknemes presented an area on the edge not inconsiderable in (onnparison with the surfice, the lelt wils surrounded by a narrow werel frame. I'nder such circumstances it was safe to assume that the absorption wats entirely by the npper surface of the felt. The experiment wals repeated al great many times. first measuring the coctlicient of absorption for one thickness for all frequencies, and then rhecking the work by conducting experiments in the other order: that is, measuring the ahsorption hy one, two. three, etce, thicknesses. for each frequency. The mean of all observations is shown in Fig. 19 and Fig. 13. In Fig. 19 the variations in pitch are pletted an abscissas, als in previons diagrams, whereas in Fig. 13 the

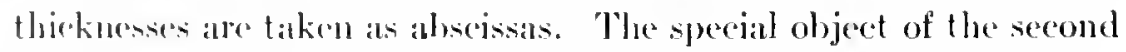
method will appear later. but a general object of adopting this method of plotting is as follows:

If we consider Fig. 12, for eximple, the drawing of the line through any one set of points should be mate not merely to best fit those points, but should be drawn having in mind the fact that it, as a "urves is one of a family" of curves, ansl that it should be drawn not merely ats a best corve through its own points, but as best fits the whole set. For eximple, in Fig. 19 the curve for four thicknesses would not hatse been drawn as there shown if drawn simply with reterence to its own points. It would have been drawn directly through the points for $\mathrm{C}_{1}$ bit and $\mathrm{C}_{2}$ 128. Similarly the curve for fire thieknesuen would have been drawn a little nearer the point for $\mathrm{C}_{2} 1$ gs and atbove insteal of below the point for $\mathrm{C}_{1}$ 6.t. Considering, 
however, the whole family of curves and recognizing flat each point is not without some error, the chlleses ats drawn are more nearly correct. The best method of reconciling the several curves to each

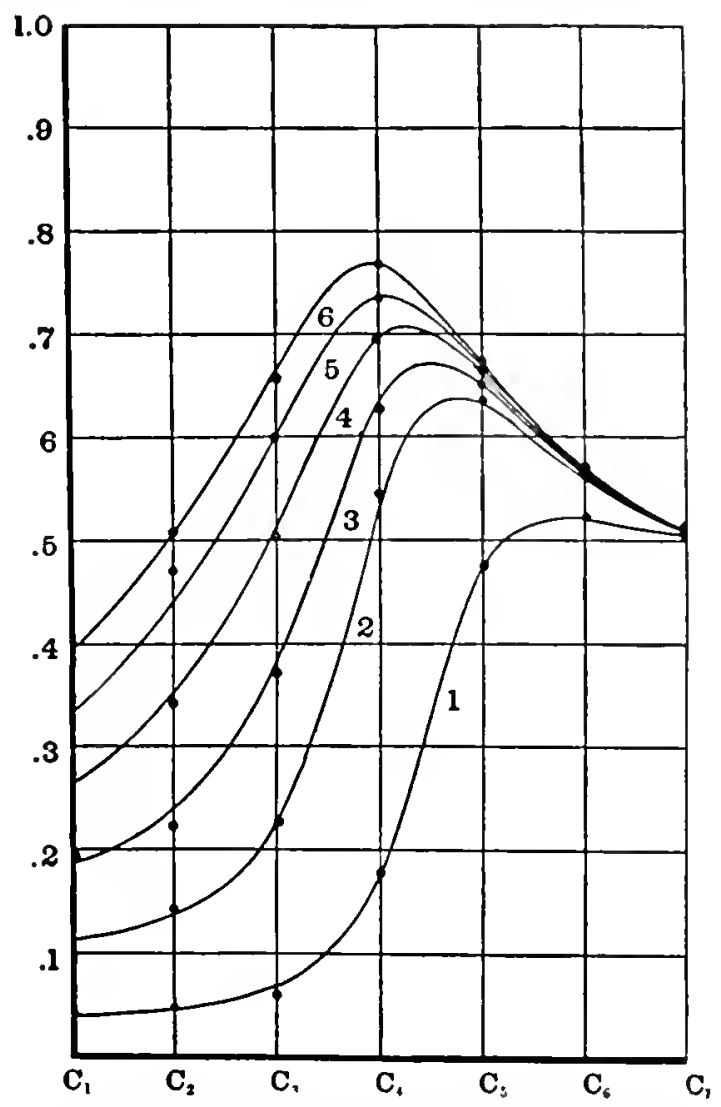

fin. 12. The alswirling power of fell of different thicknesses. foitch piene of foll was 1.1 ans. in llitekness.

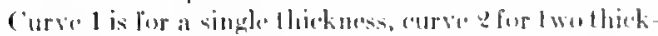

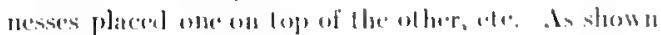

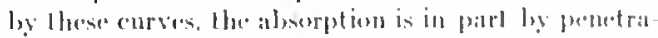

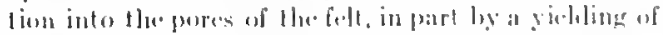

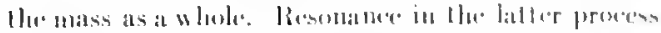

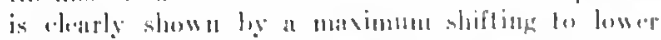

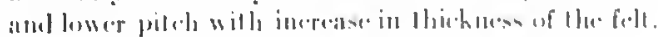
(i) (millle l:)

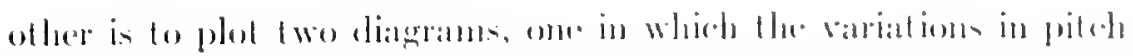

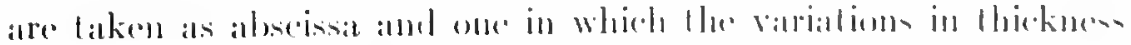

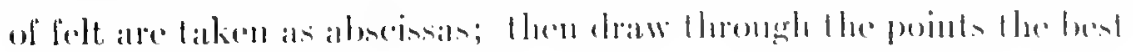


ditfing andes and alverage the colpreponding ordinates taken from

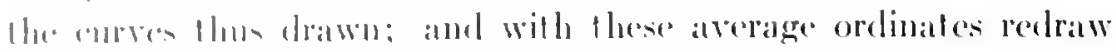
lofls fantilen of renters. The points shown on the diagram are of contre flas original results oblained experimentally. In genceral llary fall pretty elose to the curves, although at times, as iu the

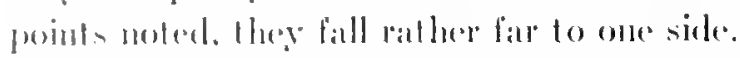

'The lollowing will serve to present the points of particular in-

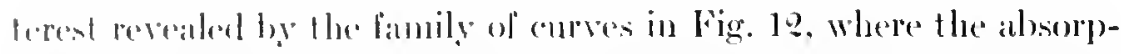
fion he the several thicknesses is plotted agamst pitele for abscissas. It in lobe oberrent that a single thickness searcely absolds the sound from the eight. fonr. and two-foot organ pipes, $C_{1}$ 64, $C_{2} 128$, and ( ${ }_{3}$ g.sti, and that its almorplon incleases rapidly for the next two octalres. alter which it remains a constant. Two thicknesses absoll,

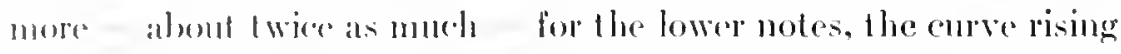
more rapidly, pasing through a maximum between $C_{4} 519$ and (' ${ }_{3}$ lest. and then falling ofl for the higher notes. 'The same is true lol greited hicknesses. All curves show a maximum, each succeding one corresponding to a linte lower note. 'The maximum for six thickmescen comedes pretty closely to $\mathrm{C}_{4} 519$. The absorption of the somud be felt may he ascribed to three canses, - porosity of structure, compression of the felt as a whole, and friction on the surface. 'The prencence of the maximum must be ascribed to the -ereoud of thene camses, the compression of the felt as a whole. As lo the third of thene three causes, it is hest to consult the curves of the $110 \mathrm{xt}$ fignture.

The following fands are rendered particularly evident by the "urven of lig. 13. For the tones emitted ly the eight-foot organ pipe. (c) (it. the absorption of the somel is very nearly proportional to the thickness of the felt over the range tested, six thicknesses, fi.c cull. The curves for notes of increasing pitch show increasing bihlue for the eoefficients of alsorption. They all show that were the thickness of the felt sufficiently great, a limit wonld be approached - a lact, of comse, self-evident - but for $\mathrm{C}_{5} 1024$ this thickless was reached wilhin the range experimented on; and of course Hae same is true for all higher notes, $C_{6} 9048$ and $C_{7} 4096$. The higher the note. the less the thickness of felt necessary to produce a maximum effect. The curves of $C_{1} 64, C_{2} 128, C_{3} 256$, and 
$C_{4} 519$, if extended lackwatrd, would pass nearly through the origin. This indicates that for at least notes of so low a pitch the abserption

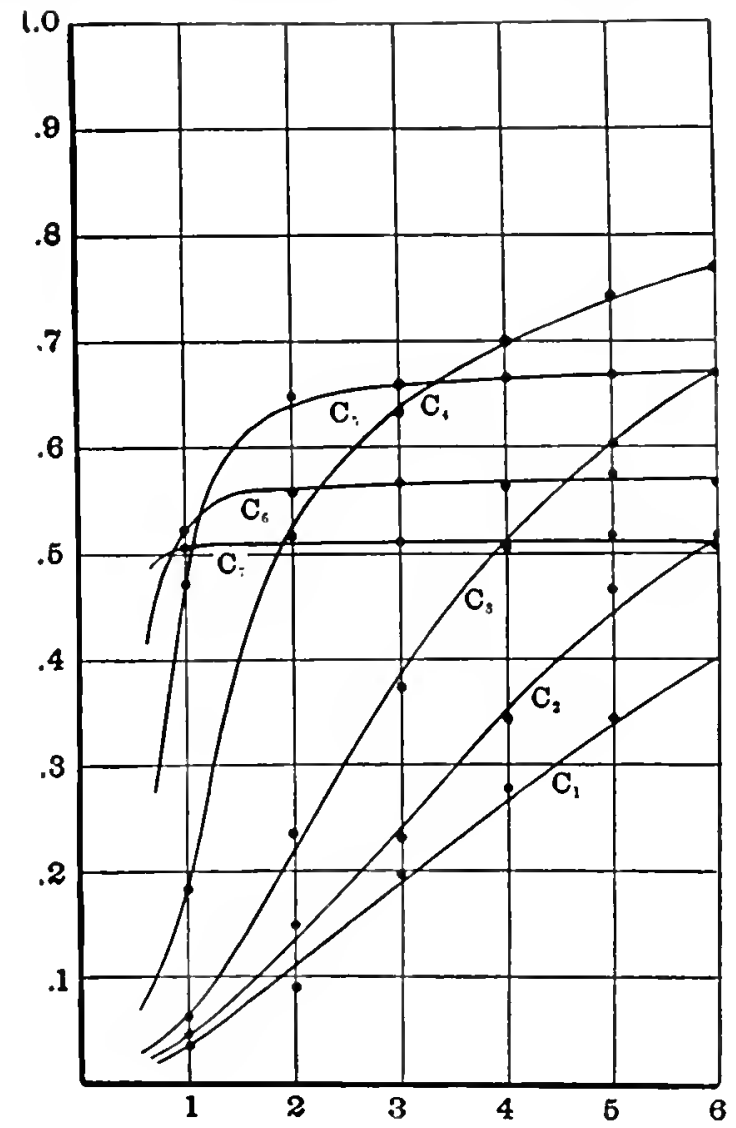

Fin, 1:3. The absorbing puser of folt of elitferent thich-

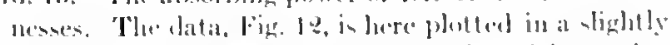
different manner horizontally on flutted increasing thickuens - and the curves are for motion of different frecpucmeryt octare interwals in piteh. Thus plotled

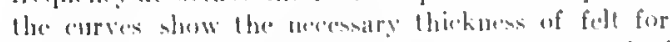

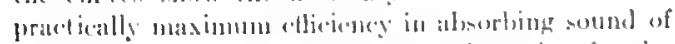

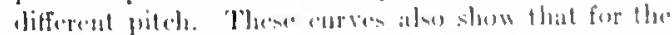

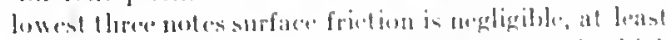
in comparionn with the other fartore. for the high

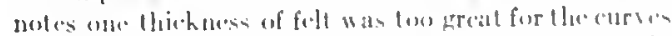

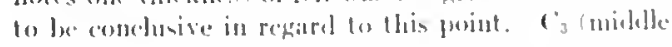
(c) 950 i.

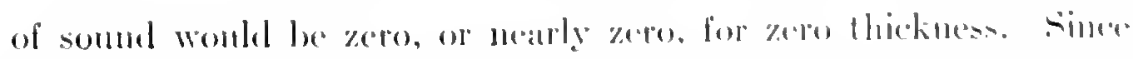

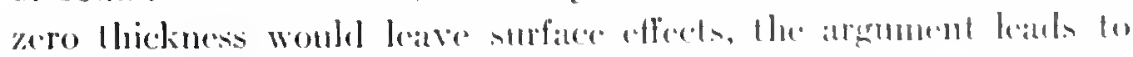




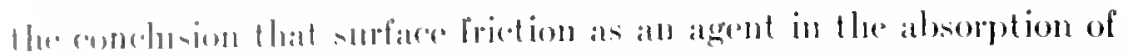

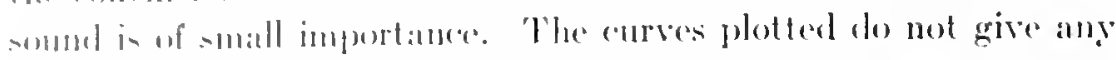

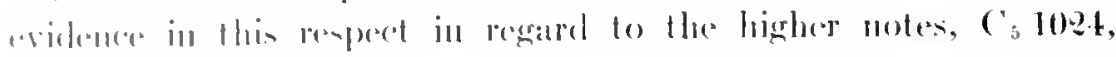
(cis

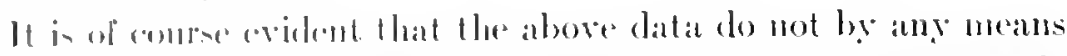

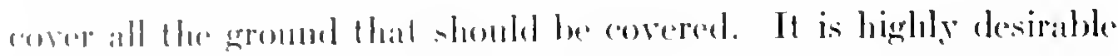

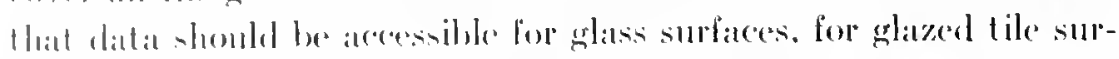

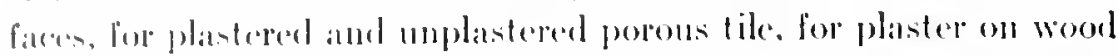

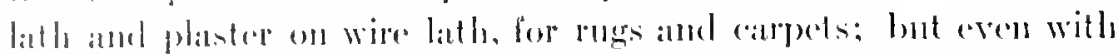
thene data collexeded the joh woulel be by no means completed. What is wanted is not merely the measmement of existing material and wall-surlaces. but an inrestignation of all the possibilities. A anderetre canes will perhapes illustrate this. If the wall-surface is to lie of wowl, there enter the guestions as to what would be the effeect of valrying the matrerial. low ash dithers from oak, and oak from walnut or pine or whitewerest: what is the effect of vatriations in

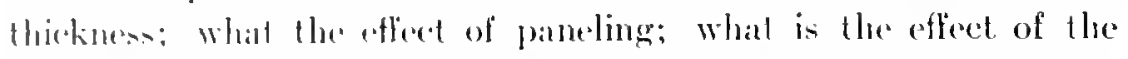
shatemg of the furming on which the wool sheathing is fastened. If the wall is lo he plaster on lath, there arises the guestion as to the ditherence betweens wood lath and wire latls, between the mortar that was fermerly used and the wall of torlay. which is made of hard and inpervions plaster. What is the effect of variations in thickHen of the plantere: What is the effect of painting the plastere in wil or in water colors: What is the effect of the elepth of the air

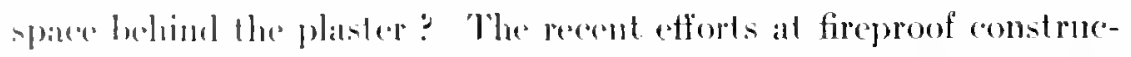
tion larve lestltad in the tlse of harder and harder wall-surfaces, and great reverbaration in the room, and in many eases in poorer aromatice. Is it possible to devise a material which shall satisfy the conditions ats to fireproof (pualities and get retain the excellence of somse of the older hut not fireproof rooms? Or, if one turns to the interion furnishings, what type of chair is best, what form of cuslisons, or what form of uplodstery: There are many forms of atulitorium Chairs and settees, and all these shonld be investigated if one propuses to applye exact calculation to the problem. These are some of Hor eflentions that bave arisen. A few datal have been obtained locking toward the answer to some of them. The difficulty in the waty of the prosecution of such work is greater, however, than ap- 
pears at first sight, the particular difficulties being of opportmity and of expense. It is diflicult, for "xample, to find roons whose walls are in liarge measure of gliss, "specially when on beatrs in mind that the room must be cmply, that its other watl-surfaces must be of a substance fully investigated, and that it must be in a localion admilting of auict work. Or, to investigate the eflecel of the different kinds of plaster and of the different methods of plastering, it is necessary to have a room, prefirally an undergroum room, which can be lined and relined. The constant-temperature room which is now available for the experiments is not at room suitable to that particular investigation, and for best results a special room should be constructed. Moreover, the expense of plistering and replastering a room - and this process, to arrive at anything like a general solution of the problem, would have to be done a great many times - would be very greal, and is at the present moment. prohibitive. A litle dala along some of these lines have been secured, but not at all in final form. The work in the past bats been largely of an analytical nature. Could the imvestigation take the form of constructive researed, and lead to new methods and greater possibilities, it would be laking its more interesting form.

The athove discussion hats been soledy with rederence to the determination of the coeflicient of ahsorption of sound. It is now proposed to discenss the cunestion of the appliention of these coeflicients to the calculation of reverberation. In the first series of papers, reverberation was dedined will referenee to C 4512 as the continnation of the sound in at room after the sonrere had ceased, the initial intensity of the sonnd heing one million times minimum indible intensily. It is debalable whether or not this definition should be extended without alteration to reverberation for other motes than Cajlg. There is a good deal to be sitd both for and anginst its retention. 'The whole. howerer. hinges on the ont conne of at pha iological or psyedological incpuiry not yed in such shape ats to leat to

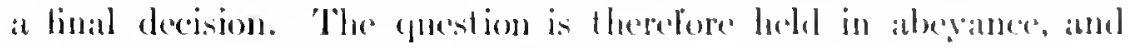
for the tine the detintion is retimed.

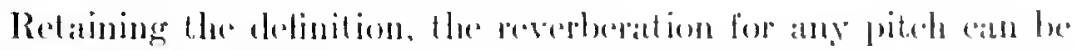
calculated by the formulit

$$
T=\frac{k l^{\circ}}{a} .
$$


where $l$ is the volume of the room, $K$ is a constant depending on the intial intensity, and a is the total absorbing power of the walls and the contaned matrial. $K$ and $l^{*}$ are the same for all pitch

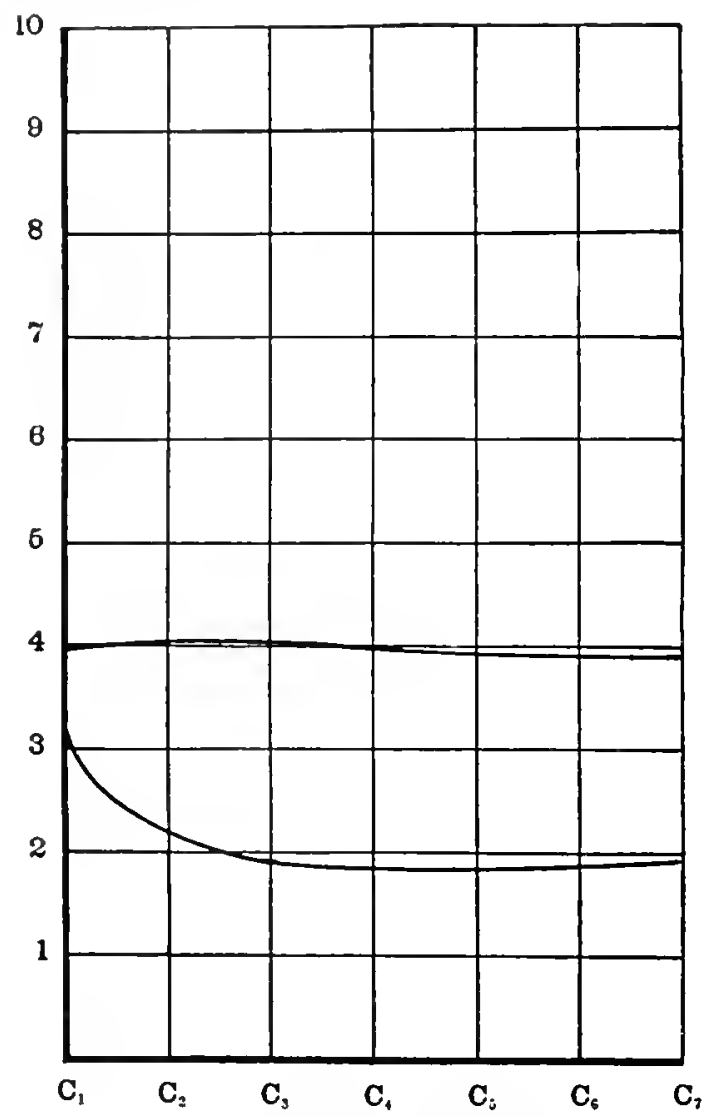

Fig. 14. Curves expressing llet reverberation in the large lecture-room of the Jefferson Physical Laboratory with (lower curve) and without (upper curve) an audience. These curves express in seconts the luration of the resichal sound in the room after the cessation of sources producing intensities $10^{6}$ times minimum audible intensity for ench note. The upper curve deseribes acoustical conditions which are very unsatisfuctory, as the hall is to be usen for speaking purposes. The lower curve descriles acoustically satisfactory conditions. $\mathrm{C}_{3}$ (midlute $\mathrm{C}$ ) 256 .

frequencies. $K$ is .16t for an initial intensity $10^{6}$ times minimum anclible intensity. The only factor that varies with the pitch is $a$, which can be determined from the ditil given above. 
In illustration, the curves in the accompunging fing. 14 give the reverberation in the liarge lecture-room of the Jefferson Plyysical Laborat ory. The upper curve defines tlue reverberation in the room when entirely empty; the lower curve defines this reverberation in the same room with an audience two-thirds filling the room. 'The upper curve represents a condition which would be entirely inpractical for speaking purposes; the lower curve represents a fairly sattisfactory condition. 



\section{MELODY AND TIIE ORIGIN OF THE MUSICAI. SCALE ${ }^{1}$}

Ix the vierepresidential andresses of the American Anowiation great latitude in the choice of subjects is allowed and taken, but there is, I believe, no precerlent for choming the review of al hook printed fifty-five years before. I Helmboltz' Tonenemfindungen, pro-

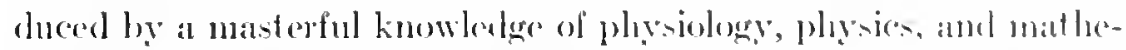
matics, and a scholar's kmowlertge of the literature of mu-ie, hats wanded off all essential criticism ly its hroattle, completelle.s, and wealth of detail. Since it wits first publinhed it hats been aldeterl to

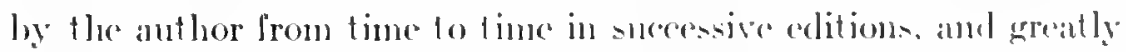
bulwarked by the scholinly notes and apperselices of its tramslator, Dr. Alexinder J. Ellis. 'The original text pembans molhomged, and nucluallenged, ats far as plysieists are concerned, in all important respecets. In taking axception at this late day to the lumblamental thesis of Part III, I derive the necessary couratge from the liket that sleould such exception be sustained, it will serve to restore lo its

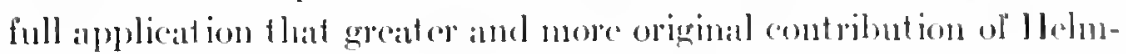
holtz which he inceluded in Part II. Having given al phesical and physiological explanation of the hambony amel aliscord of simul-

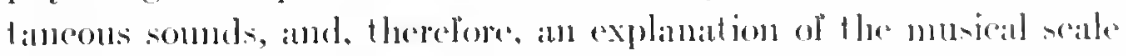
as used in modern composition, Molmbollz wis med by an appallent

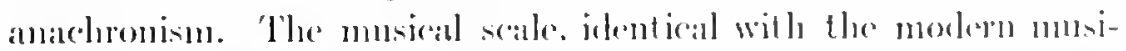
cal scale in all essentials, antedated by its use in single-part melods.

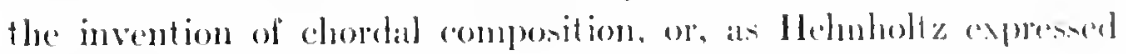

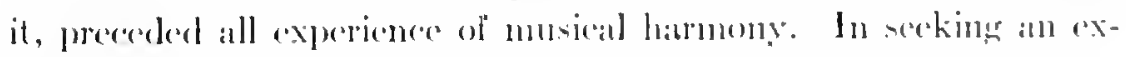

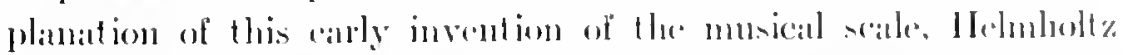
abandoned his most notalde contribution, and relegated his aplatnation of hamony and discord to the minol service of explaning a forfunate, though of course an inportant une of an alleately in-

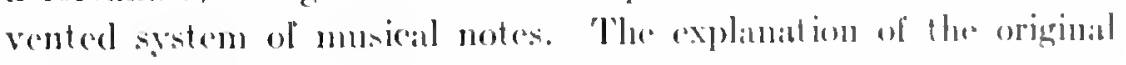

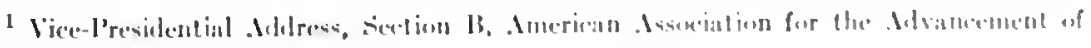

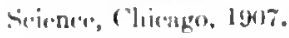


invention of 1 he musical scalle and its nse in single-part music llemgly the chassical and the early Christian eras, he sought for

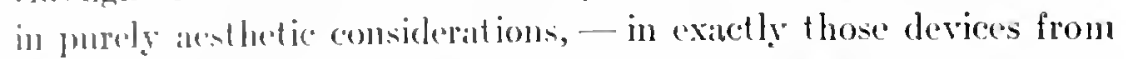
"hieh he had just succeeded in resenting the explanation of harmony and discorel.

'The human call consists of three parts, - in the nomenclature of analemy. of the onter, mildle, and inner ear. 'The onter and the imner cars alre comnected by a series of three small bones trav"lsing the milllle eatl and transmitling the vibrations of somd. 'The inner eal' is a peculialy shaped cavily in one of the hatrd bones of the skull. 'That part of the cavity with which we are here concermed is a long passiage called from its resemblance to the interior of at slatil shell the coclleal. The carity has two windows which are clesed hy nembrames. It is to the uppermost of these membranes that the train of three small homes, reaching from the drum of the ontere eal, is attached at its imnerend. It is to this upper memhrane, therefore, that the vihration is communicated, and through it the viluration reaches the fluid which fills the inner cavity. As the membrane covering the upper winkow vibrates, the nembrane corering the lower wimlow yiekling. also vibrates, and the motion of the fluid is in the nature of a slight displacement from one to the other window, to and fro. From hetween these windows a diaphragn, dividing the passageway, extends almost the whole length of the cochleat. This diaphragm is composed in part of a great number of very fine fibers stretcleel side by side, transverse to the cochlea, and called after their discoverer. fibers of Corti. On this diaphangm terminate the andit ory nerves. When the liquid vibrates, the fibers vibrate in mison, the nerve terminals are stimulated, and thus the sensation of somel is produced. These fibers of Corti are of diflerent lengths and presumahly are strelched with different teasiens. They therefore have different natural rates of vibration and at rimpathetie resonance fol different notes. The whole has beren catled a harp of several thousand strings.

Were these fibers of Corti very free in their vibution, each wenlel respond to and would respond strongly only to that particulir mote with whose frepuency it is in mison. Because of the fact that they are in a linguid, amel possibly also because of the manner 
of their terminal comnections, they are considerably damped. Becanse of this their response is both less in anomnt and less solective in character. In ficet, imeler these conditions, not cne, but many filers vilurate in response to a single pure note. A consillerable length or alrea of the diaphragm is excited. So long an the exciting somnd remains pure in quality. constant in pitch, and comstant in

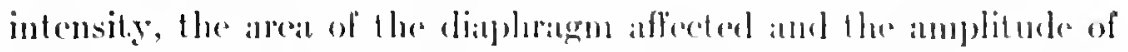
its vibration rematin unchanged. If, however, two notes alre sommed of nearly the same pitch, llee areats of the diaphragrna affected by the two notes overlap). In the orerlippling region the vibrat ion is violent when the two notes are in the sime phibre, weat when they are in opposite phase. The result is the familiar phenomenal of beats. Such beats when slow are not disaggreablute and not without musical vilue. If the difference between the two noter is incresteds the beats berome more rapid and more disagrecallese. To this riolent disturbance. to the statrting and stopping of the vibration of the

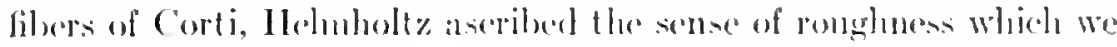
(all discorel. As the moter ate more widlely separated in pitch, the overlappling of the aflected atreas diminishes. Between proter notes

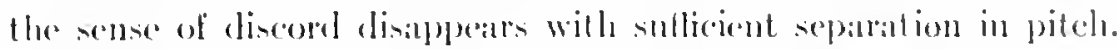
When the lwo vibrat ing atreas exactly match, berathe the two notes are of exactly the same pitell, and when the two atreas do not in the least overlap). becintse of a sulliciently wide separation in pitch. the

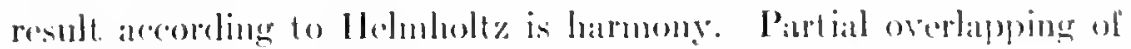

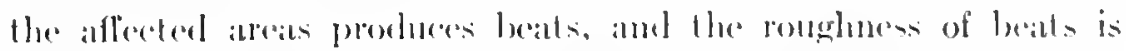

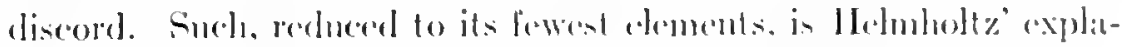

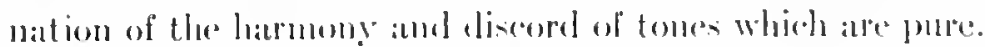

But no munseal tone is simple. It always comists of al combinittion of so-called partial tomes which bear to eateh other at mome or

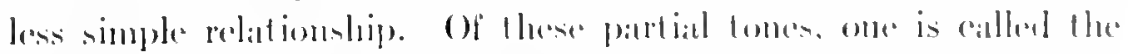

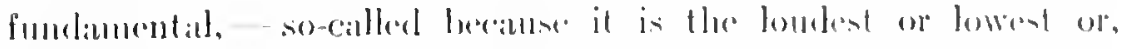

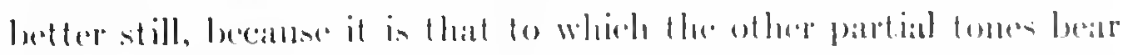

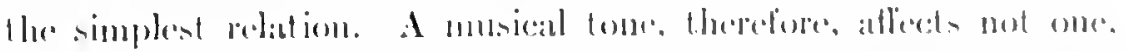

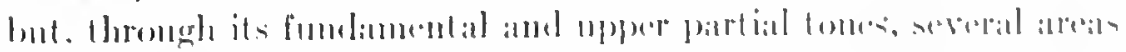

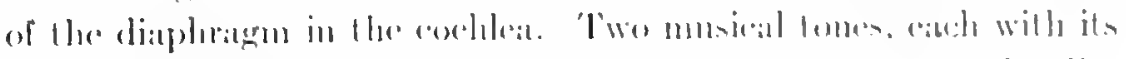

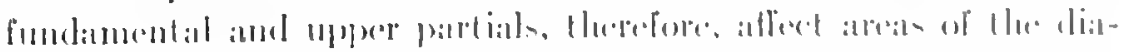

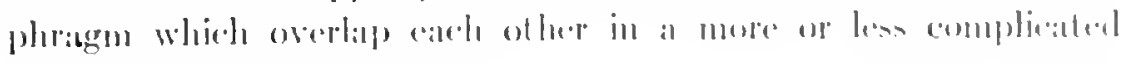


manner, degending on the relative frectuences of the fundanental tones and the relationships of therie upper partials. The exact

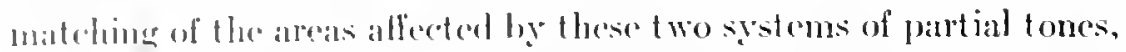
or the entire separation of the affected areas, give hamony. The oferlatpping of the ate afleceted ameats, if great, produces discord, or, if slight in amount, modifications and color of hamony.

In the grat majority of musical tones the upper partials hear simple relationships to the funclamentals, being integral multiples in ribration frefurency. Hohnholtz showed that if of two such tones onc continued to soumes uncluanged in pitch, and the other starting in unison was gradually raised in piteh, the resulting discorel would pass through maxima and minima, and that the minima woukl locate the notes of the pentatonic seate. The intermediate notes of the complete modern musical seale are detemined by a repetition of this process slarting from the notes thus determined.

If to this is added a similar consideration of the mutnal interference of the combinational tones which are themselves due to the interaction of the partial tones, we have the whole, though of course in the bricfest outline, of Hehmoltz' theory of the luarmony and diseord of simultaneously sounding musical tones.

Having thus in l'arts I and II developed a theory for the harmony and discord of simultancous somnds, and having developed a theory which explains the modern use of the musical seale in chords and harmonic music. Helmholtz pointed ont, in Part III, that the musical scale in its present form existed before the invention of harmonic music and before the use of chords.

Music may lo divided into three principal periods:-

1. "Homophonic or Lnison Musice of the ancients," including the musie of the Christian era up to the eleventh century, "to which also belongs the existing music of Oriental and Asiatic nations."

2. "Polyphonic musie of the middle ages, with several parts, but without regard to any independent musieal signifieanee of the harmonies, extending from the tenth to the seventeenth century."

3. "Ilarmonic or modern musie characterized by the independent signifieance attributed to the harmonies as such." 
Polyphonic music was the first to all for the production of simultaneous somds, and, therefore, for the leatring or the experience of musieal harmony. Ilomophonie musie, that which abone existed ny) to the tenth or celeventle century, consisted in the pro-

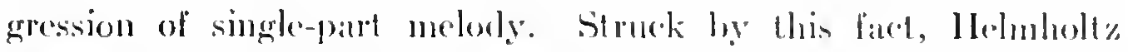
recognized the necessity of seeking another explanation for the invention and the tese of a seate of fixed moter in the muse of this period. To borrow his awn words, "scales existed long before there was any knowledge or experience of harmeny." Agitin, der-

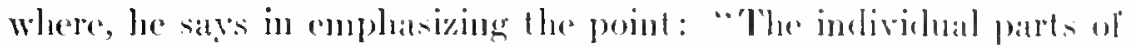

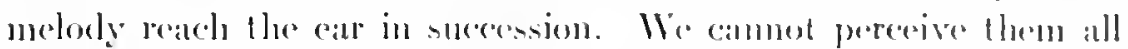

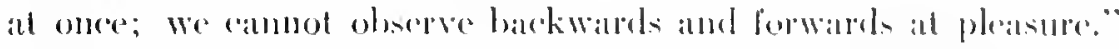

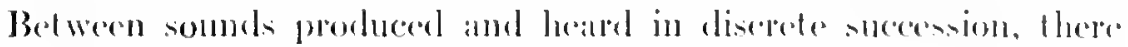
can be neither harmong nor dineord, there camnot be beats, or roughness or intermption of continnous viluations. Regrading the' someds of a medoly as not merely written in striet and nentrover-

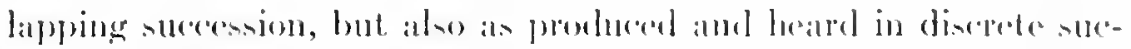

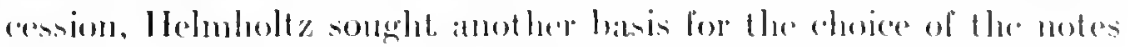

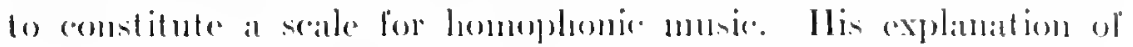

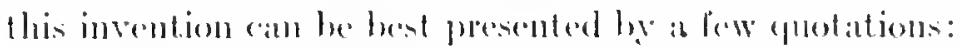

Melexly hats to experen at motion in surde at manner that the hearer maly easily, clearly, and certainly apprectiate the character of that motion ty immediate perception. This is only possible when the steps of this motion, their rapiclity, and their ammunt, are also exactly measurahle by immertiate

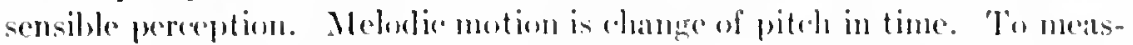
ure it perfectly, the length of time elapperel allud the distame between the pitches must be measurable. 'This is pessible for immediate andition conly.

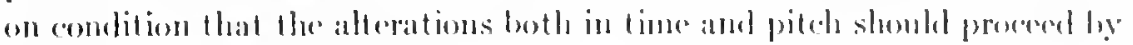
regular and determinate decrees.

Agriin lledmholt\% silys:

For a clear and sure measurement of the chatuge of pitch no means was left but progression ly determinile degrese. This series of degrees in laid down in the musical scate. When the wint howls and its piteth riven or falls in insensible gradaltions without any break, we have mothing to measure the variations of pitch, nothing ly. which we can complate the later with the earlier sounds, and comprehend the extent of the changes. The whole pluenomenon prolures a confused, unpleasant inpression. 'Tlae musical scale is as it were the divided rot, by which we meisure progrension in pitch, as rhythm measures progressien in time. 
Later he silys: -

Iot us begin with the Octave, in which the relationship to the fundamental tone is most remarkible. I et any melody be exeeuted on any inst rmment which has it good musical quality of tone, such as a human voice; the hearer must have heard not only the primes of the compound tones, but also their upper octures, amd, less strongly, the remaining upper partials. When, lhen, a higher voice afterwards executes the same melody an Oetave higher. we hear again at part of what we heard before, namely the evenly mumbered partial tomes of the former compound tones, and at the same time we lane nothing that we hat not previously heard.

What is true of the Octave is true in at less degree for the 'Twelfth. If a meloly is repealed in the 'Twelfth we again hear only what we had alreaty hard, hut the repented part of what we heard is much weaker. berallm. only the third, sixth, ninth, cte., partial tone is repeated, whereas for repetition in the octave, insteal of the third partial, the much stronger seond alml weaker fourth partial is heard, and in place of the ninth, the rimhtla and tenth oxrour, atr.

Fur the repetition an the Fifth, only a part of the new somd is idenlinal with a part of what hal been heard, but it is, nevertheless, the most perfert repetition which can be executed at a smaller interval than an (latare.

Withont catrying these quotalions further they will suffice to ilhus rate the basis which Holmholtz would ascribe to homophonic music and early metodic composition. On this explanation the hasis of melocly is purely that of rhythm and rhythm based on a soule of intervals. 'The scale of inlervils in turn is based on at recognition. comscions or subcomscions. of the compound character of musical tones, and of the existence in tones of different pitch of partiats of the same pitch. This ealls for a degree of musical insight and discrimination which it is diflienlt to credit to a primitive atel. It is in reality the skill of the highly trained musician, of a musician trained by long experience with sounds which are rich and accurate in quality. 'This power of analysis goes rather with silprene skill than with the carly gropings of an art.

After having developed a theory of hamony and discord based on clabolate experimental and mathematical investigations, which was remallkalle in bringing together three such diverse fields ats phronies, phresiologr. and antheties. he relegated it to the minor atphlication of explaining the wse in modern music of an already 
existing and highly developed musical scatle, and songht an explanation of the earlier nse of the scalle in molody and its origmal invention in the principle which is very har from possessing cither the beauty or the convineing guality of his earlier hypothesis. II" was forced to this hy a priority of medortic or homophonic composition. He saw in melerly only al succestion of notes, no two exinting at the same time, and therefore incapable of probucing harmong. or discord in a manner such ats he hatd been considering.

It is true that melody is written as a pure suecession of dincerete notes, one begimning only when the ot her has ceatsed. It is truce aho that metody is so sung and so produced on at homophonic imetrument, such ats the roice, flute, receds, or one-stringed instruments.

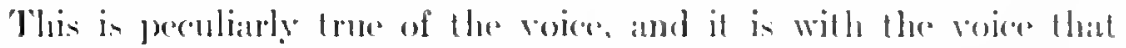
one naturatly ansociates the partient invention of the salke. But while it is true that the earliest song must have consisted of tomen produced only in suceension, it in not necessitrily true that such someds were heard as isolated notes. A somml produced in al spated which is in any wily conlined continum until it is diminished ly. tramsminion through opening or is absorbed the the retaining walls,

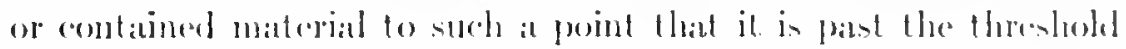
ol andibility, and this prokengation of andibility of sond is under many conditions a late tor of no inconsiderable importince. In many room of ordinary comstruction the probongalion of andibility andennte to two or there seconds, and it is not exceedlingly rame that a sound ol moderale initial intensity should continue andible for

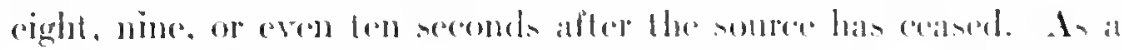

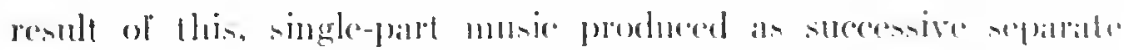

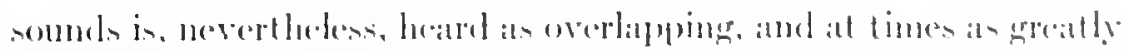

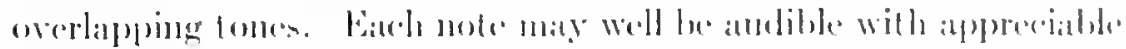

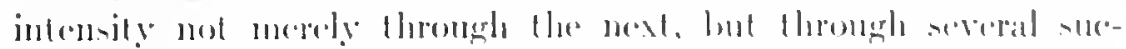

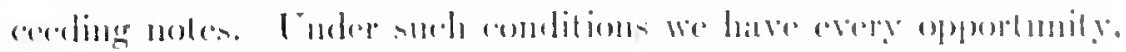

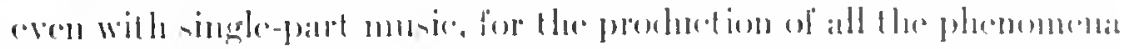

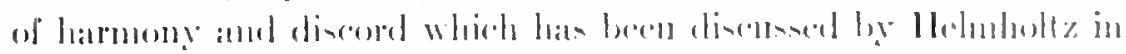

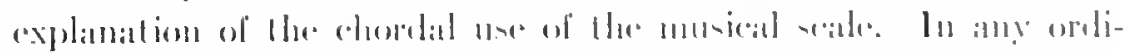

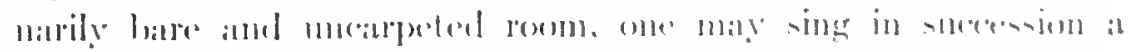

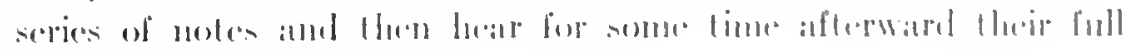
rhoridil effient. 
III the arguments that Ifelnholtz atvanced in support of his

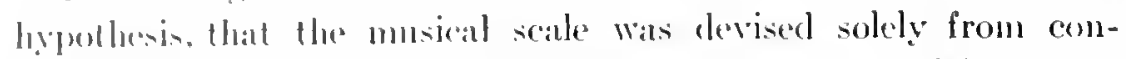
sileralions of rlypthm and fomeled on a repetition of faint upper partials. hold with expual fore in the explatuation here proposed. folue inlentity of partial tones in compound tones with diflerent Pundamentals is one of the conditiens of larmony. and the seale devined he considerations of the mutnal harmony of the notes sounded simultaneentsly, would, in every respect, be the same as that of a reate based on lepeated upper partials. In the one case the inlentity of upper partiats is an act of memory, in the other it in levermined by the harmony of sustained tones. All the arguments ly Ifelmbult hased on histerical considerations anel on ratedial and nitlonal elifferences are erqually applieable to the hypothesis of sustained tones. In fact, they take on an adelitional signifieance, for we may now riew all these differences not merely in the light of differences in racial development and temperament, hut in the light of phrsical enviromment. Itoused or muloused, dwrlling in reed huts or in tents, in honses of wood or of stone, in lomses amul temples high vaulted or low roofed, of heavy furmishing or light, in these conditions we may look for the factors which deternine the development of a musical scale in any race, which determine the rapidity of the growth of the scale, its richness, and its comsiderable use in singre-part melody.

'The duration of andibility of a somnd depends on its intial intemity and on its pitch, to a small degree on the shape of the confinerl space, and to a very large degree on the volume of the space and on the material of which the walls are composed. The eluration of amblibility is a logarithmic function of the intial intensity, and an the latter is practically ahays a large multiple of the minimmm andible intensity, this feature of the problem may be neglected when consiclering it broadly. For this discussion we nay also leave out of eonsiteration the effect of shape as being both minor and too intrieately variable. 'The pitch here considered will be the middle of the musieal scible; for the extremes of the scale the figures would be very different. 'The problem then may be reduced to two factors, volume and material. It is easy to dispose of the problem reduced to these two clements. 
The duration of atudibility of a somme is directly proportional to the volume of a room and inversely proportional to the total alssorbing power of the walls and the continined material. The volume of the room, the shatpe rematining the same, is proportional to the cube, while the area of the walls is proportional to the square of the linear dimensions. The duration of audilsility, proportional to the ratio of these two, is proportional to the first power of the lineal dimension. Other things being expal, the duration of andibility. the overlatphing of successive somuds, and, therefore, the experience of harmony in single-part music is proportional to the linear elimensions of the reom, be it dwelling lense or temple.

'limming to the question of material the following figures are slergestive: Any opening into the ontside space, provided that

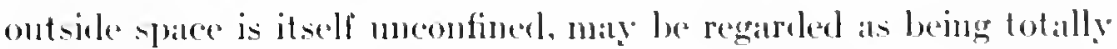

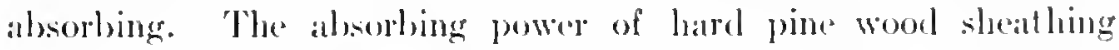
of one-latl inch thickness is (i.l per cent; of plaster on wood lath, 3.4 prer rent; of single-thickness ghlass. 9.7 per cent; of brick in Portland cement, s.i) per cent; of the simese brick painterl with oil paint, l.t pere cent. Hood sheathing is nearle double any of the rest. ()n the other hame, a matu in the ordinary clothing of todaty is equal in his absorbiug power to mearly 48 per cent of that of at square meter of unolst rueted openinge, a woman is $5 t$ per cent. and a sefuare meter of andienee at ordinary seating distance is nearly. 96 per cent. Of signifieance also in this connection is the fact that

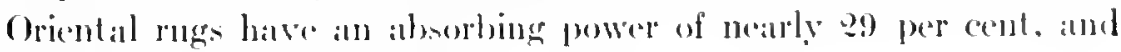
house plants of 11 pere cent.

Of conrse, the direct applicat ion of these figures in any areralate alculation of the comelitions of life anomen ditferent ratces or at different periods of time is impossible, lut they indicate in no murestetain manner the great differences acomotieatly in the emviromonent

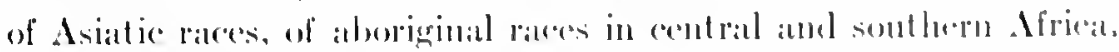

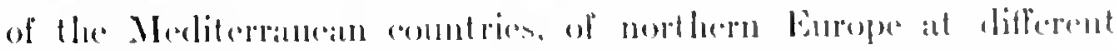

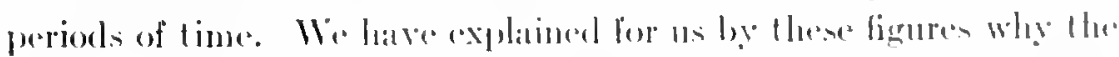

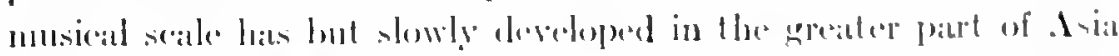

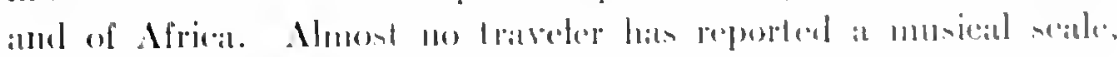

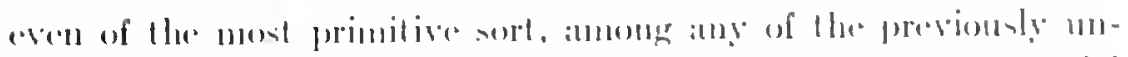

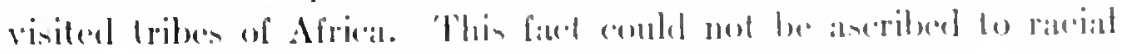


insptitude. If melody was, as llelmholt $z$ suggested, but rhythm in time and in pitch, the musical seale should have been developed in Africa if anywhere. 'These races were given to the most rhythmieal dancing, and the rhythmical beating of drums and tontoms. Rlythm in time they certainly hat. Moreover, failure to develop a musieal scalle could not be aseriber to racial inaptitude to feeling for pitch. 'Tramported to Ameriea and brought in contact with the musieal seale, the negro beeame immediately the most musical part of our population. 'The absence of a highly developed scale in Afriea must then be ascribed to enviromment.

'lurning to Europe we find the musical seale most rapidly developing among the stone-twelling people along the shores of the Mediterranean. 'The development of the scale and its increased nse kept pace with the increased size of the dwellings and temples. It showed above all in their religions worship, as their temples and churches reached eathedral size. The reverberation which accompanied the lofty and magnifieent architecture increased until even the spoken service became intoned in the Gregorian chant. It is not going heyond the bounds of reason to say that in those churches in Burope which are housed in magnificent cathedrals, the Catholic, the Lutheran, and Protestant. Episcopal, the form of worship is in part determined by their acoustieal conditions.

This presents a tempting opportumity to enlarge on the fact that the allegerd earliest evidence of a musical scale, a supposed flute, helonged to the cave dwellers of Europe. 'This and the impulse to sing in an empty room, and the ease with which even the ummusical can keep the key in simple airs under such conditions, are signifieant facts, but gain nothing by amplification. 'The same may be sald of the fact that sinec music has been written for more crowded auditorims and with harmonic accompaniment melody has become of less harmonions sectuence. 'These and many other instanees of the effect of reverberation come to mind.

In conclusion, it may not be out of place to repeat the thesis that melody may be regareled not only as rhythm in tine and rhythm in pitch, but also as harmony in sustained tones, and that me may see in the list ory of musie, cortainly in its carly beginnings, but possibly also in its subsequent development, not only genius and invention, but also the effect of physical environment. 


\title{
ARCHITECTURAL ACOUSTICS'
}

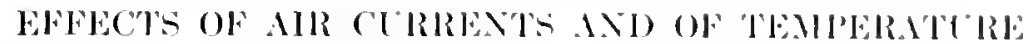

\begin{abstract}
$\mathrm{O}$
RDINARIT there is not a close comnection between the flow of air in a room and its acoustiral properties, although it hals been frequently suggested that thus the sound may he calleried eflectirely to diflerent parts. On the othel hatud, while the motion of the air is of minor importance, the distribution of temperature is of mor.

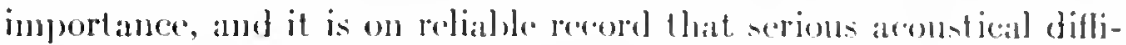
culty has arisen from abruph dillerences of temperature in an anditorimn. Finally transmission of disturbing noives threngh the ventilation ducts, perhape theoretically" a side isstle, is pratetically" a legritinate and necessiry part of the subject. The discussion will be muder these three heads.

'The first of the athore three topies, the prosible effect of the motion ol the air on the accomstical property of a roons, is the immediate subject.
\end{abstract}

\section{Vexthenton}

It wats suggesteel during the plamuing of the Boston simuphome

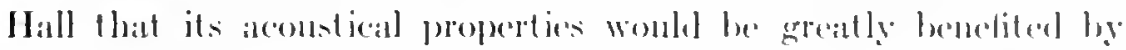
introducing the ar for ventilation at the front and exhallating at the back, thus calrying the somed by the motion of the air the lenget h of the room. 'The sime slegrest ion has heen matele to the watere by'

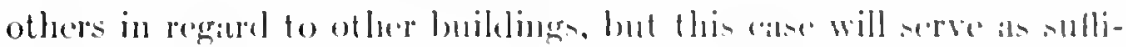

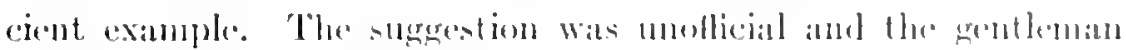
proposing it alecompanded it hy as section of a very alillerent hall from the hall designed ly . Mr. Mekim, lont ats lhis section was only at sketcl and withont dimenoions the following aslentation will be

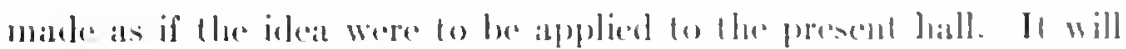
be shown that the lement then lo he secoured, while in the right

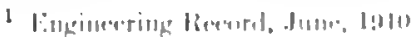


direction, is of a matenitule too small to be alppreciable. 'To make this the more decisive we shall atsume throughout the argument the mont farvorable comlitions possible.

If a sound is produced in still air in open space it spreads in a spherical wave liminishing in intensity as it covers a greater area. 'The area of a sphere being proportioned to the square of the radius, we arrive at the common law that the intensity of sound in still air is inversely proportional to the square of the distance from the source. If in a steady wind the air is moving uniformly at all altiludes, the sound still spreads spherically, but with a moving center,

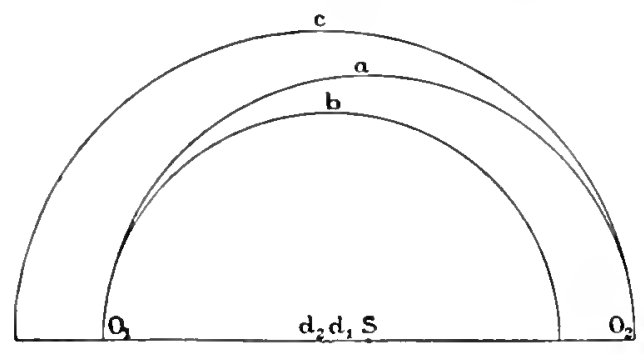

lig. 1

the whole sphere being carried along. If the air is moving toward the observer, the sound reaches him in less time than it otherwise would, therefore spread over a less spherical surface and louder. If, on the other hand, the observer is to windward, the sound has land to eome against the wind, has taken a longer time to reach him, is distributed over a greater surface, and is less loud.

The three cases are represented in the accompanying diagram. 'The stationary source of sound being at $S$, $a$ is the wave in still air arriving at both observers at the same time and with the same intensity. If the air is moving to the left, the center of the wave will be shifted by an amount $d$ to the left while the wave has spread to $0_{1}$. On arrival it will have the size $b$, less than $a$, and will be londer. On the other hand, while the wave is reaching $o_{2}$, the observer to windward, the exnter will have boen shifted to the left by an even greater anount $d_{2}$. In this ease the size of the wave will be $c$, larger thin $a$, and the sound will be less. 'The loudness of the sound in the three case's is inversely as the three surfaces $a, b$, and $c$. If the dis- 
tance of the observer from $s$ in thenoted by $r$, the lomdness of the sound in the three cases will he ats

$$
r^{2} \cdot \begin{gathered}
1 \\
\left(r-d_{1}\right)^{2}
\end{gathered}{ }^{i m d} \begin{gathered}
1 \\
\left(r+d_{2}\right)^{2}
\end{gathered} .
$$

The ahove result maty be expresed in the following more simple and practical form. Il, in the diagram, a is the ware in still air, its corresponding position when of the simme size and, therefore, of the same intensity in moving air will be $a^{\prime}$, the moxement of the air having been sulliciont to carre the watre al distance d while it hato

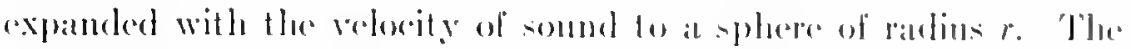

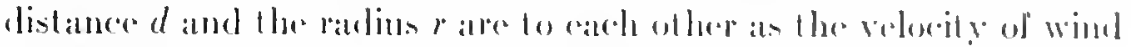

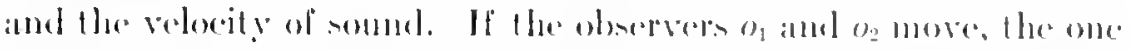

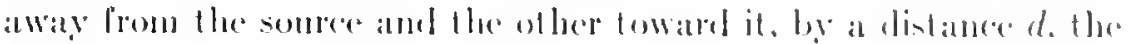

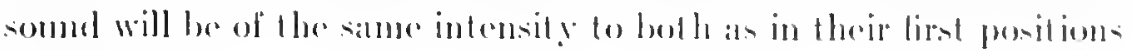
in still air.

In order to make application of this to the patticular problen in hand, we shall asome a normal atr supply to the room for rentikation purpeses of one-sebentiedt of a colbie meter per person per serond. This, if introduced all at one end and exhallsted all at the other, in at room 16.9 melers high, ge.s meters broikl, and serating

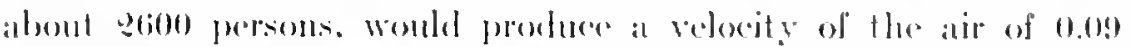

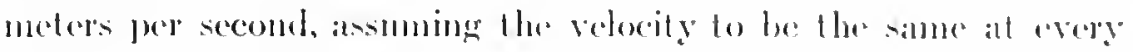

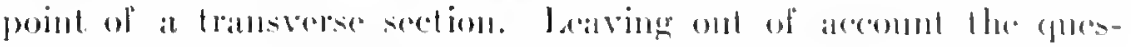

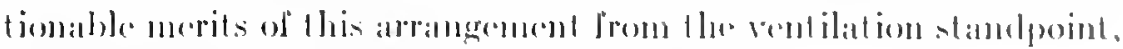

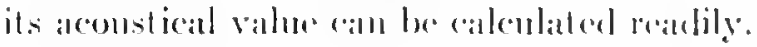

The velecity of sound moler nomal anditions being abunt

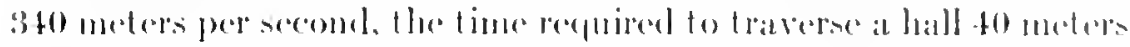
long is only about once-ninth of a serond. In this short interval of

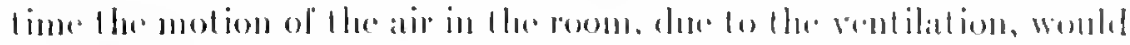

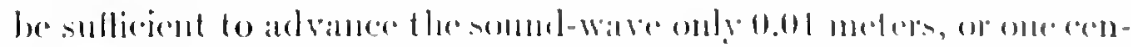

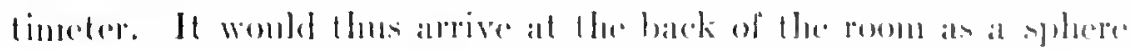

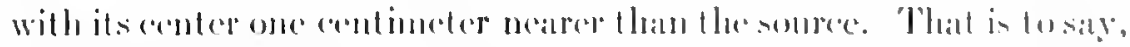

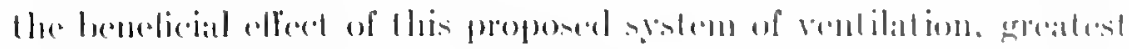

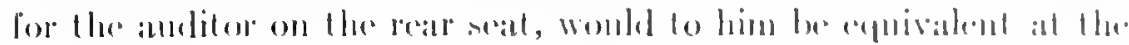

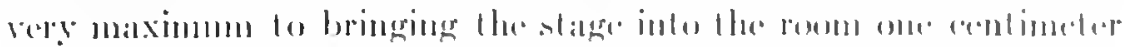
lurther, or it would be ectuivalent to bringing the aludiler on the 


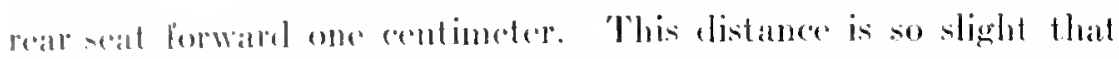
wilhonl moving in his seat. in fact, without moving his shouklers, a slight imelination of the head womlel accomplish an equivalent sanin. 'Ithus, while the eflecet is in the right direction, it is of ent irely'

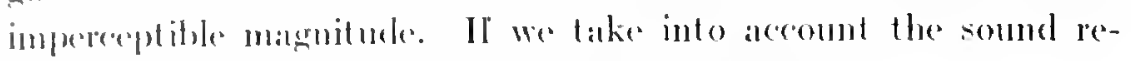

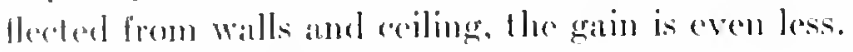

But the shegention when is the test of the present palper was not makle by one. lunt ly sereral gentlemen, and is bised on the well-recognized fact that one ain hear better, often very much hetter, with the wind than agamst it, and better than in still air. Therefore, the suggest ion is not gromelless and camnol be disposed of thus summarily, cortanly not without submitting to the same calculation the out-of-eloor experience that gave rise to the thought.

In the nomenchature of the Inited States Weather Bureau a winel of from "1 to in miles an homer is called light, 6 to $1+$ miles fresh, 1.5 to st mikes hrisk, 9.5 to 37 miles high, and a wind of from 40 to 59 miles is called a gale." Taking the case of a "high wind" is a liberal eximple, its arerage velocity is about 14 meters per secomel, or about one I wenty-lifth the velocity of somed. In such a wind the somel 1000 meters to lecward would be louder than in still air only lỵ an amount which would be equivalent to an aluproach of to meters, ar $S$ pere cent. Similarly, to windward the somed would be less loud hy an amome equivalent to increasing the distance from lono to 1040 meters. This is not at all commensurate with general experience. 'The diflerence in andihility, everyone will ighor, is arenerally greater and very much greater than this. 'The discrepane? howeres, ean be explained. The discerepaney is not letween olservation and theory, hut between observation and a very incomplete analysis of the conditions in the out-ol-door experiemer. 'lhus, the ordinary view is that one is merely hearing with or against the wind and this wind is thonght of as steady and uniform. As a matter of faret. the wind is rarely steady, and partic${ }_{11}$ arly is it of different intersity at different altitudes. Fortunately, the ont-ol'-eloor phenomenon, which in reality is very complex, has feern carefully studied in comnetion with fog signals.

The first adequate explanation of the variation in loudness of a sound will and against the wind was by the late Sir George G. 
Stokes in an article "On the Effect of Wind on the Intensity of Somd," in the Report of the British .1ssociation for the Adtuncement of seicnce for 185\%. The complete paper in als follows:

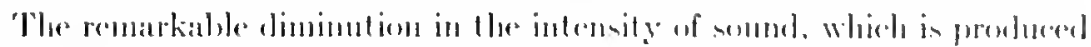

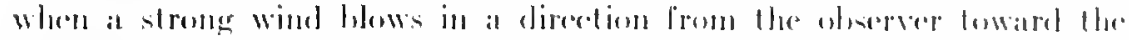

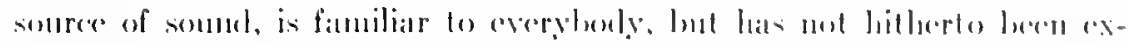

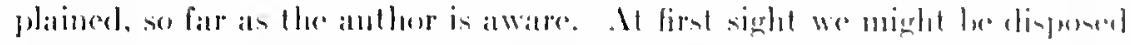

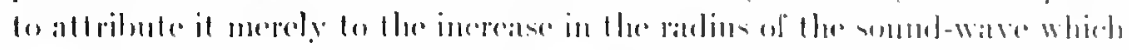

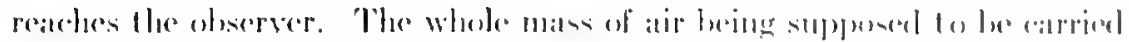

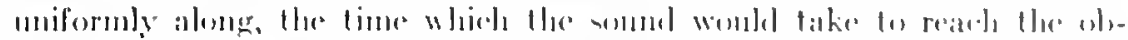

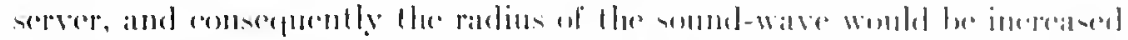

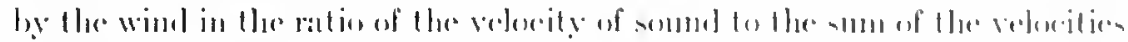

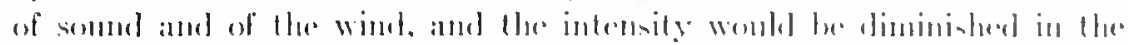

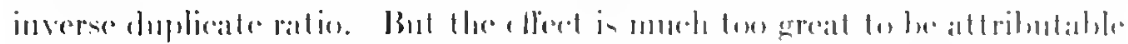

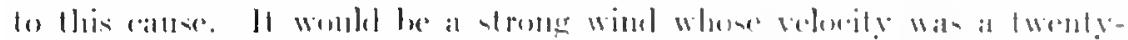

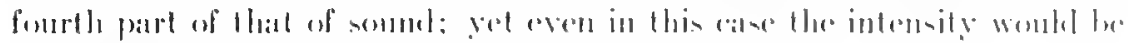
diminialued ly only athoul a twelfth part.

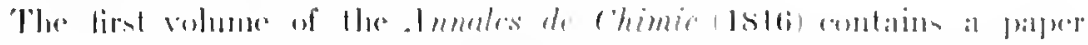

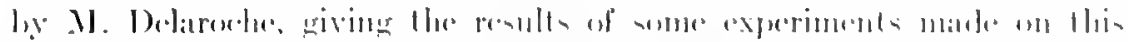

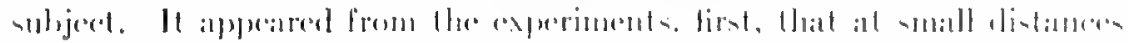

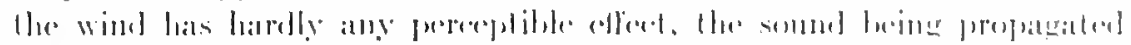

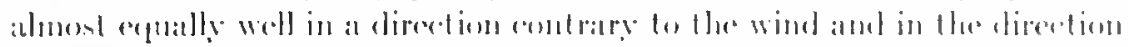

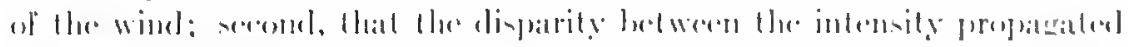

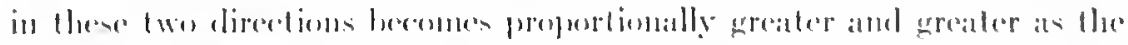

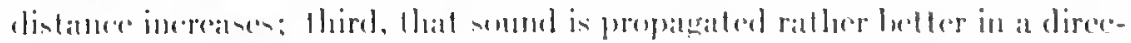

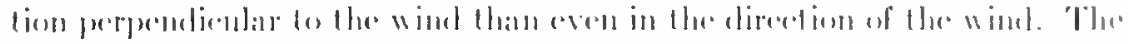

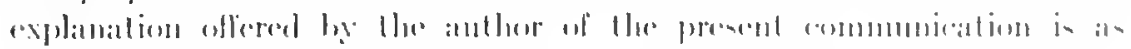
Prillow:

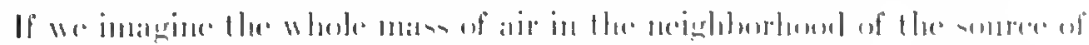

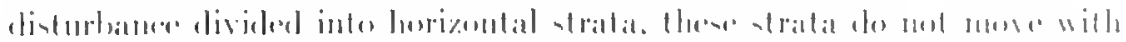

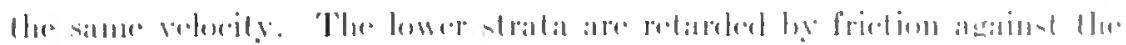

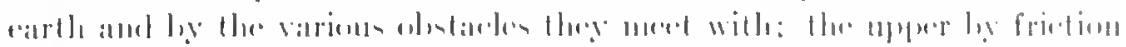

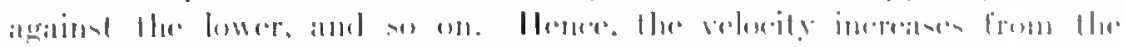

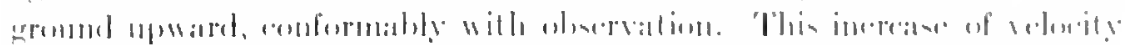

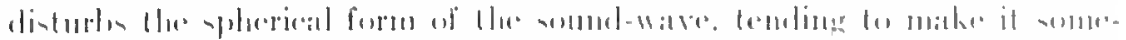

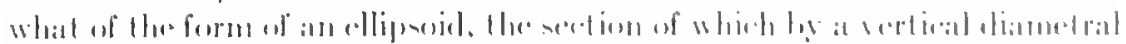

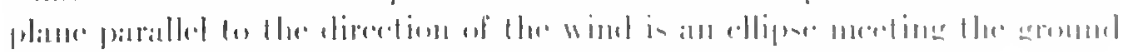

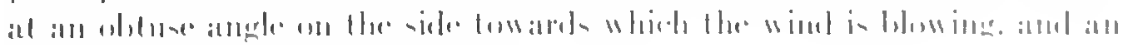
:

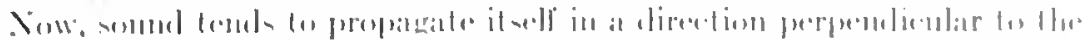

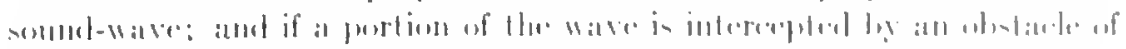

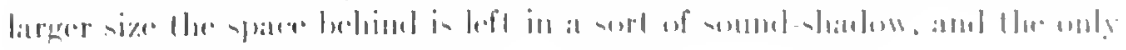


womel there heard in what diveresen from the general ware after passing

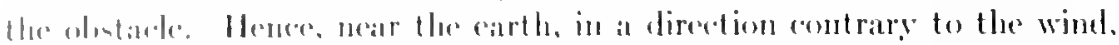

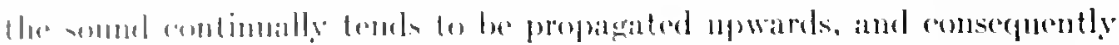
there is a continual tendeney for an olsserver in that direction to be left in

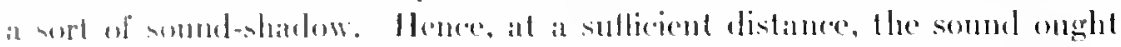

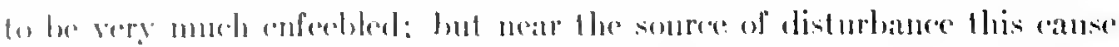

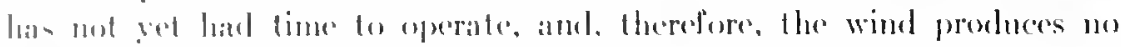

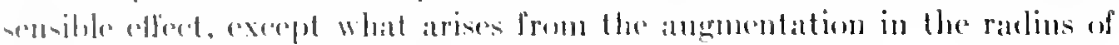

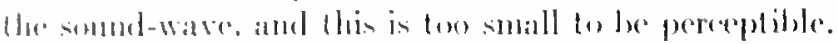

In the antrary direetion, that is, in the direetion towarels whe the wind in blowing, the somml temls lo propagate itself clownwards, and to be

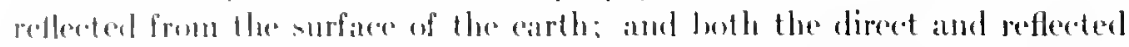
water contribute to the effect pereceived. The two watres assist each other 6) mureb the lectter, as the angle between them is less, and this angle vaninlas in a dirention perpendixular to the wind. Ilence, in the batter direction the somml anght to be prophanted a little better that even in the direstion of the wind. which angees with the experiments of M. Delarodhe. Thus, the effere in redered to two known a aluses. - the increased velocity of the ;ir in acenclingr. and the diffraction of sommd.

A. a matter of lact, the phenomenon is much more complicated when one lakes into consideration the fact that a wind is almost always of very irregulat inlensities at diflerent altitudes. The phenonnenon, in its most complicated form, has been investigated in connection with the sulbjeet of fog signals l,y Professor Osborn Revuolds and Professor Joseph Ilemry, but with this we are not at present concerned, for the ahove discussion by Professor Stokes is entirely suflicient for the problem in band.

The essence of the above explanation is, therefore, this, that the great dilference in loudness of sound with and against the wind is not due to the fact that the sound has been simply carried forward or opposed hy the wind, but rather to the fact that its direction has heren changed and its wave front distorted. 'The applieation of this consideration in the present architectural problem leads to the conclusion that the greatest benefit will come not from an attempt to carry the sound by the ventilating movenent of the air, but by using the motion of the air to incline the wave front forward and thus direct the sound down upon the audience.

This can be done in either one of two ways, by causing the air to flow through the room from front to back, more strongly at the 
ceiling than at the floor. or by eausing the air to flow from the batek lo the front, more strongly at the floor than at the ceejling. 'Tle one process carrying the upper part of the watre forwarel, the other retarding the lower part of the wate, will tip the wave in the simes way and by an equal amount.

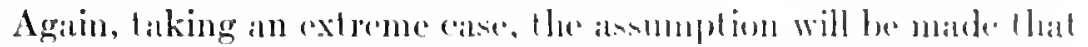
the motion of the are is such that it is mot moring al or mear the flewer. that it is moving with its maximmo veleceity at the ceiling and that the increase in velocity is gratual from floor to coiling. Kenping the same amomut of air moving as in the preceding calculation, the velocity of the air under this anrangement would be twien as groat as the average velocity at the cerling: in the preceding atae the wave wats advanced one centimeter by the nution of the air while. traveling the whole length of the hall. In this case, olswionsly, the upper part of the wave womld he carried lwien as far, twe centimelers, amel the lower part mot ablvancel at all. 'Jlhis womlel, therefore.

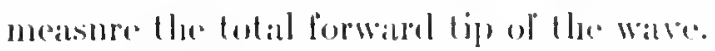

Fortmately, the acoustical value of this can be expressod in a very simple and praclieal mammer. An inclination of the sommetwave is efuivalent acoustically to an enual amgulat inclination of the fleor in the opposite clirection. The heright of the hall being 17.9 meters, the inclination forward of the sonnel-wave wemlel be Q in 1\%90. The length of the hall hering to meters an expual incli-

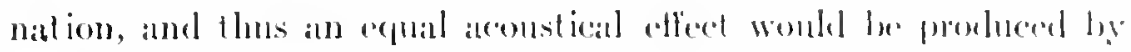

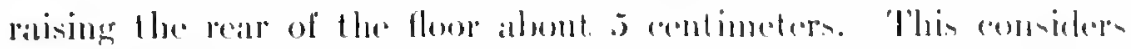

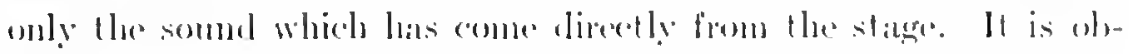

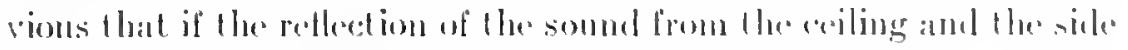

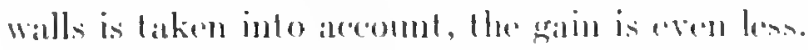

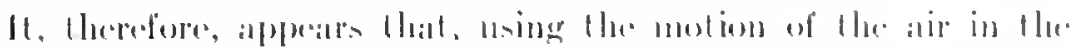

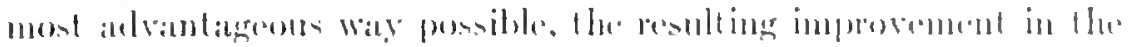

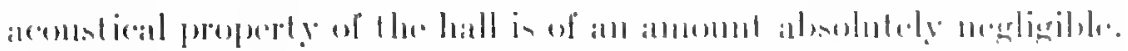

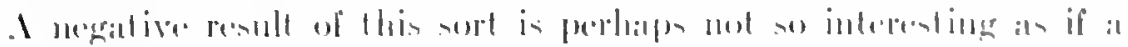

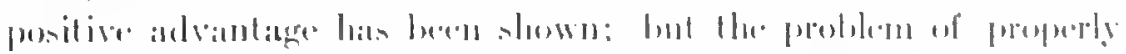

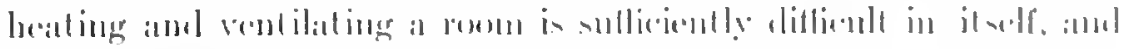

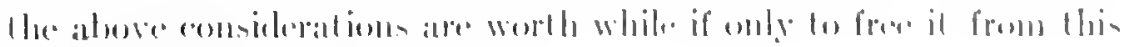
anhlitimal romplicatlion. 


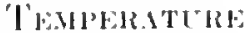

The alferet of raining the lemperature of a room, involving as it deres the entimed air and all the reflecting walls and objects, is twofold. It is not ditlendt to show that, whether we consider the lise in temperatume of the air or the rise in temperature of the walls and other reflecting surfaces, the eflect of a clange of lemperature betwern the limits which an andience can tolerate is neegligilsle, provided the rise in temperature is miform throughoul the room.

'The eflecet of miformly ratising the temperature of the air is to increase the velocity of propagation of sound in all directions. It is, Hherefore, essentially mulike llue effect produced by motion of the atr. In the case of a uniform motion of the air, the somnd spreatels spherieally hut with mehanged velocity, moving its center in the direction and with the velocity of the wind. Thus, when hlown loward the observer, it reaches him ats if coming from an nearer somere. Blown awage lom the observer, it arrives as from a more distant sontce. An increasing temperature of the ain increases the velocity hut does not shilt the center. The sound reaches the observer roming from a somere at an unchanged distanee. A rise in temperature, therefore, provided it be uniform, neither increases nor decheases the apparent intensily of the somd. 'The intensity at all points remains wholly malt ared.

'The above is on the assumption that the temperature of the air at all points is the same. If the temperalure of the air is irregular, the cfferet of such irlexulatrity maly be pronounced; for example, let If as-ontule a room in which the lemperature of the air at the upper lerels in greater than at lower levels. In order to make the catse ats simple as possible, let thisisme that the temperature increases miformly from the floor to the coiling. To make the case concrete, let 11 assmme that the hall is the same as that describerl above. practically rectangular, $40 \times 99.8 \times 17.9$ meters. The velocily of the somml at the ceiling, the air being miform, is greater than it is at the flemer. In traversing the room the sound-wave will thus be fipped lorwated. 'The effect is practically equivalent as before 10 an increased pitch of the floor or to an inereased elevation of the platform. Withoul going into the details of this very obvions calcula- 
tion, it is suflicient to saty that in the ase of the hall here taken ats ant example, a difference of lemperature top and bottom of $10^{\circ} \mathrm{C}^{\circ}$. would be exprivalent to an inerease in pitch of the Hoor sullieient to produce an increatsed clevation of the rery back of 10 centimeters.

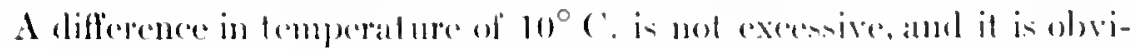
ons that this has a greatere effeed than hat that of the motion of the air.

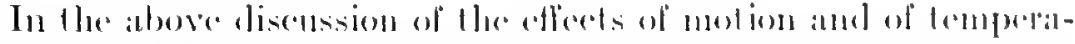

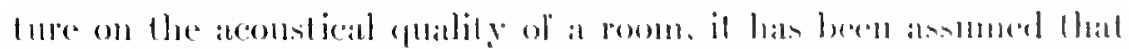

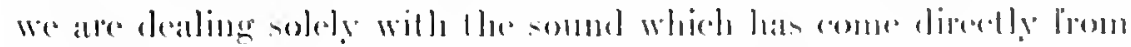

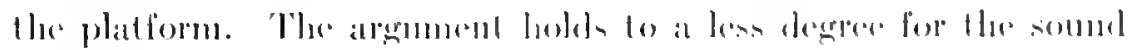

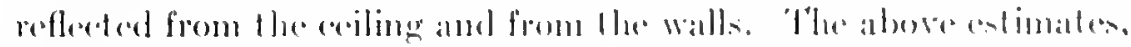

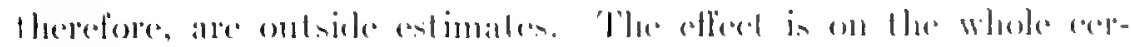

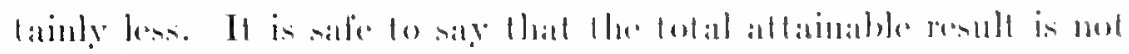

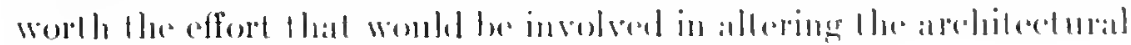

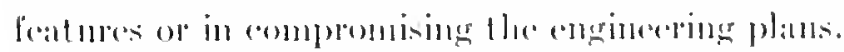

But, while nution ratriation in the mot ion or in the temperature

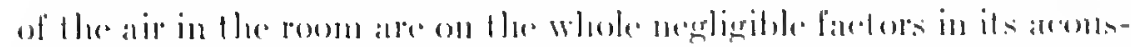

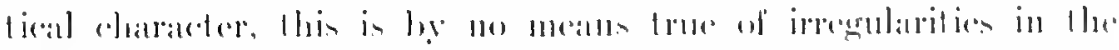

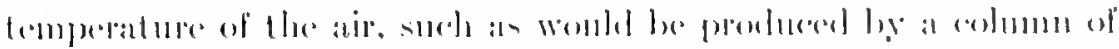
warm atr rising from a Hoor inlet. That this is a practical point in

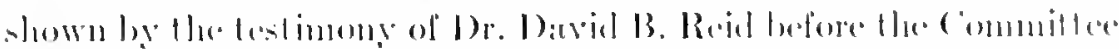

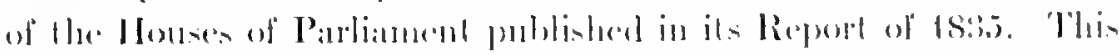

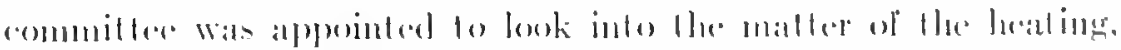

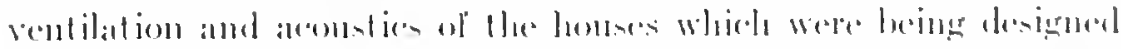

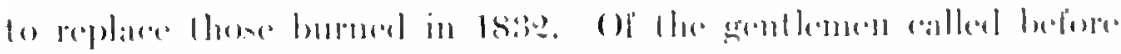

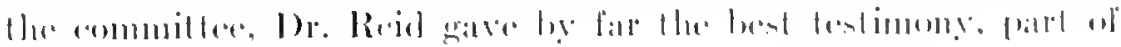
which wis als follows.

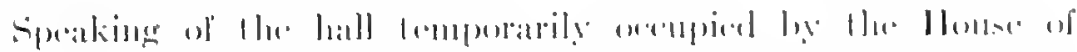

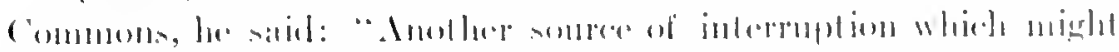

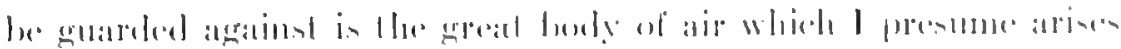

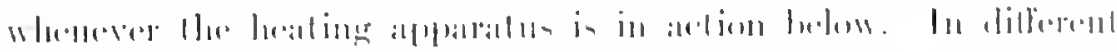

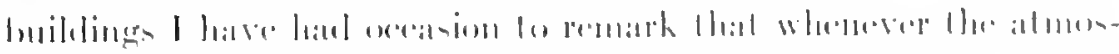

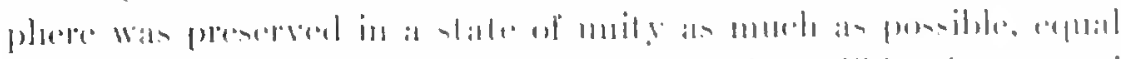

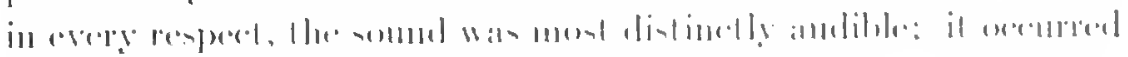

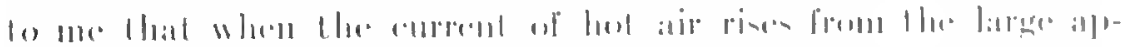

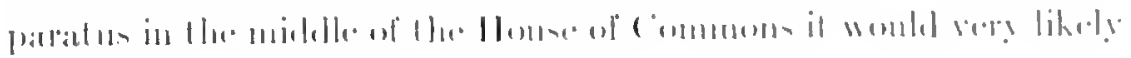


interfore with the enmmmenteation of somme. On inguiry, one of the Erontlemen now present told me he had frequently observed it was impersible to heall indivieluals who were on the opposite side of this corrent, although these at at distance were hearel distinctly where the current diel not intervenes", Elsewhere Dr. Reid said: "A current ol hot air, rising in a broatel sheert along the center of the House. reflected the somud passing from side to side and rendered the infonation indistinet. One of the members of the committec, when I explatued this circumstance, stated that he had often noticed that lee could not hear a member opposite him distinctly at particular times unless he shifted his seat along the bench, anel on examining the place referred to, it was found that he had moved to a position where the hot air current no longer passed between him and the member speakingr."

A more recent instance of this sort of difficulty was mentioned to the writer by Mr. W. L. B. Jenney, of Chicago, as oceurring in his practica, and hater was described in detail in a letter from which the following is fuoted:

The hilding I referred to in my conversation was a eourt house at lockport. No plans exist as far as I am aware. Note the sketeh I made from rememliranere.

Note the passige across the room with stove in eenter. Is the courts were held only during winter there was invariably a fire in that stove. When I examined the room the attendant that was with me informed me that the remarks made by the judge. lawyers and witness conld not be hearl by the anclience on the opposite sicle of the passageway eontaining the stover.

It that tine, the court romm not being owoped, there was no fire in the stove and the loors were chosed. I experimented: put the attendant in the julges"s stand and took position at " $1 . "$ I could hear perfeetly well. I spoke to him and he replied, "Why. I can hear vou perfectly well." I reached this conelusion. "That the heated air from the stove and the air supplied by the doors that were comstantly fanning at each end of the [masageway prohuced a stratum of air of different density from that of the other parts of the room. which areted like a curtain hanging between the sueakers and the hearers. I made my report verbally to the eommit tee that I left helow and brought them with me to the room. The experiments wre remewed and they arespted my theory. I reeommended that the stove be moved and that the warm air should be let into the room from steam coils helow at the the end " $\Delta$ " and taken out by exhaust ventilators 
at the end "B3," This was done, amel 1 wats informed hy the dhaiman of the committee that the result was very" sativactury. 'The other romditions

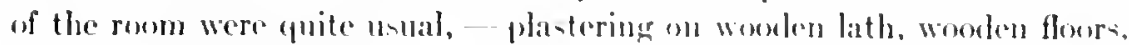
reasonable height of ceiling.

The above incidents secm to demonstrite fairly cleally that muler certan cincmustances abruph irregularities in temperature maly result in matked and, in general, unfat vorable acoustical effects. The explanation of these effects in hoth cases is somewlat as follows:

Whenever somul passies from ond medium to another of different density, or elasticity al portion of the sommel is reflected. 'Tlue sound which enters the second medium is refracted. The effects observed above were due to these two phenomenal aleting jointly.

The first of the two cases was under simpler conditions, and is, therefore, the casier to discuss. Essent ially, it consisted of a latrge

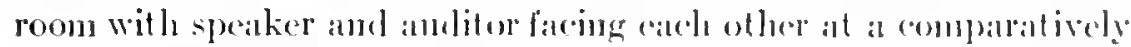
sloort distance apart, but with a cylindrical colume of hot air rising

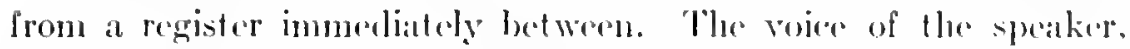
striking this colum of atr. lost a patet hy pelloctions a part ol the sound passed on, entered the column ol warm air, and rame to the serond surfiere, where a part was again reflected and the remaindele went on to the anditor. 'Thus. Hoe somul in araversing the columu

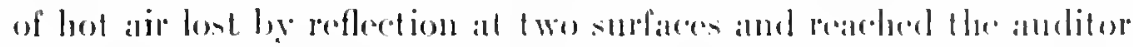
diminished in intensity. It ramelnod the andilor with diminished intonsity for another roason.

The reolumn of warm air areted like a lens. 'The effeed of the columm of air was not like that of the obelimaley convere lens. which would bring the sommel to a focoss, hut rather as a discorging

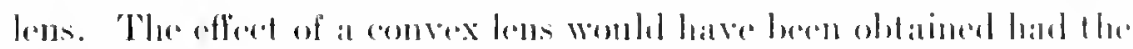

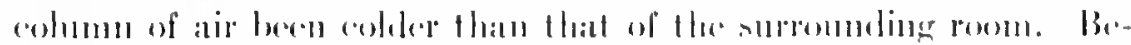

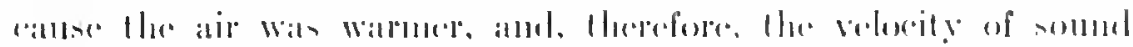

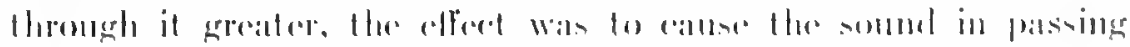

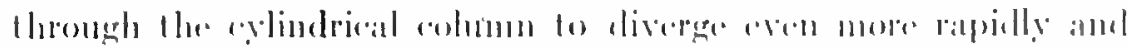

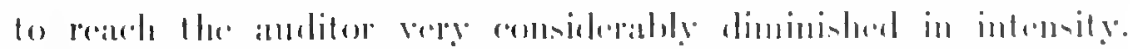

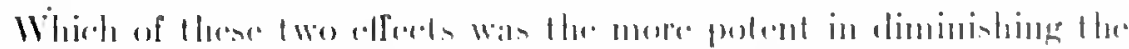

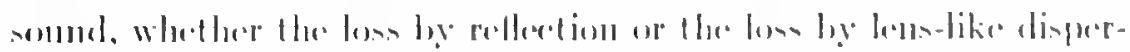

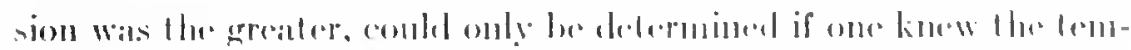

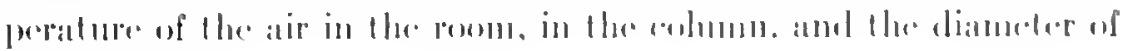


the column. It in sufliciont, perhaps, to point out on the anthority of ancheminemt menas Dr. Reid and Mr. Jenney that the phenomenen is a reat one and one lo he aroided, and that the explanation is really at hamel and comparativery simple.

It is. perhilps, wort la white pointing out that in both of the above "anes there was at govel deal of reverberation in the room, so that any comvilarathe dimimution in the intensity of the sound coming directly from the speaken to the anditor resulted in its being lost

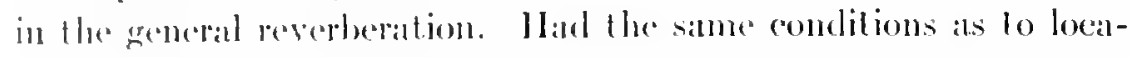
lion of spraker. anditor, column of warm air and temperature oceured ont of doors or in at room of very slight reverberation the eflecel would have been very murh lens noticeable. Severtheless.

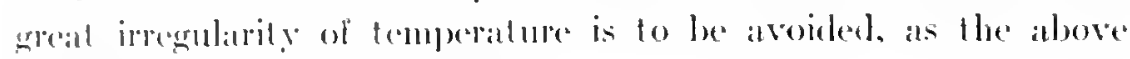
lastimony lairly chearly shows.

The abore also suggests ancther line of thought. If, instead of having a single sereen of great temperature difference between -peaker and anditor. there were many such differences in temperatture, though slight in amomt, the total effeet might be great. This compenponds, in the effeet produced. to what Tymelall calls a "floeculent condition of the atmospluere" in his discussion of the transmiscion of fog signals. 'Tymlall points out that if the at mosphere is in layers alternately warm and colel sound is transmitted with much more rapid dininution in intensity than when the atmosplere is of very uniform temperature. 'This phenomenon is, of course, much more important with such temperature differences ats oecur ont of doors than in a room, but it suggests that, in so far as it is a perceptithe effect. the temperature of a room should be homogeneous. 'This contlition of homogene ity is bent secured by that system of rentilation known as "distributed floor ontlets." It hats the additienal merit of being. perhaps, the most efficient system of ventilialion. 


\section{SENSE OF I.OUDNESS ${ }^{1}$}

$I_{T}$ will be shown here that there is a sense of relative lomderes, patrticularty of equality of louduess, of someds elillering greatly in pited,

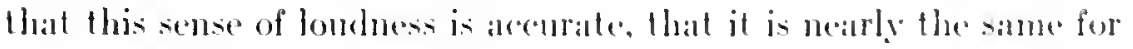
all normal ears, that it is independent of experience, amd that, therefore, it probably has a physieal and physological basis. Tho investigation lass been incirlental to a larger inventigation on the subjecet of architectural acoustices. It has hearing, however, on many other problems, such, for eximple, ats the standardizat ion of noives, and on the physiological hicory of andilion.

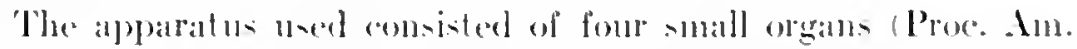

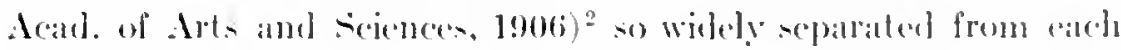

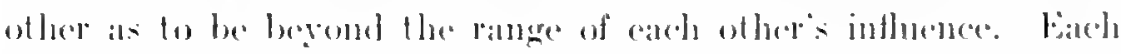
organ carried seven night-horn organ phipes at octabe intervals in

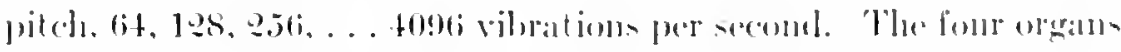

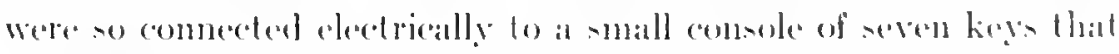

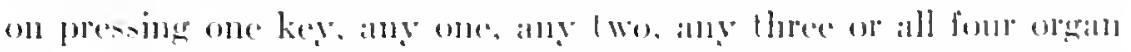
pipes of the same pitch wombl somed at omee. - the ammhination of

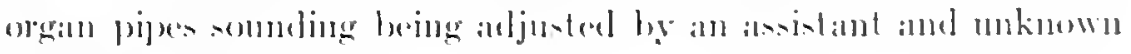
10 the obserivers.

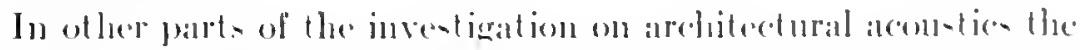

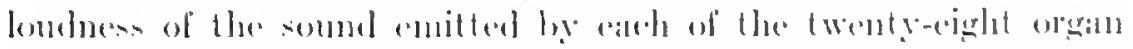

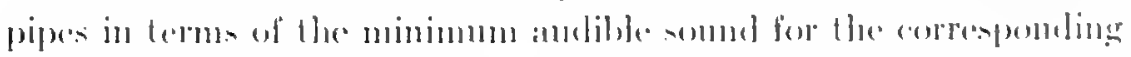

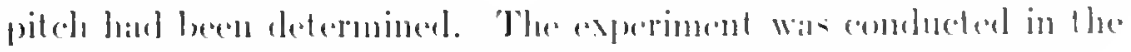

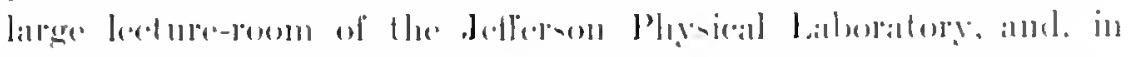

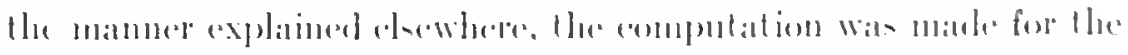

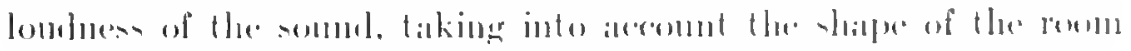

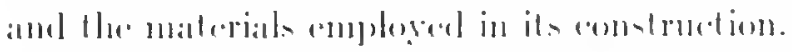

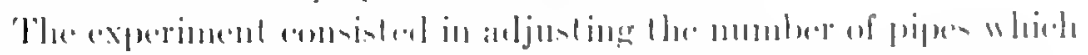

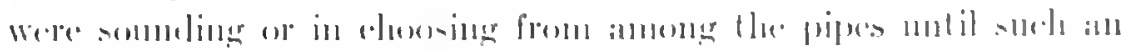

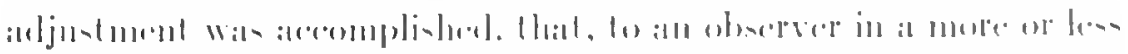

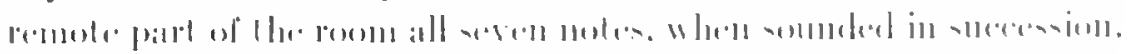

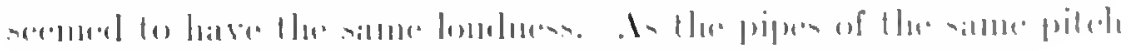

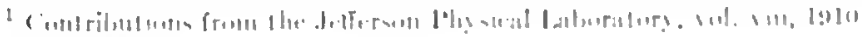
$=-a, n+1$
} 


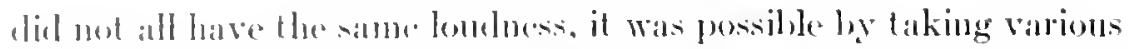
rombinations to make this andustment with consielerable acemacy. "This statcment, lowwerede, is sulpjeret to an amendment in that all four pipes of the lowest piteh were not sufferently loud and the

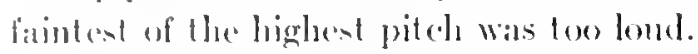

There were ten observers, and ateh observer carried ont four inelependent experinents. Speaking broally, in the case of every olservor. the four independent experiments agreed among thentselves with great alceluracy. 'This was to the great surprise of every observer, each before the trial doubting the possibility of such aljustment. The results of all ten observers were surprisingly concordant.

After the experiment with the first two observers, it secmed posible that their very close agreement arose from their familiarity with the piano, and that it might be that they were adjusting the metes to the "halance" of that particular instrument. The next userver, therefore, was a violinist. Among the olseevers there was also a cellist. Lest the fecoling of rebative loudness should come from some subconscions peeding of vocal effort, athough it is diffirolt lo see how this conkl extend over so great a range as six octaves, singers were tried whese voices were of very different register. Two of the observers, including one of the pianists, were women. Two of the observers were non-musical, one exceedingly so.

The accompanying table grives the results of the observations, the energy of ach sound being expressed in terms of minimum andilite intensity for that particular pitch, after making all correctiens for the reanforcement of the sound by the walls of the room. The observations are recorded in order, the musical characteristic of the observer being indicated.

\begin{tabular}{|c|c|c|c|c|c|c|c|}
\hline \multicolumn{8}{|c|}{ Р'itch l'Requency } \\
\hline Observers & 64 & 128 & 2.50 & 512 & 1024 & 2048 & 4096 \\
\hline 1. Piano & $7.0(+) \times 16^{4}$ & $1.7 \times 10$ & $4.4 \times 10^{6}$ & $8.0 \times 10$ & $15.0 \times 10^{i}$ & $9.6 \times 10^{5}$ & $4.5(-) \times 10^{3}$ \\
\hline Piano & $7.0+$ & 1.7 & 4.4 & 11.2 & 9.2 & 12.0 & $5.2-$ \\
\hline 3. Xon-musieal & $7.0+$ & 1.7 & 3.6 & 8.9 & 6.3 & 9.6 & $4.5-$ \\
\hline 4. Xon-musical & $7.0+$ & 1.7 & 3.7 & 7.7 & 14.5 & 14.4 & $5.6-$ \\
\hline 5. Violin & $7.0+$ & $1 . \tau$ & 3.5 & 11.7 & 13.9 & 8.0 & $3.5-$ \\
\hline (i. Violin & $7.0+$ & 1.7 & 4.0 & 11.4 & 15.5 & 15.2 & $5.2-$ \\
\hline$\because$ Cedlo & $7.0+$ & 1.7 & 4.2 & 12.0 & 13.4 & 9.6 & $5.1-$ \\
\hline s. Tenor & $7.0+$ & 1.7 & 3.9 & 13.3 & 13.5 & 10.5 & $4.0-$ \\
\hline 1). Soprano & $7.0+$ & 1.7 & +.7 & 12.9 & 17.0 & 9.6 & $5.4-$ \\
\hline \multirow[t]{2}{*}{ 10. Piano } & $7.0+$ & 1.7 & 3.5 & 13.2 & 14.5 & 8.0 & $4.9-$ \\
\hline & $\pi .0(t)$ & 1.7 & 4.0 & 11.0 & 13.3 & 10.6 & $4.8-$ \\
\hline
\end{tabular}




\section{ARCHITECTIRA, ACOUSTICS ${ }^{1}$}

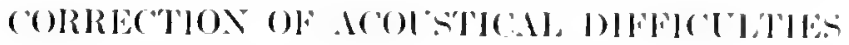

ON the completion of the Fogge Irt Muspum in 1895, I wate reguestad by the corporation of Ilarvand labersity to investigalle

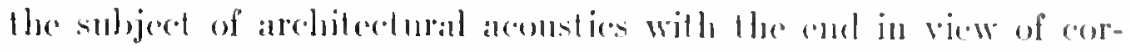

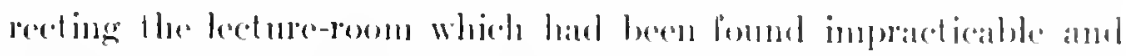

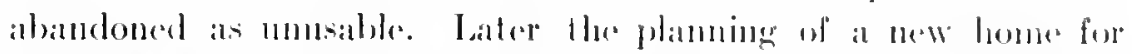

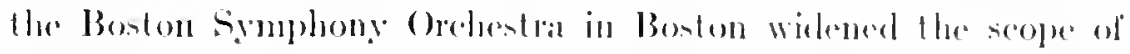

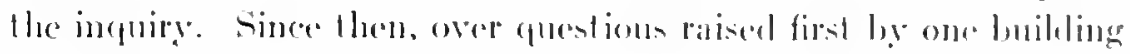

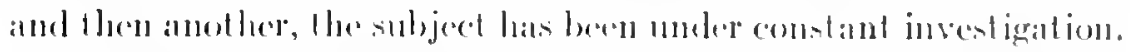

In 1900 a series of art ielese embodyeing the work of the first five

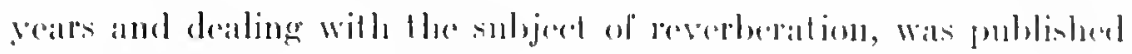

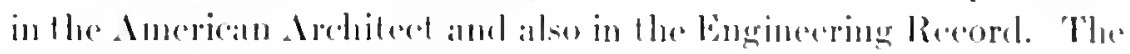

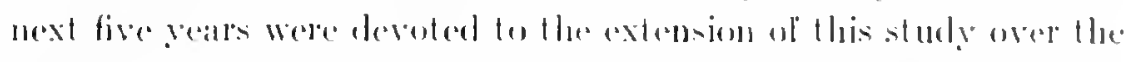
range of the musical scale amel the results were published in the Pro-

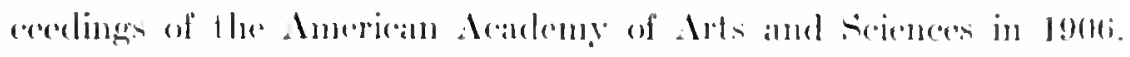

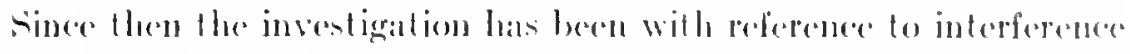

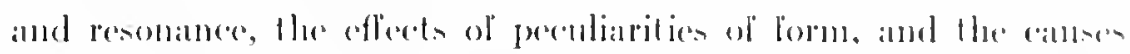
of variation in andibility in different patrts of an anditoriun. "Therese

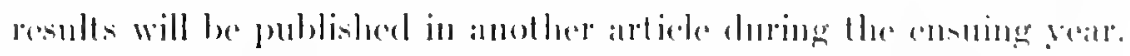

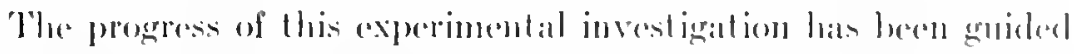

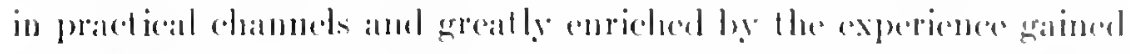

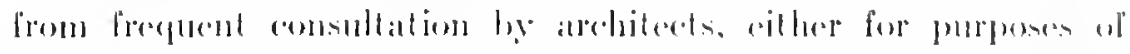

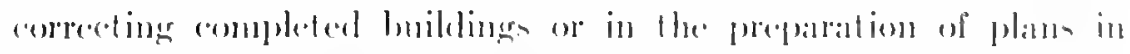

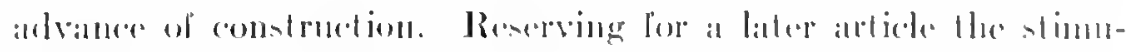

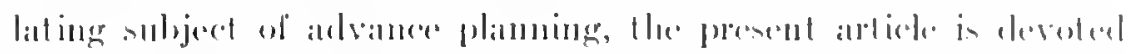

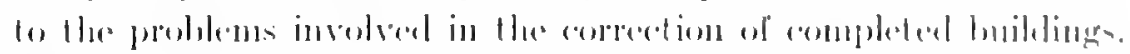

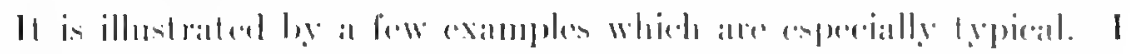

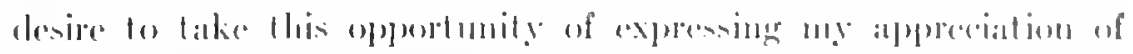

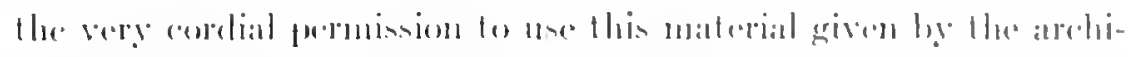

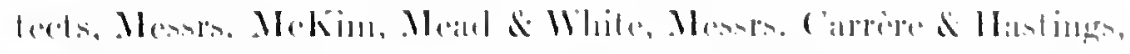

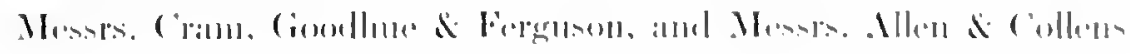

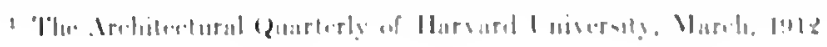


- to then and to the other architects whose confidence in this work lak resulared an extensive axperience possible.

The practional execution of this work of correction has recently buren pared on a firmer basis by Mr. ( '. MI. Swan, a lormer graduate stulent in the Tnixersily and an associate in this work, who hats taken rlanere of a clepartment in the II. WV. Joluss-Mamville Company. I an under obligations lo him and to this company for some of the illustrations used below, and lo the company, not merely for haviug placed at my disposal the mejerterials and technical experience, hut also for laving borne the expense of some recent investisations looking toward the derelopment of improved materials, with entive privilege of my making free publication of scientific le:isltis.

It is proposed to discoss here only such corrective methots as rat he emplosed withont extensive allerations in form. It is not puposed to discuss changes of dimension, changes in the position of the wall-surfaces or changes in ceiling height. It is the purpose to discoss here medicinal rather than surgical methods. Such treatument puperly plamed and executed, while not always availahle. will in the great majority of cases result in an entire renedy of the diflicultr.

Two old. but now nearly abandoned devices for remedring aconstical diflicolties are stretched wires and sounding-boards. The first is without valure, the second is of some value, generally slight, though oceasionally a perceptible factor in the final result. The stretching of wires is a method which has long been employed, and it s disfigning relices in many churehes and conrt rooms prochim at diflicully which they are powerless to relieve. Like many other traditions, it has loen abandoned lut slowly. The fact that it was wholly wilhont eilluer foumdation of reason or defense of argument math it difficult to answer or to meet. The device, deroid on the one hand of scientific foundation, and on the other of successful experience, has taken varied forms in its application. Apparently it is a matlere of no moment where the wires are stretched or in what anomit. 'There are theatres and clunches in Boston and New Tork in which four or five wires are stretehed across the middle of the room; in other anditoriums miles on miles of wire have heen 
stretched; in both it is cqually withent eflecel. In no case can one obtain more than a fllatified apploxal, and the most earmest negattives come where the wires hatre heren uned in the latrgent amomt. Occasionally the response to impuiries is that "Ile wires male latre

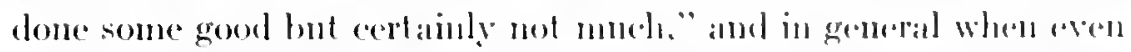
that qualified apporoval is given the installation of the wires wate

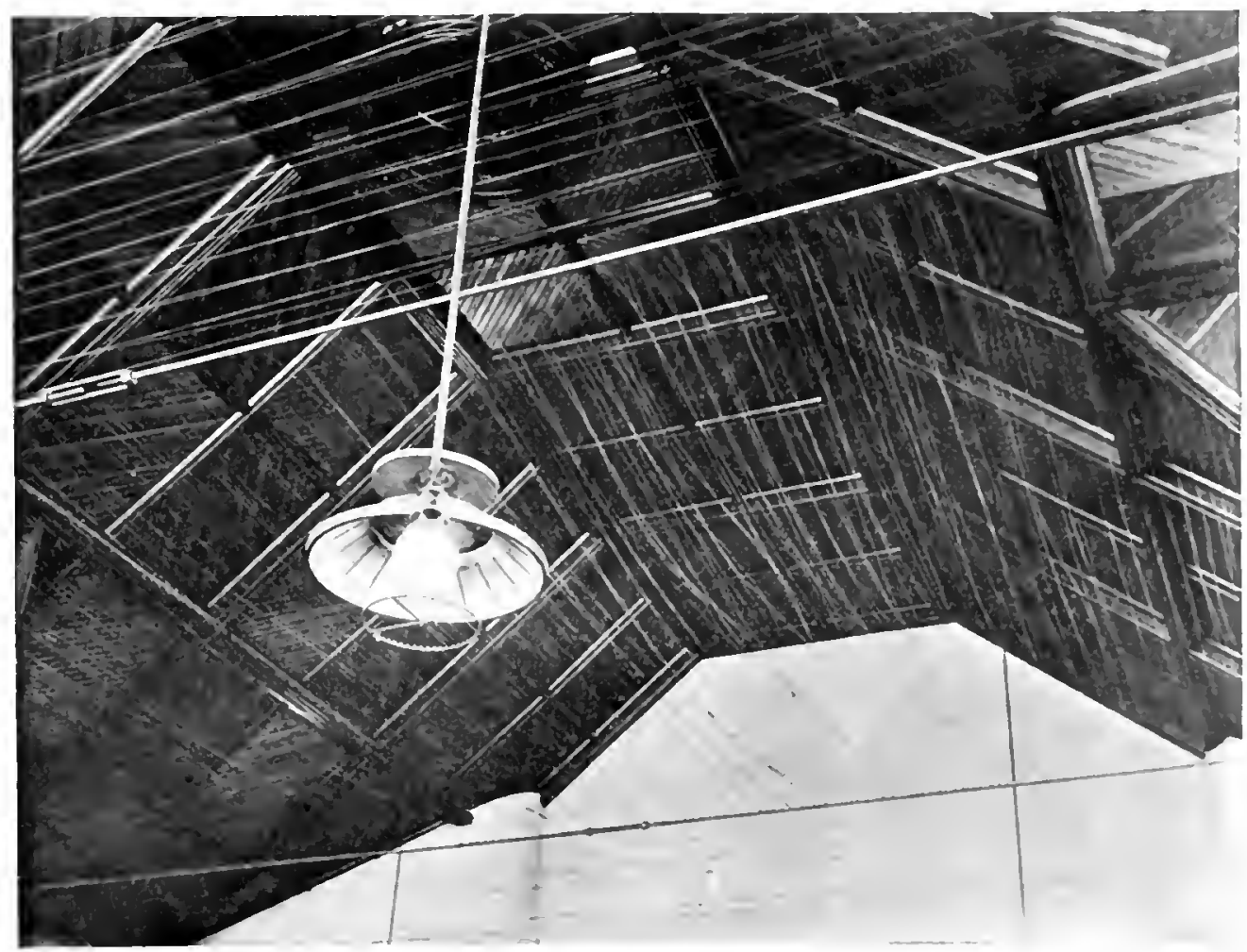

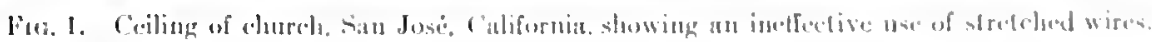

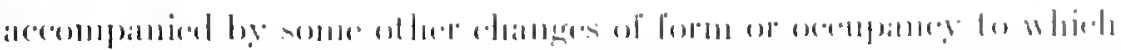

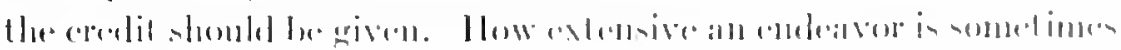

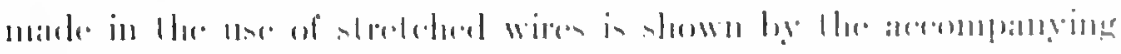

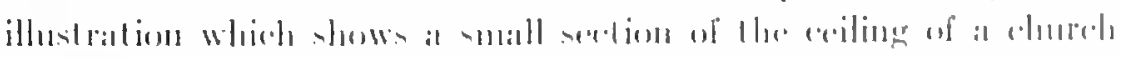

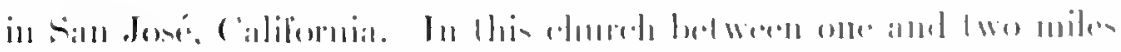

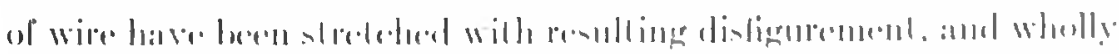

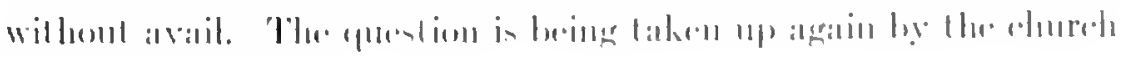
por lentrived efforl. 


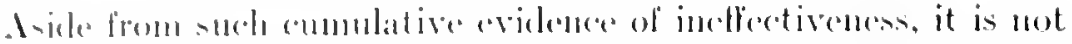

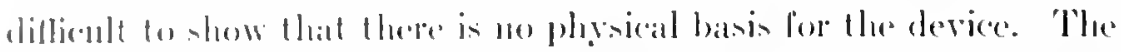

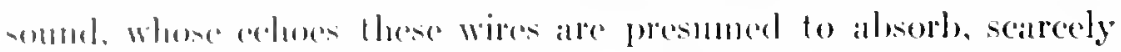
atlieet the wires, giving to them a vibration which al most is of

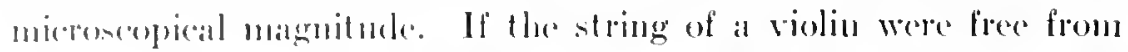
the huly of the violin. il the string of a piano were free from the

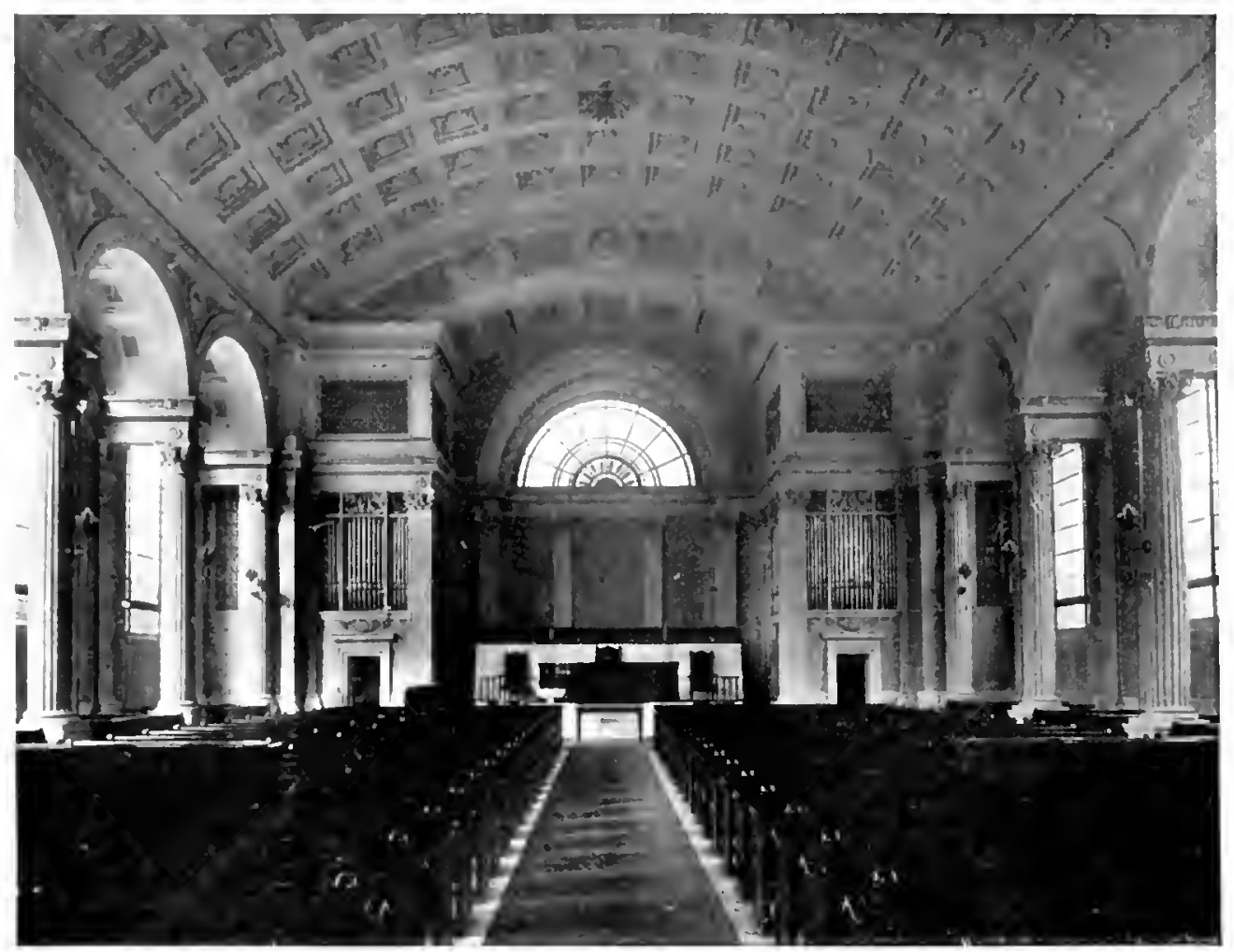

Futi. 2. Congregational Church, Naugatuck, Connecticut. Mckim, Mead and White, Architects.

somding-hoard, if the string of a harp did not touch the thin sounding-hoard which fares its slender back, when plucked they would not emit a sound which could be heard four feet away. The sound which comes from cach of these instruments is communicated to the air by the vibration of its sperial sounding-board. The string itself ents through the air with but the slightest communication of motion. ('onversely when the somel is in the room and the string at rest the vibrating air flows past it, to and fro, without disturbing 
it, and consequently without itself being atleceted by reation rither for better or worse.

The sombling-boatrd a a levere for correceting alcoustical ditliculties has at times a value; but mulens fler sommlingr-boated is 10 be al large one, the benefit to be expereted from its installation male be greatly overrated. As this particular subject calls for a line of

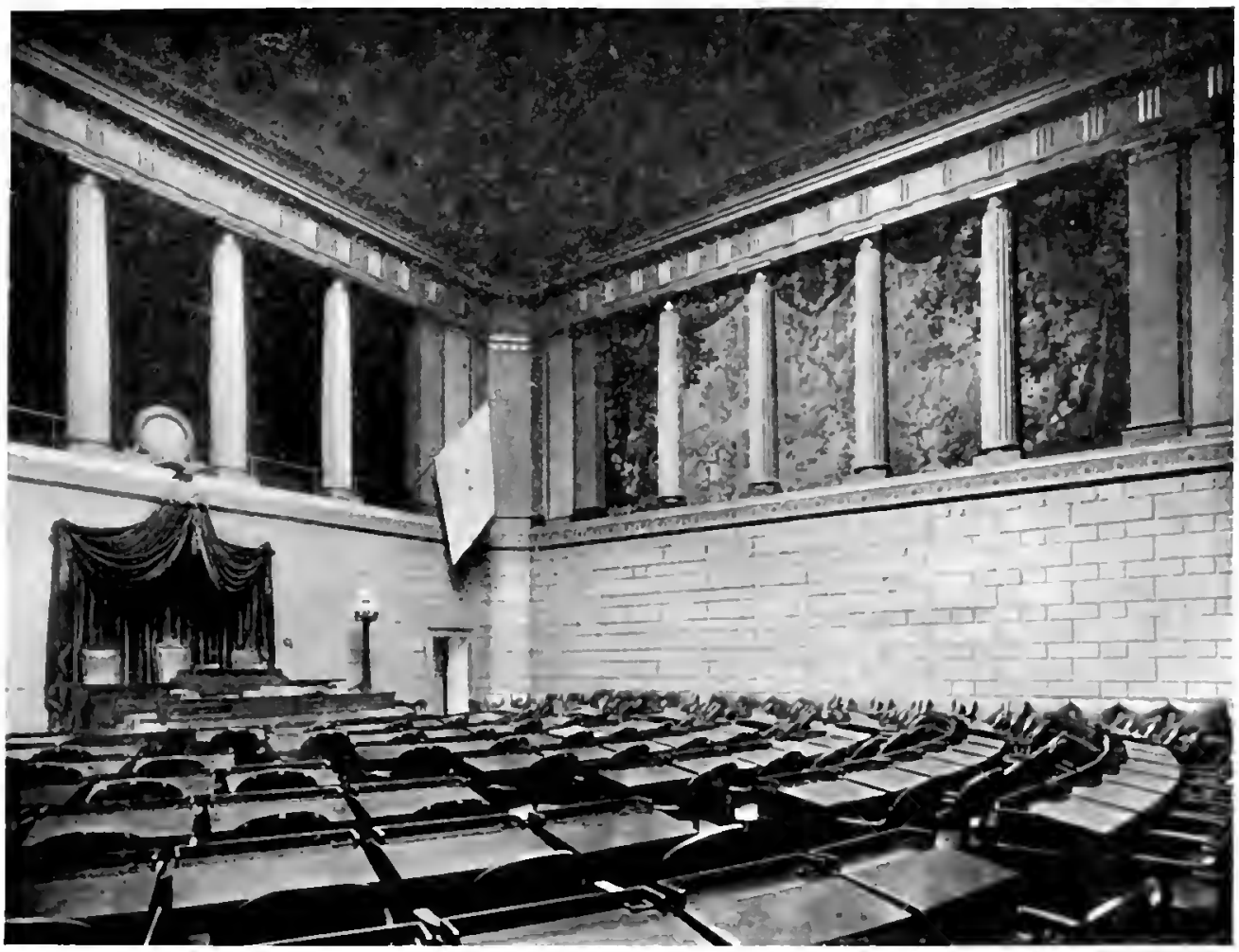

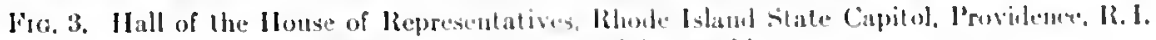
Mekim, Mean and White, Arehilacts.

argument very ditlerent from lhat of the main boly of the present paper, it will be reserved for a discussion chewhere. where. spater

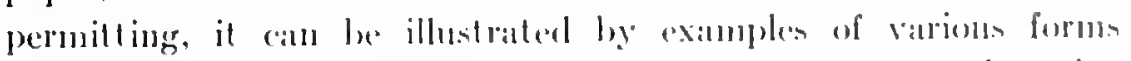
accompanied by photographls and by a mome or less exhandive discussion of their relative merits.

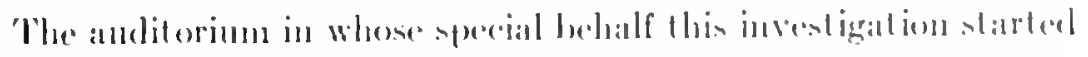

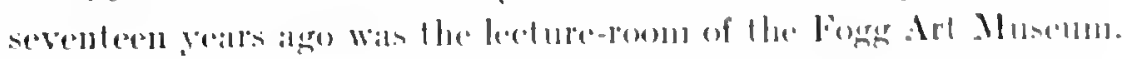




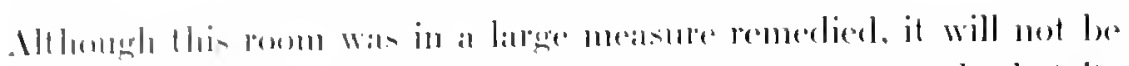

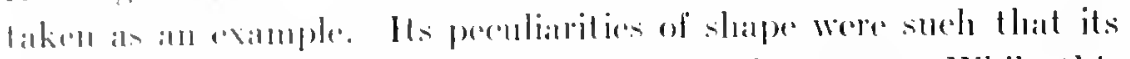

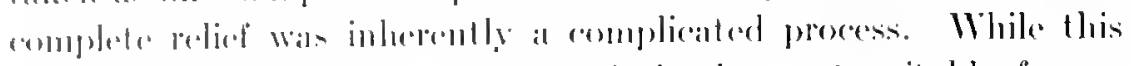

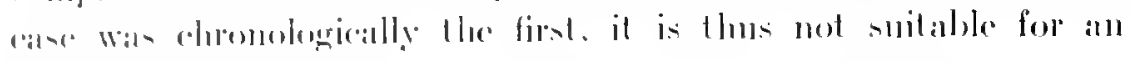
19)

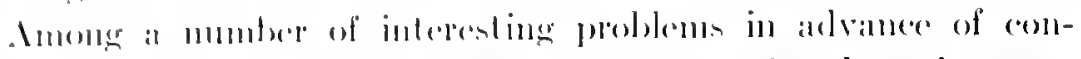

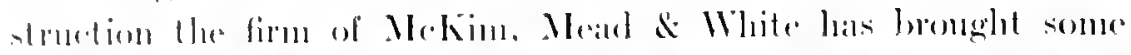

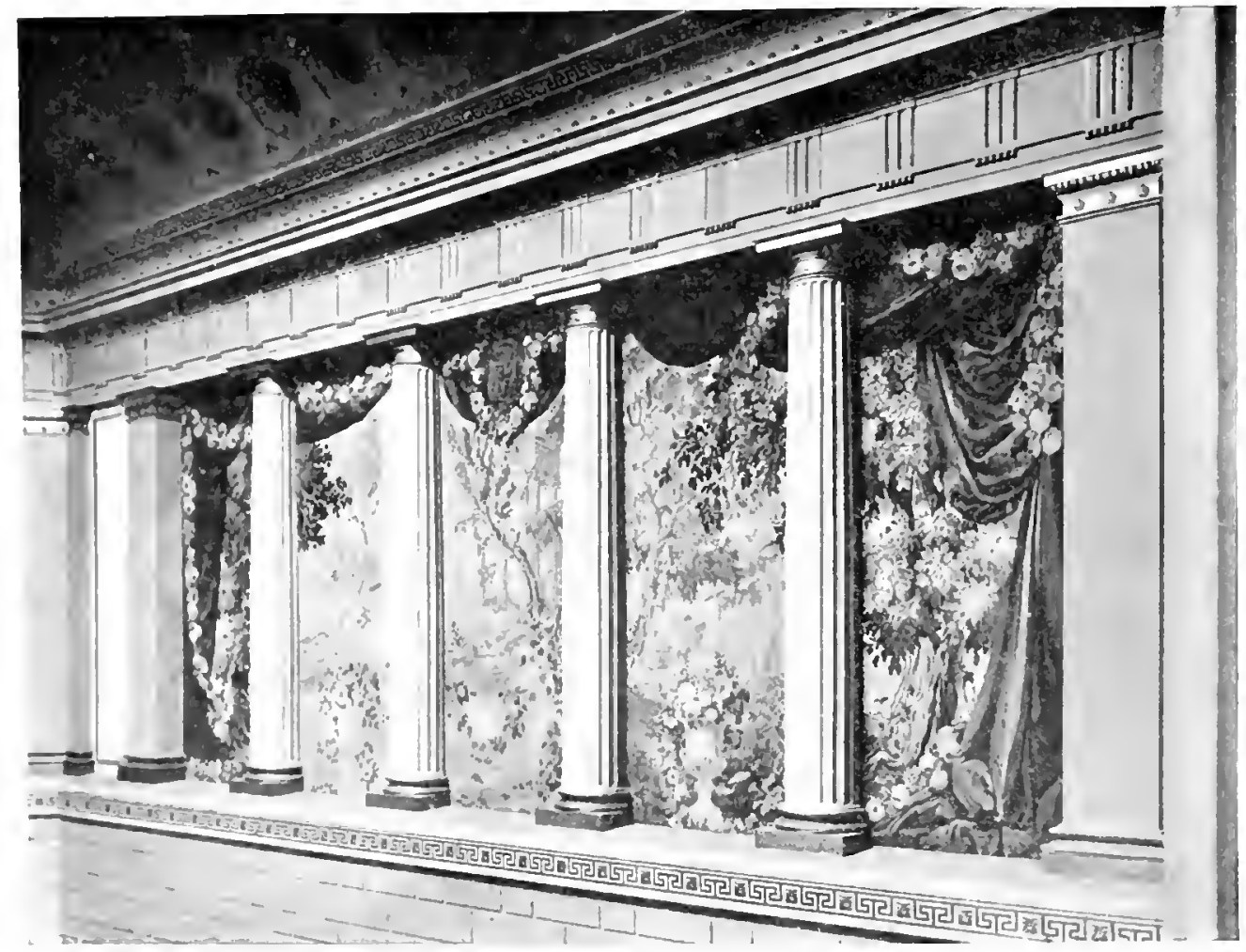

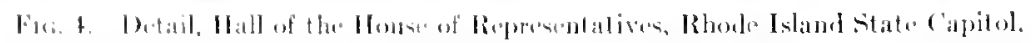
Makim, Mand and White. Irchituts.

interenting problems in arenetions, of which there will serve antmirahly an eximples becillso of therit musual directness. 'Tlue first

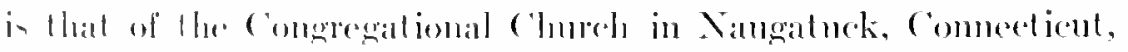

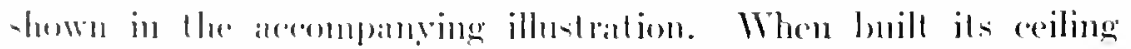
was relindrical, al now, hut -moulh. Its curvature was such als to forme a voice from the platform ujem the andience, - not al a point, but alomer a local line. for a cylindrical mirror is asligmatic. The 
difliculty was crident with the spraking, but mily be describerl more effectually with referenere to the singing. The perition of the

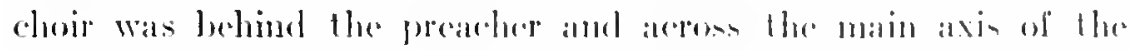

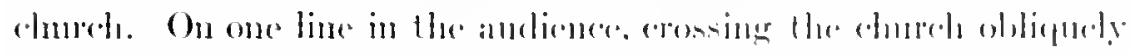

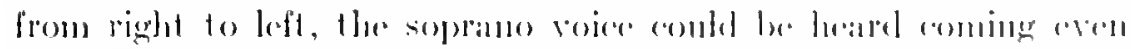

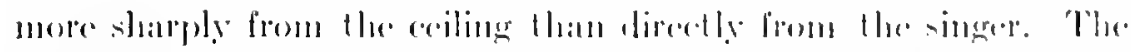

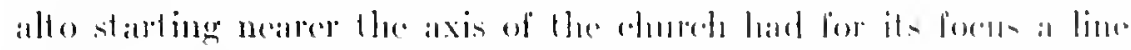

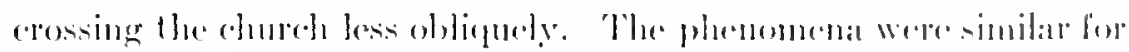

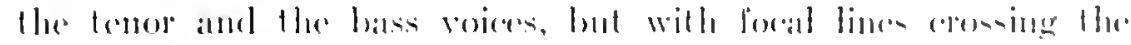

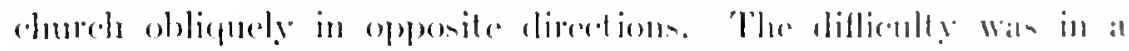

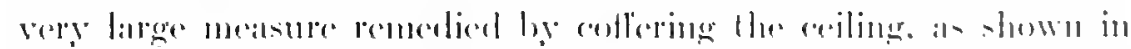

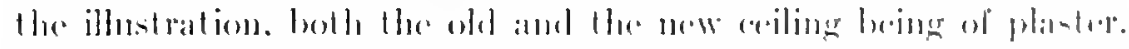

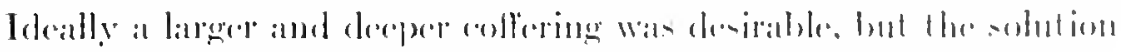

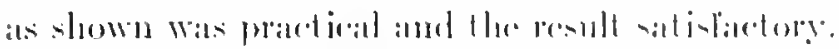

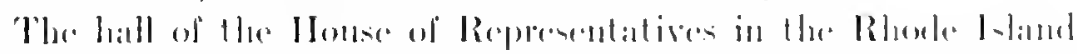

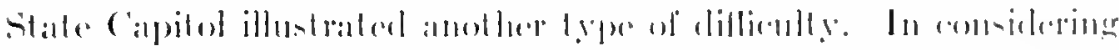

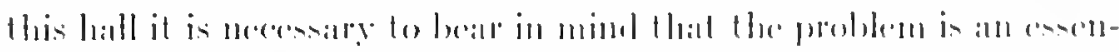

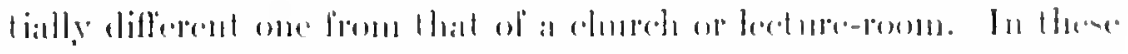

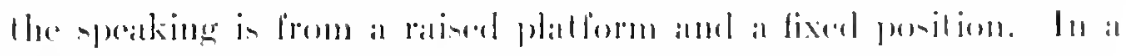

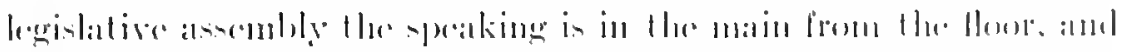

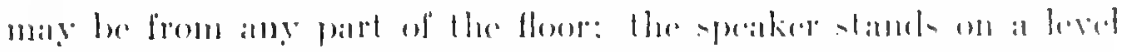

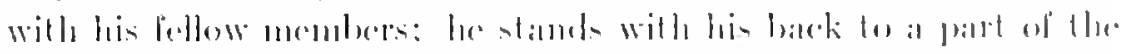

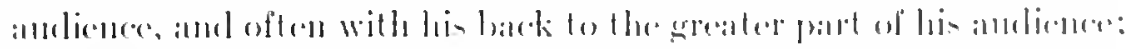

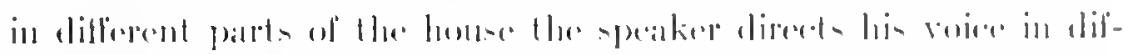

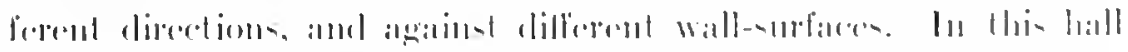

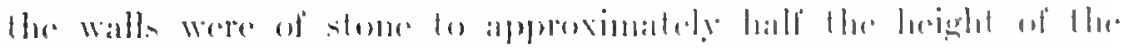

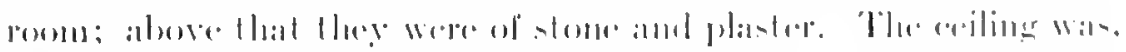

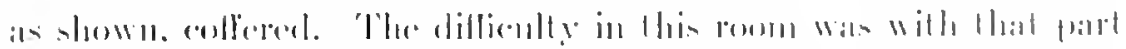

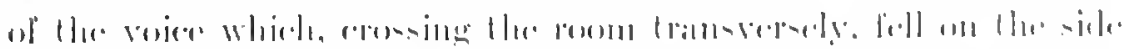

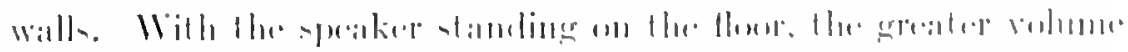

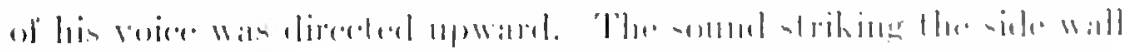

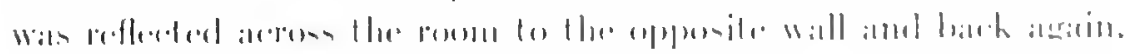

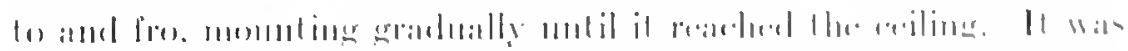

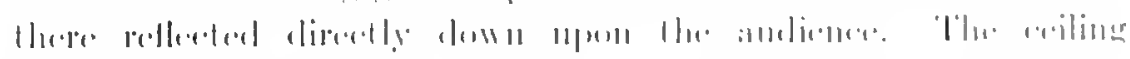
.

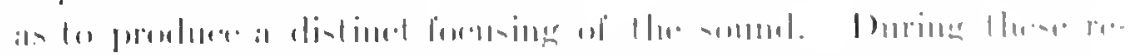

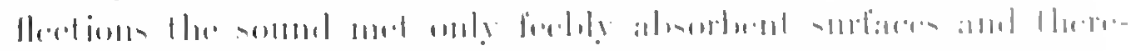

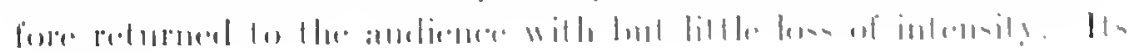




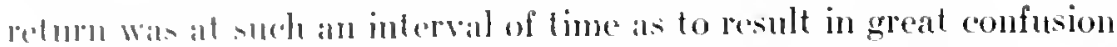
of spreceh. Only the fact that the roice, rising at different angles, lraroled diflerent paths and therefore returned at varying infervals, prevented the formestion of a distinct echo. The difficulty was remedied in this ase lọ a chamge in material without change

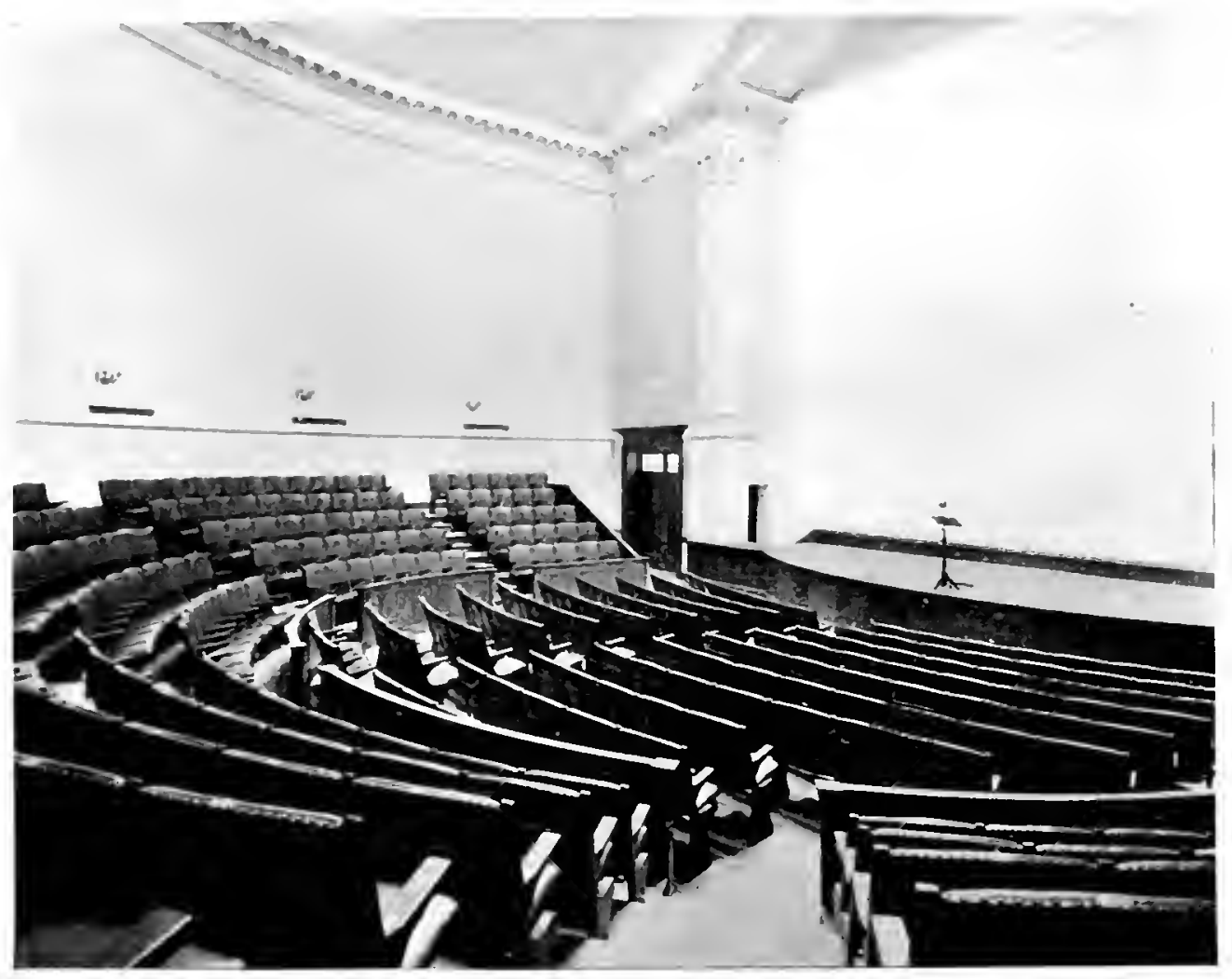

Fig. j. Lecture-room, Metropolitan Museum of Art, New York. Mchim. Mearl and White, Architects.

of form, by diminishing the reflecting power of the two side walls. 'This was done by placing a suitable felt on the plaster walls between the engaged colmuns, and covering it with a decorated tapestry. Formuately, the clesign of the room admitted of a charming exeention of this treatment. It is interesting to note that this treatment appliesl to the lower half of the walls would not have been acoustically effective. 
The lecture-room of the Metropolitan Munomm of Art illuntrates the next step in (omplexily. This hall is at semi-circular anditorim, with the semi-cirele slightly contiment be thert. straight walls. As shown in the ithestrat ions the platform is mearlys

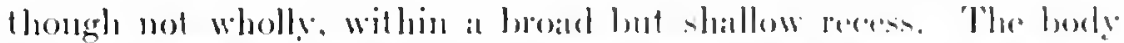

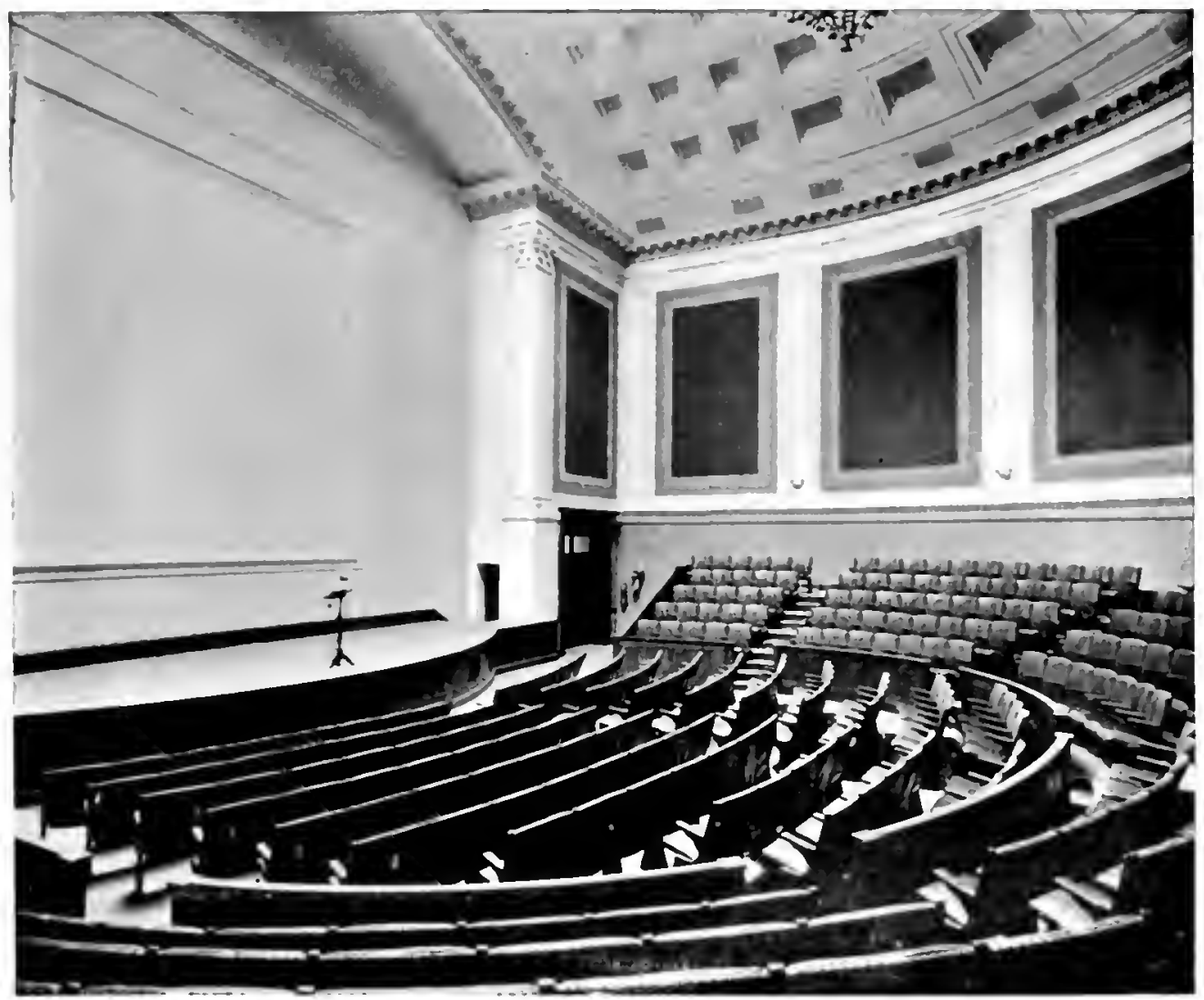

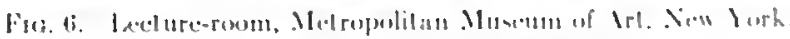
Mrkim, Mtand and Whita. Irethiteds.

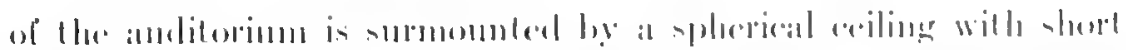

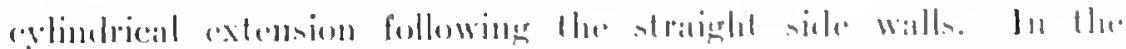

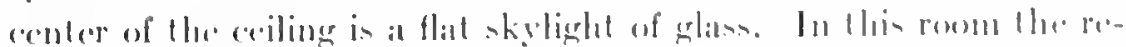

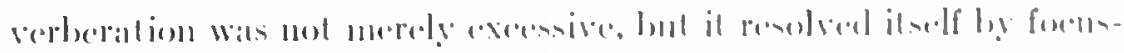

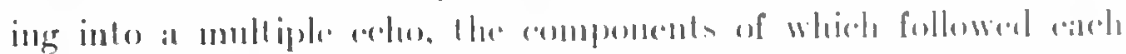

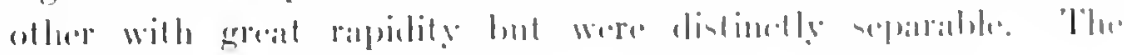




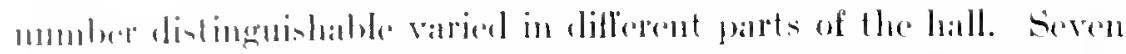

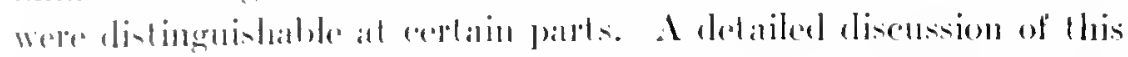

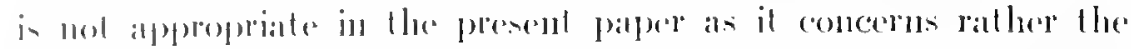

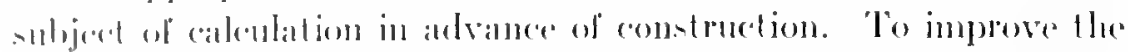

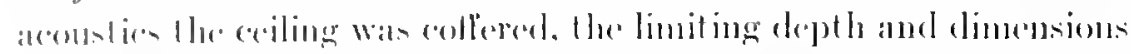

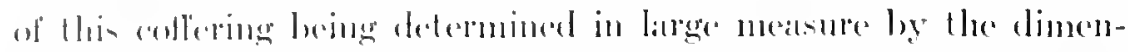

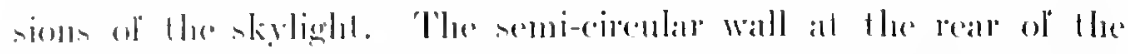

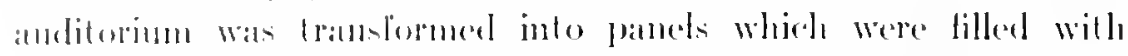

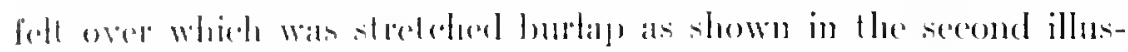

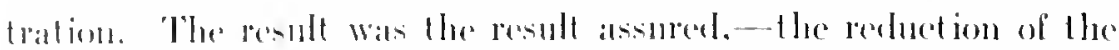
disturbanue fo a single and highly localized echo. This echo is

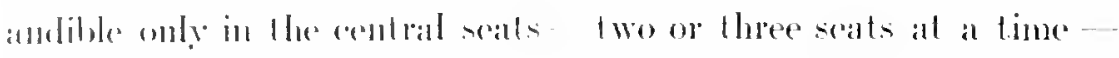

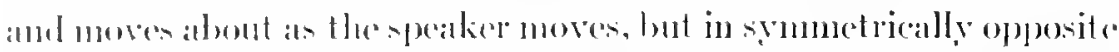

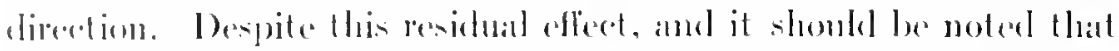

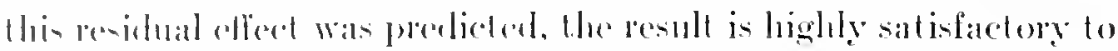

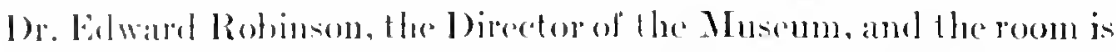

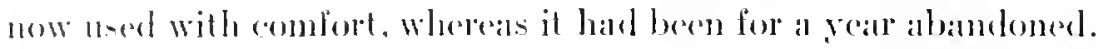

It shomb be loome in mind that "perfect acoustics" does not meall the lotal elimination of reverberation, even were that possible. landuens and reverberation are almost, though nol cuite, proportional fualitien. 'The result to be somght is a balance between the I wo pualities, dependent on the size of the anditorium and the use lo which it is to bo appliad.

Geometrically the foregoing alses are comparatively simple. In calch case the room is a simple space bounded by plane, cylindrical

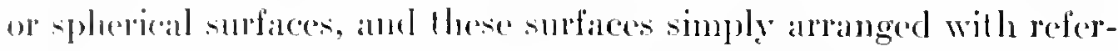
cuce lo mele other. 'The simplicity of these cases is obvious. 'The complexity of other cases is not always patent, or when patent it is not ohrions lo a merely castal inspection how best the problem shomld be attacked. A large mumber of cases, howerer, may be hamelled in a practical mamner by regarding them as connecting spaces, each with its own reverberation and pouring sound into and receiving sement from the others. An obvious case of this is the llealre, where the aggregate acoustical property is dependent on the space bedinal the proscenimu arde in which the speaker stands, as well an on the space in front of it. In another sense and to a less lecgree. the cathedral, with its chancel, transept and nave may be 


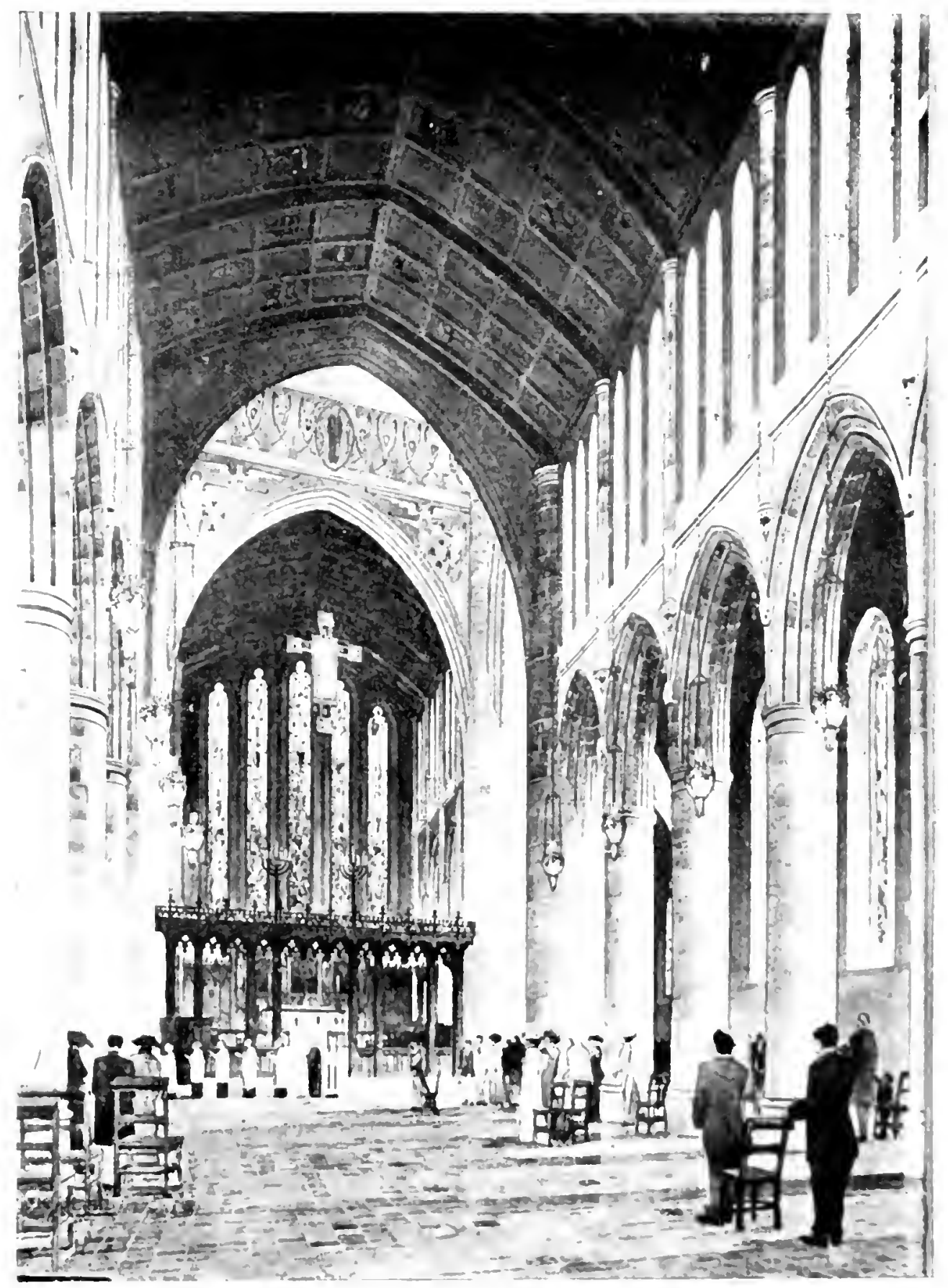

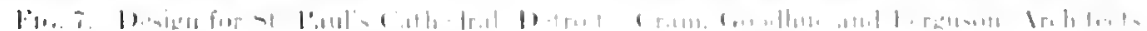


regratrded als a case of comnected spaces. The problem certainly takes (111 i simpler aspect when so attacked. An extreme and purely hypothetieal calse would be a deep and wide anditorium with a very low criling, and with a stage recess deep, high and reverberant, in fart surh a a case might oceur when for special purposes two very diflerent reoms are thrown together. In such a case the reverberation calculated on the balsis of a single room of the combined volume and the combined alsonling power would pielel an erroneous value. The speaker's voice, espectially if he stood hack some distance from the opening between the two rooms, would be lost in the production of rererberation in its own spatec. The total resulting sound, in a confused mass, would be propagated out over the auditorium. Of course this is an extreme anse and of munsual occurrence, but by its very exalggeration serves to illustrate the point. In a less degree it is not of infrefuent occurrence. It was for this reason, or rather throngh the experience of this effect, althongh only as a nice refinement, that the Boston Symphony Orchestra has its special scenery st age in ('arnegie Hall, and for this that Mr. Damrosch in addition moved his orchestra some little distance forward into the main anditorim for lis concerts in the New Theatre.

A cathedral is a good example of such geometrical complication, still further complicated by the variety of service which it is to render. It must be aldapted to speaking from the pulpit and to reatling from the lertern. It must be adapted to organ and rocal musie, and ocrasiomally to other forms of serviee, though generally of a minew innortance als to be beyond the range of appropriate consideration. Most cathedrals and modern large ehurehes lave a reverheration which is exeesive not only for the spoken but also for a large portion of the musieal service. The diffieulty is not pecoliar to any one trape of architerture. To take European examples, it eceurs in the Classie st. Panl in London, the Romanesque Durham. the Basilican Romanescue Pisal, the Italian Gothic Flor('neer, and the English Gothie York.

The most interest ing example of this type has been Messrs. Cram, Groodhue \& Ferguson's charming cathedral in Detroit, especially interesting because in the process of correcting the acoustics it was posible to carry to completion the decoration of the original design. 


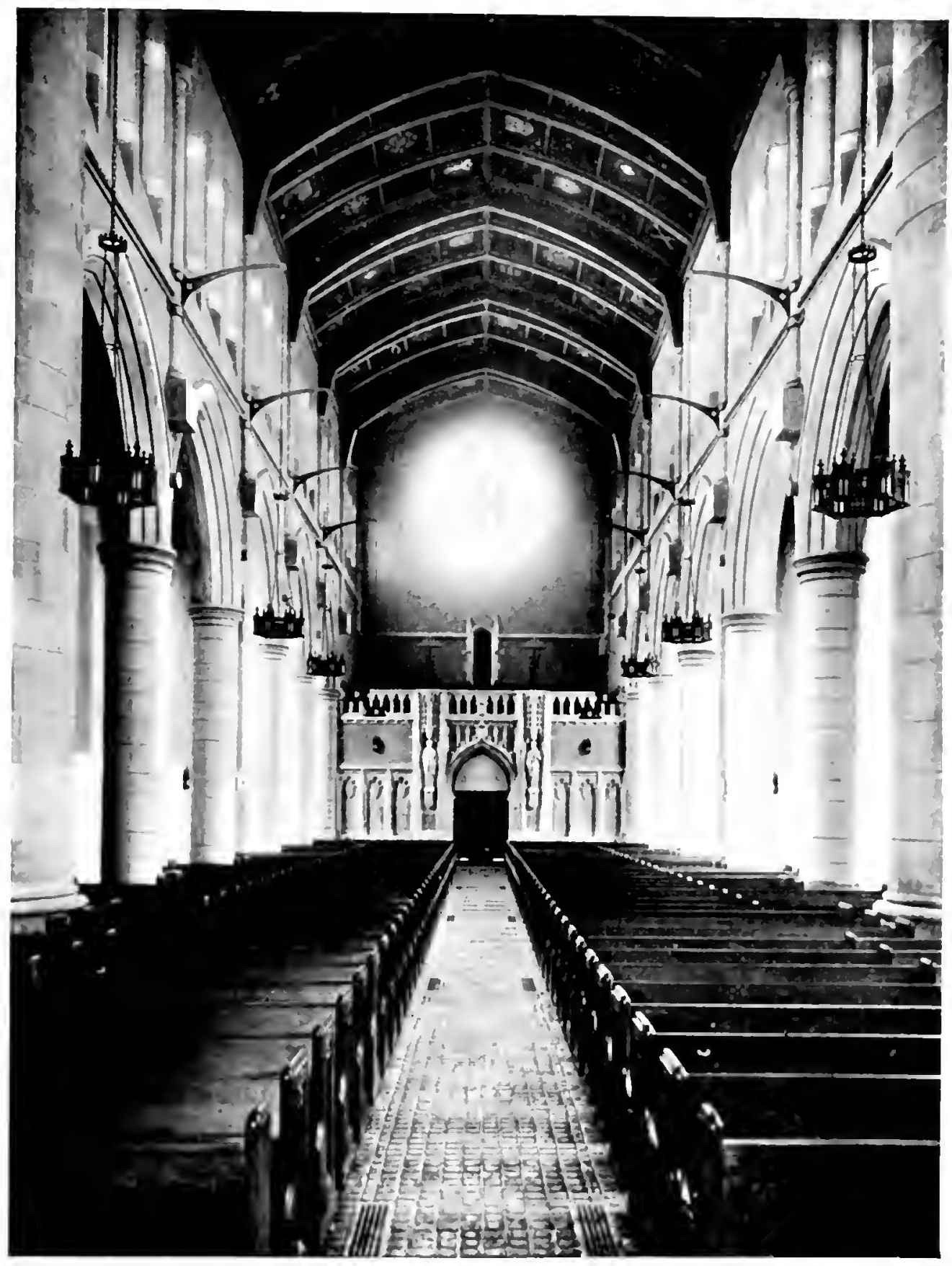

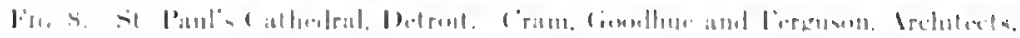




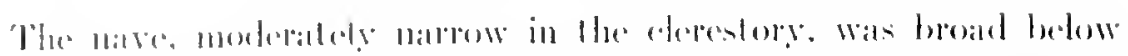

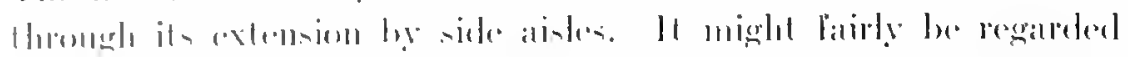

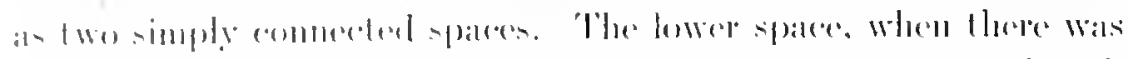

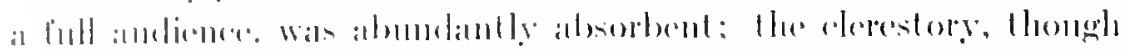

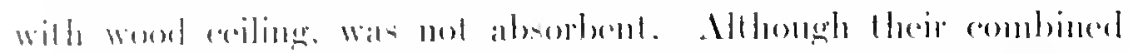

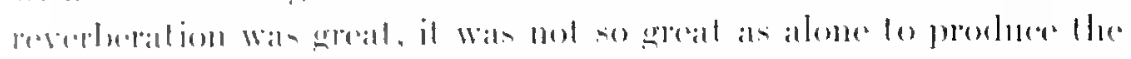

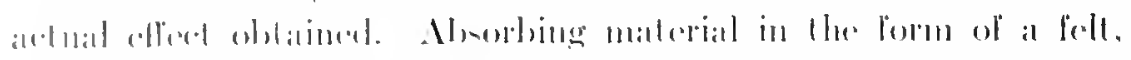

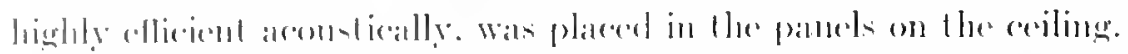

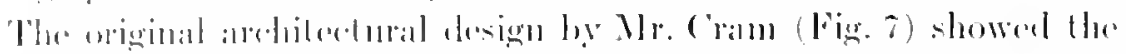

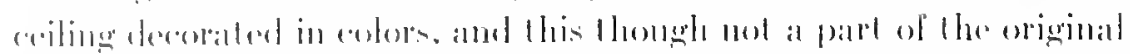

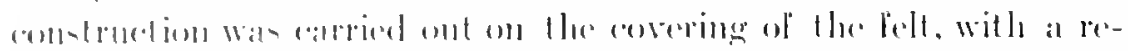

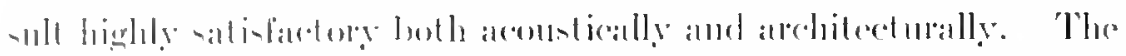

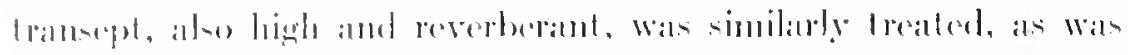

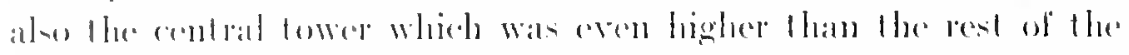

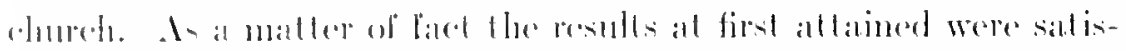

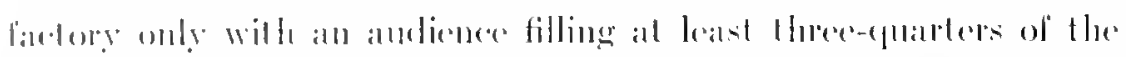

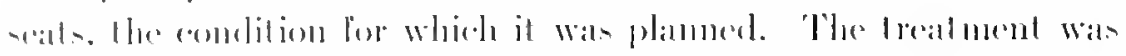

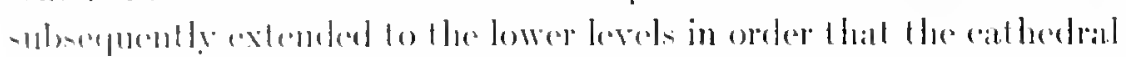
might be serverable nest merely les the mormal but for the oceat- Eumally small atulience. 'The clatured did not need and did not

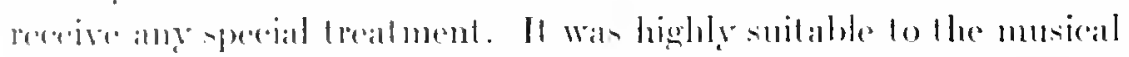

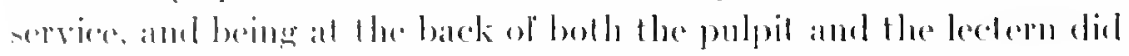

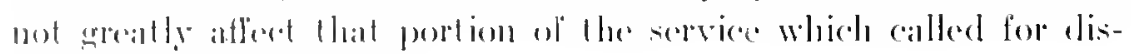
limelenes of enmuciation.

J1 ma! be rematred in passing that the lecelem is almost invarialoly a more difticolt problem than the pulpot. This is in part be-

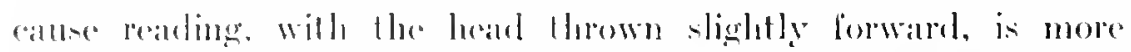

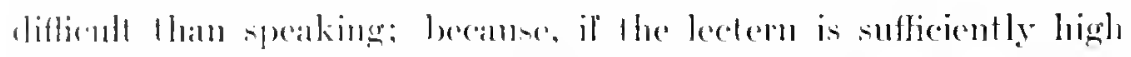

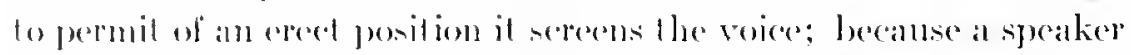
withont book or manneript. sering his andience, realizes his distance and his diflienlties: and finally, beratuse the pulpit is generally

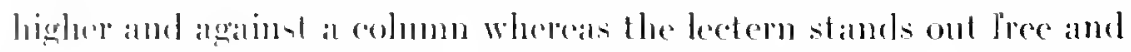

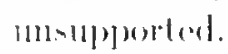

'The andilorium which has received the greatest amome of disronom rorently is the New Theatre in New York. Had it been a

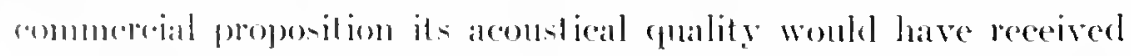
lut paraing notice. Is an institution of lange purpose on the part 


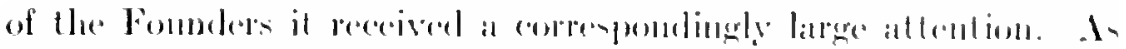

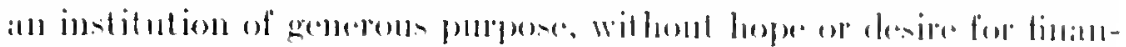

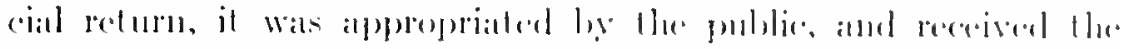

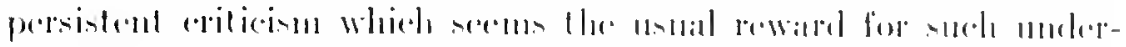

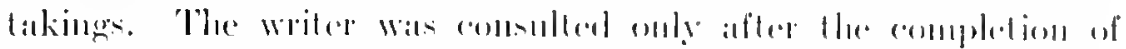

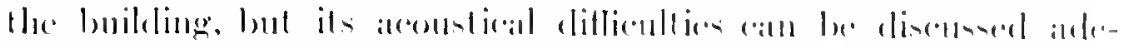

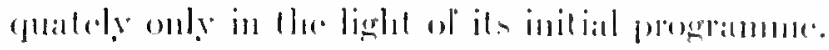

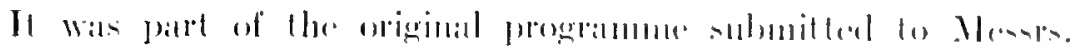

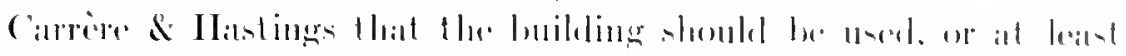

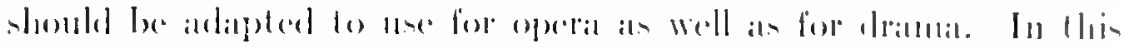

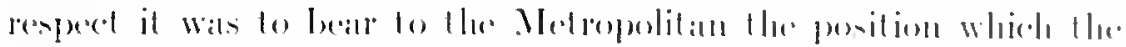

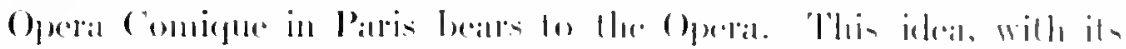

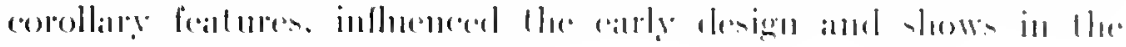
compleded structure.

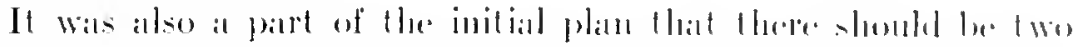

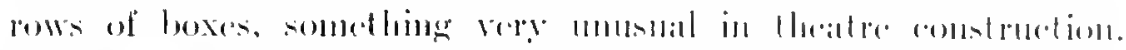

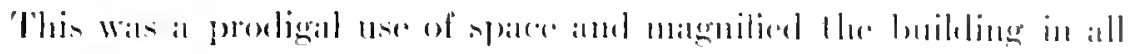

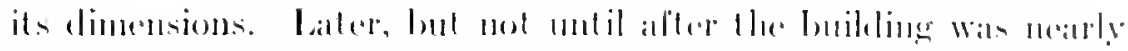

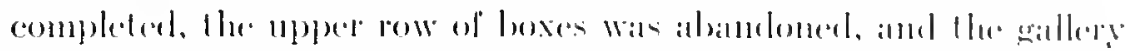

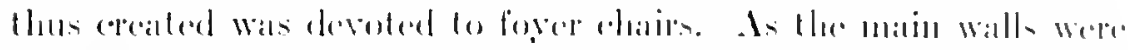

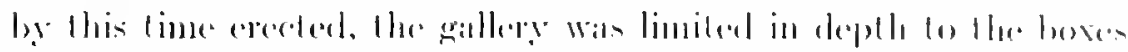

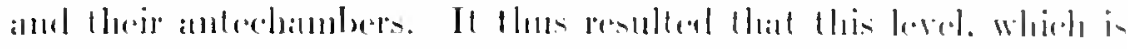

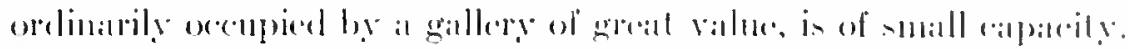

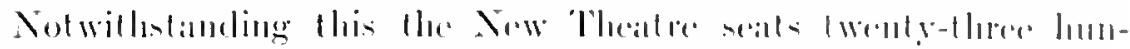

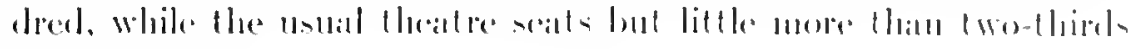
thit nound her.

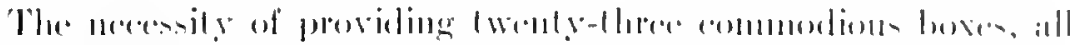

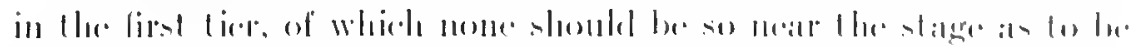

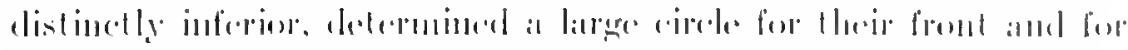

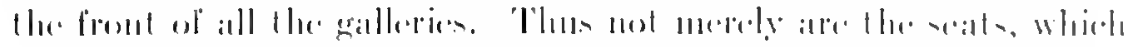

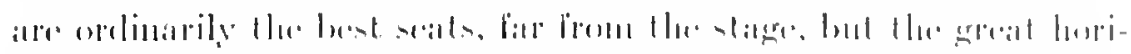

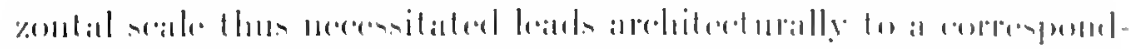

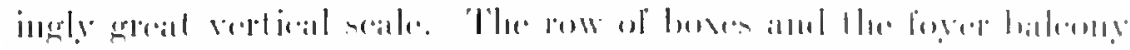

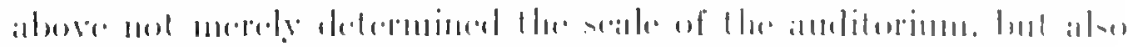

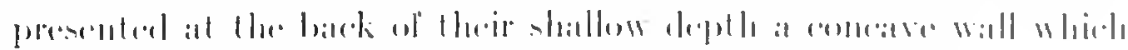

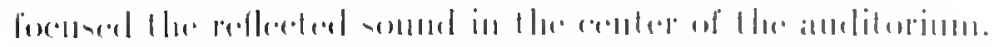

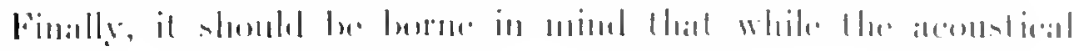




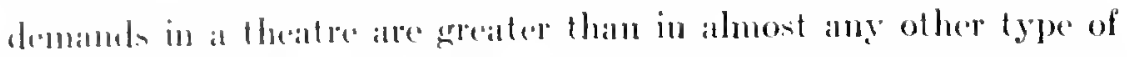
aluditurium, hecallare of the spreat modulation of the voiee in elratmatic action, tha Sill Theatre was mulertaking an even more than ustally diflienlt task, that of presenting on the one hand the older dramias with thoor lass familiar and nore diflicult phrasing, and on the other the more subte and delicate of modern plays.

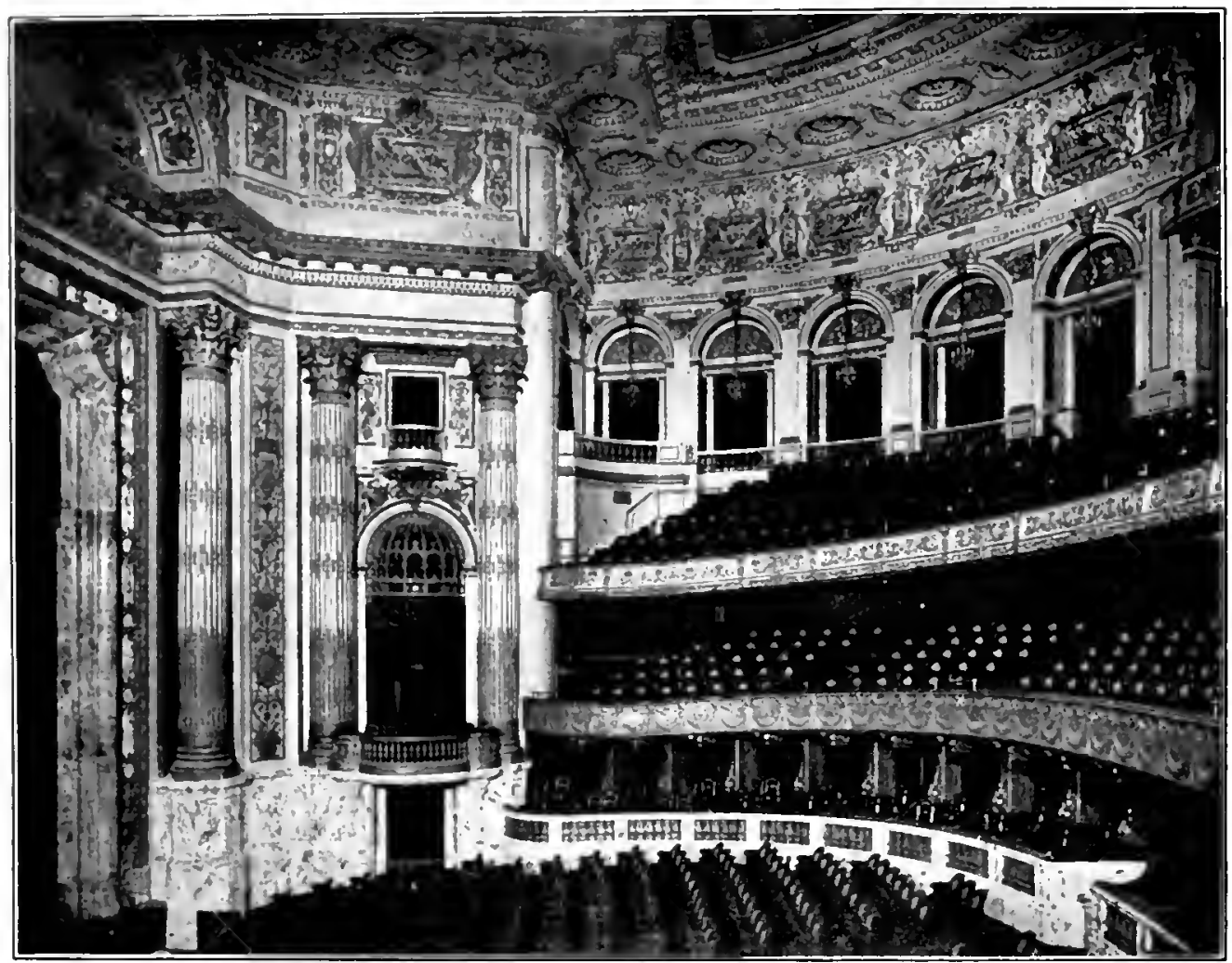

Fic. !. Itterior, the New Theatre, New York City. Carrère anı Haslings, Architects.

The conventional type of theatre construction is farly, though ouly fairly, well atelapted to the usmat type of dramatic performance. 'The Sew Theatre, with a very difficult type of performance to present, was forced hy the conclitions which surrounded the project 10 depart from the conventional type far more radically than was perlapss at that time realized.

Il're, as usual in a completed bnilding, structural changes and large changes of form were impossible, and the acoust ical difficulties 
of the anditorim could be remediad only by indiredion. 'The mothod hy which a very comsiderable improvenent wis allatined is shown by a complatrison of the line draw wing (Fig. 10) with the pluetograph of the interior of the the at re at originally completed. The bexes were changed from the first to the second herold being inter-

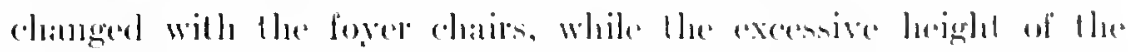

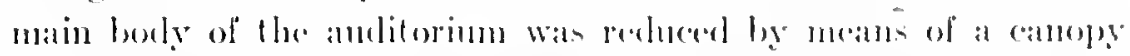
smromeling the central chandelier. This ingenions and not dis-

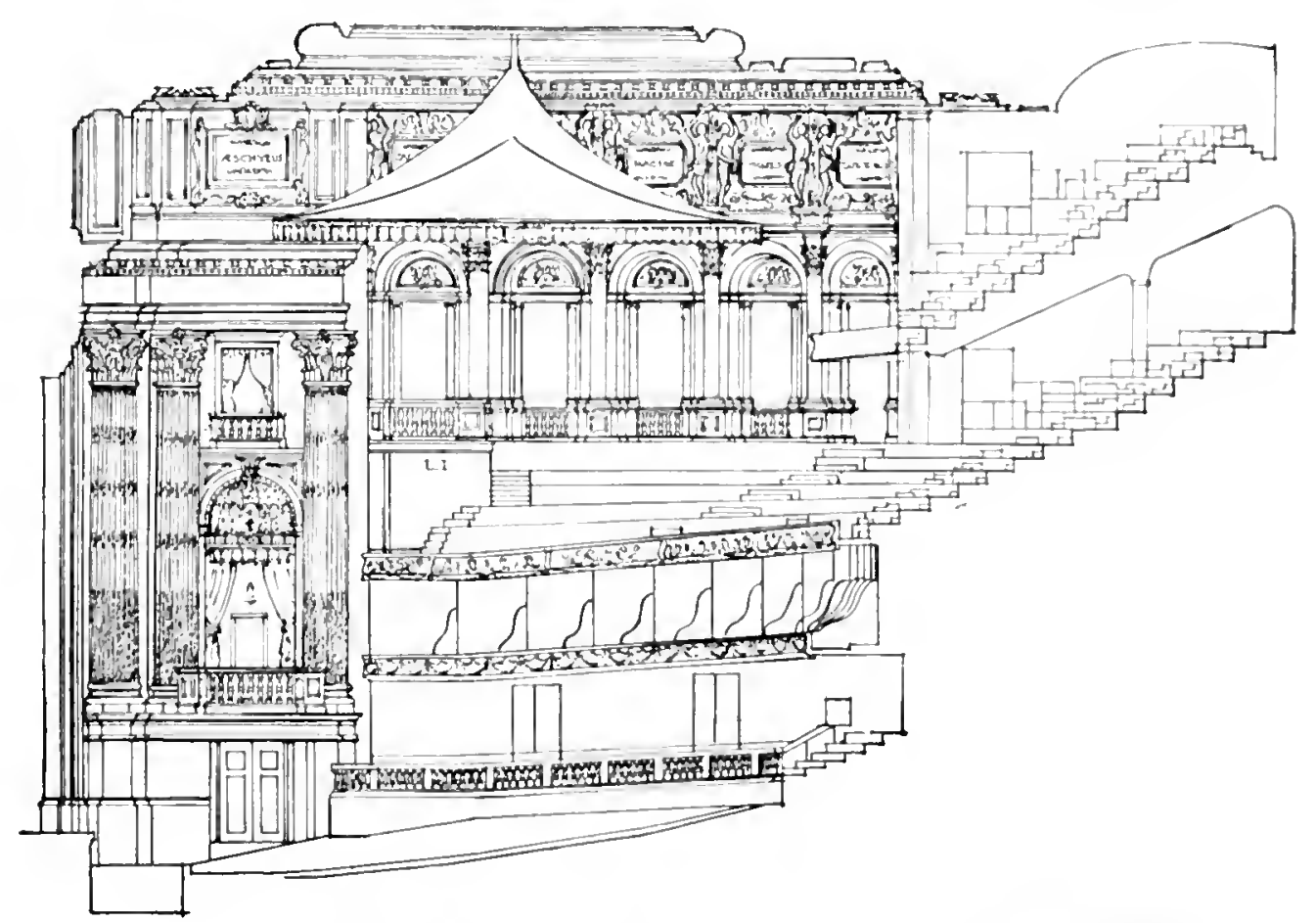

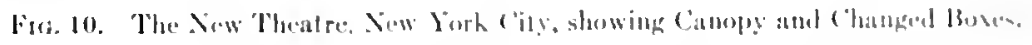

p)leasing substitute for the recommented lewering of the ceriling wat

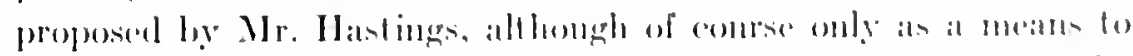

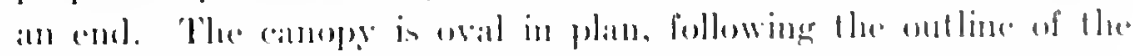

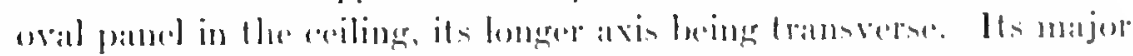

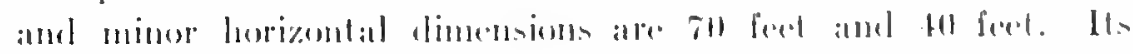

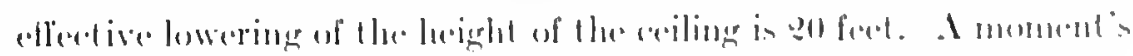
ansileration will shew that its aflective areal in proventing the

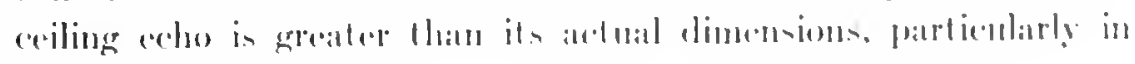


the dieretion of its minor axis. 'The imporement bronght about by this was promonned and satisfactory to the Fommlers. The

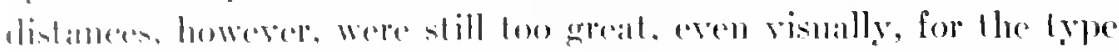
af dramalic performance for which the theatre was primarily inlembel. and sucll use was theredore discontinned. 'The New Theatre is much betler adaphed to operal llatn bo dramatic performances, and it will be a mattele of greal regred il, with its chaming solution ol many diflicull arehiterelural problems, it is nol restored to such dignified pmosere.

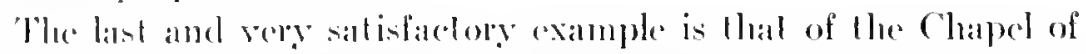
the Inion Theologieal Seminary of Mersers. Allen \& Collens. Its inleresting foature is that the compertive treatment was applied in the procesen of comstruction. It is further interesting as an example of a trathment which is not merely inconspicuous. but is anlirely indistinguinhalsle. 'The phetograph withont explanation is the best virlence of this (p. 1t9).

Ples above examples have heen chesen from mang seore as lypical of the principles involved. In each case the nature of the elifficulty has beren stated and the methos employed in its correction, or at laist its sperdal featume vere briefly described. The remainder of the palpere will he desoted ha a disenssion of the principles involved in aroustionl correction and in presenting the results of some recent (xprerimants.

In disconsing the above examples, esperially the first and the Hirrl. the comgregalional ('lumrh in Nimgaturk, and the lectureroum of the Metropolitan Musemen of Art, comsideration had to be

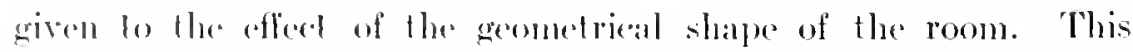
asperet of the problem of anchitertural acousties constitutes a subjoet - b large that a separate patper must be devoled to its aderpuate tratment. It involves not merely simple reflection but interlorence and liffraction, as well als the far from simple subject of the proparation of somed paralled lo or nearly parallel to the plane of an andience. It has been the object of special insestigation during

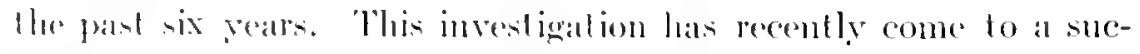
resoful isouse and will probibly be published in full during the en-

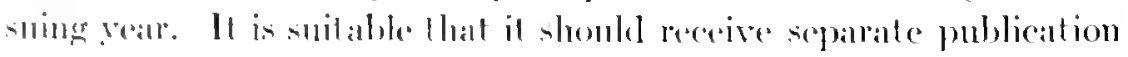
lore an it concerns shaper, it is of more value for calculation in ard- 


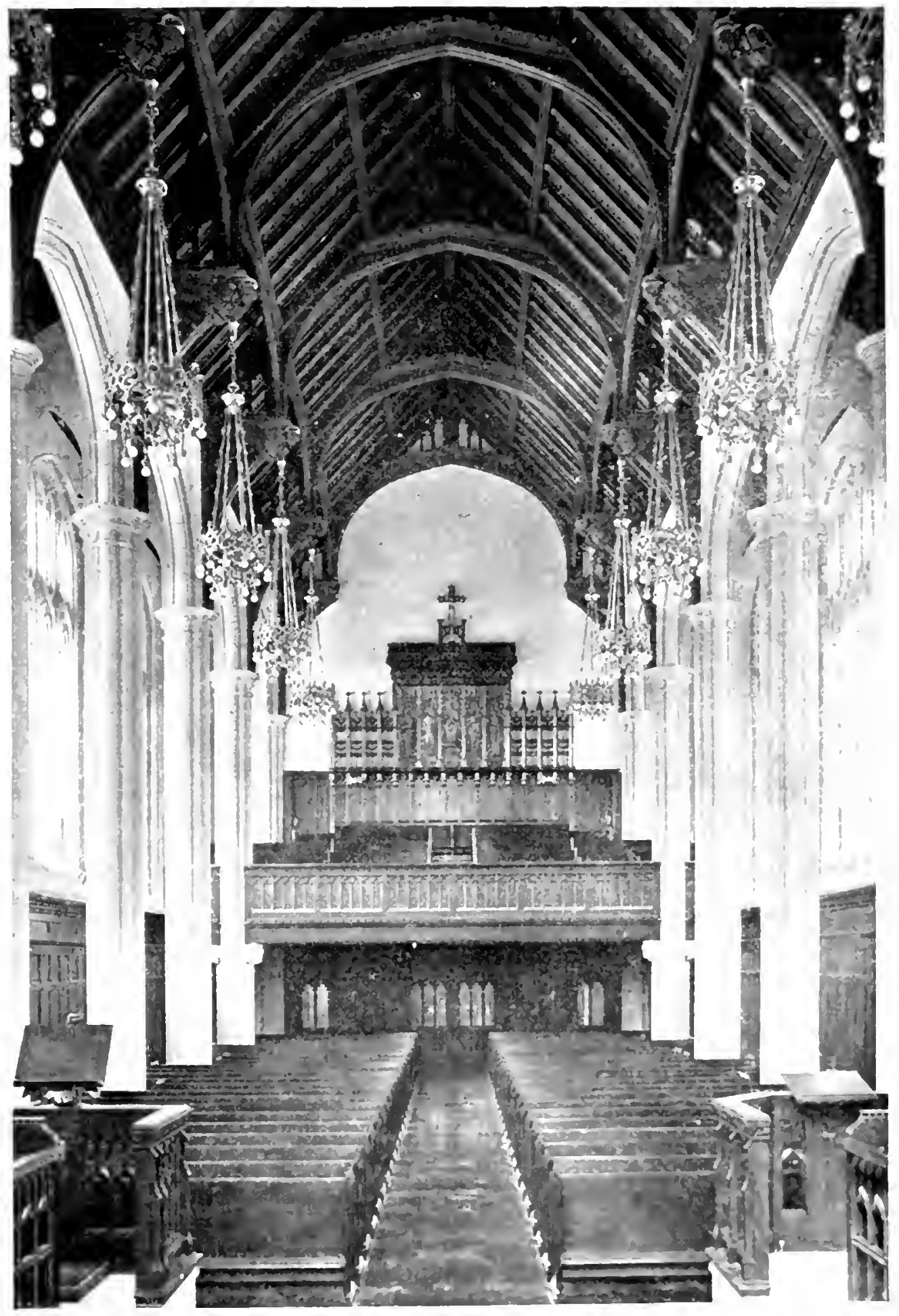




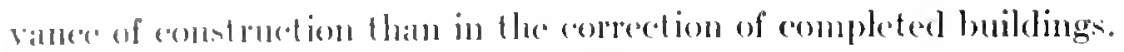
11 munt here sullies to merely imlieate the nature of the results.

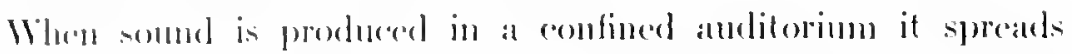

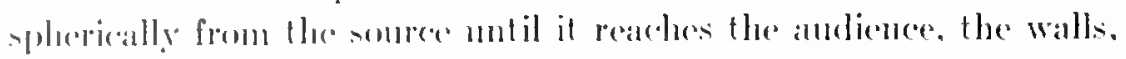
or the coiling. It is flese in part alsombed and in part reflected.

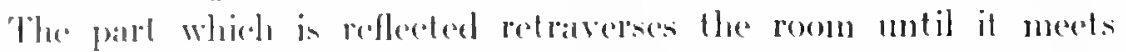
ancother surface. It is again in part absorbed and in part reflected. This process rontinues mutil, after a grealer or less number of reflections, the sonnd hecomes of neegligible intensity. Thlus at any onc linte and at ante onc point in the room there are many sombls

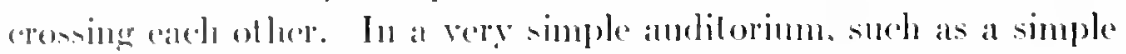

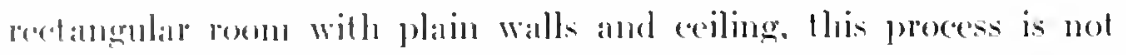
difficull lo follow, aither step by slep, or by large, but entirely arlecparte, generalizations. When the conditions are more complicatcel it is more eliflionlt to analyon; it is also more liable to be at ritally significant factor in the problem. That it has heretofore

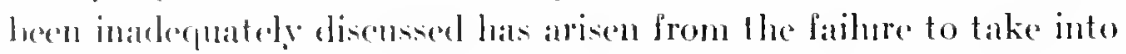
romaluleration the phenomenon of diffraction in the propagation of a somel nearly parallel to an ahsorhing audience, the phenomenon ofl difleaction in reflection from an irregular surface, and, above all, the phenomenem of interference. 'The first of these three considerattions is of prinary importance in calculating the intensity of the soumd which has come directly from the source, in calculating the efleet of distance in the andience, and in calculating the relative londeres on the flool and in the gallery, and at the pront and at the hack of the gallery. The second consideration enters into the calculation of the path of the sound after reflection from any broken or irregulat surfaces. 'The thirel is a factor of the utmost importance when the somme which are erossing at any point in the audiLorium are of comparable intensity and have traveled paths of so nearly enual length that they have originated from the same element. This latter calls for a more elaborate explanation.

In both articulate speceh and in music the source of sound is rapilly and in general, abruptly changing in pitch, quality, and lomelnesis. In musie one pitch is held during the length of a note. In articulate sperech the unit or element of constancy is the syllable. Indecel, in speech it is eren less than the length of a syllable, for the 
open vowel sound which forms the hody of a syllable usuatly hats a consonantal opening and closing, During the constaney of an element, either of musie or of speech, a train of sound-waves spreads spherically from the source, just as a I rain of circular watres spreads ont ward from a rocking boat on the surfice of still wal er. Different portions of this train of spherical waves strike difkerent surfaces of the anditorium and are reflected. After such redtection they begin to eross each other's paths. If the pir paths ale so dilferent in length that one train of waves hats entirely passed before the other arrives at a particular point, the only phemomenon at that point is prolongation of the sound. If the space between the two trains of waves be sufficiently great the effect will be that of an echo. If there be a number of such trains of waves thus widely spaced, the effect will be that of multiple echoes. On the other band if the two trains of waves have traveled so nearly ecfual pathe that they overlap, they will, dependent on the difference in length of the patlss

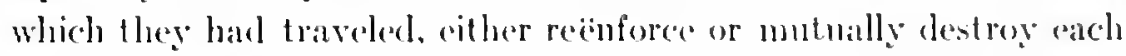
other. Just as two equal trains of watter-waves crossing each other may entirely neutralize each other if the crest of one and the trough of the other arrive together, so two somels, coming from the same sourec in erossing eareh other may produce silence. 'This phenomchom is called interforence and is a common phenomenom in all types of watre motion. Of course this phenomenon has its complement. If the two trains of water-wivess so ross that the arest of one coincieles with the crest of the other and trough with troughts. the effects will be added together. If the two sombl-witves he similarly retareded, the one on the ofleer. their effects will also be added.

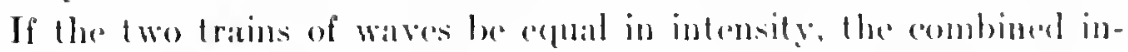

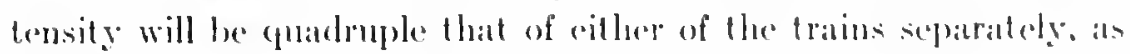
ithove axplained, or zero, depemeling on their relittive retardation. The effreet of this phemomenon is to produce regions in ant andito-

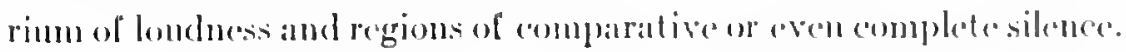

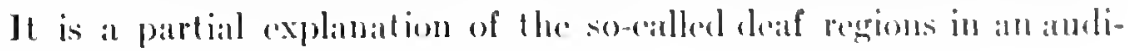
toriuntu.

It is not diflicult to ohererve thin phenomenom directly. It is

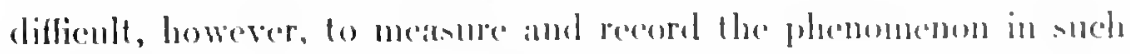

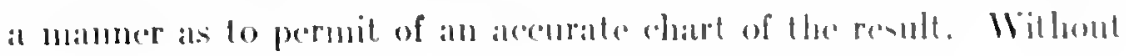


going into the details of the method cmployed the result of these measurements for a room sery similar to the Congregational Church in Nittgatuck is shown in the accompanying chart. The room experimented in wils a simple rectangttar room with plain side

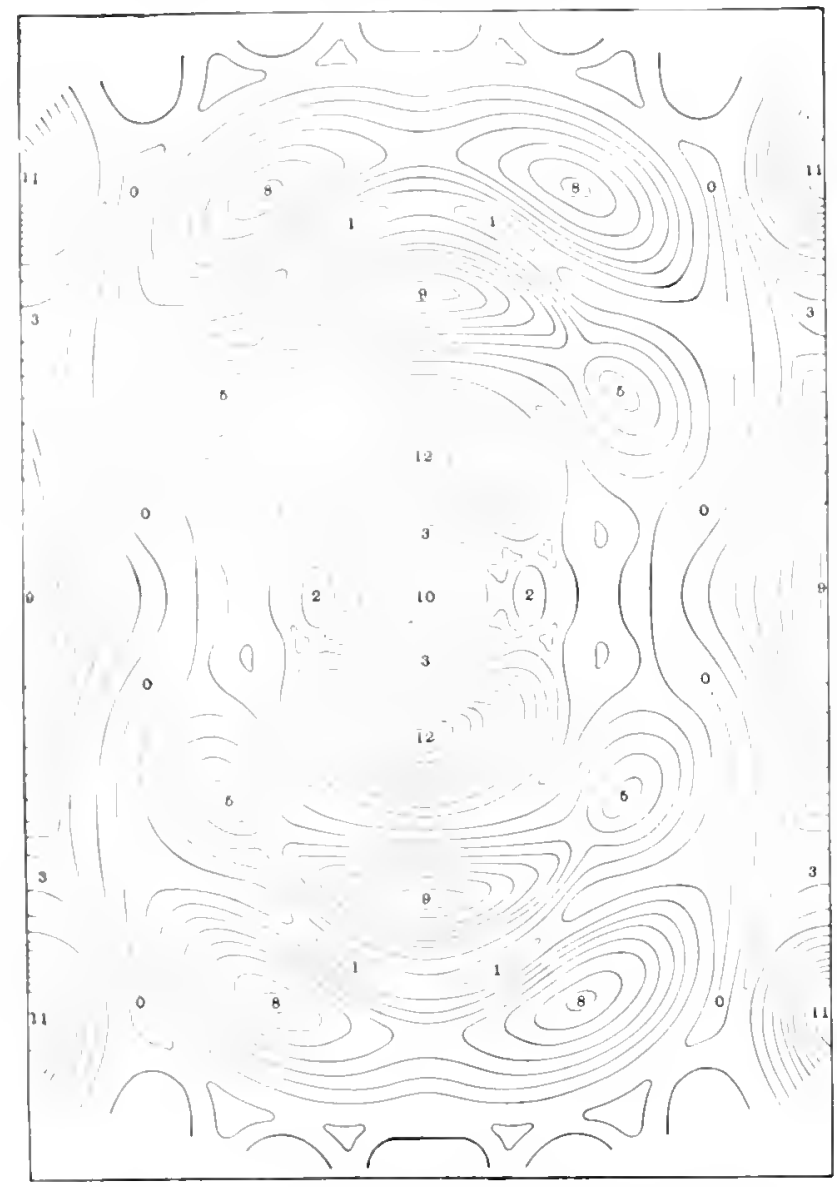

FIG. 12. Dislribution of intensity on the head level in a roon with a barrel-shaped ceiling. with center of curvature on the toor levet.

walls and ends and with a barrel or eylindrieal ceiling. The ceiling of the room wis smooth like the ceiling of the Naugatuck Church before it was eoffered. The result is elearly represented in Fig. 12, in which the intensity of the sound has been indicated by contour lines in the manner employed in the drawing of the Geodetic Survey 
maps. The phenomenon indieated in these diagrams was not ephemeral, but was constant so long as the source of sound confinned, and repeated itself with almost perfect aceuracy day after day. Nor wass the phenomenon one which eould be observed merely instrumentally. 'To an observer moving ahout in the room it wats quite as striking a phenemenon as the diagrams suggerst. At the points in the room indicated ats high maximal of intensity in the diagram the sound wass so lout ats to be disagrecable, at other points so low as to be scarcely atudible. It should be added that this distribution of intensity is with the somree of sound at the center of the room. IIad the source of sound been at one end and on the axis of the cylindrieal ceiling, the distribution of intensity would stitl have been bilatcrally symmetrieal, lut not spmmetrical about the transyerse axis.

As before stated a full disenssion of this phase of the sullject is reserved for another palper which is now about reaty for publication.

In the sccond, in the fourth, and in part in the third of the albove examples the aconstieal diflienlty was that of excessive reererberat ion.

If at sound of constant pitch is maintained in an anditorium, though only for a very brief time, the somet spreatling directly. from the source, logether with the sound which has been refleeted, arrives at a steaty state. The intensity of the sound at any one point in the room is then the result ant of all the superposed sound crossing at that point. As just shown, the mutual interference of these superposed someds gives a distribution of intensity which shows pronounced maxima and minima. llowerer, the proballa intensity at any point, als weft ats the aggeregate internsity owe the room, is the sum of the components. Whaterer the distribution of maximal and minimat the state is a stady one so long ats the source

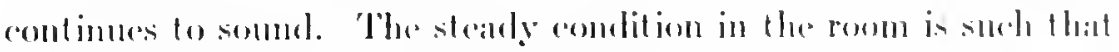

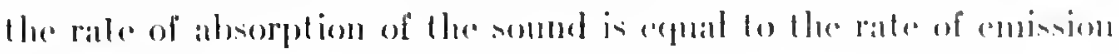
by the sourere.

If after this sleady state is established the souree is atbruptly"

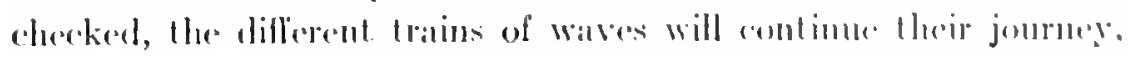
the maximat and minimat shifting positions. I'ttinsately. Ihe somel will cesise to be andible, having dininished in intrensily until it hats passed below what anrists call the "thereshold of andibility." The 
duration of amblibility after the somrce has ceased is thus dependent upon the initial intensity, upon the absorbing material, and upon the location of that absorbing material with reference to the several trains of waves. In special case's the position of the absorbing maferial is a matter of the utmost importance, but in many cases the agegregate result may be computed on the basis of the total absorbing power in the room.

The prolongation of the sound in an auditoriom after the source has coased I have ventured to call reverberation, and to measure it mumerically by the duration of audibility after the abrupt cessation of a sonere which has produced an average intensity of sound in the roon cepual to one million tines minimmm andible intensity. This is an ordinary condition in actual oceurrence.

In the 1900 papers pulplished in the Engineering Record and the Ameriean Architect. this subject of reverberation was discussed at great length, and it was there shown how it might be measured and incleed, low it might loe ealculated in advance of construction. In addition to the formula many coefficients of absorption were detormined, such data being absolutely necessary to the reduction of the subjeet to an exact scienee. 'This work related to sounds having a pitch an octave above middle C.

But it was of course olvious that the acoustical quality of an auditorium is not determined by its character with reference to a single note. 'The next series of papers, published in $\mathbf{1 9 0 6}$, therefore extended the investigation over the whole range of the musical scale giving clita for many materials and wall-surfaces, and rendering a more complete calculation possible. At the conclusion of these papers it was shown how the reverberation of an anditorium should be represented by a curve in which the reverberation is plotted against the pitch ant by way of illustration a particular case was shown, that of the large lecture-room in the Jefferson Physical laboratory, both with and without an andience. This curve is reproduced in the accompanying diagran (Fig. 13).

In the process of investigating an auditorium such a curve should be drawn as definitive of its initial condition and then in the determination of the treatment to be enployed similar curves should be drawn representing the various alterations proposed and 
taking into consideration the location of the surfaces, their areats and the nature of the proposed treaturent. The diagram (Fig. 14) shows the result of this computation for the more interesting of the above examples, St. Paul's Calleelral, Detroil. In this diagram curves are drawn plotting the reverberation of the

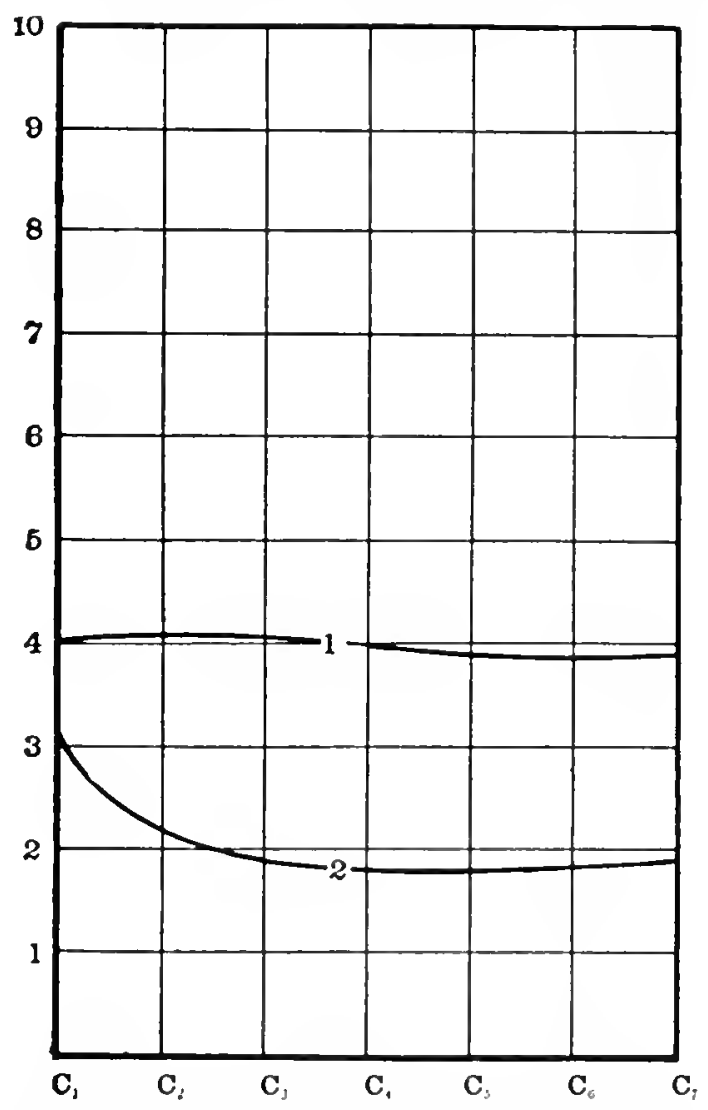

lia. 13. ("urves slowing lla reverberation in the lecture. room of Lhe defferson Plysical Iatheratory willoul an audience and will un andience filliug all the seals.

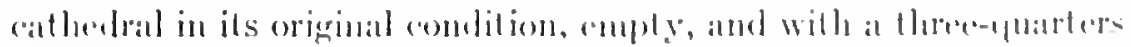

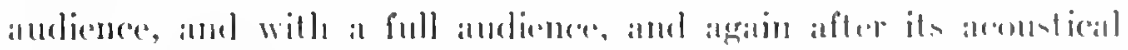
correction also empty, with a llures-quarters andience, and will at full andience.

Reprints of the patgers just mentioned were mated at the time

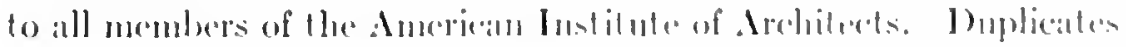


will glarly be sent to any one who may be interested in the further per'tsial of the subject.

Brief mention lats becen matle of the dependence, in speciat cases, of the efficiency of ant absorbing material on its positions in an auditorium. For eximule, in the room whose distribution of intensity

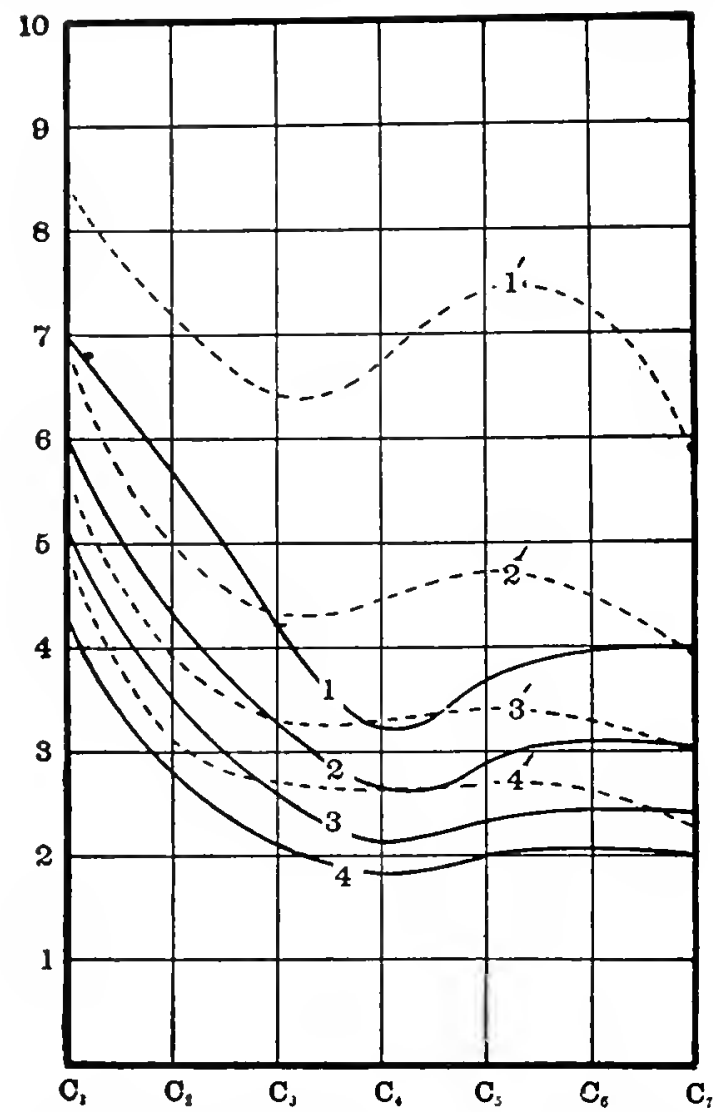

Fur. 14. Curves showing the reverberation in St. Paul's ('athedral, Detroit, before $\left(1^{\prime}, \mathbf{2}^{\prime}, 3^{\prime}, t^{\prime}\right)$ and after $(1,2$. 3. 4) corrections, empty and with a one-ruarter, onehalf, three-quarter and full audienee.

was shown in Fig. 19, the absorbing material would have much greater efficiency in reducing the reverberation if placed so as to include maxima, than if so placed as to include minima. That this would the true is obvious. The magnitude of the effect, however, is not so clear, for the maxima and minima shift as the sound dies 
away. It was therefore submitted to an ancurate experimental investigation. The results are shown in the adjacent diagram,

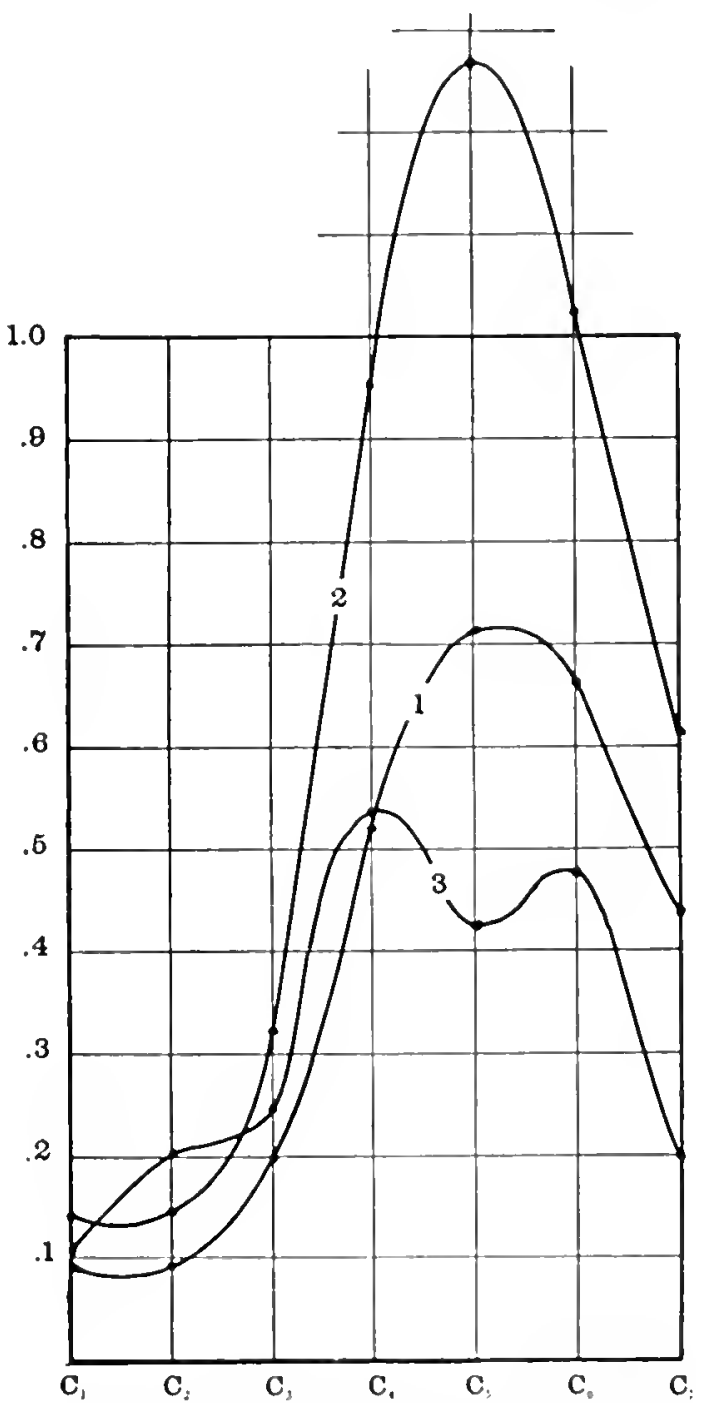

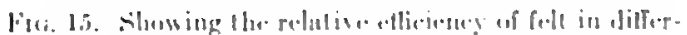

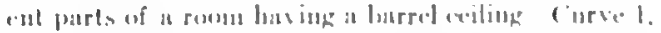

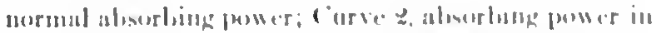

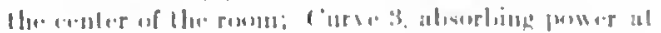

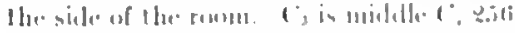

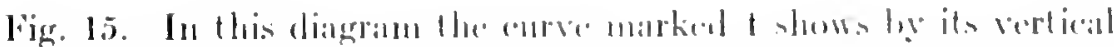

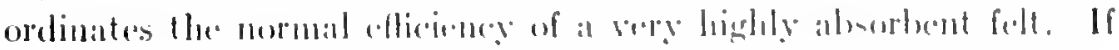


so phaced in the room as to inchude on its surface the maxina of intensity of the somml it had an effective absorbing power as shown in Curve g, a truly remarkible increase over its normal value. Curve 3 shows the officieney of the same felt when placed against the sicle wall. It there includerl more maxima than minima for the

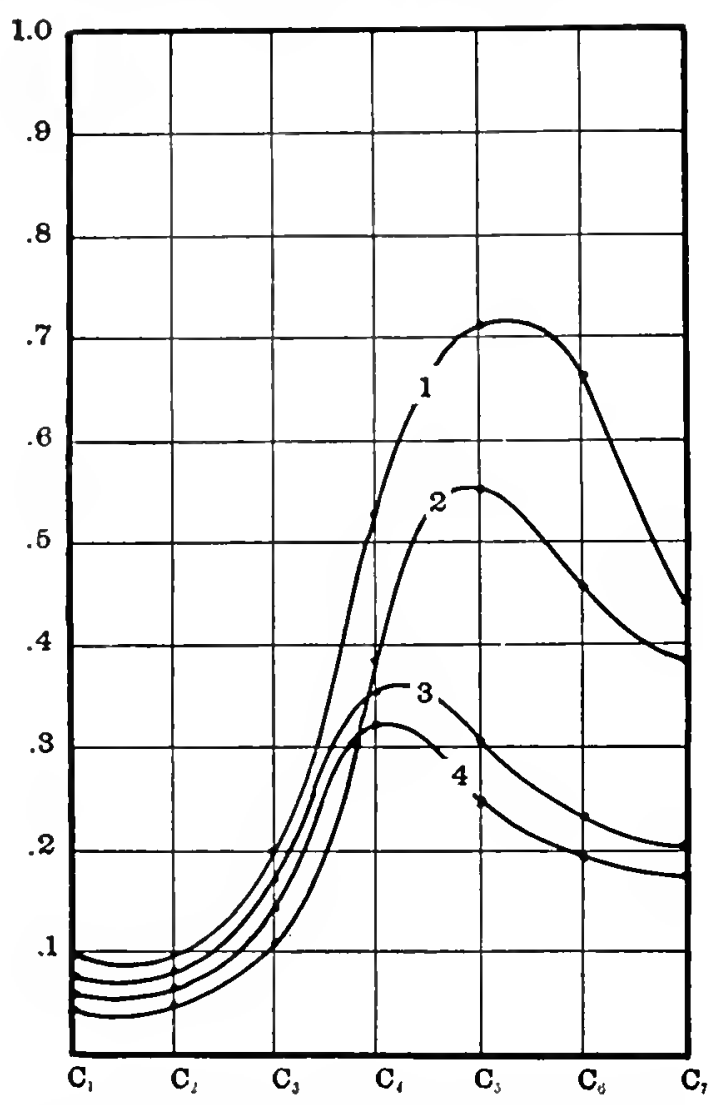

Fig. 16. Absorbing power of various hinds of felt as defined in the lext. $C_{3}$ is middle. C. 2.56.

lower notes, but more minima than maxima for the higher notes, with a resulting efficiency curve which is very irregular.

The following experiments were performed for the H. IV. JohnsManvillo Company in the search for an efficient absorbing material and an effective method of treatment. 'The absorbing efficiency of felt is dependent on the flexilility of the mass as a whole and on its porosity. It is not in large measure dependent on the material 
employed, except in so far as the nature of that material determines the nature, and therefore the closenens, of the felting process. The same materials, therefore, might very well have either at very high or a very low alssorbing efficiency, depending entirely upon the process of mimufacture. The nature of the material is here specified,

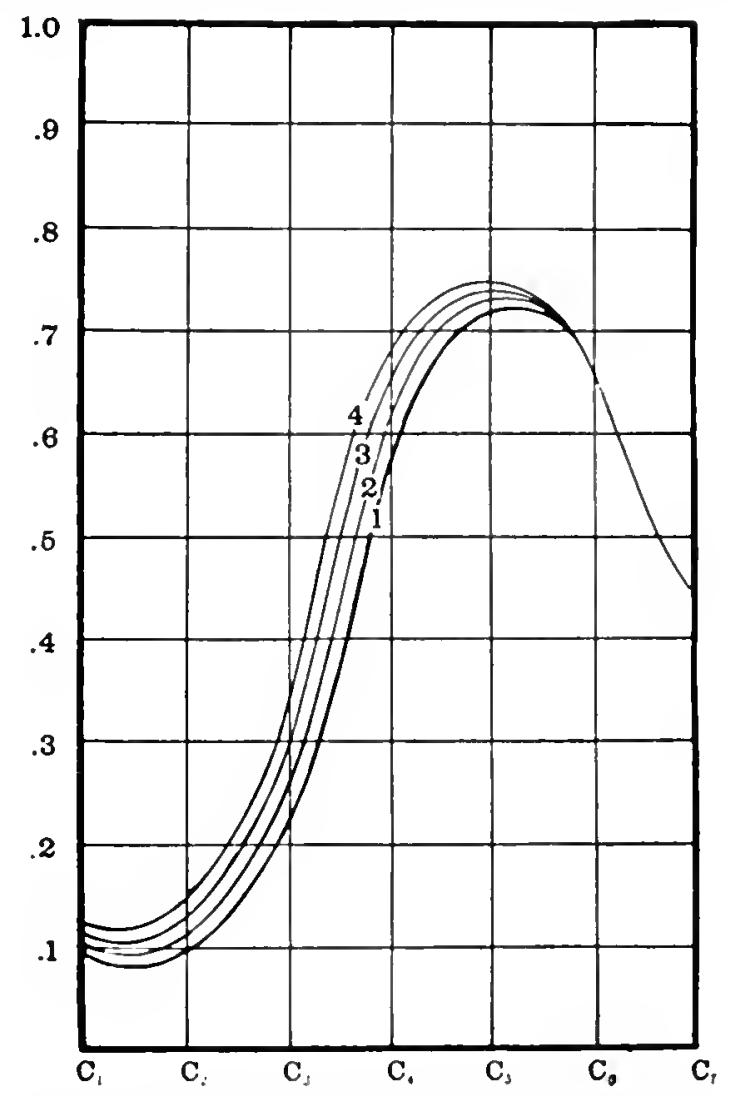

Fu. 17. litfect of air spare bedind felt. Corve 1. felt in contact with the watt; Curres 2, 3, and t, fete al dis-

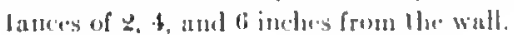

not with the ideat that it alone can determine the quality, but nuserely"

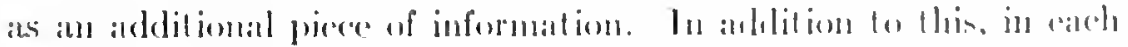

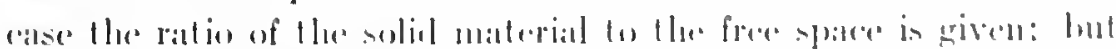

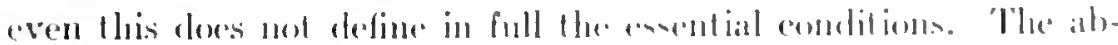

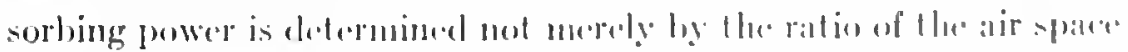
to the solid material. hut hy the size of the poren and ly the dis 
ticity and viscosity of the mass as a whole. In Fig. 16 Curve 1 is a hair felt, the one alluded to above as of exceptional efficiency. The fratction of its total rolume, which is solid material, is 0.12. ('urve 2 is a mixture of hair felt and asbestos, whose solid portion is

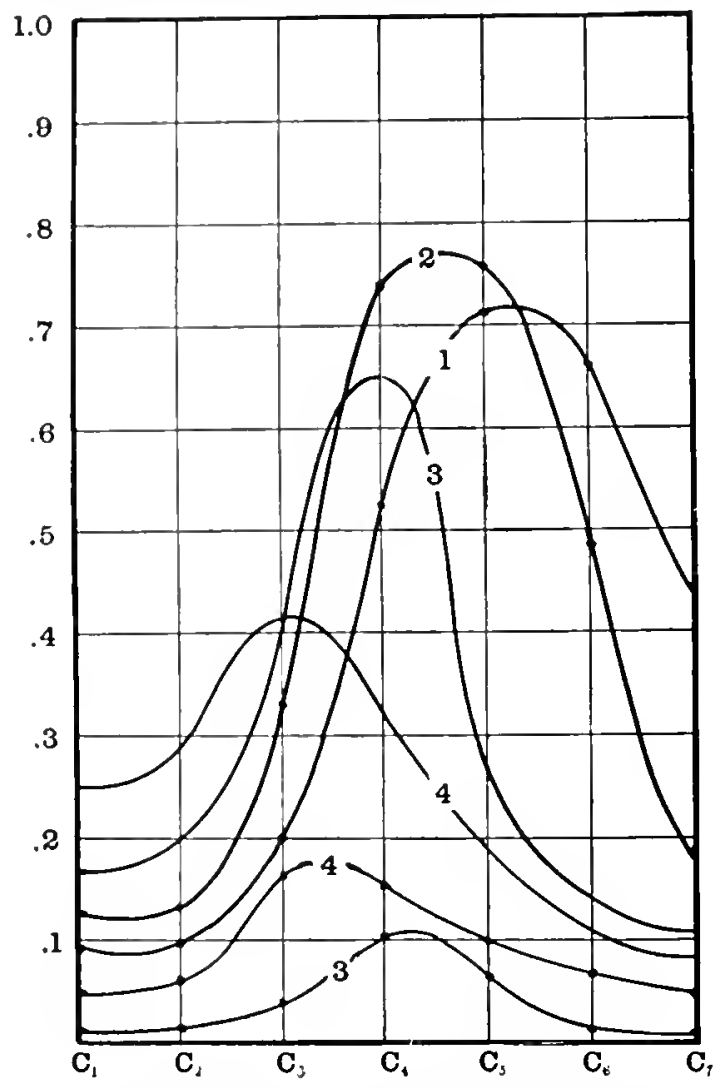

Fig. 1S. Curves showing the effeet on absorbing power of membrane covering. Curve 1, felt; Curve 2 , burlap cemented with silieate of sola; Curve 3 , light membrane as described; Curve 4, heavy membrane as described; lower Curve 3, light membrane alone; Jower Curve 4 , heavy membrane alone.

0.19 of its total volume. Curve 3 is a felt wholly of asbestos $\frac{3}{8}$ thickness, whose solid portion is 0.33 of its total volume. In this latter the asbestos fiber is felted to an asbestos clotlo which serves to strengthen it greatly. Curve 4 is for an asbestos felt without reënforement. 'That a considerable fraction of its alssorbing power 
is due to its dastic giedeling ats a whole is shown by its rather shatp maxinat.

The curves in Fig. 17 show the effect of holding the felt at diflerent distances from the wall. In each case it was held on a wire grating. Curve 1 is when the folt is ats neald the wall as the grating would permit, perhaps within at quarter of an incls of the wall. Curve 2 is when the felt was hedd ant at distance of two inches; Curve 3 at four inches: and curve tall six inches from the wall. It is erielent that there is a slight gain from an air space behind the felt, but it is also evident that this gain is so slight as to be entirely incommensinate with the cost of construction and its loss in durability.

The ('urves in Fig. 18 show the eflicieney of various coverings. Curve 1 is the nomal exposed efficieney of the felt alsove referred

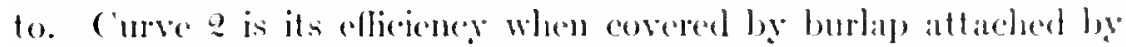
silicate of sodit. 'This covering wals so sized als to be practically" impervious. but was in contade with and a part of the felt. ('urress and + show the efliciency of eoverings which are not in contact with the feett, but which are strelched. Both coverings are impervious.3 relatively light, theary. Number 3 weigh 0.85 ounces to the square foot; munber + weights g.ss omees to the square foot. The materials of which these coverings are made hatse no bearing on the question, and would be misleading it staterl. 'The really signifieant factors are their weight, the tension with which they are stretehed. their elastieity, and their viscosity. 'The weight of the several coverings lats been stated: the other fitctors can be defined best be means of their independent al northing powers. Lewer corbes sand th indieate the absorbing power of the membrame coverings alome. It is interenting to note that the diaphragm which has by itself the leatst absorbing power has the greatent aboothing power when combined with the fell. Thes in by no meins a partadox. It is

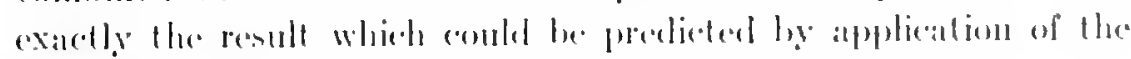
simplest of phẹsical principter. 


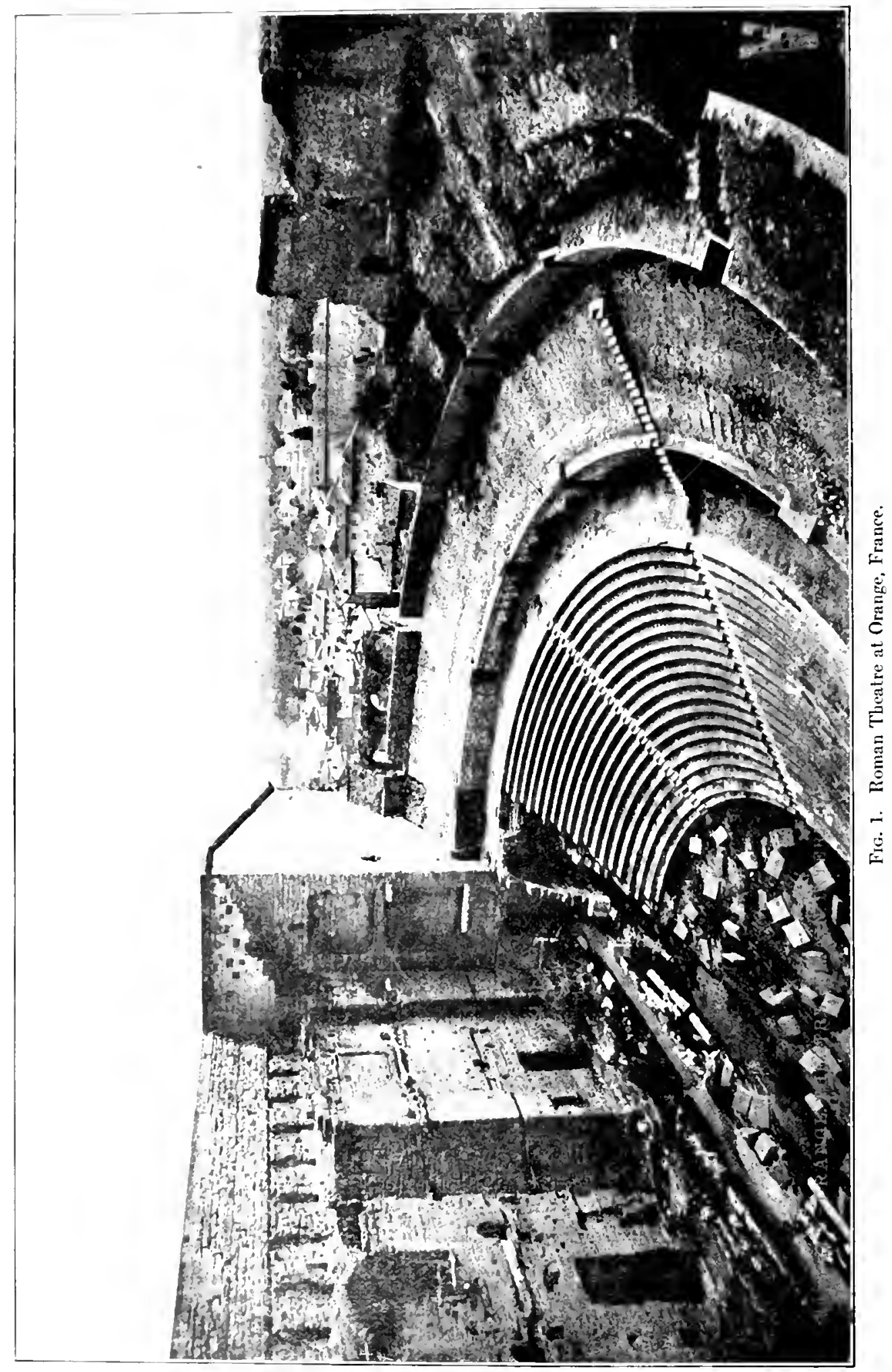




\title{
7 \\ THEATRE ACOUSTICS ${ }^{1}$
}

\author{
Vitruvres, De Architectura, Iilser. V. Cap. VIII. (De locis con- \\ sonantibus ad theatra eligendis.)
}

"All this heing arranged, we must see with even greater care that at position has been taken where the voice falls softly and is not so reflected as to produce a confused effect on the ear. 'There are some positions wfering natural obstructions to the projection of the voice, as for instance the dissonant, which in Greck are termed kainxoivtes; the circumsonint, which

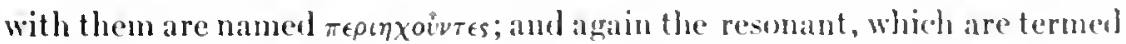

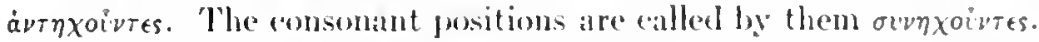

The dissonant are those places in whed the somml first ut tered is earried up, strikes against soliul borlies above, and, reflected, checks ats it falls the rise of the succeeding sonnd.

The circmusonant are those in which the roice spreading in all direetions is reflected into the midulle, where it dissolves, confusing the "in endings, and dies away in sommls of indistinct meaning.

The resonant are those in which the voire comes in contact with some solid substance and is reflected, producing an erho and making the wase terminations touble.

The consonant are those in which the voice is supported and strengthened, and reaches the ear in words which are "lear and distinet."

This is an admirable analysis of the problem of theatre acoustics. But to adapt it to modern nouncuelature, we must substitule for the word dissonance, interference; for Hae word ciremsonance, revereberation; for the word resonance, echo. For consonanee, we have unfortumately no single term, but the conception is one which in fundamental.

It is possible that in the alwere transtation and in the following interpretation I have read into the text of Vitruvius al detinitemen of conception and an aceord with modern scionee which his langragne only. fortuitonsly permits. If so, it is orring on the better side, and is

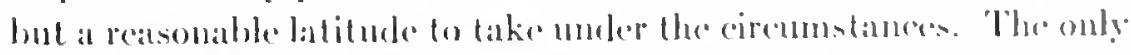

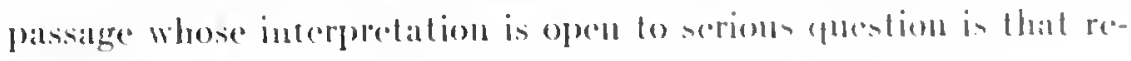

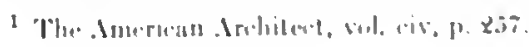


lating to dissonant places. If Vitruvius kncw that the superposition of two sounds could produce silence, and the expression "opprimit inserquentis coris elationem" permits of such interpretation, it must stand as an obscrvation isolated by many conturies from the modern knowledge of the now familiar phenomenon of interference.

\section{IXTEIRERENCE}

luterferenee is a phenomenom common to all types of wave motion. The hest introduction to its discussion is ly reforence to water-waves

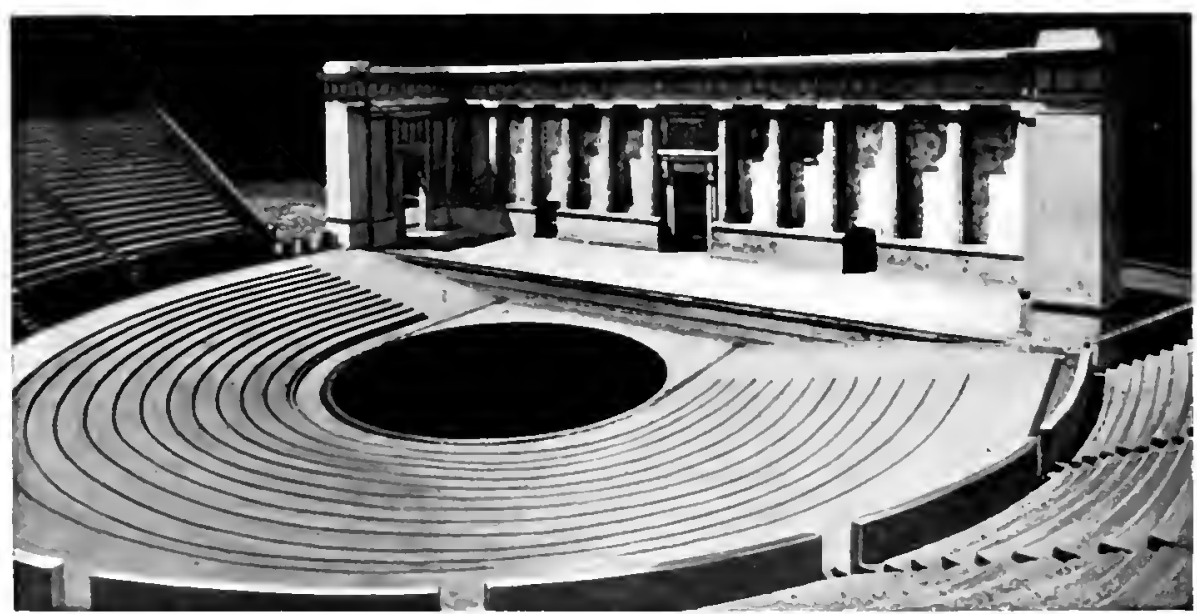

Fa. 2. Greek Thealre at the Universily of California. Mr. John Galen Howard, Architect.

and in partienlar to an interesting example of tidal interference on the 'Tongking Peninsula. 'The tide of the Paeific Ocean enters the Chinese Sea through two channels, one to the north of the Philippine Islands, between Luzon and Formosa, and the other through the Sulu Arehipelago hetween Mindanao and Borneo. The northern ehannel is short and deep; and the tide enters with very little retardation. The other elammel, although broad, is shallow, tortuous, and broken hy many small islands; and the tide in passing through is mueh retarded. The two tides thus entering the Chinese Sea produce an effeet which varies from point to point. At one port on the 'longking Peninsula, these tides are so retarded relatively to each other as to be six hours apart. It is high tide by one when it is low tide by the other. It also so happens that at this point the two tides 
are equal. Being equal and exactly opposite in phase, they nent ralize each other.

Because tidal wares are long in comprarison with the bodjes of water in which they are prepagated, their interference phenomena ure obseure except to careful amalysis. When, howerer, the waves are smaller than the space in which they are being propagated, the interference strstem becomes more marked, more complicated, and more interesting. Inder such circumstunces, there may he regions of perfect atuiet near regions of violent disturbince.

Subjecting the paralled to a more exact statement, whenever two water-wases come together the resulting disturbance at any instant is equal to the algehraie stum of the disturbances which each would produce separately. If their crests coincide, the joint effect is expal to the sum of their separate edfect. If erest and trongh coincide. their joint effect is the difference between lleem. If their relative redardation is intermediate, a wave results which is intermediate between their sum and theis ditference and whese time of maximum does not ocenr simultaneously with the maximum of either of the componests.

The phenomenon is one which may be produeed aceurately on any scale and with any type of wase motion. Thus somml consists of waves of alternate condensation and rarefaction in the air. If two trains of sound-waves cress each other so that at a given peint condensation in the two trans arrive simultaneonsly, the rarefactions will also arrive simultaneonsly, and the total disturbance is a train of waves of eomelensation and ratrefaction explat to the sum of the two eonponents. If one train is retarded so that it condensations conin-

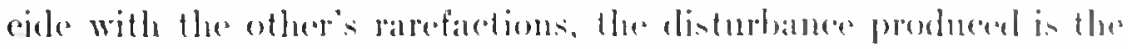
difference between that which would be produced bye the tratins of

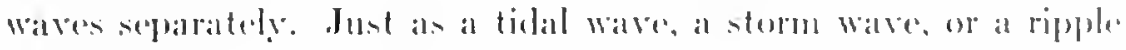

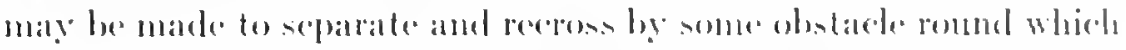
it elitfracts or froms which it is reflected, and recombininger produce.

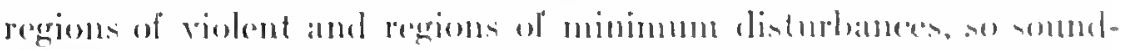
waves may be diffracted or reflected, and recemblining after tratrel-

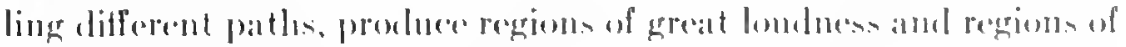
almost complete silence. In general, in an anditorinm the pheneme enon of interference is produced nest ly the croming of two trains of waves only, but by the cronsing of many, redlected from the varioms 
walls, from the ceiling, from the floor, from any obstacle whatever in the room, while still other trains of waves are produced by the diffraction of the sound around columus and pilasters.

A source of somul on whose steadiness one can rely is all that is necessary in order to make the phenomenon of interference obvions. A low note on a pure toned stop of a church organ will serve the purpose almimably. The observer ean satisfy himself that the note is sommding steadily by remaining in a fixed position. As soon, lowaver, as he hegins to move from this position by walking up and down the aisle he will observe a great change in loudness. Indeed. he may find a position for one ear which, if he eloses the other, will give almost absolute silenee, and this not far from positions where the somml is lond to the extent of being disagreeable. The observer in walking about the church will find that the phenomenon is complicated. It is, however, hy no means random in its charaeter, but definite, permanent, and accurate in its recurrenee, note for note. The phenomenon, while diffieult, is by no means impossible of experimontal investigation or of theoretical solntion. Indeed, this has been lone with great eare in connection with the study of another problem,- - that of the Central Criminal Court Room in London known as Old Bailey. The full primary explanation of the methods and results of this general investigation would be inappropriately long in an artiele dealing with the acousties of theatres; for while interference is a factor in every anditorim, it is on the whole not the most serionsly disturbing factor in theatre design.

The subject of interference would not have been given even so extended a disenssion as this in a paper dealing with theatres were it not that recently there lias been proposed in Germany a form of stage setting known as the Kuppel-horizont for sky and horizon effects, to accompany the Forluny system of stage lighting, in which interference may be a not inconsiderable factor unless guarded against. The Fortuny system, which in the opinion of some competent judges is an effective form of stage lighting, consists primarily in the use of indirect ilhmination, softened and colored by reflection from screens of silk. As an adjunet to the system, and in an endeavor to secure a considerable depth to the stage without either great height or an excessive use of sky and wing flies, a cupola is 
recommended to go with the Fortung lighting as shown in the accompanying figures taken from the pullicalions of the Berliner Allegemeine Electricitats Ciesellschuft. In ligss. 3 and 4 , the cupola is shown in section and in plan. Jights $A$ and $B$ illuminate the interior of the eupola: ( and E light the area of the stage on which the prin-
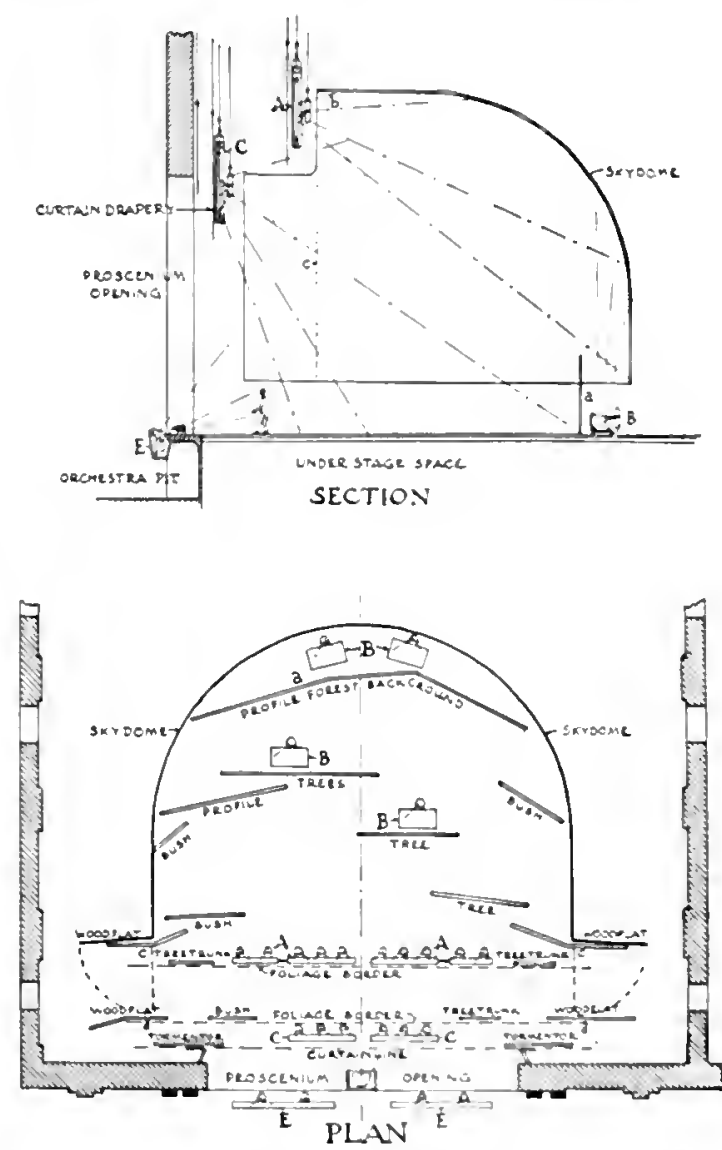

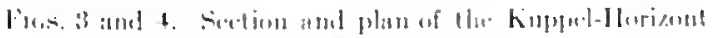

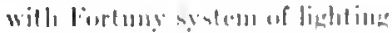

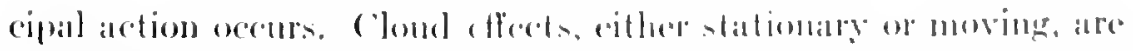

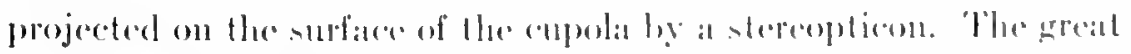

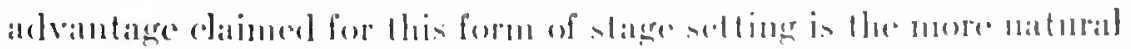

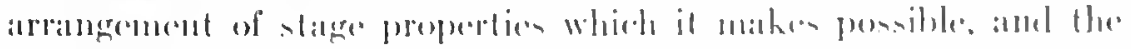

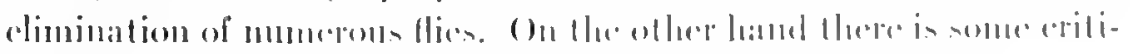

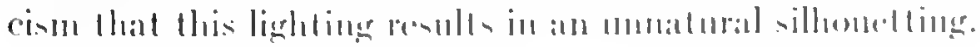


So detailed an explanation of the diagrams and the purpose of the sereral parts is necessitated hy the fact that it is as yet an unfamiliar levice in this conntry. It has been introduced recently in a number of theatres in Gernumy, althongh I bclieve not elsewhere, unless possihly in one theatre in England. It has been called to my attention by Professor bakel as a possible erpuipment of the theatre which

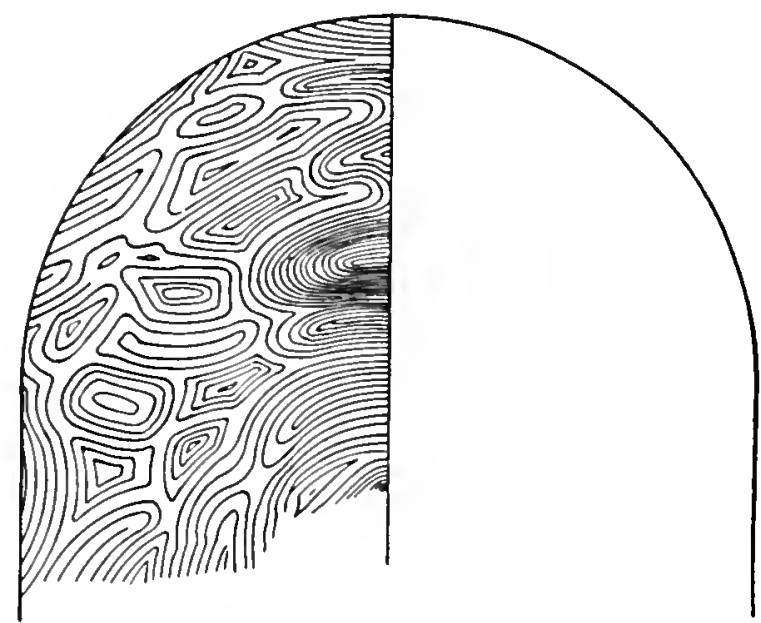

Fig. 5. Interference s.selem for tenor ('in the Kuppel-Iorizont, fuving a thirly-six foot proscenimm opening. The inlensity of sound is represented by contour lines, the maximum varislion being forty-seven fold.

is proposed for the dramatic department of Harvard Cniversity, and it is reasonable to regard it as a probahle pactor in theatre design in other comntries than Germany.

In Fig. 5 is plotted the interference system established in this space. on a standing head level of five feet from the floor of the stage, by a sustained note tenor ( in pitch. 'The intensity of the sound is indicated hy contour lines very much as land elevation is indicated on the maps of the Geodetic survey. In this plot, account has been taken of the sound reflected from the enpola and from the floor. No accomt has heen taken of the reflection from the walls of the main anditorium since this would be a factor only for sounds prolonged beyond the length of any single element in articulate speech. Even in the case of a very prolonged somel the modification of the inter- 
ference systen of the stage and cupola by the rest of the anditorium would be very slight.

The interference system on the stige in question being determined wholly by the floor and enpola, it maty be computed, and in the preparation of the chart was computed, by the so-called method of images. The sound reflected from the floor comes ats from a virtual image as far beneath the floor as the month of the speaker is above it. Each of these produce real inages he reflection from the interior of the cupola. Bearing in mind that these real inages shew the phenomenon of diffraction and sone astignation, and taking into account the phase of the sound ats determined by reflection and by distance, the calculation is laborious but not diffeult. It involves but the nost familiar processes of geometrical opties.

The disturbing eflect of this interterence sistem is not so greatt when the spesalke is well in front of the center of curvature of the cupola, and of conrese it is allument always more or less broken he the stage properties, as indicalded in Figs. 3 and t. Nevertheless, it is well to bear in mind that the chaster sphere forms, an ind arated in the diagrams, is neither necessily from the stamblyont of ithmination nor desirable from the stamblyont of acousties. Acom-tically" a llatter back with sharpererenture alsove and at the siden is preforable.

It should be repeated that the interference system in colablished only when the tomess are sustained, in this cater over onc-tenth of at second, and is mose of atn anmorance to the alelor on the tage than to the andience. With shorter tones it becomes an erehe, antel in this

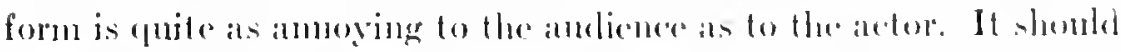
be added that the interference changer with ehalnge of pitch, but preserves extreme maximat and minima for at contral pention in at

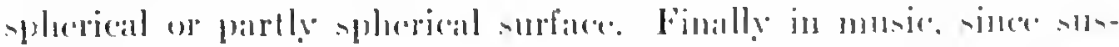

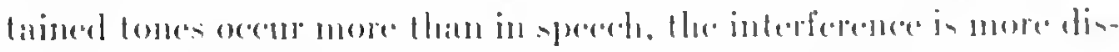

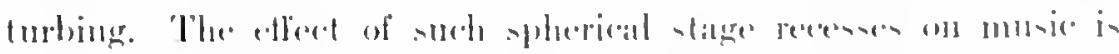

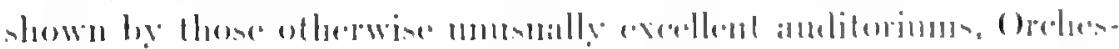

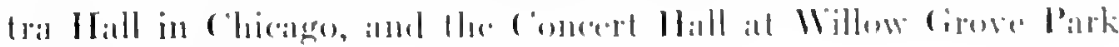
near Philickelphiar. 


\section{REVRMBRATION}

"Circumsonant places" were rare and almost wholly neghigible diflicultirs in Greek and Roman theatres. IIowever, they were common in the temples, and were cren more prononnced in some of the older Roman palaces. It must lave been in the experience of such conditions, wholly foreign to the theatre of which he was writing, that Vilmuins made this portion of his analysis of the acoustical problem. Given the fundimental lom of the Greek theatre, it required no special consideration and little or no skill to aroid such difliculties. However, this is not true of the modern theatre, in which excessive reverberation is more often the defect than any other firctor.

If a somel be prodneed briefly in a wholly empty, wholly elosed rom, having perfectly rigid walls, it will be reflected at each incidence with undiminished intensity, and. travelling to and fro across the room. will continte andible almost indefinitely. Of course no theatre. ancient or modern, satisfies these conditions and the sound loses at each reflection, diminishing in intensity, until in the course of time it closses what the experinental psychologist calls the "threshold of andibility." In the Greek theatres the duration of andilility" of the residual sound after the eessation of a souree of ordinary loudness was never more than a few tenths of a second; in a modern theatre it may be several seconds. The rapidity with which the smund dies away depends on the size of the theatre, on its shape, on the materials nsed for its walls, ceiling. and furnishings, and on the size and distribution of the andience. The size and slape of the theatre detemines the distanee travelled by the sound betricen reflections, while the materials determine the loss at each reflection. So actual wall cam be perfectly rigid. Wood sheathing, plaster on wood lath, plaster on wire lath, plaster apprlied direetly to the solid wall, rield under the vilurating pressure of sound and dissipate its energy. Even a wall of solid marble yields slightly, trannitting the energy to external space or absorbing it by its own internal viscosity.

Ahorptions by the walls and otler objects in the process of reflection, includling in this transmission through all openings into outer
\end{abstract}


space as cofluvalent to total alsonption boundary contitions in other words - are practically aleme to be coedited with the elimolution of the resibhal somul. But Vitruvius" statement that the

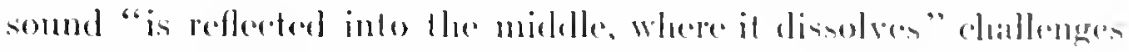
completeness and at least the mention of amothere factend, whide.

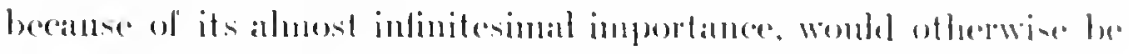
patsied willont romment.

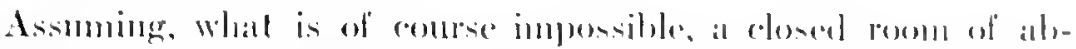

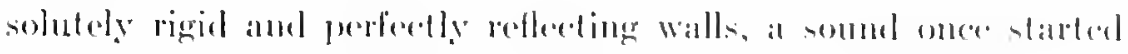

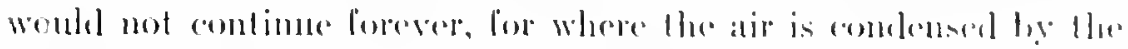
patssing of the ware of somml, it is heated, and where it is ratrefted. it

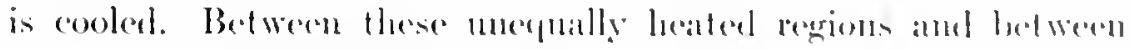
them amel the walls, there is al continual rantiation of heat, with at re-

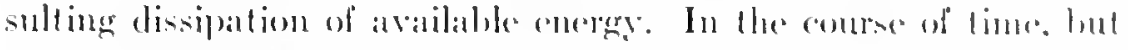

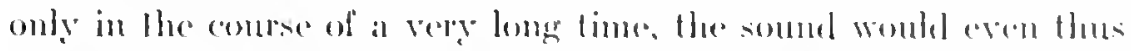
cease to be of andible intensily. This form of discipation might wedl

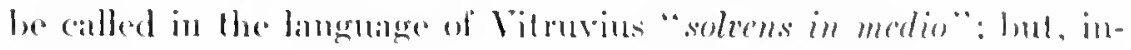
stead of being an inportant lintor, it is an contirely negligible fantor in any aletual anditorimu.

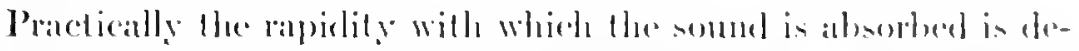
pendent solely on the nat ure of the reflecting surlaces and the length of the patlo which the somul munt tratrerse hetween reflections. 1he latter depending on the shatpe and size of the anditoriuns. It was

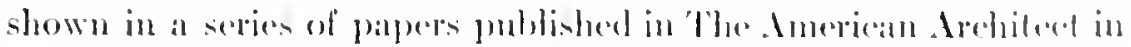

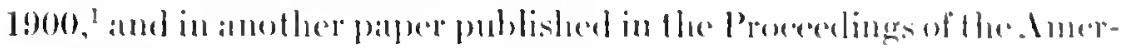

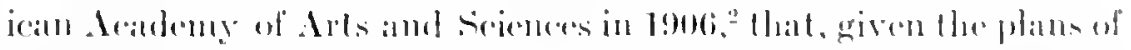

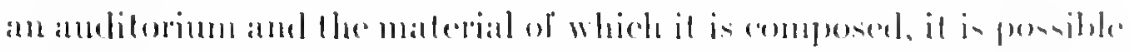

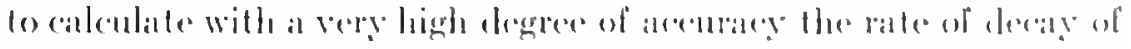
a soment in the roum and the duration of its atuelibilitg. In the fire of

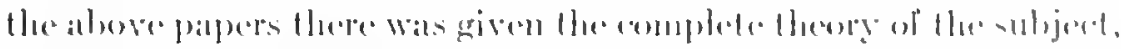

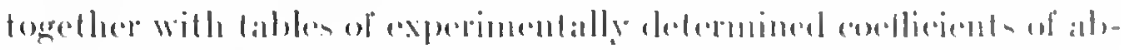

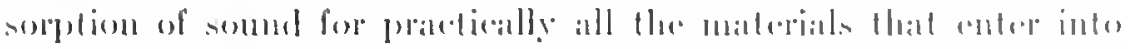

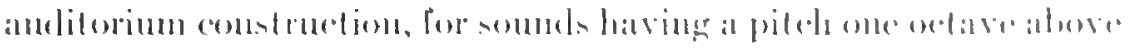

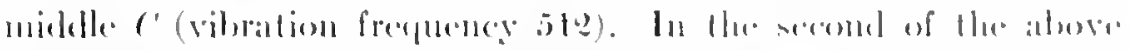

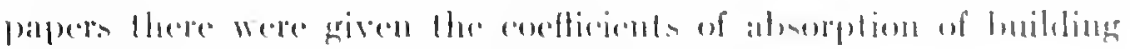
materials for the whole range of the municat salle.

$$
1 \text { sine lingo lis. }=11, i+1 .
$$


In the careful design of a room for musical purposes, the problem obviously must inchude the whole jange of the musieal scale, at least seven octaves. It is not so obvious that the study must eover so great a range when the primary nse is to be with the spoken voice. 'The nearest study to arehitectural acoustics is the highly developed science of telephony, and in this it is apparently sufficient for much of the work to adapt the theory and design to the single frequency of so0, approximately $A$ in the second octave above middle C. But for

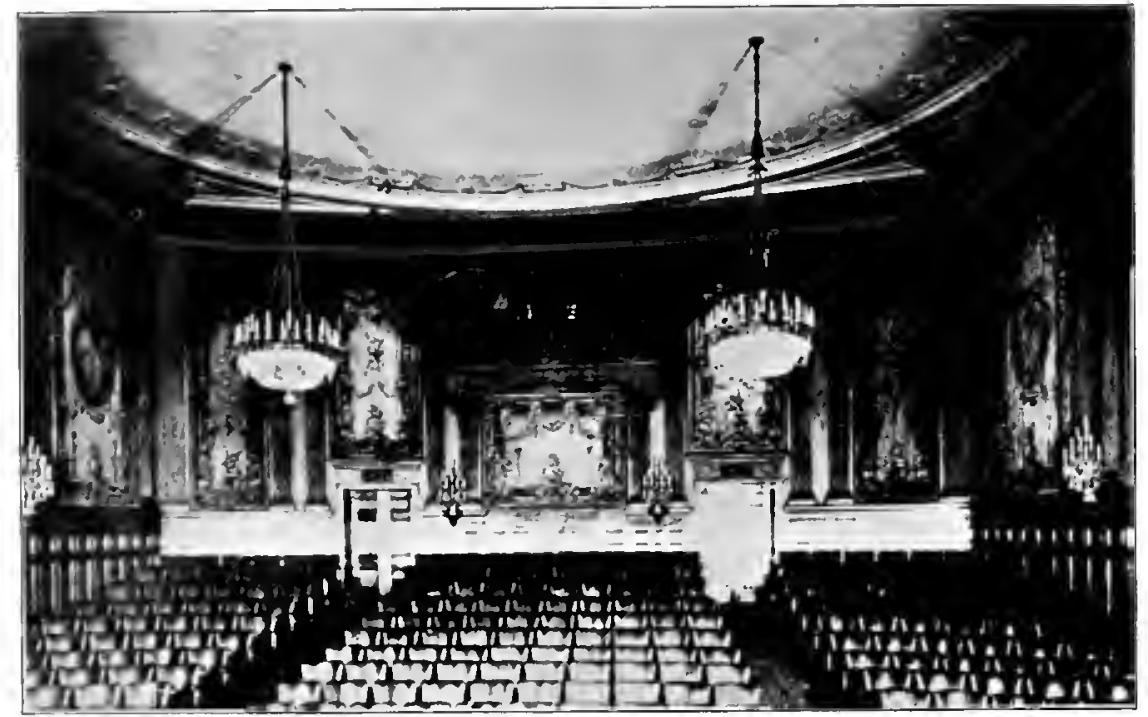

l'k. 6. The Little Theatre, New Jork. Ingalls and Hoffman, Architects.

some problems the investigation must be extended over a considerable ringe of pitch. Similarly experience in the architectural problem shows that with sonte of the materials entering into building construction there oceurs a sharp resonance within a not great range of pitch. It is, therefore, neeessary to determine the reverberation even for the speaking roice, not for a single piteh but for a considerable range, and the quality of a theatre with respect to reverberation will be represented by a curve in which the reverberation is plotted against the pitch.

Without undertaking to give again a complete discussion of the theory of reverberation, and referring the reader to the earlier (1900) numbers of 'The American Architect, it will suffiee to give a single 

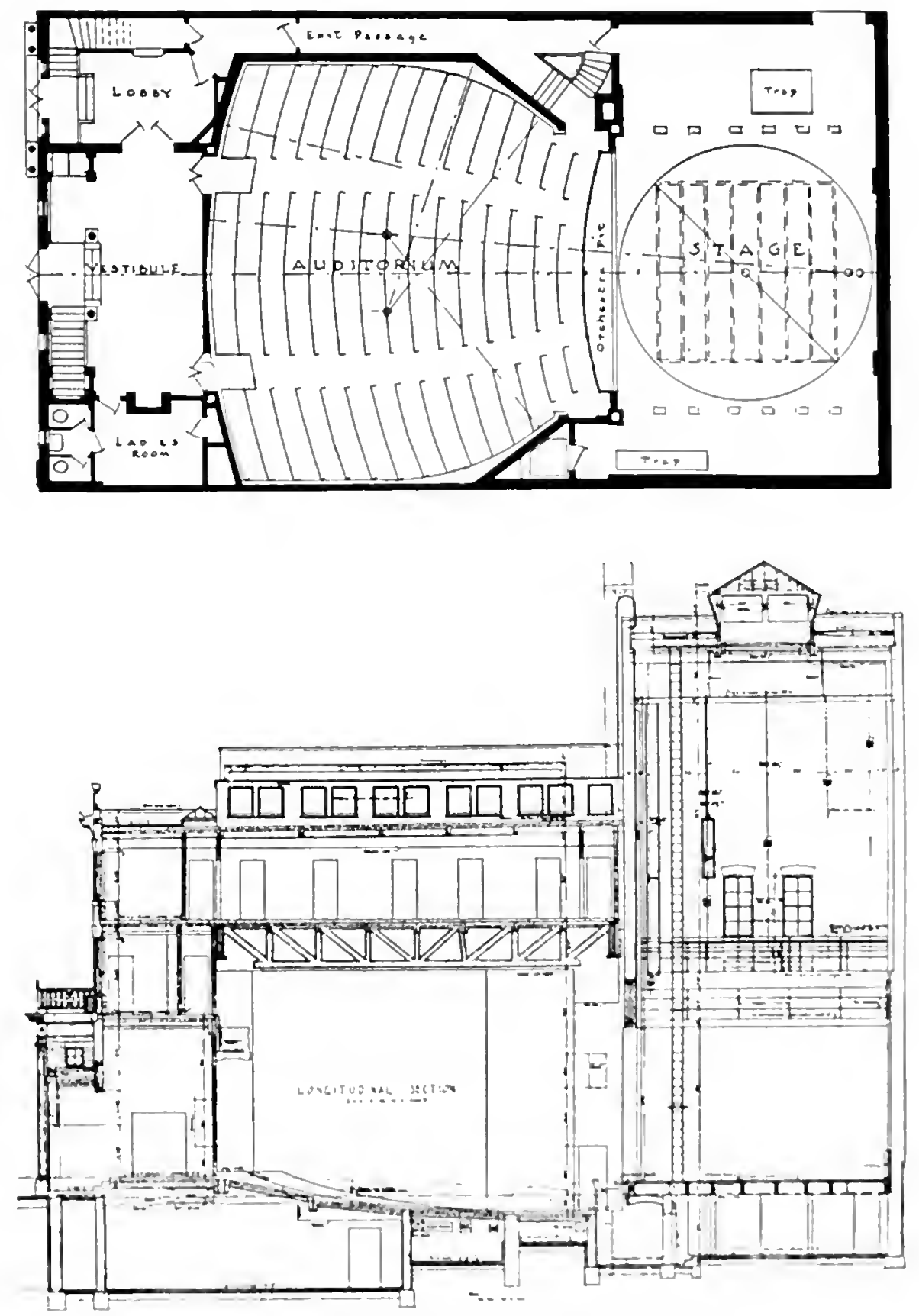

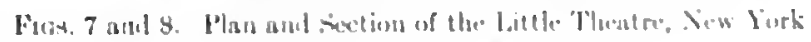

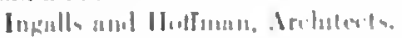


illustration. Fop this I hatre seleeted Mr. Winthrop Ames' "Little Thentre" in Xew York, desigued ly Messrs. Ingalls and IIoffman, because the purpese and use of this anditorimm was defined from the beginning with unusual precision. The purpose was the production of plin"s which eould be adequatcly rendered only by the most delieate shates of expression, which woukd be lost in considerable measure if the conditions were such ats to neessitate exaggeration of feature or of voice. The definition of its use was that it should seat just less than 300 , and that all the seats were to be as nearly as possible of ecutal excellence, with the important assurance that every seat would be oceupied at crery performance.

'The final plan and section of the Little 'Theatre are shown in Figs. $f$ and 8 . The initial peneil sketel was of an anditorim differing in many architectural cletails, acoustical considerations sharing in, hut hy no means alone dictating, the steps leading to the final solution of the problem. 'The first calculations, based on the general lines of the initial sketch, and assuming probable matcrials and plausible cletails of construetion (plaster on tile walls, plaster on wire lath ceiling, solid plaster eorniees and moulding), gave a reverberation as shown in Curve 1 in Fig. !. This would not have been in excess of that in many theatres whose aeonstical qualities are not especially questioned. But the munsual refuirements of the plays to be presented in this theatre, and the tendency of the public to criticize whatever is nneonventional in design, led both Mr. Ames and the arditects to insist on exceptional quality. The floor was, therefore, lowered at the front, the eeiling was lowered, and the walls near the stage brought in and reduced in curvature, witl, of course, corresponding changes in the arclitcetural treatment. The rear wall, following the line of the rear seats, remained unchanged in curvature. 'The side walls near the stage were curved. The net effect of these clanges was to give an auditorimu 98 feet high in front, 23 feet high at the rear, 48 feet long and 49 feet broad, with a stage opening 18 by 31 , and baving a reverberation as shown by Curve 2 . In order to reduce still further the reverberation, as well as to break acoustically the curvature of the side and rear walls, "aeoustic felt" was applied in panels. There were thrce panels, 6 feet by 13 feet, on each of the sicle walls, and seren pancls, two 4 feet 5 inches by 13 feet, two 5 


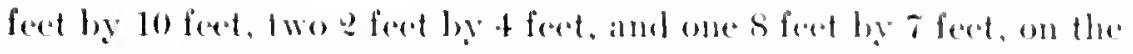
reale wall. The mentting severberation is shown by cirve 3 in the diagram. 'Throughout, consideration was laul for the aletuat path of

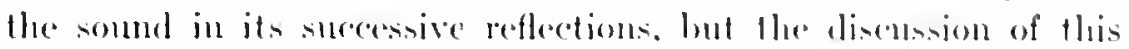

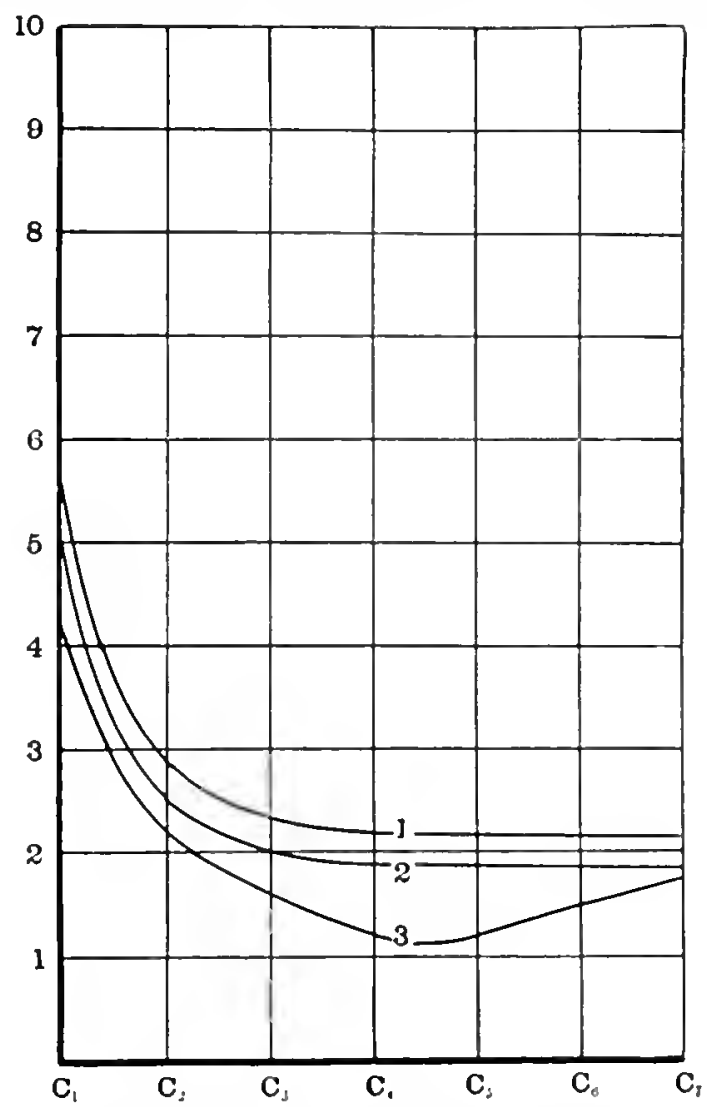

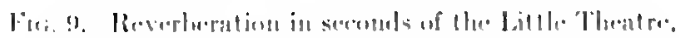

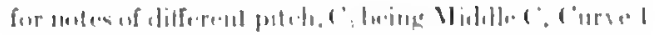

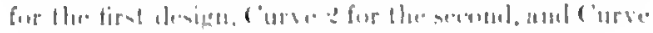
is for the lhiral and an lubilt.

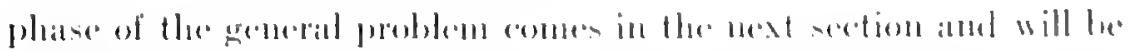
illustrated lyo other theiatren.

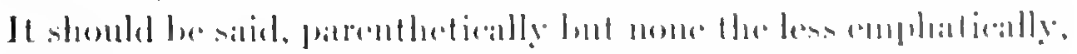

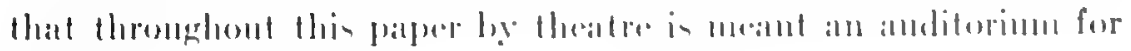
the npokind dratlit. 


\section{Fino}

When at sourece of summel is maintaned constant for a sufficiently lomg time - a few seconds will ordinarily suffice - the sound becomens stealy at erery point in the room. The distribution of the inlensity of sonnd under these conditions is called the interference

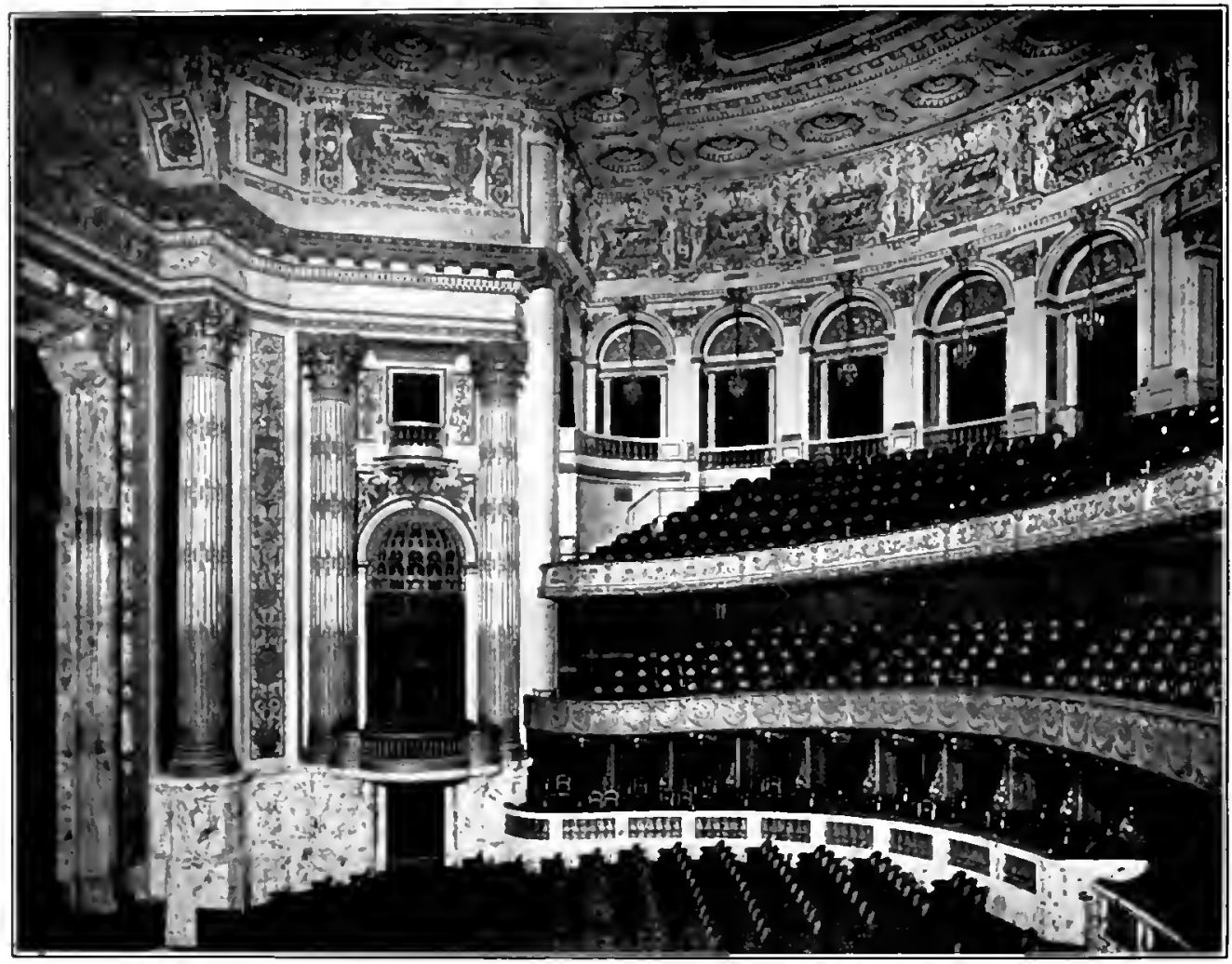

Fir. 10. Inturior, the New Theatre, New York. Carrere and Hastings, Archilects.

system, for that particular note, of the room or space in question. If the source of sound is suddenly stopped, it requires some time for the somnd in the room to be absorbed. This prolongation of sound after the source has ceased is called reverberation. If the source of somnd, instead of being maintained, is short and sharp, it travels as a diserete wave or group of waves about the room, reflected from wall to wall, produeing echoes. In the Greek theatre there was ordi- 
narily but one echo, "doubling the case ending," white in the modern theatre there are many, generally arriving at a less interval of time af ter the direct sound and therefore less distinguishable, but stronger and therefore more disturbing.

'Iluis phase of the aconstical problem will be illustrated by two examples, the New Theatre, the most important structure of the

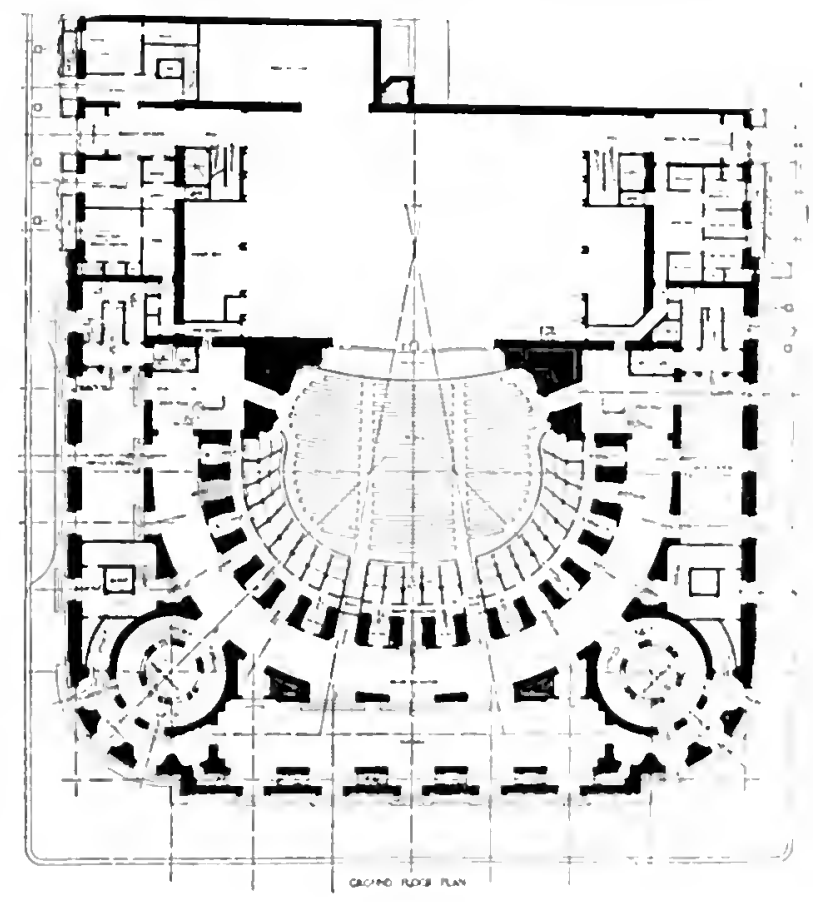

Fir. 11

kind in New York, and the plann of the theatre now huilding for the scollay Sifuare Realty Company in Beston.

Notwithstanding the fact that there was at one time eriticism of

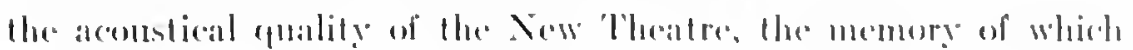
still lingers anel still colors the cannal comment, it was not werse in proportion to its sime than sereral other theatres in the city. It is.

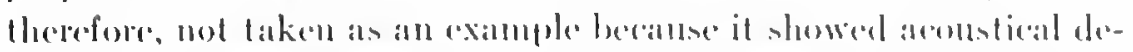

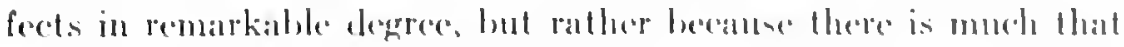

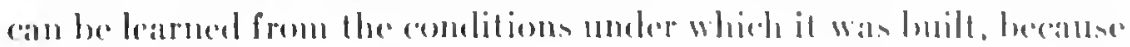
such defects as existed have been correceted in large measurese, and 
al here all in the hope of aiding in some small way in fhe restoration of a magnificent building to a dignified use for which it is in so many waty eminently suited. "The generous purpose of its Founders, the high ideals of its manager in regard to the plats to be produced, and the perfection of herwise of the building directed an exaggerated and morbid attention to this feature. Aside from the dose seruting whide

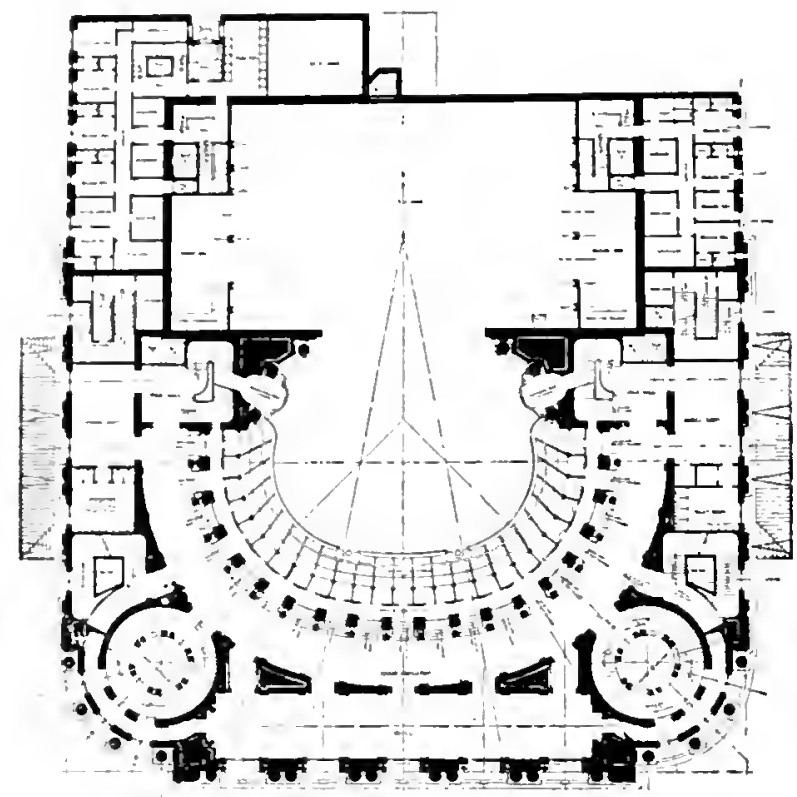

Fig. 1?

always centers on a semi-public undertaking, the architects, Messrs. Carrere and Hastings, suffered from that which probably every architect can appreciate from some similar experience of his own, - an inposible program. They were called on to make a large "little theatre," as a particular type of institution is called in England; and, through a division of purpose on the part of the Founders and Advisers, for the Director of the Metropolitan Opera was a powerful factor, they were called on to make a building adapted to both the opera and the drama. 'There were also financial difficulties, although very different from those usually encountered, a plethora of riches. This necessitated the provision of two rows of boxes, forty-eight originally, cqually commodious, and none so near the stage as to 
thereby suffer in comparison with the others. Finally, there was a change of program when the bulding was almost conplete. 'The mpper row of boxes wits abindoned and the shallow baleony thus ereated wis devoled to forer ehatirs which were reserved for the

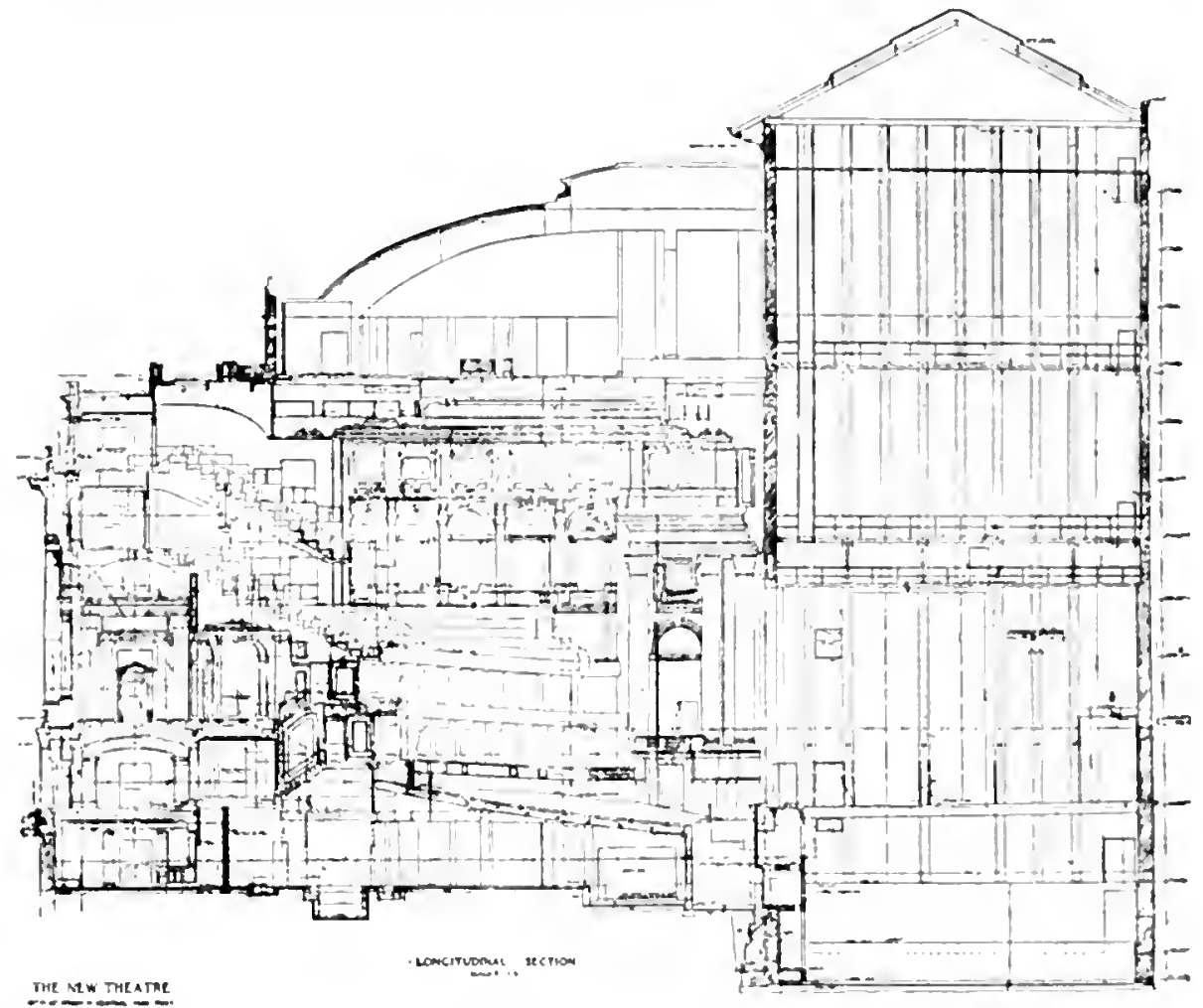

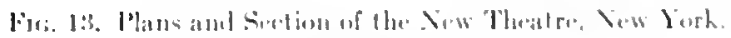

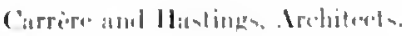

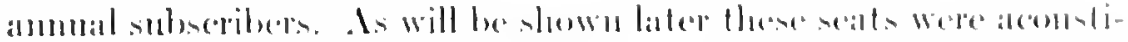
cally the poorest in the hemas.

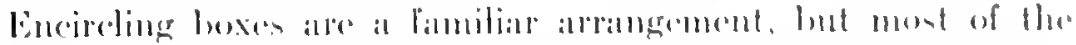

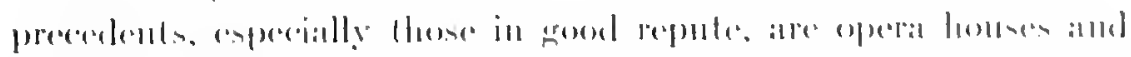

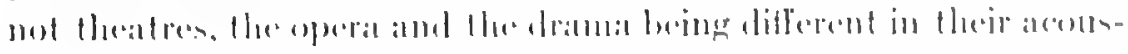

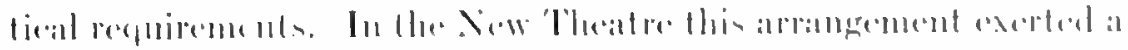

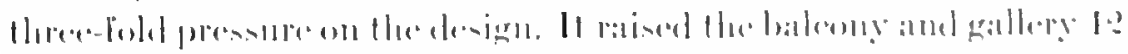

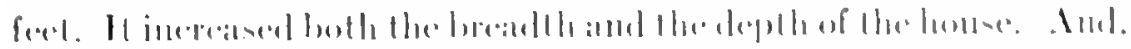

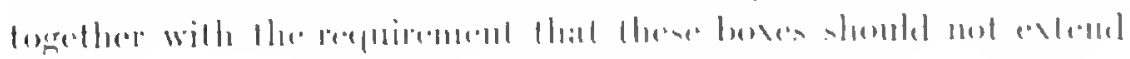


near the stage, it led to side walls whose most natural architectural treatment was such as to create sources of not inconsiderable echo.

The innediate problem is the discussion of the reflections from the ceiling, from the side walls near the stage, from the screen and parapet in front of the first row of boxes and from the wall at the rear of these boxes. 'To illustrate this I have taken photographs of the actual sound and its echoes passing through a model of the

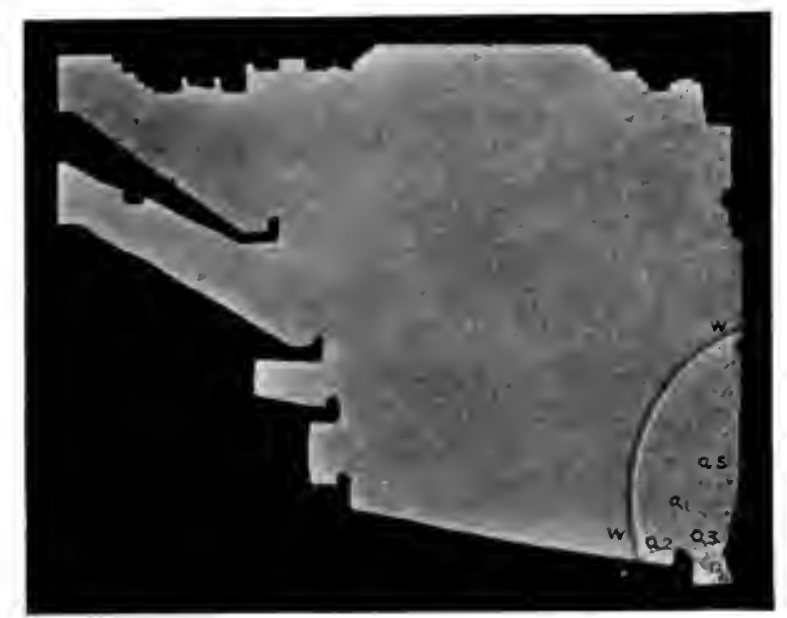

Fig. 14. Pholograph of a sound-wave, II, entering a model of the New Thealre, and of the echoes $a_{5}$, produeed by the orchestra sereen, $a_{2}$ from the main floor, $a_{3}$, from the floor of the orchestra pit, $a_{4}$, the reflection from the orchestra screen of the wave $a_{3}, a_{5}$ the wase originating at the edge of the stage.

theatre by a modification of what may be ealled the Toeppler-BoysFoley method of photographing air disturbanees. The details of the adaptation of the method to the present investigation will be explained in another paper. It is suffieient here to siy that the method consists essentially of taking off the sides of the model, and, as the sound is passing through it, illuminating it instantaneously by the light from a very fine and somewhat distant eleetric spark. After passing through the model the light falls on a photographic plate placed at a little distance on the other side. 'The light is refracted by the sound-waves, which thus act practically as their own lens in producing the photograph.

In the accompanying illustrations reduced from the photographs the enframing silhouettes are shadows east by the model, and all 


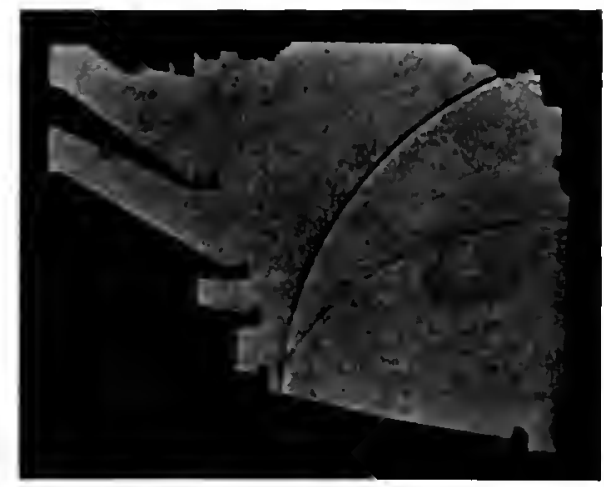

Fra. 15

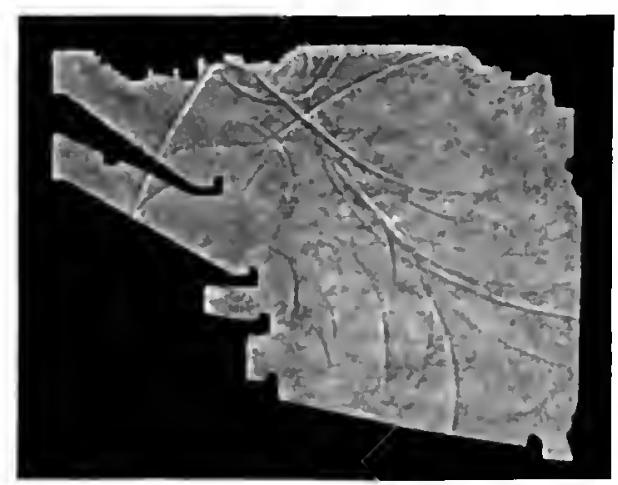

Fiff. 16

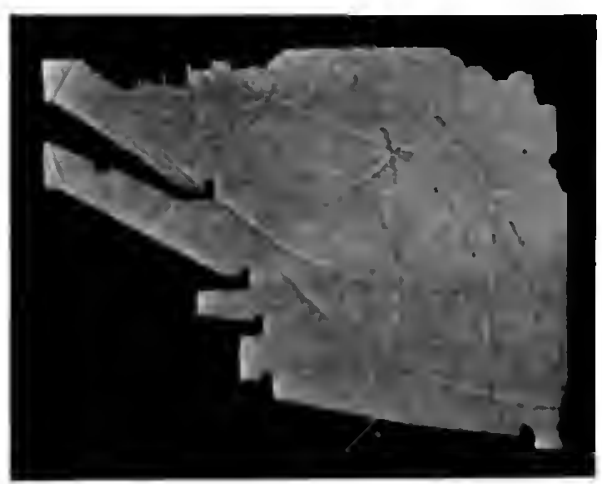

Hiti. 17

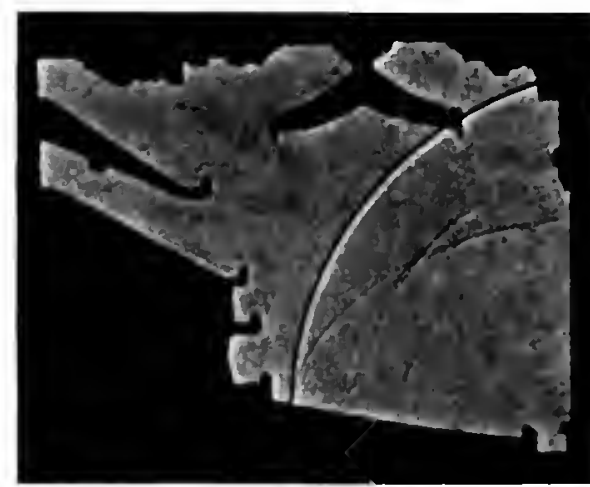

Firi. 18

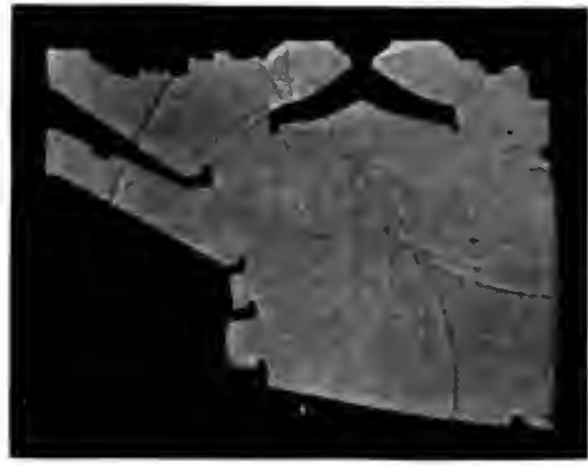

lis. 19

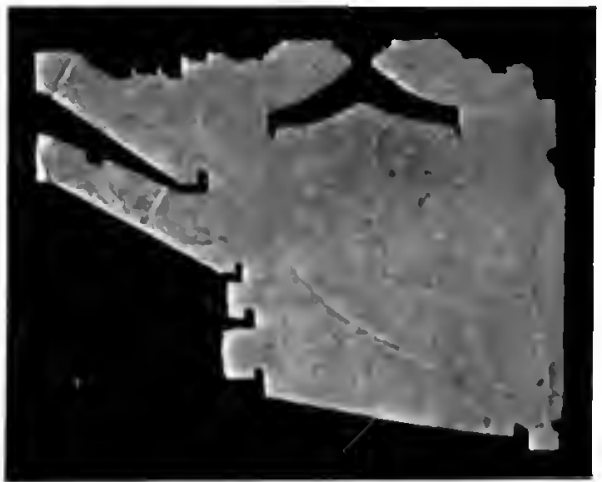

Inis.

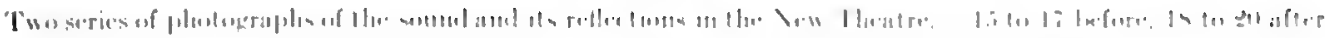

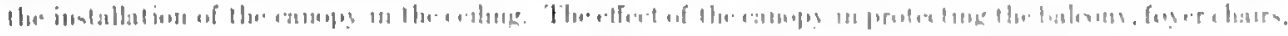

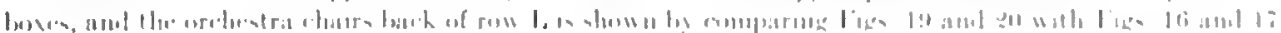


within are direct photographs of the actual sound-wave and its eehoes. For exanple, Fig. 14 shows in silhouette the principal longitudinal section of the main anditorium of the New 'Theatre. WW' is a photograph of a sound-wave which has entered the main auditorium from a point on the stage at an ordinary distance back of the proscenium arch; $a_{1}$, is the reflection from the solicl rail in front of the orchestra pit. and $a_{2}$, the reflection from the floor of the sound which has passech over the top of the rail; $a_{3}$ is the reflection from the floor

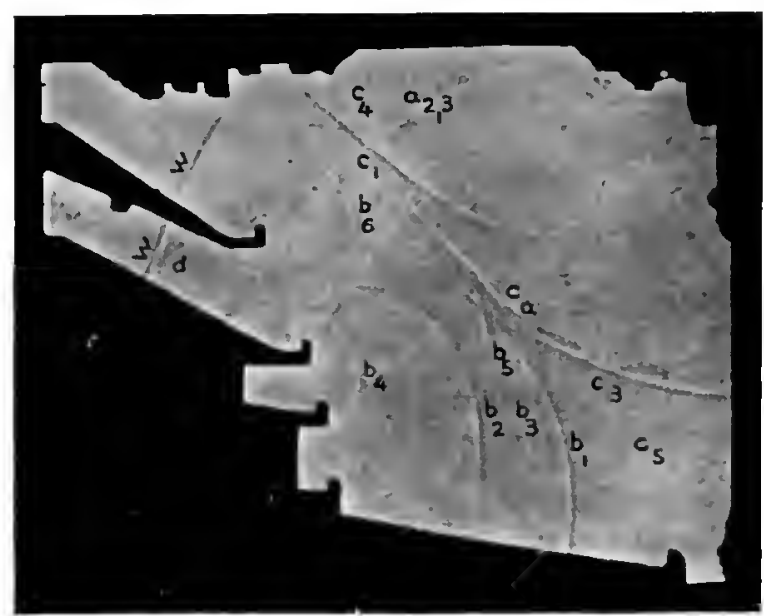

Fig. 21. Photograph of the direct sound, $\mathrm{IH}^{\circ}$, and of the echoes from the various surfaces; $a_{2,3}$ a wave, or echo, due to the combination of two waves which originated at the orchestra pit; $c_{1}$ from the oval panel in the ceiling; $c_{3}$ and $c_{s}$. from the ceiling mouldings and cornice over the proscenium arch; $c_{4}$, a group from the moulding surrounding the panel; $c_{5}$, from the proscenium arch; $b_{1}, b_{2}, b_{6}$ from the sereens in front, and the walls in the rear of the boxes, balcony and gallery.

of the pit, and $a_{4}$ the reflection of this reflected wase from the rail; while $a_{5}$ originated at the edge of the stage. None of these reflections are important factors in determining the acoustical quality of the theatre, but the photograph aflords excellent opportunity for showing the mamer in which reflections are formed, and to introduce the series of more significant photographs on page 181 .

Figures 15, 16, and 17 show the adrance of the sound through the auditorimu at $.0 \%, .10$, and $.1+$ second intervals after its departure 
from the source. In Fig. 15. Hhe wares which originated at the orchestrat pit can be readily distinguishede as woll as the mascent waves where the primary sound is striking the ceiling comile innme-

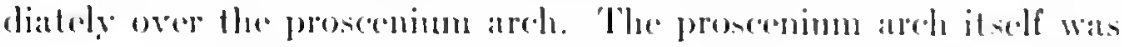
vere weell designed, for the somed passed paralled to its surface.

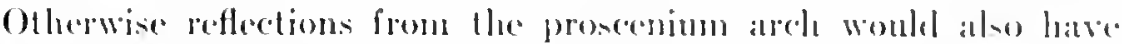
shown in the photographls. 'Ilese would have heren directerl toward the andience and might have been rerge pereeptible factors in determining the nltimate acoustical quality.

The sistem of refleceted waves in the suceereling photograph in

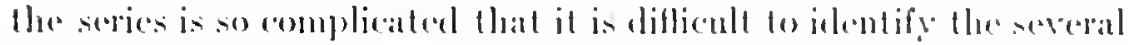
reflections by rerbal alescription. The photograph is, therefore, lee-

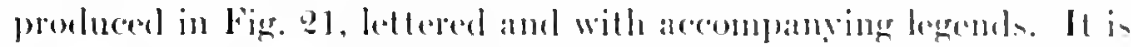
interesting to ohserve that all the reflected waves which originated at the orehestrat pit have disapperared with the exception of wares

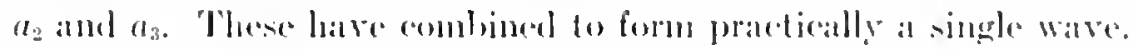
Eventhis combined ware is almont megligilshe.

'The aroustically inportant reflertions in lhe bertical sertion are

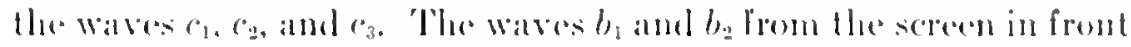
of the boxes and from the back of the boxes are also of erreat inpole-

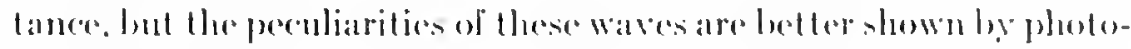

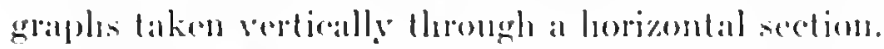

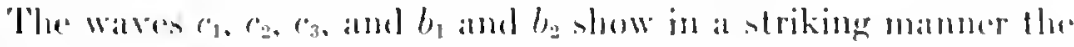
fallacy of the not ancommon representation of the preparation of

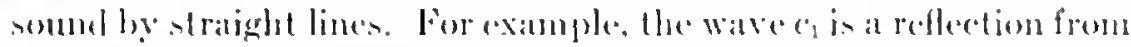
the oval panel in the coiling. The curvature of this patmel is such

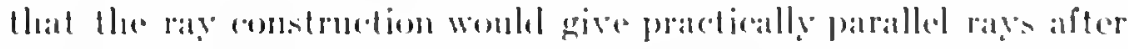

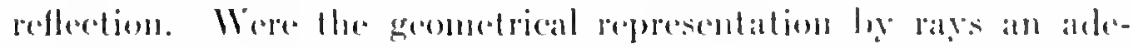

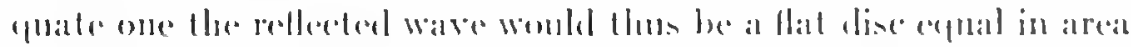

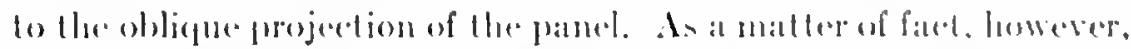

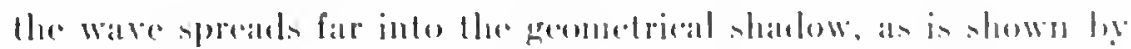

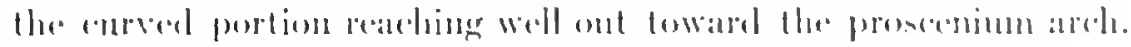

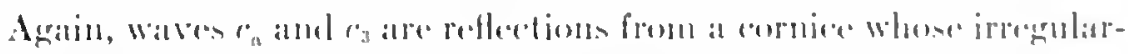

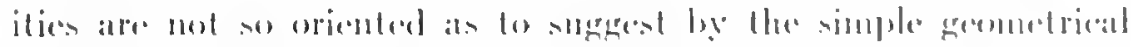

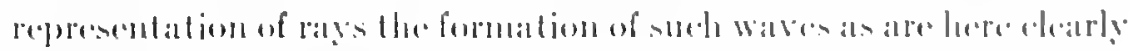

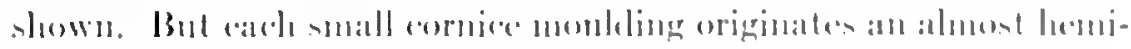

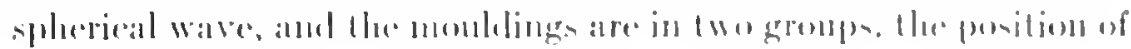


each heing sueh that the spherieal waves conspire to form these two master walves. The inalequacy of the discussion of the subject of architectural acoustics by the construction of straight lines is still further shown by the waves reflected from the sereens in front of the boxes, of the haleony, and of the gallery. These reflecting surfaces are narrow, but give, as is clearly seen in the photograph, highly divergent waves. This spreading of the wave beyond the geometrieal projection is more pronouncel the smaller the opening or the refleeting obstacle and the greater the length of the wave. The phenomenon is ealled diffraction and is, of course, one of the well-known phenomena of physies. It is more pronomeed in the long waves of sound than in the short waves of light, and on the small areas of an anditorimu than in the large dimensions of out-of-door space. It eamnot be ignored, as it has been heretofore ignored in all diseussion of this phase of the problem of arehitectural aconstics, with impunity. The method of rays, although a fairly correct approximation with large areas, is misleading under most conditions. For example, in the present ease it would have predieted almost perfect aeousties in the boxes and on the main floor.

Fignres 17 and 90 show the condition in the room when the main sound-wave has reached the last seat in the top gallery. The wave $c_{1}$ has advanced and is reaching the front row of seats in the gallery, producing the effeet of an echo. A little later it will enter the balcony, protueing there an eeho greater in intensity, more delayed, and affecting more than half the seats in the balcony, for it will eurve under the gallery, in the mamner just explained, and disturb seats whieh geometrically wonld be protected. Still later it will enter the foyer seats and the boxes. But the main disturbance in these seats and the boxes, as is well shown by the photograph, arises from the wave $c_{2}$, and in the orehestra seats on the floor from the wave $c_{3}$.

In the summer following the opening of the theatre, a canopy, oval in plan anel slightly larger than the eeiling oval, was hung from the ceiling surrounding a central chandelier. The effect of this in preventing these disturbing refleetions is show by a comparison, pair hy pair, of the two series of photographs, Figs. 15 to 17 and Figs. 18 to 20 . It is safe to say that there are few, possibly no modern theatres, or opera houses, equal in size and seating capacity, 


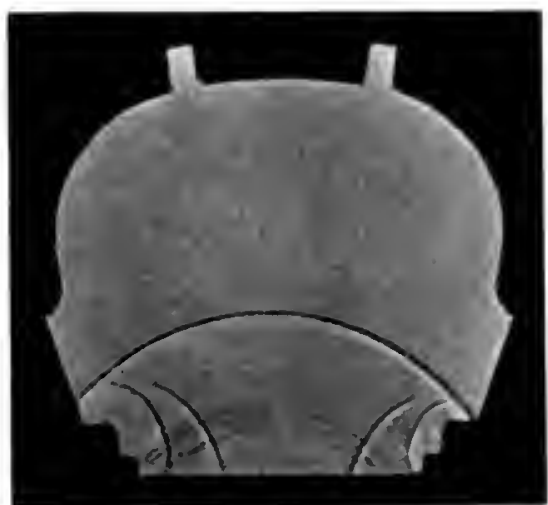

Pig. 20

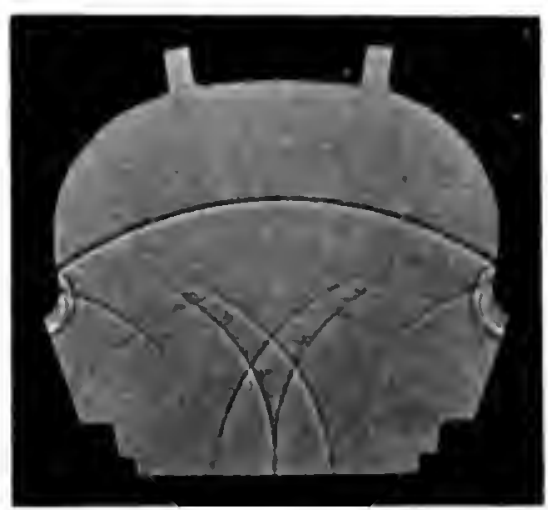

Fic. 2:3

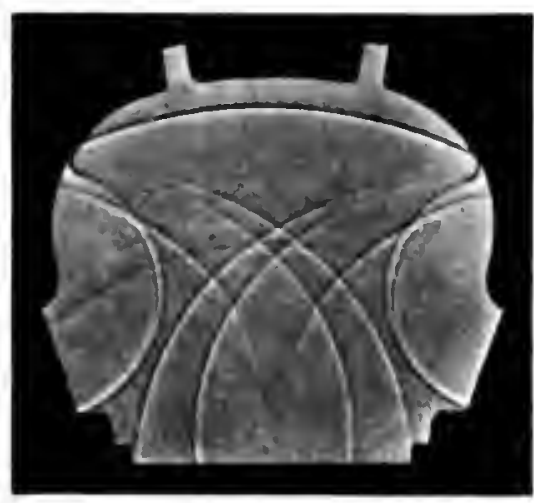

Fil: 21

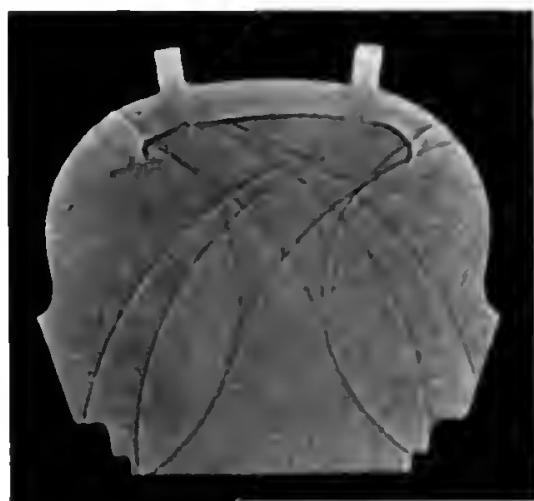

Fra.s

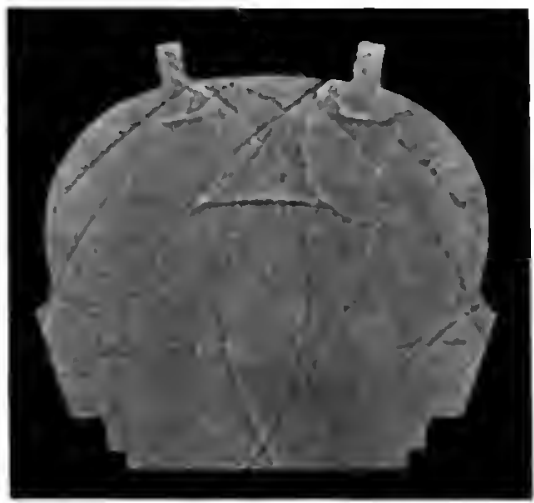

Fivio :ali

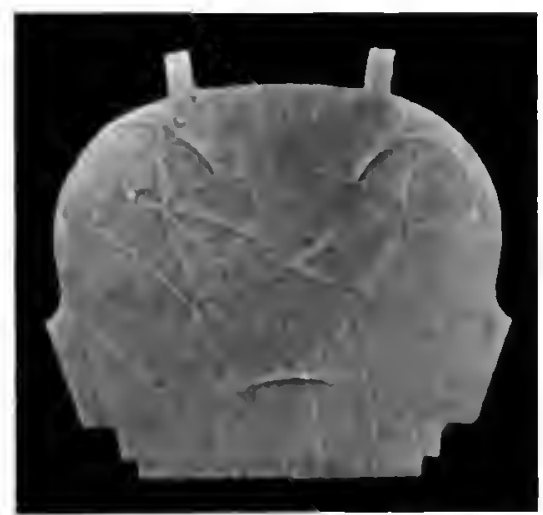

$1 \% 14,29$

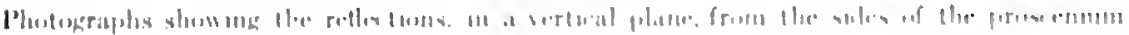

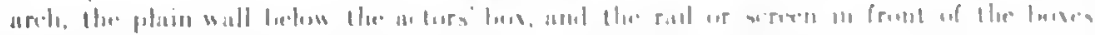

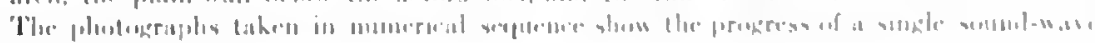
and its rellerdusts. 
which are so free from this particular trpe of disturbance as the New Theatre at the present time.

In the study of the New Theatre. photograph s, were taken throngh sereral horizontal sections. It will be suflicient for the purposes of the present palper to illustrate the effect of curved surfaces in producing converging waves by a few photographs showing the propagation of sound through a single section in a plane passing through the parapet in front of the boxes. The reflected waves shown in

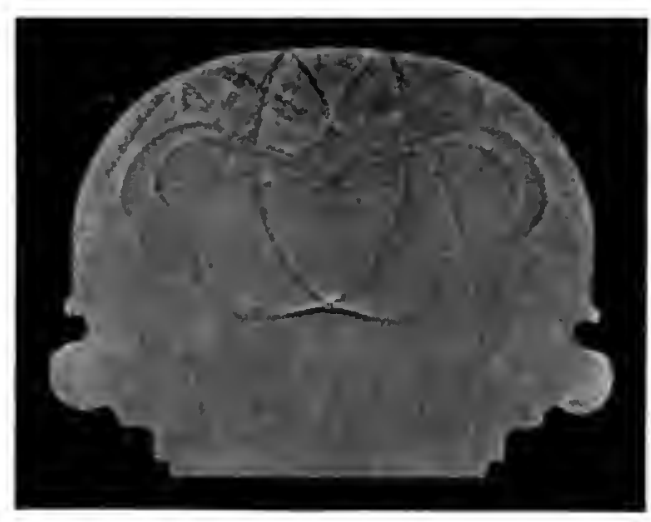

Fig. 98. A photograply one of many laken, showing in vertical section one slage of the reflection $b_{2}$, Fig. 21. These reflections were eliminated by the architects in the summer following the opening of the theatre, but have been in parl reslored by subsequent changes.

Fig. 29 originating from the edge of the proscenimm arch and from the base of the column ean be followed thronghout all the succeeding photographs. In Fig. 23 are shown waves originating from the plain wall beneath the actor's box and the beginning of some small waves from the curved parapet. It is easily possible, as it is also interesting and instructive, to follow these waves through the succeding photographs. In Fig. 95 the sound has been reflected from the rear of the parapet: while in Fig. $\mathbf{9 6}$ it has advanced further down the main floor of the auditorium, narrowing as it proceeds and gaining in intensity. The waves reflected from the parapet outside of the aisles are here shown approaching each other behind the wave which has been reflected from the parapet between the aisles. Waves are also shown in Fig. 26 emerging from the passages between the boxes. 


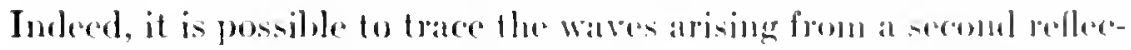

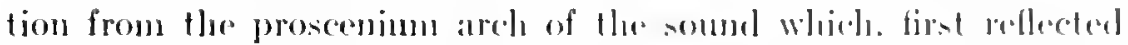

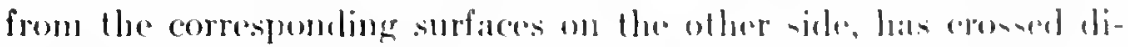
rectly in front of the stage. With a little atre. it is peresthle alon to

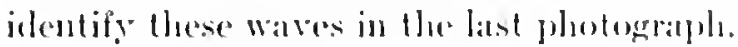

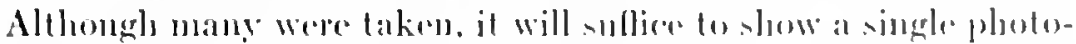

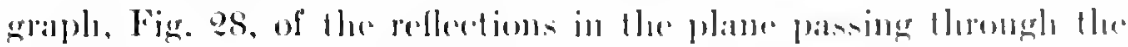

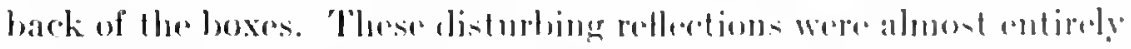
climinated in the revision of the theat re he the removal of the hoxes from the first to the second row and hy ntilizing the space vacated fogether with the anteroums as a single ballenny filled with reats.

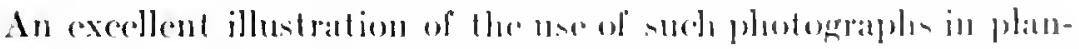
nime, bofore construction and while all the forms ame still thuid, is fo

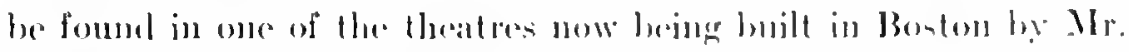

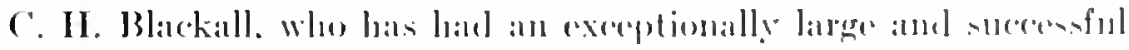

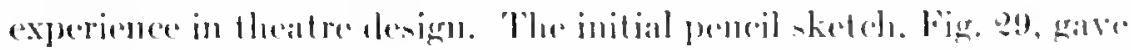

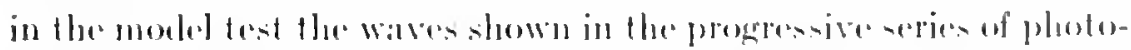

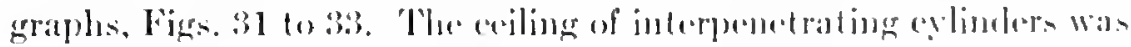

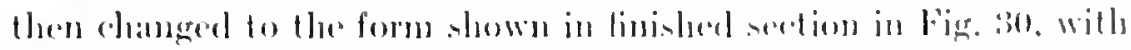

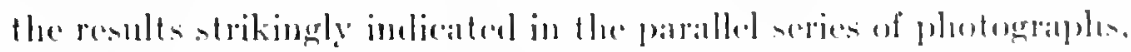

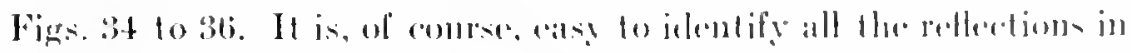

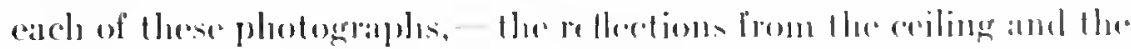

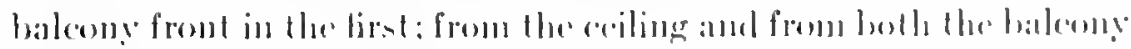
amel gallery front in the seconel: and in the thire plostongaph of the

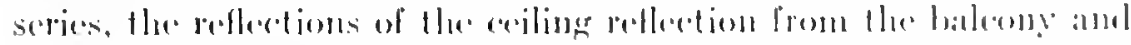

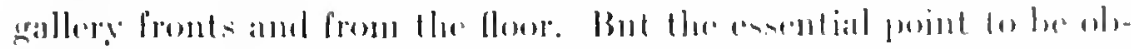

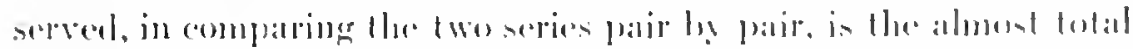

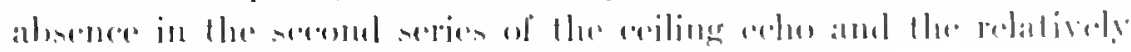

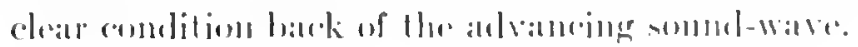

\section{fonsormor:}

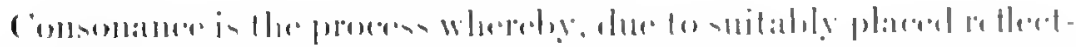

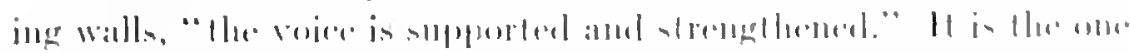

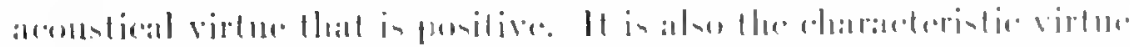

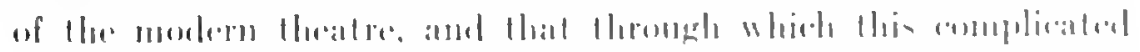

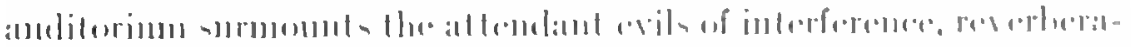

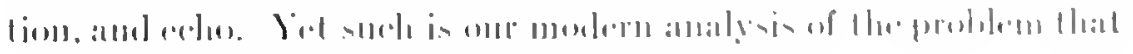


we do not even hare for it at name. On the other hand, it is the virtue which the (ireek theatre las in least degree. It is, therefore, all the nore interesting that it shonkl have been included in the analysis of Vit ruvins, and shoukl have received a name so accurately deseriptive. Inderd, one can hardly make explanation of the phenomenon better than through the very trpe of theatre in which its laek is the one admittod defect.

The Greek theatre enjoyss a not wholly well-founded reputation for extremely good acousties. In most respects it is deserved; but

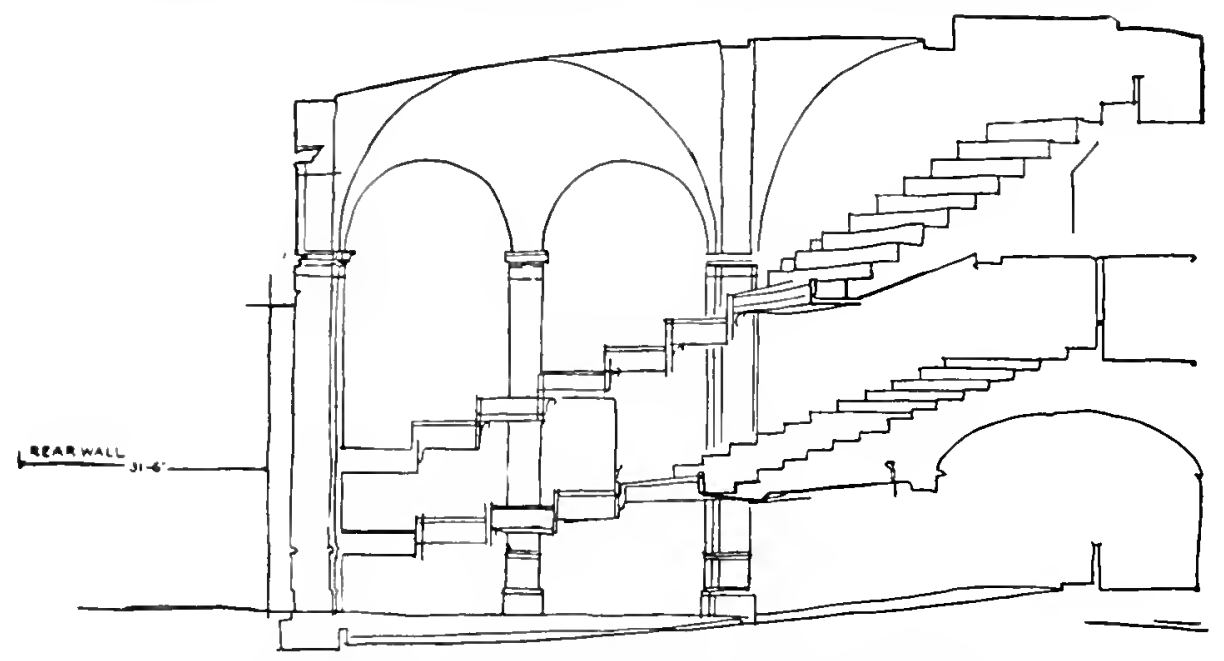

Frc. 99. Section in pencil sketch of Scollay Square Theatre, Boston. Mr. C. H. Blackall, Arehiteet.

the carcful classical scholar, however gratified he may be by this praise of a notable Creek invention, regards himself as barred by contemporaneons evidence from aceepting for the theatre unqualified praise. Every traveler has heard of the remarkable quality of these theatres, and makes a trial wherever opportunity permits, be it at beantiful Taormina, in the steep sloped theatre at Pompeii, the grat theatre at Ephesus, or the "little theatre" on the top of 'Tusculum, - always with gratifying results and the satisfaction of having confirmed a well-known fact. Perhaps it is useless to try to traverse such a test. But there is not a theatre in Italy or Greece which is not in so ruined a condition today that it in no way whatever resembles acoustically its original form. If its acousties are 
perfect today, they certainly were not originally. Complete "scanena" and enelosing walls distiuctly altered the acoustical conditions. 'The traveler has in general tested what is little more than a depression in the ground, or a hollow in a quiet comutry hillside. As a matter of fact. the theatre in its original form was better than in its ruined state. Still, with all its excellencies it was mot wholly good. Its acomstical gualities were not wholly acecplable to it contemporarjes,

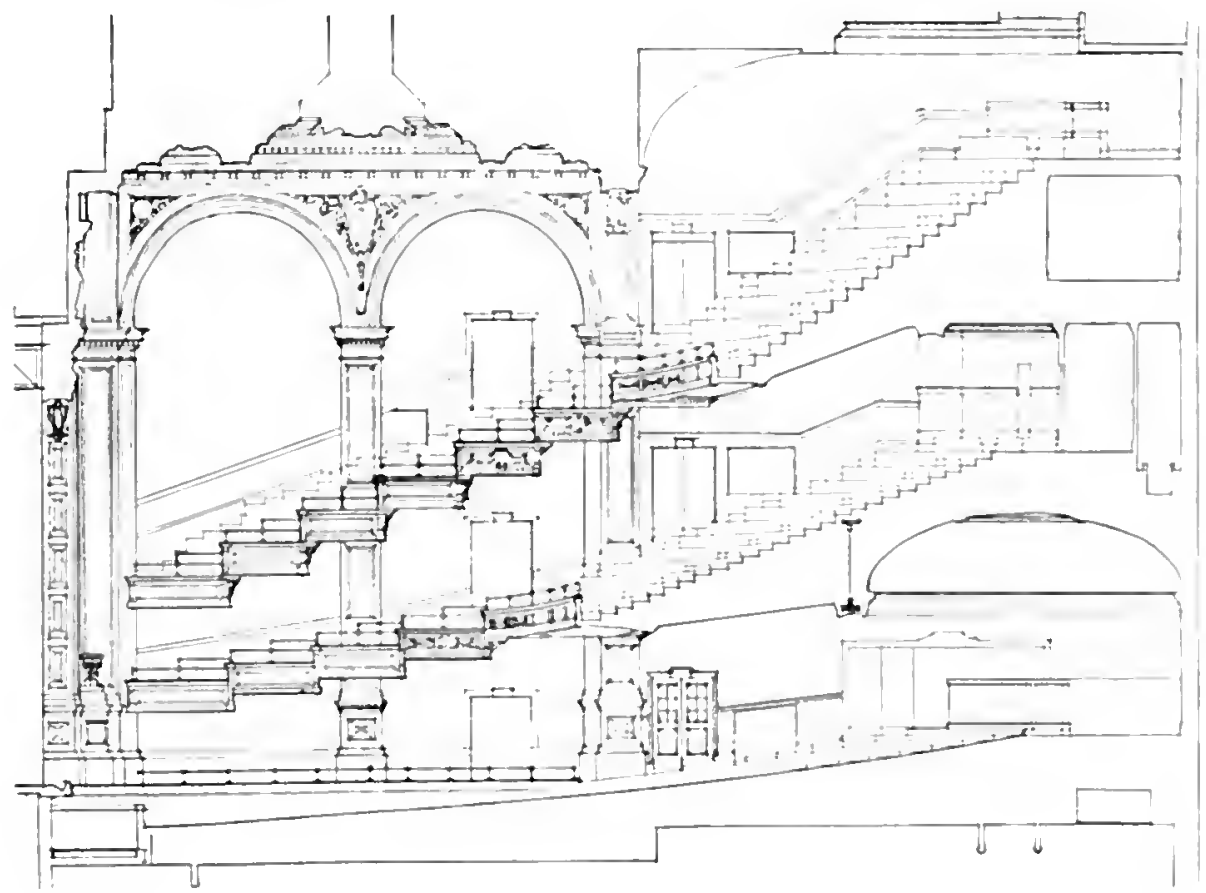

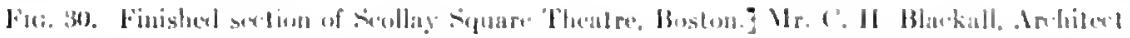

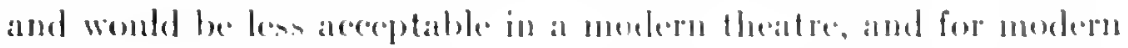
driallia.

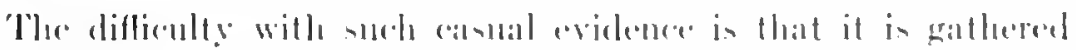

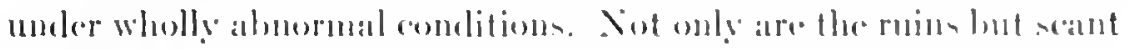

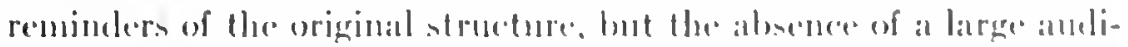

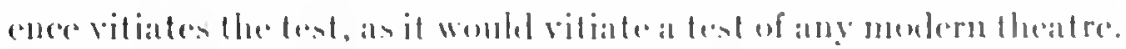

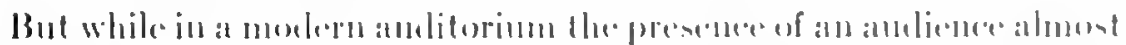

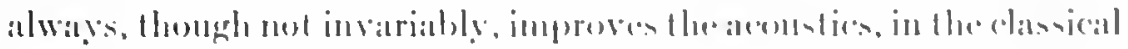

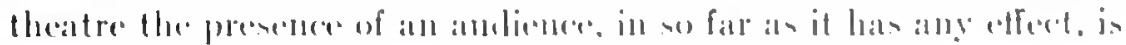


disatrantazeous. The effect of an audienee is always twofold, - it diminishes the reverheration, and it diminishes the loudness or intrensity of the voice. In general, the one cofect is advantageous, the other disadvantageous. But in the Greek theatre, occupied or unocenpied, ruined or in its original form, there was very little reverberation. In fact. this was its merit. On the ofler hand, the very face that there was little reverberation is significant that there was very slight architedural beantorcement of the voice. One might wedl be unconvinced ly sucle a priori considerations were there not excellent evidence that these theatres were not wholly acceptable a eoustically even in their day, and for drama written for and more or less adapted to them. Excellent evidence that there was insufficient consonance is to be found in the megaphone monthpieces used at times in both the tragic and lhe comic masks, and in the proposal by Vitruvius to use resonant vases to strengthen the voice.

The doubt is not as to whether at speaker, turned directly toward the andience and speaking in a sustained roice, conld make himsedf heard in remote parts of a crowded Greek theatre. It is almost certain that he could do so, even in the very large and more ncarly level theatres, such as the one at Ephesus. Better evidence of this than can be found in the easual test of a lonely ruin is the amnual performance by the staff of the Comedie Francaise in the theatre at Orange. But even this, the best preserved of either Greek or Roman theatres, is but a ruin, and its temporary adaptation for the annual performanee is more modem than classical. A much better test is in the exercises regularly held in the Greek Theatre of the University of California, designed ly Mr. John Galen Howard, of which President Wheoler weaks in most approving terms. The drama, especially morkern drana, differs from sustained speech and formal address in its range of utterance. in modulation, and above all in the requirement that at times it reaches the andience with great dymamic quality but without strain in enunciation. Mere distinctness is not sufficient. It was through a realization of this that the megaphone mouthpiece was invented, - awkward in use and neessarily destructive of many of the finer sharles of emmeiation. 'That it was only occasionally used proves that it was not a wholly satisfactory device, but does not detract its evidence of weakness in the acousties of the theatre. 


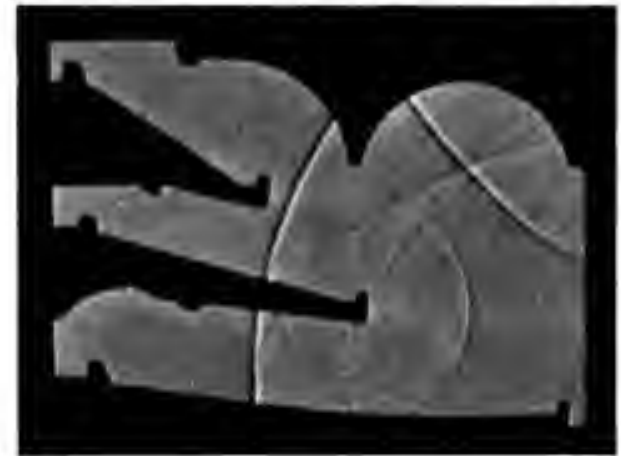

lig.:31

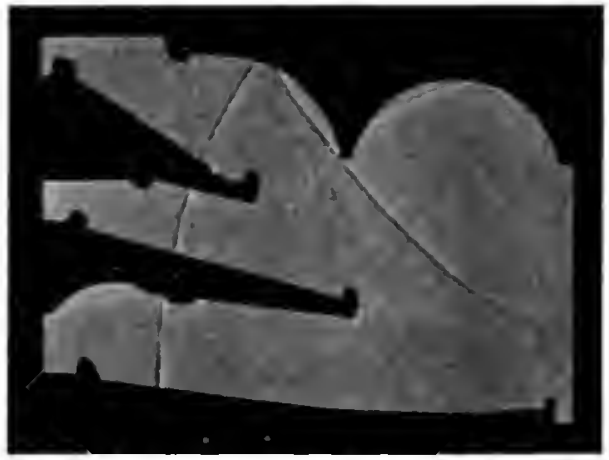

Fini. :3:

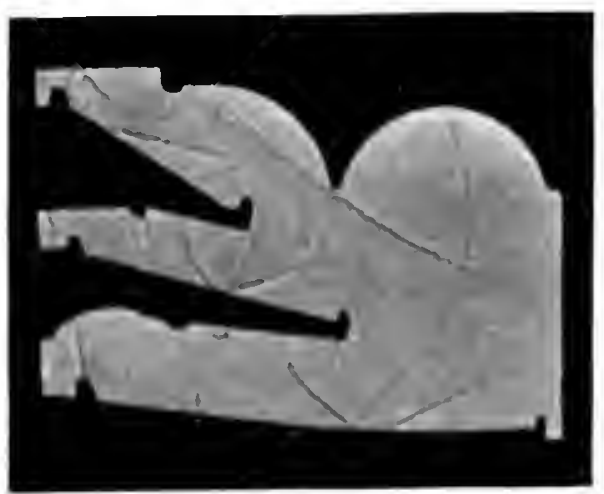

Fite. is:

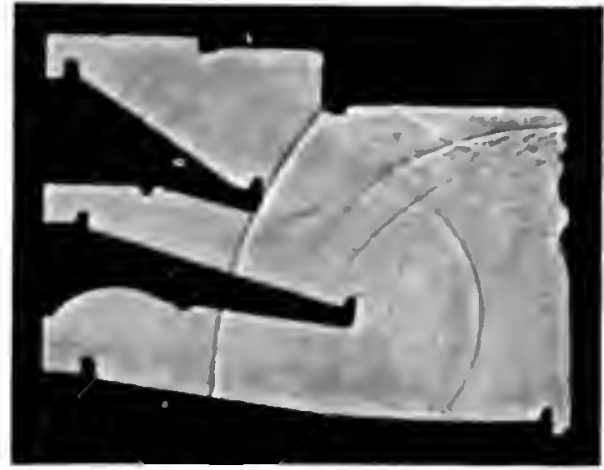

Fici.34

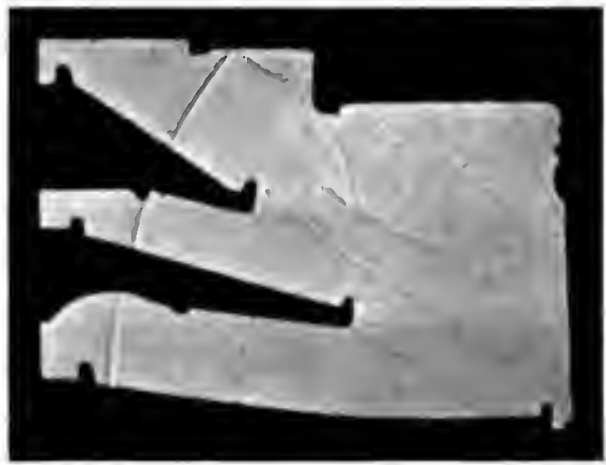

lin: 3.3

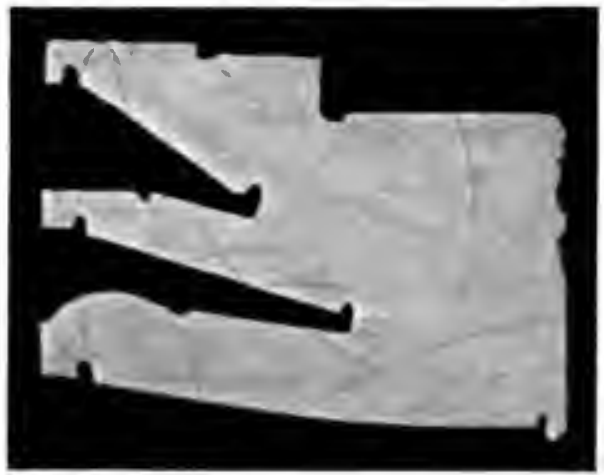

Fit: Sti

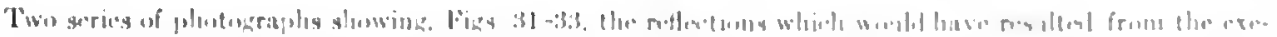

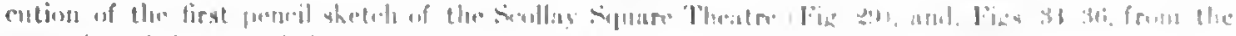

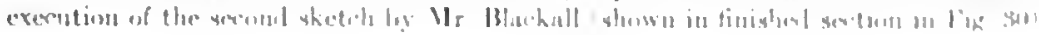


The megaphone mouthpiece bears to the acoustics of the Greek theatre the same evilence, only in a reciprocal form, that the mask itself hears to the theatre's illumination. It was not possible to see in bright davlight, particularly in the bright sunlight of the Mediterranean atmosphere, with anything like the accuracy and detail possible in at darkened theatre with illuminated stage. The pupil of the eve was contracted. and the sensitiveness of the retina cxhausted by the brilliancy of the general glare. Add to this that the distance from the stage was very much greater in the Greek than in the modern theatre, andience for audience, and one can realize the reason for the utter inpossibility of facial expression in Greek dramatization except by artificial exaggeration. The heaviness and inflexibility of these devices, and, therefore, their signifieance as proof of some inherent diffieulty in dramatic presentation, is emphasized by the delicacy of line anel fine appreciation of the hmman form shown in other contemporaneous art.

Not less significant in regard to the acoustics of the Greek theatre are the directions given by Vitruvius for the reeinforcement of the voice by the use of resonant vases:

"Aceordingly bronze vessels should be made, proportional in size to the size of the theatre, and so fashioned that when sonnded they prodnce with one another the notes of the fourth, the fifth, and so on to the double octave. These ressels should he placed in accordance with musical laws in niches between the seats of the theatre in such position that they nowhere tonch the wall, but have a clear space on all sides and above them. They should be set upside down and supported on the side facing the stage by wedges not less thin half a foot high. .. . With this arrangement, the voice, spreading from the stage as a center, and striking against the cavities of the different vessels, will be increased in volume and will wake an harmonions note in unison with itself."

There is good reason for believing that this device was but very' rarely tried. This, and the fact that it could not possibly have accomplislied the purpose as outlined by Vitruvius, is not germane. The important point is that its mere proposal is evidence that the contemporaries of the Greek theatres were not wholly satisfied, and that the defect was in lack of consonance.

It woulel be inappropriately elaborate and bevond the possible length of this paper to give in detail the method of calculating the 
loudness of sound in different parts of an anditorium. 'That subjecel is reserved for another paper in preparation, in which will be given not merely the methed of ealculation but the necessary tables for its simplification. It is, howerer, possible and proper to give a gemeral statement of the principles and processes involved.

In this discossion I shall leaverout as already aderpuately discunsed the phenomenon of interference, or rather shall dismiss the sulyaet witl a statement that when two sommels of the same pitch alre superposed in exact angecment of phatsen, the intensity of the somme is the spluare of the sum of the scpuare roots of their scparatte intemsilies: when they are in epposite phatses, it is the scplare of the lifference of the square roots of their intensities; but when several sounds of the same pitch alrive at any point in the room with at randem ditlerence of phatse their probable intensity is the simple mumerical sum of their separate intensities. It is on the assumption of a randem difference of phase and an arerage probable londuess that 1 shatl here comsider the atuestien. 'This has the adrantage of being the simpler and alkes at first approxination in an anditurinm designed for articulate speech.

When somnd spreatels from a spherically symmetrical sontere it diminishes as the sefultere of the distance. When the somed is heing propagated, still in space unrestricted he walls or coiling, but over the heads of a closely seated alldience, the law of the diminution of the sound is more rappit than the law of the inverse sefuare. 'This more

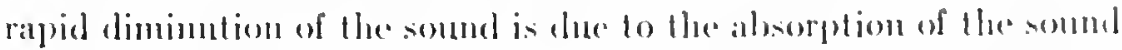

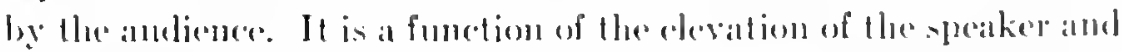
the angle of inclination of the ffowr, - in other words, the ingle between the sight lines. 'The liminution of the intensity of the soment due to distance is less the greater this angle.

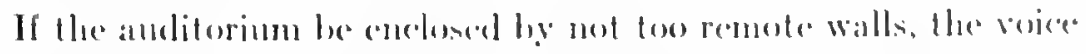
coming directly from the speaker is reanfored ly. the redlection from the retaning walls. Howevere it in whriens that the somble rethereded

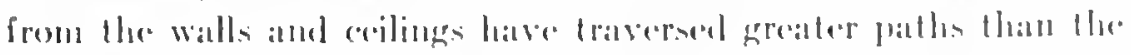

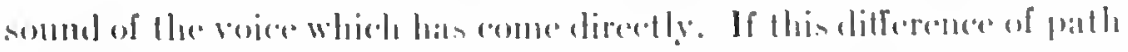
length is great, the sounds will out arrive simultamermsly. If, however, the path differences are net great. the redlected soumd will

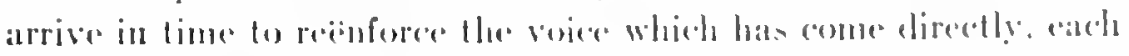

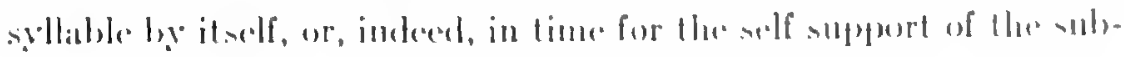


syllabic components. It is to this mutual strengthening of coneurrent sounds within each element of anticulate speech that Vitruvius hats given the name "consonance."

'Thus in the computation of the intensity of the voice which hats come direetly from the speaker across the anditorium, it is neeessary to take into consideration not merdy the diminution of intensity arcerding to the law of the inverse square of the distance and the dinimution of the intensity (he to the absorption by the clothing of

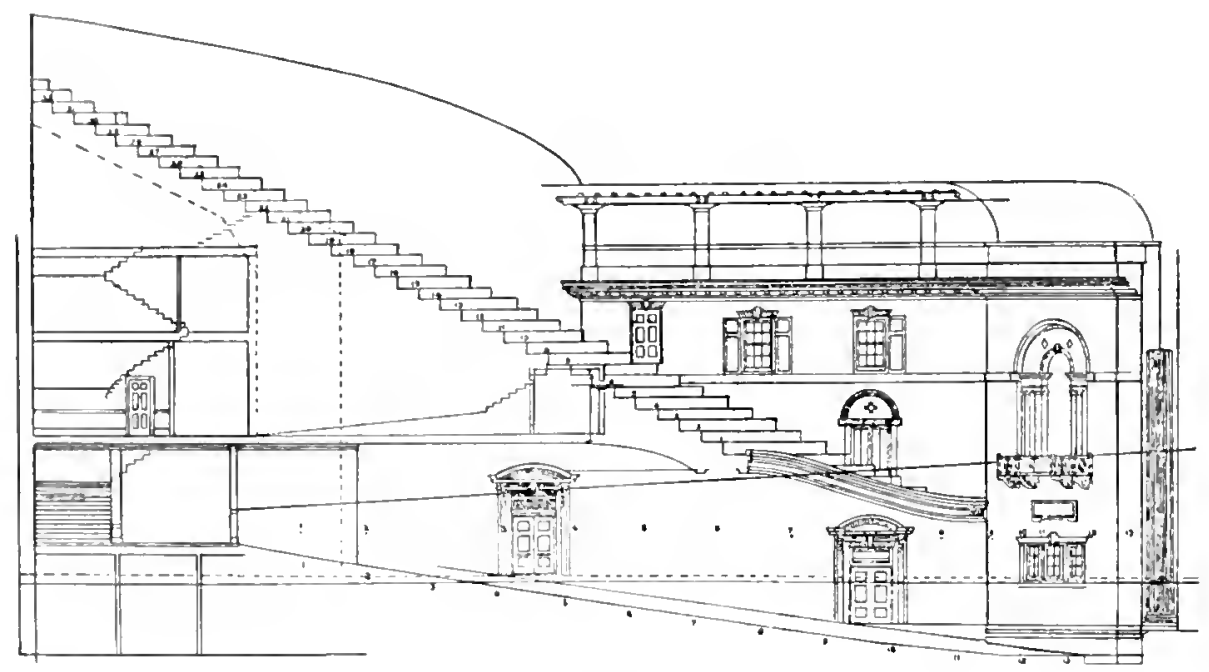

Fig. 3\%. The Inarris Theatre, Minneapolis, first desigu. Chapman and Magnę, Architects.

the andience, but also, as a compensating factor for the latter, the diffraction of the sound from above which is ever supplying the loss due to absorption, while in computing the intensity of the sound reflected from any wall or other surface onc must take into consideration all this, and also the eoefficient of reflection of the wall and the diffraction due to the restricted area of the reflecting element.

Abstract prineiples are sometimes tedious to follow even when not diffient. In Fig. 38 is shown a photograph taken in an investigation for the architects, Messrs. Chapman and Magney, of the Harris 'Theatre, to be ereeted in Mimneapolis, which affords an excellent example of both favorable and unfarorable conditions in respect to consonance. The initial sketch for this theatre offered no problems 
either of interference or reverberation, and of echo only in the horizontal section. The only very consillerable question presented by the plans was in respect to consonance and there in regard only to the more remote parts of the floor and of the batcony. 'The particular. photograph here reproduced records the condition of the sound in the room at such an instant as to bring ont this aspect of the problem in marked degree.

The forward third of the balcong in this theittre alfords an excellent example of consonince, for the reflection from the ceiling arrives so nearly simultancously with the somm which las come

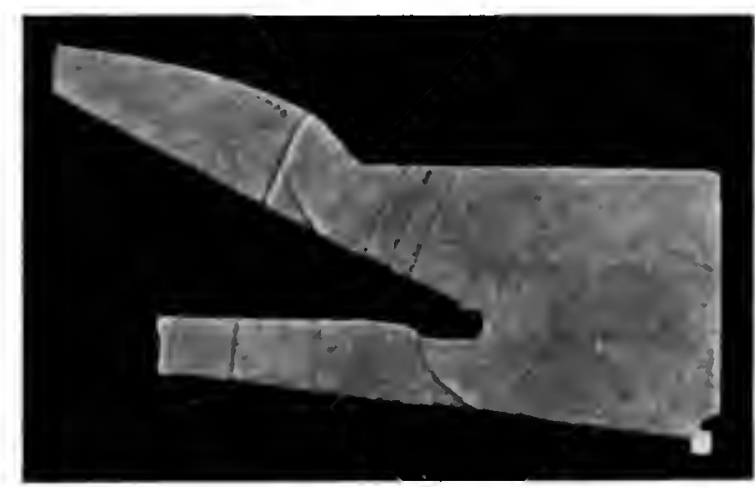

Fic. 38. Showing the consonance in the bulcong of the Harris

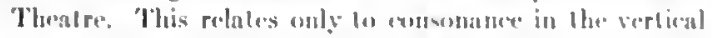
section.

directly from the stage as to "strengthen and support" it and peet "leave the words clear and distince." The intervil between the two. the direet and the reflected voires, valries from .01 second to 0 . second. Back of the first third, howerere, the consonance from the ceiling graldnatly" diminishes and is practically imperceptible beyoud the mildle of the gallery. Back of that proint the clirect voice di-

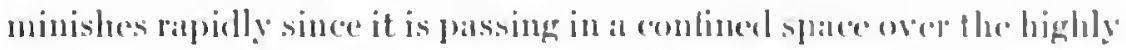
absorbent elothing of the andience. 'The loss of internsity at the reatr of the gillery is increased ly the carrying of the horizontal portion

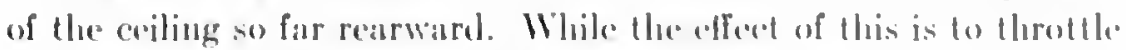

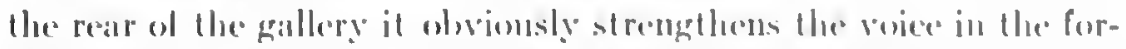
ward third. Althengle there is thus some compromation, on the whole the ferwatrol part of the gallery does not meed this servide so 
much ats the rear seats. The photograph shows this process clearly: Her main sound-ware can be seen advancing after having passed the angle in the eciling. The wave reflected from the ceiling can be seen just striking the gallory seats. It is evident that at the instant at which the photograph was taken the sound-wave was receiving the last of this support by the somel reflected from the ceiling.

The photograph also shows how the somnd after passing the ceiling angle spreads into the space above, thus losing for the moment thirty per cent of its intensity, a loss, however, to be regained in considerable part later.

On the main floor the reflection from the ceiling strengthens the lireet roice only for the long syllabic components. Nevertheless, in comparison with other theatres the forward part of the floor of this theatre will be excellent. 'There will he just a trace of echo immediately under the front of the balcony, but this nill be imperceptible beyond the first four rows of seats under the balcony. It is obrions from the photograph that there is no consonance in the rear of the main floor of the auditorium under the balcony.

A not unnatural, certainly a not uncommon, incuiry is for some statement of the best height, the best breadth, and the best depth for a theatre, for a list of commented and a list of prohibited forms and climensions. A little consideration, however, will show that this is nejther a possible nor the most desirable result of such an investigation.

For a simple rectangular auditorim of determined horizontal dimensions there is a best height. When, however, the horizontal dimensions are changed the desirable height changes, although by no mans proportionally. When the floor is inclined, when the walls are "urved, when there are galleries and connection corridors, when the material of construction is varied in character, the problem becomes -omewhit more intricate, the value of each element being dependent on the others. Moreover it is futile to attempt to formulate a standard form eren of a single type of auditorium. How greatly the design must vary is well illustrated in the four theatres which have been taken as examples, - the Little Theatre with all the seats on the main floor, the Ilarris Theatre, very long, very broad, and with 
but a single gallery, the Scollay Squalre Theat re with two galleries, and the New Theatre with two rows of boxes and two galleries. The fundanental conditions of the problem, not the entirely free choice of the architect, determined the general solution in eatch calse. Acoustical quality is never the sole com-iderations at best it is but a factor, introduced sometines atrly. sometimen latee into the elesigus. 



\section{8}

\section{BUIIDING MATERIAL, AND MUSICAL, PITCH'}

$\mathrm{T}$

$11 \mathrm{~F}$ alsorbing power of the varbous materials that enter into the construction and furmishing of an anditurium is but one phase

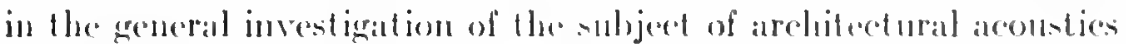
which the writer has been pronerenting for the pant eighteren gears. 1)uring the first five gealls the inventigation wal devoted almost exchusively to the determination of the corefficients of absorption

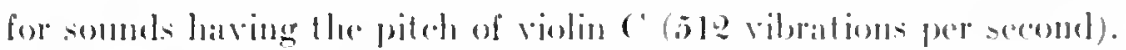
The results were published in the Ameriean Arduteret and the lin-

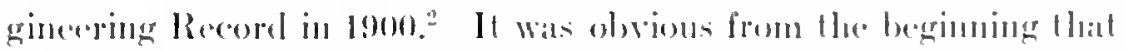

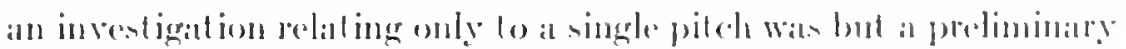
excursion, and that the complete solution of the probleden catled for an extension of the investigation to cosere the whole range in pitch

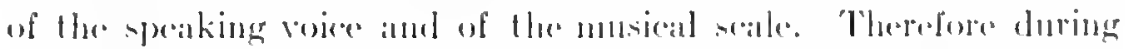

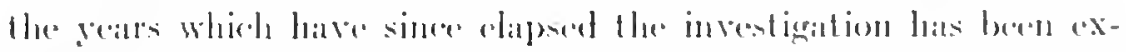

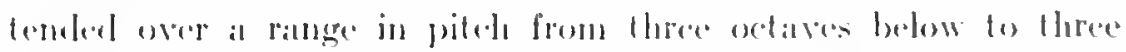

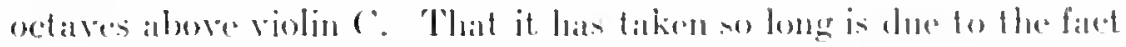

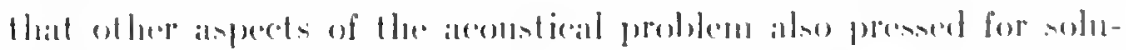

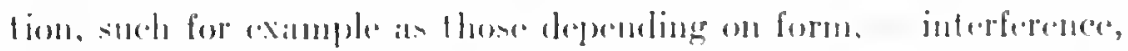

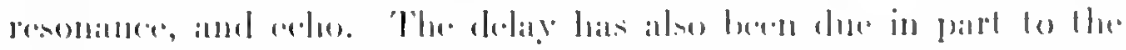

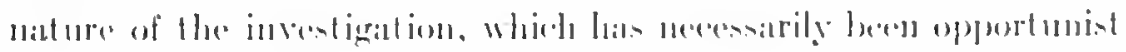

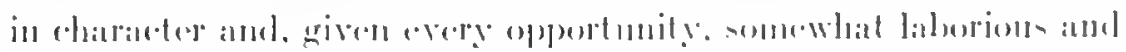

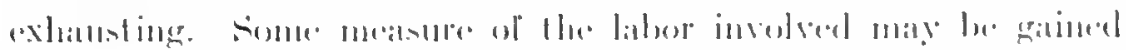

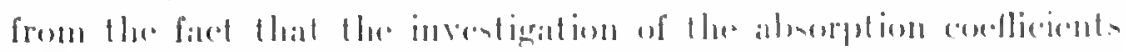

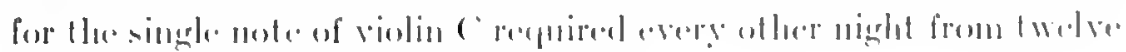

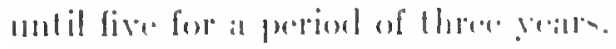

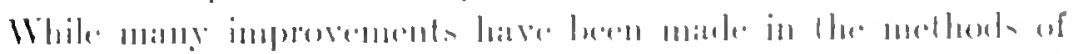

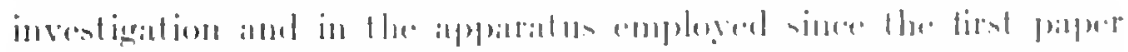

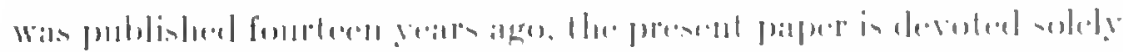

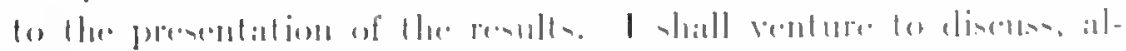

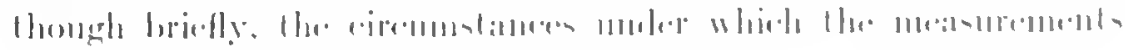

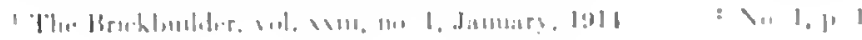


were made, my object being to so interest arehitects that they will call attention to any opportunities which may come to their notice for the further extension of this work; for, while the absorbing powers of many materials have already been detemined, it is evident that the list is still incomplete. For example. the coefficient of glass has been determined only for the note first studied, C, an oetive above middle C. In 1898 the University had just eompleted the construction of some greenhouses in the Botanieal Garelens, which, before the plants were moved in, fulfilled admirably the conditions necessary for alecurate experimenting. Glass formed a very large part of the area of the enelosing surfaces, all, in fact, except the floor, and this was of concrete whose coeffieient of ahsorption was low and had alreaty been determined with aceuracy. By this good fortune it was possible to determine the absorbing power of single-thickness glass. But at that time the apparatus was adapted only to the study of one note; and as the greenhouse was soon fully oecupied with growing plants which could not be moved without danger. it was no longer available for the purpose when the scope of the investigation was extended. Sinee then no similar or nearly so good opportunity has presented itself, and the absorbing power of this important struetural surfaee over the range of the nusical scale lais not as yet been determined. There was what seemed for the moment to be an opportunity for obtaining this data in an indoor temmis court which Messrs. MeKin, Mead and White were erecting at Rhinebeek on the Hudson, and the arehiteets undertook to secure the privilege of experimenting in the room, but inquiry showed that the tennis court was of turf, the absorption of which was so large and variable as to prevent an aecurate determination of the coefficients for the glass. 'The necessary conditions for such experiments are that the material to be investigated shall be large in areat, and that the other materials shall be small in area, low in power of absorption, and constant in charaeter; while a contributing factor to the ease and aceuracy of the investigation is that the room shall be so located as to be very quiet at some period of the day or night. The present paper is, therefore, a report of progress as well as an appeal for further opportunities, and it is hoped that it will not be out of place at the end of the paper to point out some 
of the problems which remain and ansk that interested architects call attention to any rooms in which it may be possible to complete the work.

The investigation does not wholly wait an opportunity. A special room, exceptionally well adapted to the purpose in size. shape, and location, has been constintly alvilable for the research in one form or another. 'This room, initially lined with brick set in cement, has been lined in turn with tike of various kinds, with plaster, and with plaster on wood lath, als well as finished from time to time in other surfaces. This procese, however, is expensive, and carried out in completeness would be begond what could be borme personally. Moreover, it has further limitations. For example, it is not possible in this room to determine the absorbing power of glass windows for one of the essential features of a window is that the outside spate lo which the somed is transmitted shall be opent and unobitrueted. An immer lining of glatss, crent though this be placed several inclese from the wall, would not with certainty represent normal conditions or show the efleet of windows ats ordinarily muploged in an anditorium. Nolwithstanding flese limitations. this room, carefully studied in respeet to the effects of its pecenliarities of form, especially such at arixe from interference and renonance, has becen of greilt service.

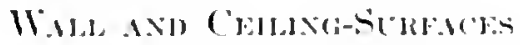

It is well to bear in mind that the aldsorption of somml hy at wall-

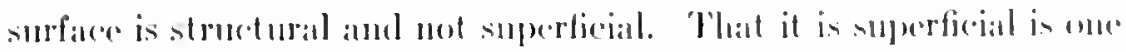

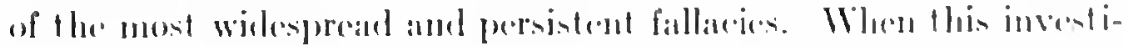

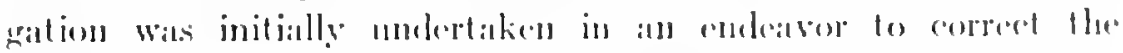

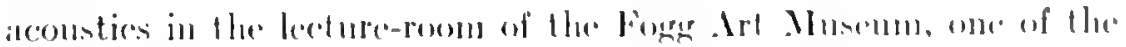

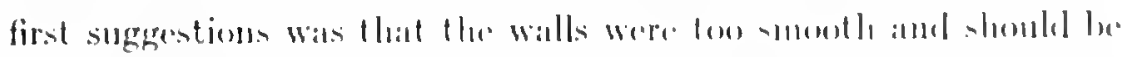

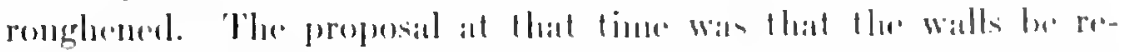

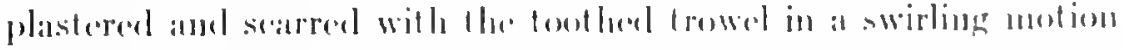

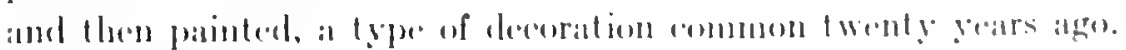

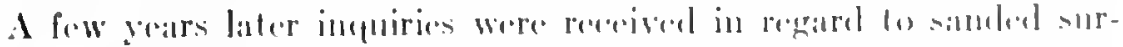

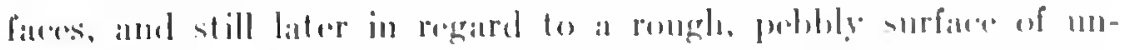
troweded plistrer: while within the past three years lhere hatse heron

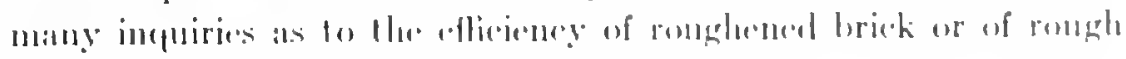


lewn stone. (On the general principle of investigating any proposal $\therefore$ long as it contained even a possibility of merit, these suggest joms were put to test. "The concerefe floor of a room was covered with a grivil so sifted that each pehble was about one-ejghth of an inch in diameter. 'This was spread over the floor so that pelsble touched peblok, making a layer of but a single pebble in thickness. It showed not the slightest absorbing power, and there was no perceptihle decrase in reverheration. The room was again tried with sanel. Of course, it was not possible in this case to insure the thickuess of a single grain only, but as far as possible this was accomplished. The result was the same. The scarred, the sanded, the pehbly phaster, and the rough hewn stone are only infinitesimally nore cflicient as absolbents than the same walls smooth or even polished. The failure of such roughening of the wall-surfaces to increase either the absorption or the dispersion of sound reflected from it is due to the fact that the somnd-waves, even of the highest notes, anc long in comparison with the dimensions of the irregularities thus introduced.

'The absorption of sound by a wall is therefore a structural phenomenon. It is almost infinitely varied in the details of its mechanism, but capable of classification in a few simple modes. The fumdamental process common to all is an actual yielding of the wall-surface to the vibrating pressure of the sound. How much the wall yields and what bereomes of the motion thus taken up, depends on the nature of the structure. The simplest type of wall is obviously illustrated by concrete without steel reënforcennent, for in this there is the nearest approach to perfect homogeneity. The anument that this wall would yield would depend upon its dimensions, particularly its thickness, and upon the density, the elasticity, and the riscosity of the material. It is possible to calculate this direclly from the elenents involved, but the process would be neither interesting nor convincing to an architect. It is in every way more satisfactory to determine the absorbing power by direct axperiment. A concrete wall was not available. In its stead, the next more homogeneous wall was investigated, an eighteen-inch wall of hrick set in cement. This wall was a very powerful reflector and its absorbing power exceedingly slight. Without going 
into the details of the experinent, it will sullice here to say that this wall aldsorbed one and one-tenth pere cont of the lowest note

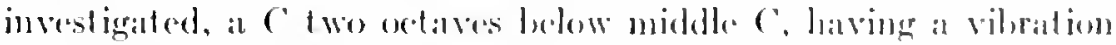

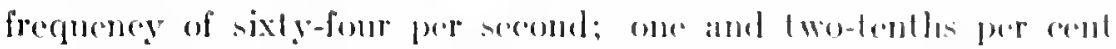

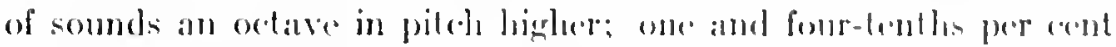

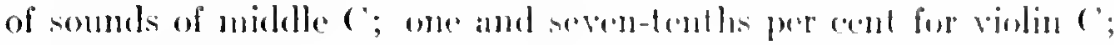

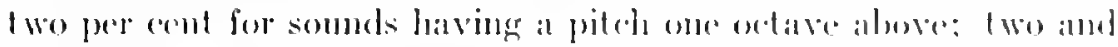

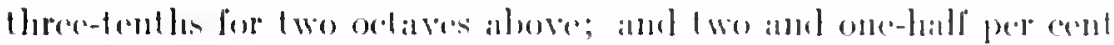

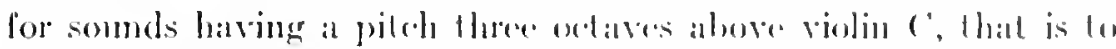
say, fogt vilurations per second, the lighlest mote incestigated. These may be written als coedliedents of absorption then:

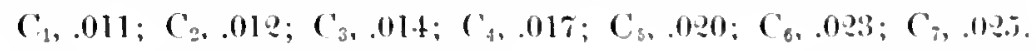

There is at graphical mothoul ol presenting these rensults which is

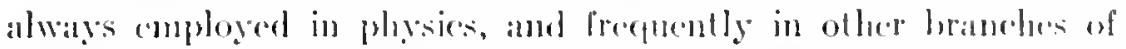
science, when the phenemenon untere investigation is sinnly progressive and dependent upon a singte variable. Whenever these conditions are soltisfocl - and they are usually sittisfed in any

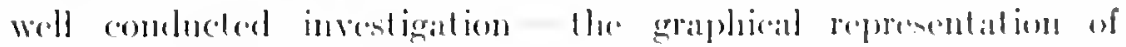
the results takes the form of al diagram in which the pesults of the meisumements alre plotted vertically at horizontal distances determined by the vilriable comblion. Thus in the following liagram (Curre 1, Fig. 1) the coeflicients of absorpt ion alre plotted vert ically,

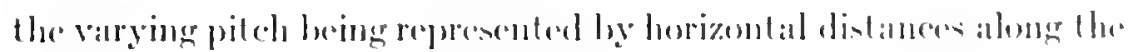

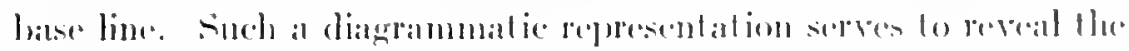
alceuracy of the work. If the phememenon is a continums one.

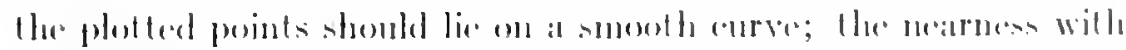

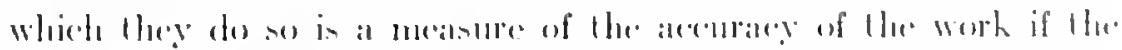

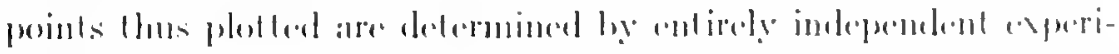

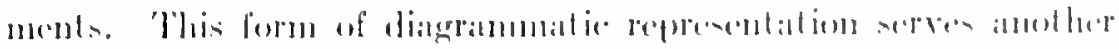

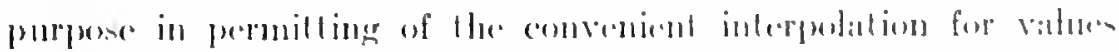

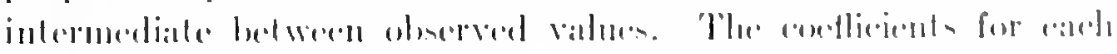

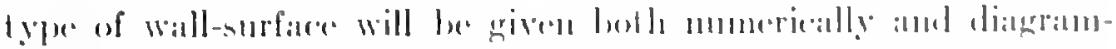

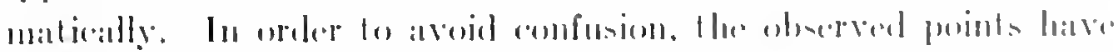

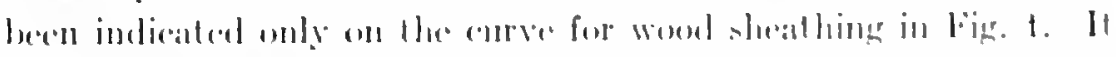

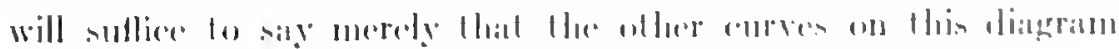

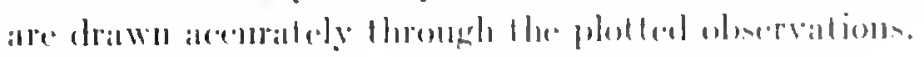


'The mext wall-surfate investigated was plaster on hollow terra cottil tike. The plister coat wats of gypsum hard plaster, the rough pliskere being fiveredighthe of an inch in thickness. The result shows a slightely greater alsworption due to the greater flexibility of a hollow

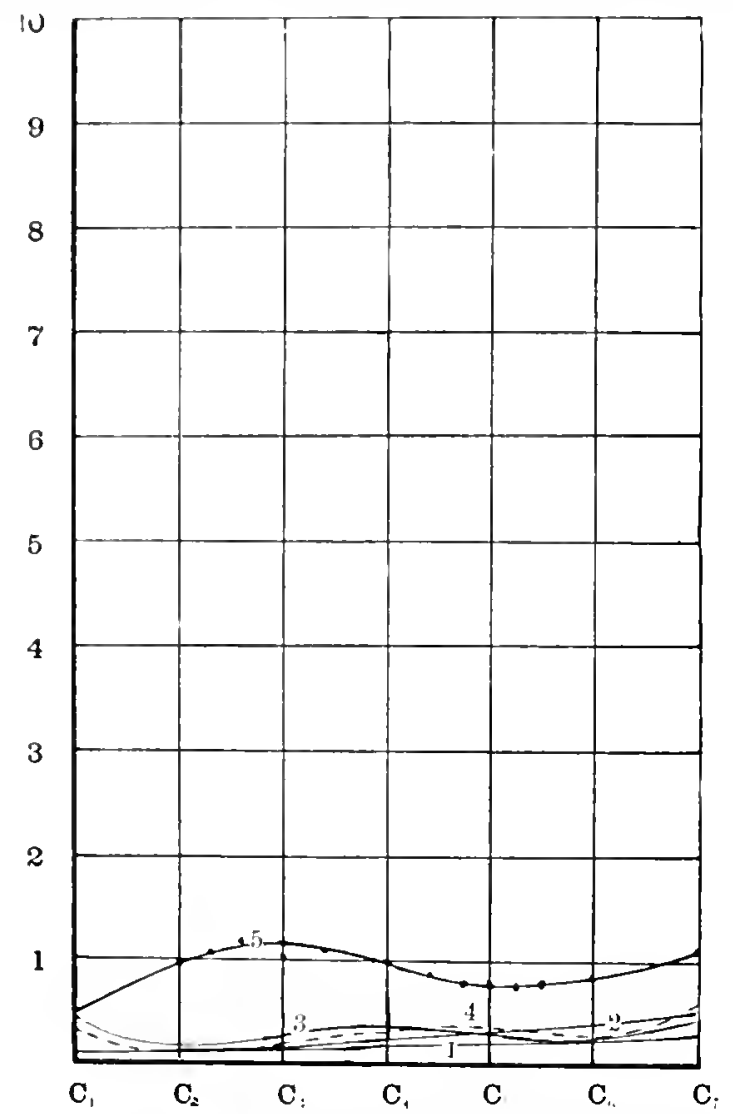

Fig. 1. Alsorbing power for sounds varying in pitch from $\mathrm{C}=6+10 \mathrm{C}=4.094$; 1 , brick wall; 2 , plaster on terra cotta hollow lile; 3 , plaster on wire lath; 4. sime will skim coatl: 5 , wood sheathing.

tile wall rather than to any direct effect of the plaster. The difference, however, is not great. The numerical results are as follows (Curve 2 . Fig. 1):

$$
\mathrm{C}_{1}, .012 ; \mathrm{C}_{2}, .013 ; \mathrm{C}_{3}, .015 ; \mathrm{C}_{4}, .020 ; \mathrm{C}_{5}, .028 ; \mathrm{C}_{6}, .040 ; \mathrm{C}_{7}, .050 \text {. }
$$

$C_{1}$ is the lowest note, 64 vilhations per second; $C_{7}$, the highest, 4,096 fer second; the other notes at octave intervals between. 
Plaster on an otherwise homogeneons sustaining wall is a first step in the direction of at componnd wall, bul al vistly grealler step is taken when the plastere instead of being applied directly to the sustaining wall is furred to a greater on lesis distance. In at homer-

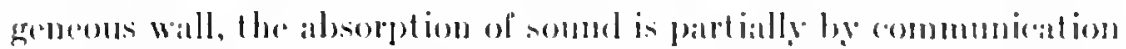
of the vibration to the material of the wall, whenere it is telephemed throughout the structure, and partly by a dichleng of the wall ats a whole, the soumd heing theon communicated to coutside spasere. In at compound wall in which the exposed surfine is fured from the main structure of the wall. the former vibutates between the furring

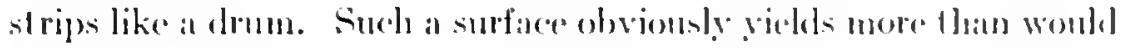
at surfice of plister alpplied direetly to tile or brick. The conergy" which is thus absorbed is pattly dissipated by the viseosity of the plaster, partly ly transmistion in the air spate behind it, and partly florough the lurring strips to the main wall. 'The mechanism of this process is interesting in that it shows how the free standing

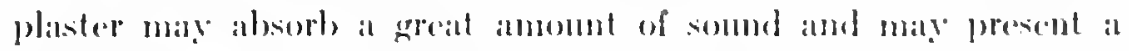
greater posisibility of resonatnce and of selective alsorption in the different registers of pitch. It is obvions that we are here dealing with a problem of more compliealed alspert. It is concervalble that the aborption coeflicient shendel depered on the nature of the

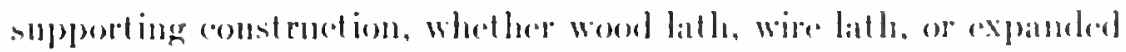
metal bath; on the distance alpart of the studdlinge or the deptls of the air spatere; or, and even more decedededly, on the nature of the

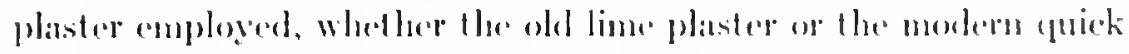

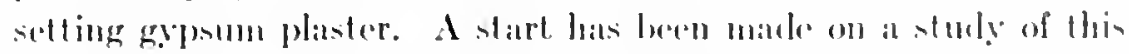

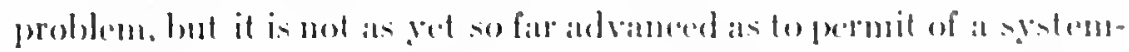
atie correlation of the results. It munt suflice to present here the values for a single constructions. The most interesting calse is that

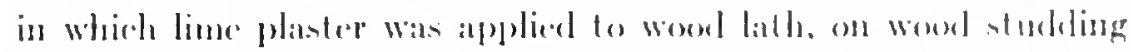

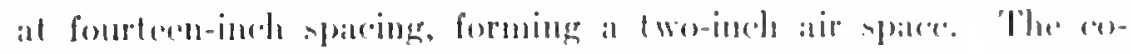

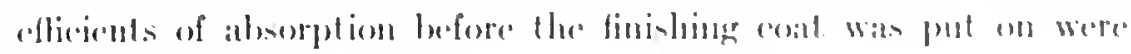
(curve 3, Jig 1):

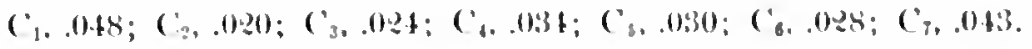

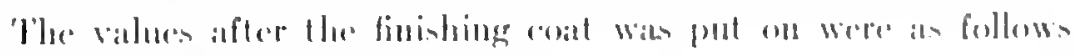
(curret, dotted, lige 1):

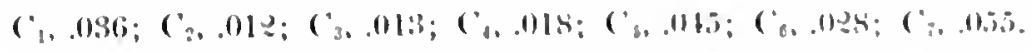


It shenlel he remalked that lle determination of these coeffieients was made within two weeks after the plaster was applied and also that the modern lime is not the same as the lime used thirty years agere cither in the manner in which it is landled or in the mamner in which it sots and flries. It is particularly interesting to note in these observations, more clearly in the plotted curves, the phenomenon of resonance as shown hy the maxima, and the effect of the increased thickness prodnecel ly the skim eoat in incleasing the rightity of the wall, elecreasing its albsorbing power, and shifting the resominnee.

The most firmly established traditions of both instrumental and archilectural acoustics relate to the use of wood and excite the liveliest interest in the effect of wook sleathing as an interior surface for auditoriums: nor are these expectations disappointed when the phenomenon is submitted to exact measurement. It was not easy to find satisfactory conditions for the experiment, for not many rooms ale now constructed in which plaster on studding, and sufliciently thin, forms a very considerable factor. After long waiting a room suitable in every respect, except location, became available. Its floor, its whole wall, indeed. its ceiling was of pine sheathing. 'The only otlee material cutering into its construction was glass in the two windows and in the door. Infortunately, the room was on a prominent street. and immediately adjacent was an allnight hunch room. Aceurate experiments were out of the question while the lunch room was in use, and it was, therefore, bought out and closed for a few nights. Even with the freedom from noise thus secured, the experiments were not totally undisturbed. The traffic past the building did not stop sufficiently to permit of any olservations until after two o'clock in the morning, and began again hy four. During the intervening two hours, it was possible to snatch periods for observation, but even these periods were disturbed through the curiosity of passers and the more legitimate concern of the police.

Anticipating the phenomenon of resonance in wood in a more marked degree than in any other material, new apparatus was designed permitting of measurements at more frequent intervals of pitch. The new apparatus was not available when the work 


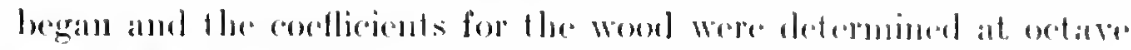
intervals, witl results as bollows:

$\mathrm{C}_{1}, .064 ; \mathrm{C}_{2}, .098 ; \mathrm{C}_{3}, .112 ; \mathrm{C}_{4}, .104 ; \mathrm{C}_{8}, .081 ; \mathrm{C}_{6}, .089 ; \mathrm{C}_{7}, .113$.

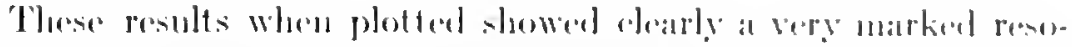

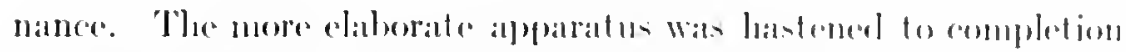
and the corflicionts of atsorption determined lome the intermediate

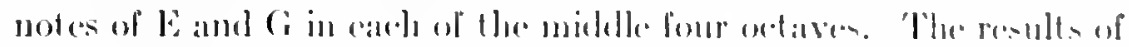
botle sets of experiments when plotted together give curve jo in

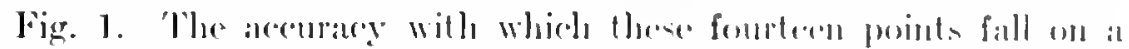

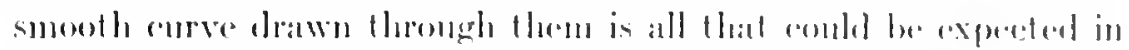

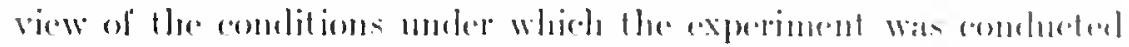

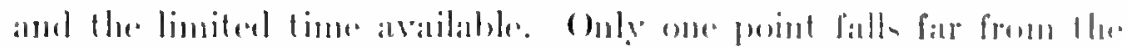

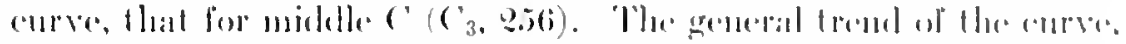

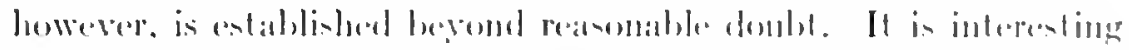

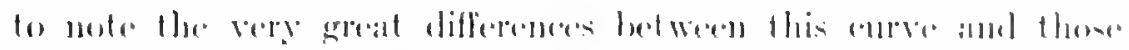

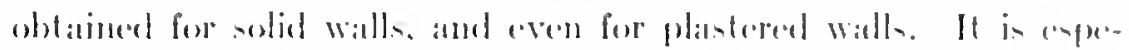

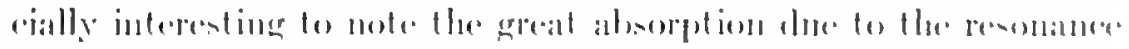

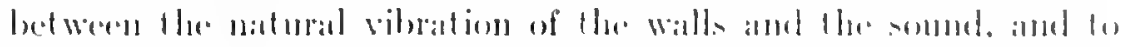

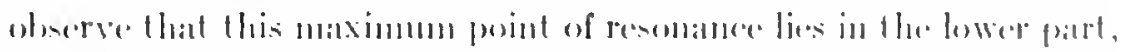

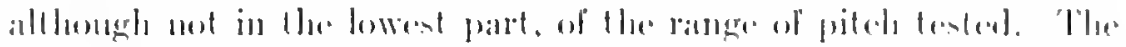

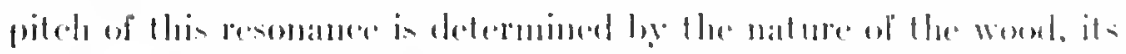

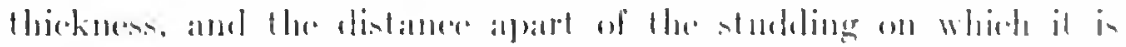

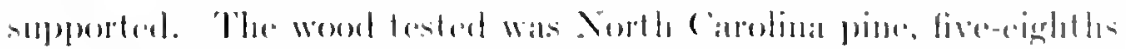

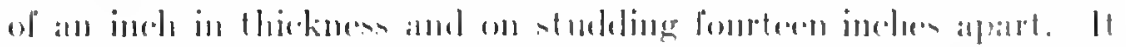

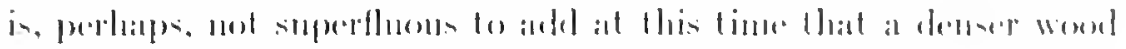

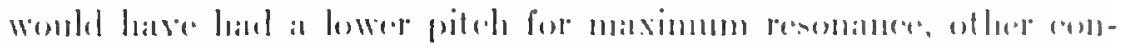

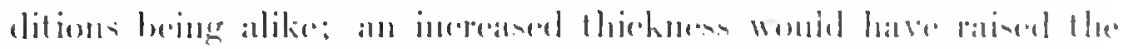

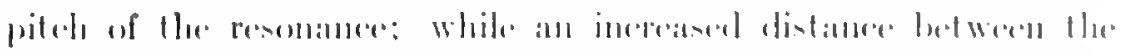

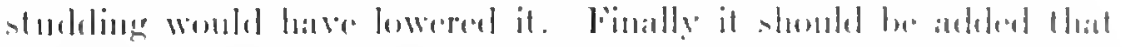

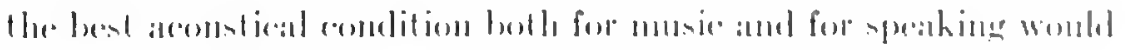

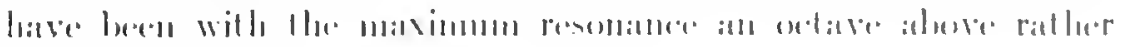
thath at milldle (')

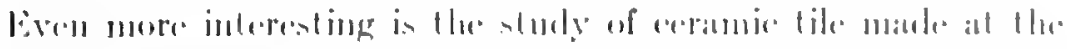

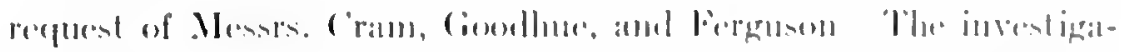

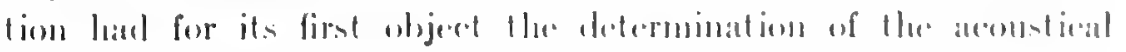

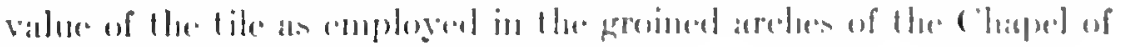


the lonited stintes Military Acarleny at West Point. The investigrat ion then widenerl its seope. and, through the skill and great knowledge of ceramie processes of Mr. Raphatel Guastavino, led to really remarkable results in the way of improved acoustical effi"iency. The resulting construction has not only been approved by architects as equal, if not better, in arehitectural appearance to weliniry tile construction. but it is, so f:ur as the writer knows, the first finished structural surface of large acoustical efficiency. Its random use does not, of course, guarantee good acoustical quality in in anditorim, for that depends on the amount used and the surface covered.

The first investigation was in regard to tile used at West Point, with the following result:

$\mathrm{C}_{1}, .019 ; \mathrm{C}_{2}, .013 ; \mathrm{C}_{3}, .018 ; \mathrm{C}_{4}, .099 ; \mathrm{C}_{5}, .040 ; \mathrm{C}_{6}, .048 ; \mathrm{C}_{7}, .053$.

These are plotted in Curve 1, Fig. 9. The first endearors to improve the tile acoustically hat very slight results, but such as they were they were incorporated in the tile of the ceiling of the First Baptist (hurch in Pittsburgl (Curve 2, Fig. 2).

$\mathrm{C}_{1}, .028 ; \mathrm{C}_{2}, .030 ; \mathrm{C}_{3}, .038 ; \mathrm{C}_{4}, .053 ; \mathrm{C}_{5} . .080 ; \mathrm{C}_{6}, .109 ; \mathrm{C}_{7}, .114$.

There was no expectation that the results of this would be more than a very slight amelioration of the difficulties which were to be expected in the church. In consequence of its use, the tile may be distinguished for purposes of tabulition as Pittsburgh Tile. Without following the intermediate steps, it is sufficient to say that the experiments were continued nearly two years longer and ultimately led to a tile which for the conveniences of tabulation we will call Acoustical 'Tile. The resulting absorbent power is far beyond what was conceived to be possible at the beginning of the investigation, and makes the construction in which this tile is incorporatcd unique in acoustical value among rigit structures. The coefficients for this construction are as follows:

$\mathrm{C}_{1}, .064 ; \mathrm{C}_{2}, .068 ; \mathrm{C}_{3}, .117 ; \mathrm{C}_{4}, .188 ; \mathrm{C}_{5}, .250 ; \mathrm{C}_{6}, .258 ; \mathrm{C}_{7}, .293$,

graphically shown in Curve 3 , Fig. 2 . It is not a panacea. There is, on the other hand, no question but that properly used it will very greatly ameliorate the acoustical difficulties when its employment 
is practicable, and used in proper lucations and anoments will render the acousties of many anditoriums axecollent which would otherwise be intolerable. It has over sixfold the absorbing power of any existing matsonry construction and one-third the alsorbing power of the

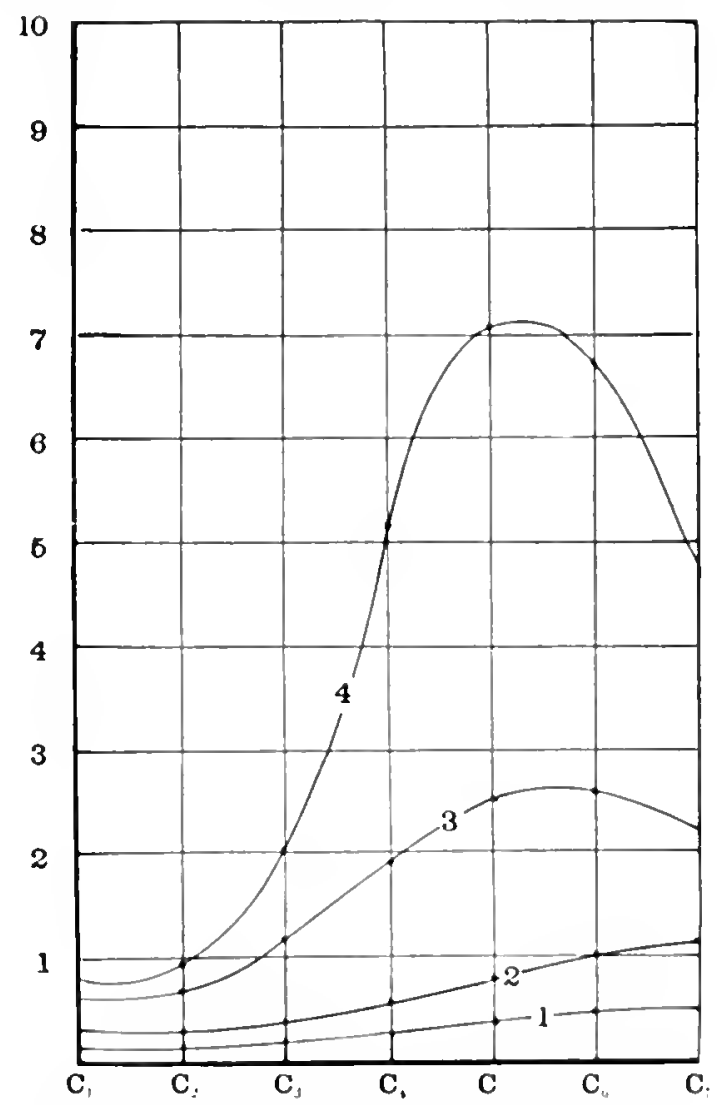

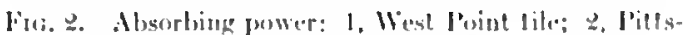

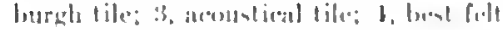

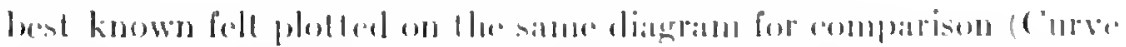

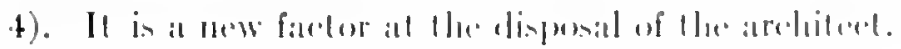

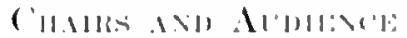

liqually inportanl will the watl allel coiling-ourfares of an

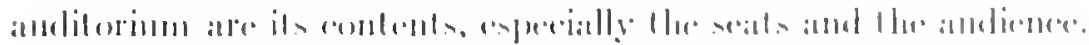

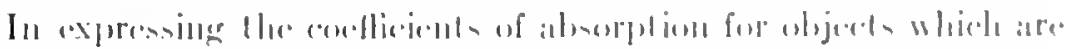

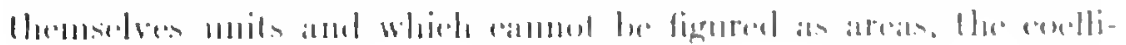


cients depenel on the sytem of measurement employed, Metric or English. While the inlermational or metric system has become universal exerpt in Jinglish speaking comt ries, and eren in England and Ameriea in miny ficlds, it has not yet been adopted by the

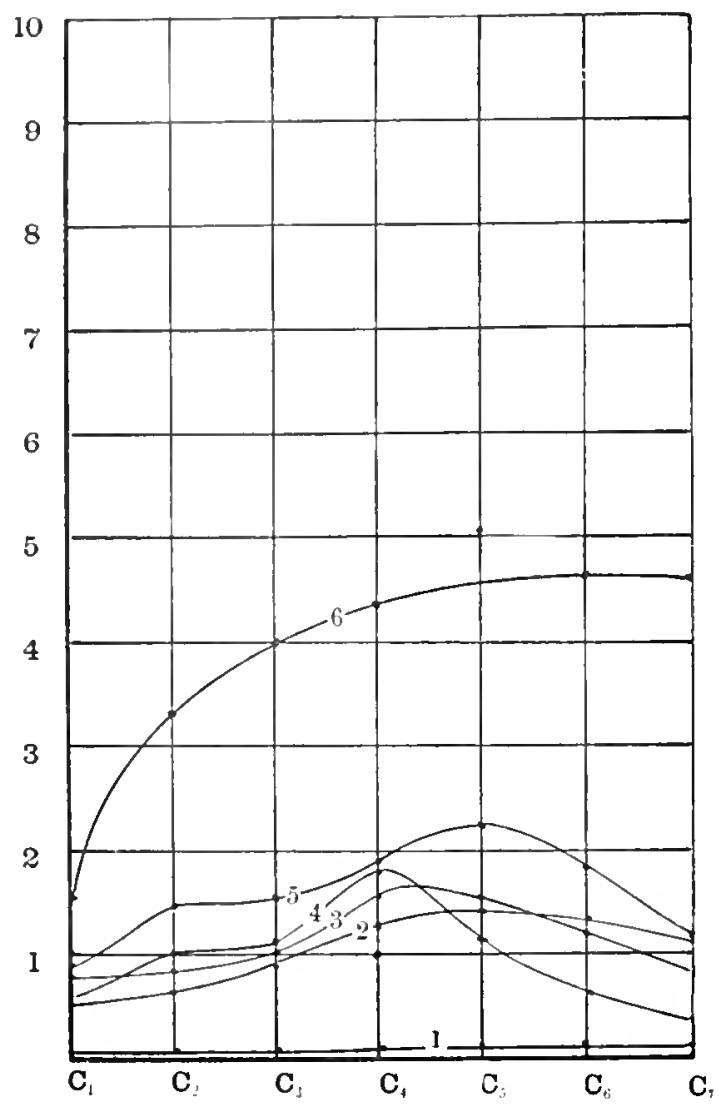

Fig. 3. Absorbing power: 1, bent wood chairs; $2,3,4$, and 5 , various kinds of pew cushions as described in texl: 6, audience per person.

arehitectural profession and by the bnilding trades, and therefore these coeflicients will be given in both systems.

Ash settces or clairs, such as are ordinarily to be found in a college lecture-room, have exceedingly small absorbing powers. Such furniture forms a very small factor in the acoustics of any anditorium in which it is employed. The coefficients for ash chairs are as follows (Curve 1, Fig. 3): 


\section{Metric}

$C_{1}, .014 ; C_{2}, .014 ; C_{3}, .015 ; C_{4}, .016 ; C_{3}, .017 ; C_{6}, .019 ; C_{7}, .031$.

\section{English}

$$
\mathrm{C}_{1}, .15 ; \mathrm{C}_{2}, .15 ; \mathrm{C}_{3}, .16 ; \mathrm{C}_{4}, .17 ; \mathrm{C}_{8}, .18 ; \mathrm{C}_{6}, .80 ; \mathrm{C}_{7}, 93 .
$$

The coefficients for setteres were also dedormined, but ditlor so little from these for edatirs that this paper will mest he burdemed with them. When, howevere, the seats are uphohtered. they immerliately. become a considerable facetor in the alcoust ies of and emply, or parr-

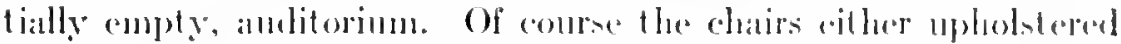
or amupleststered ane not a faretor in the acousties of the amelitorinm

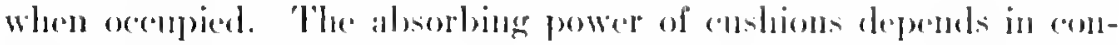
siderable measure mon the nature of the covering and upon the nat are of the patding. 'The chshions experimenterl ajom wore such

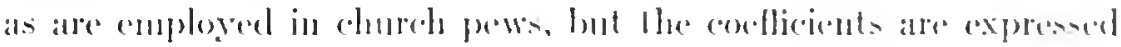

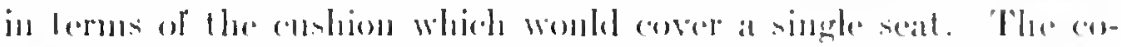

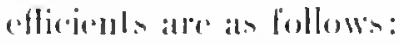

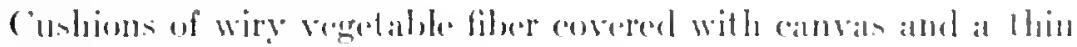

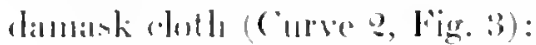

\section{Metric}

( ${ }_{1}, .060 ; \mathrm{C}_{2}, .070 ; \mathrm{C}_{3}, .097 ; \mathrm{C}_{4}, .13 .5 ; \mathrm{C}_{5}, .148 ; \mathrm{C}_{6}, .132 ; \mathrm{C}_{7}, .11 .5$.

\section{linglish}

$$
\left.C_{1}, .64 ; C_{2}, 75 ; C_{3}, 1.04 ; C_{4}, 1.45 ; C_{5}, 1.59\right) C_{6} .1 .42 ; C_{7}, 1.94 .
$$

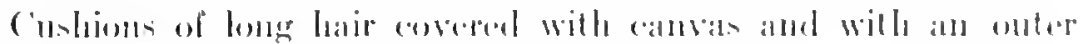

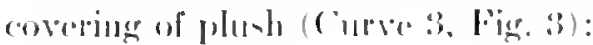

\section{Metric}

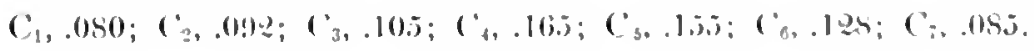

limplish

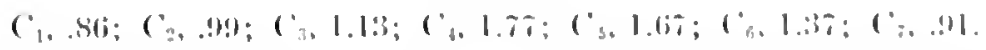

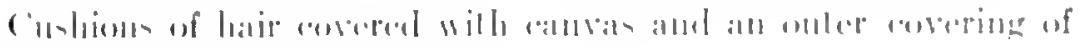

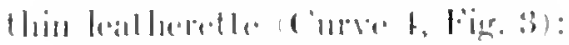

\section{Metrir}

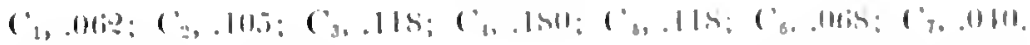




$$
\begin{gathered}
\text { English } \\
\mathrm{C}_{1}, .67 ; \mathrm{C}_{2}, 1.13 ; \mathrm{C}_{3}, 1.27 ; \mathrm{C}_{4}, 1.93 ; \mathrm{C}_{5} .1 .27 ; \mathrm{C}_{6} . .73 ; \mathrm{C}_{7}, .43 .
\end{gathered}
$$

Eilastic felt cushions of commerce, elastic cotton covered with canvas and a short nap plush (Curve 5, Fig. 3):

\section{Metric}

$\mathrm{C}_{1}, .092 ; \mathrm{C}_{2}, .155 ; \mathrm{C}_{3}, .175 ; \mathrm{C}_{4}, .190 ; \mathrm{C}_{5}, .958 ; \mathrm{C}_{6}, .182 ; \mathrm{C}_{7}, 120$.

\section{English}

$\mathrm{C}_{1}, .99 ; \mathrm{C}_{2}, 1.66 ; \mathrm{C}_{3}, 1.88 ; \mathrm{C}_{4}, 9.04 ; \mathrm{C}_{5} .2 .77 ; \mathrm{C}_{6}, 1.95 ; \mathrm{C}_{7}, 1.99$.

Of all the coeffieients of absorption, obviously the most difficult to determine are those for the audience itself. It would not at all serve to experiment on single persons and to assume that when a number are seated together, side by side, and in front of one another, the absorbing power is the same. It is necessary to make the experiment on a full audience, and to conduct such an experiment refuires the nearly perfect silence of several hundred persons, the least noise on the part of one vitiating the observation. That the experiment was ultimately successful beyond all expectation is due to the remarkable silence maintained by a large Cambridge audience that volunteered itself for the purpose, not merely once, but on four separate occasions. 'The coefficients of absorption thus determined lie, with but a single exception, on a smooth curve (Curve 6 , Fig. 3). 'The single exception was occasioned by the sound of at distant street car. Correcting this observation to the curve, the coefficients for an audience per person are as follows:

\section{Metric}

$$
\begin{aligned}
& \mathrm{C}_{1}, .160 ; \mathrm{C}_{2}, .392 ; \mathrm{C}_{3}, .395 ; \mathrm{C}_{4} . .440 ; \mathrm{C}_{5}, .455 ; \mathrm{C}_{6}, .460 ; \mathrm{C}_{7}, .460 . \\
& \text { English } \\
& \mathrm{C}_{1}, 1.72 ; \mathrm{C}_{2}, 3.56 ; \mathrm{C}_{3}, 4.95 ; \mathrm{C}_{4}, 4.72 ; \mathrm{C}_{5}, 4.70 ; \mathrm{C}_{6}, 4.95 ; \mathrm{C}_{7}, 4.95 .
\end{aligned}
$$

\section{Fabrics}

It is evident from the above discussion that fabrics are high absorbents of sound. How effective any particular fabric may be, depends not merely on the texture of its surface and the material, 
but upon the weave or felting throughout its body, and of course, also upon its thickness. An illuminating study of this question can be made by moans of the curves in Fig. t. In this figure are plotted the coefficients of alssorption for varying thicknesses of $f$ elt. Curve 1 is the absorption eurve for falt of one-half inch thickness.

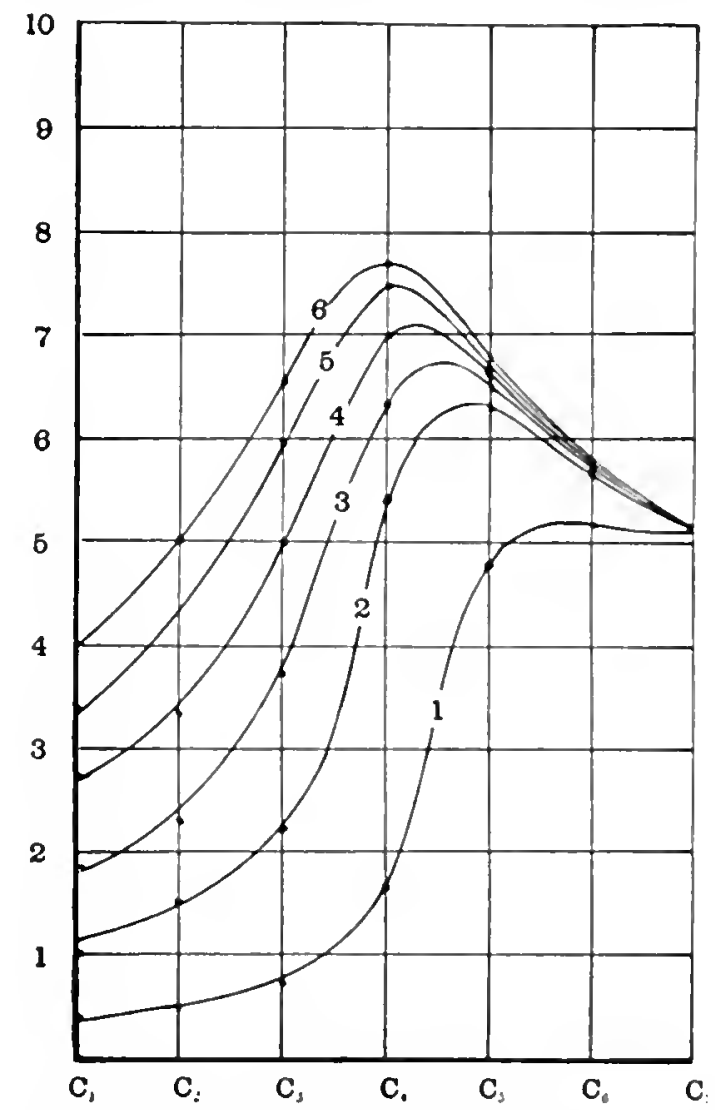

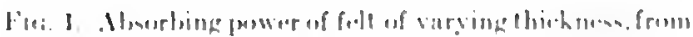

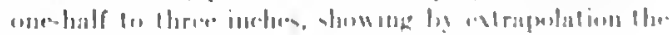

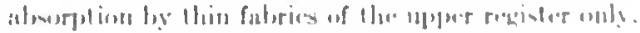

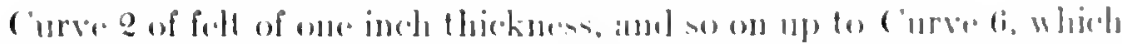

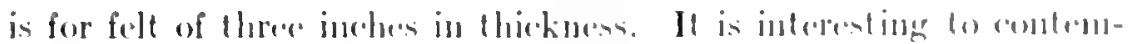
plate what the result of the prosess would he were it contiumelel to

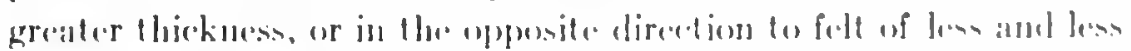

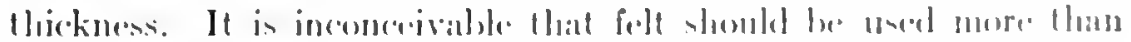

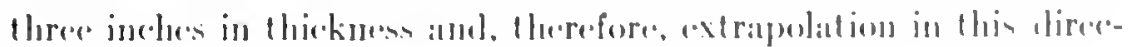


tion is of alcademie interest only. On the other hand, felt with decreasing thickness corresponds more and more to ordinary fabrics. If this process were carried to all extreme, it would show the effeed

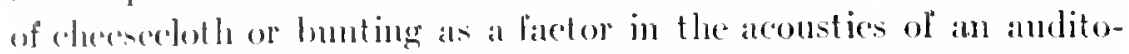
rimm. It is obvious that very thin fabries absorb only the highest motes and anc negligible factors in the range of either the speaking roice of of music. (On the other hand, it is evident that great thickness of felt absorls the lower register without increasing whatever its abouption for the upper register. Sometimes it is desirable to absuth the lowere register, sometines the upper register, but far more often it is aleinable lo absorb the somuds from $C_{3}$ to $C_{6}$. but esperially in the octave between $C_{4}$ and $C_{5}$.

'The felt used in these experiments was of a durable nature and largely componed of jute. Becanse wool felt and ordinary hair felt are subject to rapid deterioration from moths. this jute felt was the only ane which could be recommented for the correction of anditorimms until an interested participator in these investigations dereloped an especially prepared hair folt, which is less expensive than jute lelt, but which is much more absorbent. Its absorption curve is plotted in Fig. 2.

\section{LoCitION}

Such a discussion as this should not close without pointing ont the triple relation between pitch, location, and apparent power of ahoorption. 'This is shown in Fig. 5. Curve 1 shows the true coaflicient of absorplion of an especially effective felt. Curve 2 is its apparent absorption when placed in a position which is one of londness for the lower register and of relative silence for the upper register. Curve 3 is the apparent coefficient of absorption of the sime felt when placed in a position in the room of maximmm loudness for all registers. It is evident from these three curves that in onc position a felt may lose thirty per cent and over of its efficieney in the most significant register, or may have its efficiency nearly doubled. These curves relate to the efficiency of the felt in its effect on general reverberation. Its effieiency in the reduction of a discrete ceho is dependent to an even greater degree on its location than on pitch. 
The above are the coeflicients of alsorption for most materials usually occursing in anditorimm construction, but there are certain omissions which it is highly desiralle to supply, particularly noticeable among these is the aboorption corve for glasis and for old plaster.

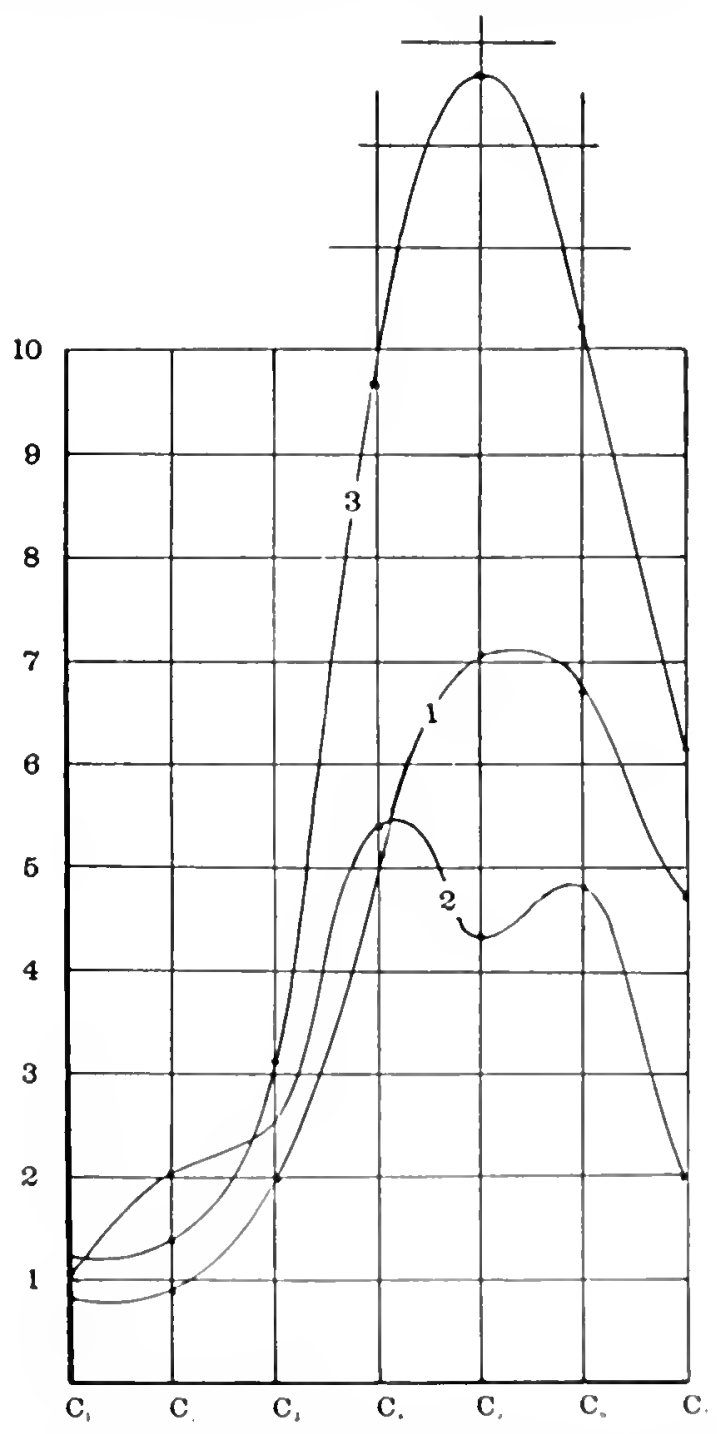

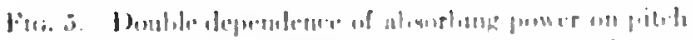

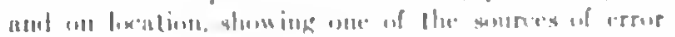

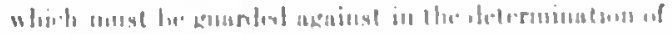

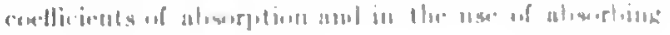
tumlerinls. 
It is necessary for such experiments that rooms practically free from furniture slould be avilatble and that the walls and ceiling of the room shomlel he composed in a large neasure of the material to be tested. 'The author would appreeiate any opportunity to carry out such experiments. The opportunity would ordinarily occur in the construction of a new buileling or in the remodeling of an old one.

It may be not wholly out of place to point out another modern acoustical elifficulty and to seek opportunities for securing the necessary data for its solution. Coincident with the increased use of reënforced concrete construction and some other building forms there has come increased complaint of the transmission of sound from room to room, either through the walls or through the floors. Whether the present general complaint is due to new materials and new methods of construction, or to a greater sensitiveness to unnecessiry noise, or whether it is due to greater sources of disturbance, heavier traffic, heavier ears and wagons, elcrators, and elevator doors, where elevators were not used before, - whatever the cause of the annoyance there is urgent need of its abatement in so far as it is structurally possible. Moreover, scveral buildings have shown that not infrequently elaborate precautions have resulted disastrously, sometimes fundamentally, sometimes through the oversight of details which to casual consideration seem of minor importance. Iere, as in the acousties of auditoriums, the eonditions are so complicated that only a systematie and accurately quantitative investigation will yield safe eonclusions. Some headway, perhaps half a year's work, little more than a beginning, was made in this investigation some years ago. Methods of measurements were devcloped and some results were obtained. Within the past month the use of a room in a new building, together with that of the room immediately below it, has been secured for the period of two years. Between these rooms the floor will be laid in reënforced concrete of two thicknesses, five inches and ten inehes, in hollow tile, in brick arch, in mill construction, and with hung ceiling, and the transmission of sound tested in each case. The upper surface of the floor will be laid in tile, in hardwood, with and without sound-deadening lining, and covered with linoleum and cork, and its noise to the tread measured. 
However, such experiments but lay the founclation. What is needed are lests of the walls and floors of rooms of varions sizes, and of the more varied construction which oecurs in practice, in rooms connecting with offsets and different floor leveds, - the complicated condition of actual building as against the simplified conditions of an orderly experinent. The one will give numerical coefficients, the other, if in sufliciently full mesisure, will give experience leatling to generalization which may be so formulated as to be of wide value. What is therefore sought is the opportunity to experiment in romm of varied but accurately known construction, espectally where the insulation has beens successful. I'nfortmately, with modern building materials aconstical diflieult ies of all sorts are very mumerons. 



\section{ARCHITECTURAI, ACOUSTICS}

B

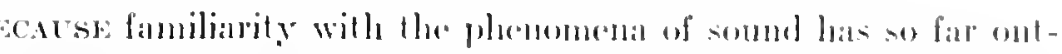
stripped the adecpuate study of the problems invelved, mang of them

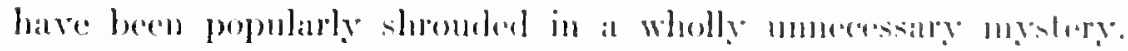

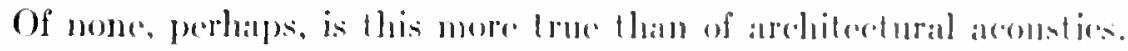
'The conditions surrounding the lamsunisom of sperech in an enclosed anditorimu are complicaled, it is toles, hul are only such as will yoeld an exact solution in the light of aldeplate datal. It is, in other words, a rational anginererime problems.

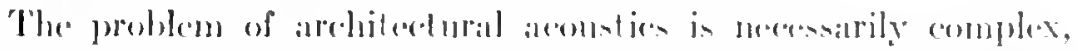

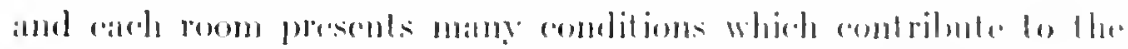

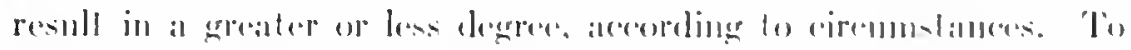

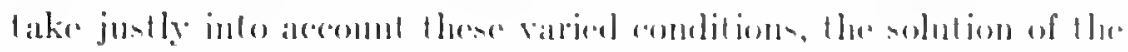

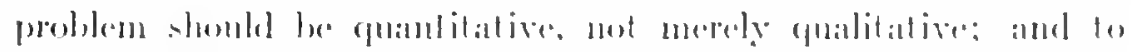

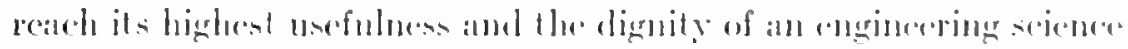

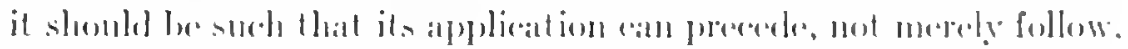
Hare comstruction of the hribling.

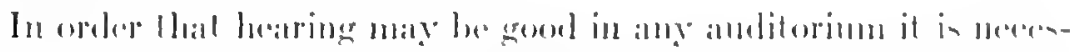

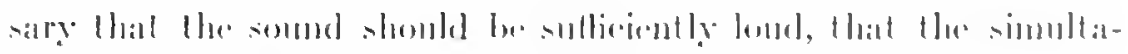

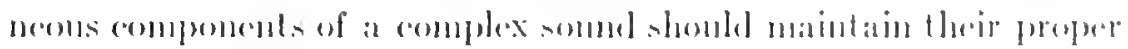

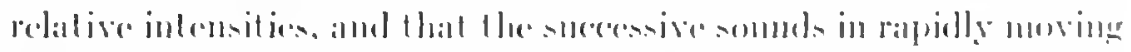

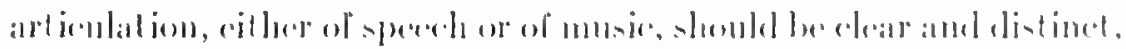

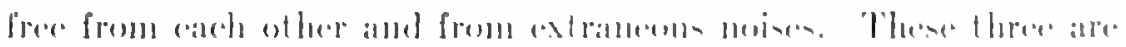

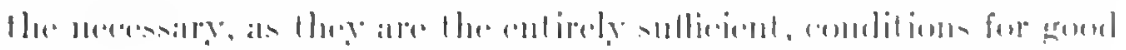

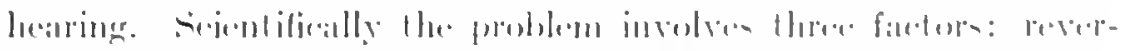

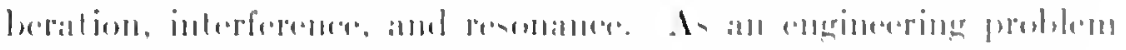

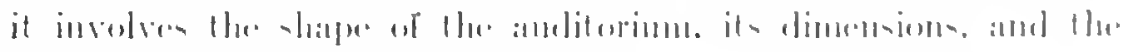
matrorials of whirds it i- anmpument.

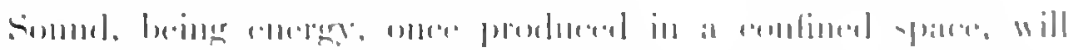

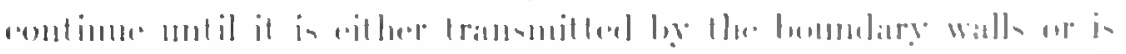

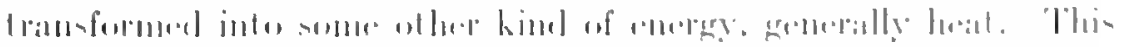

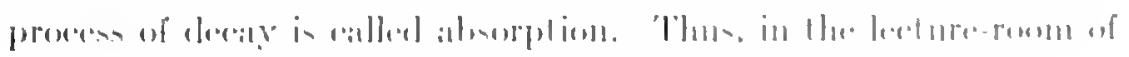

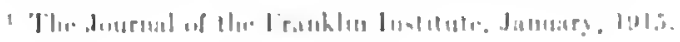


Ilarvarel Pniversity, in which, and in behalf of which, this investigation wils beernu, the rate of absorption was so small that a word spoken in an orelinary tone of voiee was audible for five and a half seconds att rwarels. During this time even a very deliberate speaker womld hare uttered the twelve or fifteen succeeding syllables. Thus the suecessive emunciations blented into a loud sound, through which and above which it was necessary to hear and distinguish the orderly progression of the speech. Across the room this could not he done; even near the speaker it could be done only with an effort wearisome in the extreme if long maintained. Witl an audience filling the roon the conditions were not so bad, but still not tolerable. This may be regarded, if one so chooses, as a process of multiple refleetion from walls, from ceiling, and from floor, first from one and then another, losing a little at each reflection until ultimately inatulible. This phenomenon will be called reverberation, including, as a special case, the echo. It must be observed, however, that, in general, reverberation results in a mass of sound filling the whole roon and incapable of analysis into its distinct reflections. It is thus more difficult to recognize and impossible to locate. The term "ccho" will be reserved for that particular case in which a short, shatrp sount is distinctly repeated by reflection, either once from a single surface, or several times from two or more surfaces. In the general case of reverberation we are concerned only with the rate of deeay of the sonnd. In the special case of the echo we are concerned not merely with its intensity, but with the interval of time elapsing between the initial sound and the moment it reaches the observer. In the room mentioned as the occasion of this investigation no dis(rete echo was distinctly perceptible, and the case will serve excellently as an illustration of the more general type of reverberation. After preliminary gropings, first in the literature and then with several optical devices for measuring the intensity of sound, all established methods were abandoned. Instead, the rate of decay was measured by measuring what was inversely proportional to it, - the duration of audibility of the reverberation, or, as it will be called here, the duration of andibility of the residual sonnd. These experiments may be explained to alvantage here, for they will give more dearly than would abstract discussion an idea of the nature 
of reverberation. Broarlly considered, there atre two, and only two, variables in a room. - shape (inclueling size) and matrials (indueling furnishings). In designing an anditorium an arrehitect ran give consideration to both; in repail work for batel aleonstic conditions it is generally injuracticable to (diange the shatpe, and only vatriations in materials and fornishings are allowable. This wats, therefore, the line of work in this calse. It Wals avident that, other things heing equal, the rate at which the reverberation would disappear was proportional to the rate at which the sound was absorbed. 'The first work, therefore, was to determine the redalive absorbing pewer

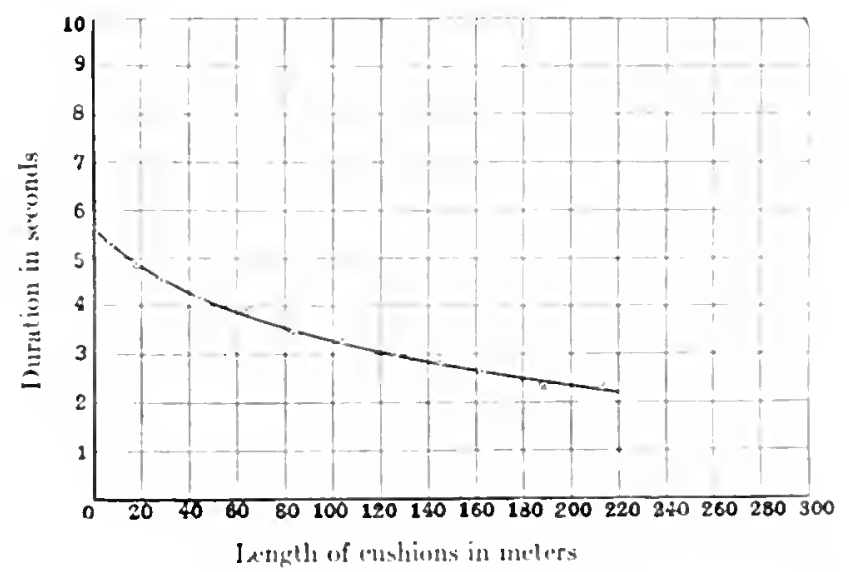

Fig. J. Curve showing the relation of the duration of the pesidual sound to the atded alowrling materiat.

of variens subatances. Witla an organ pipe as a comstant souree of

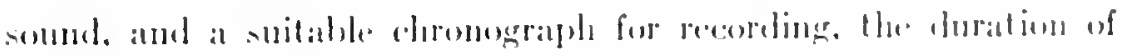

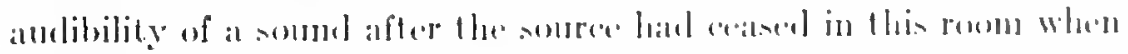

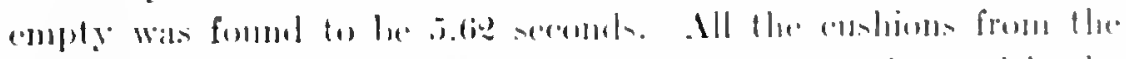

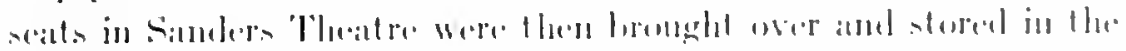

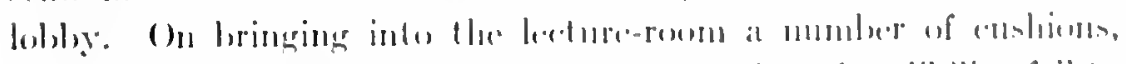

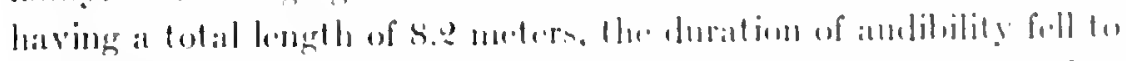

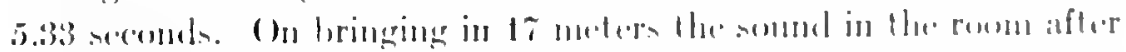

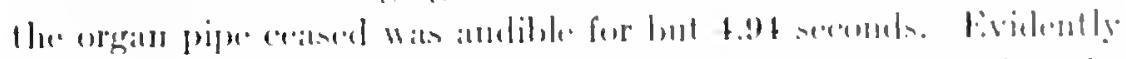

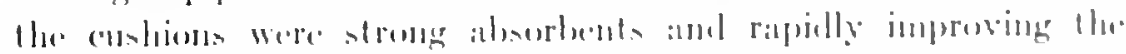

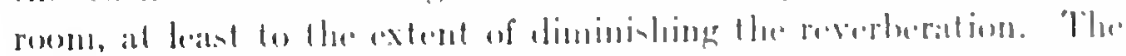

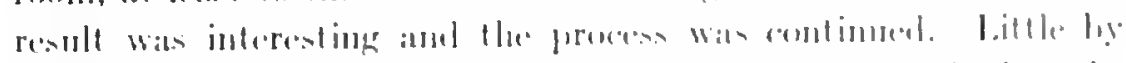

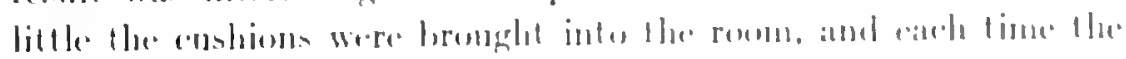


duration of andilility was measured. When all the seats (436 in numlerr) Were covereed, the sommel was andible for 2.03 seconds. 'There the aisles were coveresl, and then the platform. Still there were more cmolions.- alnost half as many more. These were bronght into the roont, al lew at a time, as before, and draped on a seaflulding that hat bern creseded around the room, the duration of the somel heing recorted each linte. Finally, when all the eushions from at theatre souting nearly fifteen humdred persons were plaeed in the room - covering the seats, the aisles, the platform, the rear wall to the ceiling - the duration of andibility of the residual somed

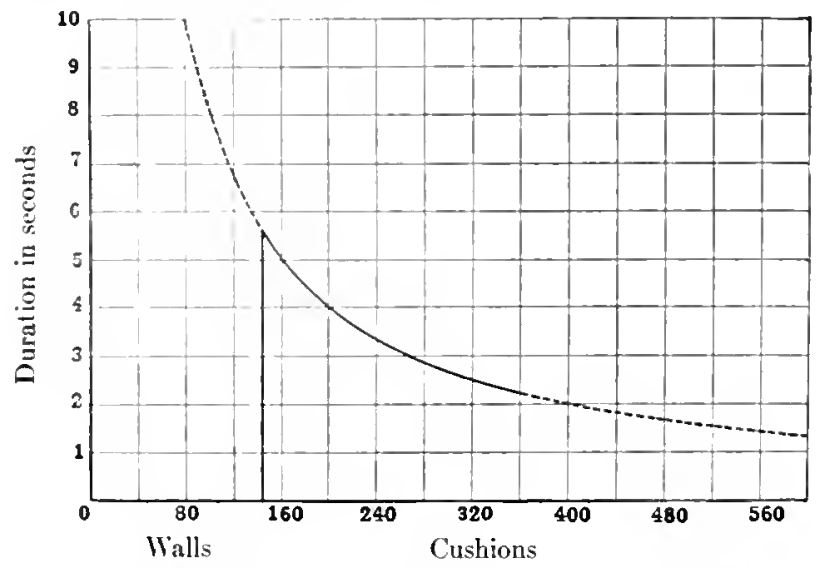

Fig. 2. Curve 5 plotted as part of its corresponding reetangular hyperbola. The solid part was determined experimentally; the displacemenl of this to the right measures the absorbing power of the walls of the room.

wats 1.14 seeonds. 'This experiment, requiring, of eourse, several nights work, having been completed, all the cushions were removed and the room was in readiness for the test of other absorbents. It was evident that a standard of comparison had been established. Curtains of ehenille, 1.1 meters wide and 17 meters in total length, were draped in the room. The duration of audibility was then 4.51 seomels. 'Tuming to the data that had just been collected, it appeared that this amount of chenille was equivalent to 30 meters of Sanders Theatre enshions. Oriental rugs (Iterez, Demirjik, and Himloostanee) were tested in a similar manner, as were also eretonne coth, canvas, and hair lelt. Similar experiments, but in a smaller 
room, determined the absorbing power of a 13 an amb of a woman, ahways by determining the number of punning meters of simnders Theatre cushions that wenld produce the same effect. Tlais process of comparing two absorbents by actually subtituting one for the other is bahorioms, and it is given here only to shew the first steps in the development of a metherl. Withent going into details, it is suflicient here to say that this method wass so perfected ate to grive not merely relative, but albsolute, coeflicients of athorption.

In this manner a mumber of coeflicients of absorption were destermined for objerts and materials which conla be bromght inte and removed from the room, for soumds having a pitch an octare above midsle $($. In the following table the mumerical values alre the atheolute coeflicients of the allamption:

\begin{tabular}{|c|c|c|}
\hline rolusive of franess & & . \\
\hline arpel rugs, . . . . & & .20 \\
\hline riental roges, extral luavy. & & 只y \\
\hline huerserelull $\ldots . .$. & & $.01 !$ \\
\hline Sretomene retett. & & .1 .5 \\
\hline urtaills & & $\therefore 3$ \\
\hline inck, s cm. from wal & . & is \\
\hline linse on flum & & .16 \\
\hline mase an themer. & & 19 \\
\hline
\end{tabular}

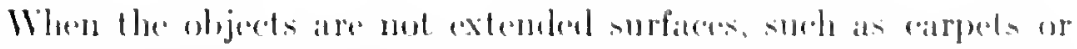
rugs, but essentially spatcial unils, it is not rasy to express the alsorption ats an absolute comeflicient. In the following table the

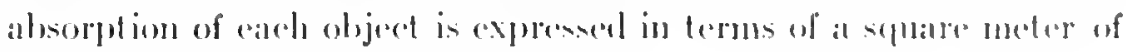
rempleteralowrotion:

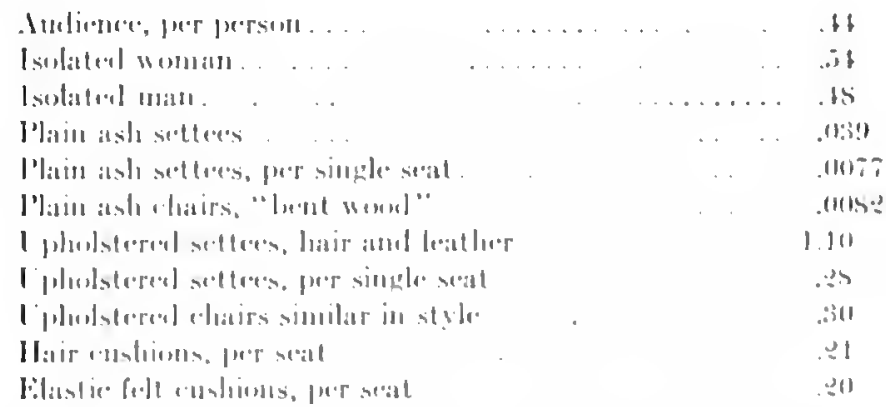

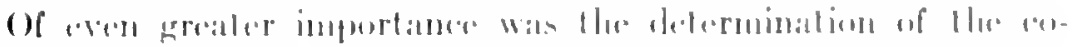

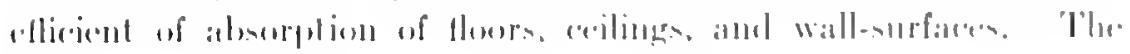


accomplishment of this called for a very" eonsiderable extension of the method adopted. If the reverberation in a roon as ehanged by the aldition of absorbing material be plotted, the resulting eurve will be found to be a portion of an lyperbola with displaced axes. An example of such a curve, as obtaned in the lectureroom of the Fogg Art Musemun, in Cambridge, is plotted in the diagram, Fig. 1. If now the origin of this eurve be displaced so that the axes of coördinates are the asymptotes of the reetangular hiperbola, the displacement of the origin measures the initial ab-

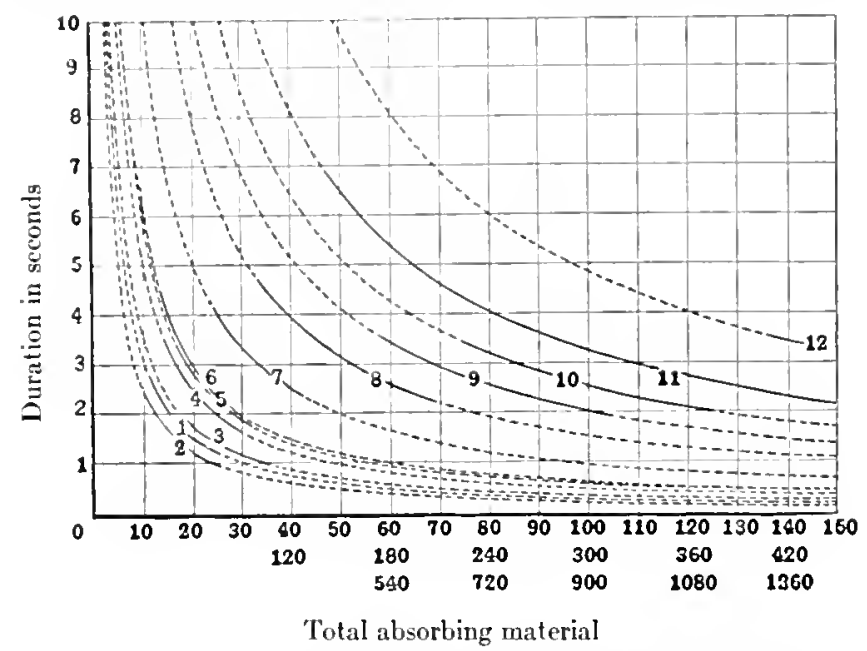

FIG. 3. The curves of Figs. 8 and 9 entered as parts of their corresponding rectangular hyperbolas. Three scales are employed for the volumes by groups 1-7, 8-11, and 12.

sorbing power of the room, its floors, walls, and eeilings. Such experiments were earried out in a large number of rooms in which the different component materials entered in very different degrees, and an elimination between these different experiments gave the following eoeffieient of absorption for different materials:

Open window . . . . . . . . . . . . . . . . 1.000

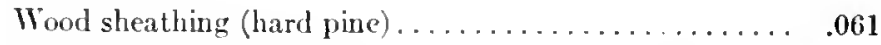

Plaster on wood lath...................... . .034

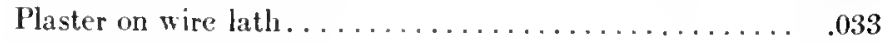

Glass, single thickness. . . . . . . . . . . . . . . . .0. .027

Plaster on tile. . . . . . . . . . . . . . . . . . . . .025

Brick set in Portland cement. . . . . . . . . . . . . . 025 
If the experinernts in these rooms are plothed in al single diatgram, the result is a family of hypertolate showing a very interenting relationshipg to the volumes of the rooms. Inderenl, if from there hyperbolats the parameter, which ecplats the product of the coordinates, be determined, it will be lound to be linearly proportional to the volume of the room. These results are plotted in Fig. 4, showing how strict the proportionality in eren over a very great range in volume. Wre have thus al halld a ready mothod of

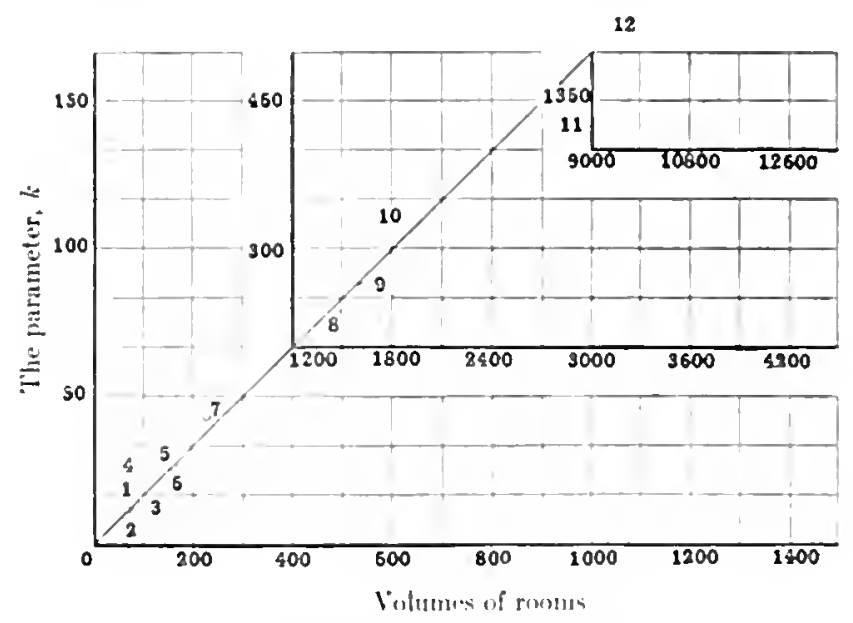

Fui, 1. The parameler, k, plothed against the volumes of the rooms. slaswing llä lwo proporlional.

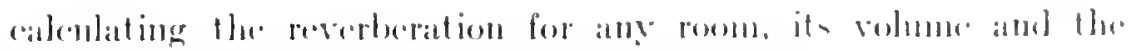
matrerials of which it is compenod bering known.

The first five yeats of the inseretigation were devoted to violin

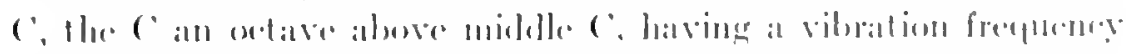

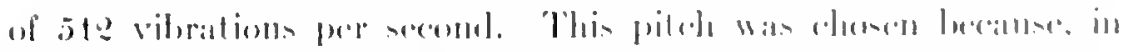

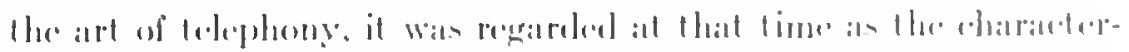

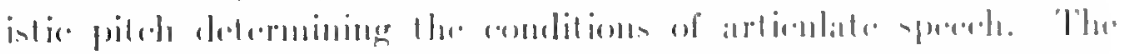

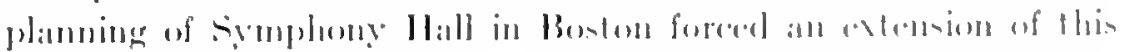

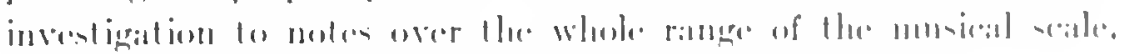

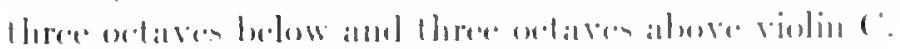

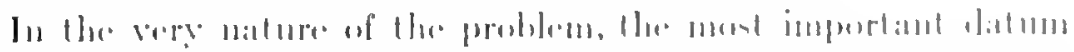

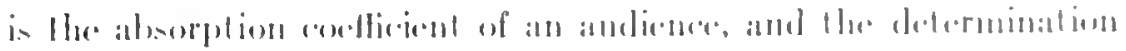

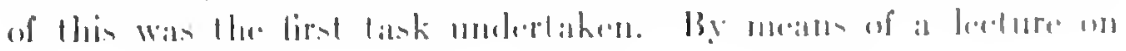


one of the leoent developments of plysics, wireless telegraphy, an andience was thus drawn logether and at the end of the leeture refunestred to reman for the aperiment. In this attempt the effort wis made to determine the coeflicients for the five octaves from

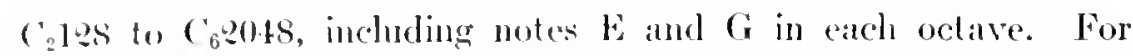
several reasoms the experinent was not a suceess. A threatening thmulerstorm mate the andience a small one, and the sultriness of the atmosphere mate open windows necessary, while the allempt to cover so many notes, thirteen in all, prolonged the experinent lergond the enthraner of the andience. While this experinent failed, another the following summer was more suceessful. In the year that had elapsed the necessity of earrying the investigation firther than the linits intended beeame evident, and now the experiment was carried from $\mathrm{C}_{1} 6+$ to $\mathrm{C}_{7}+096$. But included only the C notes, seven notes in all. Moreover, bearing in mind the experiences of the previous summer, it was recognized that even severn notes would eome dangerously near overtaxing the patience of the andience. Inasmuch as the eoefficient of absorption for $\mathrm{C}_{4} 51 \mathrm{~s}$ had already been determined six years before, in the investigations mentioned. the coeffieient for this note was not redetermined. 'The experiment was therefore earried ont for the lower three and the upper three notes of the seren. The audience, on the night of this experinent, was much larger than that which came the previous sumner, the night was a more confortable one, and it was possible to close the windows during the experiment. The conditions were thus fairly sat isfactory. In order to get as much data as possible, and in as short a time, there were nine observers stationed at different points in the room. 'These observers, whose kindness and skill it is il pleasure to acknowledge, had prepared themselves, by previous praclice, for this one experiment. 'Tle results of the experinent are slown on the lower curve in Fig. 5. This curve gives the coefficient of absorption per person. It is to be observed that one of the points falls clearly off the smooth eurve drawn through the other points.' The observations on which this point is based were, however, much disturbed by a street ear passing not far from the building. and the departure of this observation from the curve does not

1 This point, evidently on the ordinate $C_{5}$, is onitted in the original cut. - Editor. 
indicate a real departure in the coefficient, nor should it cast much doubt on the rest of the work, in view of the circumstinces under which it was secured. Comuteraeting the, perhaps, bad impression

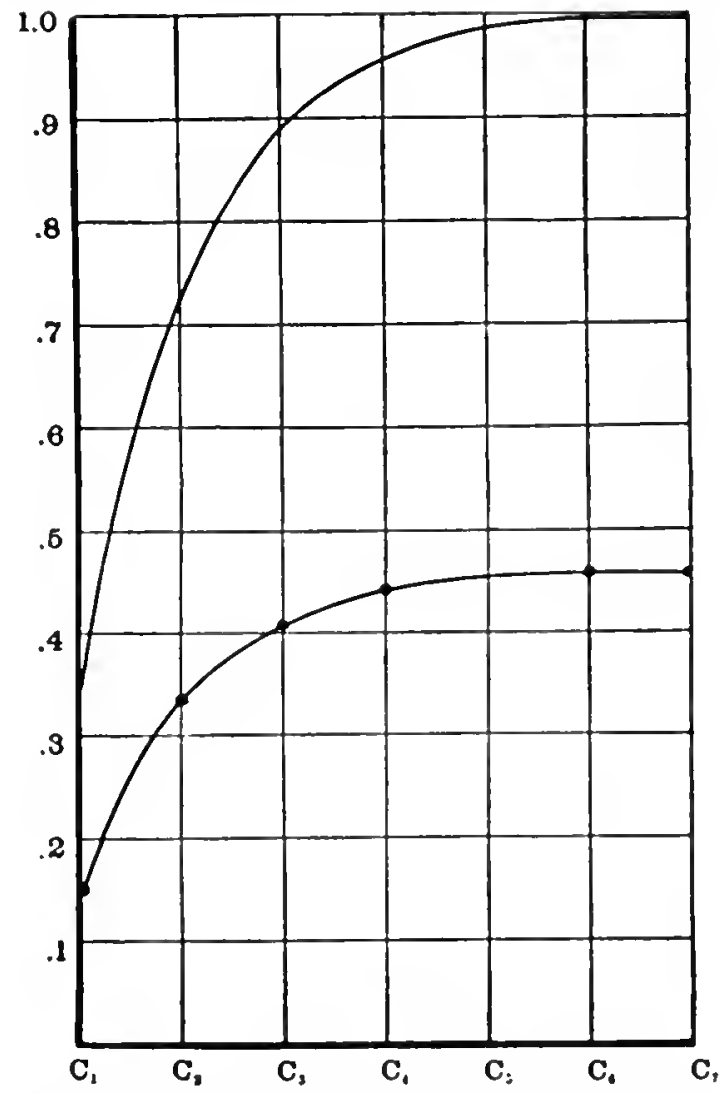

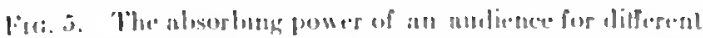

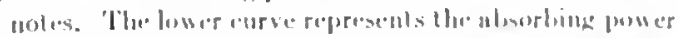

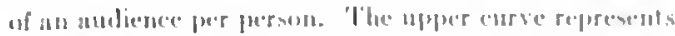

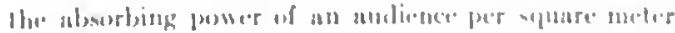

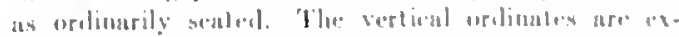

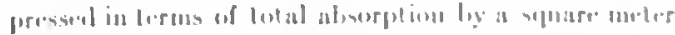

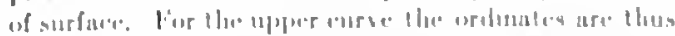

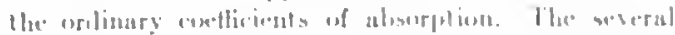

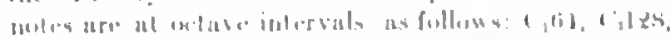

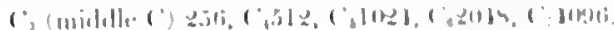

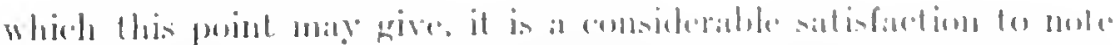

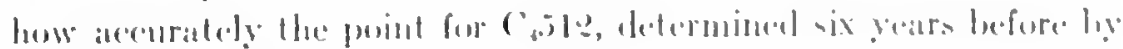

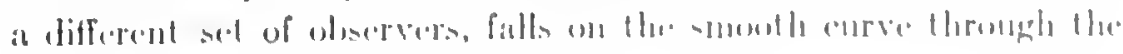


remaining points. In the audienee on whieh these observations were taken there were 77 women and 105 men. The eourtesy of the audienee in remaining for the experiment and the really remarkable silence which they maintained are gratefully acknowledged.

The next experiment was on the determination of the absorption of sound by wool sheathing. It is not an easy matter to find conditions suitable for this experiment. The room in which the absorption by wood sheathing was determined in the earlier experiments was not available for these. It was available then only because the building was new and empty. When these more elaborate experiments were under way the room became oceupied, and in a manner that did not admit of its being eleared. Quite a little searehing in the neighlorhood of Boston failed to discover an entirely suitable room. The best one available adjoined a night lunch room. The night hnels was bought out for a couple of nights, and the experiment was tried. The work of both nights was much disturbed. The traffie past the building did not stop until nearly two o'eloek, and began again at four. The interest of those passing on foot throughout the night, and the neeessity of repeated explanations to the poliee, greatly interfered with the work. This detailed statement of the conditions under whieh the experiment was tried is made ly way of explanation of the irregularity of the observations reeorded on the eurve, and of the failure to carry this particular line of work further. The first night seven points were obtained for the seven notes $\mathrm{C}_{1} 64$ to $\mathrm{C}_{7} 4096$. The reduction of these results on the following day showed variations indieative of maxima and minima, whiels, to be aecurately loeated, would require the determination of intermediate points. In the experiment the following night points were determined for the $\mathrm{E}$ and $\mathrm{G}$ notes in eaels octave between $\mathrm{C}_{2} 128$ and $\mathrm{C}_{6}$ 9048. Other points would have been determined, but time diel not permit. It is obvious that the intermediate points in the lower and in the ligher oetave were desirable, but no pipes were to be had on such short notice for this part of the range, and in their absence the data could not be obtained. In the diagram, Fig. 6, the points lying on the vertical lines were determined the first night. The points lying 
between the vertical lines were determined the second night. 'The accuracy with which these points fall on a smooth curve is, perhaps,

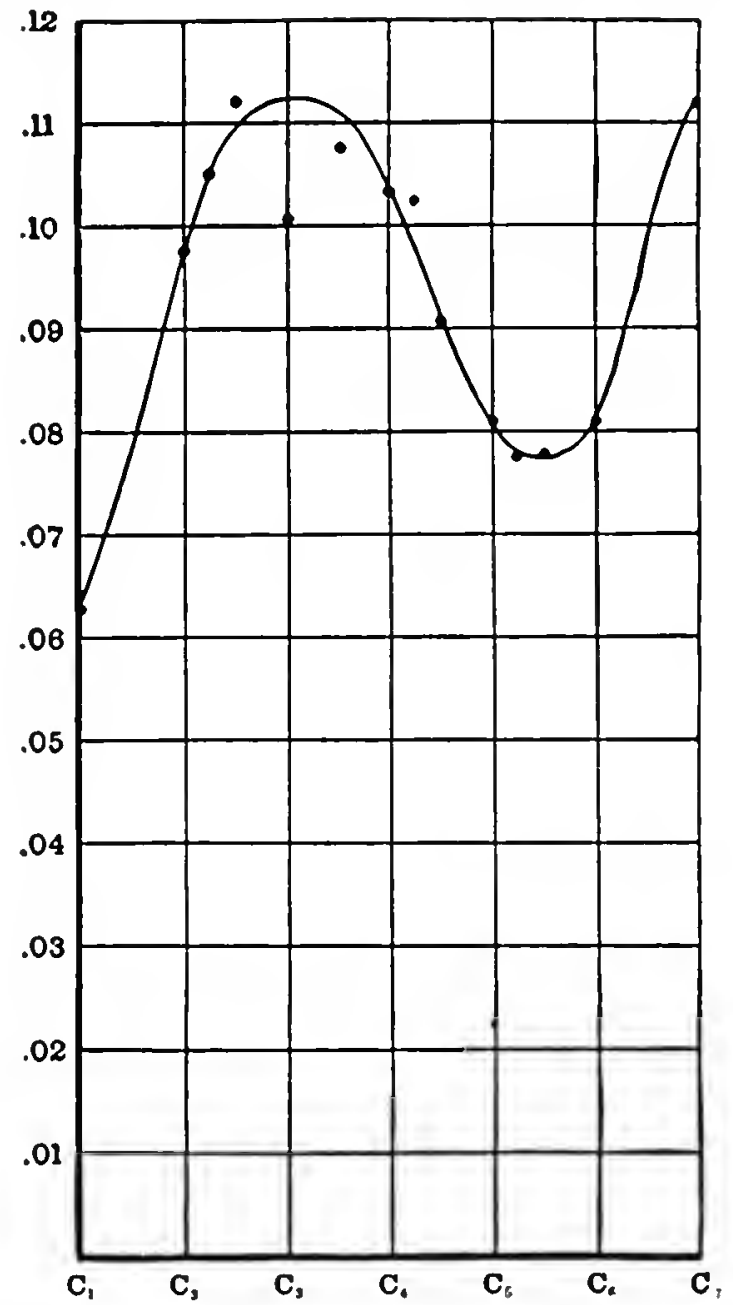

Fra. li. The absorbing powerof woud sluathing. ewo centimeters think, Xorth citrolina pine. 'l'he olservations wore make under very unsuitalole comblitions. The abserption is here alue almost "hully to yideling of the sheathing as a whole, the surface lecing shedlacked, smanth, ame non-perous. "Whe curve shows on" point of resename within the range lested, amel the probability of anotler perint of resonabee abovere It is not pussible num lo lemen as mon in regarel to the framing and arrangement of the sludefing in the particular room

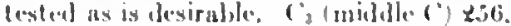


all that could be expected in view of the difliculty nuder which the observations were conducted and the linited time avalable. One point in particular falls far off from this curve, the point for $\mathrm{C}_{3} 256$, ly an anount which is, to say the least, serions, and which can be justified only by the conditions under which the work was done. 'The general trend of the curve seems, however, established beyond reasonable doubt. It is interesting to note that there is one point of maximm absorption, which is due to resonance between the walls and the sound, and that this point of maximum absorption lies in the lower part, though not in the lowest part, of the range of pitch tested. It would have been interesting to determine, had the tine and facilities permitted, the shape of the curve beyond $C_{7} 4096$, and to see if it rises indefinitely, or shows, as is far more likely, a succession of maximat.

The experiment was then directed to the determination of the absorption of somnd by cushions, and for this purpose return was made to the constant-temperature room. Working in the manner indicated in the eallier papers for substances which could be carried in and out of a room, the enrves represented in Fig. 7 were obtained. Curve 1 shows the absorption coefficient for the Sanders Theatre cushions, with which the whole investigation was begun ten years ago. 'These cushions were of a partieularly open grade of packing, a sort of wiry grass or vegetable fiber. They were covered with anvas tieking, and that, in turn, with a very thin cloth covering. Curve $\mathcal{Q}$ is for eushions borrowed from the Phillips Brooks House. They were of a ligh grade, filled with long, curly hair, and covered with canvas ticking, which was, in turn, covered by a long nap plush. Curve 3 is for the cushions of Appleton Chapel, hair covered with a leatherette, and showing a sharper maximum and a more rapid diminution in absorption for the higher frequencies, as would be expected under such conditions. Curve 4 is probably the most interesting, because for more standard commercial conditions ordinarily used in churches. It is to be observed that all four curves fall off for the higher frequencies, all show a maximum located within an oetave, and three of the curves show a curious hump in the second oct ave. 'This break in the eurve is a genuine phenomenon, as it was tested time after time. It is perhaps due to a secondary 
resonince, and it is to be observed that it is the more pronounced in those curves that have the sharper resonance in their principal maxima.

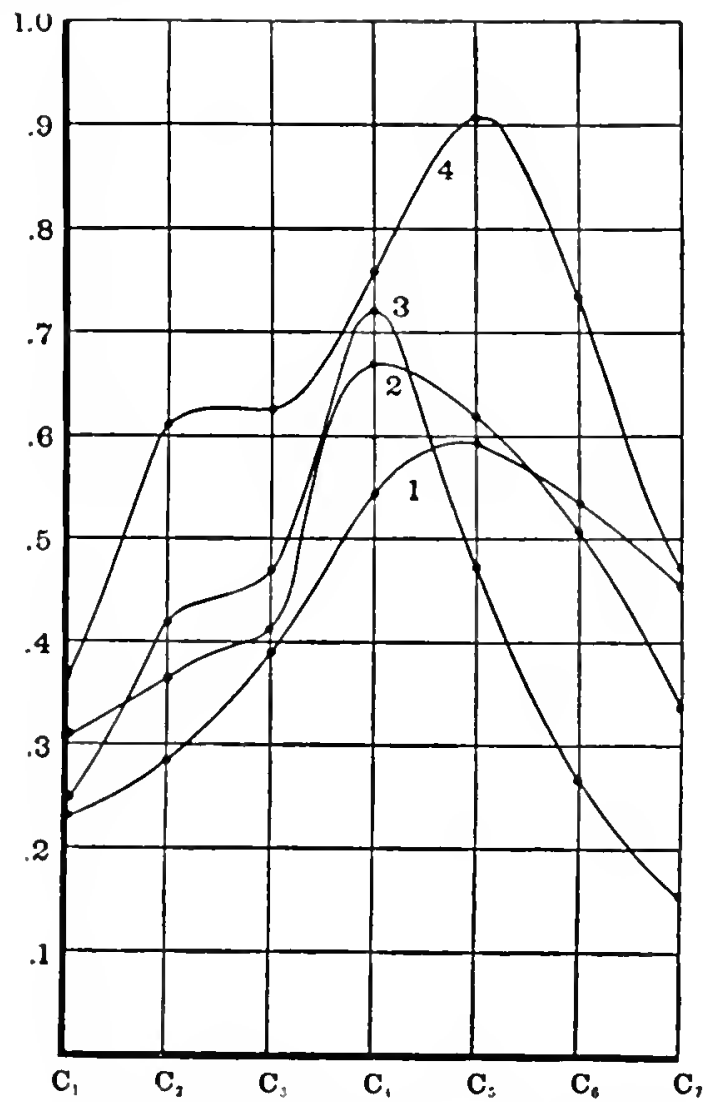

firs. 7. Whe alsorbing power of chathons. Curve 1 is for "Sanders Thealre" cushions of wiry regretable

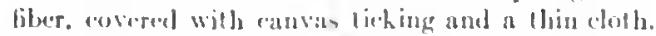
Curve $z$ is for "Brooks Hense" cushions of lomg latir. covored with the sane hind of fiching aml plush. ("urve as is for "Ippleton ("lapme" "u-hious of hair.

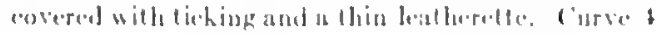

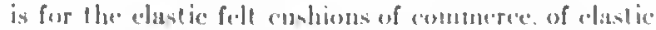

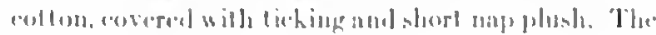
alsorbing pasure is pur sipuste methor of surface. Cis (millalle. (') zati.

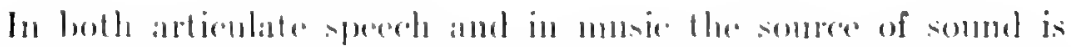

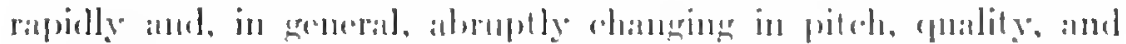

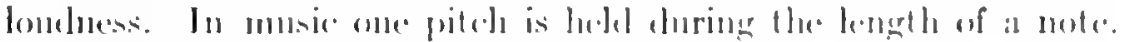


In artienlate speech the unit or element of constancy is the syllable. Indered, in speech it is cren less thin the length of a syllible, for the open rowel somet which forms the botly of a syllable usually hats al consonsulat opening and elosing. During the constancy of an alement, either of music or of speech, a train of somnd-waves spreads spherically from the source, just as a train of eircular waves spreats ontward from a rocking boat on the surface of still water. Diflerent portions of this train of splerical waves strike different surfaces of the anditorium and are reflected. After such reflection they begin to eross eale other's paths. If their paths are so different in length that one triin of waves has entirely passed before the other arrives at a particular point, the only phenomenon at that point is prolongation of the sound. If the space between the two trains of waves be sufficiently great, the effect will be that of an echo. If there be a number of such trains of waves thus widely spaced, the effeet will be that of multiple echoes. On the other haud, if two trains of waves lave traveled so nearly equal pathe that they overlap, they will, elependent on the difference in length of the patlis which they had traveled, either reënforce or mutually destroy each other. Just as two equal trains of water-waves crossing each other may entirely neut ralize each other if the crest of one and the trough of the other arrive together, so two sounds, coming from the same souree, in crossing each other may produce silence. This phenomenon is called interference, and is a common phenomenon in all types of wave-motion. Of course, this phenomenon has its complement. If the two trains of water-waves so eross that the rrest of one coincides with the crest of the other and trough with trough, the effects will be added together. If the two sound-naves be similarly retarded, the one on the other, their effects will also be added. If the two trains of waves be equal in intensity, the combined intensity will be cuadruple that of either of the trains separately, as above explained, or zero, depending on their relative retardation. The effect of this phenomenon is to produce regions in an auditorium of loudness and regions of comparative or even tomplete silence. It is a partial explanation of the so-called deaf regions in an auditorium. 
It is not difficult to observe this phenomenon directly. It is difficult, however, to masure and record the phenomenon in such a manner as to permit of an accurate chart of the result. Without going into the details of the method employed, the result of these

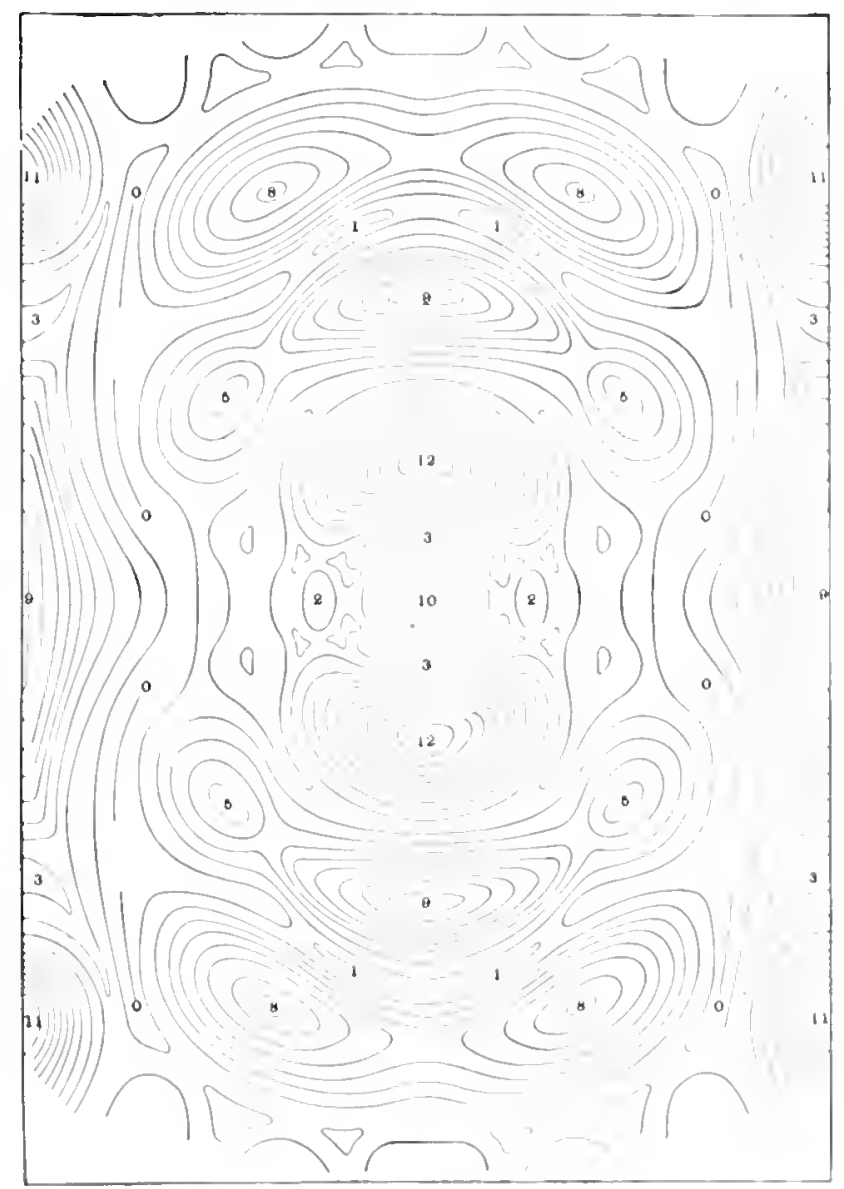

Fig. $x$. Distribution of intensity on the luad leved in at rom wills a barred-shapeal ceiling. will center of cusvalure on the floor levill.

measurements for a room very similate to the (omgregational elmude

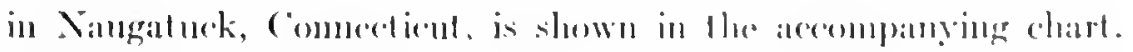
The room experimented in wis a simple, rectallgular roem with plain side walls and ands and with a barrel or colindrieal ceriling. The result is clearly represented in ligg. 8 . in which the intemsty 
of the somul has been indieated by contour lines in the manner "mployed in the drawing of the geodetic surver maps. 'The phenomrmon indieated in theses diagrams was not ephemeral, but was constant so long as the source of somnd continued, and repeated itself whil almost perfect afeellarey day after day. Nor was the phenom-

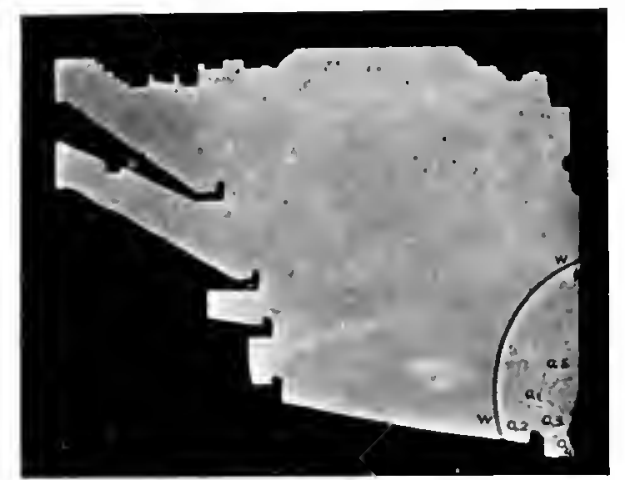

FIG. 9

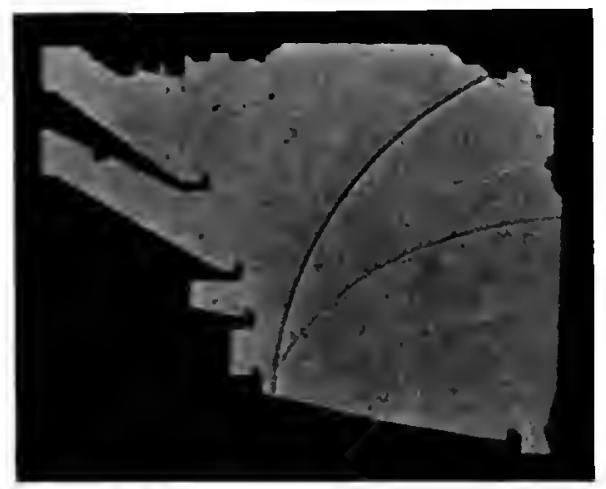

FIG. 10

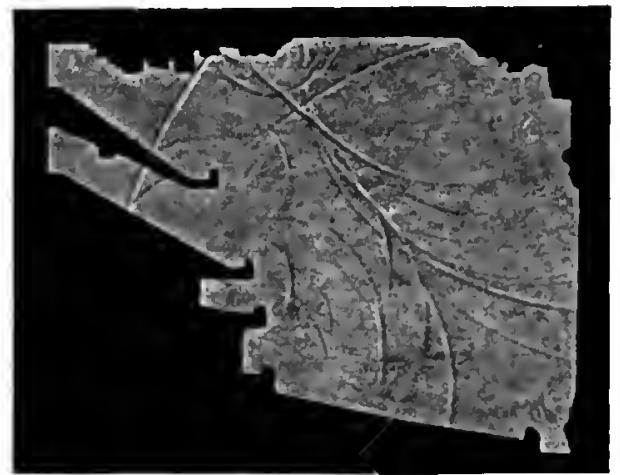

Fig. 11

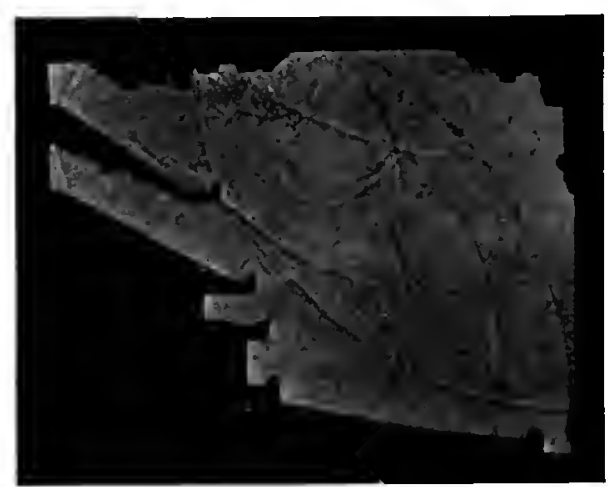

FIG. 12

(anon one which condel be olserved merely instrumentally. 'To an observer moving about in the room it was quite as striking a phenomchon as the diagrams suggest. At the points in the room indicated as high maxima of intensity in the diagram the sound was so loud as to be disagreeable, at of her points so low as to be scarcely andible. It should be added that this distribution of intensity is with the somre of sound at the center of the room. Hat the source of sound feen at one end and on the axis of the cylindrical ceiling, the dis- 
tribution of intensity would still have been bilaterally symmetrical, lut not symmetrical about the transwerse axis.

When a source of sound is maintaned constant for a suffictently long time - a few seconds will ordinarily suflice-the sound beeomes steady at every point in the room. 'The distribution of the intensity

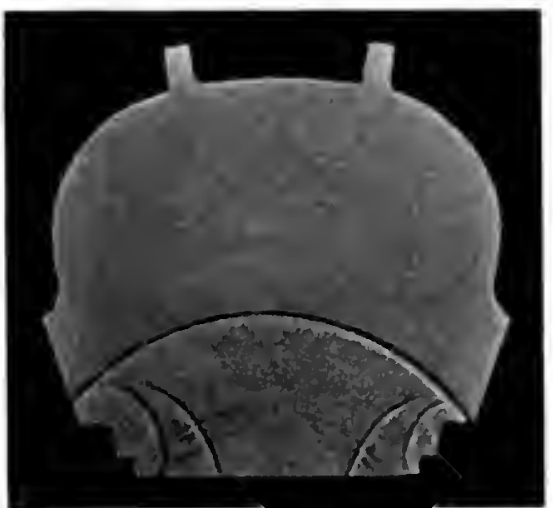

F.G. 13

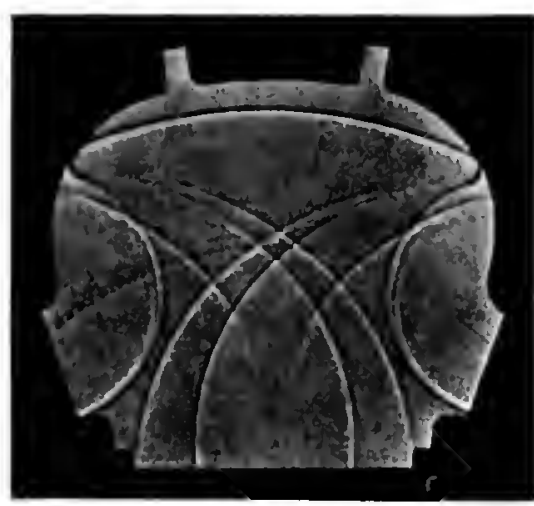

Fiti. 14

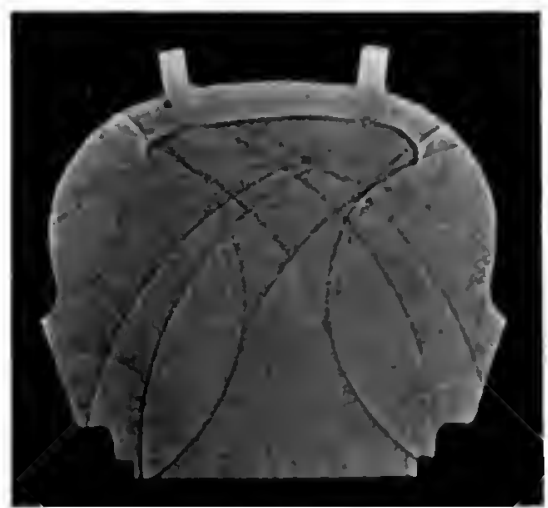

Fig. 15

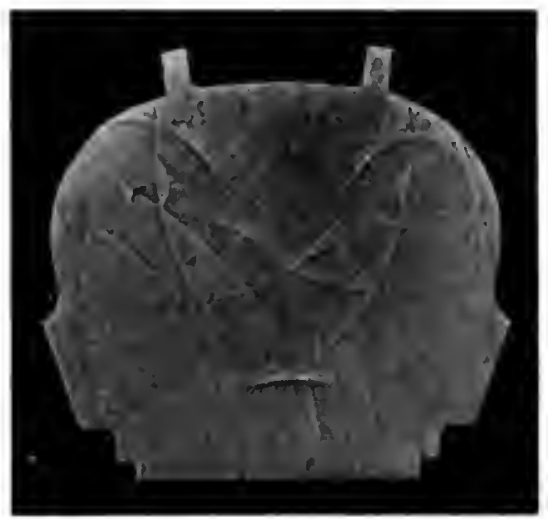

Fic. 16

of sound under these conditions is called the interference system, for that particular note, of the room or spare in question. If the somece of sombl is suddenly stopped, it recputires some time for the sound in the room to be alsorbed. This probongation of somel after

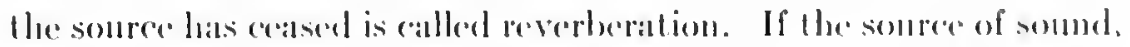
instrad of being maintained, is sloort and sharp, it tralveds ats a discrete wave or gromp of waves albont the room, reflected from wall to 
wall, produciug echoes. In the Greek theatre there was ordinarily but one echo, "doulling the case ending," while in the modern anditorium there are many, generally arriving at a less interval of time after the direet sound and therefore less distinguishable, but st rongere and therefore more disturbing.

The formation and the propagation of edhoes may be admirably studied by an adaptation of the so-ealled schlieren-1/ethode device for photographing air disturbances. It is sufficient here to say that the andaptation of this methot to the problem in hand consists in the constrnction of a model of the anditorimu to be studied to proper seale, and investigating the propagation through it of a proportionally scaled sound-wave. To examine the formation of echoe's in a vertical section, the sides of a model are taken off and, as the sound is passing through it, it is illuminated instantaneously' by the light from a very fine and somewhat distant electric spark. In the preeding illustrations, redueed from the photographs, the enframing silhouettes are shadows east by the model, and all within are direct photographs of the actual somd-wave and its echoes. The four photographs show the sound and its echoes at different stages in their propagation through the room, the particular anditorium under investigation being the New Theatre in New York. It is not difficult to identify the master wave and the various chloes which it generates, nor, knowing the velocity of sound, to compute the interval at which the ccho is heard.

To show the generation of cehoes and their propagation in a horizontal plane, the ceiling and floor of the model are removed and the photograph taken in a vertical direction. The photographs shown in Figs. 13 to 16 show the cehoes produeed in the horizontal plane passing through the marble parapet in front of the box.

While these several factors, reverberation, interference, and echo, in an anditorium at all complicated are themselves complicated, nevertheless they are capable of an exact solution, or, at least, of a solution as accurate ats are the architect's plans in actual construction. And it is entirely possible to calculate in advance of construction whether or not an anditorim will be good, and, if not, to determine the factors contributing to its poor aeoustics and a method for their correetion. 


\section{THE INSULATION OF SOUND ${ }^{1}$}

The insulation of somnd as an msolved problem in areditectural acousties was first bronglat to the writer's altention by the New England Conservatory of Music, immediately after its completion in 1904, and almost simultaneonsly in connection with a private house which had just loeen completed in New York. A few years later it was renewed by the Institute of Musical Art in New York. In the construction of all three buildings it hat been regarded as patriculary importint that conmunication of sound from room to room should be avoided, and methods to that end had been amployed which were in every way reasonable. The results showed that in this phase of architectural acousties also there had not heen a sufficiently searching and practical investigation and that there were no experimental diata on which an archited could rely. As these buildings were the oceasion for beginning this investigation, and were both instructive and suggestive, they are, with the consent of the a relitects, discelssed here at some length.

The special method of const ruction employed in the Now England Conservatory of Music was suggested to the architects by the 'Trustees of the Conservatory. The floor of ealch room was of semi-fireproof construction, cencent between iron girders, on this at layer of plank, on this paper lininge, and on top of this a floor of hatrd pine. Befwern cateh room for violin, piano, or vocal lessons was at compound wall, constructed of two partitions with an mobst ructed air spater between them. Liach partition was of two-inch plaster bleck set upright, with the finishing plaster applied diecetly to the block. The walls surromeling the organ rooms were of there such partitions

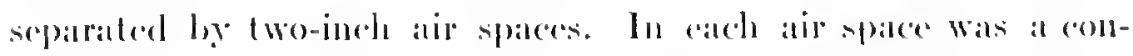

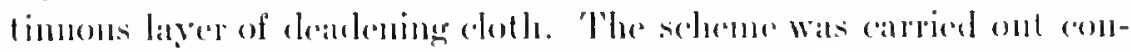
sistently and with full regarded to details, yet lesoms conduefed in

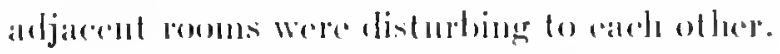

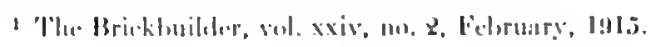


It is always anser to explain why a method does not work than to know in advance whether it will or will not. It is espeeially easy 10 explain why it does not work when not under the immediate necessity of correcting it or of supplying a better. This lighter rôle of the irresponsible eritic was alone invited in the eane of the New England conservatory of Music, nor will more be ventured at the present mement.

There is no chestion whatever that the fundamental consideration on which the device hinged was a sound one. Any diseontinuity dinninishes the transmission of sound; and the transition from masonry to air is a discontinuity of an extreme degree. Two solid masonry walls entirely separated hy an air space furnish a vastly better sound insulation than either wall alone. On the other hand, the problem takes on new aspeets if a masonry wall be replaced by a series of sereen walls, ach light and flexible, even though they aggregate in massiveness the solid wall which they replace. Moreover, wheh sereen walls can rarely be regarded as entirely insulated from each other. Granting that aceidental communieation has nowhere been established, throngh, for example, the extrusion of plaster, the walls are of necessity in eommunieation at the floor, at the ceiling, at the sides, or at the door jambs: and the conneetion at the floor, at least, is almost eertain to be good. Further, and of extreme importance, given any connection at all, the thimness of the sereen walls renders then like drumbeads and capable of large response to small exeitation.

It may seem a remote parallel, but assume for discussion two buildings a quarter of a mile apart. With the windows closed, no ordinary sound in one lnilding could be heard in the other. If, however, the buildings were eonnected by a single metal wire fastened to the eenters of window panes, it would be possible not merely to hear from within one building to within the other, but with care to talk. On the other hand, had the wires been eomeeted to the heavy masonry walls of the two buildings, such eommunication would have been impossible. 'This hypothetieal ease, though extreme, indecd perhaps the better beeause of its exaggeration, will serve to analyze the problem. Here, as in every case, the transmission of sound involves three steps, - the taking up of the vibration, 
the function of the nearer winclew pane, its transmission by the wire, and its conmunication to the air of the receiving room by the remote window. The three functions may be combined into one when at solid wall separales the two rooms, the taking up, transmitting. and emitting of the somul being scarcely separalble processes. On the other hand, they are of ten clearly separable, ans in the case of mult iple sereen wills.

In the case of a solid masonry wall, the transmission from surface to surface is alunost perfect; but becalse of the great mass and rigiclity of the wall, it lakes up hut little of the vibrat ion of the incident sound. It is contirely possilble to express by a not very complicated anatytical expation the annoment of sommet which a wall of simple dimensions with take up and transmit in terms of the mas: of the wall, its clasticity, and its viseosily, and the Precplency of vibration of the sount. But stuch an ecpuation, while of possible interest to plyysicists ats an exereise. is of mo inlerest whaterer to ardhiterts becanse of the difliculty of detemining the necessary (onellicients.

In the case of multiple screen walls. the communieation liom wall to wall, through the intermediate air space or around the edgres. is poes compared with the face to fare communication of at soliet wall. But the vihuat ion of the sereen wall exposed to the sommel, the initial step in the process of tratlsmission, is greatly enhanced hy its light and flexihle edaracter. Similarly its conuterpart, the screen wall, which $\mathrm{l}_{\mathrm{g}}$ its viluration communicates the sound to the receiving room, is light. flexille, and renponsive to redatively small forces. That this respensiveness of the walls eompersates or more tham compersates for the poor communication hedwen thems, is the probathe explanation of the transmission hetween the rooms in the New England concervitory.

The Institule of Musieal Art in New Vork presented interenting vitriations of the problem. Ilere alse the reome on the secomel and thirel flowers were intemeled for privalde inst ruetion and were designed to be somel proof from each othere from the corridor, and from the rooms alwe and betow. The walls sepalrating the peroms from the

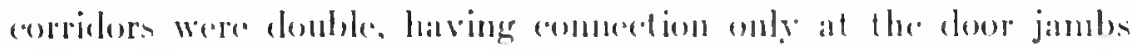
and at the flower. The seresen wall next the enorrider was of terrat 
cotta block, finished on the eorrilor sile with plaster applied directly to the tertal eotta. The wall next the room was of gypsum block, phastered and finished in burlap. In the air space between the two walls, deadening sheet was hung. The walls separating the rooms were of grpsum block and finisled in harel plaster and burlap. As shewn on the diagram (Fig. 1), these walls were cellular, one

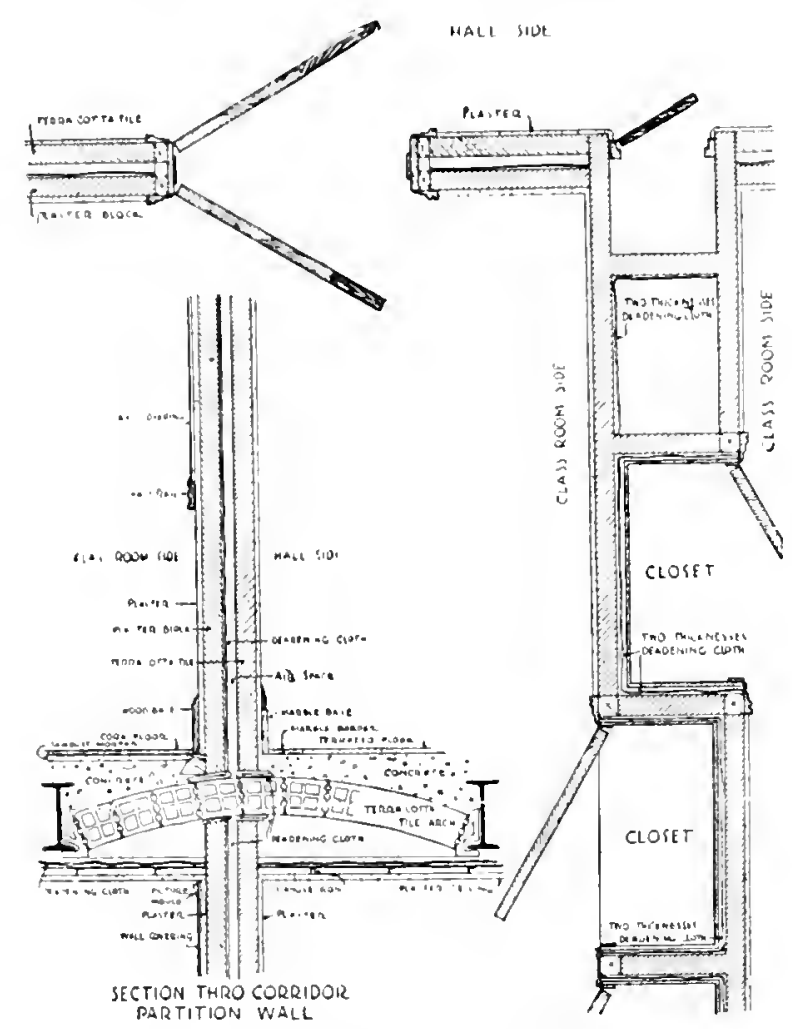

Fig. 1. Details of Construction, Institute of Musical Art, New York, N. I.

of these eells being entirely enclosed in gypsum block, the others being closets opening the one to one room, the other to the other. The elosets were lined with wood sheathing which was separated from the enelosing wall by a narrow space in whieh deadening sleet was lung in double thickness with overlapping joints. In the entirelyenelosed cell, deatlening sheet was also hung in double thiekness. 
It is not diffieult to see, at least after the fact, why the deadening sheet in such positions was entirely without effect. 'The transverse masonry webs aflorted a direct transmission from side to side of the compound wall that entirely overwhelmed the transmission through the air spaces. Had there been no necessity of closets, and therefore. no necesisty of transverse web and bad the two screen walls been truly insulated the one from the other, not merely over their areat. but at the floos, at the ceiling, and at the edges, the insulation would have been much more nearly perfect.

The means which were taken to secure insulation at the base of the sereen walls and to prevent the transmission of sound from floor to floor are excedingly interesting. 'The floor construction consisted in hollow terra cotta tile arches, on top of this cinder concrete. on this sawdust mortar, and on the top of this cork flooring. Below the recunforced concrete arches were hungt ceilings of plaster on wire lath. This hung ceiling wiss supported hy crosised angle bars which were themselves supported hy the I beans which supported the hollow terra cotta tile arches. In the air spaces between the tile arehes and the hung ceilings, and resting on the latter, wats deatening sheet. 'This compound floor of cork, sawdust mortar, cinder conerete, terra cottat tile, air space, and lumg ceiling, with deadening sheet in the air spatees, hass the air of finality, but was not successful in securing the desired insulation.

It is interesting to note also that the sereen walls were separated from the floor arches on which they rested below and on which they abutted albove by deadening sleet. It is possible that this afforeded seme insulation at the top of the wall, for the areh was not sustained by the wall, and the pressure at that point not great. At the bot ton, however, it is improbalble that the deatening sheet earried nuder the base offered aln insulation of prictical value. I'uder the weight of the wall it was probahly compressed into at compact malos, whose rigidity was still further increatsed by the pereolation throngh it of the cenent from the surromeding concrete.

Finally, after the completion of the huileling, Mr. Daturoneds, the direetor, had tried the experiment of exering the walls of one of the reoms to a depth of two inches with standaud hair felt, with some, but almost negrigible, aflect on the tramsmission of sound. 
1) Ballening sheet has been mentioned frequently. All indication of the special himd employed has been purposely omitted, for the disenssion is concermed with the larger question of the manner of its use anel not with the relative merits of the different makes.

'The house in Sew York presented a problem even more interesting. It was practieally a clouble house, one of the most imperative conditions of the buileling being the exclusion of sounds in the main part of the house from the part to the left of a great partition wall. 'This wall of solid masonry supported only one beam of the main house, was piereed by as few cloors as possible - two - and by no stean or water pipes. 'The rooms were heated by independent fircplaces. 'The water pipes commected independenty to the main. It had been regarded as of particular importance to exclude someds from the two bedrooms on the second floor. The ceilings of the rooms below were, therefore, mate of conerete arch; on top of this was spread three inches of sand, and on top of this three inches of lignolith blocks; on this was laid a hardwood floor; and finally, when the room was oceupied, this floor was covered by very heary and heavily padded carpets. From the complex floor thus constructed arose interior walls of plaster on wire lath on independent studding, supported only at the top where they were held from the masonry walls by iron brackets set in lignolith blocks. Each room was, therefore, practically a room within a room, separated below by three inches of sand and three inches of lignolith and on all sides and above by an air space. Notwithstanding this, the shutting of a door in any part of the main house could be heard, though faintly, in either bedroom. In the rear bedroom, from which the best results wore expected, one could hear not merely the shutting of doors in the main part of the house, but the working of the feed pump, the raking of the furnace, and the coaling of the kitchen range. In the basement of the main dwelling was the servants dining room. Rapping with the knuckles on the wall of this room produced in the bedroom, two stories up and on the other side of the great partition wall, a sound which, although hardly, as the architect expressed it, magnified, yet of astonishing loudness and clearness. In this case, the telephone-like nature of the process was even more clearly defined than in the other cases, for the distances concerned were much 
greater. The problem land many interesting aspects, but will hest serve the present purpose if for the salke of simplicity and clearness it be held to but one, - the transmission of sound from the servants' dining room in the basement along the great eighteen-inch partition wall up two stories to the insulated beelroom above and opposite.

It is a fairly safe hazard that the somd on reatching the berlroem did not enter by way of the floor for the eombination of reanfored concrete. three inches of sanel, three inches of lignolith hlock, and the wood flooring and airpel above, presented a combination of massive rigidity in the conerete areh, incrtness in the sand and ligmelith btock, impervionsmess in the hatrdwoed floor, and absorption in the parleled carpet which rendered insulat ion perfect, if perleet insulation be possible. No air ducts or steam or water pipes entered the room. 'The only conceivable commmicat ion, therefore, was theougl the walls or oriling. The communication to the innere walts and reeling from the surrounding struetural walls was either throught the air space or through the iron angle bars, which, set in lignolith blocks in the structural wall, retained ereet and at proper distance the inner walls. Of the two means of communication, the air and the angle bars, the liatere was probahly the more impertant. It is interesting and pertinent to follow this line of eommunicat ion, the matsonry wall, the angle hatrs, and the sereen walls, and to endeavor to discorer if possible, or at leatst to specenlate on the reason for its exereptional themgle unweleome efliciency.

from the outsed it is necessang to distinguish the transierse and the lomgitudinal tramsmission of sound in a milding member, that is, to distinguish ats somewhat dillerent processes the tramsmission

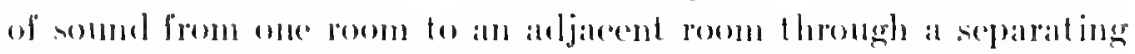
wall or ceiling, from the tramsminion of sennd along the floos from

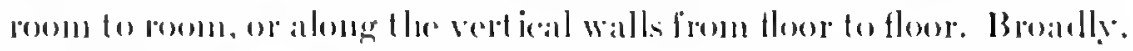
althement the two are not entirely separable phenomenas, one is

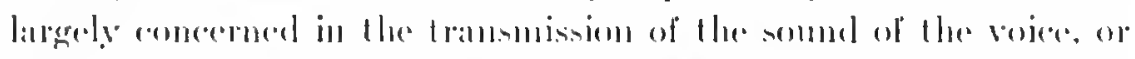
the violin, or of othere sourees free from solicl contatet with the lfoos,

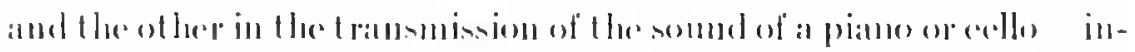

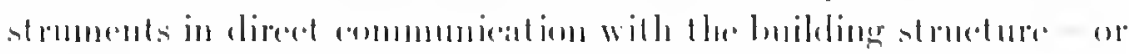

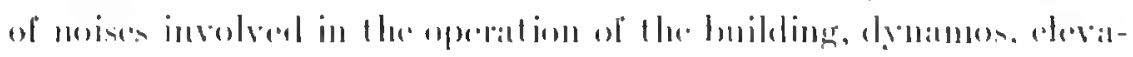

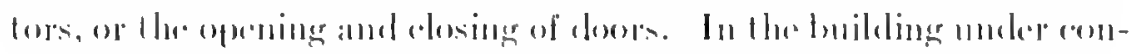


sideration, the disturbing sounds were in every ease communicated directly to the structure at a considerable distance and transmitted along the walls until ultimately communicated through the angle bars, if the angle bars were the means of eommunication, to the thin plaster walls which constituted the inner room. The special features thus empluasized were the longitudinal transmission of vibration by walls, floors, and struetural beams, and the transformation of these longritudinal vibrations into the sound-produeing transverse vibrations of walls and eeilings bounding the disturbed room. Many questions were raised which at the time could be only tentatively answered.

What manner of walls conduet the sound with the greater readiness? Is it true, as so often stated, that modern conerete construction las eontributed to the recent prevalenee of these difficulties? If so, is there a difference in this respeet between stone, sand, and cinder concrete? In this partieular building, the partition wall was of briek. Is there a differenee due to the kind of briek employed, whether hard or soft? Or does the conduetion of sound depend on the kinel of mortar with whieh the masonry is set? If this seems trivial, consider the number of joints in even a moderate distance. Again, is it possible that somnd may be transmitted along a wall without produeing a transverse vibration, thus not entering the adjacent room? Is it possible that in the case of this private house hat there been no interior sereen wall the sommd communieated to the room would have been less? We know that if the string of a string telephone passes through a room without touching, a conversation held over the line will be entirely inaudible in the room. Is it possible that something like this, but on a grant seale, may happen in a builking? Or, again, is it possible that the iron braekets which comnected the great partition wall to the screen wall magnified the motion and so the sound, as the lever on a phonograph magnifies its motion? These are not unworthy questions, even if nltimately the answer be negative.

The investigation divides itself into two parts, - the one dealing with partition walls especially constructed for the test, the other with existing structures wherever found in interesting form. The experiments of the former type were eonducted in a special room, 
mentioned in some of the earlier papers (The Brickbuilder, January, 1914), ${ }^{1}$ and having peculiar merits for the work. For an understanding of these experiments and an appreciation of the conditions that make for their accuracy, it is necessary that the construction of this room be explained at some length. The west wing of the Jefferson Physical Laboratory is in plin al latre square in the center of which rises a tower, which, for the sake of steadiness and insulation

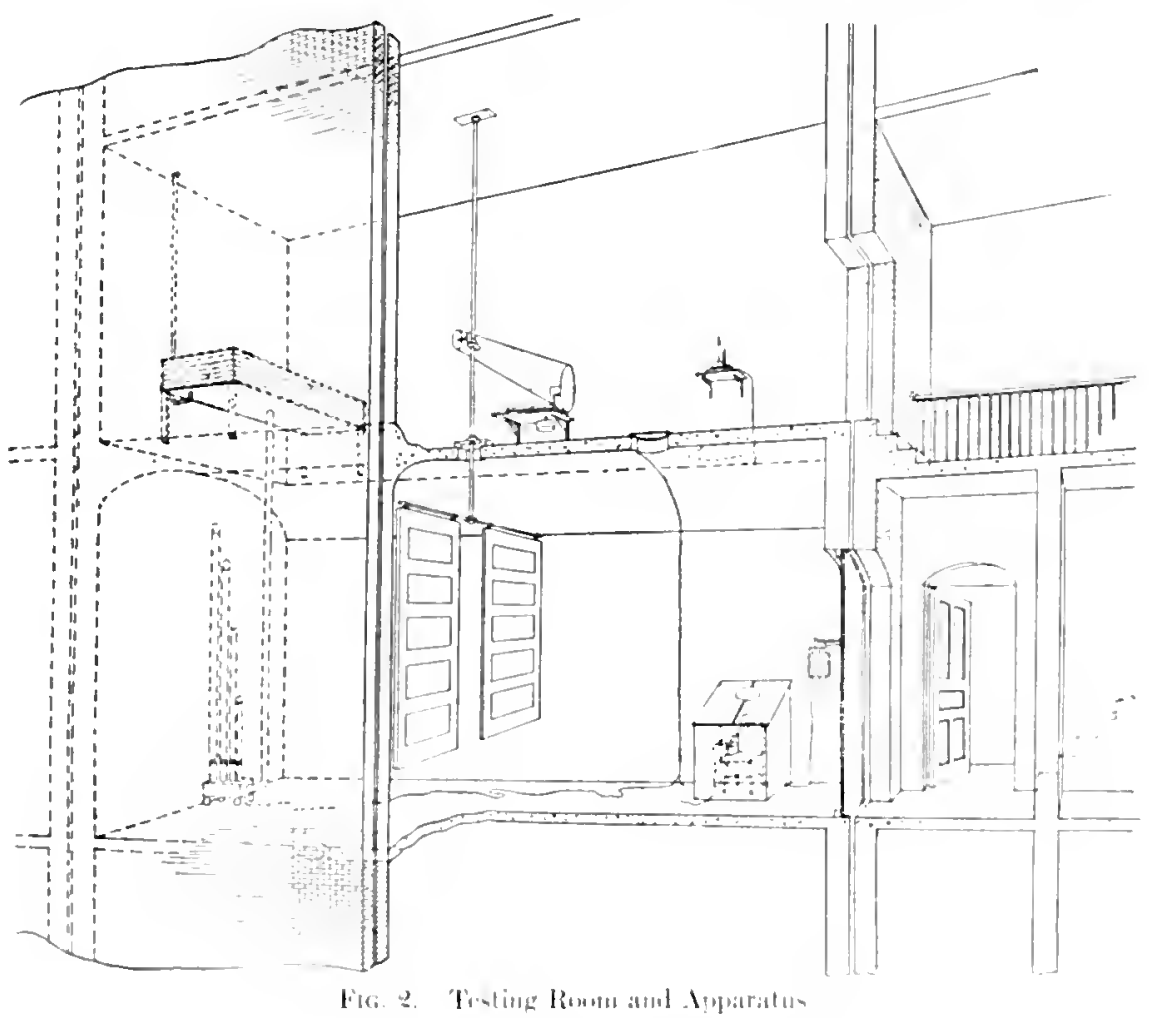

from all extemal vibrition, is mot merely of independent walls but

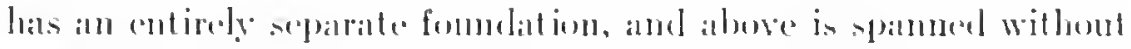
tencling by the rost of the main building. The sub-hitsement room

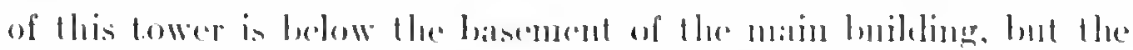

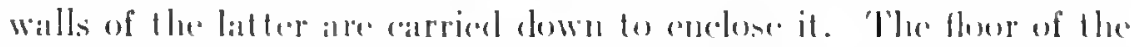

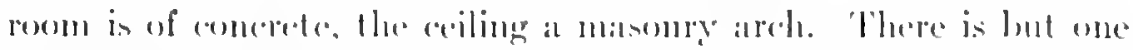
door which loads throngh a small anterenom to the statrs mounting

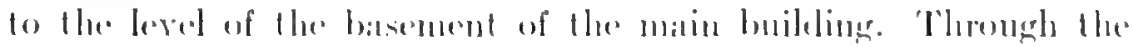


ceiling there are two snmall openings for whieh special means of closing alle provided. 'The langer of these openings barely permits the passage of an observer when mised or lowered by a block and tackle. It is necessary that there be some such entrance in order that observations maly be alken in the room when the door is closed by the wall construct ion mukergoing test.

Of prime importance, eritieal to the whole investigation, was the insulation between the rooms, otherwise than through the partition to be tested. 'The latter elosed the doorway. Other than that the two roons were separated by two eighteen-inch walls of brick, separated by a one-iuch air space, not touching through a five-story leeight and carried down to separate foundations. Around the outer wall and around the antechamber was solid ground. It is difficult to conceive of two aldjacent rooms better insulated, the one from the other, in all directions, except in that of their immediate connection.

The arrangement of apparatus, changed somewhat in bater experiments, consisted primarily, as shown in the diagram, of a set of organ pipes, winded from a bellows reservoir in the room above, this in turn being charged from an air pump in a remote part of the building, - remote to avoid the noise of operation. In the center of the room two reflectors revolved slowly and noiselessly on roller bearings, turned continuously by a weight, under governor control, in the room above. 'The chair of the observer was in a box whose folding lids fitted over his shoukters. In the box was the small organ console and the key of the chronograph. The organ and chronograph had also console and key connection with the antechamber. 'The details of the apparatus are not of moment in a paper written prinarily for architects.

Broally, the method of measuring the transmission of somnd through the partitions consisted in producing in the larger room a somnd whose intensity in terms of threshold andibility was known, and reducing this intensity at a determinable rate unti\} the sound ceased to be andible on the other side of the partition. The intensity of the sound at this instant was numerically equal to the reciprocal of the coefficient of transmission. This process involved several considerations which should at least be mentioned. 
The somed of known intemsit? was prodneed ly. organ pipes of known powers of emission, allowine being marla for the volume of the room, and the alsorbing powere of the walls. The methoul was fully explatined in ardier papers. It is to be borme in mind that there was thes determined merely the arerage of intensity. 'The intensity varied greatly in different parts of the room breatuse of interference. In order that the arerage intensity of somel against the partition in a series of observations should erfual the average

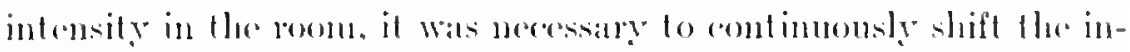
terference sestem. This wats aceomplistred lye means of resolving reflectors. This also remelered it posible to obtain a measure of alverage comelitions in the room from olsererations taken in one penition. Finally the observations in the roon were always mate by the observer seated in the box, als this remelered his chothing a negligilate factor, and the condition of the room the sane with or withont. his presenee. Consideration was also given to the aleonstical condition of the interditullore.

Two methods of reducing the somed hatse been employed. In the one the somel was allowed to die awaly natumally, the source being stoperd suddenly, and the rate at which il decreased deetermines from the constants of the room. In another type of experi-

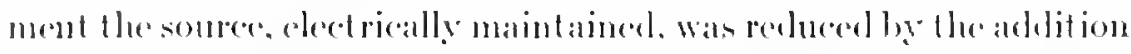
of electrieal resistane to the cirente One methed was sultable

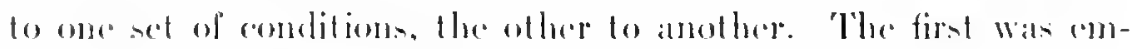
ploged in the experinents whene results ane given in this parpere.

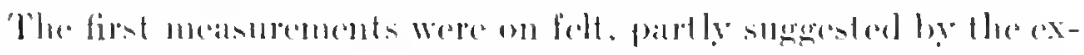
forriments of 1)r. 1):muremeth with felt on the walls of the lnstitute of

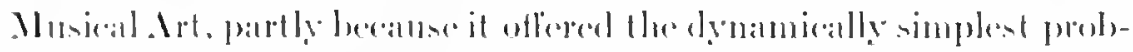

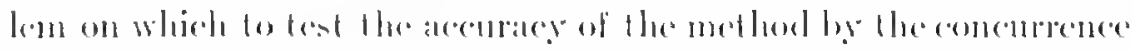

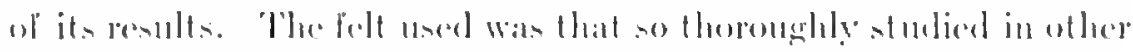

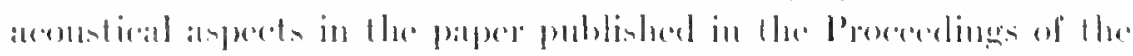

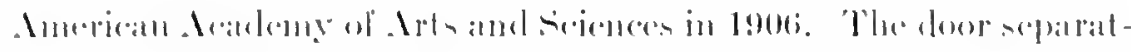

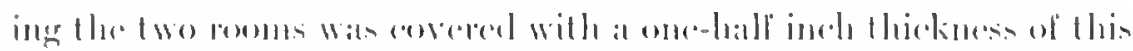

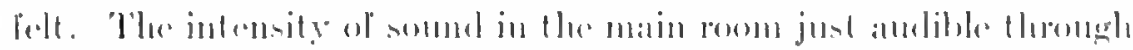

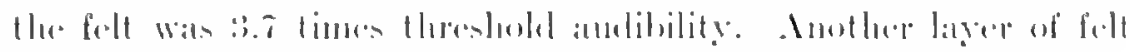

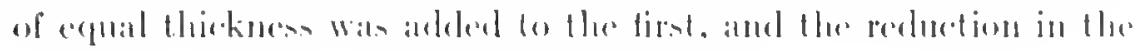


intensity of sound in passing throngh the two was 7.8 fold. Throngh three-thickness, each one-hall, the reduction was $\mathbf{1 5 . 4}$ fold, throngh fonr 30.4, five 47.5, and six 88.0. This test was for sounds having the pitch of violin $C$, first $\mathrm{C}$ above middle $\mathrm{C}, 519$ vibrations per second.

There is another way of stating the above results which is perlaps of more service to arehitects. The ordinary speaking intensity of

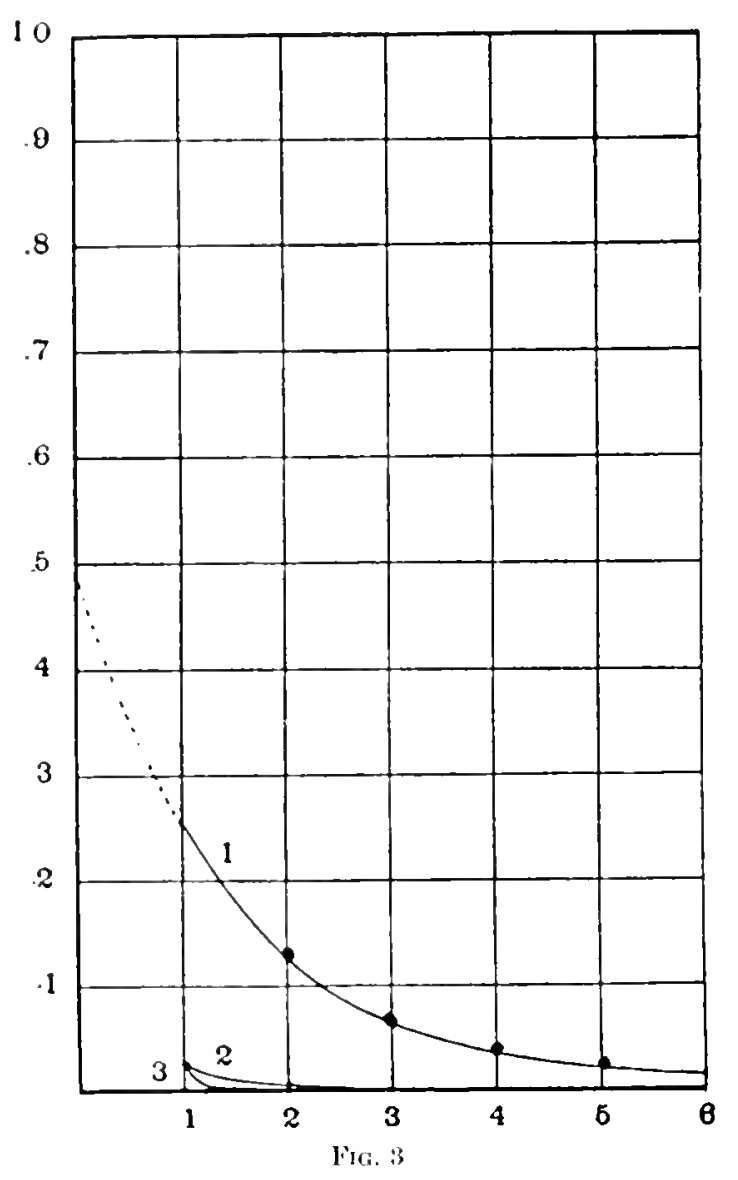

the voice is - not exaetly, of course, for it varies greatly - but of the order of magnitude of $1,000,000$ times minimum audible intensity. Assume that there is a sound of that intensity, and of the piteh investigated, in a room in one side of a partition of half-inch felt. Its intensity on the other side of the partition would be 270,000 times minimum audible intensity. Through an inch of felt 
its intersity would be 198,000. 'Therough six layers of suth foll, that is, through three inches, its intensity would be 11,400 times minimum andible intensity - very andible, inderd. The diminishing

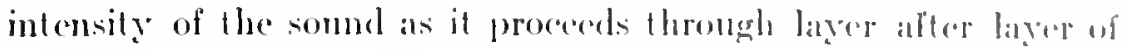
lelt is plotted in the diagram (Curse 1, Fig. 3), in which all the. points recorded are the dired results of observat tons. The intensity. inside the room is the full ordinate of the diagram. The "urve drawn

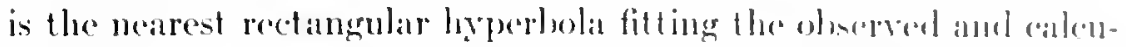
lated points. The significance of this will be discoldenel latter. It is sufficient for the present purpose to sily that it is the theoretical

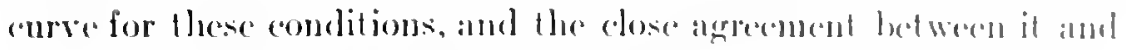
the observed points is a matter for comsideralde sittifiactiont.

The next partition fested was of shecet iron. Thlis, of conrres, is not a normal building material and it may therefore serm disappointing and without interest to allediteds. But it is necenalry to

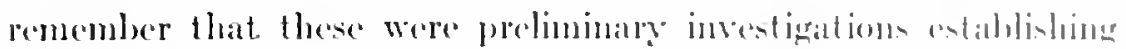

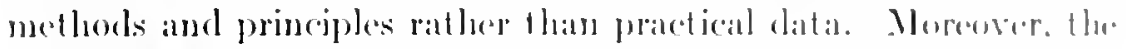

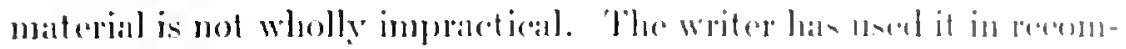
mendations to an ardutert in one of the most interenting and sureressful cases of sound insulalion on far undertakent that in an

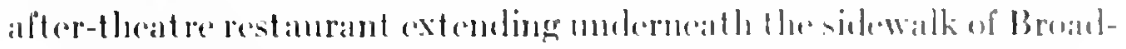
way and 4od Street in Xew York.

The successive layers of sheret iron were heded at al distance. crach

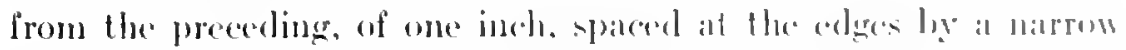
strip of wood and fell, and presed loeme by wasleress of folt. After

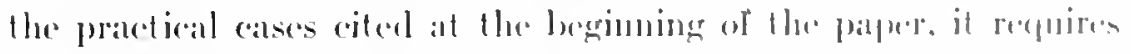
conrage and some hardihood to saly that any innulation is genet. It

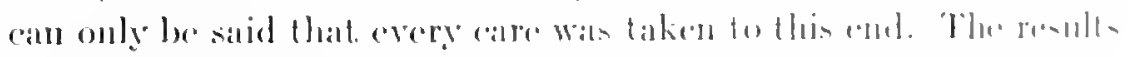

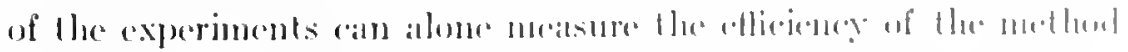

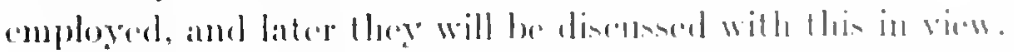

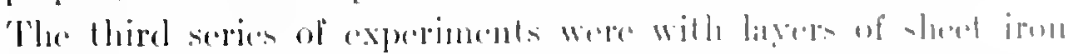

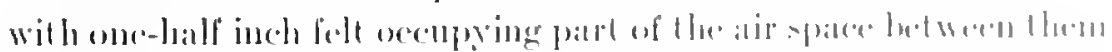

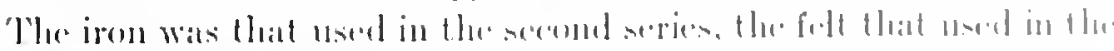

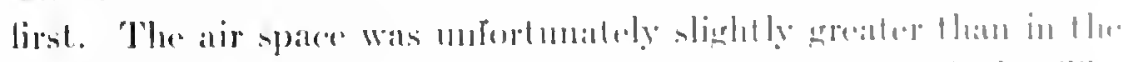

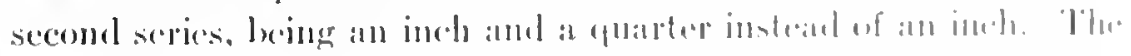

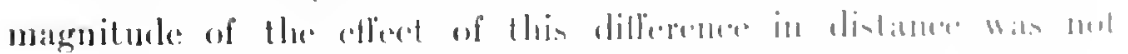

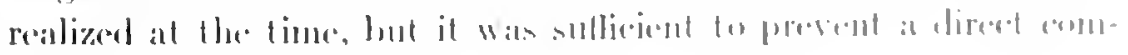




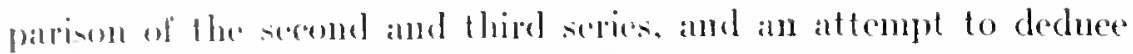
the latter from the formere with the atd of the first. When this was reatized, other conchitions wereso ditlerent as to make a repetition of the serlies diflicalt.

lut the lollowing tahle is given the results of these three series of experinuents in such form as to admit of asy comparison. To this cond they are all reshered to the values which they would have had with an intensity of somm in the inner room of $1,000,000$. In the first columm each succeeding figure is the intensity outside an adelifional half inch of felt. In the serond celumm, similarly, each succeceling figure is the intensily ontside an alditional sleet of iron. In the third column, the second figure is the intensity outside a single sheet of iron, and alter that each succeeding fignre is the infensity outside of an adelitional felt and inon doublet with air sparee.

\begin{tabular}{|c|c|c|}
\hline $1.0001,0000010$ & 1.00010 .0000 & $1.0000,0000$ \\
\hline 980.0000 & 然.7(16) & 93,000 \\
\hline 198,0001 & 8,8001 & 3,300 \\
\hline$(0.5,0000$ & 4,850 & 600 \\
\hline 83,0000 & 3.1 .50 & 980 \\
\hline 81.5000 & 9.1)(60) & 1.50 \\
\hline $11 .+100$ & 1,520 & 88 \\
\hline
\end{tabular}

The sound transmitted in the second and third series is so mude lans than in the first that when an attempt is made to plot it on the sane diagram (Curves and 8 . Fig. 9) it results in lines so low as to be scarcely distinguishable from the base line. Magnifỵing the seate tenfolel (Fig. 4 ) throws the first series off the diagran for the earlier values. but renders visilble the second and third.

The method of representing the lesults of an investigation erraphically has sereral ends in view: it gives a visual impression of the phenomenon; it shows by the neamess with which the plotted values lie to a smooth curve the accuracy of the method and of the work; it serves to interpolate for intermediate values and to extrapolate for points which lie beyond the observed region, forward or backward; finally, it reveals significant relations and leads to a

${ }^{1}$ In reprotucing from the plotted diagrams for Figs. 3,4 , and 5, the dots, in sone cases. which indicated the plutted values of the otserved points, do not clearly appear in distinetion on the lines. The greatest divergenee, in any eatse. from the line drawn was not more than twice tlu breadth of the line itself. 
more effective discussion. It in worth while thus exantinging the three curves.

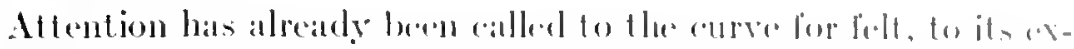

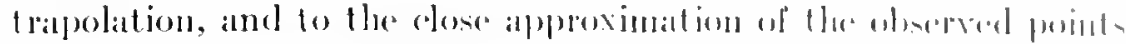

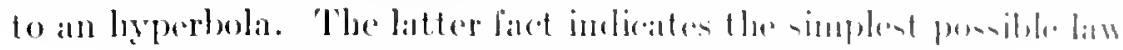

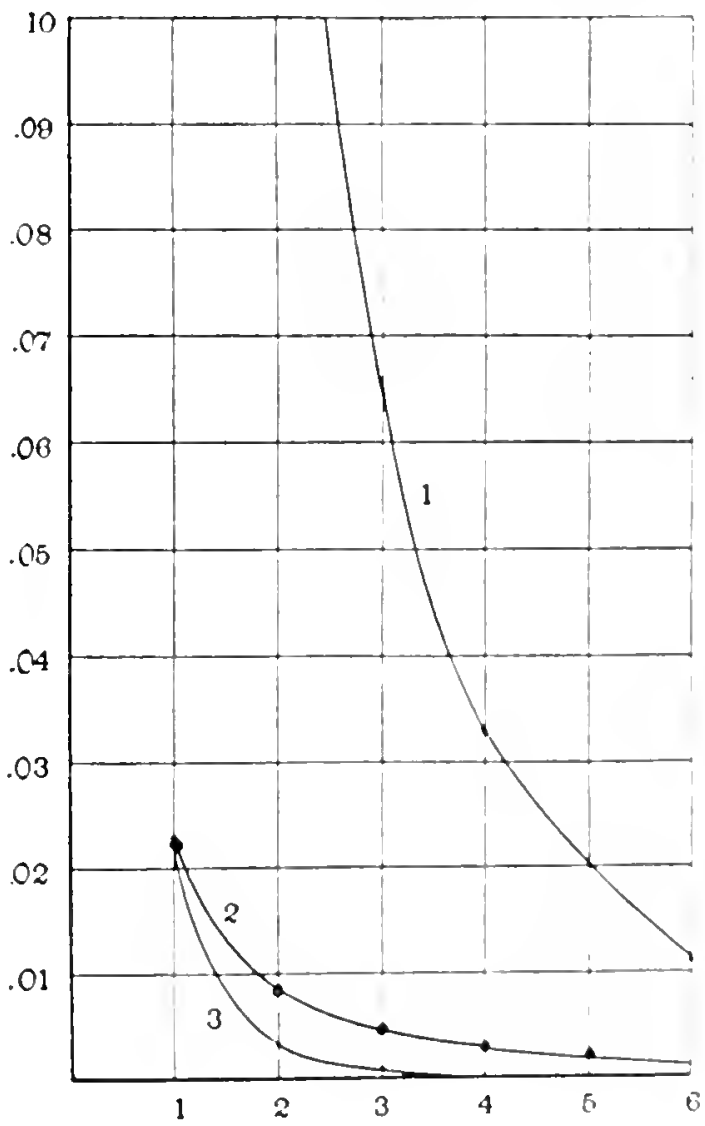

lil: 1

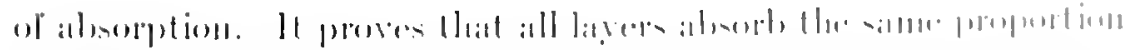

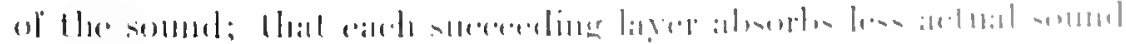

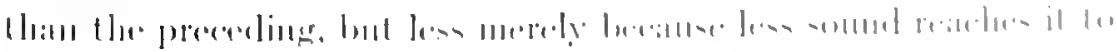

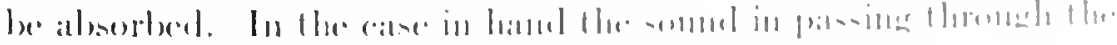

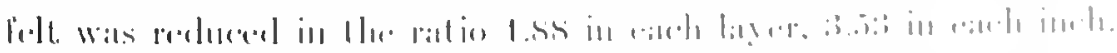

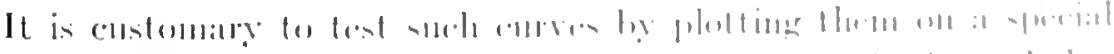

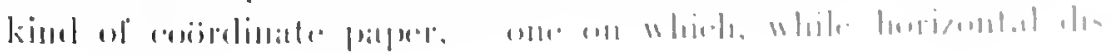


lances alle miformly scaled an before, vertical distances atre sealed with greater and greater reduction, tenfold for each unit rise. On such coiredinate paper the vertical distances are the power to which 10 must he raised to equal the number plotted - in other words, it is the logarithen of the number. Plotted on sueh paper the curve for

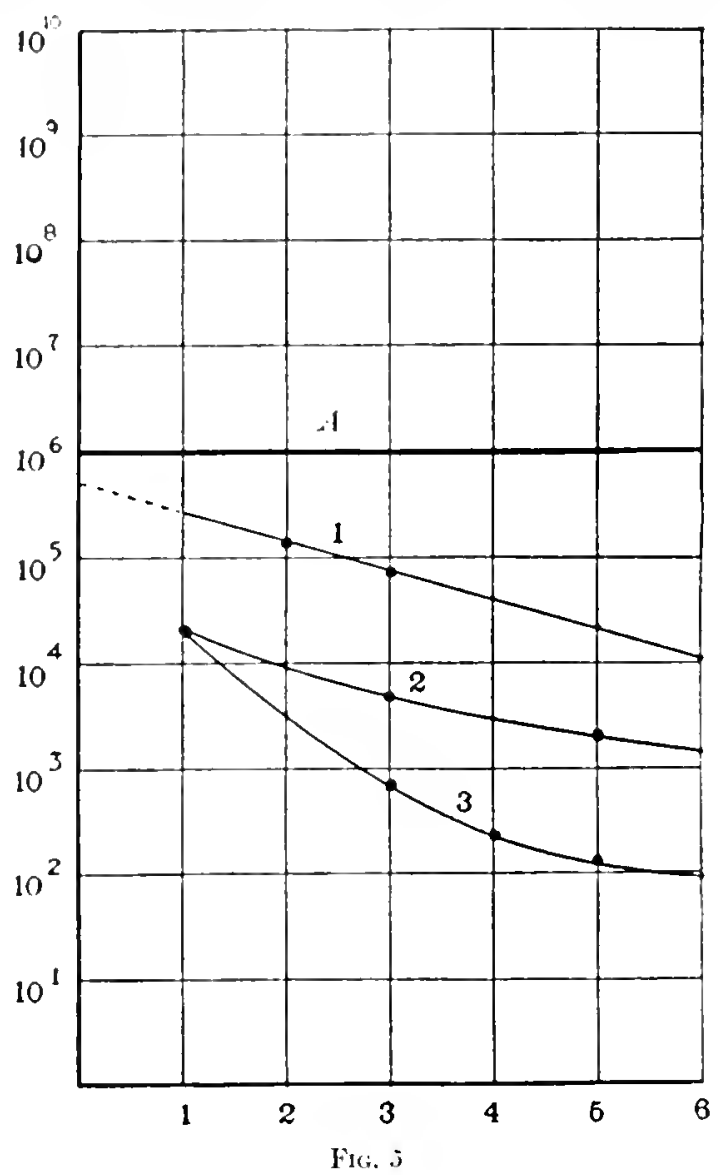

felt will result in a straight line, if the curve in the other diagran wats an hyperlola, and if the law of absorption was as inferred. How alcurately it does so is slown in Curve 1, Fig. 5.

When the observations for iron, and for felt and iron, are similarly. plotted (Curves 2 and 3. Fig. 5), the lines are not straight, but strongly curved upward, indicating that the corresponding curves in the preceding diagram were not liperbolis, and that the law of 
constant coefficient did not hold. This must be explatined in one or the other of two ways. Either there was some ly-pass for the sound, or the efficiency of each succeding mit of construction was les.n.

The by-pass as a possible explanation ean le quickly disposed of Take, for example, the extreme casse, that for felt and iron, and make the extrene assmmption that with the completed series of six serecells all the somd has come by some hy-palss, the surroundling walls, the foundations, the eciling. or by some soliel comnert ion from the innermost to the out ermost sheet. A calconlation hased on these asomuptions gives a plol whose curvature is contirely at the lower end and bears no relat ionship to the ohservert values. In the other catse, that of the iron only, a similar calculat ion givess a similate reatult; merewer, the much loner limit to which the felt and iron screens redlued the sound wholly climinates any hy-patsis ant ion an a vital farder in the iron-only experinent.

The other explanation is not merely necensary he climination.

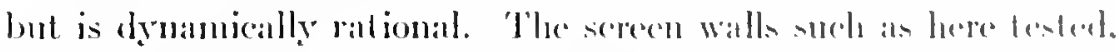
as wedl ats the sereen walls in the actual comstruetion derseribed has way of introchetion, do not aet by absorptions an in the case of the

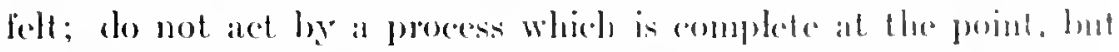
rather by a process which in the first screnen maty be likened ter re-

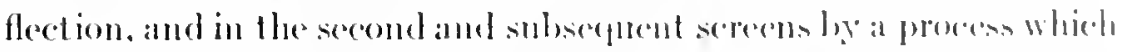
may be more or less likened to refleet ion, but which being in at con-

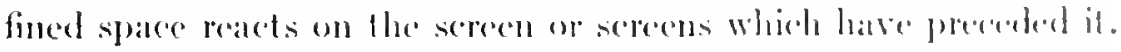
In fact, the process must be regarded not als a sectuenere of inde-

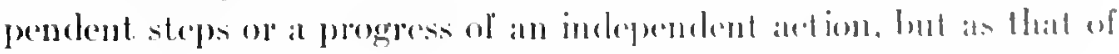

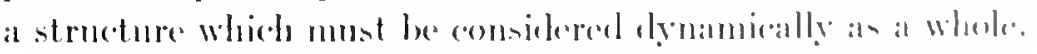

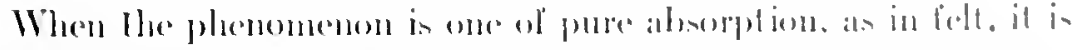
possible to express by a simple lormulat the intemity ar the sumbl 1 . at any distance $x$. in terms of the intitial internity. $I_{\text {... }}$

$$
I=I_{n}, 1 / K \text {. }
$$

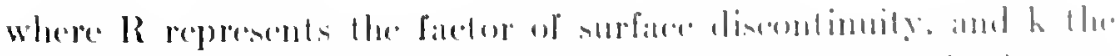

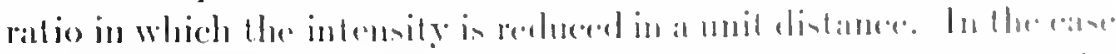

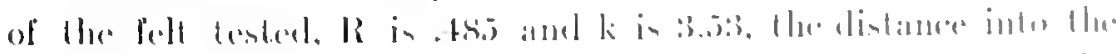

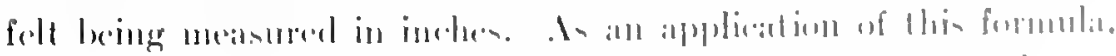

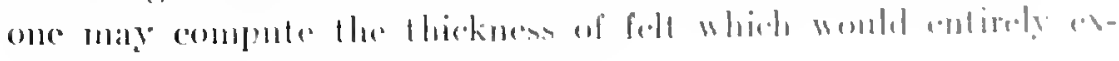


tinguinh a somol of the intensity of ordinary speech, - 10.t inches. It is not fosible to express hy such a formula the transmission of somul through either of the more complex structures. However, it is pomithe lo extrapolate empirieally ancl show that 10.t inches of meither wonkl aceomplish this ideal result, although they are both lar superior to felt for theknesses up to three inches in one case and five and ome-hall inclese in the of her.

A mumber of ot here axperiments were t ried during this preliminary siage of the investigation, such, for exumple, as increasing the distance between the sereen walls, hut it is not neeessiry to recomot them licere. Enomgh has already been given to show that a method hat been chereloped for accurately measuring the insulating value of structures; more would but confuse the purpose. At this point the apparatus was improved, the method recast, and the investigation begmen anew, thenceforwarel to deal only with standard forms of construction, and for sounds, not of one pitch only, but for the whole range of the musical scale. 


\section{1}

\section{WHISPERING GALIERIES}

$\mathbf{I}_{\mathrm{T}}$ is probable that all existing whispering galleries, it in certain that the six more famons ones, alre alecielents; it is erplally certain that all could have been predetermined withont ditliculty, and like mont

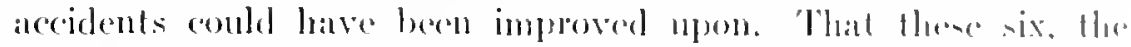
Dome of St. Paul's Cathedral in Lomdon, Statuary Hall in the ('ap)itol at Washington, the valses in the salle des ('ariatides in the Lonver

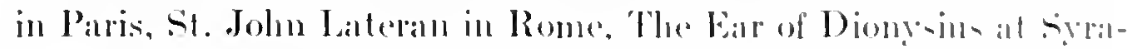

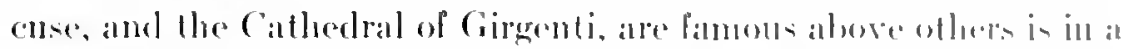
measure due to some incident of place or anowelation. Fonr are fat-

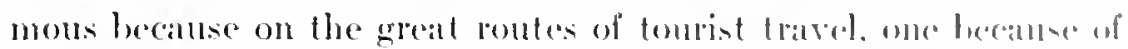
datsical traditions, and one, in an exeredingly inareesoblbe city and

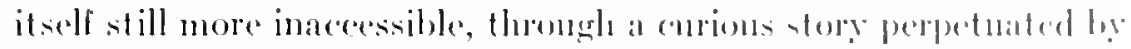
Sir John W. Herschel in the Encyelopedia Metropoliteme. I Hewerer, all show the phenomenon in a striking manner and meril the interent which lley excite, an interest probaldy anhanced by the mistery

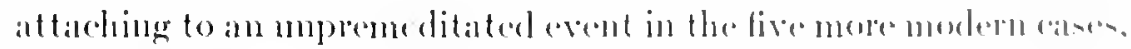

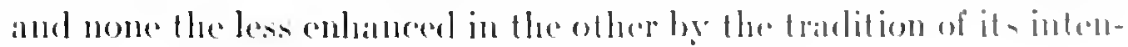
lional design and as evidencer of al "lont art."

The whisperiug gallerye in the (appitel at Waslingeten in of the simplest posilible type.

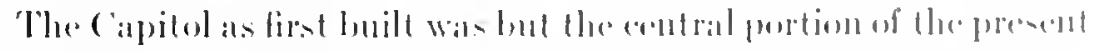

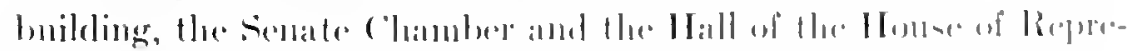

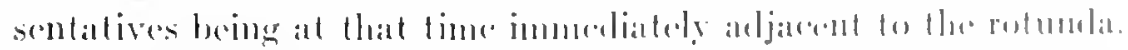

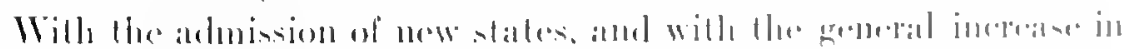

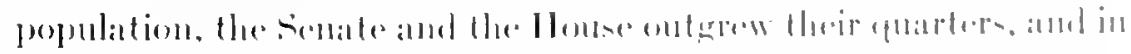

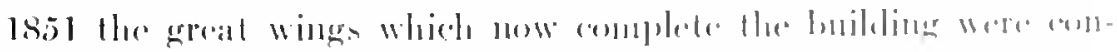

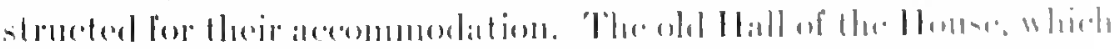

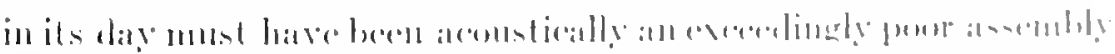

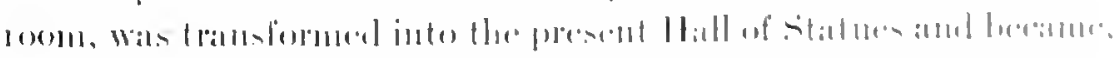

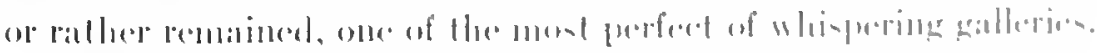

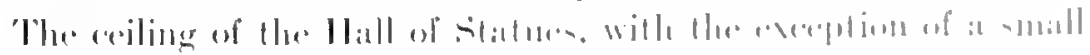

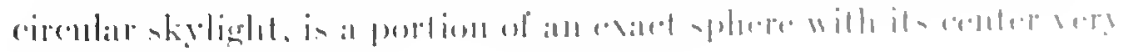




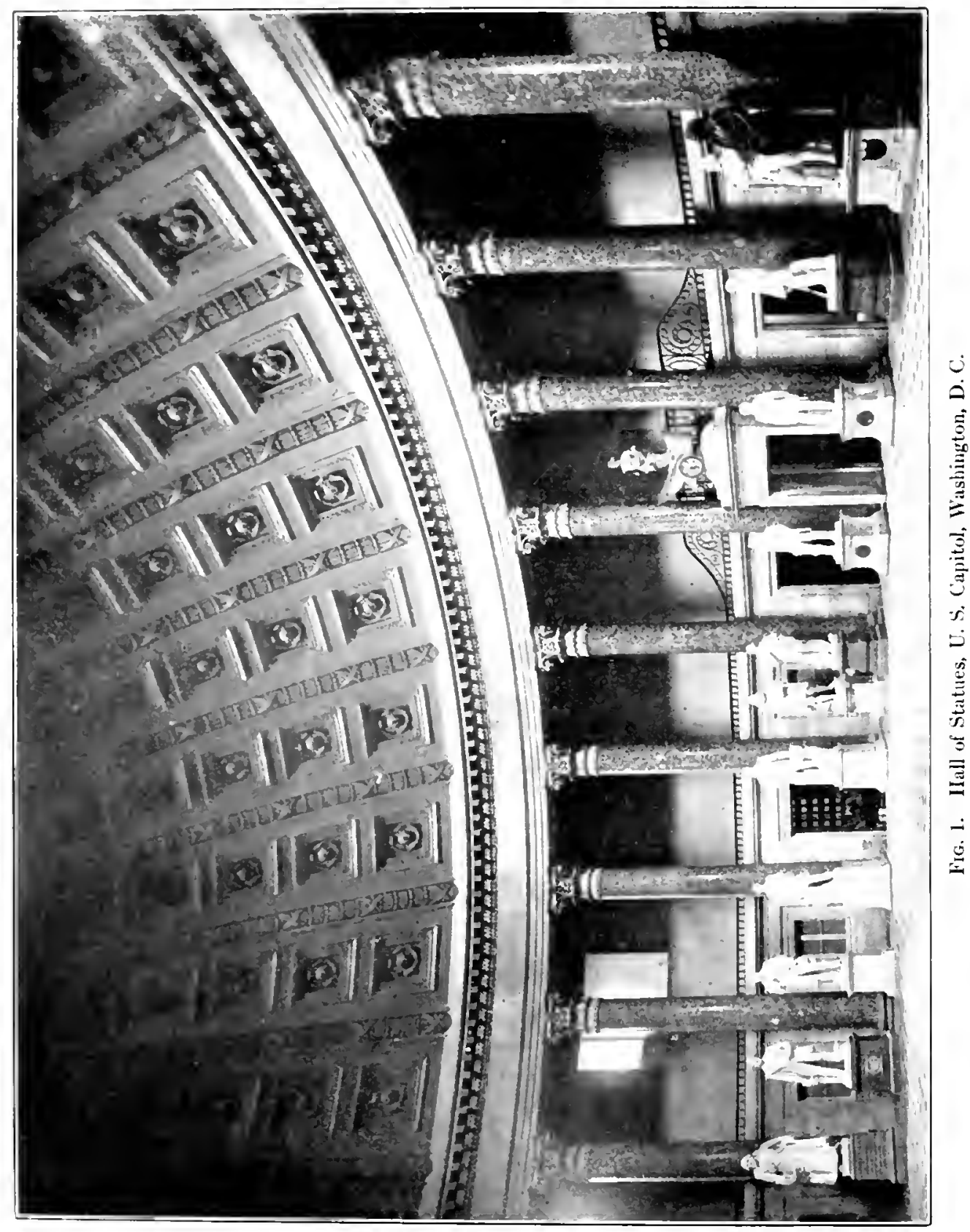


nearly at head level. As shown in the illustrations the coiling is coffered. As originally constructed, and as it remained until 1901. the ceiling was perfectly smooth, being of wood, papered and painted in a manner to represent coffering. In 1901 , a lire in the ("hamber of the Supreme Court, also in the Cappitol, led to a general overhanling of the building, and among other dangerous eonstruet ions the criling of wood in the Hall of Statues was replaced by a lireproof eonts rusetion of steel and plaster. Instead of bejug merely painterl. the new ceiling latd recessed pancels with monlelings and rits in rellid (Fig. 1). In consequence of this construction, the whispering gillery lost a large part of its unique quality.

During the years preceding the remodeling of the ceiling. the whispering gallery had been of great interest to tourists and deep bollows were worn in the malthe tile where the olservers stwol. 'The experinent wats usually tried in eithere one of two ways. 'The visiter to the gallery was placed at the censter of conrature of the coiling and fold to whisper, when the slightest sombls were returned to him from the ceiling. The elfect was mude mere st riking than ome womld suppose from this simple description. The slight lipese of time required for the soumel to travel to the ceiling and hatek, togedhere with one's keen sense of direction, gave the effect of an invisible and morking presenee. Or the guide would plate the tomrists at symunetrieal points on either side of the center, when they (a) led with the help of the ceiling whisper to eated other aleross distances over which ther. comld not be heard directly. The explanation of this particolat whispering gallery is exceedingly simple.

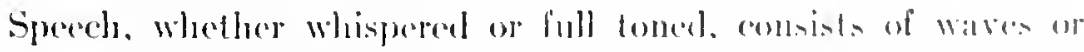

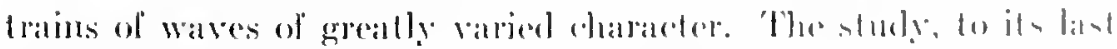
refinement, of whispering gallery phenomena insolsen at comsiderat-

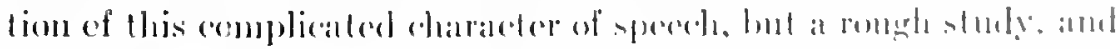

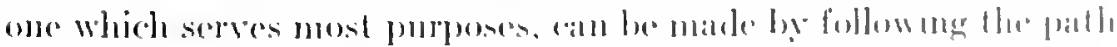

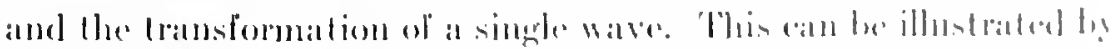

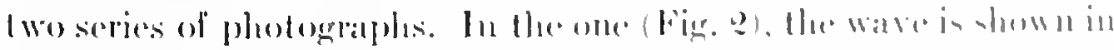

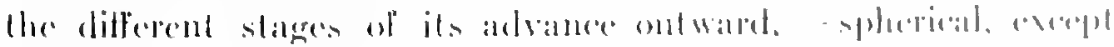

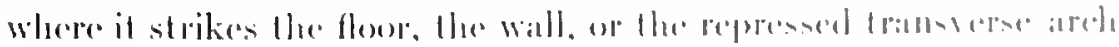

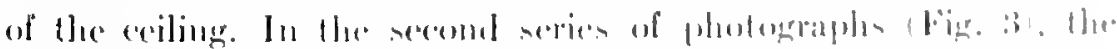

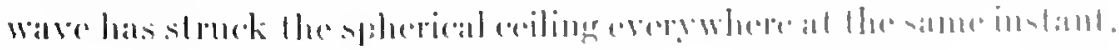



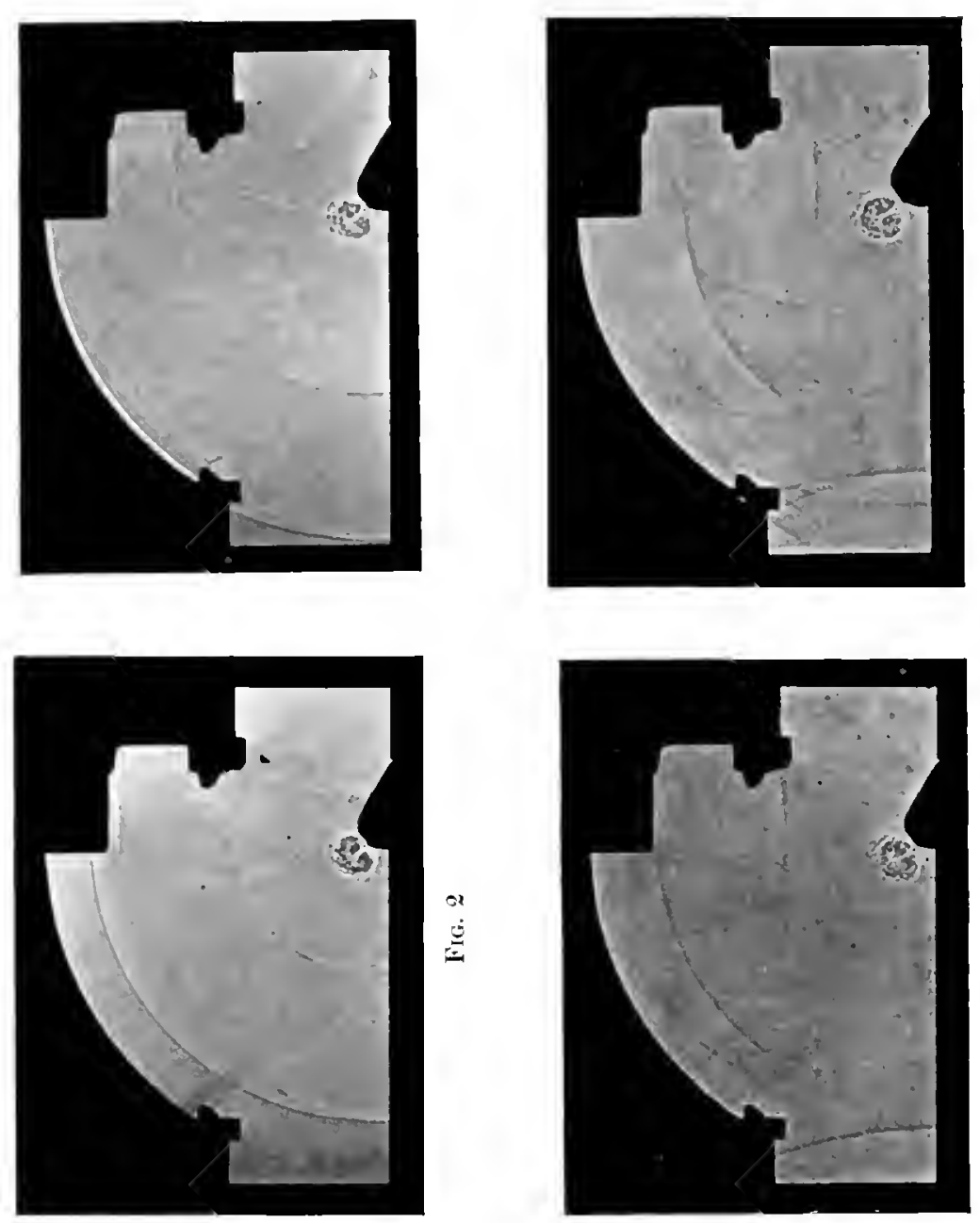

$\stackrel{9}{\stackrel{0}{=}}$
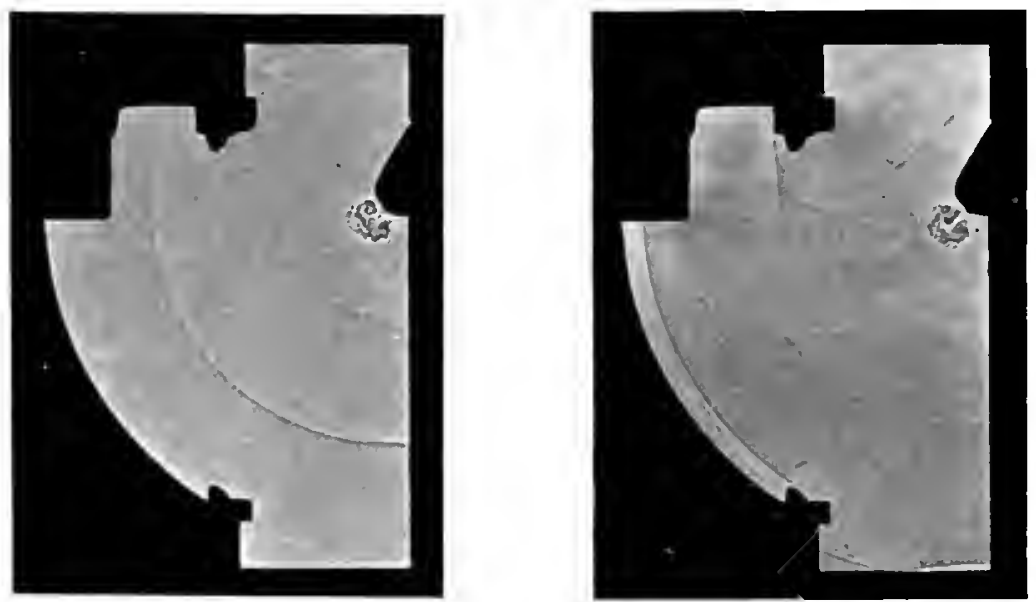
and, reversed in direction, gains in jutensity as it gatherm tomerther lowared the point from which it jssued. 'llhe sound refleceled from the othere surfaces may be seen dividing and subdividing in multiple reflection amb losing in intensily, while the somed reflected from the

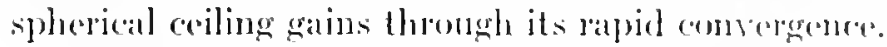

These and ofher similar photograples anded in this invenligaliom were taken in al small sectional model, oms-sixlenentl of an inch to

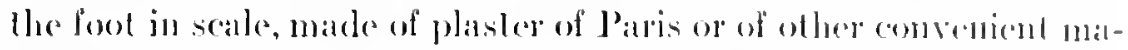

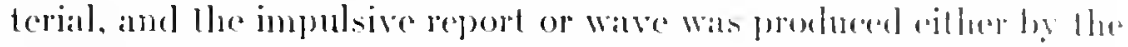

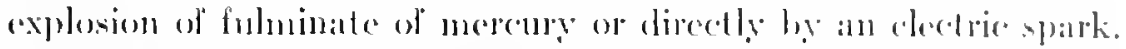

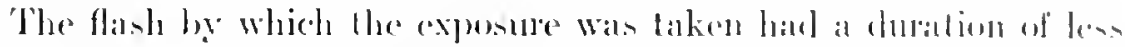

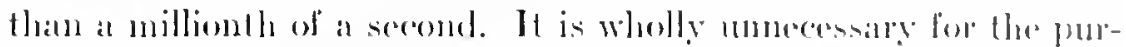

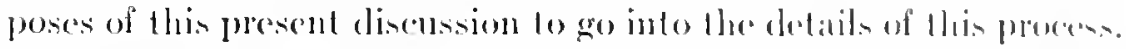

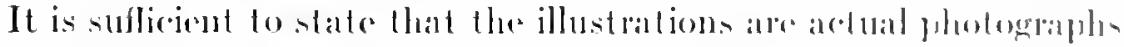

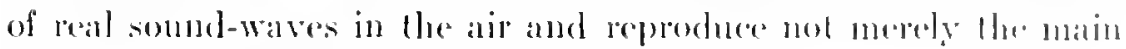
but the suborelinale phomomenas.

In citing this gallery in an anticle on Whispering Gallerien in slur-

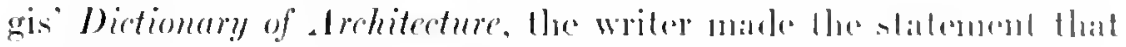

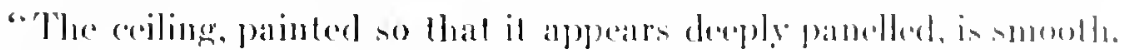

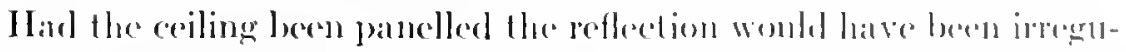

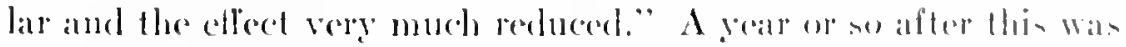

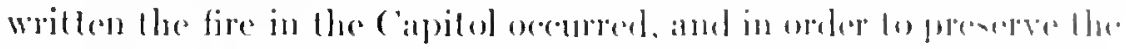

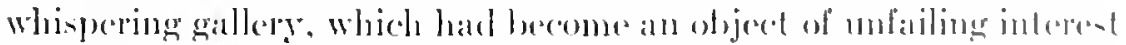

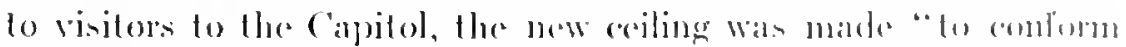

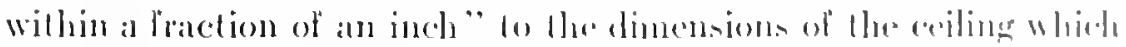

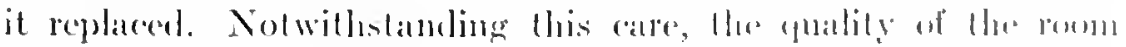
which hand long mande it the best and the hent known of whi-purieg

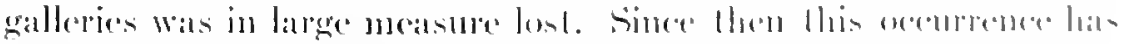

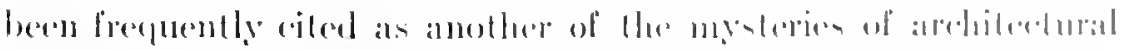

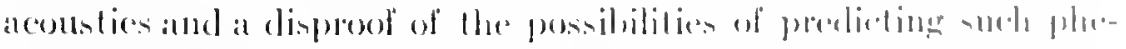

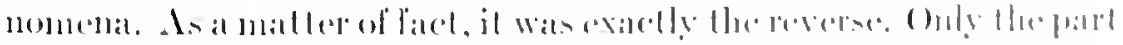

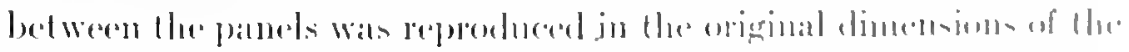

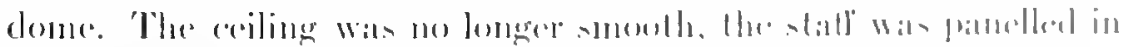

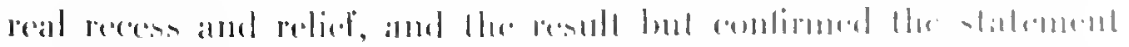

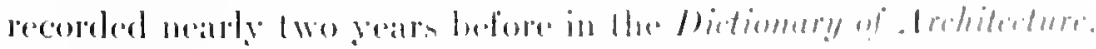

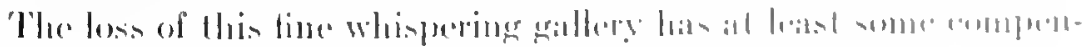

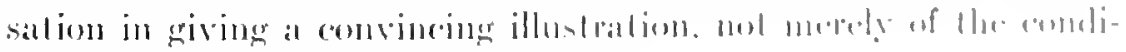


tions which make towards excellence in the phenonenon, but also of the ronditions which destroy it. The effect of the paneling is obvious. Fach facet on the complex ceiling is the source of a wavelet and as these facets are of elifferent deptlıs the resulting wavelets do not conspite to form the single focusing wave that results from a perfectly smooth clome. In a measure of course in this particular case the waveles do eonspire, for the reflecting surfaces are systematieally placed and at one or the other of two or three depths. The dispersion of the somml, and the destruction of the whispering gallery is, therefore, not complete.

An instructive parallel may be drawn between acoustical and optical mirrors:

Ahnost any wall-surface is a much more perfect reflector of sound than the nost perfect silver mirror is to light. In the former casc, the reflection is over 96 per cent, in the latter case rarcly orer 90 .

On the surfaces of the two mirrors scratches to produce equally injurious effects must be comparable in their dimensions to the lcngths of the waves reflected. Audible sounds have wave lengths of from half an inch to sixty feet; visible light of from one fortythousandth to one eighty-thousandth of an inch. Therefore while an optical mirror can be scratched to the complete diffusion of the reflected light by irregularities of microscopical dimensions, an acoustical mirror to be correspondingly scratched must be broken by irregularitics of the dimensions of deep coffers, of pancls, of engaged columms or of pilasters.

Moreover, just as remarkable optical phenomena are produced when the scratches on a mirror are parallel, equal, equal spaced, or of equal depth, as in mother of pcarl, certain bird feathers, and in the optical grating, so also are remarkable acoustical phenomena produced when, as is usually the case in architectural construction, the relief and recess are equal, equally spaced, or of equal depth. 'The panels in the dome of the Hall of Statues of course diminish toward the apex of the dome and are thus neither equal nor equally spaced, but horizontally they are and produce corresponding phenomena. The full details of these effects are a matter of common knowledge in Physics but are not within the scope of the present 
discussion. It is sufficient to say that the general result is a disperersion or a distortion in the form of the foens and that the gerneral effect is to greatly reduce the effieioncy of the whispering gallery, but to ly no means wholly destroy it, as would he the case witld eomplete irregularity.

By the term whispering gallery is msually umlerstomd a rown, either aldificial or natural, so shaned that haint sommls cau he heard across extraordinary distances. For this the IIall of Statues wan illadapted, partly because of a number of minol circumstances, fut primarily because a spherical surface is aceurately adaptenl only to return the somed directly upon itsell. When the l wo points betweren which the whisper is to be eonveyed are separaterl, the eorreet form of reflecting surface is an ellipsoid having lhe lwo points ats fori. When the two points are near togetleer, the ellipsoid rescmulles nure and more a splere, and the latter may be regarded as the liniting case when the two points coineide. On the other hand, when the two foci are very far apart the available part of llue ellipsoid near onte of the foed resembles more and more a paraboloid, and this may he regarded ats the othere extrene limiting ease when one of the fuce in at an infinite or very great distance. I know of no huidding a comsiderable portion of whose wall or coiling surlatee is part of an cxalet allipsoiel of revolution, but the great Momom 'labernarede in salt laike City is a near approximation. Plans of this rematrable lunilding alo not exist. lor it was latid ont on the grommel withont the ald of formal drawings soon alfor the settlers had completed their wealry pilerrimalge across the [tal desert and settled in therir isolated valley. It was

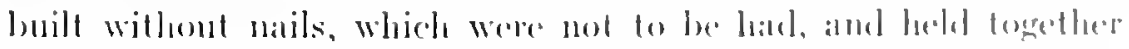

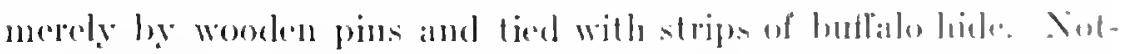
withstamling this construction, and untwithatamling the fanct that it

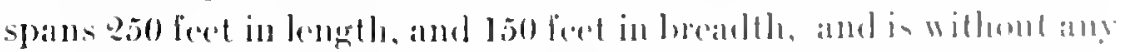

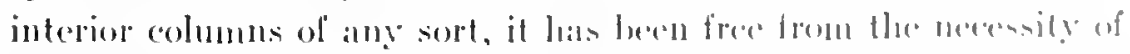

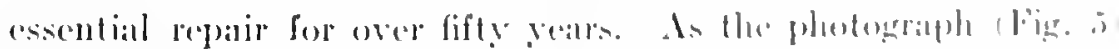

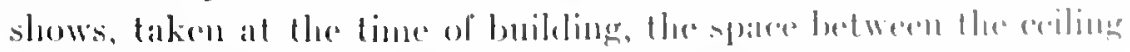

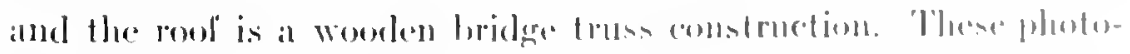

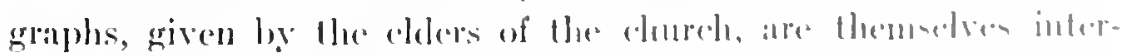

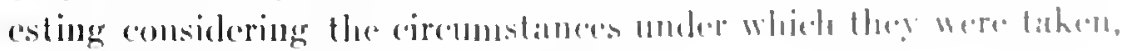
the early dale and the remote location. 


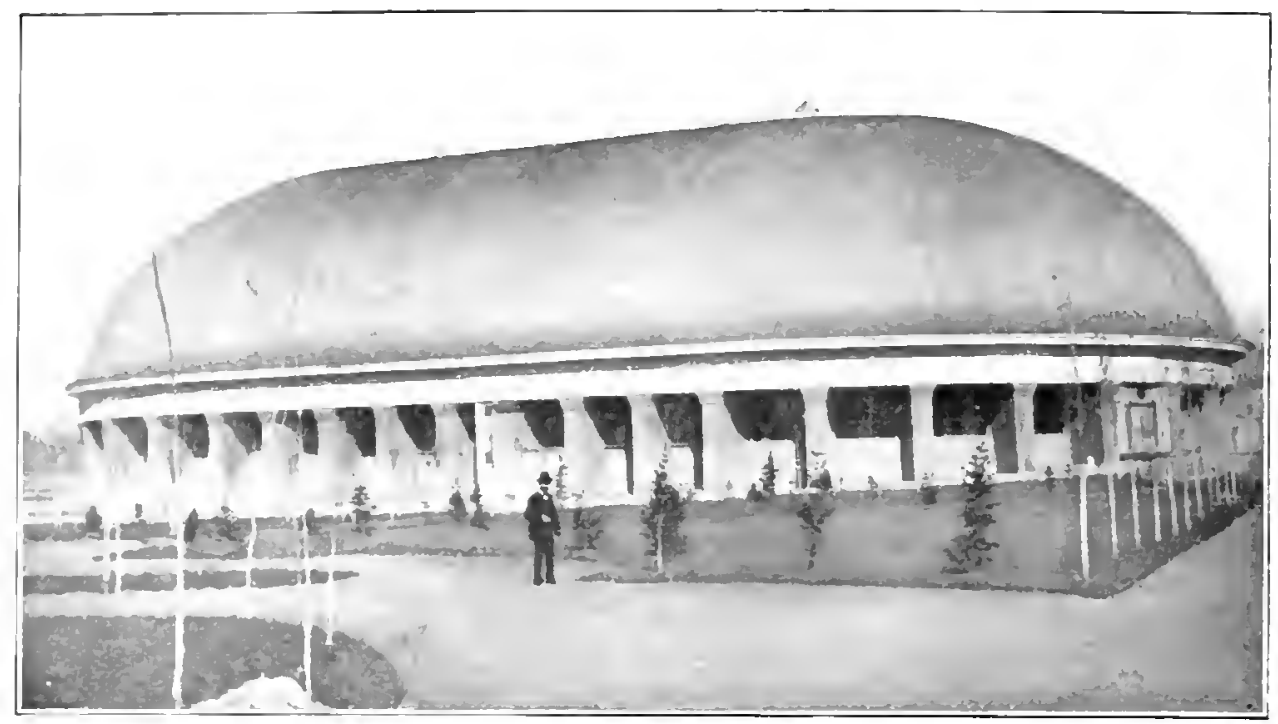

Fuci. 4. Exterior. Mormon Tabernarle, Salt Lake City, L'ath.

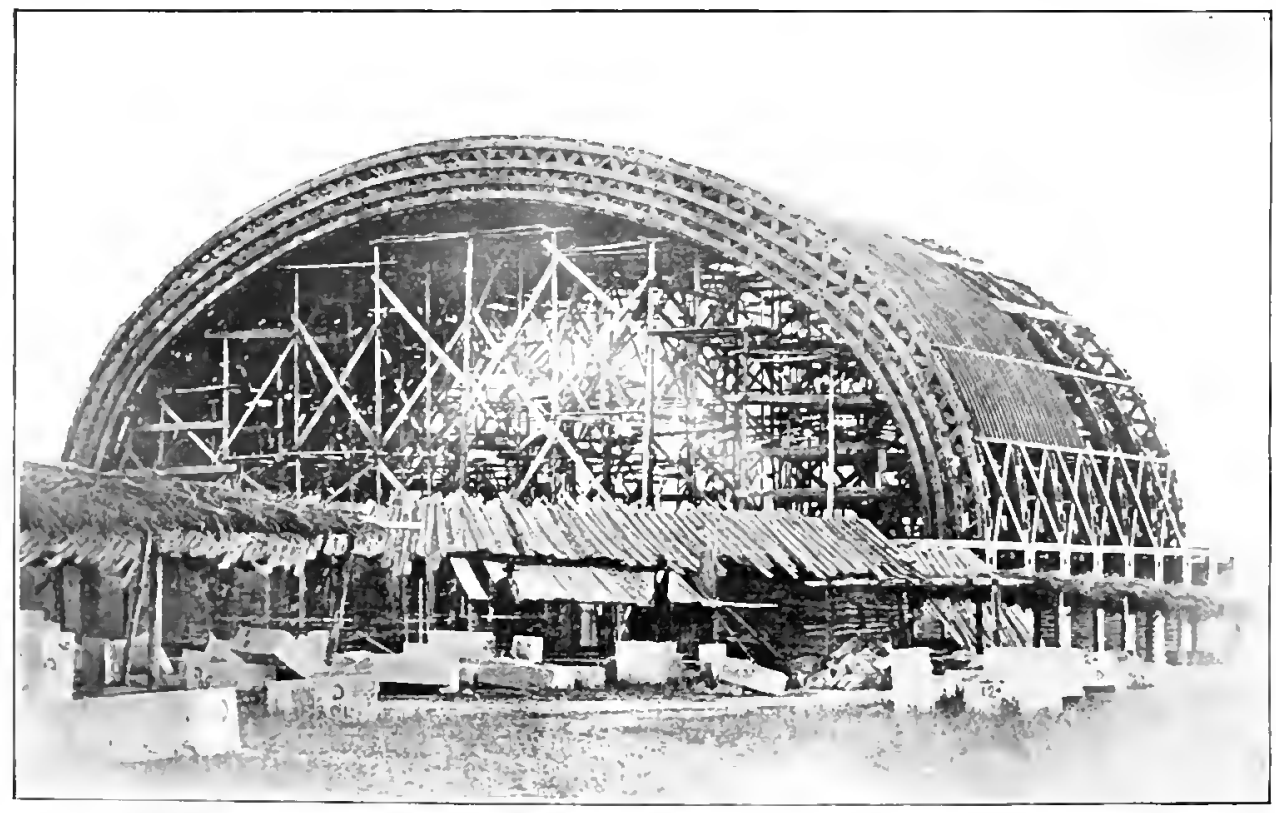

FIg. 5. Plhotograph showing Construction, Mormon Tabernacle, Salt Lake Cits, Utah. 

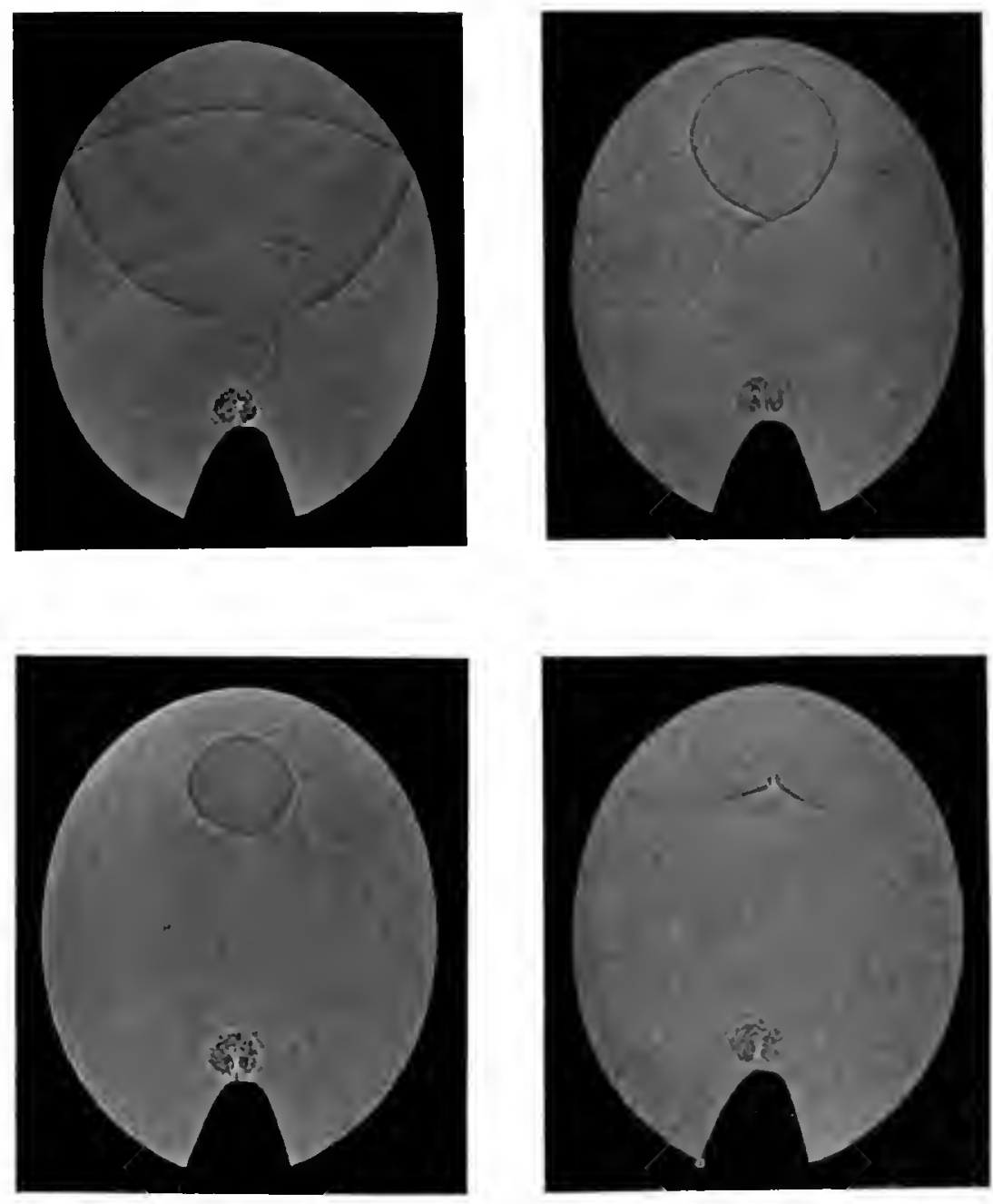

FIa. 6 
It is diffieult for an interior photograph of a smooth ceiling to give an impression of its shape. An idea of the shape of the interior of the Tabernacle may be oblained, however, from a photograpls of its exterior. It obvionsly sonewhat resembles an ellipsoid of revolution. It is equally olyious that it is not exactly that. Nevertheless there are two points between which faint sounds are carried with remarkable distinetness, - the reader's desk and the front of the baleony in the rear.

'The essential geometrieal property' of an ellipsoid of revolution is that lines drawn to any point of the surface from the two foei make equal angles with the surface. It follows that sound diverging from one focus will be reflected toward the other. The preeeding photographs (Fig. 6) show the progress of a sound-wave in the model of an idealized whispering gallery of this type in which the reflecting surface is a portion of a true ellipsoid of revolution.

The most notable whispering gallery of this type is that deseribed by Sir John Hersehel in one of the early seientific encyclopedias, the Eucyclopedia Metropolitana as follows:

In the Cathedral of Girgenti in Sicily, the slightest whisper is borne with perfeet distinctness from the great western floor to the cornice behind the high altar, a distance of 250 feet. By a most unlucky coincidence the preeise foeus of divergenee at the former station wis cliosen for the place of the confessional. Seerets never intended for the public ear thus became known. to the dismay of the confessor and the scandal of the people, by the resort of the curious to the opposite point, which seems to have bcen discovered by accident....

Aside from the great distanee between the foci, the circumstances related had many elements of improbability and the final discussion of this subject was postponed from year to year in the hope that the summer's work, which has usually been devoted to the study of Enropean anditorimms, would carry the writer near Girgenti, an interesting but rather inaeeessible city on the southwestem eoast of Sieily. Finally, failing any especially favorable opportunity, a fying trip was made from the north of Europe with the study of this gallery and of the Ear of Dionysius at Syracuse as the sole objective. On the way down the perplexity of the case was inereased by finding in Baedeker the statement that there is a noteworthy whispering gal- 


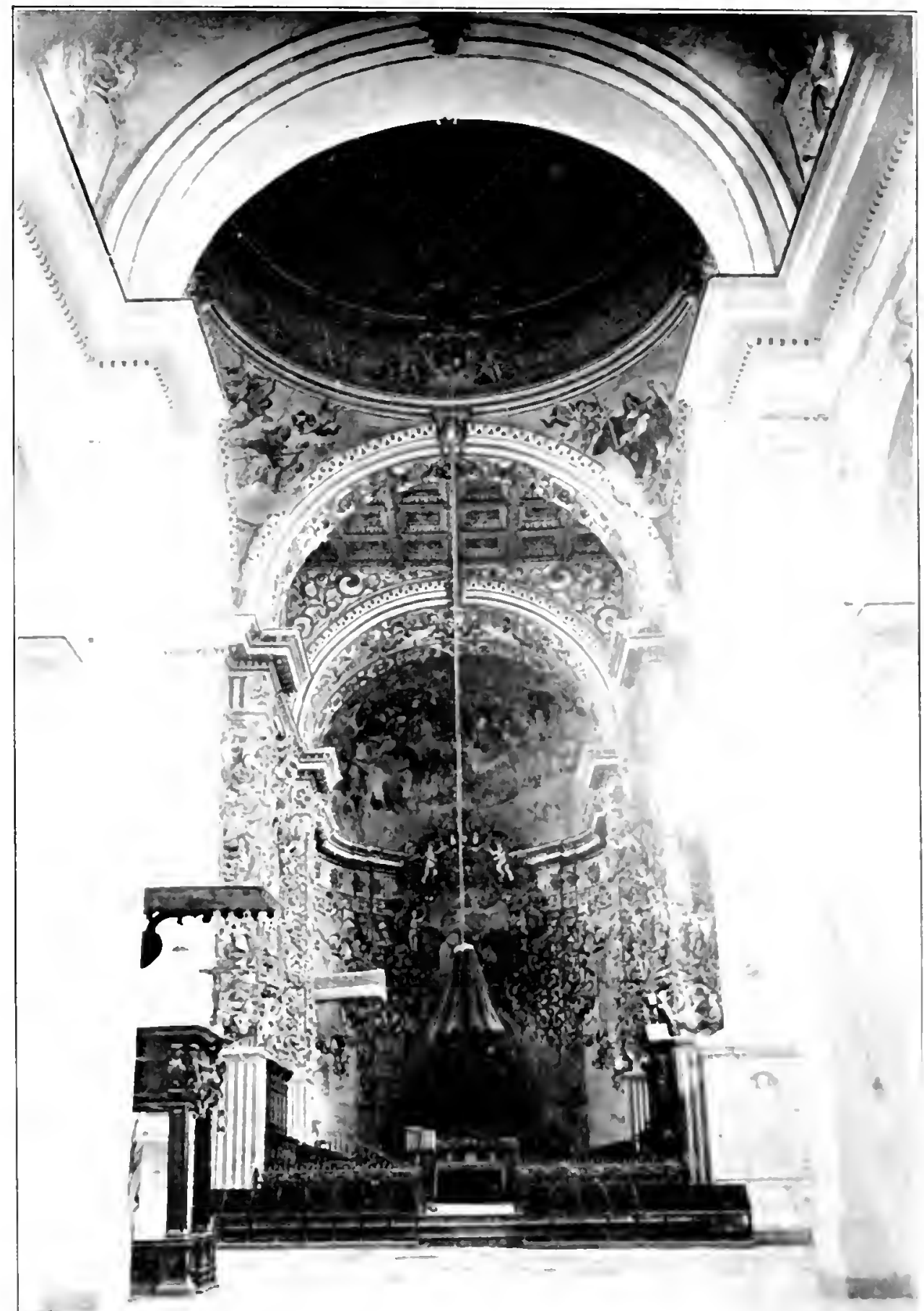

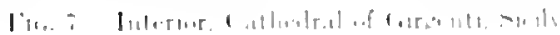


lery hetween the west entrance of the cathedral and "the steps of the high altar." Such a whispering gallery is wholly inconceivable. The fachs showed a whispering gallery between the tod as described by Irsehel, althomgh the aceompanying story is remelered improb"bhle by the extreme inacessibility of the more remote foens, and its rery conspicuous position. Yor is the distanee so great as stated by Irerschel, being a little over 100 fect instead of 250 feet. However, the interest in this whispering gallery arises not because of any ineident attending its diseovery, but becanse it illustrates, albeit rather erudely, the form of surface giving the best results for whispering betwen two very widely separated points.

As already stated the strietly eorreet form of surface for a whispering gallery is an ellipsoid of revolution whose foci coineide with the two points between whieh there is to be communication. In the whispering gallery in the Cathedral of Girgenti (Fig. 7), the foensing surface consists of a yuarter of a sphere prolonged in the shape of a half cylinder forming the ceiling over the ehancel. This is obviously not a true paraboloid, and. sueh as it is, it is interrupted by an arch of slight reveal where the cylinder joins the sphere; moreover, the two points of observation do not lie on the axis of revolution as they should for the best result. But a hemisphere and a continuing cylinder make a fair approach to a portion of a paraboloid; and while the two points of ohservation are not on the axis of revolution, they are on a secondary axis, the station by the door being below, and the foens in the chancel being at a corresponding distance above the principal axis.

In all the preceding galleries, there is but a single reflection between the radiant and the reeciving foei. There are others in which there are several such reflections. Well-known examples are the church of St. John Lateran in Rome and in the Salle des Cariatides in the Jourre.

In the Chureh of St. John Lateran (Fig. 8), each bay in the great side aisles is a square having a eeiling which is approximately a portion of a sphere. At best, the approximation of the eeiling to a sphere is not elose and the eciling varies from bay to bay, not intentionally but merely as a matter of variation in construction. In one bay more closely than in the others the ceiling, regarded as an acoustieal 


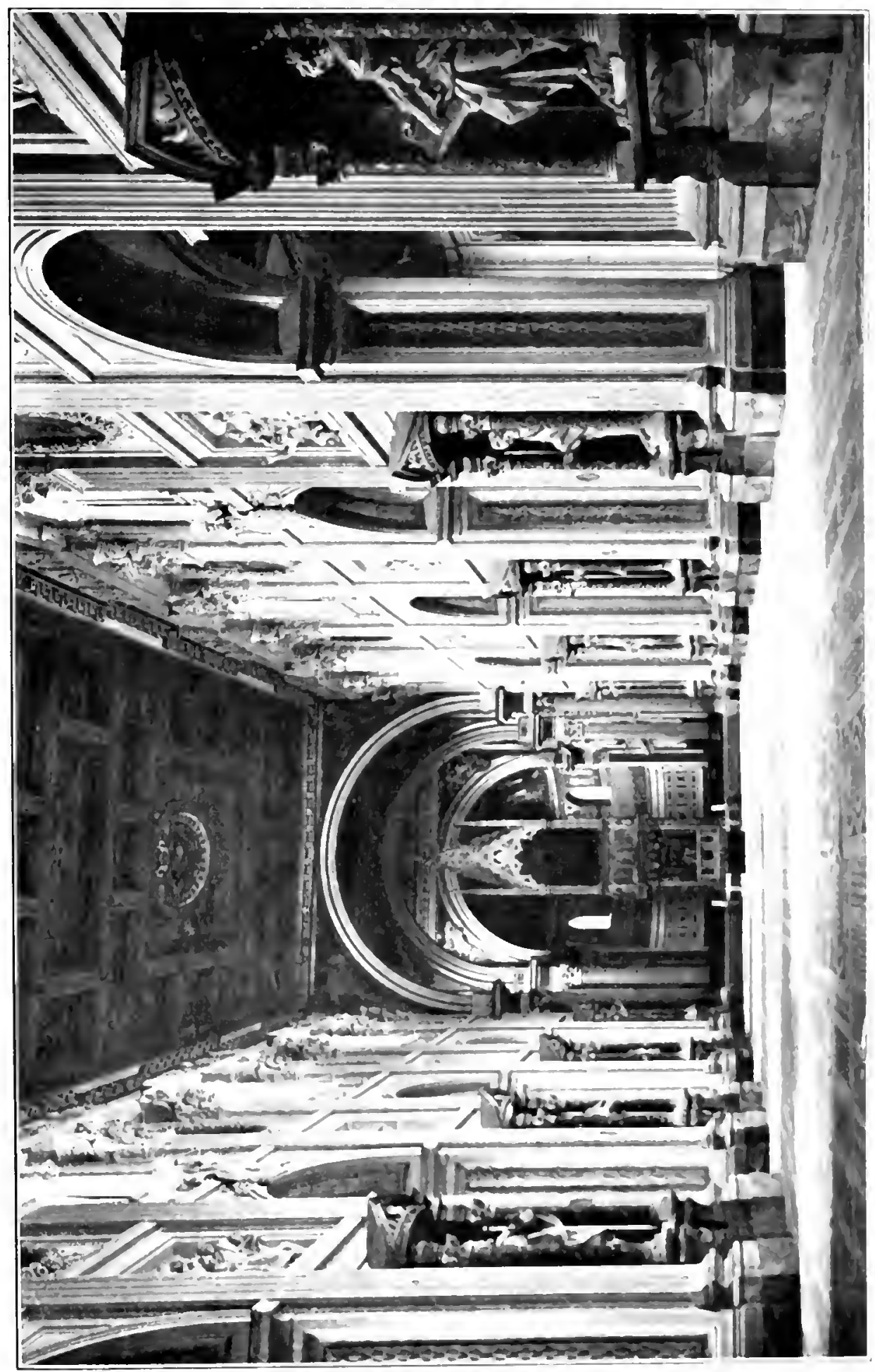


mirror, has its foci nearly at head level. In eonserpuence of this, wo observers standing al opposite corners can whisper to each other with the coiling als a reftecting surface. The curvature even in this bay is not ideal for the production of a whispering gallery, so that thus used the gallary is far from notalble. It so happens, however, that the great stuare columms wheh form the eorners of each bay have, instead of sharp corners, a reantering eove or fluting in the arc of a circle and over twelve inches aeross in opening. If the observers. instead of attempting to spealk directly to the eciling, turn baek to back and face the columns standing elose to them, this great fluting gathers the sound from the speaker and directs it in a eoncentrated cone of the ceiling: this returning from the ceiling to the opposite angle of the bay is concentrated by the opposite fluting on the other ohierver. In more scientific language, borrowed from the nonenclature of the makers of optical instruments, the flutings inerease the angular anperture of the system.

An almost exact duplicate of this whispering gallery is to be found in the vestibule of the Conservatoire des Arts et Metiers in Paris. This vestilunle, itself also an exhiljition room but called sinee the discovery of its peculiar property La Salle-Echo, is square with rounded eorner's and a low domical ceiling. Here, as in St. John Lateran, the observers fice the comers and the whisper undergoes three reflections between the foei. The fact that the two observers are back to back diminishes the sound which would otherwise pass directly between them and makes the whispering gallery more pronounced and the phenomenon mud more striking. In both galleries it is the eustom for the observers to take their positions in a somewhat random manner. The correct position is at a distance from the eoneave cylindrical surface a little less than half the radius of enrrature.

In these whisprering galleries the surfaees are not theoretically correct and the phemomenon is far from perfect. This failure of loudness and distinctness in most of the multiple refleetion galleries arises not from any progressive loss in the many reflections, for the loss of energy in reflection is practieally negligible. Indeed, given ideally shaped suffaces, multiple reflection whispering galleries are capable of producing exceptional effect: for if two of the surfaces be very near the observers they may, even though they themselves be of 


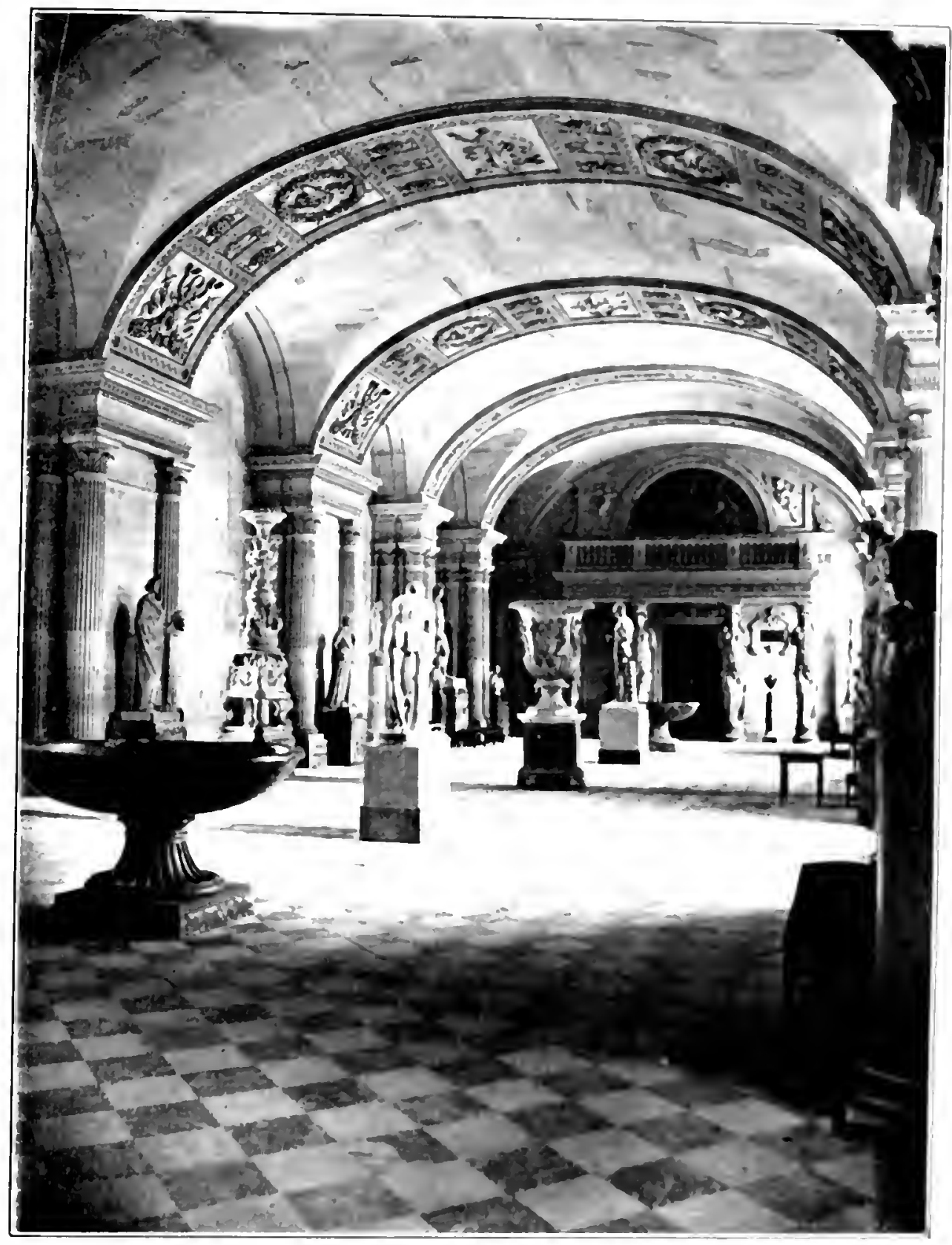

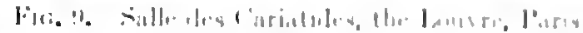


small dimensions, gat ther into the phenomenon very large portions of the energent and of the foensed whisper. In both St. John Lateran and La sille-Litwe, the condensing mirrors ane cylindrieal and gather the souml horizontally only. In the rertical plane, they are wholly without atleet.

It is not difficult to determine the eorrect forms for the extreme mirrors. If the eeiling be flat, the reflecting surfaces near the two otservers slemble be parabolice with the axis of the paraboloid directed toward the ecenter of the ceiling, the eorrect position for the mouth of the speaker and the ear of the anditor being at the foei of the two palaholoids. If the ceiling be curved, the simplest design is when the first and last reflectors are portions of an cllipsoid, each with one focus at the center of the ceiling and the other at one of the foei of the system ats a whole. Finally, if the reiling be curved, there is still another theoretical shape for the end reflectors, determined by the curvature of the ceiling; in this case the ideal surface is not a conic surface, nor otherwise geometrically simple, but is such that the converging power of the ent mirror with half the eonverging power of the midlde mirror will give a plane wave.

It is olvious that the aceurate fulfilling of these eonditions by aecident is improbable, but they are at least approached in the whispering gallery in the salle des (ariatides in the Lourre (Fig. 9). Along the axis of the room, and at no ineonsiderable distance apart, are two large shallow antique vases. A whisper uttered a little within the rim of one is partially focused by it, is still further focused by the barrelshaped eeiling. and is bronght to a final focus srmmetrieally within the rim of the further vase. It is evident that the effect is dependent on only a portion of each vase, but this portion satisfies the necessary conditions to a first approximation in both longitudinal and in transverse seetion. When the eorreet foci are found this whispering gallery is very distinct in its emuneiation. It would be even more distinet if the ceiling of the roon were slightly lower, or, keeping the height the sime, if its ritlins of eurvature were slightly greater. It would be still better if the vases were slightly deeper.

'The whispering gallery which has received the greatest amount of disenssion, and a discussion eurionsly inadequate in view of the eminence of the authorities engiged, is the eireular gallery at the base of 


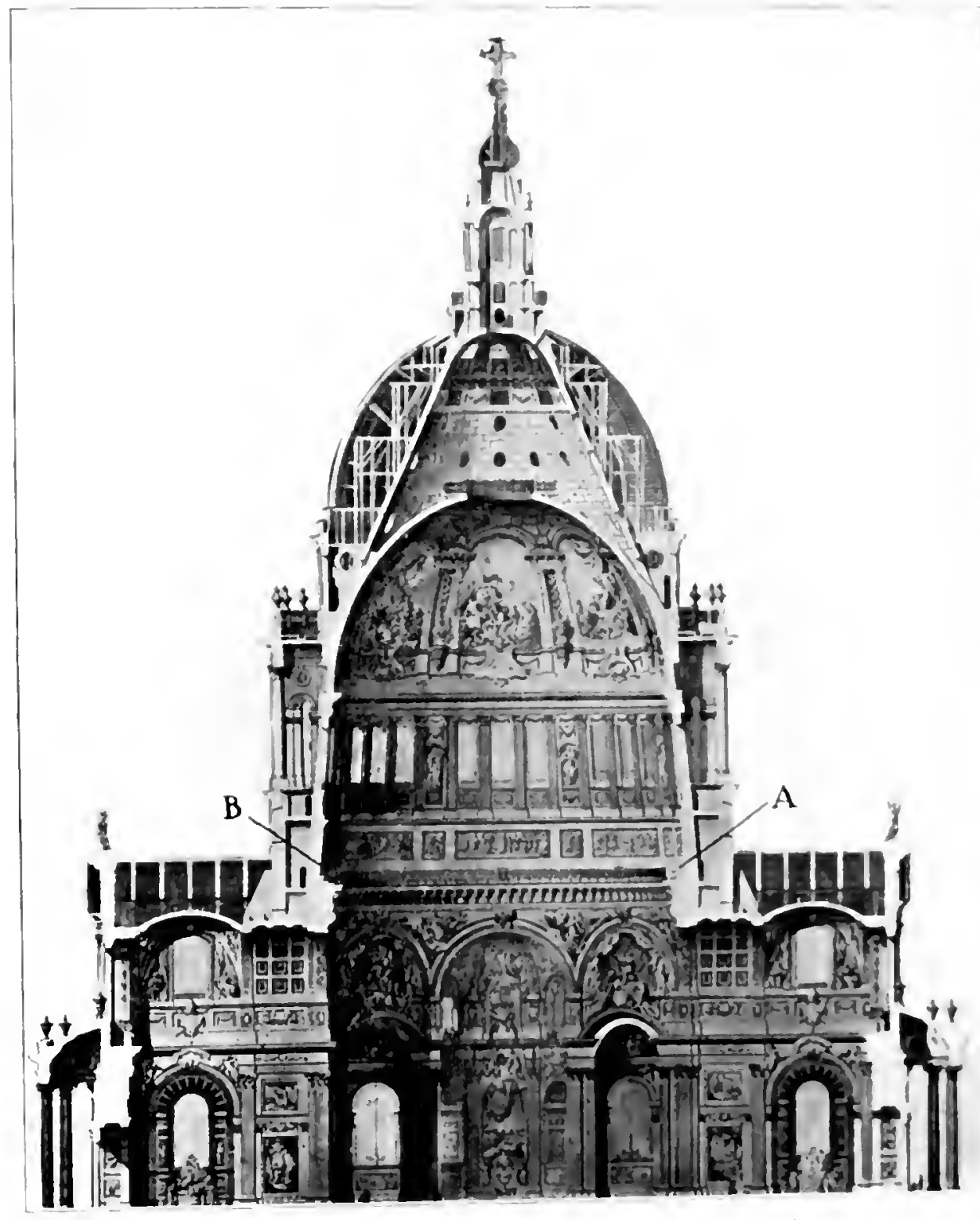

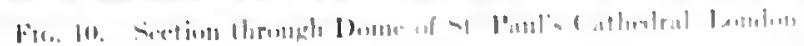


the done of st. Panl's Cathedral in London. 'This gallery was first brouglat into scientific eonsideration hy Sir John Iterschel, who in describing it stated that "the faintest sount is faithfully conveyed from one side to the other of the clome, but is not hearel at any intermediatle point." According to Lorel Rayleigh, whose reference, howcver. I am muable to verify, anel either in page or edition must be in error, an early explantation of this was by Sir George Airy, the Astronomer Royal, who "ascribed it to the reflection from the surface of the dome overheatel." Airy conld have been led into such error only by the optieal illusion whereby a done seen from within seems lower than it is in reality. A monent's inspection of the preceding illnstration (Fig. 10), which the Clerk of the Works kindly had reproduced from an olfl engraving in the possession of the cathedral, shows that this explanation would be incorrect. The guide who does the whispering usually oecupies the position marked "A": the other focus is in the position marked "B." 'The focus accounted for by Airy" would be high up in the dome. Lort Rayleigh taking exception both to the statement of fact by Herschel and the explanation by Airy wrote "I am disposed to think that the prineipal phenomenon is to be explained somewhat differently. The abnormal loudness with which a whisper is heard is not eonfined to the position diametrically opposite to that oeenpied by the whisperer, and therefore, it would appear. does not elepend materially upon the symmetry of the dome. The whisper seems to (reep around the gallery horizontally, not neeessarily along the shorter are, but rather along that are toward which the whisperer faces. This is in consequence of the very unequal audihility of a whisper in front of and behind the speaker, a phenomenon which may easily be observed in the open air." Lord Rayleigh's explanation of the phenomenon in this case as due to the "creeping" of the sound around the circular wall inmediately surrounding the narrow gallery aceessible to visitors is unquestionably correct. It is but another way of plurasing this explanation to say that the intensification of the sound is due to its accumulation when turned on itself by the restraining wall. It is obvious that the main intensification arises from the curved wall returning on itself. Vertically, the sound spreads almost as it would were the curved wall developed on a plane. This rertical spreading of the sound is in a 


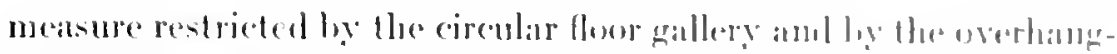

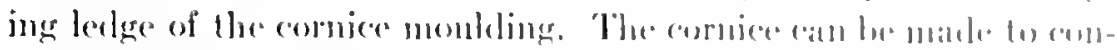

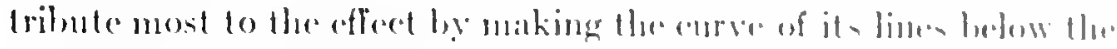

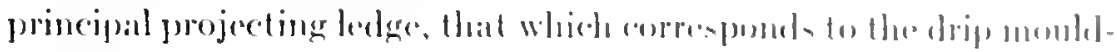

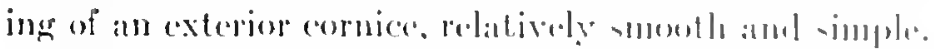

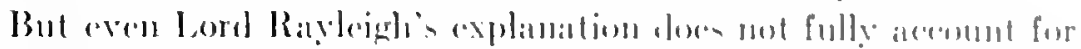

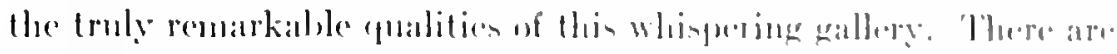

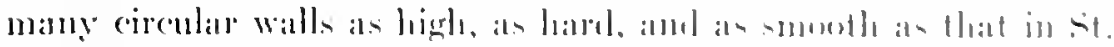

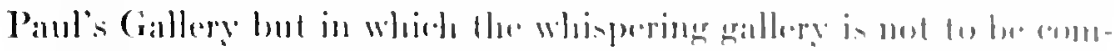

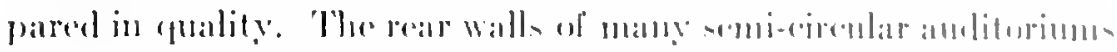

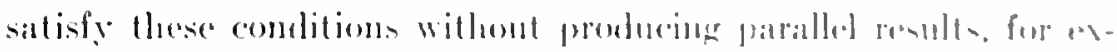

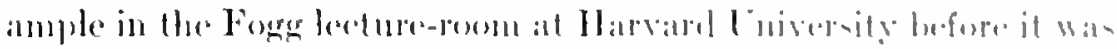

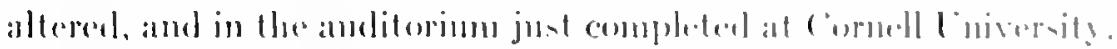

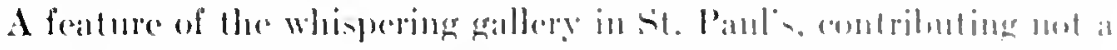

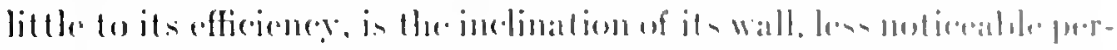

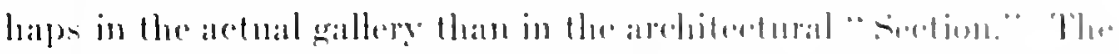

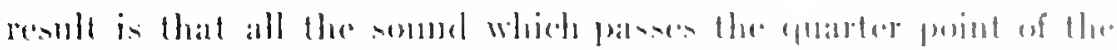

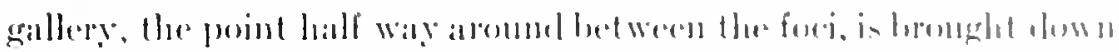

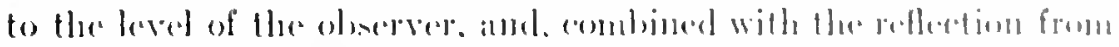
the ledge which constitutes the hroad seat rumbing entirely arutuml

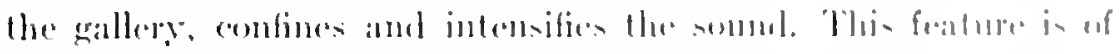

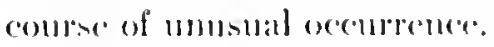

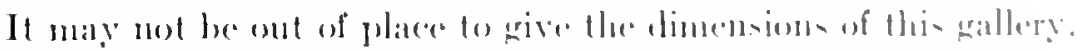

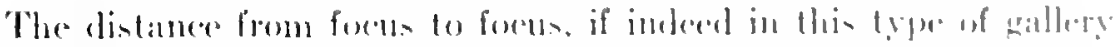

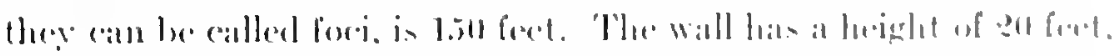

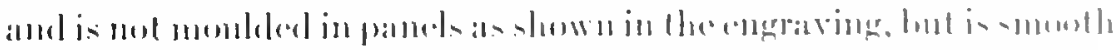

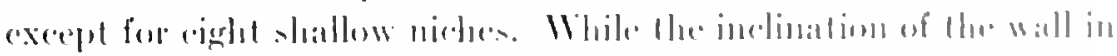

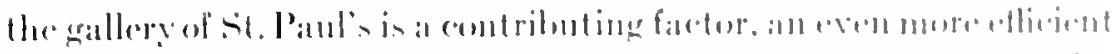

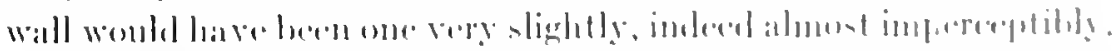

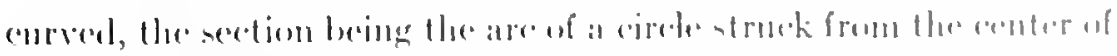

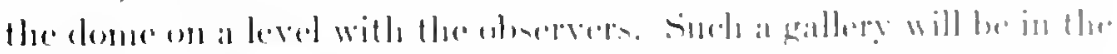

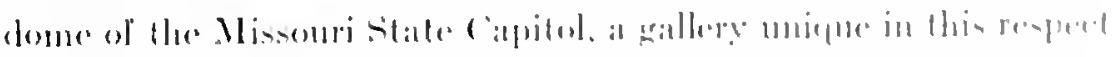

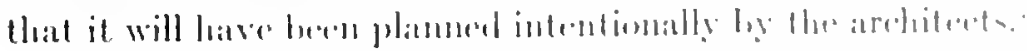

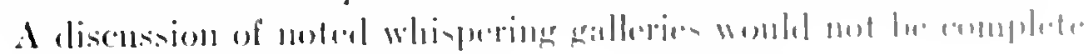

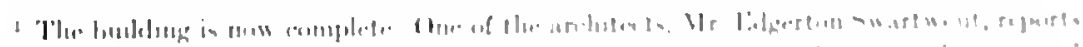

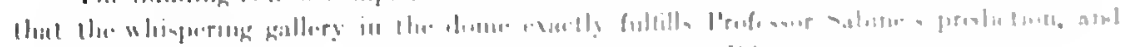

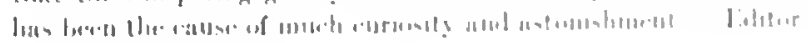


without mention of the famons Far of Dionysins at Syracuse. A mile out from the present city of Syracise. on the slope of the terrace
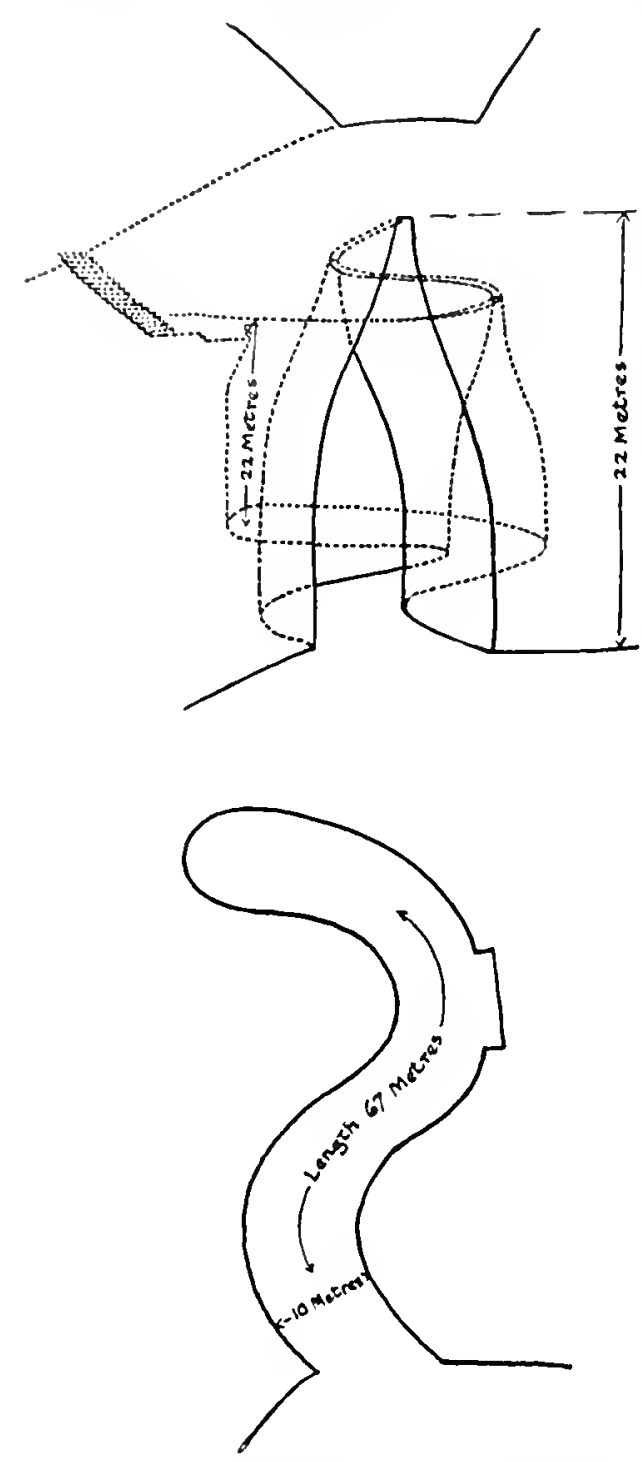

Frc. 11. Plan and Elevation, with Sectional Indication. of Far of Dionysius, Syracuse, Sicily.

cal opening four or five feet square, scarcely visible, certainly not notieeable, from below. This opening is into a short passageway' the ancient city are the remains of a qualry entered on one side on the level but cut back to perpendicular walls from al humdred to a humdred and thirty foet in hecight. 'This old quarry. now overgrown ly a wild and luxurious regetation, is known as the Latomia del Paradiso. At its western angle is a great grotto, shaped somewhat like an open letter $S, 210$ feet in winding length, $7+$ feet high, 35 feet in widtl at the base and narrowing rapidly toward the top. The innermost end of this grotto is nearly circular, and the rear wall slopes forward as it rises preserving in revolution the same contour that eharacterizes the two sides throughout their length. The top is a narrow chamnel of a uniform height and but a few feet in width. At the innermost end of this channel, at the apex of the lialf cone which forms the inner end of the grotto, is a rertioccupied by the Nealpolis of 


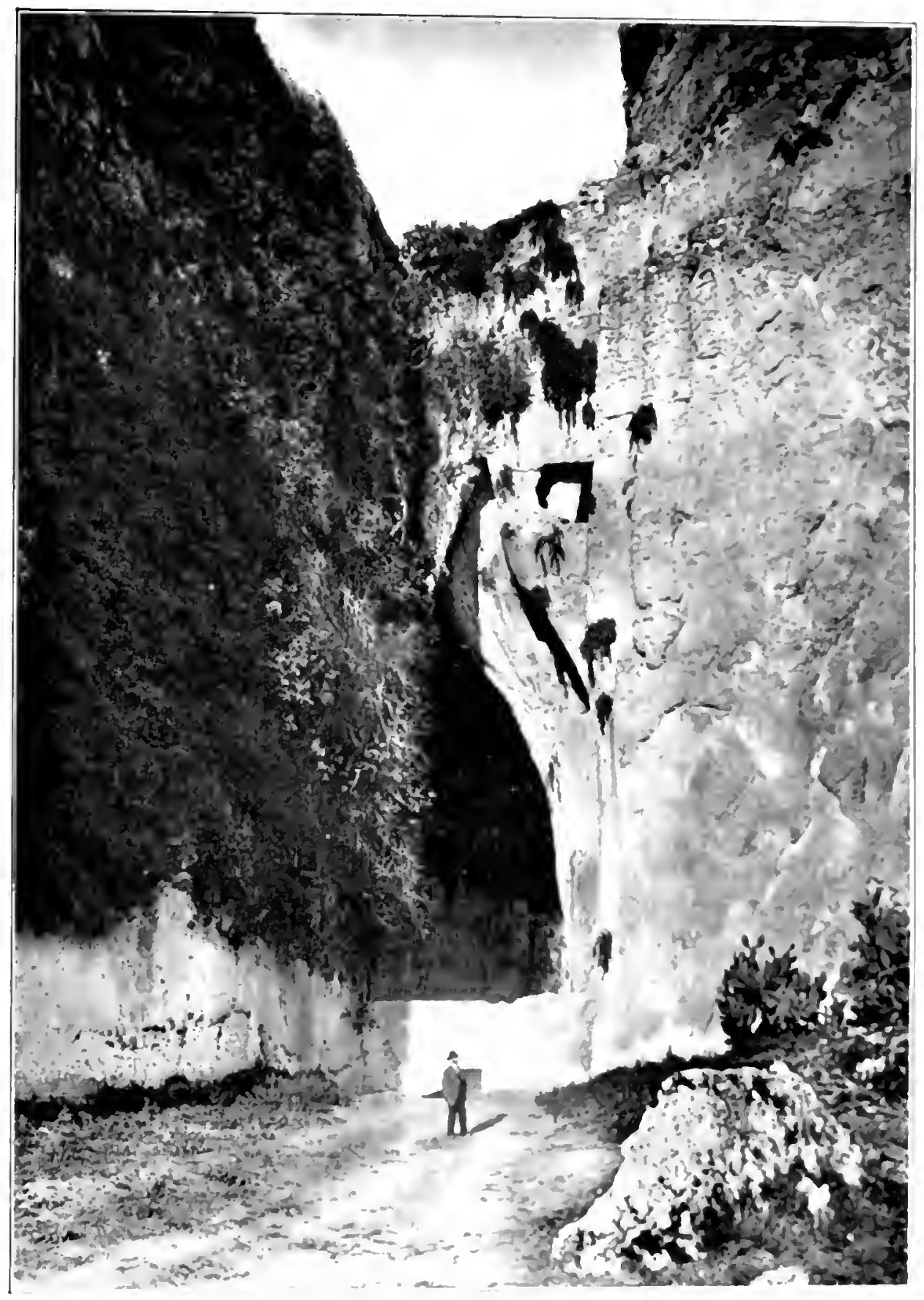

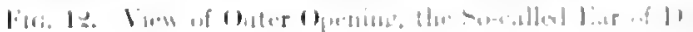


which leads to a flight of steps and thence to the ground above (Fig. 11). The grotto is noted for two somewhat inconsistent acoustical propertics. When being shown the grotto from below, one's attention is called to its very remarkable reverberation. When above, one's attention is called to the ability to hear what is sajd at any point on the floor.

It is related that Tyrant Dionysius, the great builder of Syracuse, so designed his prisons that at certain concealed points of observation lie comld not merely see everything that was done, but, through remarkable acoustical design, could hear every word which was spoken, roch when whispered only (Fig. 12). There is a tradition, dating back however only to the sixteenth century, that this grotto, since then ealled the Ear of Dionysins, was such a prison. Ruarries were plausible prisons in which captives of war might have been compelled to work, and there are, surromeling this quarry, traces of a wall and sentry houses, but there is no direct evidence associating this grotto with Dionysins, unless indeed one regards its interesting acoustical properties taken in connection with classical tradition as sucli eridence.

In its acoustical property this grotto resembles more a great ear trumpet than a whispering gallery in the ordinary sense of the word. It is, of course, in no sense a focusing whispering gallery of the type represented by the vases and curved ceiling in the Lonvre. It more nearly resembles the gallery in St. Paul's Cathedral, but the sound is not spoken close to the deflecting wall, one of the essentially characteristic conditions of a true whispering gallery of that type, and the wall is not contimuously concave. In fact, in other ways also its acoustical property is not very notable, for distinctness of enumciation is blurred by excessive reverberation.

It is conceivable that whispering galleries should be of use and purposeful, but it is more probable that they will remain arehitectural euriosities. When desired, they may be readily woven into the design of many types of monumental buildings. 


\section{APPENIIX}

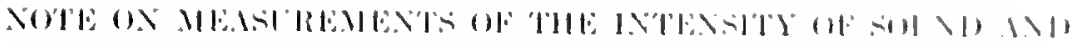

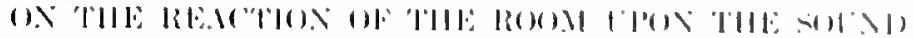

\section{D}

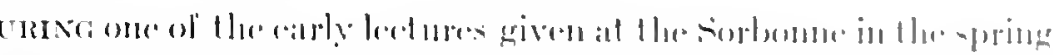

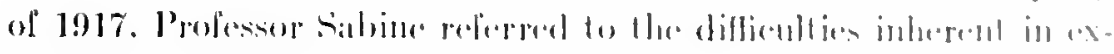

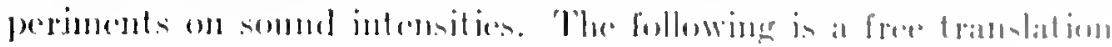

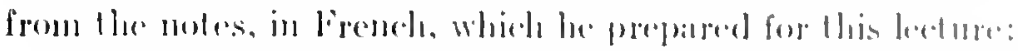

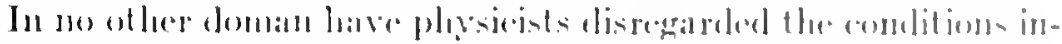

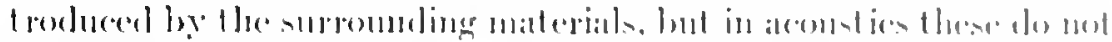

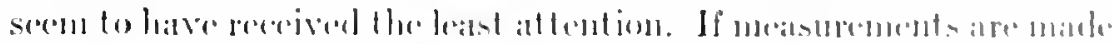

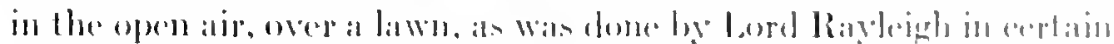

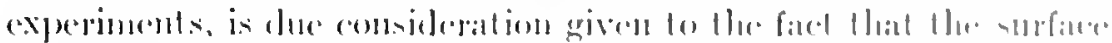

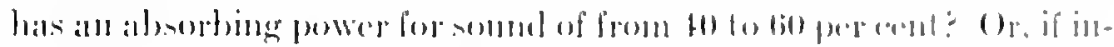

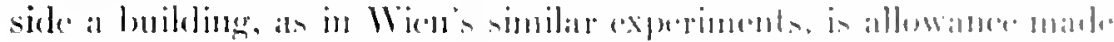

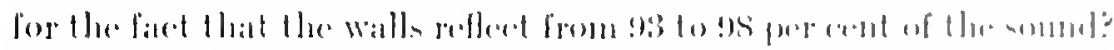

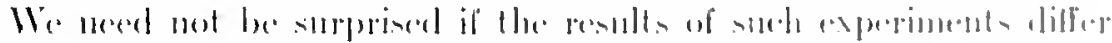

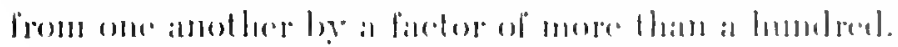

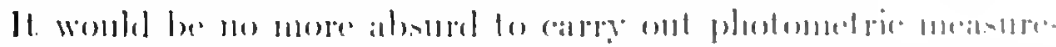

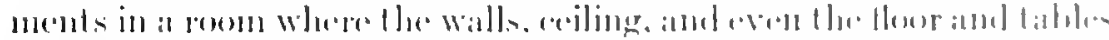

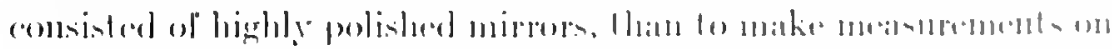

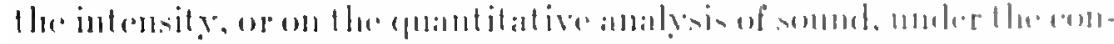

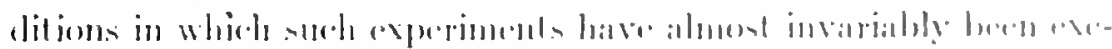

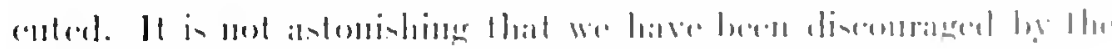

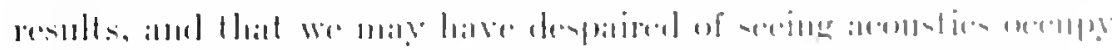

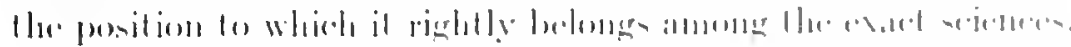

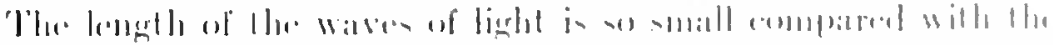

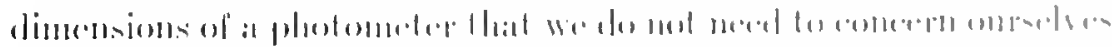

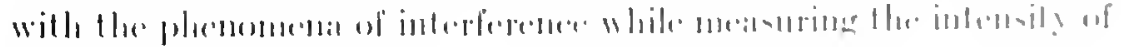

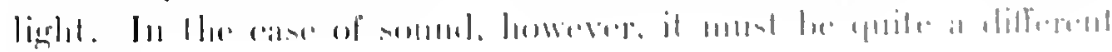
miattiol.

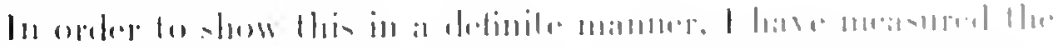

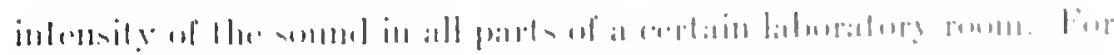

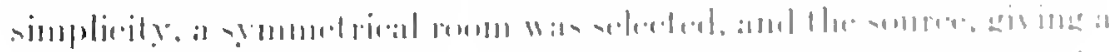

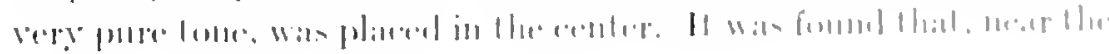


sontere cren at the songere it self, the intensily was in reality less than at a distance of fire leet from the source. And yet, the deverexperinenter. Wien, and the no less skillful psychologists Wimdt and Miinsterlyerg have assumed under similar comdit ions the law of variation of intensity with the inverse stpuare of the distance. It makes one wonter how they were able to draw any eonchusions from their merasurements.

Sot only do the walls reflect somel in such a way that it becomes many timses more intense than it of herwise woukl be; and not only does the interference of somel exist to such an extent that we find regions of maximum and regions of minimum of sound in a room; but even the total quantity of soumd emitted by the souree itself may he greatly affeeted by its position with regard to the interference system of the room.

This will be nore readily umblerstood if illust rated by an incielent drawn from the actual experiments. A special sort of felt, of strong absorbing power, was brought into the room and placed on the floor. The effect was two-fold. First, the int roduction of the felt increased He absorption of the sommd, and thus tended to diminish the total intensity of sound in the room, theoretically to a third of its previous value. But actually it had the contrary effeet; the sound becane much loutere than before. The lelt was so placed on the floor as to shift the interference system in the room, and thus the reaction of the sound vibrations in the room upon the source itself was modified. The source was a vibrating diaphragm situated at the base of a resonating chamber. In its first loeation, the souree was at a node of eondensation. where the motion of the somnd which had accumulated in the room coincided with that of the diaphragm. It was thus ditficult for the diaphragm to impart any adelitional motion to the air. In the second case, however, the vibrations of the two were opposite; the diaphragm was able to push upon the air, and although the amplitude of it s motion was somewhat reduced by the reaclion of the air upon it, the emitted sound wis louder. When under these conditions the diaphragm was foreed to vihrate with the same amplitude as at first, the emitted somel beeame eight times louder.

Naturally these two positions in the interference system were designedly selected, and they show exceptional reaet ions on the source. 
However, in the case of a rerge complex -

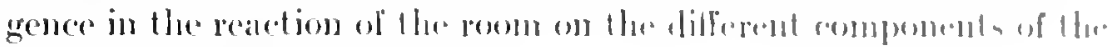
sound would be probilble.

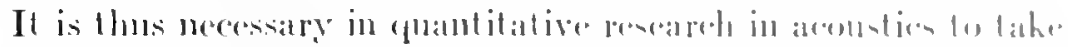

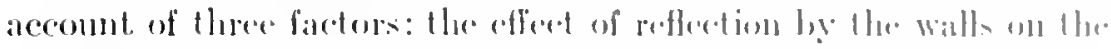

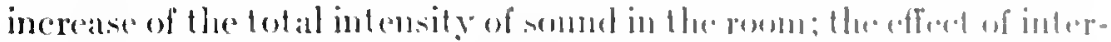
ference in greatly" altering the dist ribution of thi intemity: and the.

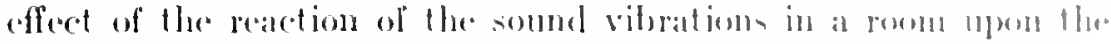
soures itself. ...

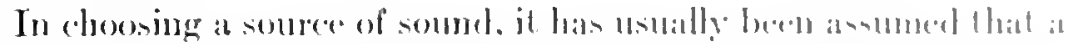

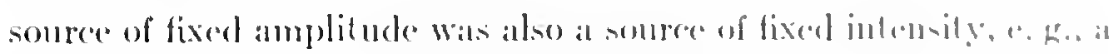

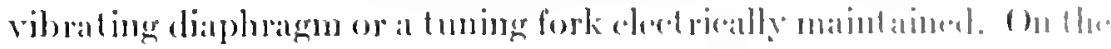

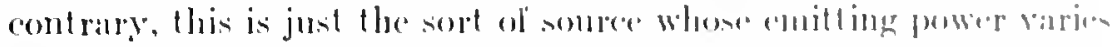

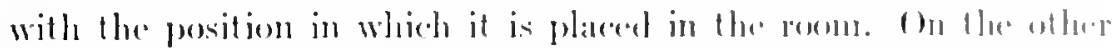

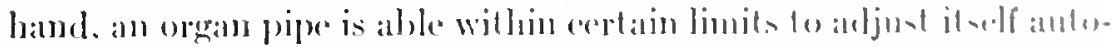

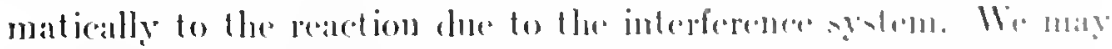

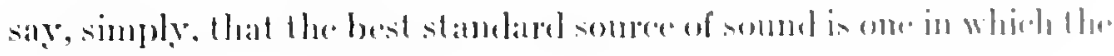

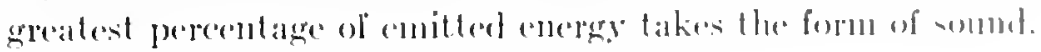


I'IRIXTEI AT

THE H IRVARI LNIVERSITY PKESS

C.MBIRDGE, MLAS., U.S. A. 


- ve $28005 \cdot 21522$

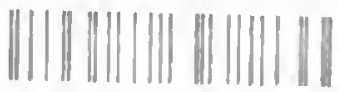

LoOf 257 i.4B ;

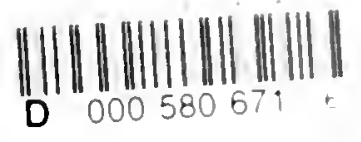




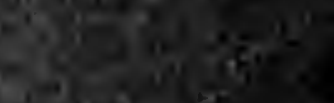

